\title{
Patenting human embryonic stem cell related inventions in China
}

Citation for published version (APA):

Peng, Y. (2018). Patenting human embryonic stem cell related inventions in China: a comparative perspective. [Doctoral Thesis, Maastricht University]. Maastricht University. https://doi.org/10.26481/dis.20180924yp

Document status and date:

Published: 01/01/2018

DOI:

10.26481/dis.20180924yp

Document Version:

Publisher's PDF, also known as Version of record

\section{Please check the document version of this publication:}

- A submitted manuscript is the version of the article upon submission and before peer-review. There can be important differences between the submitted version and the official published version of record.

People interested in the research are advised to contact the author for the final version of the publication, or visit the DOI to the publisher's website.

- The final author version and the galley proof are versions of the publication after peer review.

- The final published version features the final layout of the paper including the volume, issue and page numbers.

Link to publication

\footnotetext{
General rights rights.

- You may freely distribute the URL identifying the publication in the public portal. please follow below link for the End User Agreement:

www.umlib.nl/taverne-license

Take down policy

If you believe that this document breaches copyright please contact us at:

repository@maastrichtuniversity.nl

providing details and we will investigate your claim.
}

Copyright and moral rights for the publications made accessible in the public portal are retained by the authors and/or other copyright owners and it is a condition of accessing publications that users recognise and abide by the legal requirements associated with these

- Users may download and print one copy of any publication from the public portal for the purpose of private study or research.

- You may not further distribute the material or use it for any profit-making activity or commercial gain

If the publication is distributed under the terms of Article $25 \mathrm{fa}$ of the Dutch Copyright Act, indicated by the "Taverne" license above, 
Patenting Human Embryonic Stem Cell Related Inventions in China A Comparative Perspective

Yaojin Peng 
Lay-out and print by: ProefschriftMaken // www.proefschriftmaken.nl ISBN: 978-94-6380-034-1 
Patenting Human Embryonic Stem Cell Related Inventions in China

A Comparative Perspective

Dissertation

To obtain the degree of Doctor

At Maastricht University

On the authority of the Rector Magnificus,

Prof.dr. Rianne M. Letschert

In accordance with the decision of the Board of Deans,

To be defended in public

On 24 September 2018, at 16:00 hrs

By

Yaojin Peng 


\section{Supervisors:}

Prof. dr. Anselm Kamperman Sanders

Prof. dr. Cees A.M. Mulder

\section{Assessment Committee:}

Prof. dr. D. van Engelen (Maastricht University) (chair)

Dr. A. Ramalho (Maastricht University)

Dr. C. Heath (Boards of Appeal, European Patent Office)

Prof. dr. D. Townend (Maastricht University)

Prof. dr. Kung-Chung Liu (National Tjing Hua University) 


\section{ACINOWLEDGEMENTS}

One day in the late autumn of 2013, I took a twelve-hour flight as well as a three-hour train to get to Maastricht, which is a beautiful and quiet city located in the southern part of the Netherlands. It was my first time to travel and study abroad. After that, I have started my PhD research at Maastricht University. Time flies! More than four years have been passed. At the moment of closing my thesis, I would like to sincerely acknowledge the financial support from the China Scholarship Council (CSC), the Faculty of Law of Maastricht University, and the School of Law of Singapore Management University (SMU). I also want to mention many individuals who have contributed to the completion of this thesis. Without their advice as well as supports, this thesis would not have been possible.

First of all, I am deeply indebted to my PhD supervisor Prof. Anselm Kamperman Sanders, who inspired me to start my research career in the Intellectual Property (IP) field. Without his patience, guidance, advice and support, this thesis would not have kept on track and finally been finished. He provided me with vast opportunities to attend academic activities, to practice my academic skills, and to communicate with academia closely. He has been not only a mentor, but also a true friend. I am extremely grateful to him for the freedom that he has offered me in choosing my PhD research direction and topic.

Special thanks go to my co-supervisor Prof. dr. dr. Cees A.M. Mulder, who generously and kindly offered me help during the drafting stage of this thesis. Our discussions over the structure and outline of the thesis, and his careful proofreading and comments regarding the early manuscripts helped me rethink and improve the manuscript substantially.

I am also indebted to the invaluable support of Prof. Kung-Chung Liu, who very generously provided me a great opportunity to conduct my research in Faculty of Law, SMU, and complete the final version of the thesis there. Since then, Prof. Liu has become my friend and mentor in a Chinese style. I would also like to acknowledge Prof. Shunde Li (Institute of Law, CASS), since during the initial drafting of my PhD research proposal, he gave me some pieces of useful advice, which inspired me to focus on the subject.

A special word goes to my colleagues, Dr. Tianxiang He and Dr. Jie Wang, as well as Tian Lü, who kindly shared with me their office at Faculty of Law, Maastricht University during the first two years of my PhD research. In the office, we shared valuable research experiences, namely how to draft and publish articles in international journals, and we also encouraged each other. We really had quite a productive and memorable time. 
Special thanks are also due to Profs. Yong Wan, Peter K Yu, Sean M O'Conner, and M Desantes Real, who have contributed to the completion of my thesis as well as other research articles and projects. I thank them for their invaluable advice concerning my research. What is more, I am very grateful to my colleagues in the Faculty of Law, Maastricht University: Dr. Dyebo Shabalala, who gave me some advice especially in terms of the structure of my thesis when he still was working in Maastricht University; Dr. Anke Moerland, Dr. Ana Ramalho, who helped me and suggested how I should conduct research; Liuhu Luo, and Liang Yu, who are my best friends during my life at Maastricht.

Last, but not least, I am deeply indebted and enormously grateful to my family. My wife Zhenyu gave me great support not only in life but also in academic research. Since she was pursuing her PhD in Leiden University Medical Center, during the first two years, we had to live separately and became a weekend couple. Nevertheless, she never complained. When I was conducting my third year of PhD studies in the Netherlands, Zhenyu brought me our beautiful little angel Heya in the later summer of 2016, in Leiden. I thank Zhenyu for giving me selfless love; Heya for giving me energy and happiness; and my parents and parents-in-law, particularly my mother and mother-in-law, for helping us take care of our little angel. Without their help, this thesis would not have been completed successfully. Thanks to all the people who have helped me and contributed to my PhD research during the last several years.

Singapore, 25 February 2018 


\section{CONTENTS}

Acknowledgements $\quad$ V

$\begin{array}{lll}\text { Contents } & \text { VII }\end{array}$

$\begin{array}{ll}\text { Abbreviations } & \text { XI }\end{array}$

Chapter 1 Introduction $\quad 1$

1. Dilemmas of Patenting hESC-related Inventions 3

2. Challenges for Patenting hESC-related Inventions in China 5

3. Research Questions 11

4. Methodology and Outline $\quad 14$

Chapter 2 The Marriage of Patent Protection and Human Embryonic Stem 21 Cell Technology

1. Introduction 21

2. The Role of Patent Rights $\quad 22$

2.1. Foundations of the Patent System 23

2.2. Functions and Effects of Patents 25

2.3. Patents and Innovation in Developing Countries 30

3. Biotechnology and hESC Technology 33

3.1. The Rise of Modern or Advanced Biotechnology 33

3.2. Emerging hESC-related Technologies $\quad 35$

$\begin{array}{ll}\text { 3.2.1. HESCS } & 35\end{array}$

3.2.2. Possible Alternative Sources of hESCs 42

3.2.3. Why hESC Research Is Necessary 46

4. The Marriage of Patent Protection and hESC Technology 47

4.1. General Challenges of Biotechnology 48

4.2. General Moral Debate Over hESC Research and Patenting 50

4.2.1. Resolute Opposition $\quad 50$

4.2.2. Amelioration of Pain and Suffering 52

4.2.3. Extension of the Debate from Research to Patenting 53

5. Conclusion $\quad 55$

Chapter 3 Public Perceptions of Patents and the Status of the Embryo in $\quad 57$ China

1. Introduction $\quad 57$

2. Public Perceptions of Patents in China 58

2.1. The Development of the Chinese Patent System 59 
2.2. Public Perceptions of Patents 61

3. Moral and Legal Status of a Human Embryo 63

3.1. European Perspectives 64

3.2. Chinese Perspectives Concerning Moral Status 66

3.2.1. A Person or Not? $\quad 67$

3.2.2. Acceptance of the Destruction of a Human Embryo 69

3.3. Legal Status of a Human Embryo in China $\quad 75$

$\begin{array}{ll}\text { 3.3.1. Legislation Concerning Embryos } & 75\end{array}$

3.3.2. Yixing Frozen Human Embryo Case $\quad 76$

$\begin{array}{ll}\text { 3.3.3. Viewpoints of Chinese Academia } & 77\end{array}$

4. Human Dignity and the Human Embryo $\quad 79$

4.1. The Concept of Human Dignity and its Extension to Human Embryos $\quad 79$

4.2. Human Dignity and the Human Embryo in China 82

4.2.1. International Human Rights Instruments 83

4.2.2. Human Dignity and the Chinese Constitution 84

4.2.3. The Attitude of the Chinese Government Towards Human Dignity $\quad 85$

5. Other Possible Factors Influencing the Acceptability of Manipulating hESCs $\quad 87$

$\begin{array}{ll}\text { 5.1. The Impact of Scientism } & 87\end{array}$

5.2. Influence from the West 88

$\begin{array}{ll}\text { 6. Conclusion } & 89\end{array}$

Chapter 4 Governments' Policy Towards hESC Research 93

1. Introduction $\quad 93$

2. Approaches Taken by the US $\quad 94$

2.1. The US Federal Approaches $\quad 95$

2.1.1. The History of Federal Policy on Embryo Research 95

$\begin{array}{ll}\text { 2.1.2. Dickey-Wicker Amendment } & 97\end{array}$

2.1.3. Policies Before the Obama Administration 98

2.1.4. The Obama Policy: Lifting the Restriction 101

2.1.5. The Trump Policy: Still Unclear 104

2.2. Policy Approaches at the State Level 105

3. Policies and Regulatory Frameworks in the EU 107

3.1. Policy Approaches at the EU Level 107

3.2. Policy Approaches at EU Member States 109

3.2.1. Liberal or Very Permissive Policies and the UK 110

3.2.2. Intermediate or Permissive Compromise Policies and the 117 Netherlands

3.2.3. Restrictive Compromise or Blank Prohibition Policies and 119 Germany

4. Governing and Development Degree in China 
4.1. Initial Motivation for Regulating hESC research

4.2. Drafting the Ethical Guidelines for hESC Research 125

4.3. Ethical Guidelines for hESC Research 127

4.4. Investment and Encouragement Policies $\quad 130$

4.5. HESC Research and Industry in China 131

4.5.1. The Development of hESC Research 132

4.5.2. The Development of hESC Industry 134

$\begin{array}{ll}\text { 5. Conclusion } & 137\end{array}$

Chapter 5 A Comparative Analysis of Patenting hESC-related Inventions $\quad 139$ Under Current Legal Frameworks of the US, EU, and China

1. Introduction 139

2. Patent Legal Frameworks 140

2.1. Article 27 of the TRIPS Agreement 140

2.2. Excluded Subject Matter in Each Jurisdiction 142

$\begin{array}{ll}2.2 .1 \text {. The US } & 142\end{array}$

$\begin{array}{ll}2.2 .2 \text { The EU } & 149\end{array}$

$\begin{array}{ll}2.2 .3 \text { China } & 155\end{array}$

2.3. Moral Exceptions to Patentability 158

$\begin{array}{ll}2.3 .1 \text { The US } & 159\end{array}$

2.3.2. The EU 162

2.3.3. China 168

3. Policy Approaches of Patent Offices under Current Legal Frameworks $\quad 171$

3.1. The USPTO 172

3.1.1. Patent Eligible Living Organisms 173

3.1.2. Bar on Patenting "Human Organism" 173

$\begin{array}{ll}\text { 3.1.3. Morality Judgment in the USPTO } & 174\end{array}$

$\begin{array}{ll}\text { 3.1.4. Products of Nature } & 175\end{array}$

3.1.5. WARF's Patents in the US 178

3.2. The EPO 181

3.2.1. Harvard/Oncomouse 182

3.2.2. Greenpeace v. Plant Genetic Systems 183

3.2.3. Howard Florey/Relaxin 184

3.2.4. Approaches and Standards to Apply the General Morality Provision 185

3.2.5. Decisions Regarding hESC-related Inventions 186

3.3. The SIPO 192

3.3.1. Phase 1: Initial Touch 193

3.3.2. Phase 2: Persistence of Complete Prohibition 194

$\begin{array}{ll}\text { 3.3.3. Phase 3: Momentous Change } & 198\end{array}$

3.3.4. Definition of A “Human Embryo" and the SIPO's ISCO Case 202 
4. Judicial Decisions Concerning Patenting hESC-related Inventions 205

4.1. Opinions of the EGE 206

4.2. Oliver Brüstle v. Greenpeace eV at the CJEU 206

4.3 German Court's Decision (X ZR 58/07) Following Brüstle 208

4.4. ISCO Case at the CJEU 209

5. Assessing the Issues in China 211

5.1. To Remove Moral Assessment 211

5.2. The Case for Keeping Moral Assessment in China 213

$\begin{array}{ll}\text { 5.3. Assessing the Issues } & 220\end{array}$

$\begin{array}{ll}\text { 5.3.1. General Legislation and Policies } & 220\end{array}$

$\begin{array}{ll}\text { 5.3.2. Specific Issues } & 224\end{array}$

$\begin{array}{ll}\text { 6. Conclusion } & 231\end{array}$

Chapter 6 Conclusions and Recommendations $\quad 235$

1. Introduction $\quad 235$

2. Findings and Conclusions $\quad 237$

3. General Policy Recommendations 246

4. Recommendations to the SIPO's Guidelines 248

5. Limits and Future Research 250

$\begin{array}{ll}\text { Bibliography } & 253\end{array}$

$\begin{array}{lr}\text { Summary } & 287\end{array}$

$\begin{array}{lr}\text { Samenvatting } & 291\end{array}$

List of Publications $\quad 295$

$\begin{array}{lr}\text { Curriculum Vitae } & 297\end{array}$

$\begin{array}{ll}\text { Valorization Addendum } & 299\end{array}$ 


\section{ABBREVIATIONS}

\begin{tabular}{|c|c|}
\hline AG & Advocate General \\
\hline AIA & Leahy-Smith America Invents Act \\
\hline ANT & Altered Nuclear Transfer \\
\hline BPAI & Board of Patent Appeals and Interferences \\
\hline BRCA & Breast Cancer Gene \\
\hline CAFC & Court of Appeals for the Federal Circuit \\
\hline cDNA & Complementary DNA \\
\hline CFR & Code of Federal Regulations \\
\hline CIRM & California Institute of Regenerative Medicine \\
\hline CJEU & Court of Justice of the European Union \\
\hline CPC & Communist Party of China \\
\hline CPL & Patent Law of the People's Republic of China \\
\hline CRISPR & Clustered Regularly Interspaced Short Palindromic Repeats \\
\hline CSL & Chinese Succession Law \\
\hline DNA & Deoxyribonucleic Acid \\
\hline EAB & Ethics Advisory Board \\
\hline EBA & Enlarged Board of Appeal \\
\hline ECHRB & European Convention on Human Rights and Biomedicine \\
\hline ED & Examining Division \\
\hline EGE & European Group on Ethics in Science and New Technologies \\
\hline EPC & European Patent Convention \\
\hline EPC Rules & Implementing Regulations to the EPC \\
\hline EPO & European Patent Office \\
\hline ESchG & Embryo Protection Act of Germany or Gesetz zum Schutz von Embryonen \\
\hline EU & European Union \\
\hline FCJ & Federal Court of Justice \\
\hline FDA & Food and Drug Administration \\
\hline FTC & Federal Trade Commission \\
\hline $\mathrm{HCJ}$ & High Court of Justice \\
\hline hEGCs & Human Embryonic Germ Cells \\
\hline hESCS & Human Embryonic Stem Cells \\
\hline HEW & Department of Health, Education and Welfare \\
\hline HFE & Human Fertilization and Embryology \\
\hline HFEA & Human Fertilization and Embryology Authority \\
\hline HHS & Health and Human Services \\
\hline hiPSCs & Human Induced Pluripotent Stem Cells \\
\hline hPGSCs & Human Parthenogenetic Stem Cells \\
\hline ICM & Inner Cell Mass \\
\hline IEG & Interim Eligibility Guidance \\
\hline
\end{tabular}




\begin{tabular}{|c|c|}
\hline IP & Intellectual Property \\
\hline IPO & Intellectual Property Office \\
\hline IPR & Intellectual Property Right \\
\hline iPSCs & Induced Pluripotent Stem Cells \\
\hline IRPL & Implementing Regulations of the Patent Law of the PRC \\
\hline ISCO & International Stem Cell Corporation \\
\hline IVF & In Vitro Fertilization \\
\hline $\mathrm{MOH}$ & Ministry of Health \\
\hline MOST & Ministry of Science and Technology \\
\hline MPEP & Manual of Patent Examining Procedure \\
\hline MTAs & Materials Transfer Agreements \\
\hline NBAC & National Bioethics Advisory Commission \\
\hline $\mathrm{NIH}$ & National Institutes of Health \\
\hline NPC & National People’s Congress \\
\hline NSFC & Natural Science Foundation of China \\
\hline OD & Opposition Division \\
\hline РCT & Patent Cooperation Treaty \\
\hline PED & Patent Examination Department \\
\hline PGS & Plant Genetic Systems \\
\hline PGSCS & Parthenogenetic Stem Cells \\
\hline pPSCs & Primate Pluripotent Stem Cells \\
\hline PRB & Patent Re-examination Board \\
\hline PRC & People's Republic of China \\
\hline$R \& D$ & Research and Development \\
\hline S\&T & Science and Technology \\
\hline SCNT & Somatic Cell Nuclear Transfer \\
\hline SIPO & State Intellectual Property Office of the People's Republic of China \\
\hline StZG & $\begin{array}{l}\text { Stem Cell Act of Germany or Gesetz zur Sicherstellung des Embryonen- } \\
\text { schutzes im Zusammenhang mit Einfuhr und Verwendung menschlicher } \\
\text { embryonaler Stammzellen }\end{array}$ \\
\hline TBA & Technical Board of Appeal \\
\hline TRIPS & Agreement on Trade-Related Aspects of Intellectual Property Rights \\
\hline UK & United Kingdom \\
\hline UN & United Nations \\
\hline US & United States of America \\
\hline USC & United States Code \\
\hline USPTO & United States Patent and Trademark Office \\
\hline WARF & Wisconsin Alumni Research Foundation \\
\hline WTO & World Trade Organization \\
\hline
\end{tabular}




\section{Introduction}

With the rapid evolution of the biotechnology industry, inventions have started to involve living matter, even human beings. ${ }^{1}$ The biotechnology industry, not surprisingly, has had an increasingly close relationship with human beings over the last several decades. At the same time, the fast pace of the biotechnology industry and the growing ability to intervene in human beings have posed critical challenges to the current global patent regime. In 1980, the United States (US) Supreme Court decision in Diamond v. Chakrabarty overturned its previous case law and allowed granting patents upon living matter, such as an oil-degrading bacterium. ${ }^{2}$ Since then, patenting biotechnological inventions has become a standing practice. Thousands of biotechnological inventions, such as micro-organisms, genes, and cell lines, have been made, and patents have been issued by patent offices globally each year. However, the fundamental debate over the patent eligibility of certain biotechnological inventions has never ceased. ${ }^{3}$

Taking a careful look at patent-related issues in the field of biotechnology, one might observe something interesting: the patenting of inventions related to human embryonic stem cells (hESCs) has become one of the biggest debates involving biotechnology both in legal academia and practice. ${ }^{4}$ Derived from an early stage human embryo, hESCs are pluripotent, which means that this type of stem cell has the capacity of self-renewal, dividing indefinitely, and the ability to give rise to almost all cell types of a human body. ${ }^{5}$ Based on the unique characteristics of hESCs, research on these stem cells is

$\overline{1}$ See e.g., Oliver Mills, Biotechnological Inventions: Moral Restraints and Patent LaW (Revised Edition) 8-9 (Ashgate Publishing Limited 2010); see generally, e.g., DAVID CASTLE, THE ROLE Of INTELLECTUAL PROPERTY RIGHTS

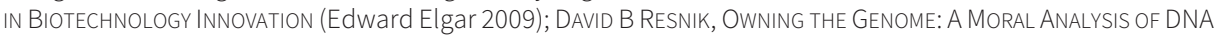
PAtenting (State University of New York Press 2004); AndREA STAZI, BIOteChnologICAL InVEntIOnS AND PATENTABILITY OF LIFE: THE US AND EUROPEAN EXPERIENCE 9 (Edward Elgar 2015).

2 See Diamond v. Chakrabarty 447 US 303 (1980).

3 See generally, e.g., Aurora Plomer \& PAul Torremans, Embryonic Stem Cell PATENTS: European LAW ANd ETHICS (Oxford University Press 2009); RESNIK, supra note 1; STAZI, supra note 1.

4 See generally, PLomer \& TORREMAns, supra note 3.

5 See Nikica Zaninovic, et al., Derivation of Human Embryonic Stem Cells (hESC), in HUMAN FERTILITY: METHODS AND PROTOCOLS 121 (Zev Rosenwaks \& Paul M Wassarman ed., Springer 2014). Concerning a specific discussion on the special properties of hESCs and their potential applications, please see infra Sect. 3.2.1, Chap. 2. 
considered to hold great promise for biomedical science-from helping us investigate disease mechanisms, to assisting in drug discovery and testing, providing regenerative medicine, and cell replacement therapy, and developing cell-based therapies for diabetes, heart failure, Parkinson's disease, and many other conditions that affect millions of people. ${ }^{6}$ Thus, it is believed that hESC research has opened the door to a wide variety of new therapies and other medical applications for mankind. ${ }^{7}$ However, one of the most problematic issues in hESC research is that the starting material of such research involves hESC lines, the derivation of which normally necessitates the use and destruction of human embryos. ${ }^{8}$ Due to the close relationship between hESCs, human embryos, and human beings, not only hESC research per se, but also by extension the patenting of hESC-related inventions has become controversial. Admittedly, some alternative sources, such as induced pluripotent stem cells (iPSCs), altered nuclear transfer (ANT), human embryonic germ cells (hEGCS), and human parthenogenetic stem cells (hPGSCS) have emerged, ${ }^{9}$ but research on hESCs and by extension patenting hESC-related inventions still cannot be fully replaced by these alternatives.

In order to illustrate why the patenting of hESC-related inventions has become a problem for a jurisdiction to deal with and why it also is a crucial challenge for China nowadays, it is reasonable to first sketch the dilemma in general and the corresponding challenges in China in particular. Given this, the dilemma of patenting inventions related to hESCs is summarized in Section 1 in this chapter, and the challenges for China are briefly discussed in Section 2. Subsequently, the research question is explained in detail in Section 3, and the methodology and outline of the thesis are delineated in the last section (Sect. 4).

$6 \quad$ See e.g., Sharon Gerecht-Nir \& Joseph Itskovitz-Eldor, The Promise of Human Embryonic Stem Cells, 18 BEST PRACTICE \& ReseARCH Clinical OBSTETRICS \& GYNAeCOLOGY 843 (2004); Sharon Gerecht-Nir \& Joseph ItskovitzEldor, Cell Therapy Using Human Embryonic Stem Cells, 12 Transplant Immunologr 203 (2004); Michal Golan-Mashiach, et al., Design Principle of Gene Expression Used by Human Stem Cells: Implication for Pluripotency, 19 The FASEB JouRnaL 147 (2005); European Group on Ethics in Science and New Technologies (EGE), Opinion No. 16: Ethical Aspects of Patenting Inventions Involving Human Stem Cells, 4 (May. 7, 2002), http://biotech.bioetica.org/new/ege16_complet_en.pdf; NIH, Stem Cell Basics VII (2009), STEM CELL INFORMATION, https://stemcells.nih.gov/info/basics/7.htm.

7 See infra Sect. 3.2.1, Chap. 2. See also Tandis Vazin \& William J Freed, Human Embryonic Stem Cells: Derivation, Culture, and Differentiation: A Review, 28 Restorative Neurology And Neuroscience 589, 590 (2010); James A Thomson, et al., Embryonic Stem Cell Lines Derived from Human Blastocysts, 282 SCIENCE 1145, 1145 (1998); NIH, Stem Cell Basics III, STEM Cell Information, https://stemcells.nih.gov/info/basics/3.htm. For more discussion concerning therapeutic potential of hESCS, please see Olle Lindvall, et al., Stem Cell Therapy for Human Neurodegenerative Disorders-How to Make It Work, 10 NATURE MEDICINE S42, S42 (2004); Martin F Pera, et al., Human Embryonic Stem Cells, 113 Journal of CelL SCIENCE 5, 5 (2000).

8 See Vazin \& Freed, supra note 7, at 591; T 2221/10 (Culturing stem cells/TECHNION) [2014], at 11.

9 In order to sidestep ethical or moral issues of hESC research, in addition to trying to find other approaches to generate hESC lines without destroying human embryos, much work has been devoted to sources of stem cells other than hESCS. For discussion about possible alternative sources of hESCs, please see infra Sect. 3.2.2, Chap. 2 of this thesis. 


\section{DILEMMAS OF PATENTING HESC-RELATED INVENTIONS}

Patent protection is assuming increasing importance in the field of biotechnology. ${ }^{10}$ There seems to be no other domain of research and industry as dependent on strong patent protection as biotechnology. ${ }^{11}$ Patent protection is able to provide incentives to inventors to create, ${ }^{12}$ to encourage the disclosure of secret knowledge as early as possible, ${ }^{13}$ and to stimulate patent owners to efficiently use and commercialize unrealized ideas. ${ }^{14}$ Without patent protection, there may exist little incentive for investors and inventors to invest in making, developing, and marketing new biotechnological products, and without investment, biotechnology would come to a standstill. ${ }^{15}$ By the same token, there is no doubt that the development of hESC technology, as one important part of biotechnology, also strongly relies on the legal protection of patents.

Nevertheless, patenting hESC-related inventions has not proved to be an easy issue. Although, as mentioned above, hESC research holds great promise for biomedical science, ${ }^{16}$ it generates vast social and moral concerns, primarily since hESC research involves the use and destruction of human embryos. As Mr. George W. Bush, the former President of the US, pointed out when discussing the issue of hESC research, "as the discoveries of modern science create tremendous hope, they also lay vast ethical mine fields." ${ }^{17}$ At the same time, based on the debate over hESC research per se, the patenting of hESCs and related inventions has also been controversial and fraught with political, economic, and moral concerns, ever since Professor James Thomson, in 1998, announced the successful derivation of the first line of hESCs. ${ }^{18}$ This is primarily because moral arguments also enter the patent arena directly through the gateway of morality clauses, ${ }^{19}$ such as Article 53(a) of the European Patent Convention (EPC) ${ }^{20}$ and Article

10 For more detailed discussion about the importance of patent protection to the biotechnology research and industry, please see infra Sect. 2.2, Chap. 2.

11 See Brenda M Simon \& Christopher T Scott, Unsettled Expectations: How Recent Patent Decisions Affect Biotech, 29 NATURE BIOTECHNOLOGY 229, 229 (2011).

12 See Fritz Machlup, An Economic Review of the Patent System: Study of the Subcommittee on Patents, TradeMARKS, AND COPYRIGHTS OF THE COMMITTEE ON THE JUDICIARY 33 (US Government Printing Office 1958).

13 See id., at 21.

14 See Edmund W. Kitch, The Nature and Function of the Patent System, 20 JournAL OF LAW AND ECONomics 265 , 270-271 (1977).

15 Regarding the role of patents, this thesis will discuss it in detail later; please see infra Sect. 2. Chap. 2.

16 See also infra Sect. 3.2.1, Chap. 2.

17 George W Bush, President Discusses Stem Cell Research, THE White House, (Aug. 9, 2001), http:// georgewbush-whitehouse.archives.gov/news/releases/2001/08/20010809-2.html.

18 See generally, Thomson, et al., supra note 7.

19 See MILLS, supra note 1 , at 11.

20 The Convention on the Grant of European Patents (the European Patent Convention or the EPC) was issued by European countries on 5 Oct. 1973, intended to establish a unified legal framework for the granting of European patents. It was revised by the Act revising Art.63 EPC of 17 Dec. 1991 and the Act revising the EPC of 29 Nov. 2000. 
5(1) of the Patent Law of the People's Republic of China (the Chinese Patent Law, CPL). ${ }^{21}$ Debates in the research field therefore have crossed over into patenting, namely the debate over whether hESCs and inventions based on uses of them should be excluded from being protected by the patent system on moral grounds.

One current dilemma raised by patenting hESC-related inventions is firmly connected with moral concerns about the technology in itself. On the one hand, hESC research is considered to hold great promise for biomedical science and, thus, as an incentive patent law should be used to promote the development of the hESC industry and research so as to ultimately benefit health care; but one the other hand, hESC research and by extension hESC-related inventions involve moral or ethical concerns, based on which the patenting of these inventions is highly controversial. For instance, many commentators hold that the human embryo, from the moment of conception, should be considered a human being, and thus be protected. ${ }^{22}$ They oppose granting any patents over hESCs and related inventions, essentially because the process of creating hESCs normally involves the destruction of a human embryo, which has the potential to develop into a human being. In addition, a number of opponents consider hESC-related patents to be the commercialization of human beings and the degrading of human dignity. ${ }^{23}$ Some opponents also worry that the granting of patents over hESC-related inventions may result in manufacturing embryos for industrial and commercial purposes, a moral and ethical disaster. Such worry demonstrates that hESC-related patents may violate fundamental principles regarding the ownership of human beings. ${ }^{24}$

21 Zhonghua Renmin Gongheguo Zhuanli Fa (中华人民共和国专利法) [Patent Law of the People's Republic of China] was adopted at the 4th Meeting of the Standing Committee of the 6th National People's Congress on March 12, 1984. The current version was the 3rd amended and adopted on Dec. 27, 2008. Article 5 of the $\mathrm{CPL}$, as the general clause, has become the central tenet in determining immoral inventions since the first CPL in 1984. At present, Article 5(1) of the CPL sets forth that "no patent right shall be granted for any invention-creation that is contrary to the laws or social morality or that is detrimental to public interest". In Europe, the EPC also does not allow issuing patents on "inventions the publication or exploitation of which would be contrary to ordre public or morality" (Article 53(a) EPC). The Directive 98/44/EC of the European Parliament and of the Council of 6 July 1998 on the Legal Protection of Biotechnological Inventions (hereinafter the EU Biotech Directive) also contains an exclusion from patentability for inventions the commercial exploitation of which is contrary to ordre public or morality. In contrast, the US patent system contains no statutory basis for the USPTO or a court to eliminate biotech subject matter from being patented on moral grounds. More details on moral issues in patenting, see e.g., Margo A Bagley, Patent First, Ask Questions Later: Morality and Biotechnology in Patent Law, 45 WILlIAM AND MARY LAW REvIEW 469 (2003); Matthew Rimmer, The Attack of the Clones: Patent Law and Stem Cell Research, 10 Journal of Law and Medicine 488, 500 (2003).

22 See Katrien Devolder \& Christopher M Ward, Rescuing Human Embryonic Stem Cell Research: the Possibility of Embryo Reconstitution After Stem Cell Derivation, 38 METAPHILOSOPHY 245, 245 (2007).

23 See AM Viens, Morality Provisions in Law Concerning the Commercialization of Human Embryos and Stem Cells, in Embryonic Stem Cell Patent: European LaW and Ethics 109 (Aurora Plomer \& Paul Torremans ed., Oxford University Press 2009). See also Alternative Sources of Human Pluripotent Stem Cells, THE PRESIDENT'S COUNCIL ON BIOETHICS, (May 2005), http://www.bioethics.gov/.

24 See Matthew Rimmer, intellectual Property and Biotechnology: Biological Inventions 249 (Edward Elgar 2008). 
Moreover, another dilemma concerning patenting hESC-related inventions arises, based on the fact that on the one hand patents can promote scientific progress, which further can be conducive to health care, while on the other hand, patents can also impede access to the health care as a result of both the need for a license to use them and the fees that will have to be paid to the patent holders. ${ }^{25}$ Opponents against granting any patent over hESCs per se and their differentiated cells believe that this type of patent may impede the access to basic research tools, and further hinder follow-on research and development, particularly if patentees license such patents exclusively or on restricted terms. ${ }^{26}$ Biotechnology involves cumulative innovation, in which each new innovation relies on or, at least, requires access to anther innovation. ${ }^{27}$ There is a typical scenario where the initial invention is a basic material or technology, which forms the basis for various applications in multiple technological fields. ${ }^{28}$ This typical accumulative innovation maps very well onto research and development in the area of stem cells. ${ }^{29}$ Balancing incentives among those who carry out the initial research and those who engage in follow-on research has become a pivotal issue in this field.

As a result, it can be clearly seen that applying patent rights to protecting hESC-related inventions nowadays is facing critical challenges. In general, the current problems raised by patenting hESCs and related inventions mainly intertwine with moral and economic concerns. It is hard to find a solution. Countries around the world have been struggling to seek their own appropriate ways of determining whether and how to patent hESC-related inventions.

\section{CHALLENGES FOR PATENTING HESC-RELATED INVENTIONS IN CHINA}

Due to the tremendous significance of hESC research for biomedical science, China has practical reasons to develop this research and industry. First, China has a high population growth rate and a high birth defect rate. Each year, approximately 900,000 birth defect cases (about 5.6\%) occur in the newborns, constituting the second leading cause

\footnotetext{
25 See EGE, supra note 6, at 14.

26 See generally, Ren-How Harn, Keeping the Gates Open for Human Embryonic Stem Cell Research, 13 Cardozo Public LaW, Policy \& Ethics Journal 525 (2015). See also Rimmer, supra note 24, at 249; Aurora Plomer, Towards Systemic Legal Conflict: Article 6(2)(c) of the EU Diretive on Biotechnological Inventions, in Embryonic Stem Cell Patents: European Law and Ethics 202 (Aurora Plomer \& Paul Torremans ed., Oxford University Press 2009).

27 See CASTLE, supra note 1, at 363. See also Alberto Galasso \& Mark Schankerman, Patents and Cumulative Innovation: Causal Evidence from the Courts, 130 THE QuARTERLY JOURNAL OF ECONOMICS 317, 321 (2015) (investigating the effect that patents have on the process of cumulative innovation, finding out that patent rights block downstream innovation in the biotechnological field. However, this empirical research mainly focused on the US. It may be premature to extrapolate concerns about the effect that patent rights have on downstream innovation from the United States to other jurisdictions.)

28 See Tur-Sinai, Cumulative Innovation in Patent Law: Making Sense of Incentives, 50 IDEA 723, 731 (2009).

29 See CASTLE, supra note 1 , at 364.
} 
of infant deaths in China, and this is rising, ${ }^{30}$ placing a tremendous burden on Chinese families and society. Second, China's population is aging, ${ }^{31}$ and the spectrum of disease has been changing. It is predicted that by 2050 more than a quarter of China's population $(28.9 \%)$ is going to be older than 60 years. ${ }^{32}$ With an increase in the number of people with degenerative diseases, the scale of China's greying could place a great strain on the healthcare system. ${ }^{33}$ China already has an enormous number of people with aging diseases such as type 2 diabetes, Parkinson and Alzheimer's disease. Moreover, in China the spectrum of disease has been changing. Chronic diseases and metabolic diseases have become major threats to people's health. China has the world's largest diabetes epidemic, and approximately $11.6 \%$ of Chinese adults have diabetes. Even worse, the number continues to grow at a fearsome pace. ${ }^{34}$ Endemic hepatitis B virus infection affects more than 150 million patients across the country, approximately one-third of the world's total. ${ }^{35}$

Third, China has the biggest population in the world, and it is suffering from a serious shortage of replacement organs. Traffic and workplace accidents have caused many more spinal cord injuries in China than in any other country. ${ }^{36}$ There is no doubt that China needs quite a lot of replacement tissue and organs because of people aging, diseases and trauma. However, there is a tremendous deficit between supply and demand of tissue and organs appropriate for transplantation. ${ }^{37}$ By way of example, it is reported that each year in China there are around 300,000 people in need of organ transplants, but China has one of the world's lowest rates of organ transplants, with a mere 10,000 procedures each year. ${ }^{38}$ Although China launched a voluntary donation scheme in 2010, between that year and 2013 only 1,448 people donated organs, which is only a drop in the ocean compared with the huge demand for organ transplants. ${ }^{39}$ Only 0.6 per 1

30 See MOH of China, Zhongguo Chusheng Quexian Fangzhi Baogao 2012 (中国出生缺陷防治报告 (2012)) [China's Birth Defect Prevention Report 2012], www.GOV.cn, (Sept. 12, 2012), http://www.gov.cn/gzdt/201209/12/content_2223371.htm; Li Yun, Chinese Birth Defects Number Around 900,000 Cases Annually, EPOCH TIMES, (Sept. 19, 2012), http://www.theepochtimes.com/n3/1481726-chinese-birth-defects-numberaround-900-000-cases-annually/.

31 See Colin Shek, Stem Cell Research in China: Regenerative Economics, CKGSB KnowledGe, (May 5, 2014), http://knowledge.ckgsb.edu.cn/2014/05/05/technology/stem-cell-research-in-china-regenerativeeconomics/. See also UndP China and Development Research Center of the State Council of China, China

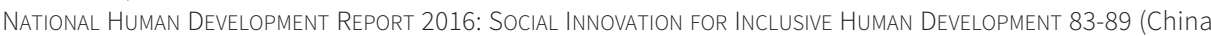
Translation \& Publishing House 2016).

32 See id., at 84.

33 See id., at 85-86.

34 See Yu Xu, et al., Prevalence and Control of Diabetes in Chinese Adults, 310 Jama 948, 948-949 (2013).

35 See Jie Liu \& Daiming Fan, Hepatitis B in China, 369 The LANCET 1582, 1582 (2007).

36 See Weiping Yuan, et al., Stem Cell Science On the Rise in China, 10 CeLL STEM CELL 12, 14 (2012).

37 See Shawn HE Harmon, et al., Organ Transplantation in China and Beyond: Addressing the 'Access Gap', 10 MEDical LAW INTERNATIONAL 191, 192 (2010).

38 See Katie Hunt, Why China Will Struggle to End Organ Harvesting from Executed Prisoners, CNN, (Dec. 5, 2014), http://edition.cnn.com/2014/12/05/world/asia/china-prisoners-organs/. 
million people have signed up to donate their organs when they die. ${ }^{40}$ China also announced that it would stop obtaining organs from death-row prisoners as of 1 January 2015, which exacerbates the already serious shortage of replacement organs in China. ${ }^{41}$

As a result, finding appropriate ways both to tackle such a shortage of replacement organs and to treat chronic illnesses is becoming a top priority for China. To stave off a healthcare crisis in the long run, facilitating stem cell research, including hESC research, is considered to be a promising solution for tissues and organs replacement. ${ }^{42}$ Moreover, while hESC research has great therapeutic potential and may help China to cope with the medical demand, it is also believed that the growth of the hESC-based industry will further strengthen China's economy. Thus, it is not surprising that China is in dire need of breakthroughs and technological innovation in stem cell research and industry based on its strategic needs. ${ }^{43}$

In order to promote the advancement of hESC research and industry, the Chinese government has invested enormous amounts of money and provided various encouragement policies in the field. ${ }^{44}$ However, it is evident that merely relying on governmental funding without private investment would not be sufficient for a country to promote the development of hESC research and industry. Patent protection has been proved to be imperative for the biotechnology industry. At least, with regard to facilitating private investment in hESC research and industry, the role that patent law plays cannot be ignored. Moreover, even intending to take full advantage of its generous institutional patronage in the field of hESC research, the country also needs to seek an appropriate patent system suitable to its particular legal system, moral culture and economic situation.

40 See id. See also China to stop harvesting executed prisoners' organs, BBC NEws, (Dec. 4, 2014), http://www. bbc.com/news/world-asia-china-30324440.

41 See Kirk C Allison, et al., Historical Development and Current Status of Organ Procurement from Death-row Prisoners in China, 16 BMC MEDICAL ETHICS 85, 85 (2015).

42 The greatest therapeutic promise of hESCs is to give rise to particular cells to replace ailing or destroyed tissues or organs in patients who are suffering from diverse degenerative diseases. For more discussion on the great promise of hESC research for biomedical science, please see infra Sect. 3.2.1, Chap. 2.

43 See Guojia Zhong Changqi Kexue yu Jishu Fazhan Guihua Gangyao (2006-2020) (国家中长期科学和技术发展 规划纲要 (2006-2020)) [The outline of the National Medium- and Long-Term Program for S\&T Development (2006-2020)], issued by The Central People's Government of the PRC in 2006, http://www.gov.cn/jrzg/200602/09/content_183787.htm. See also Qi Zhou (周琪), et al., Mianxiang Weilai de Xin Yilun Yiliao Jishu Geming_-_Ganxibao yu Zaisheng Yixue Yanjiu Zhanluexing Xiandao Keji Zhuanxiang Jinzhan (面向未来的新一轮 医疗技术革命一一干细胞与再生医学战略性先导科技专项进展) [Confronting Coming Medical Renovation: Progress on Stem Cell and Regenerative Medicine Research], 30 ZHongGUO KEXUEYUAN YUAN KAN [中国科学院院刊] (CHINA ACADEMIC JoURnAL ELECTRONIC PUBLISHING HOUSE) 262, 262-263 (2015).

44 Concerning the discussion about the investment and encouragement policies of China within hESC research and industry, please see infra Sect. 4.4, Chap. 4. 
With respect to getting a patent, the patent eligibility of the subject matter is the first hurdle. ${ }^{45}$ Whether and how to patent hESC-related inventions is becoming critical for hESC research and industry in China. As mentioned previously, the debate over hESC research in China has crossed over into patenting hESC-related inventions as well, since moral arguments enter the patent arena through Article 5(1) of the CPL. ${ }^{46}$ This provision sets a morality assessment requirement for determining the patent eligibility of subject matter. It specifically prevents the State Intellectual Property Office of the People's Republic of China (SIPO) ${ }^{47}$ from issuing patents over inventions that are incompatible with the laws, social morality, or public interest. In fact, moral considerations have been taken into account in the patent system since the first CPL was issued. ${ }^{48}$ Arguably, this general morality clause within the CPL was "copied" into the law from patent laws of other jurisdictions without initially fully appreciating what this clause might imply. ${ }^{49}$ Not surprisingly, this provision does not provide any specific information regarding patenting hESC-related inventions.

Based on this general morality clause, the SIPO has introduced two specific moral exclusions in relation to patenting hESC-related inventions into its Guidelines for Patent Examination (hereafter SIPO's Guidelines or Guidelines).$^{50}$ The first is the human embryo exclusion, ${ }^{51}$ the wording of which is almost the same as Article 6(2)(c) of the Directive 98/44/EC of the European Parliament and of the Council of 6 July 1998 on the Legal

45 See Eneda Hoxha, Stemming the Tide: Stem Cell Innovation in the Myriad-Mayo-Roslin Era, 30 BERKELEY TECHNOLOGY LAW JOURNAL 567, 590 (2015).

46 See Article 5(1) of the CPL, supra note 21.

47 Article 3 of the CPL provides that "the patent administration department under the State Council is responsible for the patent work throughout the country. It receives and examines patent applications, and grants patent right for inventions-creations in accordance with the law." The patent administration department mentioned in the provision is the SIPO.

48 See supra note 21.

49 In fact, China did not have any substantive patent law historically. Concerning the development of China's patent system, it will be discussed in Sect. 2.1, Chap. 3. At that moment of drafting the first CPL, the legislators and policy makers of China did not have any experience concerning the patent regime. See YUANGUO ZHAO (赵元果), ZHONGGUO ZHUANLIFA DE YUNYU YU DANSHENG (中国专利法的孕育与诞生) [THE DRAFTING HISTORY OF THE PATENT LAW OF CHINA] 42 (Zhishi Chanquan Chubanshe (知识产权出版社) [Intellectual Property Publishing House] 2003). In this regard, the first CPL was drafted primarily based on referring to patent laws from other jurisdictions, such as the US, Japan, France, Germany, Switzerland, Sweden, Italy, the Soviet Union, Romania, Yugoslavia, Poland, Hungary, North Korea, the UK, Brazil, India, Thailand, Mexico, Honduras, and Taiwan, as well as the EPC, Patent Cooperation Treaty (PCT), WIPO Model Law for Development Countries on Inventions, Paris Convention for the Protection of Industrial Property, etc. See id., at 47. Although the final version of the first CPL contained the general morality clause, this clause did not cause any debate in 25 drafts. See id., at 208-300. In fact, at the time when the legislators of China started to draft their first patent law in 1979, the general morality clause in patent law was rarely employed in practice and, thus, did not cause any debate.

50 Zhuanli Shencha Zhinan (专利审查指南) [Guidelines for Patent Examination], which was revised and promulgated by the SIPO, and entered into force on Feb. 1, 2010. A number of provisions of the SIPO's Guidelines were revised on Feb. 28, 2017. However, these revised provisions do not involve the patenting of hESCrelated inventions.

51 See Part II, Chap. 1, Sect. 3.1.2, para. 2 of the SIPO's Guidelines. 
Protection of Biotechnological Inventions (the Biotech Directive or the Directive) ${ }^{52}$ It explicitly excludes the patenting of "use of human embryos for industrial or commercial purposes" on moral grounds under Article 5(1) of the CPL. ${ }^{53}$ The second is to precisely exclude the patent eligibility of "hESCs per se and the preparation methods of them" on moral grounds. ${ }^{54}$

As in the EU Biotech Directive, by far the most problematic provision in the SIPO's Guidelines has been the exclusion of patents on commercial and industrial uses of human embryos covered by the general morality clause (i.e., Article 5(1)) within the CPL. In the matter of this human embryo exclusion, the SIPO's Guidelines do not provide any further explanation or interpretation. The terms "human embryos" and "use of human embryos", for instance, in this exclusion are not explained in detail, which has resulted in different interpretations in the SIPO's practice..$^{55}$ In addition, although "hESCs per se and the preparation methods of them" are excluded from patent eligibility, in terms of downstream hESC technologies, such as the differentiation and enrichment of hESCs, until now the SIPO's Guidelines have remained silent, ${ }^{56}$ which has caused uncertainty in respect of patenting hESC-related inventions and, thus, may further confuse inventors and investors in this research field in China.

The CPL aims to promote technical innovation and the dissemination of its fruits, eventually realizing the promotion of economic and social development. ${ }^{57}$ Yet, the ambiguity of the CPL as well as the SIPO's Guidelines concerning patenting hESC-related inventions has caused uncertainty in the field, which would, arguably, go against China's strategic need to advance hESC research and industry, as mentioned above. The contentious debate and inconsistency concerning patenting hESC-related inventions before the Patent Re-examination Board (PRB) of the SIPO over the last decade are reflective of the problem as well. ${ }^{58}$ More interestingly, evidence shows that the Chinese social morality is relatively pragmatic and utilitarian as regards the use and destruction of human embryos. Some cases show that, due to the moral culture, health care, and economic considerations of China, research on hESCs and even human embryos is accepted and

See Article 6(2)(c) of the EU Biotech Directive.

Part II, Chap. 1, Sect. 3.1.2 of the SIPO's Guidelines.

Part II, Chap. 10, Sect. 9.1.1.1 of the SIPO's Guidelines.

The same situation can also be found in the EU Biotech Directive, which will be discussed later in Chap. 5. See Yaojin Peng, The Patentability of Human Embryonic Stem Cell Technology in China, 34 NATURE BIOTECHNOLOGY 37, 38 (2016).

57 Article 1 of the CPL provides that "this Law is enacted for the purpose of protecting the lawful rights and interests of patentees, encouraging invention-creation, promoting the application of invention-creation, enhancing innovation capability, promoting the advancement of science and technology and economic and social development".

58 See generally, Peng, supra note 56. It also will be discussed in Chap. 5. 
supported. ${ }^{59}$ From this perspective, it also appears that the appropriateness of these specific moral exclusions in the SIPO's Guidelines needs a rethink.

Moreover, the development of the hESC research and industry of different countries may vary, and even in the same country scientific progress may change with time. The stages of research with which patents are concerned are of extreme importance to the role of patents in innovation, whether positive or negative, and further ultimately influence policymaking regarding whether and how to provide patent protection in this research field. ${ }^{60}$ Put another way, providing patent protection in an emerging economic and legal power (e.g., China), especially in a research field in which China is falling behind technologically advanced countries, may give foreign applicants an advantage over domestic ones and slow the progress of domestic research, thereby making it difficult for the country to catch up with its counterparts. In this regard, the place of China's hESC research and development in the world, as well as the stage of hESC research in China, also makes patenting hESC-related invention in this country more complicated. In short, patenting hESC-related inventions in China is extremely complex and its further development involves historical, cultural, political and economic considerations.

Recently, there have been an increasing number of studies on patent-related issues in the field of biotechnology in China. ${ }^{61}$ At the same time, there is considerable scholarship on patent-related issues concerning hESC research in Western countries, particularly in

59 See e.g., Xiangxing Qiu (丘祥兴), et al., Renlei Peitai Ganxibao Yanjiu Lunli Wenti de Diaocha he Taolun (人类 胚胎干细胞研究伦理问题的调查和讨论) [A Survey and Discussion on Ethical Issues of Human Embryonic Stem Cell Research], 25 YIXUE YU ZHEXUE (医学与哲学) [MEdicIne AND PHILOSOPHY] 8 (2004); Yan Zhou (周燕), Woguo Ganxibao Yanjiu Zhong de Lunli Weiji yu Falü Kunhuo jiqi Guojia Guanli de Yanjiu (我国干细胞研究中的伦理危机 与法律困惑及其国家管理的研究) [Research on Ethical Crisis and Legal Issues Related to Stem Cell Research and National Regulatory Framework in China] 96, 100 Di San Junyi Daxue (第三军医大学) [Third Military Medical University of Chinese PLA] (2009).

60 See also Yahong LI, Imitation to Innovation in China: the Role of Patents in Biotechnology and Pharmaceutical INDUSTRIES 8 (Edward Elgar 2010).

61 See e.g., id; QINGKUI ZHANG (张清奎), YIYAO JI SHENGWU JISHU LINGYU ZHISHI CHANQUAN ZHANLÜ SHIWU (医药及生物技 术领域知识产权战略实务) [STRATEGY AND PRACTICE OF INTELLECTUAL PROPERTY IN THE FIELDS OF MEDICINE AND BIOTECHNOLOGY] (Zhishi Chanquan Chubanshe (知识产权出版社) [Intellectual Property Press] 2008); XIAODU ZHANG (张 晓都), ZHUANLI SHIZHI TIAOJIAN (专利实质条件) [SUBSTANTIAL REQUIREMENTS FOR PATENT] (Chengsi Zheng ed., LaW Press 2002); ZHIKANG TIAN (田志康), SHENGMING XINGSHI ZHISHI CHANQUAN JI GUOJIA ZHENGCE (生命形式知识产权及 国家政策) [INTELLECTUAL PROPERTY RIGHT OF LIFE Form AND NATIONAL POlICIES] (Zhongguo Nongye Chubanshe ( 中国农业出版社) [China Agriculture Press] 2003); YINLIANG LIU (刘银良), SHENGWU JISHU DE FALÜ WENTI YANJIU (生 物技术的法律问题研究) [STUDIES ON LEGAL ISSUES FOR BIOTECHNOLOGY] (Kexue Chubanshe (科学出版社) [Science Publishing House] 2007); Deming Liu, Now the Wolf Has Indeed Come! Perspective on the Patent Protection of Biotechnology Inventions in China, 53 THE AmERICAN JOURNAL OF COMPARATIVE LAW 207 (2005). 
Europe and in the US. ${ }^{62}$ However, very little research can be found on patenting hESCrelated inventions in China, which has made considerable progress in this research field over the past decade. Moreover, previous studies using a comparative law analysis did not take into consideration China's specific social and moral culture or the domestic development stage of hESC research and industry, and instead only took the current legislation and practice of other jurisdictions as a reference, ${ }^{63}$ which may result in an inappropriate patent system for China's current research and industry environment.

\section{RESEARCH QUESTIONS}

On the one hand, China is in dire need of breakthroughs and technological innovation in $\mathrm{hESC}$ research and industry, and the Chinese government holds a positive attitude on $\mathrm{hESC}$ research and invests increasing amounts of money in this frontier technology. On the other hand, in the matter of promoting innovation and investment in the field of hESC research with the patent system, China may face social, moral, political, and economic challenges. Patent protection has long been regarded as the way to provide incentives for inventors and investors to benefit society, as well as to promote the development and dissemination of science and technology (S\&T). Given the significance of hESC research to China and the incentives of patent protection for hESC-related innovation, it is interesting and crucial to analyze the patent law that regulates $h E S C$ research, particularly the patent eligibility of hESC-related inventions, and suggest how it may be improved so as, on the one hand, to ensure that the biotechnology industry has sufficient incentives to continue to research and develop hESC-related products while, on the other hand, recognizing the value of Chinese and outside moral culture.

This thesis is not intended to be so ambitious as to address all problems regarding patenting hESC-related inventions. Instead, it merely concentrates on issues regarding the patent eligibility of hESC-related inventions. Thus, it does not look at other key determinants in patent validity, such as novelty and the inventive step criterions. To answer the primary research question mentioned above, a number of sub-questions need to be addressed first: What is the public perception of patents in China? How might the Chinese public respond to hESC research and by extension the patenting of hESC-related inven-

62 See e.g., Plomer \& TORREMAnS, supra note 3; Ulrich Storz, The Limits of Patentability: Stem Cells, in LIMITS of Patentability: Plant Sciences, Stem Cells and NuCleic Acids (Andreas Hübel, et al. ed., Springer 2013); Gerard Porter, et al., The Patentability of Human Embryonic Stem Cells in Europe, 24 NATURE BIOTECHNOLOGY 653 (2006); Geertrui Van Overwalle, Patenting Stem Cell Research in Europe and in the United States, in CrossInG Borders: Cultural, Religious and Political Differences Concerning Stem Cell Research (W Bender et al. ed., Agenda Verlag 2005); Albert Wai-Kit Chan, et al., A Patent Perspective on US Stem Cell Research, 32 NATURE Biotechnology 633 (2014); Margo A Bagley, Stem Cells, Cloning and Patents: What's Morality Got to Do with it? 39 NEW ENGLAND LAW REVIEW 501 (2004).

63 See generally, LI Jiang, Regulating Human Embryonic Stem Cell in China: A Comparative Study on Human Embryonic STEM CELL'S PATENTABILITY AND MoRALITY IN US AND EU (Springer 2016). 
tions? What is the moral and legal status of a human embryo in China? Can the human dignity argument be raised in China to oppose the granting of patents over hESC-related inventions? How do the governments of the US, EU, and China regulate hESC research? What are the considerations behind regulating hESC research in these jurisdictions when dealing with highly contentious and sensitive moral issues? What is the current development level of China's hESC research and industry? Is there any international consensus on the patenting of hESC-related inventions? What are the specific provisions regarding the patent eligibility of hESC-related inventions in the three systems (i.e., the US, EU, and China)? How have these pertinent provisions been applied and construed by the courts or patent offices of the three jurisdictions and why? Is it necessary to assess moral issues when a patent office or a court determines the patent eligibility of subject matter? Is there any need to reform the Chinese patent rules or policies concerning patenting hESC-related inventions? Is it proper for China to follow the US or the EU approach in terms of dealing with this issue? How can China's current approach be improved?

Based on the main research question and additional sub-questions, it is evident that China is the major topic of this thesis. The reason is as follows: at present, China, the US, and the EU are three of the most rapidly developing jurisdictions within the field of hESC research, but China is the only newly emerging power, and it is also the only jurisdiction where the public has not been influenced very much by religious ideas, especially Christian morality, which gives the problem of patenting hESC-related inventions in China its unique flavor. In other words, the patenting of hESC-related inventions in China can offer a fresh look at how an emerging economic and legal power with its own socio-cultural, religious, economic, and historical considerations will utilize patent law to serve its own development of research and industry. In addition, the practice of China in terms of patenting hESC-related inventions can provide an attractive alternative model for other developing countries that are struggling to catch up economically and technologically in the present international economic system.

The thesis investigates the rationale, history, debates, practice, and possible effects of patenting hESC-related inventions in China. To answer the research questions mentioned above, the thesis focuses on several separate but interrelated topics. It analyzes the science of hESC-related inventions and the rationale behind patenting biotechnological inventions, particularly regarding hESC-related inventions. ${ }^{64}$ It considers the public debate over hESC research and by extension the patenting of hESC-related inventions, and a particular focus is placed on the relevant social morality in China. ${ }^{65}$ Moreover, one of the primary difficulties raised by patenting hESC-related inventions

64 See infra Sect. 3.2, Chap. 2.

65 See infra Sect. 4, Chap. 2 and Chap. 3. 
is the nature of the relationship between the moral assessment requirement within patent law and related applicable moral controls outside patent law, especially in regulation of research on human embryos and hESC research. ${ }^{66}$ Given this, the thesis provides a discussion of the ethical controls on $\mathrm{hESC}$ research in China, and compares the issues there with those in Europe and the US. ${ }^{67}$ It also discusses whether it is proper to abandon the moral controls to be applied within Chinese patent law. It analyzes the substantive legal frameworks, patent policies, and judicial decisions concerning the patenting of hESC-related inventions in the US, EU, and China, to establish how these three jurisdictions cope with these issues. ${ }^{68}$ To determine whether Western experience is acceptable from the Chinese view system, the thesis examines whether possible solutions can be subject to China's social morality and national conditions. ${ }^{69}$

This thesis tries to provide one of the first comprehensive, systematic, comparative treatments of hESC technology and patent protection concerning Chinese law, which is increasingly important in the context of China's growing internal strategic needs and the growing impact of this country on the global stem cell market. It is an important narrative that suggests that developing countries, with a relatively advanced technology capability, such as China, can tailor an optimal patent policy to promote the advancement of their domestic hESC research and industry. Moreover, the findings of the thesis will contribute to the setting of international and/or domestic patent rules and the tailoring of patent policies not just restricted to hESC-related inventions, but extending to other biotechnological inventions, since the controversy over patenting hESC-related inventions is merely one of the most typical representatives of patenting biotechnological inventions in the past several decades. In this regard, legal scholars, who have problems, especially concerning patents, underlying the international and national regulation of stem cell research, will find in this thesis a relatively useful case study of China. The unique situations in China discussed in this thesis can provide observers a ready resource for future research. Certainly, executives and investors who are going to conduct investment and research and seek reliable patent protection in China will also find value in this text. The exploration of these issues will be of interest to lawyers and law practitioners curious about patenting hESC-related inventions and even other biotechnological inventions, in China, as well as scientists and researchers around the world who intend to conduct research or collaborate with their peers in the field of hESC research in China.

66 See Plomer \& TORREMANS, supra note 3 , at xxxviii.

67 See infra Chap. 4.

68 See infra Chap. 5.

69 Seeid. 


\section{METHODOLOGY AND OUTLINE}

Aiming to enhance and improve the Chinese legal system regarding patenting hESCrelated inventions, the main methodology employed in this thesis encompasses black letter analysis and comparative law. The most significant reason to choose comparative analysis is that the Chinese patent system in essence is an exotic intellectual property (IP) system, which China traditionally did not have until it introduced this system from the Western world about a century ago. ${ }^{70} \mathrm{New}$ China has learned the experience from the Western world since 1984 when it established its first patent law. ${ }^{71}$ Indeed, different jurisdictions may have distinct considerations, such as cultural, economic and political reasons, development of industry and research, etc., and they may have different levels of rules. Yet, their patent systems "share common principles." ${ }^{72}$ The approaches in terms of patenting hESC-related inventions in other jurisdictions may provide China references, insights, and more options to solve the problems in the development and improvement of the biotechnology patent system. It is critical for China to learn the lesson from other industrial nations about how to utilize the patent system to facilitate innovation and how to deal with social and public concerns. ${ }^{73}$ Moreover, a comparison with other jurisdictions can also contribute to an enriched understanding of patenting biotechnological inventions globally.

The US patent system and the patent systems under the EPC and EU Biotech Directive are chosen because these jurisdictions are considered to be more advanced than China not only in patent protection, but also in $\mathrm{hESC}$ research. The US has been chosen as the jurisdiction that does not have a moral requirement in its patent system in the matter of the patenting of hESC-related inventions. In Europe, controversies over how to protect hESC-related inventions reasonably through patent protection and how to balance public interests, as well as how to face moral and ethical issues have been ongoing for a long time. ${ }^{74}$ In the discussion of the American and European experience, the thesis relies mostly on black letter analysis, which mainly focuses on case law, statutes, and other legal documents. In addition, academic commentary is also covered in this thesis, because existing literature on patent-related issues concerning hESC research in

70 See infra Sect. 2.1, Chap. 3.

71 See generally, Peter K Yu, Building the Ladder: Three Decades of Development of the Chinese Patent System, Drake University LaW School Research PaPer (2012). See also Deming Liu, Reflections on Lack of a Patent System throughout China's Long History, 12 The Journal of WorLd InTellectual Property 122, 122 (2009).

72 Peter Drahos, Biotechnology Patents, Markets and Morality, 21 EUROPEAN INTELLECTUAL Property ReVIEW 441, 442 (1999).

73 See generally, LI, supra note 60. See also Commission on Intellectual Property Rights, Integrating Intellectual Property Rights and Development Policy, (Sept. 2002), http://www.iprcommission.org/papers/pdfs/ final_report/ciprfullfinal.pdf. (pointing out that developing countries can seek to learn from the experience of developed countries in devising their own IP systems suitable to their particular legal system and economic situation.)

74 See generally, PLOMER \& TORREMANS, supra note 3. 
Europe already provides a good analysis of the issues. Since the author's language skills are English and Chinese, the thesis primarily focuses on the areas where English and Chinese literature could provide sufficient and fruitful references.

Besides the Introduction (Chap. 1), this thesis consists of five chapters. Following the introduction chapter of the thesis, Chapter 2 attempts to build a fundamental basis for the subsequent discussion about the patenting of hESC-related inventions. It begins with an analysis of important theories that justify the patent system most pertinent to the biotechnology industry, particularly the hESC research and industry. It explores the role that patent protection may play in developing countries. ${ }^{75}$ As a next step, in Chapter 2, the scientific background of hESC-related technologies is explored while explaining some characteristics of hESC molecular biology and physiology, which helps us better understand the concerns surrounding the patenting of hESC-related inventions. ${ }^{76}$ It then covers the "marriage" between patent protection and hESC technology in depth, providing an overall discussion of social and moral debates concerning hESC research per se and by extension the debate, in particular morally, over patenting hESC-related inventions. ${ }^{77}$ It observes that the question of how to perceive "a human embryo" lies at the heart of the moral debates concerning both hESC research and the patenting of hESC-related inventions. In this regard, it is essential to explore the moral and legal status of a human embryo in China.

In Chapter 3, a historical analysis is conducted at the beginning of Chapter 3 to show the introduction of the patent system into China and further to discuss the public perception of patents there, ${ }^{78}$ since this to some extent influences the determination of whether to provide patent protection to certain subject matter, especially in controversial areas, such as hESC research. It finds that patents have an almost "omnipotent" presence in front of the Chinese people. Moreover, a sociological legal perspective is used in Chapter 3, in order to explore the specific situation in China, especially attempting to provide a sketch of how the Chinese public might respond to hESC research and patenting relevant inventions. Thus, this chapter dissects the specific moral culture concerning the human embryo in China, ${ }^{79}$ and at the same time analyzes the legal status of the human embryo from the Chinese perspective. ${ }^{80}$ It shows that the Chinese public does not have any strong moral concerns about the human embryo, but it is still necessary to show certain respect for the embryo under Chinese moral culture.

See infra Sect. 2, Chap. 2.

See infra Sect. 3, Chap. 2.

See infra Sect. 4, Chap. 2.

See infra Sect. 2, Chap. 3.

See infra Sect. 3.2, Chap. 3.

80 See infra Sect. 3.3, Chap. 3. 
Chinese morality concerning the human embryo, to some extent, can be regarded as pragmatic and utilitarian. This chapter also investigates the potential human dignity concerns that might be proposed to argue against patenting hESC-related inventions in China through the general morality clause (i.e., Article 5(1)) within the CPL. ${ }^{81}$ At last, the chapter tries to offer additional explanations for the moral concerns regarding the acceptability of hESC research in China. ${ }^{82}$ In the context of the Chinese public's favourable view of patents, and the public's pragmatic moral position concerning the human embryo, as well as the Chinese government's considerable support for hESC research, the thesis concludes that the Chinese public will not have much strong moral resistance to patenting most hESC-related inventions, except for to the inventions that directly involve the destruction of human embryos.

Chapter 4 discusses the policy approaches that the three jurisdictions (i.e., the US, EU and China) have taken towards hESC research. The exploration of regulating hESC research as well as associated debates in these jurisdictions will lead to a better understanding of the concerns surrounding patenting hESCs-related inventions, and ultimately contribute to figuring out the options for tackling problems raised by the patent eligibility of hESC-related inventions in China. To be specific, Chapter 4 of the thesis first examines the approaches that the US federal government has taken as well as the policy approaches at the state level. ${ }^{83}$ It then analyzes the policy approaches that EU member states have taken towards hESC research, ranging from permissive (e.g., the United Kingdom (UK)), to intermediate (e.g., the Netherlands), to restrictive (e.g., Germany), and meanwhile digs deeply into the underlying reasons behind each policy choice. ${ }^{84}$ It also explores the policy approach that the Chinese government has taken towards regulating hESC research, and at the same time considers the place of China's hESC research and development in the world as well as the stage of hESC research in this country. ${ }^{85}$ The result of this analysis shows that regulating hESC research has proven to be a highly controversial issue in the US and EU, but in China it does not seem to be contentious. China primarily relies on its Ethical Guidelines for Human Embryonic Stem Cell Research (hereafter Ethical Guidelines), ${ }^{86}$ rather than laws or regulations, to regulate hESC research. It shows that China has not established a comprehensive regulatory framework in terms of governing hESC research; the Chinese approach is

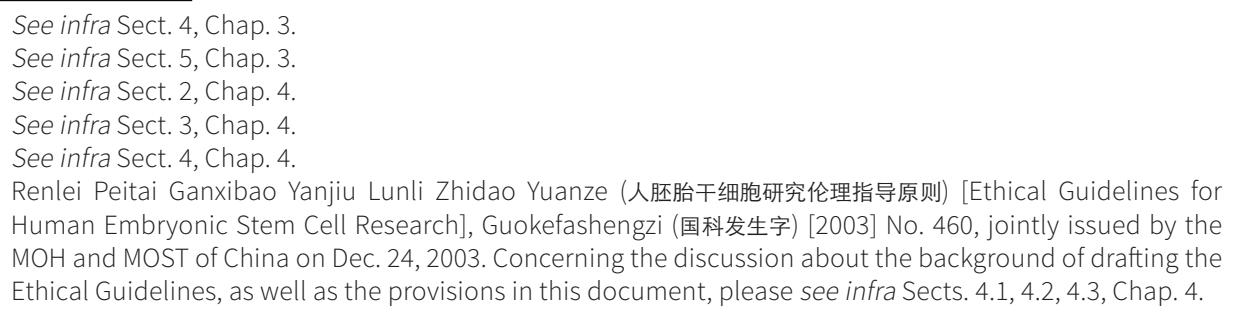
Human Embryonic Stem Cell Research], Guokefashengzi (国科发生字) [2003] No. 460, jointly issued by the $\mathrm{MOH}$ and MOST of China on Dec. 24, 2003. Concerning the discussion about the background of drafting the Ethical Guidelines, as well as the provisions in this document, please see infra Sects. 4.1, 4.2, 4.3, Chap. 4. 
considerably permissive, and the underlying rationale is primarily economic and S\&T development considerations. It also reveals that China is still lagging behind its technologically advanced counterparts in the field of hESC research.

In Chapter 5, black letter law analysis is conducted to explore the details and specific provisions of the three jurisdictions to clarify legal issues regarding the patent eligibility of hESC-related inventions. ${ }^{87}$ It analyzes how these pertinent provisions have been applied or construed by patent offices (i.e., the US Patent and Trademark Office (USPTO), European Patent Office (EPO), ${ }^{88}$ and SIPO), and courts (e.g., the Court of Justice of the European Union (CJEU)), and sees what else can be deduced from doing so. ${ }^{89}$ More importantly, comparative analysis is conducted in this chapter as well. Although the comparison in this part mainly focuses on the aforementioned three jurisdictions, in some cases, the legislation and case law of other jurisdictions, such as Germany, the UK, as well as the international standards, such as the Agreement on Trade-Related Aspects of Intellectual Property Rights (TRIPS Agreement), ${ }^{90}$ are also covered here because, on the one hand, the cases under discussion in these jurisdictions are closely connected with cases at the European level; on the other hand, Chinese law to some extent is continuously influenced by the laws of these jurisdictions and the TRIPS Agreement, and some approaches used by them provide helpful insight as well.

Chapter 5 reveals that the US patent system focuses more on the scientific and economic issues, but in the EU and China, moral issues have taken top billing. It questions the idea of removing the morality assessment requirement from the Chinese patent system, that is, following the US model. ${ }^{91}$ This chapter argues that simply following the US model, which has abandoned the moral assessment in patent law, is not ideal in the case of patenting morally controversial biotechnological inventions in China. Meanwhile, it is also naive to indiscriminately imitate the current EU approach, in particular considering that the provisions within the EU Biotech Directive and EPC, as well as the approaches that the CJEU and EPO have adopted, are essentially based on the European situation,

87 See infra Sect. 2, Chap. 5.

88 Based on the EPC, in the EU most patents currently are granted via the EPO, which simply serves as an initial filter on European patents. In essence, a European patent is just a "bundle of national patents", and the legal validity of these patents is subject to the review of each national court. See CN Pehlivan, The Creation of a Single European Patent System: From Dream to (Almost) Reality, 34 EUROPEAN INTELLECTUAL ProPERTY REvIEW 453, 455 (2012); Aurora Plomer, Human Dignity, Human Rights, and Article 6(1) of the EU Directive on Biotechnological Inventions, in EMBryonic STEM CelL PATENTS: EuROPEAN LAW AND ETHICs 225 (Aurora Plomer \& Paul Torremans ed., Oxford University Press 2009).

89 See infra Sects. 3 and 4, Chap. 5.

90 Agreement on Trade-Related Aspects of Intellectual Property Rights (TRIPS Agreement), Marrakech Agreement Establishing the World Trade Organization, Annex 1C, Legal Instruments-Results of the Uruguay Round (Marrakesh, 15 April 1994, 33 ILM 1197 (1994)). See infra Sect. 2.1, Chap. 5.

91 See infra Sect. 5, Chap. 5. 
while China has a different degree of domestic development of research and industry, ${ }^{92}$ a specific local moral culture and legal system concerning the human embryo, ${ }^{93}$ and an immature regulatory system. ${ }^{94}$ Put another way, completely excluding hESC-related inventions from patent eligibility on moral grounds, like in the EU and EPO, is not suitable in China's case.

After analyzing China's legislation and policies, Chapter 5 demonstrates that China's current approach is primarily based on the SIPO's policy: as long as the patent application avoids contents of isolating or obtaining hESCs from a human embryo, and provides sufficient evidence to prove that the invention uses already established hESC lines which are obtainable from commercial channels, then downstream hESC inventions would be regarded as patent eligible. ${ }^{95}$ Chapter 5 also assesses this approach. In consideration of the specific Chinese social morality, as evidenced in Chapter 3, and China's regulatory environment and scientific development level concerning hESC research, as identified in Chapter 4, as well as the specific challenges that the Chinese patent system is facing within the field of hESC research and industry at present, as demonstrated in Chapter 5 , the last part of Chapter 5 deduces that China's current approach towards patenting hESC-related inventions, to some extent, on the one hand, satisfies the Chinese social morality to show respect for the human embryo, and on the other hand, has in mind the need for the development of S\&T. ${ }^{96}$ However, a number of adjustments and further clarification still need to be conducted within the SIPO's Guidelines, such as to redefine the concept of the "human embryo", to narrowly interpret the term "use" in the human embryo exclusion, and to remove the specific exclusion of "hESCs and their preparation methods".97

After the theoretical discussion and comparative analysis of the three jurisdictions in the previous chapters, Chapter 6 presents the main findings of the research, makes final conclusions, and summarizes the recommendations from the perspectives of general policy and the improvement of the SIPO's Guidelines. It also briefly conducts a discussion of limitations of the thesis and future research.

Since the thesis takes a stand on a considerably disputable topic, the author realizes that it is impossible to convince every reader, and even many readers may not concur with the reading of findings and interpretations, particularly of the morality concern-

92 See infra Sect. 4.5, Chap. 4

93 See infra Sect. 3, Chap. 3 (discussing the moral and legal status of a human embryo in China); Sect. 4, Chap. 3 (discussing human dignity and the human embryo).

94 See infra Sect. 4, Chap. 4.

95 See infra Sect. 3.3, Chap. 5.

96 See infra Sect. 5.3.1, Chap. 5.

97 See infra Sect. 5.3.2, Chap. 5. 
ing the human embryo and hESC research in China, as well as proposed solutions in the thesis. Nevertheless, the author hopes that even those who do not concur with the viewpoints in this thesis can benefit from the discussion, and that this thesis can be a starting point for further discussion and debate for advancing social policy. 



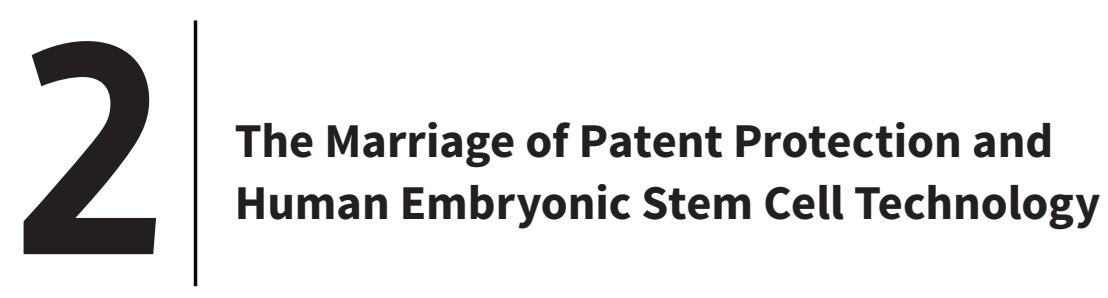

\section{INTRODUCTION}

Conventionally, the perception of an "invention" in patent law was conditioned by man's experience in manipulating and altering inanimate matter. ${ }^{1}$ Nevertheless, with the rapid evolution of the biotechnology industry, inventions have started to involve living matter, even including human beings. ${ }^{2}$ The complexity of today's innovative or advanced biotechnology, not surprisingly, has thrown traditional conceptions of patent law into turmoil. Serious doubts have been generally expressed on the patent eligibility of biological materials. ${ }^{3}$ In particular, one of the more recent and controversial areas of patenting biotechnological inventions is that of hESC research and technology. Before tackling the topic of patenting hESC-related inventions, it is useful to provide the general reader with the rationale for patent protection, and some scientific background in terms of hESC research, as well as the general debate over patent law and stem cell research.

This chapter begins by providing a fundamental basis for discussing patent issues regarding hESC-related inventions in specific jurisdictions, i.e., the US, EU, and China, in the following chapters. ${ }^{4}$ To be specific, it lays out important theories that justify the

\footnotetext{
1 See Oliver Mills, Biotechnological inventions: Moral Restraints and Patent Law (Revised Edition) 7 (Ashgate Publishing Limited 2010); Andrea StazI, Biotechnological InVEntIons And PATENTABiLity of LifE: The US And EUROPEAN EXPERIENCE 9 (Edward Elgar 2015).

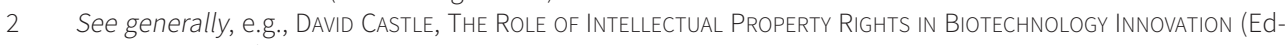
ward Elgar 2009); MILLS, supra note 1; DAVID B RESNIK, OWNING THE GENOME: A MORAL ANALYSIS OF DNA PATENTING (State University of New York Press 2004); STAZI, supra note 1.

3 See e.g., NS SREenivasulu \& CB Raju, Biotechnology and Patent LaW: Patenting Living Beings (Manupatra 1st ed. 2008); ANDREAS HüBEL, et al., LImits of PATENTABILITY: PLANT SCIENCES, STEM CellS AND NuCLeIC ACIDS (Springer Science \& Business Media 2012); MATtheW RIMmer, InTELLECTUAL PROPERTY AND BIOTECHNOLOgY: BIOLOGICAL INVENTIONS (Edward Elgar 2008); RESNIK, supra note 2; Ulrich Storz, The Limits of Patentability: Stem Cells, in LIMITS of PATEnTAbility: Plant SCienCes, Stem Cells And NuCleic Acids (Andreas Hübel, et al. ed., Springer 2013). See infra Chaps. 5 and 6.
} 
patent system most pertinent to the biotechnology industry, particularly hESC research and industry (Sect. 2). It also considers potential adverse impacts that patents may have upon stem cell research, as well as the role that patent protection is playing in developing countries, particularly in China (Sect. 2). Subsequently, Section 3 first briefly examines the rapid development of modern biotechnology, which is helpful to understand the controversy over patenting hESC-related inventions in the context of the challenge that modern biotechnology has brought to patent law. Moreover, in order to orchestrate the debate over patenting hESC-related inventions and to fully understand the issues surrounding regulating hESC research, ${ }^{5}$ it is necessary to understand what, technically speaking, hESC-related technologies can and cannot do. ${ }^{6}$ In this regard, Section 3 of this chapter continues to demonstrate the scientific background of hESC-related technologies, and explain some characteristics of hESC molecular biology and physiology that are of crucial significance when analyzing their patent eligibility. Meanwhile, hESCs' potential in research and treating modern medical challenges, as well as other types of stem cell research, are also briefly discussed in Section 3, which is helpful to understand why the debate concerning the patenting of hESC-related inventions is so fierce and special. Then Section 4 of this chapter goes in depth covering the "marriage" between patent protection and hESC technology in general, providing an overall discussion of social and moral debates concerning hESC research and by extension the debate, in particular morally, over patenting hESC-related inventions.

\section{THE ROLE OF PATENT RIGHTS}

This thesis mainly examines patent issues in the field of hESC research. For this purpose, before dealing with patent law and the patent eligibility of hESC-related inventions more specifically, it is useful and necessary to explore some important theoretical foundations of patent protection, especially over biotechnology. This section starts with the discussion of the foundations of the patent system (Sect. 2.1), followed by an examination of the literature on the functions and effects of patents (Sect. 2.2). Since this thesis targets patent issues in China, which remains the largest developing country, as well as a technology-importing country in terms of hESC research, ${ }^{7}$ the third part of this section gives a brief overview of the debates on the role of patents in innovation in developing countries (Sect. 2.3), which is helpful in making a more objective judgment on the issues of this thesis.

5 See infra Chap. 4, which will investigate the policy approaches that the US, EU, and China have taken towards regulating hESC research; See also infra Chap. 5, which will conduct a comparative analysis of patenting hESC-related inventions in these three jurisdictions.

6 See Andrew McCoy, Biotechnology and Embryonic Stem Cells: A Comparative Analysis of the Laws and Politics of the United States and Other Nations, 8 Loyola LAW AND TECHNOLOGy ANNUAL 63, 65 (2008).

7 Concerning the development of China's hESC research and industry, as well as this country's position in the world in terms of this research, please see infra Sect. 4.5, Chap. 4. 


\subsection{Foundations of the Patent System}

Many scholars have attempted to justify the existence of the patent system. Several theories have been generated, and supposedly provide such justifications. One most influential justification for the existence and emergence of IP rights in general, and patent rights in particular, appeals to libertarian ideals relating to property. ${ }^{8}$ John Locke (1632-1704), a British political philosopher, established the natural rights approach to politics and morality. Locke's theory considers that a person becomes entitled to a "natural right" over things by adding labor to them. ${ }^{9}$ The nineteenth-century German political philosopher Friedrich Hegel (1770-1831) asserted that property provides people with a medium to develop and express themselves. ${ }^{10}$ Society has the obligation to recognize property rights, so as to ensure that people have the degree of control over objects necessary to develop and express themselves. Accordingly, property rights are morally justified since they promote human freedom.

The other most influential justification for patent rights appeals to utilitarianism. ${ }^{11}$ The theory of classical utilitarianism, fathered by Jeremy Bentham, considers that "it is the greatest happiness of the greatest number that is the measure of right and wrong."12 It is believed that the reason the patent system exists is utilitarian, in order to solve a market failure. ${ }^{13}$ In accordance with rule utilitarianism, one version of utilitarianism, policies and rules should be assessed in terms of their possible good and bad effects on society. The optimal policy is the one that can generate the most net social utility, maximizing benefits and minimizing harms. Thus, in accordance with utilitarianism, patent rules and related policies should be evaluated on the basis of their possible effects on social goods, such as human happiness, health, scientific progress, and economic development. $^{14}$

The utilitarian rationale, which views the patent system as a means of promoting scientific and technological progress and economic development, for patent law is set forth precisely in the Chinese patent system. In China, there is an unwritten rule in legislation that normally the first article of a law or a regulation is to be regarded as the purpose

8 See RESNIK, supra note 2, at 35; Emir Crowne, The Utilitarian Fruits Approach to Justifying Patentable Subject Matter, 10 John Marshall ReVIeW of InTELLECTUAL PROPERTY LAW 753, 756 (2011).

9 See John Locke, SeCOnd Treatise of Government 19 (CB Macpherson ed., Hackett Publishing Company 1980).

10 See RESNIK, supra note 2, at 36.

11 The debate concerning libertarianism and utilitarianism is beyond the scope of the discussion of this thesis. Instead, this thesis mainly focuses on the utilitarian approach, which China has already incorporated into its patent system, and which will be discussed later in this section.

12 James H Burns, Happiness and Utility: Jeremy Bentham's Equation, 17 UTILITAS 46, 46 (2005).

13 See David S Olson, Taking the Utilitarian Basis for Patent Law Seriously: The Case for Restricting Patentable Subject Matter, 82 TEMPLE LAW REVIEW 1, 3 (2009).

14 See RESNIK, supra note 2, at 35. 
clause, ${ }^{15}$ and the CPL is no exception. Article 1 of the CPL, the purpose clause, stipulates that "this Law is enacted for the purpose of protecting the lawful rights and interests of patentees, encouraging invention-creation, promoting the application of inventioncreation, enhancing innovation capability, promoting the advancement of science and technology and economic and social development." ${ }^{16}$ The CPL has enumerated five purposes. ${ }^{17}$ As a matter of fact, the purposes for enhancing innovation capability, as well as promoting the advancement of S\&T and economic and social development were not introduced into the CPL until the latest amendment of the CPL in $2008 .{ }^{18}$ This introduction is based on China's national strategy of making it an innovative country and promoting economic and social development. ${ }^{19}$ Considering the great importance being given to "independent innovation" ${ }^{20}$ by the Communist Party of China (CPC $)^{21}$ and the Chinese government, it is not surprising these two purposes have been introduced into the CPL. While the purpose clause of the CPL appears to describe five different aspects, it is not difficult see in the last four purposes an inherent consistency. That is, the CPL aims to promote technical innovation and the dissemination of its fruits, and to finally realize the promotion of economic and social development. Put simply, China attempts to utilize its patent system to serve as a tool to improve its indigenous technological capabilities and enhance its international competitiveness, so as to make this country an innovative one. ${ }^{22}$

15 See XINTIAN YIN [尹新天], ZHONGguO ZHUANLIFA XIANGJIE (中国专利法详解) [INTRODUCTION TO THE PATENT LAW OF CHINA] 10 (Zhishi Chanquan Chubanshe (知识产权出版社) [Intellectual Property Press] 2011) (pointing out that in laws formulated by the National People's Congress (hereafter NPC) and its Standing Committee, administrative regulations formulated by the State Council, local laws and regulations, and department regulations formulated by the State Council's various departments, without any exception, the first article normally is to be regarded as the purpose clause. The advantage of providing the legislative purpose in the first place is to facilitate people's understanding of why the rules or laws are formulated.)

16 Article 1 of the CPL.

17 It is typical for Chinese legislature to pursue multiple goals, which sometimes makes it harder to understand the legislative purpose. Yin has questioned the appropriateness of listing "protecting the lawful rights and interests of patentees" as the purpose of the CPL, since he believes that only by formulating the CPL and granting patent rights over inventions can the lawful rights and interests of patentees be protected. Thus, Yin points out that the first listed purpose in Article 1 of the CPL is to make people to feel that patent rights have already existed without patent law. However, since the similar statements can also be found in the Trademark Law of China and Copyright Law of China, and it is difficult to change it, the statement still remains in place. See YIN, supra note 15, at 10-11.

18 This can be seen through a brief comparison between the $2000 \mathrm{CPL}$ and $2008 \mathrm{CPL}$.

19 See YIN, supra note 15, at 14.

20 "Independent innovation" (Zizhu Chuangxin, 自主创新) is a term frequently used by the Chinese government, and represents the aim of China to promote its indigenous innovation. See e.g., Yuehui Wu (吴月 辉) \& Siluan Yu (喻思娈), Jinping Xi: Chuangxin Ganwei Tianxia Xian (习近平: 创新要敢为天下先) [Xi Jinping: Innovation, Dare to be the First in the World], RENMIN RIBAO (人民日报) [PEOPLE'S DAILY], 10 Jun. 2017, at 2.

21 The CPC is the founding and ruling political party of the PRC.

22 See Guowuyuan Guanyu Yinfa Guojia Zhishi Chanquan Zhanlüe Gangyao de Tongzhi ( 《国务院关于印发国家知 识产权战略纲要的通知》国发[2008]18 号) [Outline of the National Intellectual Property Strategy], issued by the State Council of the PRC on 5 Jun. 2008. 
As can be seen, the purpose clause of the current CPL has incorporated the utilitarian approach. In fact, when drafting the first CPL in 1980s, Li Wan, then Chinese vice premier, pointed out three purposes: "firstly, to mobilize people to invent; secondly, to promote and facilitate the application of inventions; thirdly, to encourage the introduction of advanced foreign advanced technologies." 23 This statement explicitly indicated that the establishment of the Chinese patent system was totally out of utilitarian consideration. The first CPL (1984) precisely excluded certain subject matter, such as food, and pharmaceuticals, from being patented, which is also based in utilitarian consideration. ${ }^{24}$ Through a brief examination of the development of the Chinese patent system and the legislation history of the $\mathrm{CPL},{ }^{25}$ one also can observe that utilitarianism dominates China's patent legislation. ${ }^{26}$ As such, there is no doubt that the Chinese patent system has adopted the utilitarian approach. In other words, when setting forth China's patent rules or tailoring patent policies, it is necessary to consider various interests and evaluate the possible effect of these rules and policies on social goods, such as human happiness, health, scientific progress, and economic development.

\subsection{Functions and Effects of Patents}

As mentioned above, China's patent legislation is dominated by utilitarianism. In this regard, this part primarily discusses functions of patents based on general utilitarian theory, which supposes the necessity of patent protection to solve the market failure problem in the form of "free riding" by copycats using inventions made by others. Specifically, as many scholars have pointed out, inventions are public goods which are costly to create but hard to control once they are disclosed to the public. ${ }^{27}$ Without legal rights in inventions allowing inventors to control and profit from goods, there will be

23 Kunyi Huang (黄坤益), Guanyu Zhonghua Renmin Gongheguo Zhuanli Fa (Cao'an) de Shuoming (关于《中华 人民共和国专利法 (草案) 》的说明) [Explanation on the Patent Law of the People's Republic of China (Draft)], (Dec. 2, 1983), http://www.npc.gov.cn/wxzl/gongbao/2000-12/26/content_5001493.htm.

24 Id. (This contains a description concerning the patent policy of the patentable subject matter stating that "given the current level of science and technology, and because industrial development of China is not high, coupled with a lack of experience in the implementation of the patent system, the Draft limits the scope of protection to be relatively stringent... After requiring experience of implementation of the patent system for a period, we will broaden the protection scope gradually. Currently, the scope of patent protection temporarily excludes some new substances, such as pharmaceuticals, food and new varieties of synthetic chemicals, and also eliminates animals and plant new varieties and so forth, which are not suitable for patent protection. This is because these substances will affect Chinese livelihoods, health and the processing industry.")

25 See infra Sect. 2.1, Chap. 3 of this thesis, which will show the development of the Chinese patent system and the legislation history of CPL.

26 See GUOBIN CUI (崔国斌), ZHUANLI FA YUANLI YU ANLI (专利法: 原理与案例) [PATENT LAW: CASES AND MATERIALS] 5 (Beijing Daxue Chubanshe (北京大学出版社) [Peking University Press] 2012).

27 See Robert P Merges, et al., Intellectual Property in the NeW TeChnological Age 127 (Wolters Kluwer Law \& Business 2007). See also Dan L Burk \& Mark A Lemley, Policy Levers in Patent Law, VIRGINIA LAW REVIEW 1575, 1580 (2003); Dan L Burk \& Mark A Lemley, Biotechnology's Uncertainty Principle, 54 CASE WESTERN RESERVE LAW REVIEW 691, 693 (2003) (due to the public goods nature of inventions, they are expensive to produce but costless to reproduce or to appropriate once they have been created. The patent system generally aims to address the public goods problem that arises in the matter with industrial or technological inventions.) 
little incentive for inventors or investors to invest in making, developing, and marketing new products. Branching out from this initial explanation of the patent system, more complementary theories have been developed to explain the functions and effects of patents.

It has widely been accepted that one important function of the patent system is motivating innovation, which means that patent protection is able to provide incentives to inventors to create. ${ }^{28}$ At the same time, patents are also believed to have the function of encouraging the disclosure of secret knowledge as early as possible, which was pointed out by the exchange-for-secret theory. This theory presumes a bargain between the inventor and the public; the inventor relinquishes the possession of secret knowledge in exchange for the protection of a temporary exclusivity in its industrial use. ${ }^{29}$ It assumes that without patent protection, inventors would be inclined to keep inventions confidential, and secrets might be perpetually lost to society with the death of inventors. ${ }^{30}$ It is believed that the optimal option is offering the inventor exclusive patent right in exchange for public revelation of the invention. ${ }^{31}$ However, in the field of basic research, pure scientists' might be motivated to publish their research results as early as possible even without patents, primarily because the thing that they care about most is their reputation within academia. ${ }^{32}$

Another essential function of the patent system is to provide incentives to patent owners to efficiently use and commercialize unrealized ideas, just as the privatized land can encourage the owner to use it efficiently. ${ }^{33}$ This function was proposed in Edmund Kitch's "prospect" theory of the patent system. Kitch mainly focused on the capacity of patent ownership to encourage the efficient use and commercialization of inventions through licensing once these inventions are created. ${ }^{34}$ In practice, patent law normally does not require the invention claimed in a patent application to be a mature product on the market. Instead, almost all the patented inventions are still far from the market, and need great investment for improvement and marketing. In this case, unless a patent owner possesses the patent or investors have made previous arrangements with the owner of the patent, they will have little incentive to improve and market their

28 See fritz Machlup, An Economic Review of the Patent System: Study of the Subcommittee on Patents, TradeMARKS, AND COPYRIGHTS OF THE COMMITTEE ON THE JUDICIARY 33 (US Government Printing Office 1958).

29 See id., at 21.

30 Seeid.

31 Seeid.

32 Seeid.

33 See Edmund W Kitch, The Nature and Function of the Patent System, 20 JournAL OF LAW AND ECONOMICS 265, 270-271 (1977).

34 See id., at 276-278. 
invention, since they may suffer all the investment risks, but copycats can quickly reap the benefits of the improvement and marketing efforts. ${ }^{35}$

The biotechnology industry is one of the most innovative, competitive and researchintensive industries in the field of science. ${ }^{36}$ In this industry, most inventions require a lengthy and expensive development process, due to several complicated factors, such as the randomness and consequently risky nature of the biotechnological invention process, and technical obstacles. ${ }^{37}$ If biotechnological inventions are to be translated into safe and effective clinical products resulting from discoveries in basic research (e.g., the transition from discovery of hESCs to hESC therapy), they must endure much longer and more expensive development, and need to jump high regulatory hurdles. ${ }^{38}$ However, in the field of biotechnology, products or processes are relatively easy to reproduce or imitate, often with radically lower costs and much less uncertainty. ${ }^{39}$ Based on the discussion above, it is not difficult to imagine that without patent protection, it would be difficult for investors and inventors to recoup their investments, and they would not have sufficient incentive to invest in making, developing, and marketing new biotechnological products. Without investment, biotechnology would come to a standstill. Particularly for small startup biotechnology companies, patent protection is especially vital, since often patents they own can be viewed as almost their only business assets, which they can count on to attract investment for them to survive. ${ }^{40}$ In this regard, in order to promote innovation and guarantee sufficient investment within the biotechnology industry, exclusive patent protection is important.

A number of commentators have put forward the notion that alternative incentives to the advancement of biotechnology, such as the first-mover advantage, competition with technological rivals, or the race for scientific discovery, may be sufficient, ${ }^{41}$ but nowadays there seems to be little doubt that patent protection still plays a crucial role in the growth and innovation of the biotechnology industry. ${ }^{42}$ There has not been any

35 Moreover, Kitch also enumerated several other functions of the patent system, such as to lower the cost between the owners of technological information (compared with trade secret), to reduce the amount of duplicative investment in innovation, to reduce the cost of maintaining control over technology. See id., at 276-280.

36 See STAZI, supra note 1 , at 5.

37 See Yusing Ko, An Economic Analysis of Biotechnology Patent Protection, 102 YALE LAW JournAL 777, 786 (1992).

38 See Claude Barfield \& John E Calfee, Biotechnology and the Patent System: Balancing Innovation and PropERTY RIGHTS 31 (The AEI Press 2007).

39 See id, at 32.

40 See BARFIELD \& CALFEE, supra note 38, at 27. See also Commission on Intellectual Property Rights, Integrating Intellectual Property Rights and Development Policy, 21 (Sept. 2002), http://www.iprcommission.org/ papers/pdfs/final_report/ciprfullfinal.pdf.

41 See Ko, supra note 37, at 792-793.

42 See Graham Dutfield, Intellectual Property Rights AND the LIFE SCIENCE INDUSTRIES: PASt, PRESENT AND FUtURE 191-211 (World Scientific 2nd ed. 2009). 
evidence that these proposed alternative incentives can completely substitute for patent protection in promoting the advancement of biotechnology. Hence, for the moment, providing patent protection in the field of biotechnology is still of great importance.

In additional to the abovementioned key functions of the patent system, certain potential effects of patents need to be analyzed in evaluating potential challenges to innovation in biotechnology, specifically in the field of hESC research. The condition needing to be discussed here first is cumulative innovation, which demonstrates a situation in which a subsequent invention results not just from a previous invention covered by a valid patent, but from one or more improvements to that invention. ${ }^{43}$ In other words, many innovations are enhancements of prior generations of related technologies. ${ }^{44}$ Since in such a unique situation the subsequent inventor does not own the previous patent, patent law needs to strike a balance between the rights granted to previous inventors and improvers. ${ }^{45}$ In other words, it poses difficult questions in respect of balancing incentives among those who carry out the initial research and those who engage in follow-on research. ${ }^{46}$

Biotechnology involves cumulative innovation, in which each new innovation relies on or, at least, requires access to anther innovation. ${ }^{47}$ There is a typical scenario where the initial invention is a basic material or technology, which forms the basis for various applications in multiple technological fields. ${ }^{48}$ This typical accumulative innovation maps very well onto research and development in the area of stem cells. ${ }^{49}$ Specifically, although stem cell research and industry have many facets, generally in this field of research an established stem cell line is the basic material, and is considered to be a fundamental research tool, an "essential facility" in biotechnological research, ${ }^{50}$ indispensable for both upstream and downstream stem cell research. ${ }^{51}$ Without established,

43 See Ofer Tur-Sinai, Cumulative Innovation in Patent Law: Making Sense of Incentives, 50 IDEA 723, 731 (2009); Burk \& Lemley, supra note 27, Policy Levers in Patent Law, at 1607.

44 See Alberto Galasso \& Mark Schankerman, Patents and Cumulative Innovation: Causal Evidence from the Courts, 130 The QuARTERLY JOURNAL OF ECONOMics 317, 317 (2015).

45 See Tur-Sinai, supra note 43, at 731; Howard F Chang, Patent Scope, Antitrust Policy, and Cumulative Innovation, 26 THE RAND JOURNAL OF ECONOMICS 34 (1995) (discussing the most desirable balance of protection between initial and follow-on innovator.)

46 See BARFIELD \& CALFEE, supra note 38 , at 33.

47 See CASTLE, supra note 2, at 363. See also Galasso \& Schankerman, supra note 44, at 321 (investigating the effect that patents have on the process of cumulative innovation, finding out that patent rights block downstream innovation in biotechnological field. However, this empirical research mainly focused on the US. It may be premature to extrapolate concerns about the effect that patent rights have on downstream innovation from the United States to other jurisdictions.)

48 See Tur-Sinai, supra note 43 , at 731.

49 See CASTLE, supra note 2, at 364.

50 See Amy Rachel Davis, Patented Embryonic Stem Cells: The Quintessential "Essential Facility"? 94 GEORGETOWN LAW JOURNAL 205 (2005).

51 See Marton Varju \& Judit Sándor, Patenting Stem Cells in Europe: The Challenge of Multiplicity in European Union Law, 49 COMmon Market LAW ReVIEW 1007, 1022 (2012). 
stable stem cell lines, downstream research (e.g., creating specialized cells and tissues by differentiating stem cell lines) cannot proceed. The follow-on innovations need to build on the previous innovative steps and products, which may be covered by a patent, of other researchers or companies. The cumulative nature of stem cell research therefore raises the danger that patenting stem cells (the research tool) could hinder advances from basic research to marketable products.

Besides cumulative innovation, scholars have become interested in the "tragedy of the anticommons", which is another potential problem with regard to patenting inventions in the field of biotechnology. ${ }^{52}$ The anticommons theory points out that granting too many different patents over a particular piece of property may hinder further advance and marketing of new products, because making the new product needs licensing from many different patent rights, and multiple patent owners may block one another, so that no one party is capable of efficiently using the property. ${ }^{53}$ One major feature of the anticommons is fragmented property rights, and in order to make efficient use of the property, the aggregation of such rights is quite essential. ${ }^{54}$ However, such aggregation would make it very costly to search for and negotiate with multiple patentees whose authorizations are necessary to conduct further development. ${ }^{55}$ In addition, strategic behaviors may happen during licensing negotiation, leading to the failure of licensing, especially when patent owners ask an extremely high price, perhaps even close to the value of the entire project. Thus, although transferring rights can normally address an anticommons, ${ }^{56}$ transaction costs, strategic behaviors, and cognitive biases will sometimes prevent aggregation of the necessary rights. ${ }^{57}$

52 See Michael A Heller \& Rebecca S Eisenberg, Can Patents Deter Innovation? The Anticommons in Biomedical Research, 280 SCIENCE 698 (1998); Burk \& Lemley, supra note 27, Policy Levers in Patent Law, at 1624-1627. Based their studies, it seems that the anticommons theory was designed with DNA in mind. However, the question of whether it maps well onto stem cell research needs more study.

53 See Heller \& Eisenberg, supra note 52 (identifying anticommons in biomedical research and pointing out that more patents may result in fewer useful products.) Heller initially proposed his anticommons theory in Michael A Heller, The Tragedy of the Anticommons: Property in the Transition from Marx to Markets, 111 HARVARD LAW REVIEW 621 (1998), and further discussed it in Michael A Heller, The Boundaries of Private Property, 108 YALE LAW JoURNAL 1163 (1999). See also Arti K Rai, The Information Revolution Reaches Pharmaceuticals: Balancing Innovation Incentives, Cost, and Access in the Post-Genomics Era, 2001 UNIVERSITY OF ILLINOIS LAW REVIEW 173 (2001) (holding that upstream patents in biotechnology could lead to bargaining breakdown and deter further innovation.)

54 See Heller, supra note 53, at 670-672.

55 See Burk \& Lemley, supra note 27, Policy Levers in Patent Law, at 1611.

56 See Heller \& Eisenberg, supra note 52, at 698.

57 See id., at 700-701. See also Burk \& Lemley, supra note 27, Policy Levers in Patent Law, at 1611; Michael S Mireles, States as Innovation System Laboratories: California, Patents, and Stem Cell Technology, 28 CARDOZO LAW REVIEW 1133, 1164 (2006). 
The essence of the anticommons problem lies in the number of rights with different owners that must be aggregated, but not necessarily the scope of those patents. ${ }^{58} \mathrm{Ac}-$ cordingly, two solutions have been proposed to address this problem. ${ }^{59}$ Specifically, the majority of the relevant literature proposes that the solution is to grant fewer patents, and especially to exclude upstream inventions like research tools or basic biology materials from patentability. ${ }^{60}$ However, several scholars seem to favor the solution of consolidating ownership of rights among fewer patentees, such as consolidating rights at a single company or collective rights organization, or in a patent pool. ${ }^{61}$ It is evident that these two solutions can lead to different patent policies, but as Burk and Lemley note, "the anticommons theory does not necessarily dictate particular policy results."62

\subsection{Patents and Innovation in Developing Countries}

The abovementioned theories, however, mainly focus on developed countries. It is beyond question that patents benefit developed countries, and matter to the biotechnology research and industry in those countries. Regarding the question of whether patent rights would benefit developing countries, some commentators take the view that there is no reason why a system that works for developed countries could not do the same in developing countries. ${ }^{63}$ However, some argue that the relationship between patents and innovation in developing countries might be another case. Since China remains the largest developing country, as well as a technology-importing country in terms of hESC research, ${ }^{64}$ a brief overview of the debates on the role of patents in innovation in developing countries would be helpful in reaching a more objective judgment on the issues of this thesis.

58 See Burk \& Lemley, supra note 27, Policy Levers in Patent Law, at 1613; Matthew Erramouspe, Staking Patent Claims on the Human Blueprint: Rewards and Rent-Dissipating Races, 43 UCLA LAW REVIEW 961, 998 (1995) (pointing out that too many patents have been granted over components or inputs into products for different owners. "[B]y setting stricter limits on gene patentability, the patent system can make the appropriate adjustment to reduce further rent dissipation among gene hunters.")

59 See Burk \& Lemley, supra note 27, Policy Levers in Patent Law, at 1613 (pointing out that the two solutions are either to limit the scope of patentable subject matter or to consolidate ownership of rights on fewer patentees.)

60 See Philippe Jacobs, Gene Patents: A Different Approach, 23 EUROPEAN INTELleCtUAL ProperTY REVIEW 505 (2001) (holding that DNA cannot constitute patentable subject matter, but downstream medical products can); Arti K Rai, Fostering Cumulative Innovation in the Biopharmaceutical Industry: The Role of Patents and Antitrust, 16 Berkeley TeChnology LaW Journal 813, 838 (2001) (pointing out that patent law should make sure "that the most upstream research remains outside the bounds of patentability.")

61 See Burk \& Lemley, supra note 27, Policy Levers in Patent Law, at 1613. For a discussion of collective rights organizations, see Robert P Merges, Contracting into Liability Rules: Intellectual Property Rights and Collective Rights Organizations, 84 CALIFORNIA LAW REVIEW 1293 (1996).

62 See Burk \& Lemley, supra note 27, Policy Levers in Patent Law, at 1613.

63 See Commission on Intellectual Property Rights, supra note 40, at 1.

64 See infra Sect. 4.5, Chap. 4, which analyzes the place of China's hESC research and development in the world, as well as the development stage of hESC research and industry in China. 
In general, the role of patents in innovation in developing countries is still under debate and far more unclear than in developed countries. Some feel that patents not only do little to promote inventions in developing countries, but even play a negative role in innovation there. An early study by Grundmann in 1970 found that for developing countries the optimal way to facilitate the creation of new technology was not providing patent protection, but strengthening investment in education in technology and science. ${ }^{65}$ A 1990 study by Braga concluded that it was difficult to find a positive relationship between stronger patent protection and domestic R\&D in developing countries. ${ }^{66}$

Some believe that patents in developing countries restrict the option of technological learning through imitation. ${ }^{67}$ In other words, their concerns are that the patent system allows competitors from technologically advanced countries to drive out domestic competition through gaining patents in developing countries, and in turn to impede the advancement of domestic research and industry. A recent survey suggested that patent protection could have a significantly positive impact upon encouraging the creation of innovation in high-income countries and the importation of technology in low-income ones, but for middle-income countries it might lead them to suffer from offsetting losses because of the reduced diffusion of knowledge and imitation. ${ }^{68}$ Similarly, a Korean report concerning IP rights and technological development pointed out that in the very early stage of industry development, patent protection is not an important issue for catching-up economies. ${ }^{69}$ Many China scholars also have put forward the concern that providing patent protection in the early stage would benefit foreign competitors more than domestic ones, slow domestic research progress, and further make it difficult for China to catch up with its Western counterparts. ${ }^{70}$ Moreover, some scholars accuse

65 See Helge E Grundmann, The Economic Arguments for Patents and Their Validity for Developing Countries, 19 INDIAN ECONOMIC JOURNAL 193, 193 (1970).

66 See C Primo Braga, The Developing Country Case For and Against Intellectual Property Protection 69-87 (Wolfgang E Siebeck ed., The World Bank 1990).

67 See Commission on Intellectual Property Rights, supra note 40, at 1.

68 See Rod Falvey, et al., Intellectual Property Rights and Economic Growth, 10 REVIEW OF DEVELOPMENT ECONOMICS 700, 712 (2006).

69 See Keun LEE, et al., Industrial Property (IP) Rights and Technological Development in the Republic of Korea, 119 (Apr. 2003), http://webcache.googleusercontent.com/search?q=cache:ZfISifmnp4QJ:www. keunlee.com/modules/board/bd_download_db.html\%3Fid\%3Deng_research_book\%26no\%3D201+\&cd= $1 \& h l=e n \& c t=c \ln k \& g l=s g$.

70 See e.g., Ping Zhang (张平), Shengwu Yixue Lingyu zhong de Zhishi Chanquan Baohu (生物医学领域中的知识 产权保护) [Intellectual Property Protection in Biomedicine Field], 39 JournAL OF PEKIng UnIVERSITY (HEALTH SCIENCES) 101, 104 (2007); Deming Liu, Now the Wolf Has Indeed Come! Perspective on the Patent Protection of Biotechnology Inventions in China, 53 THE AMERICAN JournaL OF COMPARATIVE LAW 207 (2005); Peter K Yu, From Pirates to Partners: Protecting Intellectual Property in China in the Twenty-first Century, 50 AMERICAN UNIVERSITY LAW 131, 189-190 (2000); Handong Wu (吴汉东), Zhishi Chanquan Zhanlüe Shishi de Guoji Huanjing yu Zhongguo Changjing (知识产权战略实施的国际环境与中国场景) [The International Environment of Implementing Intellectual Property Strategy and China's Situation], 2 FAXUE (法学) [LAW SCIENCE] 3, 7 (2012). 
patents of increasing the costs of vital medicines and agricultural inputs, particularly causing harm to poor people and farmers in developing countries. ${ }^{71}$

However, it is worth noting that developing countries are not homogeneous. They have diverse social and economic circumstances, as well as technological capabilities. ${ }^{72}$ The UK Commission on IP Rights found that there is some evidence that patent protection becomes crucial only at the stage when a country is well into the category of upper middle income developing countries. ${ }^{73}$ In other words, patents benefit, especially in the form of promoting inventions and technological innovation, only technologically advanced developing countries. ${ }^{74}$ Instead, for technologically deprived countries, in order to gain an opportunity to enjoy, at no cost, the technological innovations of others, providing no patent protection would be an optimal national strategy. ${ }^{75}$ Moreover, a study on genomic medicine in three developing countries, Mexico, India and Thailand, showed that patent protection is crucial to the establishment of a private sector and the commercialization of products in these countries. ${ }^{76}$ Another study on Brazil's biotech industry pointed out that patents are crucial to health biotechnology development, and an inefficient patent system fails to encourage local innovation in Brazil. ${ }^{77}$ Despite being a developing country, through decades of development China already possesses a relatively advanced capability in scientific and technological areas, including biotechnology. ${ }^{78}$ In this regard, Professor Yahong Li considers patents to be indispensable to stimulate innovation in present China. ${ }^{79}$ Moreover, it has been widely accepted in China that patents are related to the advancement of research and industry, including the biotechnology industry, and the promotion of the wellbeing of society.

Consequently, although the impact of patents on developing countries is still under controversy, there is increasing evidence that patents have become of importance to the biotechnology industry in more technologically advanced developing countries. Remarkably, on the one hand patent rights may be important to the growth and financing of the Chinese biotechnology industry, but on the other hand, since as Li has already pointed out, patents may hinder developing countries from gaining access to technolo-

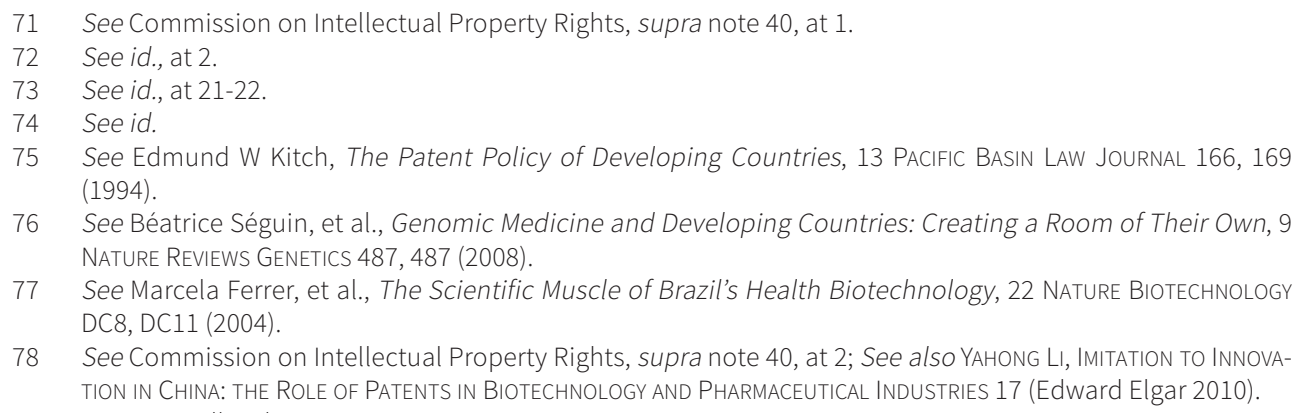

76 See Béatrice Séguin, et al., Genomic Medicine and Developing Countries: Creating a Room of Their Own, 9 NATURE REVIEWS GENETICS 487, 487 (2008).

77 See Marcela Ferrer, et al., The Scientific Muscle of Brazil's Health Biotechnology, 22 NATURE BIOTECHNOLOGY DC8, DC11 (2004).

78 See Commission on Intellectual Property Rights, supra note 40, at 2; See also YAHONG LI, ImITATION TO INNOVA-

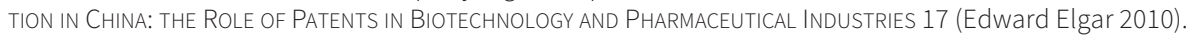

79 See generally, id. 
gies that are required for their development, achieving a fair balance between patent rights and the need to access knowledge and technologies would be vital for China, and meanwhile may difficult for Chinese policy makers. ${ }^{80}$

\section{BIOTECHNOLOGY AND HESC TECHNOLOGY}

As one can see from the above, patent protection is of importance to creation and innovation in research and industry, especially regarding the field of biotechnology. However, over the last several decades, biotechnology has experienced extremely rapid development, and the striking changes in it pose a formidable challenge to patent law. One of the more recent and controversial areas of patenting biotechnology is that of hESC research and technology. A brief investigation of the rise of modern or advanced biotechnology is helpful to understand the challenges that this field has brought to patent law. In this regard, this section first provides a concise history of the manipulation of biotechnology (Sect. 3.1). Importantly, the patent regime cannot work well unless it respects the key characteristics of the research field and industry in which patents are important. Any effort to alter or reform legal rules and policies concerning patents cannot ignore the nature of the technologies which patents affect. ${ }^{81}$ In this regard, before tackling the topic of patenting hESC-related inventions, it is useful to provide the general reader with some scientific background relating to human embryonic development and the production of hESCs, as well as the practical applications of hESCs (Sect. 3.2). Moreover, this section delineates possible alternative sources of hESCs, and discusses the need for conducting hESC research, particularly compared with the alternative sources as mentioned, which is helpful to understand why the debate over the patenting of hESC-related inventions continues to be so fierce and special.

\subsection{The Rise of Modern or Advanced Biotechnology}

Biotechnology refers to a wide range of techniques which use or modify biological material, microorganisms or animals, or modify inorganic material with biological methods. ${ }^{82}$ In effect, biotechnology has been used for millennia, such as the use of microorganisms and metabolic products in vinting, brewing, baking etc. to wine, cheese, or bread. ${ }^{83}$ For thousands of years, humans have manipulated the genetic material of living organisms

\footnotetext{
80 See id., at 17.

81 See Roger Brownsword, et al., Human Genetics and the Law: Regulating a Revolution, 61 THE MODERN LAW REVIEW 593, 595 (1998). See also MILLS, supra note 1, at 1.

82 In accordance with the Convention on Biological Diversity (Rio de Janeiro, 5 June 1992), "biotechnology means any technological application that uses biological systems, living organisms, or derivatives thereof, to make or modify products or processes for specific use." See also Ko, supra note 37, at 783 ("biotechnology is the science of manipulating and modifying the genetic make-up of living matter"); STAZI, supra note 1 , at 1 .

83 See Andreas hübel, et al., Biopatent LaW: Patent Strategies and Patent Management 1 (Springer Science \& Business Media 2012); MILLS, supra note 1, at 8.
} 
through selective breeding only. This is regarded as traditional biotechnology. Over the last century, with the revolution of technology, many new biotechnological methods and products have arisen.

In 1928 a Scottish scientist, Alexander Fleming, discovered penicillin (the first antibiotic), the serendipitous observation of which began the modern era of antibiotic discovery. ${ }^{84}$ Upon figuring out the double helix structure of DNA in the 1950s, characterizing the basic principles of genetic information, such as the genetic code and messenger RNA, became reality. ${ }^{85}$ Subsequently, after the first gene transfer into Escherichia coli in $1973,{ }^{86}$ gene transfer in microbes, animal and plant cells became a well-established biotechnology. ${ }^{87}$ Since then, several fundamental methods in biotechnology have been developed, such as gene transfer in higher plants or vertebrates, sequencing of genes and entire genomes, and cloning of animals. And recently, the clustered regularly interspaced short palindromic repeats (CRISPR) and CRISPR- associated protein 9 (Cas9) system (CRISPR/Cas9) has become available for easy genome editing both in vitro and in vivo. ${ }^{88}$ Technological breakthroughs have provided new possibilities in ways of modifying living organisms. ${ }^{89}$

Advanced biotechnology has been playing an increasingly significant role in the field of healthcare, agriculture and environment. There is no doubt that biotechnology can provide technical improvements and solutions for technical problems in today's fast developing societies. ${ }^{90}$ It surely will have an ever more important impact on our way of

84 See David Ho, Bacteriologist Alexander Fleming, TIME, (Mar. 29, 1999), http://content.time.com/time/magazine/article/0,9171,990612,00.html. See also Armin Fiechter, Preface, in HISTORY OF MODERN BIOTECHNOLOGY II IX (Armin Fiechter ed., Springer 2000) (the antibiotic industry offered processing strategies for strain improvement (selection of mutants) and the search for new strains (screening) as well as the technologies for aseptic mass culture and downstream processing); Carole Bos, Alexander Fleming and Penicillin-"The Wonder Drug”, AwESOMESTORIES.COM, (May 25, 2015), https://www.awesomestories.com/asset/view/ Alexander-Fleming-and-Penicillin-The-Wonder-Drug- (Subsequently, Dr. Howard Florey and his team found a method for efficiently extracting the penicillin from the mold cultures, and tested the effectiveness of these antibiotics. In 1941, they used penicillin for human testing. In terms of patents, for ethical reasons, Florey did not apply for a patent.)

85 American biologist James Watson and English physicist Francis Crick discovered DNA in the 1950s, and held that the DNA molecule exists in the form of a three-dimensional double helix.

86 In 1973, Professor Stanley N. Cohen and his research group invented the basic technique for creating recombinant DNA. For more discussion about how to cut a gene from the DNA, how to recombine it, and how to transfer the recombinant gene into the cells of a host organism, please see Stanley N Cohen, et al., Construction of Biologically Functional Bacterial Plasmids In Vitro, 70 PROCEEDINGS OF THE NATIONAL ACADEMY OF SCIENCES 3240 (1973).

87 See Fiechter, supra note 84, at IX-X.

88 The CRISPR/Cas9 system was found as an adaptive immune system in bacteria and archaeal defending viruses and phages infection through CRISPR-associated RNA guidance and Cas9 cleavage. With the increasing demand for programmable site-specific nucleases for genome editing, the race of harnessing the CRSPR/Cas9 system has been greatly accelerated. See Yaojin Peng, The Morality and Ethics Governing CRISPR-Cas9 Patents in China, 34 NATURE BIOTECHNOLOGy 616, 616 (2016).

89 See MILLS, supra note 1 , at 8-9.

90 See HüBEL, et al., supra note 83 , at 2. 
life. Yet, as shown above, in the long history of the manipulation of biotechnology, only in the last several decades have humans managed to manipulate and alter biological matter at the cellular and molecular levels based on gene transfer. ${ }^{91}$ It is thus evident that over a very short period, biotechnology has been progressing with an amazing speed, from traditional to modern methods, from manipulating individual organisms to altering biological matters at the cellular and molecular levels, and it surely will advance even more rapidly in the future.

\subsection{Emerging hESC-related Technologies}

In 1998, the Thomson group at the University of Wisconsin announced the successful derivation of the first hESC line from human embryos. ${ }^{92}$ Since then, the patenting of hESC-related inventions has become one of the great challenges to patent offices and courts globally. ${ }^{93}$ This section continues to discuss scientific background relating to human embryonic development and the production of hESCs, as well as the practical applications of hESCs (Sect. 3.2.1). At the same time, Section 3.2.2 of this part delineates a number of possible alternative sources of hESCs, such as induced pluripotent stem cells (iPSCS), ANT, human embryonic germ cells (hEGCs), and human parthenogenetic stem cells (hPGSCs). Section 3.2.3 then discusses the need for conducting hESC research, particularly compared with the alternative sources as mentioned. Since this part (Sect. 3.2) only presents introductory material for a lay audience, readers who are familiar with hESC research and biotechnology may skip ahead to the next section.

\subsubsection{HESCS}

To better understand the underpinnings of hESCs and related technologies, it is essential to get familiar with the processes involved in human embryonic development, especially in the matter of blastocyst formation. A cell is regarded as the fundamental unit of life. An adult human body comprises 50 trillion cells of approximately 200 different kinds, each with a specialized function, such as eye, muscle or blood cells. ${ }^{94}$ In the beginning, a sperm and an egg unite to form a fertilized oocyte, i.e. a zygote. Then, over a matter of hours, the zygote undergoes cleavage (a series of mitotic cell divisions) into a number of small cells, which are called blastomeres. ${ }^{95}$ At this beginning period of approximately 3 or 4 days, these stem cells, including the zygote and early embryo stage

91 See Ko, supranote 37, at 783 .

92 See generally, id.

93 This thesis primarily focuses on the patenting of hESC-related inventions in the US, EU, and China. See infra Chap. 5, which will discuss in detail how this issue has been dealt with by patent offices and courts in these jurisdictions.

94 See Graeme Laurie, Patenting Stem Cells of Human Origin, 26 European INTELLECTUAL Property ReVIEW 59, 60 (2004).

95 See Keith L Moore, et Al., The Developing Human: Clinically Oriented Embryology 38 (Elsevier Sauders 9th ed. 2013). 
blastomeres, are regarded as totipotent, and each is capable of developing into all the embryonic and extra-embryonic lineages that eventually form the complete embryo. ${ }^{96}$ By days 5 to 7 , totipotency has been gradually lost and these totipotent cells begin to specialize and form a sphere with a cavity, around 100 cells, called a blastocyst.

At the blastocyst stage, the organism is composed of an inner cell mass (ICM), referred to as the embryoblast, and the outer layer of cells, called the trophoblast. ${ }^{97}$ Each cell of the ICM is pluripotent, and has the capacity to divide indefinitely and generate all cell types arising from the three germ layers (ectoderm, mesoderm, and endoderm) ${ }^{98}$ The trophoblast eventually gives rise to the placenta, chorion, and the umbilical cord.$^{99}$ In fact, hESCs are derived from the ICM at the blastocyst stage. ${ }^{100}$ The first hESC line was derived successfully by the Thomson group in 1998 at the University of Wisconsin. ${ }^{101}$ Thus, hESCs essentially are pluripotent cells, incapable of forming separate embryos. ${ }^{102}$ In other words, hESCs have the ability to develop into most tissue types, but they cannot, on their own, form into a human being. ${ }^{103}$

\subsubsection{Properties and Potential Applications of hESCS}

Since hESCs are derived from the ICM and are one type of pluripotent stem cell, they possess two unique characteristics which make them so remarkable: potentially unlimited capacity for self-renewal, and plasticity. First, hESCs have the ability to divide

96 See Nikica Zaninovic, et al., Derivation of Human Embryonic Stem Cells (hESC), in HUMAN FERTILITY: METHODS AND PROToCols 121 (Zev Rosenwaks \& Paul M Wassarman ed., Springer 2014); Laurie, supra note 94, at 60. Since totipotent cells possess the capacity of developing into entire human embryos and potentially human beings, they may be construed as containing human beings. In this regard, in many jurisdictions, such as in the US, EU, and China, totipotent stem cells cannot be patented. See infra Sects. 2.2.1.1 and 2.3.2.1.3, Chap. 5. In China, Part II, Chap. 10, Sect. 9.1.1.2 of the SIPO's Guidelines provides that "the human body, at the various stages of its formation and development, including a germ cell, an oosperm, an embryo and an entire human body shall not be granted the patent right in accordance with the provisions of Article 5(1) [of the CPL]."

97 See Tandis Vazin \& William J Freed, Human Embryonic Stem Cells: Derivation, Culture, and Differentiation: A Review, 28 Restorative NeuRology And NeURoscience 589, 589 (2010); Zaninovic, et al., supra note 96, at 124.

98 Moreover, aside from totipotent and pluripotent stem cells in organisms, multipotent and unipotent cells are the other two stem cell types. See Zaninovic, et al., supra note 96, at 121.

99 See Vazin \& Freed, supra note 97 , at 589.

100 See James A Thomson, et al., Embryonic Stem Cell Lines Derived from Human Blastocysts, 282 SCIENCE 1145,1145 (1998).

101 See generally, id.

102 See Laurie, supra note 94, at 60 (stating that "as time passes, the organism-which we might now wish to call an embryo-will continue to grow so long as it is furnished with an appropriate environment and nutrition. These are provided by implantation in the lining of the womb, from which a blood supply can be drawn (occurring around day 8 of development). It is arguable that it is not until this point that the organism achieves the potential for 'humanness'- a distinction which is very important in one's consideration of the status of the embryo in the petrie dish.")

103 See Erin P George, The Stem Cell Debate: The Legal, Political and Ethical Issues Surrounding Federal Funding of Scientific Research on Human Embryos, 12 AlBANy LAW JoURnAL OF SCIENCE \& TeCHNOLOgy 747, 777 (2001). To see how the key scientific issue, that an entity does not have the capability of developing into a human being, affects the patent eligibility of hESC-related inventions, please read the legal analysis in infra e.g., Sects. 3.2.5.3, 3.3.4, 4, 5.3.2.1, Chap. 5. 
and self-replicate for unlimited periods, sometimes even after long periods of inactivity. They can be cultured in vitro and expanded in unlimited numbers in a primitive, undifferentiated state (retaining pluripotency), even if they are cultured in vitro throughout a long period. ${ }^{104}$ Put another way, under certain appropriate conditions, hESCs are able to proliferate indefinitely in an undifferentiated state and still retain their pluripotency. Second, as pluripotent stem cells, hESCs can be induced to differentiate into particular cell and tissue types under defined conditions. ${ }^{105}$

Based on their capacity of self-renewal, and their ability to give rise to differentiated progeny, ${ }^{106}$ hESCs and their differentiated cell lines are considered to be of great importance in regenerative medicine, cell replacement therapy, and investigating disease mechanisms, as well as drug discovery and testing. ${ }^{107}$ The greatest therapeutic promise of hESCs is to give rise to particular cells to replace ailing or destroyed tissues in patients who are suffering from diverse degenerative diseases. ${ }^{108}$ Also, hESCs can be used to treat a range of blood and genetic disorders related to the immune system, cancers, and other disorders. It is expected that hESCs will be used to treat neurological diseases and injuries, such as Parkinson's disease, and spinal cord trauma. ${ }^{109}$ Additionally, hESCs can be used as tools for studying the complicated mechanisms concerning the growth of particular cells and establishment of organ structures, or as models for further understanding cancer and disease progression. Aside from the promise in regenerative medicine and investigating disease mechanisms, hESCs also possess tremendous potential in other areas, such as being used for toxicological testing and drug design. Testing of new drugs and toxicological agents could be conducted on hESCs instead of animals or humans, which could reduce the number of animals required for experiments of toxicity and pharmacology studies.

104 See Martin F Pera, et al., Human Embryonic Stem Cells, 113 JournAL OF CELL SCIENCE 5, 5 (2000); Vazin \& Freed, supra note 97 , at 589.

105 See European Group on Ethics in Science and New Technologies (EGE), Opinion No. 16: Ethical Aspects of Patenting Inventions Involving Human Stem Cells, 4 (May. 7, 2002), http://biotech.bioetica.org/new/ ege16_complet_en.pdf; NIH, Stem Cell Basics I (2009), STEM CELL INFORMATION, http://stemcells.nih.gov/info/ basics/pages/basics1.aspx.

106 See Zaninovic, et al., supra note 96, at 121.

107 See e.g., Sharon Gerecht-Nir \& Joseph Itskovitz-Eldor, The Promise of Human Embryonic Stem Cells, 18 BEST PRACTICE \& RESEARCH Clinical OBSTETRICS \& GYNAECOLOGY 843 (2004); Sharon Gerecht-Nir \& Joseph ItskovitzEldor, Cell Therapy Using Human Embryonic Stem Cells, 12 Transplant Immunology 203 (2004); Michal Golan-Mashiach, et al., Design Principle of Gene Expression Used by Human Stem Cells: Implication for Pluripotency, 19 THE FASEB Journal 147 (2005); EGE, supra note 105, at 4; NIH, Stem Cell Basics VII (2009), STEM CELL INFORMATION, https://stemcells.nih.gov/info/basics/7.htm.

108 See Vazin \& Freed, supra note 97, at 589; Shulamit Levenberg, et al., Endothelial Cells Derived from Human Embryonic Stem Cells, 99 ProceEdings of THE nATIONAL ACADEMY of SCIENCES 4391, 4391 (2002) (stating that "human embryonic stem cells have the potential to differentiate into various cell types and, thus, may be useful as a source of cells for transplantation or tissue engineering.")

109 See Olle Lindvall, et al., Stem Cell Therapy for Human Neurodegenerative Disorders-How to Make It Work, 10 NATURE MEDICINE S42, S42 (2004); Thomson, et al., supra note 100, at 1147. For more applications envisioned for hESCs, please see Pera, et al., supra note 104, at 5. 
Some potential applications of hESCs have already been realized and put into practice. ${ }^{110}$ However, more effort is required to overcome technical obstacles, like developing the ability to control the differentiation of stem cells into a desired cell type (like a heart or nerve cell) and to avoid undesired adverse effects, such as cancer and immune rejection. ${ }^{111}$ Even so, hESC research has attracted massive media attention and already given a glimmer of hope for the sufferers of serious illness and injury around the world. ${ }^{112}$ There is no doubt that hESCs and related research are playing an increasingly important role in our modern life.

\subsubsection{Derivation of hESCs and the Destruction of Embryos}

The standard method of deriving hESCs involves isolating cells from the ICM of the blastocyst, via immunosurgical or mechanical isolation or by whole embryo culture with subsequent isolation of the ICM outgrowth. ${ }^{113}$ In the process of deriving hESCs, the trophoblast layer of the blastocyst is selectively removed, and the ICM is further cultured for deriving hESCs. As a result, the human embryo used as the source for the ICM at the blastocyst stage is destroyed. ${ }^{114}$ It is important to make clear here that the blastocyst,

110 For instance, in February 2012, a Japanese research team, led by professor Jun Takahashi of Kyoto University's Institute for Frontier Medical Sciences, announced improvement in the symptoms of Parkinson's disease in monkeys by transplanting nerve cells created from hESCs into their brains. See Stacy Pyre, Stem Cell for Parkinson's Disease? Prof. Jun Takahashi Study-Kyoto University, STEm CELL TherAPy JournaL, (Mar. 14, 2012), http://stemcelltherapyreviewjournal.com/stem-cells-can-treat-parkinsons-prof-jun-takahashikyoto-university-study/. Currently, in the US, FDA-approved clinical trials using hESCs involve the treatment of macular degeneration. See Steven D Schwartz, et al., Embryonic Stem Cell Trials for Macular Degeneration: A Preliminary Report, 379 THE LANCET 713 (2012). See also Safety and Tolerability of Sub-retinal Transplantation of Human Embryonic Stem Cell Derived Retinal Pigmented Epithelial (hESC-RPE) Cells in Patients With Stargardt's Macular Dystrophy (SMD), CLINICALTRIALs.Gov, https://clinicaltrials.gov/show/ NCT01469832; Steven D Schwartz, et al., Human Embryonic Stem Cell-derived Retinal Pigment Epithelium in Patients with Age-related Macular Degeneration and Stargardt's Macular Dystrophy: Follow-up of Two Open-label Phase 1/2 Studies, 385 THE LANCET 509 (2015) (which has proved the medium- to long-term safety of cells derived from hESCs transplanted into patients.) Geeta Shroff \& Petra Hopf-Seidel, Use of Human Embryonic Stem Cells in the Treatment of Parkinson's Disease: A Case Report, 17 INTERNATIONAL Journal of EmERgency Mental HeAlth and Human ResilienCE 661, 661(2015) (indicating that heSC therapy showed beneficial effects in a patient with Parkinson's disease.)

111 See Judith A Johnson \& Edward C Liu, Stem Cell Research: Science, Federal Research Funding, and Regulatory Oversight, 7 (Jan. 17, 2012), https://www.hsdl.org/?view\&did=707460.

112 See Gerard Porter, The Drafting History of the European Biotechnology Directive, in EMBRYONIC STEM CELL PATENTS: EuROPEAN LAW AND ETHICS 23 (Aurora Plomer \& Paul Torremans ed., Oxford University Press 2009).

113 See Zaninovic, et al., supra note 96, at 125. For more information about immunosurgical ICM isolation of hESCs, please see Thomson, et al., supra note 100. For more information about mechanical ICM isolation of hESCs, please see e.g., Shin Yong Moon, et al., Generation, Culture, and Differentiation of Human Embryonic Stem Cells for Therapeutic Applications, 13 Molecular Therapy 5 (2006); Hee Sun Kim, et al., Methods for Derivation of Human Embryonic Stem Cells, 23 STEM CELLS 1228 (2005); Michal Amit \& Joseph Itskovitz-Eldor, Derivation and Spontaneous Differentiation of Human Embryonic Stem Cells, 200 JournaL OF ANATOMy 225 (2002). Concerning derivation of hESCs via whole embryo culture, please see Kim, et al., STEM CELLS (2005); Nico Heins, et al., Derivation, Characterization, and Differentiation of Human Embryonic Stem Cells, 22 STEM CELLS 367 (2004).

114 SeeVazin \& Freed, supra note 97, at 591 ("Generation of hESC lines from the inner cell mass at the blastocyst stage has thus far obligated the destruction of the embryo.") See also T 2221/10 (Culturing stem cells/ TECHNION) [2014], at 11. 
from which hESCs are derived, has no recognizable human features or form. ${ }^{115}$ It is in such an early stage of embryonic development that the cells it contains have not yet differentiated, or taken on the properties of any specialized organs or tissues. ${ }^{116}$ But even so, due to the necessity of the use and destruction of human embryos, hESC research has raised potential ethical and political concerns. ${ }^{117}$ In order to circumvent ethical or moral issues of hESC research, scientists around the world have either attempted to find other approaches to generate hESC lines without destroying human embryos, or tried to figure out alternative sources so as to replace hESC research. ${ }^{118}$

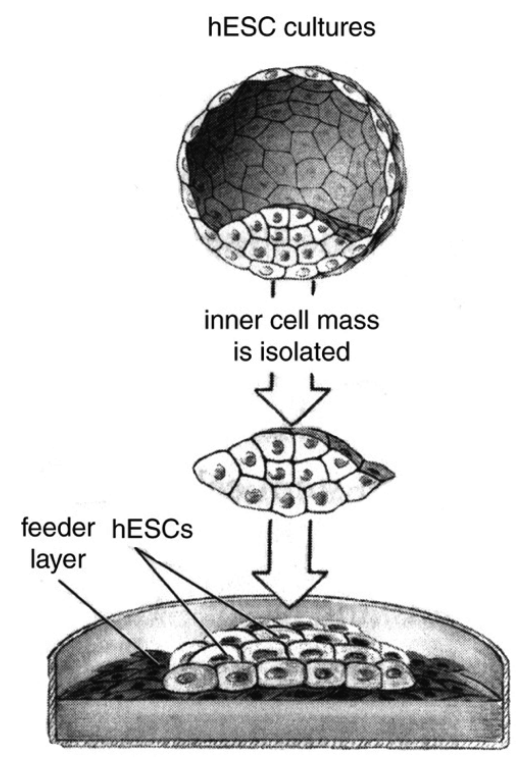

Figure 1: The Thomson process derives an hESC line by removing cells of the ICM and plating them on a fibroblast feeder layer. ${ }^{119}$

Besides the standard method of deriving hESCs from the ICM at the blastocyst stage, scientists have attempted to derive hESCs from several pre-blastocyst stages: morula, cleavage embryos and even isolated blastomeres. Some scientists claim to have discovered a method of isolating one cell from a single blastomere at the 8-cell or morula

115 See Michael J Sandel, The Case Against Perfection: Ethics in the Age of Genetic Engineering 112-113 (Belknap Press of Harvard University Press 2007).

116 See id., at 113.

117 In terms of the discussion of the moral concerns and debate about hESC research in general, please see infra Sect. 4.2, Chap. 2. Moreover, this thesis will discuss in detail later the issues involved in the political concerns about hESC research and the relevant regulatory approaches; see infra Chap. 4.

118 Concerning several typical alternative sources to replace $h E S C$ research, the thesis will briefly discuss them later in this section; see infra Sect. 3.2.2, Chap. 2.

119 See Figure 1 in Kenneth S Taymor, et al., The Paths around Stem Cell Intellectual Property, 24 NATURE BIOTECHNOLOGY 411 (2006). 
stage to form an hESC line, with using culture media supplemented with laminin. It has also been proposed that a biopsied human embryo could continue to develop into a blastocyst. ${ }^{120}$ This approach to creating hESC lines is regarded as just as efficient as conventional methods employed to retrieve hESC lines from blastocysts. ${ }^{121}$ Thus, blastomere-derived hESC may find a solution to the inherent ethical hurdles that people encounter in "destroying the embryo". However, it is unsure whether a biopsied embryo will indeed remain viable, ${ }^{122}$ and the single cell isolated from a blastomere is, in effect, a totipotent stem cell, which could still theoretically develop into a human being, thus these blastomere-derived hESC lines may still raise the same ethical concerns as blastocyst-derived hESC lines. Moreover, it is still unknown whether there are possible differences between hESC lines derived from totipotent blastomeres and those from pluripotent blastocyst ICM cells. ${ }^{123}$

\subsubsection{Sources of Embryos for Deriving hESCs}

HESC lines can be derived from several sources of embryos. One of the major sources of embryos for deriving hESC lines is surplus embryos donated by in vitro fertilization (IVF) patients. ${ }^{124}$ Specifically, embryos that have been created by IVF of infertile couples may be left over, primarily because more embryos are created for an infertility treatment than normally necessary. ${ }^{125}$ Then the couples could choose to donate these surplus IVF embryos for use in hESC research. It is worth mentioning here that these embryos are viable and could result in birth if implanted into a uterus. ${ }^{126}$

120 See e.g., Young Chung, et al., Human Embryonic Stem Cell Lines Generated Without Embryo Destruction, 2 CELL STEM CELL 113 (2008); Martin H Johnson, Human ES Cells and a Blastocyst from One Embryo: Exciting Science but Conflicting Ethics?2 CeLL STEM CELL 103 (2008); Dusko Ilic, et al., Derivation of Human Embryonic Stem Cell Lines from Biopsied Blastomeres on Human Feeders with Minimal Exposure to Xenomaterials, 18 STEM CELLS AND DEVELOPMENT 1343 (2009).

121 See Vazin \& Freed, supra note 97 , at 591.

122 See Zaninovic, et al., supra note 96, at 129. See also Sven Bostyn, et al., Final Report of the Expert Group on the Development and Implications of Patent Law in the Field of Biotechnology and Genetic Engineering, 163-164 (May 17, 2016), https://www.ivir.nl/publicaties/download/Report-of-Biotech-Expert-Group.pdf.

123 See Zaninovic, et al., supra note 96, at 129.

124 See e.g., Thomson, et al., supra note 100, at 1147; Benjamin E Reubinoff, et al., Embryonic Stem Cell Lines From Human Blastocysts: Somatic Differentiation in vitro, 18 NATURE BIOTECHNOLOGY 399 (2000); Susan E Lanzendorf, et al., Use of Human Gametes Obtained from Anonymous Donors for the Production of Human Embryonic Stem Cell Lines, 76 FERTILITY AND STERILITY 132 (2001); Amit \& Itskovitz-Eldor, supra note 113; Johnson \& Liu, supra note 111 (pointing out that nowadays the majority of hESC lines used in research are obtained from embryos produced via IVF.)

125 See Danish Council of Ethics, The Ethics of Patenting Human Genes and Stem Cells (Conference Report and Summaries), 83 (2004), http://etiskraad.dk/en/Udgivelser/ /media/bibliotek/rapporter/2004/2004Patenting-Human-Genes-and-Stem-Cells.ashx. See also EmILY Jackson, Regulating Reproduction: LAW, TECHNOLOGY AND AUtONOMY 230 (Hart Publishing 2001) ("given the imprecision of IVF, it would also be impossible to fertilise only the exact number of eggs that will be transferred to the woman's uterus in any one treatment cycle.") Moreover, conducting pre-implantation genetic diagnosis (PGD) upon embryos may lead to the identification of chromosomal abnormalities, and make these embryos medically unsuitable for clinical use. See NIH, National Institutes of Health Guidelines on Human Stem Cell Research, US DEPARTMENT OF HEALTH \& HUMAN SERVICES, (2016), http://stemcells.nih.gov/policy/pages/2009guidelines.aspx. 
Another important potential source of deriving hESC lines is the process of somatic cell nuclear transfer (SCNT) or cloning, which is used to create a viable embryo from a somatic cell and an oocyte. Within the SCNT technique, a somatic cell nucleus is implanted into an enucleated oocyte, and then the somatic cell nucleus is reprogrammed by the host oocyte and re-enters a state like that of a naturally fertilized zygote. ${ }^{127}$ The created zygote is capable of forming an embryo via electrical stimuli. Accordingly, a cloned embryo is created, and it can be used to derive hESCs. However, as can be seen, the derivation of hESCS via SCNT requires cloning an embryo first and then destroying the embryo. As such, it raises the same, sometimes much greater, moral concerns as deriving hESCs from surplus IVF embryos. ${ }^{128}$ In order to bypass the moral concerns, reprogramming adult somatic cell nuclei to a pluripotent state by fusion with hESCs has been proposed. ${ }^{129}$ But it has proven to be difficult to isolate the hESC-derived nuclei efficiently from such tetraploid "stembrids" and get a cell line with a normal karyotype and the genotype of the somatic cell donor. ${ }^{130}$

In addition, there are some other sources for deriving hESCs, such as poor morphological quality embryos (either slow developing or with suboptimal morphology) which have been discarded or donated, ${ }^{131}$ mono-pronuclear human zygotes, ${ }^{132}$ and triploid embryos formed by an extra set of male or female chromosomes. ${ }^{133}$ Nevertheless, almost all of these sources need the creation of a zygote or a human (or triploid) embryo first, then the destruction of the zygote and embryo. Thus far, surplus IVF embryos and embryos created via SCNT specifically for hESC research are the two primary sources for creating hESC lines, and these two are often at the heart of moral, political and legal debate.

127 See Mahendra Rao \& Maureen L Condic, Alternative Sources of Pluripotent Stem Cells: Scientific Solutions to An Ethical Dilemma, 17 Stem Cells and Development 1, 2 (2008).

128 Seeid.

129 See generally, Danièle Pralong, et al., Cell Fusion For Reprogramming Pluripotency: toward Elimination of the Pluripotent Genome, 2 Stem Cell Reviews 331 (2006); Yury Verlinsky, et al., Cytoplasmic Cell Fusion: Stembrid Technology for Reprogramming Pluripotentiality, 2 STEM CELL REVIEWS 297 (2006).

130 See Rao \& Condic, supra note 127 , at 2.

131 See e.g., Maisam Mitalipova, et al., Human Embryonic Stem Cell Lines Derived from Discarded Embryos, 21 STEM CELLS 521 (2003); Xin Zhang, et al., Derivation of Human Embryonic Stem Cells from Developing and Arrested Embryos, 24 STEm Cells 2669 (2006); Hong Chen, et al., The Derivation of Two Additional Human Embryonic Stem Cell Lines from Day 3 Embryos with Low Morphological Scores, 20 HUMAN REPRODUCTION 2201 (2005); Donald W Landry \& Howard A Zucker, Embryonic Death and the Creation of Human Embryonic Stem Cells, 114 Journal of Clinical InVESTIGATION 1184 (2004) (Donald and Howard have suggested that hESCs could be derived from clinically dead embryos, which fail to develop normally and are discarded.)

132 See generally, Jacob Levron, et al., Male and Female Genomes Associated in A Single Pronucleus in Human Zygotes, 52 Bıology of ReProduction 653 (1995); Edith Suss-Toby, et al., Derivation of a Diploid Human Embryonic Stem Cell Line from A Mononuclear Zygote, 19 HumAn REPRODUCTION 670 (2004).

133 See Hossein Baharvand, et al., Generation of New Human Embryonic Stem Cell Lines with Diploid and Triploid Karyotypes, 48 DeVELoPMENT, GROWTH \& DifFERENTIATION 117 (2006) (this source for deriving hESC lines has been proved to possess normal hESC characteristics and the ability to differentiate in vitro.) 


\subsubsection{Possible Alternative Sources of hESCs}

As mentioned previously, based on the necessity of the use and destruction of human embryos, hESC research has raised heated ethical concerns, which further leads to political and legal debates. In order to sidestep ethical or moral issues of hESC research, in addition to trying to find other approaches to generate hESC lines without destroying human embryos, much work has been devoted to alternative sources of stem cells than hESCs, particularly those sources that do not require destroying human "life". ${ }^{134}$ The advantages and drawbacks of these alternatives, from both practical and ethical perspectives, are discussed briefly below.

\subsubsection{Induced Pluripotent Stem Cells}

Induced pluripotent stem cells (iPSCs), embryonic-like stem cells, were first established by two research groups in $2007 .{ }^{135}$ In the process of making human iPSCS (hiPSCs), scientists just use several transcription factors to reprogram somatic cells, such as hair keratinocytes or blood cells, ${ }^{136}$ rather than using human embryos. Accordingly, the derivation of hiPSCs is not necessarily in connection with invasive procedures, ${ }^{137}$ and it is proposed that hiPSC approach could circumvent the ethical obstacles raised by hESC research. Besides the reduced moral concerns over hiPSCs, there appears to be another critical advantage of hiPSCs over hESCs. Since the generation of hiPSCs can use somatic cells from the patients themselves, the transplanted cells or tissues created by hiPSCs would theoretically not be identified as foreign and would thus be less prone to rejec-

134 See Presedent's Council on Bioethics, A White Paper: Alternative Sources of Human Pluripotent Stem Cells, (May 2005), https://bioethicsarchive.georgetown.edu/pcbe/reports/white_paper/index.html (discussing the ethical and scientific soundness of alternative sources of human pluripotent stem cells, including pluripotent stem cells derived from "dead" embryos; pluripotent stem cells via blastomere extraction from living human embryos, i.e., extracting a few stem cells from the pre-blastocyst embryo while retaining its viability; pluripotent stem cells derived from biological artifacts, i.e., artificial, "less than human" embryos similar enough to "true" human embryos to derive pluripotent stem cells from them; and pluripotent stem cells derived from somatic cell dedifferentiation, i.e., reprogramming differentiated adult stem cells to restore an undifferentiated pluripotency typical of embryonic stem cells). See also Domestic Policy Council, Advancing Stem Cell Science Without Destroying Human Life, THE WHITE HOUSE, (Apr. 2007), https:// georgewbush-whitehouse.archives.gov/dpc/stemcell/2007/.

135 See Kazutoshi Takahashi \& Shinya Yamanaka, Induction of Pluripotent Stem Cells from Mouse Embryonic and Adult Fibroblast Cultures by Defined Factors, 126 CELL 663 (2006) (they generated iPSCs in mice by the expression of the transcription factors Oct4, Sox2, Klf4, and c-Mcy in somatic cells); Kazutoshi Takahashi, et al., Induction of Pluripotent Stem Cells from Adult Human Fibroblasts by Defined Factors, 131 CELL 861 (2007) (they successfully generated human iPS cells by reprogramming differentiated human somatic cells); Junying Yu, et al., Induced Pluripotent Stem Cell Lines Derived from Human Somatic Cells, 318 SCIENCE 1917 (2007) (they announced success in reprogramming human cells, again by inserting four factors, but two of the factors are different from those Yamanaka used.)

136 See Takahashi, et al., supra note 135 (Scientists reprogram somatic cells to generate iPS cells, with four transcription factors, such as Oct-4, Klf-4, Sox-2, and c-Myc.)

137 See Atara Novak, et al., Enhanced Reprogramming and Cardiac Differentiation of Human Keratinocytes Derived from Plucked Hair Follicles, Using a Single Excisable Lentivirus, 12 CelluLAR Reprogramming 665 (2010); Alexandra Haase, et al., Generation of Induced Pluripotent Stem Cells from Human Cord Blood, 5 CELL STEM CELL 434 (2009). 
tion by the patient's immune system. ${ }^{138}$ Given this, there are many individuals against hESC research, contending that "scientific reasons alone will now incline even the most willful researchers to leave the human embryo alone.... [The iPS technique] is so simple and powerful. The embryonic stem cell debate is over." ${ }^{39}$ However, others consider it premature to cease research on hESCs, although development of iPSCs may reduce the demand for hESC research. ${ }^{140}$ Moreover, it has been found that isogenic iPSCs may still provoke an immune response. ${ }^{141}$ Immune intervention in the recipient host may still be necessary for successful hiPSCs grafts. ${ }^{142}$ Currently, researchers are in the process of searching for other, safer factors or exploring chemical methods for achieving the same results. $^{143}$

\subsubsection{Altered Nuclear Transfer}

Altered nuclear transfer (ANT) is a variation on the theme of adult cell reprogramming, which was proposed by Dr. William Hurlbut at first for obtaining pluripotent stem cells without destroying the embryo. ${ }^{144}$ It is proposed that ANT should also use the technology of SCNT, but with the somatic cell nucleus inserted into the oocyte after first altering the somatic cell nucleus or the cytoplasm of the enucleated oocyte, or both. By creating such alterations, no embryo will be generated, but pluripotent stem cells will be made. ${ }^{145}$ Stem cells produced by ANT will be genetically similar to the donor of the somatic cell nucleus, and thus might be differentiated into immune-compatible cells for patient-specific tissue transplantation. ${ }^{146}$ However, the feasibility of the proposed ANT has been questioned. ${ }^{147}$ Also, it is still unclear whether ANT actually prevents embryogenesis rather than creating a defective embryo. ${ }^{148}$ More importantly, it is hard to say that a defective embryo would not raise any moral or political concerns, since

138 See Tongbiao Zhao, et al., Immunogenicity of Induced Pluripotent Stem Cells, 474 NATURE 212, 212 (2011); Lili Barad, et al., Human Embryonic Stem Cells vs Human Induced Pluripotent Stem Cells for Cardiac Repair, 30 CANADIAN JOURNAL OF CARDIOLOGY 1279, 1281 (2014).

139 See Charles Krauthammer, Stem Cell Vindication, THE WASHIngton Post, (Nov. 2007), http://www.washingtonpost.com/wp-dyn/content/article/2007/11/29/AR2007112901878.html.

140 See Johnson \& Liu, supra note 111, at 4. See also Constance Holden \& Gretchen Vogel, A Seismic Shift for Stem Cell Research, 319 SCIENCE 560, 561 (2008).

141 See generally, Zhao, et al., supra note 138.

142 See Barad, et al., supra note 138 , at 1281.

143 See Johnson \& Liu, supra note 111, at 4.

144 See generally, William B Hurlbut, Ethics and Embryonic Stem Cell Research: Altered Nuclear Transfer as a Way Forward, 21 BIoDRugs 79 (2007); ML Condic, Alternative Sources of Pluripotent Stem Cells: Altered Nuclear Transfer, 41 CELL PROLIFERATION 7 (2008).

145 See Hurlbut, supra note 144 , at 82.

146 Seeid.

147 See W Malcolm Byrnes, The Flawed Scientific Basis of the Altered Nuclear Transfer-oocyte Assisted Reprogramming (ANT-OAR) Proposal, 3 STEM CeLL ReVIEWs 60 (2007) (it argues that ANT is based on "a flawed understanding of stem cell biology, and emphasizes that, in this debate about embryonic stem cells, scientists must strive to accurately and realistically assess the feasibility of the embryo research strategies they propose.")

148 See generally, Condic, supra note 144. See also Rao \& Condic, supra note 127, at 4. 
a defective embryo might also be considered an embryo. Thus, scientific and moral issues in the ANT proposal still exist.

\subsubsection{Human Embryonic Germ Cells}

Human embryonic germ cells (hEGCs) also are one type of pluripotent stem cells, and are regarded as another alternative source of hESCs. ${ }^{149} \mathrm{HEGCs}$ are derived from embryos at 5-9 weeks after fertilization, ${ }^{150}$ or from primordial germ cells found in the gonadal ridge of a later embryo that give rise to the reproductive cells (i.e., sperm cells or oocytes). ${ }^{151}$ HEGCs may be genetically identical to the donor, and therefore might serve as a customized source for patient-specific tissue- or cell-replacement therapies. ${ }^{152}$ However, compared with hESCs, it seems that hEGCs are not as easy to propagate, or do not have the same degree of self-renewal as hESCs. ${ }^{153}$ There might be differences between hESC and $\mathrm{hEGC}$ lines as a result of genomic imprinting. ${ }^{154}$ More importantly, the derivation of hEGCs still requires manipulating embryos which are even much more mature than those used for the derivation of hESCs. In this regard, the process of deriving hEGCs may still raise ethical concerns similar to those for hESCs, and even more serious ones.

\subsubsection{Human Parthenogenetic Stem Cells}

Human pluripotent stem cells derived by a method called parthenogenesis ${ }^{155}$ can be another alternative source of hESCs derived from typical human embryos. ${ }^{156}$ As mentioned

149 See Yuqiong Pan, et al., In Vitro Neuronal Differentiation of Cultured Human Embryonic Germ Cells, 327 Biochemical and BIOphysical ReSEARCH COMmUnications 548, 548 (2005). See generally, James A Thomson \& Jon S Odorico, Human Embryonic Stem Cell and Embryonic Germ Cell Lines, 18 TRENDS IN BIOTECHNOLogy 53 (2000).

150 See Michael J Shamblott, et al., Derivation of Pluripotent Stem Cells from Cultured Human Primordial Germ Cells, 95 ProceEdings of THE NATIONAL ACADEMy of SCIENCES 13726, 13726 (1998); Pan, et al., supra note 149, at 548.

151 See Thomson \& Odorico, supra note 149, at 53.

152 See Rao \& Condic, supra note 127 , at 4.

153 Seeid.

154 See Thomson \& Odorico, supra note 149, at 54.

155 See Nikolay Turovets, et al., Derivation of Human Parthenogenetic Stem Cell Lines, in HUmAN PLURIPOTENT STEM CELLS 38 (Philip H Schwartz \& Robin L Wesselschmidt ed., Springer 2011) (Parthenogenesis is a form of asexual reproduction occurring in nature in which females produce eggs that develop without the contribution of spermatozoa.) See also Demian D Chapman, et al., Virgin Birth in a Hammerhead Shark, 3 BIoLoGY LETTERS 425, 425 (2007) (Parthenogenesis has been documented in all jawed vertebrate lineages, such as bony fishes, amphibians, reptiles and birds, except mammals.) TAL Brevini \& F Gandolfi, Parthenotes as a Source of Embryonic Stem Cells, 41 CELL PROLIFERATION 20, 21 (2008).

156 See Qingyun Mai, et al., Derivation of Human Embryonic Stem Cell Lines from Parthenogenetic Blastocysts, 17 Cell Research 1008, 1008 (2007); ES Revazova, et al., Patient-specific Stem Cell Lines Derived from Human Parthenogenetic Blastocysts, 9 CLoning AND STEM Cells 432 (2007); Turovets, et al., supra note 155, at 37-54; Brevini \& Gandolfi, supra note 155, at 27. With regard to the patenting of inventions concerning parthenogenesis, there is an important judicial decision issued by the CJEU. The thesis will discuss this case in detail; please see infra Sect. 4.4, Chap. 5. Moreover, there is a re-examination decision concerning these inventions by the SIPO; please see infra Sect 3.3.4, Chap. 5. In these cases, particularly the definition of a human embryo, provided by the court or patent office, has significant impact on the patenting of hESC-related inventions. 
before, hESCs typically are derived from blastocysts generated by fertilized oocytes. However, through laboratory-induced parthenogenesis, scientists use chemicals to induce or "activate" human oocytes to begin developing to reach the blastocyst stage as if these oocytes had been fertilized. ${ }^{157}$ The ICM of such a human parthenogenetic blastocyst can give rise to human parthenogenetic stem cell (hPGSC) lines. ${ }^{158}$ The hPGSCs demonstrate typical characteristics displayed by hESCs, including infinite division and in vitro and in vivo differentiation into different kinds of human cells and tissues. ${ }^{159}$ Since hPGSCs do not contain male genetic materials, they match the tissue of the oocyte donor, presumably allowing for a successful stem cell transplant, and have immune-matching advantage compared with typical hESCs. ${ }^{160}$ Moreover, since an hPGSC contains no paternal genetic material, it cannot develop into a viable embryo or fetus. ${ }^{161}$ Given this, the oocytes are not fertilized, and no viable embryo is created or destroyed. The destruction of parthenogenetic "embryos" allegedly raises fewer ethical concerns than does the destruction of other human embryos.

Nevertheless, hPGSC research still confronts not only certain potential ethical concerns, but also great technical obstacles. By way of example, some ethicists, such as Mark Latkovic, have argued that since parthenogenetically activated oocytes develop in a characteristically human way, at least for several days, we should presume they are human embryos and act accordingly. ${ }^{162}$ Another example is that the definitions of human embryos in the US National Institutes of Health (NIH ${ }^{163}$ Stem Cell Guidelines and US federal law include oocytes, ${ }^{164}$ which to some extent means that isolating new hPGSCS

157 The process of inducing the oocyte to begin developing is called parthenogenetic activation. Currently, several different parthenogenetic activation techniques have been developed, such as using electrical or chemical stimuli. See Turovets, et al., supra note 155, at 38-39. See also Mai, et al., supra note 156.

158 See Turovets, et al., supra note 155, at 38; Mai, et al., supra note 156.

159 See Turovets, et al., supra note 155, at 37; Mai, et al., supra note 156.

160 See Turovets, et al., supra note 155, at 38. See also Mai, et al., supra note 156, at 1008.

161 See Brittany Daughtry \& Shoukhrat Mitalipov, Concise Review: Parthenote Stem Cells for Regenerative Medicine: Genetic, Epigenetic, and Developmental Features, 3 StEm Cells TransLATIONAL MEDICINE 290, 291 (2014) (Parthenogenetic fetuses cease development due to abnormal placental formation and other anomalies); Brevini \& Gandolfi, supra note 155, a 21 (after parthenogenetic activation, mammalian parthenotes can develop to various pre-term stages, depending on the species.)

162 See E Christian Brugger, Stem Cells and Parthenogenesis: Are Parthenotes Human Embryos? CULTURE OF LIFE Foundation, (Mar. 3, 2011), http://www.cultureoflife.org/2011/03/03/stem-cells-and-parthenogenesis-areparthenotes-human-embryos/.

163 The $\mathrm{NIH}$, one of eleven operating divisions which constitute the HHS, is in charge of allocating federal funds involving biomedical and health-related research. The NIH is composed of 27 different institutes and centers. The $\mathrm{NIH}$ budget in 2013 was $\$ 29.15$ billion. For more information please see National Institutes of Health, https://www.nih.gov.

164 Pursuant to the Dickey-Wicker Amendment, US federal law defined the phrase "human embryo or embryos" as including "any organism, not protected as a human subject under 45 CFR 46 as of the date of enactment of the Act, that is derived by fertilization, parthenogenesis, cloning, or any other means from one or more human gametes." See the Dickey-Wicker Amendment, Pub. L. No. 104-99 § 128, 110 Stat. 26, 34 (1996). The definition of human embryos in the 2009 National Institute of Health Guidelines on Human Stem Cell Research is in line with that in the Dickey-Wicker Amendment. 
may raise ethical concerns. Additionally, the process of obtaining donated oocytes may also raise ethical concerns. Besides potential ethical concerns, hPGSC research also confronts great technical obstacles. ${ }^{165}$ Unlike typical hESCs, the status of hPGSCs in vitro is not so stable, and is much easier to differentiate; thus, it is very dependent on cultural conditions and operating techniques. Moreover, creating clinical-grade cells for each patient is cost- and time- intensive. For these reasons, currently, the practical use of hPGSCs for personalized therapies is unfeasible. ${ }^{166}$

\subsubsection{Why hESC Research Is Necessary}

It seems that some alternative stem cell research, especially such as hiPSC and hPGSC research, may replace hESC research. However, it is hard to draw a definitive conclusion here, since with the development of biotechnology, everything is possible. One day this might be the case, but for the foreseeable future, side-by-side research on all types of stem cells is necessary. ${ }^{167}$ Although, as already mentioned when analyzing the possible alternative sources of hESCs, each technology has its own advantages over hESC research, so far each still has many shortcomings. It is worth stressing that stem cell research is still at a very early stage and there are lots of unknowns. ${ }^{168}$ The laboratory manipulations have not yet been perfected and can produce abnormal, potentially unsafe cells. Much more careful research is required to prove they are stable and safe. As Elisabeth Knust (a developmental biologist, as well as research group leader and a director at the Max Planck Institute of Molecular Cell Biology and Genetics) has stated, scientists are still "at the stage where [they] need to measure the potential of iPS cells against a standard, and that standard is human EC cells." 169 Moreover, it appears that these technologies cannot entirely circumvent moral issues, and they more or less cause some moral concerns. It is thus difficult for us to have sufficient reason to stop investment and abandon hESC research. It might also be noted that hESC research is happening around the world, and many countries have been providing enormous funding to this research field. Therefore, in the foreseeable future, research on hESCs is still necessary, and certainly will be ongoing until one or more alternative sources which can really replace hESCs emerge.

165 See Daughtry \& Mitalipov, supra note 161, at 296 (abnormal imprinting and high levels of homozygosity may make applications of hPGSCs in regenerative medicine complex.)

166 See id., at 290.

167 See generally, Austin Smith \& Clare Blackburn, Do We Still Need Research on Human Embryonic Stem Cells? EUROSTEMCELL, (Feb. 1, 2012), http://www.eurostemcell.org/commentanalysis/do-we-still-need-researchhuman-embryonic-stem-cells.

168 See Jane Qiu, Stem-cell Research and Regenerative Medicine in China, 3 NATIOnAL SCIENCE ReVIEW 257, 259 (2016).

169 Alison Abbott, German Science Organizations Slam European Court over Stem-cell Ruling, NATURE NEWS, (Dec. 8, 2011), 10.1038/nature.2011.9606. 
To sum up, based on hESCs' capacity for self-renewal, and their ability to give rise to almost any cell type of the body, hESC research has been considered to be of extreme significance in scientific research and health care. Although the realization of potential therapeutic benefits of hESC research still requires more efforts, and technical obstacles still need to be overcome, such research has already given people a glimmer of hope. However, the derivation of hESCs, which are considered to be a fundamental research tool in both upstream and downstream hESC research, necessitates the use and destruction of an embryo, which is normally created via IVF treatment or SCNT (or cloning). Thus, hESC research has caused fierce moral, legal and political controversies, which this thesis will return to many times. In order to circumvent moral issues raised by $\mathrm{hESC}$ research, tremendous attempts have been made to generate alternative sources of hESCs rather than using and destroying embryos. But it is arguable that currently hESCs still have their advantages over other alternative sources, and thus side-by-side research on all types of stem cells is necessary and will continue.

\section{THE MARRIAGE OF PATENT PROTECTION AND HESC TECHNOLOGY}

Based on the detailed analysis above, it is not difficult to observe in the field of hESC research that there are a number of potential hESC-related patents. On the technical side, besides the derivation of hESCs, there are several other main hESC technologies, such as the characterization, maintenance and differentiation of these cells. ${ }^{170}$ In this regard, generally hESCs, purified or isolated hESC lines, differentiated stem cells, and genetically modified stem cells, which are biological matter, may be eligible for patents. ${ }^{171}$ Moreover, various possible hESC-related processes can involve patents: ${ }^{172}$ processes for isolation of hESCs from the embryo; processes for enrichment of hESCS from a mixture of cells; processes for producing, replicating, and culturing of hESCs; processes for genetically modifying hESC for specific applications; processes for differentiating hESCs into specific cell-types for particular applications (e.g., neural or blood cells); and processes for the use of hESCs or hESC compositions (e.g., therapeutic uses of specific types of hESCs for the treatment of particular illnesses).

At the same time, hESC-related products also are candidates for patenting, such as cell culture devices, cell isolation equipment, and medical treatment instruments. Nevertheless, these products are beyond the scope of discussion of this thesis, since although they are necessary in some kind of hESC research and product manufacturing, they are general equipment or instruments and do not necessitate the use of hESCs.

\footnotetext{
170 See Vazin \& Freed, supra note 97 , at 590.

171 See EGE, supra note 105, at 11. See also Sina A Muscati, "Some More Human Than Others": Assessing the Scope of Patentability Related to Human Embryonic Stem Cell Research, JURIMETRICs 201, 205 (2004).

172 See EGE, supra note 105, at 10-11. See also Muscati, supra note 171, at 205.
} 
Moreover, organisms into which particular hESC lines have been introduced or which have engaged in some other hESC-related genetic modification may be eligible for patents. Some specific proteins and genes employed in culturing, replicating, and differentiating hESCs also can be covered by patent applications. ${ }^{173}$ However, these subject matters are also beyond the scope of this thesis's discussion, because they are entirely other categories of biotechnological products, and deserve other specific studies.

After the above sketch of possible hESC-related patents, this section continues to conduct a brief general investigation of the challenge that modern biotechnology has created to patent law (Sect. 4.1), which is helpful to understand the controversy over patenting hESC-related inventions. Since one of the most controversial issues concerning patenting hESC-related inventions is the moral issue, this section primarily focuses on moral debates in respect of hESC research and by extension patenting hESC-related inventions (Sect. 4.2).

\subsection{General Challenges of Biotechnology}

In the history of patent protection, the traditional perception of invention was conditioned by man's experience in manipulating and altering inanimate matter. ${ }^{174}$ Created products were built from simple components. ${ }^{175}$ Given this, it was reasonable that any technical application could be characterized by simply listing the structural features. ${ }^{176}$ In other words, conventionally if an invention met the requirements of being novel, containing an inventive step, and being capable of industrial application, then a patent right could be conferred. However, as shown previously in this chapter, with the advent of modern innovative or advanced techniques, researchers in the field of biotechnology have started to deal with living matter, including plants, animals, and even human beings. ${ }^{177}$ Accordingly, biotechnology poses remarkable challenges for patent law, where biotechnological inventions do not fit as neatly into the classical model as do those of a mechanical nature. ${ }^{178}$ In other words, precisely in view of this nature of the technology itself (i.e., using or manipulating living matter), together with its complexity and rapid pace of evolution, biotechnology has thrown traditional conceptions of patent law into turmoil. $^{179}$

\footnotetext{
173 Seeid.

174 See MILLS, supra note 1, at 7; STAZI, supra note 1, at 9.

175 See MILLS, supra note 1 , at 7.

176 Seeid.

177 See supra Sect. 3.1, Chap. 2.

178 See MILLS, supra note 1 , at 7.

179 See Ko, supra note 37 , at 777. STAZI, supra note 1 , at 9.
} 
The biotechnology industry first has to fight a long battle against patent law so as to attain the desired patent protection. ${ }^{180}$ In particular, great scepticism has been expressed on the patentability of biological materials in general. ${ }^{181}$ For instance, one of the biggest threats to the patentability of genetic and biological materials, in effect, comes from the requirement that the invention be regarded as a non-obvious advance in the specific field of technology compared to the prior art. Novelty and industrial applicability (utility) are also extremely important for biological materials to obtain patent protection. ${ }^{182}$ As mentioned in Chapter 1 , the thesis only focuses on the patent eligility of hESC-related inventions, and thus the key determinants in patentability, including the novelty, inventive step (non-obviousness), and industrial applicability (utility), are beyond the scope of this thesis. In terms of the patentable subject matter issue concerning biotechnological inventions, one of the most frequently mentioned challenges is that differentiating the man-made from the natural can be puzzling, since many biotechnological forms of "invented" matter, such as microorganisms, and human genes, as well as proteins, may be considered mere discoveries, rather than inventions. ${ }^{183}$ For instance, in 2013 the US Supreme Court invalidated Myriad's claims to isolated genes, holding that merely isolating genes that are found in nature does not make them patentable. ${ }^{184}$ Moreover, a monopoly on a natural product invention, such as a gene and stem cell per se which are research tools, has also raised concerns about potential hindrance of further and future research in the field of biotechnology. ${ }^{185}$

In addition, manipulating and patenting living matter may lead to concerns that such patenting contravenes basic ethical or moral norms, and thus is not permitted. Indeed, patent laws in some jurisdictions, recently, have been adjusted to take more moral considerations into account when considering the patent eligibility of claimed inventions, due to the principle of patent law that patents should not be granted for immoral inventions. ${ }^{186}$ The relationship between patent law and morality has been uncomfortable, and

180 See Thomas Gummer, Rethinking Morality: Human Embryonic Stem Cell Innovation, to Patent or Not to Patent? THE StUdent JOURNAL OF LAW (2012), https://sites.google.com/site/349924e64e68f035/issue-3/stemcells.

181 See e.g., Geertrui Van Overwalle \& Nele Berthels, Patents and Venus: About Oocytes and Human Embryonic Stem Cells, in Stem Cells and Women's Health - Cellules souches et SAnté des femmes - Stamcellen en VRouWENGEZONDHEID 147 (Anthemis-Intersentia 2007); Peter S Menell, Forty Years of Wondering in the Wilderness and No Closer to the Promised Land: Bilski's Superficial Textualism and the Missed Opportunity to Return Patent Law to Its Technology Mooring, 63 STANFORD LAW REVIEW 1289, 1291 (2011).

182 See Hector MacQueEn, et al., Contemporary Intellectual Property: LAW ANd Policy 514-521 (Oxford University Press 2008).

183 See id., at 512.

184 On this point see Association for Molecular Pathology v. Myriad Genetics, Inc., 133 S. Ct. 2107 (2013), decided on Jun. 13, 2013. This case will also be discussed later in Sect. 2.2.1.2.3, Chap. 5.

185 See supra note 182, at 513. See also supra Sect. 2.2, Chap. 2. Moreover, the thesis will discuss this point in more detail later, see infra e.g., Sects. 2.2, 4.1, and 5.3.2.3, Chap. 5.

186 See Lionel Bently \& Brad Sherman, Intellectual Property LaW 515 (Oxford University Press 4th ed. 2014). See also HÜBEL, et al., supra note 83, at v. 
patenting biotechnological inventions has produced vast difficulties for patent law. ${ }^{187}$ Particularly in recent years, serious concerns have been similarly raised in terms of patenting hESC-related inventions, the controversy over the patent eligibility of which has also proven to be fierce.

\subsection{General Moral Debate Over hESC Research and Patenting}

As mentioned above, one of the most controversial issues in the biotechnology patenting field is the moral issue. ${ }^{188}$ Patenting hESC-related inventions is no exception. In fact, the moral debate originates from hESC research and subsequently extends to the patent system. This part of the thesis first sketches the moral debate in respect of hESC research and then continues to go through the debate over patenting hESC-related inventions. The aim of this section is to provide a general picture of the moral debate over patenting hESC-related inventions, which is helpful for a thorough discussion and understanding of controversial issues in specific jurisdictions.

As indicated previously in this chapter, almost all hESC-related research is based on the employment or manipulation of hESCs, the derivation of which normally necessitates both the use and destruction of human embryos. ${ }^{189}$ British philosopher John Harris has put forward that the use or the destruction of human embryos is one of three constitutional characteristics of hESC research that invoke moral concerns from Western society. ${ }^{190}$ In general, regarding the continuous debate over hESC research, there are two juxtaposing moral positions. One position maintains resolute opposition, perceiving a human embryo as a human being or a potential human being, arguing to protect human life in all its phases, and considering interference with a human embryo to be morally unacceptable. The opposite position insists on the amelioration of human pain and suffering, and supports the use of embryos as component for hESC research and therapy. This section first sketches the moral debate in respect of hESC research from these two perspectives (Sect. 4.2.1 and Sect. 4.2.2). Then, it continues to go through the moral debate regarding patenting hESC-related inventions (Sect. 4.2.3).

\subsubsection{Resolute Opposition}

The main opposition to hESC research is based on the standpoint that destroying a human embryo is morally abhorrent, even if the embryo is in its earliest stages of development or in a test tube and not implanted in the human body, and even if for the

187 Seeid.

188 See also supra note 182 , at 521-522.

189 See supra Sect. 3.2.1, Chap. 2.

190 The other two are: the inevitable cloning of totipotent stem cells and regenerative therapy accompanying life enhancement technology. See Joy YUEYUE ZHAng, THE CosmopolitanizATIOn of SCIENCE: Stem Cell GoverNANCE IN ChInA 6 (Palgrave Macmillan 2012). 
sake of noble ends (e.g., to save or improve thousands of people's lives); it is like killing a child to save other people's lives. ${ }^{191}$ Those opponents, especially many religious and socially conservative individuals, consider research involving hESCs is morally problematic, since they hold that a human embryo, from the moment of conception, should be considered a human being, and thus be protected or worthy of respect. ${ }^{192}$ In their eyes, a human embryo possesses the same moral status as a fully developed human being. Religious beliefs often underlie this moral position, similar to the pro-life stance from the Catholic Church and Orthodox Christian groups. ${ }^{193}$ The pope, for example, has openly opposed practices that belittle human life at any stage of life, stating that "a free and virtuous society, which America aspires to be, must reject practices that devalue and violate human life at any stage from conception until natural death." ${ }^{194}$ This resolute opposition limits the use or creation of embryos only to the goal of developing into human beings, leaving no room for other purposes. ${ }^{195}$

In addition to objecting to embryo and hESC research with recourse to religion, another, similar fundament of the opposition is about human dignity. Opponents consider hESC research to be a violation of the inherent dignity of human beings from conception to natural death. ${ }^{196}$ For instance, the following statement clearly illustrates the human dignity argument: "human beings are not things; their lives must not be sacrificed against their will, even for the sake of good ends, like saving other people's lives. The reason human beings must not be treated as things or used merely as means to an end is that they are inviolable. They are, to borrow Kant's language, ends in themselves, worthy of respect ... Infants are clearly inviolable, and few people would countenance harvesting organs for transplantation even from a fetus. Every human being-each one of us-began life as an embryo. If our lives are worthy of respect, and hence inviolable, simply by virtue of our humanity, it would be a mistake to think that at some younger

191 See SANDEL, supra note 115, at 104; Katrien Devolder \& Christopher M Ward, Rescuing Human Embryonic Stem Cell Research: the Possibility of Embryo Reconstitution After Stem Cell Derivation, 38 METAPHILOSOPHY 245, 245 (2007); Janice M Mueller, Patenting Human Embryonic Stem Cells in the United States: The Legal and Ethical Debate, 14 CASRIP NEWSLETTER 1, 1 (2007).

192 See Devolder \& Ward, supra note 191, at 245. See NATIONAL RESEARCH COUNCIL (US) AND INSTITUTE OF MEDICINE (US) Committee on the Biological and Biomedical Applications of Stem Cell Research, Stem Cells and the Future of Regenerative Medicine 44 (National Academies Press (US) 2002).

193 See SANDEL, supra note 115, at 104 (pointing out that a moral belief may be rooted in religious conviction and thus it is a mistake to consider strong religious conviction on the question to be non-rational argument or analysis.)

194 Pope John Paul II Addresses President Bush, American CATHolic.org, (Jul. 23, 2001), http://www.americancatholic.org/News/StemCell/pope_to_bush.asp.

195 See Wybo Dondorp \& Guido de Wert, Embryonic Stem Cells Without Moral Pain? 10 (Health Council of the Netherlands 2005).

196 See World Youth Alliance Commends Recommendation to Deny Patents for Embryonic Stem Cell Research, WORLD YOUTH ALLIANCE, http://www.wya.net/op-ed/world-youth-alliance-commends-recommendation-todeny-patents-for-embryonic-stem-cell-research-2/. 
age or earlier stage of development we were not worthy of respect." ${ }^{197}$ This thesis will return later to this argument which attaches human dignity to a human person already born and even to potential persons, including human embryos. ${ }^{198}$

Moreover, others opposed to hESC research worry that even though such research is not wrong in itself, it would open the way to a slippery slope of dehumanizing practices, such as embryo farms, cloned babies, the use of fetuses for spare parts, and the commodification of human beings. ${ }^{199}$ Once an item is put into the market, it would be difficult to hold back or control the corrupting impact of money and commercial interests. ${ }^{200}$ In effect, the slippery slope argument has been proposed in various areas of controversy in bioethics, such as DNA patenting, voluntary physician-assisted suicide, the selling of gametes, tissues, and organs, surrogate pregnancy, and prenatal genetic testing. ${ }^{201}$ However, most slopes are imagined and lack empirical evidence, and they are just not terrifically slippery. Moreover, by adopting regulatory safeguards, these slippery slope concerns can be tackled. For instance, contract pregnancy and the selling of gametes in the US have not resulted in treating children as property, and these practices are highly unlikely to ever have that influence. ${ }^{202}$ So far little evidence has been found to support the slippery slope argument against hESC research. It is believed that the slippery slope concern can be addressed by strong social and legal institutions in society to prevent embryo research from devolving into nightmare scenarios of exploitation and abuse. ${ }^{203}$

\subsubsection{Amelioration of Pain and Suffering}

Due to the far-reaching promise of hESC research in alleviating and preventing suffering for millions of patients, many people, especially scientists, consider the destruction of human embryos and the experimental use of hESCs to be acceptable. Those who hold this viewpoint believe that the embryo at an early stage is merely a cluster of cells and not a fetus; it has no recognizable human features or form. ${ }^{204}$ In this regard, they hold that it cannot be considered a human being, or, at least, cannot be regarded to have the same moral status as a human being. They point out that if equal moral status is carried by the early embryo to that of a human being, then why do societies not "encourage the

197 See SANDEL, supra note 115, at 113-114.

198 See infra Sect. 4, Chap. 3.

199 See SANDEL, supra note 115, at 112; Daniel S McConchie, Using Stem Cells from Embryos Will Make Human Flesh Profitable, THE CENTER FOR BIOETHICS \& HumAn DigniTY, (Jun. 29, 2001), https://cbhd.org/content/ using-stem-cells-embryos-will-make-human-flesh-profitable (pointing out that some people worry that increased embryonic stem cell research will result in a black market for human organs.)

200 See RESNIK, supra note 2, at 104.

201 See id., at 122-123.

202 See id., at 128.

203 See SANDEL, supra note 115, at 112. See also RESNIK, supra note 2, at 127-128.

204 See SANDEL, supra note 115, at 112-113. 
ritual mourning of the loss of embryonic stem cells" ? ${ }^{205}$ For these people, sacrificing the early stage human embryos in pursuit of curing painful patients is completely justified. However, those who hold this moral position are always opposed by those who view the intervention in embryos as akin to crimes against humanity.

Simply stated, some individuals might perceive hESC research as immoral and abhorrent, whilst others may view it as a great opportunity to enhance human health and welfare. There is a lack of substantive and coherent moral justification in the matter of how and which considerations should place limits on hESC research. The complication of moral and ethical issues in this research field also can be reflected in the highly contentious and ever-changing American approach to regulating $\mathrm{hESC}$ research during the past decades. ${ }^{206}$ One thing is clear here, though: the moral status of a human embryo-whether a human embryo is considered to be a human being-in a society plays a crucial role in the debate concerning hESC research. Whether these arguments in the debate indicated above are persuasive or not is beyond the discussion scope of this thesis. The significant role of showing these arguments is to understand the moral debate related to related patenting in this field.

\subsubsection{Extension of the Debate from Research to Patenting}

As can be seen from the above, based on the shortcoming of the traditional method of deriving hESCs, namely necessitating the destruction of human embryos, it is evident that $h E S C$ research has generated a number of complicated moral and ethical debates. ${ }^{207}$ Meanwhile, the social and moral concerns about hESC research also have crossed over into patenting hESC-related inventions, ${ }^{208}$ since moral arguments enter the patent arena directly through the gateway of the morality exclusion clauses. ${ }^{209}$ That is to say, not only is hESC research ethically problematic, but patenting hESC-related inventions also raises several fundamental ethical or moral concerns. ${ }^{210}$ Interestingly, almost on similar grounds, those who support research on human embryos and hESC research regard patenting hESC-related inventions as acceptable, especially in view of the great

205 See nancy E Snow, Stem Cell Research: New Frontiers in Science and Ethics 29 (University of Notre Dame Press 2003).

206 See infra Sect. 2, Chap. 4 of this thesis.

207 For more discussion about the political and legal debates concerning hESC research in specific jurisdictions, such as the US, EU, and China, see infra Chap. 4.

208 See Varju \& Sándor, supra note 51, at 1011 (stating that ethical controversies surrounding biotechnology have an impact on the patentability of biotechnological inventions). See also DB Resnik, Embryonic Stem Cell Patents and Human Dignity, 15 HeALTH CARE ANALYsis 211, 211 (2007).

209 See MILLS, supra note 1, at 11. Several examples of the morality clauses in patent laws are Article 53 of the EPC, Article 6(1) of the EU Biotech Directive, and Article 5(1) of the CPL. The patenting of hESC-related inventions concerning these morality clauses will be discussed in detail in Chap. 5.

210 See Audrey R Chapman, The Ethics of Patenting Human Embryonic Stem Cells, 19 KENNEDY INSTITUTE OF ETHICS JOURNAL 261, 261 (2009); T 
therapeutic potential of these inventions. ${ }^{211}$ They expect patenting hESC-related inventions to facilitate the advancement of research and therapeutic applications, which give hope for sufferers of debilitating diseases. The underlying reasoning of the support is that they do not consider the use and the destruction of human embryos to derive hESCs morally wrong. At least, between the potential benefits of hESC research and moral concerns, they prefer the former by means of granting patents to promote the progress of such research.

In contrast, those who oppose embryo research and hESC research strongly consider patenting hESC-related inventions to be unacceptable. ${ }^{212}$ For instance, some opponents put forward that hESC patents raise concern about the commodification of human beings and the worry that it may lead to a slippery slope towards moral devaluation of the human body. ${ }^{213}$ Their stance is that hESC patents may violate fundamental principles in the matter of the ownership of human beings. ${ }^{214}$ However, it seems that the slippery slope argument here assumes that it is impossible to draw a principled distinction between hESCs and the human embryo or human being. Moreover, it presupposes that patenting hESC-related inventions may change the attitude towards human beings, and ultimately cause the patenting of human embryos or human beings. As mentioned earlier, the slippery slope concerns in research can be tackled by adopting regulatory safeguards. At the same time, the slippery slope concerns in patenting hESC-related inventions may be addressed by drawing a principled distinction between hESCs and the human embryo or human being, and by providing a specific exclusion of human embryos and human beings from patent eligibility. This thesis will attempt to draw this distinction in the context of patent law by clarifying the meaning of the terms "human embryo" and "use" in the human embryo exclusion in China.

In fact, the most well-known argument against patenting such inventions is based on the moral concerns raised by the technology per se. In other words, the core objection to patenting hESC-related inventions seems to be that hESC research in itself is considered to be intrinsically wrong, even if the net benefits outweigh the harm caused. To be specific, opponents believe that the derivation of hESCs necessitates the destruction of an otherwise viable embryo, and this very research is therefore morally unacceptable;

211 See EGE, supra note 105, at 13. This viewpoint is very similar to that of utilitarianism on embryo research; the utilitarian approach argues that there are no principled reasons not to produce, destroy, and use embryos for research and purposes. See Torbjörn Tännsjö, Why No Compromise is Possible, 38 METAPHILOSOPHY 330, 331 (2007).

212 See EGE, supra note 105 , at 13.

213 See id., at 15 ("Such isolated cells are so close to the human body, to the foetus or to the embryo they have been isolated from, that their patenting may be considered as a form of commercialisation of the human body.")

214 See RIMMER, supra note 3, at 249. 
patenting hESC lines per se and related inventions, therefore, should also be prohibited. $^{215}$

To sum up, although hESC research has great potential and significance in basic scientific research and medical treatment, it has generated vast moral, political and legal concerns. Meanwhile, these debates have also crossed over into patenting hESC-related inventions, by virtue of the gateway of the morality exclusion clause in patent law. Through briefly exploring the moral controversies surrounding hESC research and the pertinent debates with respect to patenting hESC-related inventions, it is evident that the moral and legal status of a human embryo lies at the heart of debates regarding patenting hESC-related inventions, at least in those jurisdictions which have incorporated moral assessment into patent law. Moreover, there is copious literature arguing that denying patents in the field of biotechnology, including in hESC research, on moral grounds is not an appropriate way to regulate this scientific field. ${ }^{216}$ Indeed, before considering the moral issues of patenting hESC-related inventions, one significant question should be raised: whether moral considerations should be exercised in the patent system. This thesis will return to this question in Chapter 5 after discussing and comparing the patent issues among the US, EU, and China. ${ }^{217}$

\section{CONCLUSION}

Providing patent protection, not surprisingly, is considered indispensable to stimulate innovation and crucial to the establishment of a private sector and the commercialization of products in the field of biotechnology. Nevertheless, biotechnology has evolved at an amazing speed over the last several decades, creating serious challenges to patent law, particularly to patent eligibility. Recently with the marriage of hESC technologies and patent protection, patent law has been thrown into turmoil once again.

Through analyzing the scientific background of hESCs and relevant techniques, it is evident that hESCs and associated research are of considerable importance, and there is no easy way to find any other research to completely replace such research. The hESCs are derived from an early stage of human embryos, and are different from human embryos. They are essentially pluripotent cells and incapable of forming into human beings on their own. However, the most problematic issue in hESC research is that the creation of hESCs, which are used as the material basis of the research, normally necessitates the use and destruction of otherwise viable human embryos. Partly based on

215 See Overwalle \& Berthels, supra note 181, at 165.

216 See MILLS, supra note 1 , at 11.

217 See infra Sects. 5.1 and 5.2, Chap. 5. 
this, not only are hESC research per se and regulation of such research under moral, political and legal controversies, but also social or moral concerns about hESC research have crossed over into the patenting of hESC-related inventions, since moral arguments enter the patent arena directly through the gateway of the morality exclusion clauses in patent law. One part considers the granting of patents in the field of hESC research to be morally unacceptable, due to their belief that a human embryo possesses the same moral status as a fully developed human being, as well as based on the human dignity argument. Others, however, perceive the patenting of hESC-related inventions as acceptable, since they view it as a great opportunity to promote the development of hESC research and further enhance human health and welfare. Thorough consideration of these public policy and moral issues shows that the patenting of hESC-related inventions is quite a complex issue.

Moreover, taking into consideration the cumulative innovation and the possible "tragedy of the anticommons" with regard to patenting inventions in the field of hESC research, it is important to ensure that the granting of patents will not hinder further advances and marketing of innovation in the field. In terms of China, this country, in principle, remains a developing and technology-importing country in the matter of hESC research, at least at present. It is critical to consider the potential negative impact upon the advancement of China's domestic research and industry when tailoring patent rules and policies. Given this, achieving a fair balance between granting patents and the need to access knowledge and technologies in this research field in China is vital. In addition, it is arguable that the Chinese patent system is dominated by the utilitarianism. In this regard, in accordance with utilitarianism, when setting forth China's optimum patent rules or policies for hESC research and industry, it is necessary to consider various interests and values, and evaluate the possible effects of these rules and policies. 


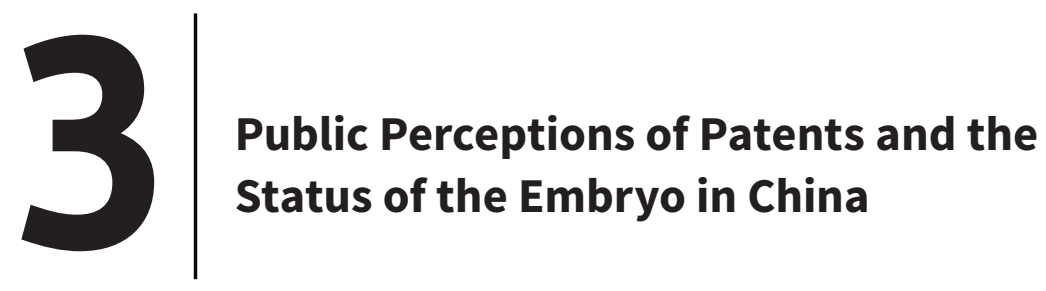

\section{INTRODUCTION}

As the discoveries of modern science bring human beings tremendous hope, they also lay extensive ethical mine fields. ${ }^{1}$ Likewise, as described in Chapter 2, although hESC research has great potential in the regenerative medicine, drug discovery, cell replacement therapy, and promising tools to investigate disease mechanisms, it generates vast social and moral concerns and debates. Indeed, within the field of hESC research, the use of human embryos as base materials to derive hESCs is inevitable, and one of the shortcomings of the traditional method of deriving hESCs is the necessary destruction of the embryo. Partly based on this, hESC research has generated a number of complicated moral and ethical debates, and has "reawakened a long dormant academic debate about the morality of destroying developing life." ${ }^{2}$ Meanwhile, the moral concerns about hESC research have crossed over into patenting hESC-related inventions. Put another way, not only is hESC research ethically controversial, but also patenting hESC-related inventions raises several fundamental ethical or moral concerns. ${ }^{3}$ Interestingly, although regulating hESC research and patenting hESC-related inventions

See George W Bush, President Discusses Stem Cell Research, THE WHITE HousE, (Aug. 9, 2001), http:// georgewbush-whitehouse.archives.gov/news/releases/2001/08/20010809-2.html.

2 See Michael Ruse \& Christopher A Pynes, The Stem Cell Controversy: Debating the Issues 151 (Prometheus Books 2006); Rosario M Isasi \& Bartha M Knoppers, Towards Commonality? Policy Approaches to Human Embryonic Stem Cell Research in Europe, in EMBRYonic STEM CeLl PATENTS: EUROPEAN LAW AND ETHICS 32 (Aurora Plomer \& Paul Torremans ed., Oxford University Press 2009).

3 See Audrey R Chapman, The Ethics of Patenting Human Embryonic Stem Cells, 19 KENNEDY INSTITUTE OF Ethics Journal 261, 261 (2009); HeCtor MacQueEn, et al., Contemporary InTELlectual Property: LAW AND Policy 525 (Oxford University Press 2008). 
have provoked extremely fierce debates in Europe and the US, ${ }^{4}$ it appears that there has never been any heated public debate on the issue in China. This chapter offers some explanations for this phenomenon, along with a sketch of how the Chinese public might respond to $\mathrm{hESC}$ research and the patenting of related inventions.

In general, the question of how the Chinese public might respond to hESC research and the patenting of related inventions primarily depends on two factors: one is the public perceptions concerning patents and inventions, and the other is the status of the human embryo in China. To be specific, since the public perception concerning patents and inventions, to some extent, influences the determination of whether to provide patent protection to certain subject matter, especially in controversial areas, such as the field of hESC research, this chapter first attempts to discuss the public perceptions of patents in China (Sect. 2). Since the acceptability of research on hESCs and patenting relevant inventions in this research field is often closely related to the views surrounding the moral and legal status of a human embryo, Section 3 of this chapter attempts to deeply examine the status of the embryo in China, and meanwhile the issues in the West are also briefly referred to. Dissecting the specific moral culture concerning the human embryo in China can be helpful in analyzing the fundamental reasons for the social and moral concerns bearing on patenting hESC-related inventions in this thesis. Moreover, appeals to human dignity as a criterion for embryo policy are also frequent. In this regard, this chapter further explores the potential human dignity concerns that might be proposed to argue against patenting hESC-related inventions in China through the general morality clause in patent law (Sect. 4). At last, Section 5 of this chapter attempts to offer some extra explanations for the moral concerns regarding the acceptability of hESC research in China, before drawing a conclusion.

\section{PUBLIC PERCEPTIONS OF PATENTS IN CHINA}

In China, the general morality clause in its patent law has made patenting hESC-related inventions a source of social and moral debate. Under the general morality clause in the $\mathrm{CPL}$, morality generally refers to ethical or moral norms and rules regarded as justifiable and accepted by the public. ${ }^{5}$ One thing clear here is that whether inventions are against

4 See e.g., Aurora Plomer \& Paul Torremans, Embryonic Stem Cell Patents: European Law and Ethics (Oxford University Press 2009); Geertrui Van Overwalle \& Nele Berthels, Patents and Venus: About Oocytes and Human Embryonic Stem Cells, in Stem Cells And Women's HeAlth - Cellules souches et SANTÉ des femmes - STAMCELLEN EN VROUWEngeZondheId (Anthemis-Intersentia 2007); Amy Rachel Davis, Patented Embryonic Stem Cells: The Quintessential Essential Facility, 94 GEORGETOWN LAW Journal 205 (2005); Margo A Bagley, Stem Cells, Cloning and Patents: What's Morality Got to Do with it? 39 NEW ENGLAND LAW REVIEW 501 (2004); Janice M Mueller, Patenting Human Embryonic Stem Cells in the United States: The Legal and Ethical Debate, 14 CASRIP NEWSLETTER 1 (2007).

5 See Part II, Chap. 1, Sect. 3.1.2, Para. 1 of the SIPO's Guidelines. 
social morality or not and then excluded from patent eligibility should be ultimately decided by the public. Hence, the public perception concerning patents and inventions, to some extent, influences the determination of whether to provide patent protection to certain subject matter, especially in controversial areas, such as the field of hESC research. This section primarily discusses the public perceptions of patents in China.

In order to analyze how the Chinese public perceive patents and inventions, or how the concept of patents has been comprehended in China, it is necessary first to understand how the patent system established in this jurisdiction. A brief review of the short period development of the Chinese patent system also provides us with a point of reference to identify subsequent changes in patent legislation and by extension patent policy in China. Thus, this section begins by briefly reviewing the development of the Chinese patent system (Sect. 2.1), then analyzes the public perceptions of patents (Sect. 2.2).

\subsection{The Development of the Chinese Patent System}

For quite a long time in ancient China, the rulers preferred a penal code rather than a civil code, and civil issues were always left to custom and usage. Based on the incomplete development of the civil law system, there was no room for a patent system to progress. ${ }^{6}$ A patent system in the modern sense was never developed into legislation in imperial China. ${ }^{7}$ After the Opium War with the British in 1840 , when China was forced to open its doors to the world, some Chinese intellectuals started thinking about changing the situation, including the introduction of a patent system. However, by the end of old China in 1911, still no major legislative events concerning IP had been developed. Thus, for a long period time in old China there was no patent system.

In 1911, the Qing dynasty came to an end, after which China was controlled by the Republican, Kuomintang government. In 1912, the Ministry of Commerce and Industry of the Republic of China issued a substantive national patent law, the Temporary Statue on Technology Reward. ${ }^{9}$ However, this law provided very little patent protection to foreign patentees despite the statement on paper. ${ }^{10}$ In 1944, the year before the Second World War ended, the Kuomintang government issued a new patent law, which was regarded as the first of its kind in China. ${ }^{11}$ Although some efforts had been made by the

6 See ChUntiAn LIU (刘春田), ZHISHI CHANQuAN FA (知识产权法) [INTELLECTUAL PROPERTY LAW] 151 (Xianyi Zeng (曾 宪义) \& Liming Wang (王利明) ed., Zhongguo Renmin Daxue Chubanshe (中国人民大学出版社) [China Renmin University Publishing] 4th ed. 2009).

7 See id., at 151-152.

8 See Deming Liu, Now the Wolf Has Indeed Come! Perspective on the Patent Protection of Biotechnology Inventions in China, 53 THE AMERICAN JOURNAL OF COMPARATIVE LAW 207, 211 (2005).

9 See LIU, supra note 6, at 153.

10 See Chengsi Zheng \& Michael D Pendleton, Chinese intellectual PRoperty and technology transfer LAW 52 (Sweet \& Maxwell 1987).

11 See LIU, supra note 6, at 153. 
Kuomintang government, years of wars, famines, and revolutions scarcely left any room for the development of the patent system in China. ${ }^{12}$ Eventually in 1949, the Kuomintang government was defeated by the Communist movement in the Civil War, and again the effect of the 1944 Patent Law was minimal in China. ${ }^{13}$ Hence, during the long wartime period of the Republican era, patent laws had very little influence in China. Meanwhile, the Chinese had almost no concept of patents during that period as well.

After the PRC was established in 1949, the Communist government repealed all previous laws and regulations that had been enacted by the Kuomintang government, including the patent law, and started with a clean slate. At that moment, China, like other communist countries, modelled its earliest patent legislation on the Soviet system. Initially, China introduced a "double-track" system of patent and certificates of authorship, which permitted applicants to freely choose patents or certificates of authorship to apply. The primary purpose of this system was to implement the policy of national reconstruction on the one hand, and on the other hand to pacify Chinese intellectuals and holders of substantial private property, whose participation was needed to rebuild the country. ${ }^{14}$ Subsequently, due to ten years of the Cultural Revolution, China's legal system, including the patent system, was almost completely destroyed. The "double-track" system was replaced by a single system of awards. ${ }^{15}$ Thus, at the end of the Cultural Revolution in late 1970s China had still not established a modern patent system.

With the "Gang of Four" being overthrown and the end of the Cultural Revolution, China made a great decision called "the reform and opening up", and commenced a new "long march" for economic and industrial development. ${ }^{16}$ After 1978 , the Chinese government started to consider establishing its own patent system. After several years of intensive debates about whether or not China needed a patent law, ${ }^{17}$ Deng Xiaoping, the Chinese leader, determined that China should adopt a modern patent law, ${ }^{18}$ which was considered a significant policy tool to help this country play economic and technological catch-up. ${ }^{19}$ In 1984, China issued its first comprehensive patent law, ${ }^{20}$ the aim of which was to pursue economic development and technology advancement and renovation

See Peter Feng, Intellectual Property in China 3 (Sweet \& Maxwell Asia, 2d ed. 2003).

See LIU, supra note 6, at 153.

See William P ALFORD, TO STEAL A BOOK IS AN ELEGANT OFFENSE : INTELLECTUAL PROPERTY LAW IN CHINESE CIVILIZATION 58 (Stanford University Press 1995).

See LIU, supra note 6, at 154.

See Liu, supra note 8, at 217.

See ALFORD, supra note 14, at 67-69.

See id., at 69.

See Peter K Yu, Building the Ladder: Three Decades of Development of the Chinese Patent System, 5 DRAKE UNIVERSITY LAW SCHOOL RESEARCH PAPER (2012).

20 The first Patent Law of the PRC was issued on Mar. 12, 1984. 
through encouraging foreign investment and technology transfer. ${ }^{21}$ This saw modern China usher in the dawn of a new era in its establishment of a modern patent system. Only since then has the Chinese public really started to come into contact with patents.

\subsection{Public Perceptions of Patents}

As can be seen from the above, the concept of patents is a historical import to Chinese culture. In other words, for Chinese the patent system is exotic. Initially, China aimed to encourage foreign investment and technology transfer by means of establishing a patent system. Then with economic development, China expected to take advantage of the patent system to promote its indigenous innovation, and further advance its domestic S\&T, so as to catch up with its technologically advanced counterparts in the scientific arena. Ever since the issuing of the 1984 Patent Law, the Chinese government has made huge efforts to promote its patent system throughout the country. However, China introduced the modern patent system less than 40 years ago. Due to the short period of contact with the patent system, the Chinese public has not established a comprehensive perception of patents.

Some empirical research has been conducted showing that although most Chinese have some idea of IPRs, the public's understanding of them is relatively low. By way of example, a 2006 survey investigated the common people's (e.g., civil servants, company employees, students, teachers, farmers, and freelancers) perception of IPRs, and showed that $93 \%$ of respondents knew of IPRs, and most respondents (83\%) felt that IPRs contributed to China's economy. ${ }^{22}$ Another survey, conducted in 2016 in a relatively backward region-Guangxi Zhuang Autonomous Region which is in South Central China-demonstrated that while most interviewees (86.8\%) had an idea of IPRs, none of them acknowledged understanding them well. ${ }^{23}$ It is worth noting that currently, even with decades of rapid economic advance, China still has more than 0.6 billion people in its rural areas. ${ }^{24}$ Because of their low level of education, rural public awareness of IPRs, including patents, is considerably low. In accordance with a 2017 survey, no more than

21 See Liu, supra note 8, at 218. See also Kunyi Huang (黄坤益), Guanyu Zhonghua Renmin Gongheguo Zhuanli Fa (Cao'an) de Shuoming (关于 《中华人民共和国专利法 (草案)》的说明) [Explanation on the Patent Law of the People's Republic of China (Draft)], (Dec. 2, 1983), http://www.npc.gov.cn/wxzl/gongbao/2000-12/26/ content_5001493.htm.

22 SeeHua Liu (刘华) \& Ying Zhou (周荣), Woguo Shehui Gongzhong Zhishichanquan Yishi Xianzhuang Diaocha Fengxi ji Duice Yanjiu (我国社会公众知识产权意识现状调查分析及对策研究) [Survey of Chinese Public's IP Protection Awareness and Sone Recommendations], 10 ZHONGGUO RUANKEXUE (中国软科学) [CHINA SOFT SCIENCE] 103, 105 (2006)

23 Nian Wang (王念), Guangxi Shehui Gongzhong Zhishichanquan Renzhidu Diaocha yu Fenxi ji Silu Tantao (广 西社会公众知识产权认知度调查与分析及思路探讨) [The Survey, Analysis, and Discussion on Public Perceptions of IP in GuangXi], 3 XIANDAI SHANGYE (现代商业) [MOdERn BusINESS] 175, 176 (2016).

24 According to the data from the National Bureau of Statistics of China, in 2015 the total population of China was about 1.37 billion, and the rural population was about 0.6 billion; please see http://data.stats.gov.cn/ index.htm. 
$2 \%$ of respondents considered themselves to have a common sense notion of IP-related laws and regulations. ${ }^{25}$ Most of the rural public knew nothing about the IP rules.

In addition, a survey of Chinese college students' knowledge about IPRs in 2011 showed that $41.4 \%$ of respondents held that patents meant a good quality product or a good business reputation of the manufacturer. ${ }^{26}$ At the same time, $41.1 \%$ of the respondents considered patents to represent advanced technologies. ${ }^{27}$ This implied that the college students had a poor understanding of the concepts of patents and trademarks, nor could they distinguish between them properly. ${ }^{28}$ While the abovementioned surveys reflected the Chinese public perceptions of IPRs, including patents, from only a few aspects, it can be seen that the Chinese public has limited knowledge of patents; most of them have only heard of the concept of patents, ${ }^{29}$ and misunderstand what they represent. No wonder Tian Lipu, the former commissioner of the SIPO, pointed out that "the most fundamental shortcoming of IP work in China should be that the whole society's awareness of IP in China has yet to be further improved."30

In order to improve the Chinese public's understanding of patents, the Chinese government has made huge efforts. The governments at various levels and public institutions in China have tailored many policies, to strengthen the construction of IP culture on the one hand, and boost the number of patents granted on the other hand. For example, a patent (either an invention patent or utility patent) can be used by a student to get bonus points in entrance examinations. Doctors, technicians, teachers, and researchers can get extra points in their professional title evaluation if they possess patents. Moreover, patents can help civil servants or officials to eliminate any record of disciplinary action and demerit punishment. Patent owners can get rewards from local governments. Patents also can help creative prisoners to get out of jail earlier, since Chinese

25 See Ying Tan, et al., Nongcun gongzhong dui Zhishichanquan de Renzhidu ji Guanzhudu Yanjiu (农村公众对 知识产权的认知度及关注度研究) [Research on Rural Public's Awareness and Attention to Intellectual Property Rights], 17 西北农林科技大学学报 (社会科学版) [JOURNAL OF NORTHWEST A\&F UNIVERSITY (SOCIAL SCIENCE EDITION)] 144,146 (2017).

26 See Yanjuan Meng (孟彦娟) \& Tiancai Meng (孟天财), Zhishi Jingji Shidai de Daxuesheng Zhishichanquan Yishi he Renzhi Zhuangkuang Yanjiu (知识经济时代的大学生知识产权意识和认知状况研究) [A study on University Students' Awareness and Cognition of Intellectual Property in an Era of Knowledge-based Economy], 24 南 京理工大学学报（社会科学版）[JOURNAL OF NANJING UNIVERSITY OF SCIENCE AND TECHNOLOGY] 96, 97 (2011).

27 Seeid.

28 Seeid.

29 See also Huanfeng He (何焕锋), Daxuesheng Zhishichanquan Jiaoyu Tanxi--Yi Shandongsheng Daxuesheng zhishichanquan Yishi Diaocha wei Jichu (大学生知识产权教育探析一一以山东省大学生知识产权意识调查为基 础) [Analysis on the Education of Intellectual Property for College Students], 27 山东青年政治学院学报 [JOURNAL of SHANDONG YOUTH UNIVERSITY OF POLITICAL SCIENCE], 42 (2011) (conducting a survey on the college students in Shandong Province, located in eastern China, and showing that the general awareness of college students concerning IP was low.)

30 Muqian Zhishi Chanquan Gongzuo Zui Genben Buzu shi Zhishi Chanquan Yishi Jiaoruo (目前知识产权工作 最根本不足是知识产权意识较弱) [Currently the Most Fundamental Problem of IP Work is the Relatively Weak Awareness of IPRS], www.Gov.cn, (Apr. 23, 2007), http://www.gov.cn/zxtt/tt12/content_592314.htm. 
laws provide that if prisoners obtain invention patents, they can get their sentences reduced. ${ }^{31}$

However, due to China's excessive intervention to boost the number of patents granted, a patent in this country not only represents a market monopoly that allows the patentee to recuperate their investment, but also has more functions, as mentioned above. The introduction of these policies to some extent thus distorts the understanding of patents by the public. Probably because of the vigorous promotion of the concept of patents by the government as well as their brief contact with patents, the Chinese public to a large extent hold a sense of the sacred concerning patents. As the survey mentioned above showed, many Chinese almost think of patents and high-tech products as equivalent. ${ }^{32}$ Indeed, for them a patent stands for a guarantee of quality from the central government. They believe that a patent represents technical authority and advanced technology. To the Chinese public, patenting is just like the government giving an endorsement to a high-tech product or process.

Collectively considering that the patent is exotic for Chinese citizens, and that China has had its patent system only a very short time, and additionally taking into account the utilitarian promotion by the government, it is not surprising that to the Chinese people, a patent is a thing with a sense of mystery, and even a sense of the sacred. To some extent, a patent has an almost "omnipotent" presence in front of the Chinese people. This is the fact, and it is unlikely that the misunderstanding of patents by the Chinese people will be changed in a short time.

\section{MORAL AND LEGAL STATUS OF A HUMAN EMBRYO}

Since the moral and legal status of a human embryo lies at the heart of debates over patenting hESC-related inventions, ${ }^{33}$ this section mainly analyzes these issues in the context of China. These issues in the Western world, particularly Europe, also are briefly explored, so as to help understand the issues when conducting comparison in the fol-

31 See Article 78(1) of the Criminal Law of the PRC and Article 29(3) of Prison Law of the PRC. See also Zhifeng Qiao (乔志峰), Jiangyu Famingjia Shi Shuide Faming (“监狱发明家”是谁的“发明”) [Who Invents “Jail Inventors”], NewsSinA, (Jan. 19, 2015), http://news.sina.com.cn/o/2015-01-19/162831417619.shtml; Mark Molloy, Prisoners in China Use Ingenious 'Loophole' to Get Out of Jail Early, TelEGRAPH, (Jan. 21, 2015), http://www. telegraph.co.uk/news/worldnews/asia/china/11359514/Prisoners-in-China-use-ingenious-loophole-toget-out-of-jail-early.html.

32 See Meng \& Meng, supra note 26, at 97.

33 See supra Sect. 4.2, Chap. 2, and generally infra Sects. 2.3.2.1.2 and 2.3.2.2, Chap. 5. In addition, for instance, the key issue in the 2011 Oliver Brüstle v. Greenpeace eV case before the CJEU was the scope and definition of a human embryo. For discussion of the Brüstle case, please see infra Sect. 4.2, Chap. 5. Similarly, in China the key issues in the SIPO's patent practice concerning patenting hESC-related inventions are the morality of destroying a human embryo as well as the definition of a human embryo, which are based on the moral and legal status of a human embryo in China. See infra Sect. 3.3, Chap. 5. 
lowing part of the thesis. Since Europe is composed of many countries, figuring out the exact status of a human embryo in this area would be extremely difficult, and it is not the main purpose of this thesis. In this regard, the first part of this section only briefly sketches the European perspectives concerning the moral status of a human embryo (Sect. 3.1). Then, it attempts to explore in detail the moral status (Sect. 3.2), as well as the legal status (Sect. 3.3) of a human embryo in China.

\subsection{European Perspectives}

In Europe, different countries hold different moral perspectives concerning human embryos based on diverse social cultures and religions. Due to this fact, it can be hard to find any Europe-wide moral view on human embryos. ${ }^{34}$ This idea is also emphasized by the decision of the Opposition Division (OD) of the EPO in the Edinburgh patent case. ${ }^{35}$ In some European countries, the human embryo has been bestowed with human dignity. For instance, in the matter of stem cell research and patenting, the Danish Council of Ethics considers "all forms of stem cell patenting problematic", because "patenting stem cells involves commercializing and commodifying the human organism, which is incompatible with the respect for the dignity of mankind." 36 The constitutions of other countries, such as France, Germany, the Netherlands, Spain, Italy, Austria, and Ireland, generally mention the notion of human dignity or similar concepts. ${ }^{37}$ With the aim of protecting the dignity of a human embryo, Estonia, Finland, Sweden, and Switzerland forbid abusing or damaging an embryo. ${ }^{38}$

Most European countries hold intermediate or gradualist moral views on the human embryo, in which they consider an embryo's moral status to progressively rise with its

34 See Aurora Plomer, et al., Stem Cell Patents: European Patent Law and Ethics Report, 50-63 (Jul. 28, 2006), http://www.nottingham.ac.uk/ Ilzwww/StemCellProject/project.report.pdf. See also Geertrui Van Overwalle, Patenting Stem Cell Research in Europe and in the United States, in CROSSING BORDERS: CULTURAL, Religious and Political Differences Concerning Stem Cell Research 533 (W Bender et al. ed., Agenda Verlag 2005).

35 The Edinburgh patent is a European Patent No. 0695351, owned by the University of Edinburgh, entitled "[i] solation, selection and propagation of animal transgenic stem cells". In 2002, the Edinburgh patent case, as the first of its type, was brought to the EPO. The Opposition Division (OD) found that there was no uniform approach concerning hESCs in legislation, or conventionally held standards of morality in European culture. See Gerard Porter, The Drafting History of the European Biotechnology Directive, in EMBRYONIC STEM Cell Patents: European Law and Ethics 25 (Aurora Plomer \& Paul Torremans ed., Oxford University Press 2009).

36 Danish Council of Ethics, The Ethics of Patenting Human Genes and Stem Cells (Conference Report and Summaries), 107-108 (2004), http://etiskraad.dk/en/Udgivelser/ /media/bibliotek/rapporter/2004/2004Patenting-Human-Genes-and-Stem-Cells.ashx.

37 See Isasi \& Knoppers, supra note 2, at 34.

38 See id. Estonia, Embryo Protection and Artificial Fertilisation Act, (1997); Finland, Medical Research Act No. 488, (1999); Sweden, Act 1991: 115 on Measures for Purposes of Research and Treatment Involving Fertilized Human Ova (Amendment in force on Apr. 1, 2005); Switzerland, Federal Act on Research on Surplus Embryos and Embryonic Stem Cells (Embryonic Research Act) (Approved by referendum in Nov. 2004). 
development..$^{39}$ Under this gradualist position, the human embryo is bestowed with a special or symbolic respect, because of its potential to develop into a human being. Research on human embryos or hESC research is prima facie ethically acceptable. For instance, the Irish Council of Bioethics holds that "the Council adopts a gradualist position, granting significant moral value rather than full moral status to human embryos. The moral value they are seen to possess is based on recognition of their potential to develop into persons, as well as the value they derive from representing human life in its earliest stages". 40 Similar positions are also adopted by the Dutch Health Council, and the Belgian Comité Consultatif de Bioéthique. ${ }^{41}$

At the level of Europe, the European Group of Ethics (EGE) considers the principle of respect for human dignity to be a fundamental ethical principle in stem cell research. ${ }^{42}$ A similar viewpoint can be found in both the EU Sixth and Seventh Framework Programmes, where conducting stem cell research is required to be combined with "fundamental ethical principles" including inter alia the "protection of human dignity". ${ }^{43}$ However, in Europe there is no statement explaining how the concept "human dignity" should be understood or applied. ${ }^{44}$ Simply stated, due to diverse social cultures in Europe, there is a lack of consensus in Europe on the moral, and also legal, status of the human embryo, and thus no pan-European consensus on the ethical acceptability of hESC research can be found. ${ }^{45}$ Most European countries grant the human embryo intermediate or gradualist moral status, in which they consider the moral status progressively rises with the development of the embryo. A small number of countries have bestowed a human embryo with human dignity. Meanwhile, human dignity is considerably emphasized at the European level.

39 See Isasi \& Knoppers, supra note 2, at 33.

40 Irish Council of Bioethics, Ethical, Scientific and Legal Issues concerning Stem Cell Research: Opinion, THE IRISH COUNCIL OF BIOETHICS, 41 (2008), http://health.gov.ie/wp-content/uploads/2014/07/Ethical_Scientific_Legal_Issues1.pdf.

41 See Isasi \& Knoppers, supra note 2, at 33-34.

42 See European Group on Ethics in Science and New Technologies (EGE), Opinion No. 15: Regarding Ethical Aspects of Human Stem Cell Research and Use Brussels, 14 (Nov. 14, 2000), http://www.mpvroma.org/wpcontent/uploads/2012/11/UECE01.pdf.

43 Decision No. 1513/2002 of 27 June 2002 of the European Parliament and the Council concerning the Sixth Framework Programme of the European Community for Research, Technological Development and Demonstration Activities, Contributing to the Creation of the European Research Area and to Innovation (20022006) Annex I [2002] OJ L232/1; Decision No. 1982/2006/EC of the European Parliament and of the Council of 18 December 2006 concerning the Seventh Framework Programme of the European Community for research, technological development and demonstration activities (2007-2013) 1982/2006/EC [2006] OJ L $54 / 1$.

44 See Isasi \& Knoppers, supra note 2, at 35.

45 See Gerard Porter, supra note 35, at 23. 


\subsection{Chinese Perspectives Concerning Moral Status}

In April 2015, Junjiu Huang, a biologist at the Sun Yat-sen University in Guangzhou, published a paper on gene editing in human embryos with CRISPR-Cas9. ${ }^{46}$ This event has sparked a fierce global debate in the Western world. In particular, a number of Western media outlets used this event as an example to condemn China as a country lacking moral standards ${ }^{47}$ In contrast, Chinese scientists and public believe that there is a deep misunderstanding in the West about what is going on in China and the moral culture of this country. ${ }^{48}$ They even felt that "many media and researchers in the West do not know-and probably do not want to know-the real situation in China.. ${ }^{49}$ With respect to patenting hESC-related inventions in China, it is necessary to have a deep understanding of the moral status of a human embryo in the context of this country. However, discussing the status of the human embryo is an extremely difficult issue because the debate is often put into the context of when the embryo is to be regarded as a human being in a moral sense. ${ }^{50}$ Based on this context, several most pertinent questions arise: Can a human embryo be considered a person from the Chinese perspective? If not, does this mean the destruction of human embryos is morally acceptable? Or does the human embryo at an early stage have any moral status from the Chinese perspective?

China has had a characteristic culture for thousands of years, and it is believed that three teachings-Confucianism, Taoism and Buddhism-have profoundly affected the societal and ethical framework, and the norms of this country. ${ }^{51}$ Confucianism is the dominant one and is deeply embedded in Chinese minds and in many social conventions. In the decades after 1949 when the People's Republic of China (PRC) was founded, the Chinese version was influenced by Marxism-Leninism. Then, due to the reform and opening up in 1987, with China's gradual integration into the international community, this country has been, increasingly, influenced by Western culture, such as its liberalism and feminism. Meanwhile, with China's construction of a market economy and rule by law, economic and legal factors have become very important over the past

46 See generally, Puping Liang, et al., CRISPR/Cas9-mediated Gene Editing in Human Tripronuclear Zygotes, 6 PROTEIN \& CELL 363 (2015).

47 See e.g., David Cyranoski \& Sara Reardon, Chinese Scientists Genetically Modify Human Embryos, NATURE, (Apr. 22, 2015), doi:10.1038/nature.2015.17378; Sarah Knapton, China Shocks World by Genetically Engineering Human Embryos, THE TELEGRAPH, (23 Apr. 2015), http://www.telegraph.co.uk/news/science/11558305/China-shocks-world-by-genetically-engineering-human-embryos.html.

48 See Jane Qiu, Stem-cell Research and Regenerative Medicine in China, 3 NATIONAL SCIENCE REVIEW 257, 257 (2016).

49 See id.

50 See Ronald M Green, Stem Cell Research: A Target Article Collection Part III-Determining Moral Status, 2 THE AMERICAN JOURNAL OF BIOETHICS 20, 20 (2002).

51 See Russell Kirkland, "Enhancing Life?" Perspectives from Traditional Chinese Value-Systems, 36 The Journal of Law, Medicine \& Ethics 26, 27 (2008); JING-BAO NIE, BEHIND THE SILENCE: CHINESE VoICES On ABortion 72 (Rowman \& Littlefield Publishers 2005); Renzong Qiu, Cloning Issues in China, in CRoss-CULTURAL ISSUES IN Bioethics: The Example of Human Cloning 51 (Heiner Roetz ed., Rodopi 2006). 
few decades. ${ }^{52}$ Thus, in this part of the thesis, these complicated factors are taken into consideration when discussing the moral status of a human embryo in China.

\subsubsection{A Person or Not?}

As mentioned above, the first critical question concerning the moral status of a human embryo in China needing to be tackled is whether a human embryo can be considered a person from the Chinese perspective. It is extremely difficult to answer this question since it in large part depends on one's specific religious, moral and/or cultural background. This section tries to draw a full-scale picture of the moral status of a human embryo in China. The sketch in this section is primarily based on the research achievements of Renzong Qiu, who is regarded to be the founder of China's modern medical ethics. Qiu has comprehensively explored the necessary and sufficient conditions for being a human person from the Chinese perspective. ${ }^{53}$

Firstly, Qiu has transformed the question into another fundamental issue relating to the criteria which demarcate persons from non-persons. Qiu argues that there are two necessary conditions and one sufficient condition for an entity to be considered a person. The first necessary condition for being regarded as a person is the biological dimension. ${ }^{54}$ Possessing the unique human genetic make-up with 23 pairs of chromosomes and their genes is listed first in the biological dimension of a person. Besides the human genome, a person should possess a body and the human brain. ${ }^{55}$ Although some Chinese believe in some supernatural beings like ghost, most Chinese, and Confucians in particular, do not believe in such beings. ${ }^{56}$ Thus, the first necessary condition of being a person should be possessing the human genome with a human body and brain.

However, possessing the human genome, human brain and human body is not sufficient to be a person. Another criterion for qualifying a is the psychological dimension. In other words, having the capacity for self-consciousness is the second necessary condition of being a person. Specifically, it is self-consciousness which makes an entity qualified as a person. Although many animals possess the capacity for consciousness

$52 \quad$ See id., at 51-52.

53 See generally, Renzong Qiu, Reshaping the Concept of Personhood: A Chinese Perspective, in THE MORAL Status of Persons: Perspectives on Bioethics 129-147 (Gerhold K Becker ed., Rodopi 2000); Renzong Qiu (邱 仁宗), Renlei Peitai Ganxibao Yanjiu de Lunli Wenti (人类胚胎干细胞研究的伦理问题) [Ethical Issues of Human Embryonic Stem Cell Research], 7 Qun YAN (群言) [POPULAR TRIBUNE] 18, 19 (2002). Qiu holds that Confucians and Taoists rarely treated the fetus as a human being. In Chinese social culture, a human embryo (including fetus) is not regarded as a human being, and thus the destruction of human embryos is not killing. But Qiu acknowledges that the human embryo deserves certain respect.

54 See Qiu, supra note 53, Reshaping the Concept of Personhood: A Chinese Perspective, at 132.

55 See id., at 134 (holding that an entity that only has the human genome cannot be viewed as a person, and "the claim that reduces a person to a chain of genes is a version of biological determinism, genetic determinism, or genetic essentialism.")

56 See id., at 132. 
and are aware of things surrounding them, Qiu presumes that they do not have selfconsciousness. Thus, the capacity for self-consciousness is necessary, although not sufficient, to qualify an entity as a human person. ${ }^{57}$

Finally, the social dimension is the last condition which is sufficient for qualifying a being as a human person from the Chinese perspective. That is, an entity qualifying as a human person should live in society and interact with other persons. For instance, Confucians consider a person to be a psycho-somatic-social unity, who not only should have a body ( $t$ ) (体) or shape (xing) (形) and a psyche (shen) (神), but also should have interpersonal relationships, such as filial piety (xiao) (孝) and kindness (ci) (慈) between children and parents, fraternity (ti) (悌) between brothers and sisters, trustworthiness (xin) (信) and propriety (yi) (义) between friends, kindheartedness (ren) (仁) and beneficence (hui) (惠) between physicians and patients, etc. ${ }^{58}$ Mencius, a Chinese philosopher and one of the most famous Confucians in ancient China, deemed that the distinction between a person and a non-person rests with the feelings of commiseration, shame and dislike, respect and reverence, and right and wrong. ${ }^{59}$ Xun Kuang, when talking about why a person is a person (Ren zhi suoyi wei ren) (人之所以为人), stressed that the distinction between a person and an animal rests with the fact that a person can interact with other persons and organize society (Ren neng qun) (人能群). ${ }^{60}$ Similarly, Karl Marx considered that the sum of the social relationships is the essence of a person. ${ }^{61}$ Without living in society and interacting with others, an entity is only born biologically, but would not be able to have the status of personhood, and its self-consciousness would never develop. ${ }^{62}$

In short, from the Chinese perspective the biological and psychological dimensions are necessary conditions for an entity to be a person, and the social dimension is a sufficient condition for it being regarded to be a person. In other words, possessing the human genome with a human body and brain, and possessing the potential for self-consciousness constitute the necessary conditions for an entity to be a person, and possessing the capacity to communicate and interact with other persons constitutes a sufficient condition for being a person. ${ }^{63}$ Thus, in terms of the question of whether a

See id., at 135-137.

See id., at 138.

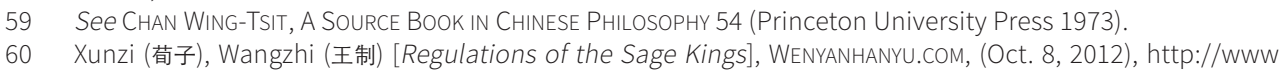
wenyanhanyu.com/xunzi/7445.html.

61 See KARL MARX, THESES ON Feuerbach (VOL. 5) 4 (Karl Marx \& Frederick Engels eds., Lawrence \& Wishart 2010) ("the essence of man is no abstraction inherent in each single individual. In its reality it is the ensemble of the social relations.")

62 See Qiu, supra note 53, Reshaping the Concept of Personhood: A Chinese Perspective, at 135.

63 See id., at 129-139. 
human embryo is a person in the eyes of Chinese people, the answer seems evident: personhood is not granted to the fetus, ${ }^{64}$ let alone an early human embryo.

As discussed previously in Chapter 2, hESCs are mainly retrieved from human embryos at the blastocyst stage, which is an early stage of human embryogenesis. The human embryo used to produce hESCs has not yet developed to contain the human body and brain, though it possesses the whole set of human genomes. Moreover, it also does not have the capacity for self-consciousness, and it is in the dark womb or in the petri dish ,without any social interaction with persons. In short, the human embryo is not a person from the Chinese perspective. We do not eliminate the possibility that a very few Chinese, especially adherents of particular religions, do consider an embryo to be a person. But we believe that most Chinese do not think of the human embryo as a person, based on China's specific religious, moral and cultural background.

\subsubsection{Acceptance of the Destruction of a Human Embryo}

As indicated above, a human embryo is not considered to be a person from the Chinese perspective. Does this imply that it is acceptable to destroy a human embryo to derive hESCs in China? Concerning this issue, it also is necessary to consider the cultural characteristics of the country and the people, because it has a unique culture, which has profoundly influenced the moral viewpoint of its people for thousands of years. Both traditional culture (Sect. 3.2.2.1) and modern viewpoints (Sect. 3.2.2.2) of Chinese people are taken into consideration in this part.

Before entering into a more in-depth analysis of Chinese morality concerning a human embryo, one important thing needs to be clarified first. In Chinese, life can be referred to by two terms, shengming (生命) and shenghuo (生活). Shengming refers to life in the biological sense; shenghuo means life in the social sense. ${ }^{65}$ Only when an individual has an interpersonal relationship with others can he or she be said to have shenghuo, which is considered to be the social dimension of qualifying as a person in the Chinese perspective as mentioned above. In this regard, in the eyes of Chinese a human person has a biological life (shengming), but in turn a human life does not necessarily mean it is a human person, unless it satisfies the aforementioned conditions for an entity to be considered a person.

64 See id., at 142.

65 See id., at 138. 


\subsubsection{The Heritage of Imperial China}

There was little discussion in relation to the moral issues of destroying a human embryo in imperial China. ${ }^{66}$ However, there were other issues, with similar moral messages, which can be discussed to reflect Chinese people's and the government's attitudes towards the destruction of human embryos, as well as the moral status of the embryo. In Confucianism, cheyin (恻隐) and ren (仁), probably as the most fundamental ethical concepts, mean compassion and humaneness, respectively. ${ }^{67}$ Confucianism advocates that people love each other and to have a moral capacity to feel for each other. In Confucianism, to do no harm is the art of ren. If you do not want to harm yourself, you ought not do harm to others. Shengsheng (生生), as a Confucian moral principle, means to preserve and nourish life. ${ }^{68}$ In Taoism, we are exhorted to cherish life, and to respect the value of a person's life. For instance, a famous traditional Chinese medicine doctor of the Sui and Tang dynasty, Simiao Sun (about 581-681), ${ }^{69}$ influenced by Confucian and Taoist ethics, greatly respected life, especially human life. ${ }^{70}$ He explicitly expressed his opposition to the practice of using drugs derived from animals, a practice that has been widely used in Chinese medicine from ancient times to the present. ${ }^{71}$ In short, China's Confucianism and Taoism both cherish and respect human life.

Regarding the view towards a human embryo, one can find that ancient Chinese already knew about human embryos for a long time, if we pay close attention to traditional Chinese culture. Taoism holds that an embryo is a life, and has spirituality. In an ancient Chinese Taoist writing Lord Lao's One Hundred Eighty Precepts, precept number 13 specifically warns one not to kill the unborn babies. ${ }^{72}$ Also another Taoist writing, Talking About the One Hundred Diseases, states that abortion, or causing anyone to kill her fetus, is a disease. ${ }^{73}$ Moreover, there is a description in the Taoist classic Huainanzi which states that "the spirit [jingshen] is received from Heaven and physical form is the endowment of Earth. So it is said that One created Two, Two creates Three, and Three

\footnotetext{
66 For more than 2000 years, from 221 BC until AD 1912, China was ruled by emperors.

67 Further more information about Cheyin, please see NIE, supra note 51, at 88.

68 See id.

69 See id., at 78 (the Chinese regard Simiao Sun as "the King of Medicine". He was the first physician in ancient China and, as such, one of the most influential figures in ancient Chinese medicine. He dealt with medical ethics and combined elements of Buddhism, Confucianism, and Daoism.)

70 See id., at 88.

71 Seeid., at 78.

72 See Kirkland, supra note 51, at 29 ("one should not take part in the killing of people, even unborn children, as precept number 13 quite explicitly states.”)

73 See Joshua Whitehill, Patenting Human Embryonic Stem Cells: What is so Immoral? 34 BROOKLYN JOURNAL OF INTERNATIONAL LAW 1045, 1045 (2008) (stating that the hESC controversy draws lines through the population which are similar, although not identical, to those in the abortion battle.) Thus, some parts of this thesis take abortion as an example to analyze. Here, this thesis is concerned not with the moral issues surrounding abortion in China, but with the moral message it carries about the Chinese and the government's attitudes towards the destruction of human embryos or fetuses, because abortion is also one form of destruction of a human embryo.
} 
creates the myriad things. All things are yin (阴) behind and yang (阳) in front. With the effusion of qi (气) they unite. So it is said that in the first month there is a blob of fat, in the second a thread, and in the third a fetus [tai]. In the fourth month there are pulses, in the eighth it is active, in the ninth it is boisterous, and in the tenth it is born." ${ }^{74}$ This description on the one hand reflects the Chinese cosmology, ${ }^{75}$ and on the other hand also indicates that ancient Chinese had an ambiguous concept of the human embryo. Another interesting thing is the theory of prenatal education or Taijiao (胎教), which traditional Chinese medicine developed. The notion of prenatal education is regarded as deriving from Confucian culture. ${ }^{76}$ It was believed that through prenatal education, emotional or physical impressions from the outside world could be instilled into the unborn in the womb. ${ }^{77}$ One may notice that even without modern high-tech, such as B-ultrasound, ancient Chinese still evidently knew a great deal about what happens in the womb after conception, ${ }^{78}$ in despite of an ambiguous concept of the embryo.

All in all, with a close look at traditional Chinese culture, although little information can be found to shed light on how traditional Chinese culture perceived the status of a human embryo, two things are clear here: First, ancient Chinese people were aware of the development of embryos in the human body (even though not as accurately as modern people), and to some extent regarded the human embryo as a human life at a certain stage of pregnancy. ${ }^{79}$ Second, ancient Chinese people highly respected a life, including an unborn human life. Because of the belief that a human embryo is a human life, the underlying attitudes strongly suggest an opposition to the destruction of human embryos by ancient Chinese people. Hence, it can be understood that the destruction of human embryos is viewed as immoral in traditional Chinese social morality.

However, traditional Chinese social morality does not assert that human life, including the human embryo, should be protected without exception. By way of example, Confucianism holds that to sacrifice one's life for the sake of moral values, such as ren (仁) and

74 See Charlotte Furth, A Flourishing Yin: Gender In China's Medical History, 960-1665 101 (University of California Press 1999). See also Wenxuan Piao (朴文铉), Daojia de Shengming Lunli he Ganxibao Yanjiu de Wenti (道家的生命伦理和干细胞研究的问题) [Ethical View of Life in Taoism and Stem Cell Research], 9 WUHAN KEJI DAXUE XUEBAO (SHEHUI KEXUE BAN) (武汉科技大学学报（社会科学版）) [JOURNAL OF WUHAN UNIV. OF SCIENCE AND TEChnology (SOCIAL SCIENCE Edition)] 109, 111 (2007).

75 Particularly for Confucians and Taoists, the universe and all things are composed of qi, which has two basic forms, yin and yang.

76 See NIE, supra note 51, at 84.

77 See Frank Dikötter, Sex, Culture and Modernity in China: Her Tumultuous Life's Journey to the West (Vol. 1) 93 (Hong Kong University Press 1995).

78 See Qun Cheng (程群), Daojiao Shengsi Guan Yanjiu (道教生死观研究) [Research on Taoist View of Life and Death] 56-58 Sichuan Daxue (四川大学) [Sichuan University] (2007) (discussing the knowledge of fetal development from conception to birth in ancient Chinese society); NIE, supra note 51, at 80-82.

79 See id., at 75; Piao, supra note 74, at 112. 
yi (义/義) (righteousness), is sometimes justifiable. ${ }^{80}$ Despite both Confucians and Buddhists deeming abortion immoral and opposing it in principle on ethical grounds, ${ }^{81}$ they appeared to tolerate the destruction of human embryos in practice. ${ }^{82}$ Especially when certain elements prevailed over the principle of opposing the destruction of human embryos, such as the mother's health being in danger, many ancient Chinese would have had no hesitation in terminating the pregnancy. ${ }^{83}$ This is arguably the underlying reason why very few comprehensive legal bans can be found on deliberately terminating a pregnancy in ancient China, ${ }^{84}$ even though the destruction of human embryos was viewed as immoral in traditional Chinese social morality. Therefore, while on the one hand traditional Chinese morality considered the destruction of human embryos as immoral, on the other ancient Chinese were willing to tolerate their destruction in certain circumstances. This was a specific trait of traditional Chinese social morality, and in fact it remains the same in contemporary China.

\subsubsection{Perspectives of Contemporary China}

Moral norms are not static; societal views about the rightness and wrongness of a matter may change as time goes by. ${ }^{85}$ In the same token, the understanding of the destruction of the human embryo may change with time and social progress. After exploring traditional Chinese social morality regarding the destruction of human embryos, the thesis goes on to analyze the perspectives the modern Chinese people have on this issue.

In today's China, artificially terminating a pregnancy is common. There are approximately 13 million abortions each year in China, compared to 20 million births. ${ }^{86}$ Meanwhile, the real figure may be even higher because many abortions occur at unregistered clinics. ${ }^{87}$ The rate of abortion in China is well above the global average. ${ }^{88}$ For Chinese people, there are several reasons for having an abortion, ranging from unwanted preg-

80 See NIE, supra note 51, at 88.

81 Seeid., at 79.

82 See id.

83 Seeid.

84 See Bernard Hung-kay Luk, Abortion in Chinese Law, THE AMERICAN JOURNAL OF COMPARATIVE LAW 372,379 (1977) (there was no comprehensive legal ban on deliberately terminating a pregnancy. Only a few Chinese laws can be found in the late Qing Dynasty, the Republican period, and the first decade of the People's Republic, which regulated the performance of and access to abortion.)

85 See Bagley, supra note 4, at 502 (regarding reasons for the changing of morality, Professor Bagley has stated that "for one thing, as humans, we are susceptible to de-sensitization, and issues that once seemed shocking can, over time, begin to seem less so. Moreover, self-interest can play a role in shifting views of morality; the discovery that a controversial technology can be beneficial to us on a personal level can, in some instances, impact our view about whether it is moral.")

86 See China Concerned about Abortions, BBC NEws, (Jul. 30, 2009), http://news.bbc.co.uk/2/hi/asia-pacific/8175864.stm.

87 See id.

88 See Chengcheng Jiang, Women Take the Pill: 13 Million Abortions, TImE, (Sept. 30, 2013), http://world.time. com/2013/09/30/what-happens-when-only-1-2-of-chinese-women-take-the-pill-13-million-abortions/. 
nancy and personal convenience to preference for a male child and the requirements of the national population policy. ${ }^{89}$ Many Chinese oppose abortion mainly on the grounds that the act endangers women's physical and mental health, ${ }^{90}$ rather than any concern for the moral status of human embryos. Nevertheless, this does not imply that the contemporary Chinese public morally accepts the destruction of human embryos.

A survey in China, conducted in 2004 (the 2004 survey) and focusing on physicians, found that more than $50 \%$ of physicians did not regard the early embryo (younger than 14 days) as a human being of moral significance, and over $70 \%$ of physicians expressed their support for hESC research. ${ }^{91}$ Nonetheless, in another survey conducted in 2009 (the 2009 survey), ${ }^{92}$ which was also carried out in hospitals, about $49 \%$ of respondents felt that "human life begins from a zygote, and the destruction of human embryos is killing a life". ${ }^{93}$ Most respondents (around $79 \%$ ) held that a human embryo was a human life and, therefore, deserved respect. ${ }^{94}$ It is worth stressing that in the 2009 survey a large majority of respondents (approximately 80\%) expressed their support for research on human embryos for the sake of public health, such as trying to cure infertility and facilitating the understanding of congenital diseases. ${ }^{95}$ The total percentage of respondents who supported therapeutic human cloning was above $90 \%,{ }^{96}$ which suggests most respondents had ethical attitudes that were positive in this respect.

89 In China, there has been a clear acknowledgment of the traditional preference for males. Under China's national population policy, which used to be the one-child policy, many women choose to abort fetuses after ultrasonography when they know the fetus is not a male. See Jing-Bao Nie, The Problem of Coerced Abortion in China and Related Ethical Issues, 8 CAMBridge QuARTERLY OF HeALTHCARE ETHICS 463, 463 (1999). From the perspective of governmental policy, one of the main reasons given for abortion is a lack of government approval for pregnancy under the national population policy. See MAX WEBER, et al., THE RELIGION of ChInA: Confucianism And TAOISM 111 (Collier Macmillan 1964). China's one-child policy was introduced in 1979, and was regarded as a fundamental state policy of the Chinese government. It was intended to control family size and slow population growth. It provideed that a couple should have only one child. Currently, the national population policy has changed into a two-child policy, which allows married couples to have a second child, but the legislation banned additional births, as of 29 October 2015.

90 See Karen Hardee, et al., Family Planning and Women's Lives in Rural China, 30 INTERNATIONAL FAMILY PLANNING PERSPECTIVES 68, 68-76 (2004) (conducting a recent survey of 11,936 graduate students in China, $79.3 \%$ of males and $85.5 \%$ of females agreed that abortion endangers women's physical and mental health.)

91 See Xiangxing Qiu (丘祥兴), et al., Renlei Peitai Ganxibao Yanjiu Lunli Wenti de Diaocha he Taolun (人类胚胎 干细胞研究伦理问题的调查和讨论) [A Survey and Discussion on Ethical Issues of Human Embryonic Stem Cell Research], 25 YIXUE YU ZHEXUE (医学与哲学) [MEDICINE AND PHILOSOPHY] 8 (2004) (this survey was carried out in 8 hospitals of the third class in two cities (Shanghai, Xi'an) of China, adopting the method of random sampling and billing in the questionnaires voluntarily and anonymously.)

92 See Yan Zhou (周燕), Woguo Ganxibao Yanjiu Zhong de Lunli Weiji yu Falü Kunhuo jiqi Guojia Guanli de Yanjiu (我国干细胞研究中的伦理危机与法律困惑及其国家管理的研究) [Research on Ethical Crisis and Legal Issues Related to Stem Cell Research and National Regulatory Framework in China] 88-100 Di San Junyi Daxue (第三军医大学) [Third Military Medical University of Chinese PLA] (2009) (the survey was conducted in four top-three hospitals and one municipal maternal and child care service center in Chongqing city of China, and the respondents were doctors in these institutions.)

93 See id. at 92.

94 Seeid.

95 Seeid. at 96

96 Seeid. at 100. 
Another survey was conducted by Nie in 2005 (the 2005 survey) focusing on the question of "when a human life begins". ${ }^{97}$ Compared with the 2004 and 2009 surveys, the 2005 survey was much more comprehensive, reflecting a larger section of the public, including Catholics, Buddhists, Protestants, medical students, biomedical students, and many others. ${ }^{98}$ In the 2005 survey, a large proportion (72\%) of respondents considered human life to begin at some point before birth. ${ }^{99}$ There is a striking similarity between the 2005 survey and 2009 survey, in that almost half (48\%) of the respondents believed a human life starts at conception. In the 2005 survey, 84\% of respondents agreed with the statement: "a fetus is a life". ${ }^{100}$

It is evident that nowadays most Chinese people are inclined to perceive a human life as beginning at some stage between conception and birth, which is in line with traditional Chinese morality. In addition, these surveys also reveal that the Chinese do consider the destruction of human embryos as immoral, primarily since they believe a human embryo to some extent is a life. However, to a certain extent the Chinese are more likely to tolerate the destruction of human embryos, particularly when certain elements prevail over the interests of the human embryo. In other words, for the Chinese the destruction of human embryos is prima facie morally wrong, and if it is necessary it requires substantial justification. They support hESC research, for example, for the sake of achieving cures and hope for sufferers of debilitating diseases.

For Chinese people a human embryo is not considered a human person; rather, it is just some kind of biological life. There are many transformations in the process from embryo to newborn. The transformation from an embryo to a newborn baby is something like the transformation from a seed to a plant. Although the development from a seed to a plant is a continuum, the seed is definitely different from the plant. By the same token, although an embryo has potential to develop into a human person, it is not a human person, but just some kind of biological life. Thus, the Chinese do consider a human embryo to be a life and to have some inherent moral status, ${ }^{101}$ but they just do not consider a human embryo sacred from the moment of conception, which is quite different from religiously inspired, particularly Catholic, thinking that human life is sacred from the moment of conception.

\footnotetext{
97 See NiE, supra note 51, at 106-112.

98 Seeid.

99 Seeid.

100 See id., at 107.

101 Some commentators have misunderstood and pointed out that most Chinese do not consider the human embryo to have any inherent moral status. See Fiona Murray \& Debora Spar, Bit Player or Powerhouse? China and Stem-cell Research, 355 NEW ENGLAND JournAL OF MEDICINE 1191, 1194 (2006).
} 


\subsection{Legal Status of a Human Embryo in China}

In a way, the legal status of a human embryo in a jurisdiction also may have impact upon the patent rules and policies in terms of patenting hESC-related inventions. Moreover, in a given epoch and society, political and legal decisions concerning the ethical aspects of human embryos may influence the understanding of what it means to be a human being. ${ }^{102}$ This part first goes through a review of current legislation in China (Sect. 3.3.1), then explores a recent landmark judicial decision, which involved a heated debate regarding the legal status of a (frozen) human embryo (Sect. 3.3.2), and last of all, discusses several influential viewpoints of Chinese academia (Sect. 3.3.3) before drawing a summary.

\subsubsection{Legislation Concerning Embryos}

Under the General Principles of the Civil Law (GPCL), citizens in China enjoy civil legal rights from the moment of birth until death, but a fetus has no civil legal capacity under the law. ${ }^{103}$ Meanwhile, neither the GPCL nor the Supreme People's Court views on the GPCL recognize the interests of fetuses or human embryos. Taken collectively, this would indicate that from the perspective of civil law, China does not recognize an unborn fetus, let alone an early stage human embryo, to be a natural person. A similar specific consideration is also reflected in the 1985 Chinese Succession Law (CSL). ${ }^{104} \mathrm{Ar}$ ticle 28 of the CSL sets out that "at the time of the partitioning of the estate, reservation shall be made for the share of an unborn child. The share reserved shall, if the baby is stillborn, be dealt with in accordance with statutory succession" ${ }^{105}$ Although this article appears to provide protection for a fetus, the nature of this protection, in the eyes of commentators, is not to recognize its civil legal capacity, but merely to offer protection in advance for the future interests of the potential child. ${ }^{106}$ The lack of general protection for a fetus' interests is said to be a deliberate arrangement for satisfying the one-child policy of China at the time. ${ }^{107}$

102 See European Group on Ethics in Science and New Technologies (EGE), Opinion No. 16: Ethical Aspects of Patenting Inventions Involving Human Stem Cells, 13 (May 7, 2002), http://biotech.bioetica.org/new/ ege16_complet_en.pdf.

103 Article 9 of the Zhonghua Renmin Gongheguo Minfa Tongze (中华人民共和国民法通则) [General Principles of the Civil Law of the People's Republic of China], stipulating that "a citizen shall have the capacity for civil rights from birth to death and shall enjoy civil rights and assume civil obligations in accordance with the law." See also Nie, supra note 89, at 469.

104 Zhonghua Renmin Gongheguo Jicheng Fa (中华人民共和国继承法) [Law of Succession of the People’s Republic of China] (hereinafter Chinese Succession Law, CSL). The CSL was adopted at the Third Session of the 6th NPC and promulgated by No. 24 of the President of the PRC on Apr. 10, 1985.

105 Article 28 of the CSL.

106 See Rou Tong (佟柔), ZHongGUo Minfa XUE MINFA ZONGZE (中国民法学民法总则) [CHINESE CiviL LAW SCIENCE: GeneRAL PRINCIPLES OF CIVIL LAW] 96 (Zhongguo Gong'an Daxue Chubanshe (中国公安大学出版社) [Peoples Public Security University of China Press] 1990).

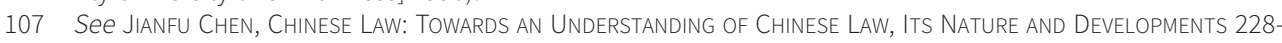
229 (Kluwer Law International 1999). 
Similarly, within the newly promulgated General Rules of the Civil Law, ${ }^{108}$ Article 16 prescribes that where a fetus is involved in inheritance, acceptance of gifts or any other protection of his/her interests, the fetus shall be deemed as having the capacity for civil rights. However, if the fetus is born dead, the capacity for civil rights shall be deemed non-existent since the beginning. ${ }^{109}$ Based on this new provision, only in several specific situations, such as inheritance or acceptance of gifts, can a fetus be deemed to have civil legal capacity. Nevertheless, a fetus is never considered to be a natural person. Article 51(1) of the Law of the PRC on the Protection of Rights and Interests of Women sets out that "women have the right to child-bearing in accordance with relevant regulations of the state as well as the freedom not to bear any child". ${ }^{110}$ This article manifests that in China abortion is legal. Since 1979, in order to control the rapid growth of its population the Chinese government has implemented its national population policy, which is dependent on almost universal access to abortion in China. ${ }^{111}$ Artificial abortion has been used as an important measure of birth control under the national population policy. ${ }^{112}$ Many women have been required, persuaded, and even forced by the government to have abortions. ${ }^{113}$

The implications of the aforementioned legal articles are that under Chinese law, a human embryo is not regarded to be a person; there is no legal principle whereby it should be treated as such. Human beings only become part of the community of law at the moment of birth. Nevertheless, it does not mean that unborn life has no legal protection at all. In addition, it is worth noting a recent landmark judicial decision in China, which involved a debate concerning the moral and legal status of a (frozen) human embryo.

\subsubsection{Yixing Frozen Human Embryo Case}

In 2012, a young couple in Yixing, a small city in China's eastern Jiangsu Province, established four frozen embryos through artificial fertilization by the Reproductive Center of Gulou Hospital in Nanjing. On March 20, 2013, the couple died in a tragic car accident five days before the implantation surgery was scheduled to take place. However, the legal vacuum in the regulations, which ambiguously fail to define a frozen embryo as either a human person or an object, left alone the question of whether the frozen em-

108 See Zhonghua Renmin Gongheguo Minfa Zongze (中华人民共和国民法总则) [General Rules of the Civil Law of the People's Republic of China], adopted at the 5th Session of the 12th NPC of the PRC on Mar. 15, 2017, effective on Oct. 1, 2017.

109 Article 16 of the General Rules of the Civil Law of China.

110 Zhonghua Renmin Gongheguo Fu'nü Quanyi Baozhang Fa (中华人民共和国妇女权益保障法) [Law of the People's Republic of China on the Protection of Rights and Interests of Women] was passed on April 3, 1992 and amended on August 28, 2005.

111 See Nie, supra note 89, at 469.

112 See NIE, supra note 51 , at $70,77$.

113 See Therese Hesketh, et al., The Effect of China's One-child Family Policy After 25 Years, 353 NEw England JOURNAL OF MEDICINE 1171, 1171 (2005). 
bryos could be inherited by the deceased couple's parents. Their families went to court to fight for the inheritance of these frozen embryos. ${ }^{114}$ This case has attracted public attention, and caused disputes about the legal status of (frozen) human embryos. In other words, should a frozen human embryo be regarded as a person, property, or something else? Here, the important things to this thesis are the legal and ethical considerations of the Chinese courts, as well as debates concerning the legal status of a human embryo in China.

The first instance court, Yixing Court, ruled that the embryos generated by IVF embryo fertilization surgery carried the potential to develop into a human being. As a "special thing" containing future life features, the embryos could not be transferred or voluntarily inherited as common personal property. ${ }^{115}$ The appeal court, Intermediate People's Court of Wuxi City of Jiangsu Province, stated that a fertilized embryo had the potential to develop into a human being, which carried both maternal and paternal genetic materials. The appeal court considered the human embryo something between a person and an object; it should have higher moral status than inanimate objects, and deserve special respect and protection. ${ }^{116}$ At last, the appeal court revised the decision of the first instance and ruled that the parents of the deceased couple shared the rights to custody and dispose of the frozen embryos.

It appears that both levels of Chinese courts agreed on the nature of frozen embryos, and held that frozen embryos were "special things with the development of potential life and future life character". ${ }^{117}$ Thus, at least in this case, concerning the legal status of (frozen) embryos, Chinese courts have refused to treat embryos as either property or human beings, but consider them property enjoying special (not full, but modest) respect and protection.

\subsubsection{Viewpoints of Chinese Academia}

Concerning the legal status of frozen human embryos, there are primarily three theories in China: embryo as property theory, embryo as a human being theory, and embryo deserves special respect theory. Most legal experts and academia in China hold that the "embryo deserves special respect theory". Specifically, they hold the viewpoint that a human embryo should be regarded as a special object, which has the potential to develop into a human being. Although a human embryo cannot be regarded as a hu-

114 Jiangsu Wuxi Yixing Lengdong Peitai Jiufen An (江苏无锡宜兴冷冻胚胎纠纷案) [Shen Xinnan and Shao Yumei v. Liu Jinfa and Hu Xinxiang], (Intermediate People's Court of Wuxi, Xi Min Zhong Zi No. 01235, Sep. 17, 2014) ( 江苏省无锡市中级人民法院 (2014) 锡民终字第01235号) (China).

115 See id. See also Fei Lanfang \& Zhou Peng, The Law Itself is not Above Human Beings: Comments on China's First Case on Frozen Embryos, 29 International Journal of LAW, POLICY AND THE FAMILY 260, 263 (2015).

116 See Shen Xinnan and Shao Yumei v. Liu Jinfa and Hu Xinxiang, supra note 114.

117 See Lanfang \& Peng, supra note 115 , at 267. 
man being, it indeed is close to a real human life, and thus deserves special respect and treatment. ${ }^{118}$ A famous civil law scholar Lixin Yang, while at Renmin University of China, proposed considering organs and tissues isolated from human bodies, including frozen human embryos, as ethical objects possessing the property of personhood. ${ }^{119}$ He holds that once human organs or tissues are isolated from a human body, they do not have the property of personhood any more, and should be seen as objects. But this does not mean frozen human embryos do not have their own special status. As ethical objects, human embryos deserve special respect. ${ }^{120}$ Most legal experts and academics in China consider a human embryo neither as pure property nor as a human being. They prefer to treat a frozen human embryo as a special object, which is almost the same as the standpoint of Chinese courts.

In addition, it is worth noting a questionnaire survey, conducted in a city of Hunan province (located in south central China) in 2014, in the matter of how people perceive the status of frozen human embryos, especially concerning the three categories mentioned above. ${ }^{121}$ This survey was conducted in the court and prosecutorial systems. In total there were 300 respondents ranging from young to old. One half were selected from 1020 staff of the two levels of courts and the other were from 1008 staff of the two levels of the prosecutorial system. The result of the survey showed that respondents had some notions about frozen human embryos. $11.6 \%$ of respondents viewed an embryo as the object of rights, and $16.3 \%$ perceived a frozen human embryo as the subject of rights. More importantly, $72.1 \%$ respondents held a middle view, that is "embryo deserves special respect theory".

To sum up, under Chinese law, a human embryo is not considered to be a person; there is no legal principle whereby it should be treated as such. Human beings only become

118 See Liangguo Sun (孙国良), Fuqi Jian Lengdong Peitai Chuli Nanti de Falü Jiejue (夫妻间冷冻胚胎处理难题的 法律解决) [Legal Countermeasures of Issues in Frozen Embryo Disposition between the Couple], 23 GUOJIA JIANCHA GUAN XUEYUAN XUEBAO (国家检察官学院学报) [JOURNAL OF NATIONAL PROSECUTORS COLLEGE] 110, 111-113 (2015); Xiao Han (韩啸), et al., Lengdong Peitai de Lunli Wenti Yanjiu (冷冻胚胎的伦理问题研究) [An Analysis on the Ethical Problem of Frozen Embryos], 15 KUnMING LIGONG DAXUE XUEBAO (昆明理工大学学报) JOURNAL OF Kunming UnIVERSity of SCIENCE AND TeChnology 15 (2015); Haiyan Xu (徐海燕), Lun Tiwai Zaoqi Renlei Peitai de Falü Diwei ji Chufen Quan (论体外早期人类胚胎的法律地位及处分权) [The Legal Status of Early Embryos and the Right of the Disposition of Frozen Embryos], 29 FAXUE LUNTAN (法学论坛) [LEGAL FORUM] 146 (2014).

119 See Lixin Yang (杨立新), Lengdong Peitai shi Juyou Ren'ge Shuxing de Lunli Wu (冷冻胚胎是具有人格属性的伦理 物) [Frozen Human Embryos are Ethical Objects Possessing the Property of Personality], JIANCHA RIBAO (检察 日报) [PROSECUTE DAILY], (Jul. 19, 2014), http://newspaper.jcrb.com/page/1/2014-07/19/03/2014071903_pdf. pdf.

120 See id.

121 Zhiwei Deng (邓志伟) \& Lishi Luo (罗理事), Lun Zeren Lunli Shijiao Xia Lengdong Peitai Baohu Guize de Sifa Xuzao_-Cong Woguo Shouli Lengdong Peitai de Jicheng Jiufen'an Qieru (论责任伦理视角下冷冻胚胎保护规 则的司法续造——从我国首例冷冻胚胎的继承纠纷案切入) [Judicial Enforcement of Frozen Embryo Protection Rules from the Perspective of Ethics of Responsibility: the First Succession Dispute Case Concerning Frozen Embryos in China], QUANGUO FAYUAN DI 26 JIE XUESHU TAOLUNHUI LUNWENJI (全国法院第二十六届学术讨论会论文集) [THE 26TH SYMPOSIUM OF COURTS IN CHINA] 1262, 1267 (2015). 
part of the community of law at birth. Nevertheless, this does not mean a human embryo has no legal protection whatsoever. In the aforementioned influential Yixing Frozen Human Embryo case, both the first instance court and the appeal court agreed that a human embryo was neither a person nor just a simple object or property. The courts considered the embryo to have great potential to develop into a human being, and thus ruled that it should be regarded as property deserving special respect and protection. This standpoint is also supported by most Chinese legal experts and academia.

\section{HUMAN DIGNITY AND THE HUMAN EMBRYO}

Human dignity has quite special importance in patenting hESC-related inventions, particularly in the EU. The EU Biotech Directive specifically incorporates safeguarding human dignity and the integrity of the person into its fundamental principles. ${ }^{122}$ Also, the Directive specifies that "processes, the use of which offend against human dignity, such as processes to produce chimeras from germ cells or totipotent cells of humans and animals, are obviously also excluded from patentability." ${ }^{123}$ Article 6(1) of the Biotech Directive contains a general morality clause whereby inventions cannot be patented if against ordre public or morality. Human dignity is specifically regarded as a guiding interpretive principle in the EU Biotech Directive. ${ }^{124}$ In this regard, in the EU, various critics, scholars, consumer advocates, religious people, and even scientists have contended that hESC-related patents, especially those patents on hESCs per se and the preparation methods, violate human dignity. Similarly, the CPL also contains a general morality clause, ${ }^{125}$ which allows the SIPO to refuse to grant patents on moral grounds. Consequently, the human dignity concerns can also be a potential argument against patenting hESC-related inventions in China. First, this section explores the roots of the concept of human dignity and considers the link between human dignity and embryos (Sect. 4.1). Then, it discusses the human dignity issue concerning the human embryo in China (Sect. 4.2).

\subsection{The Concept of Human Dignity and its Extension to Human Embryos}

To better understand how hESC-related patents might offend, go against, or violate human dignity, it is critical to consider the roots of human dignity first. In fact, the concept of dignity is based on Western ideas. It has roots in the rise of individual liberalism and human rights in Western moral and political thinking in the 18 th century. ${ }^{126}$ There were

\footnotetext{
122 See Recital 16 of the EU Biotech Directive.

123 Recital 38 of the EU Biotech Directive.

124 See Aurora Plomer, Human Dignity, Human Rights, and Article 6(1) of the EU Directive on Biotechnological Inventions, in Embryonic Stem Cell PATENTS: EuROPEAN LAW AND ETHICS 204 (Aurora Plomer \& Paul Torremans ed., Oxford University Press 2009).

125 See Article 5(1) of the CPL.

126 See Plomer, supra note 124, at 206.
} 
three essential elements to human rights in the 18th century: rights are natural or inherent in human beings; rights are possessed equally by all human beings; and rights are universal. To have human rights, people had to be perceived as separate individuals who had the capacity of exercising independent moral judgement. ${ }^{127}$ The idea of dignity was defended by an 18th century German philosopher, Immanuel Kant (1724-1804). He defined dignity as a "universal attribute, an offshoot of the capacity for self-consciousness and practical reason, and the capacity for self-legislation and the control of the will by the categorical imperative belongs to all of us, and is the foundation of the right to respect and to treatment as an end rather than as a means." 128 Dignity is considered to be a fundamental underlying moral value underpinning all moral values and rights. In accordance with the Kantian idea and classical philosophical traditions, the bearer or subject of dignity can only be a separate, embodied individual or person with consciousness and the capacity for self-determination. ${ }^{129}$ The subject of human dignity, in other words, is tied to a being's capacity for sentience or awareness; nevertheless, no versions of human dignity provide any further reason to ascribe human dignity to early embryos. $^{130}$

Subsequently, the idea of human dignity became "married" with religious thinking, particularly Catholic theology. ${ }^{131}$ With the increasing influence of the religiously inspired, in particular Catholic, thinking in the 20th century that human life is sacred from the moment of conception, dignity for fully developed human beings gradually extended to the early stage of human embryos, which do not have personal, physical attributes, such as sentience. ${ }^{132}$ That is to say, by virtue of the fusion of Catholic thinking, which is not universally shared, and the concept of human dignity, human embryos have gradually been assimilated into fully developed human beings as the subject of dignity.

It was hard to find any mentions of the term "human dignity" in European human rights instruments originally, but recently increasing references to this term have emerged. ${ }^{133}$ In the original text of the European Convention on Human Rights (1950), for instance,

\footnotetext{
127 Seeid.

128 Simon BlackBurn, THE OXford Dictionary of Philosophy 100 (Oxford University Press 2nd ed. 2005).

129 See Plomer, supra note 124, at 206-207.

130 See id., at 208.

131 See Jeff Malpas \& Norelle Lickiss, Perspectives on Human Dignity: A ConVersation 12 (Springer 2007).

132 See Plomer, supra note 124, at 208 (In this paper, the author also has listed three main grounds of the Catholic Church's opposition to hESC research: "(1) On the basis of a complete biological analysis, the living human embryo is-from the moment of the union of the gametes-a human subject with a well-defined identity... (2) From this it follows that as a human individual it has the right to its own life; and therefore every intervention which is not in favour of the embryo is an act which violates that right... (3) Therefore, the ablation of the ICM of the blastocyst, which critically and irremediably damages the human embryo, curtailing its development, is a gravely immoral act and consequently is gravely illicit.")
}

133 See id., at 212. 
there was no express reference to human dignity. ${ }^{134}$ Even though the first mention of human dignity is in the Protocol on the abolition of the death penalty (2002), ${ }^{135}$ the context is irrelevant to biotechnologies and makes clear that dignity can only involve human beings already born. ${ }^{136}$ Recently, several references to human dignity can be found in documents issued by the Council of Europe, such as the Convention for the Protection of Human Rights and Dignity of the Human Being with regard to the Application of Biology and Medicine: Convention on Human Rights and Biomedicine (hereafter, "European Convention on Human Rights and Biomedicine" or "ECHRB"). ${ }^{137}$ In the ECHRB, human dignity is emphasized several times, such as in the Preamble and even the title. ${ }^{138}$ From the context of the ECHRB and the explanatory report of the ECHRB, it appears that human dignity can extend not only to human beings already born but can also involve human embryos. ${ }^{139}$ Nevertheless, the ambiguity with regard to concepts of human dignity in the ECHRB creates internal tensions within the Convention and could potentially allow for a variety of moral and cultural perspectives to be reflected in the interpretation and application of bearers of human dignity. ${ }^{140}$

In addition, at the EU level, the concept "human dignity" has already translated into the fundamental ethical principle in regulating hESC research. In 2000, the European Parliament, the Council and the Commission announced the Charter of Fundamental Rights of the European Union (EU Charter). ${ }^{141}$ In this EU document, human dignity has been emphasized not only as a fundamental right per se, but also as the basis of all the fundamental rights. Specifically, in this EU Charter human dignity has been recognized as one basic point that the EU is founded on. ${ }^{142}$ Moreover, human dignity has been introduced into Article 1 of the EU Charter, which states "[h]uman dignity is inviolable.

\footnotetext{
134 Seeid.

135 Protocol No. 13 to the Convention for the Protection of Human Rights and Fundamental Freedoms, concerning the abolition of the death penalty in all circumstances, Vilnius, 3.V.2002, ETS 187. The preamble proclaims that "convinced that everyone's right to life is a basic value in a democratic society and that the abolition of the death penalty is essential for the protection of this right and for the full recognition of the inherent dignity of all human beings".

136 See Plomer, supra note 124, at 213.

137 Convention for the Protection of Human Rights and Dignity of the Human Being with regard to the Application of Biology and Medicine: Convention on Human Rights and Biomedicine, Oviedo, 4.IV.1997, ETS 164.

138 In the preamble of the ECHRB, it proclaims that there is "the need to respect the human being both as an individual and as a member of the human species and recognising the importance of ensuring the dignity of the human being; Conscious that the misuse of biology and medicine may lead to acts endangering human dignity."

139 See Plomer, supra note 124, at 213.

140 See id., at 214.

141 The European Parliament, the Council and the Commission, Charter of Fundamental Rights of the European Union (2000/C 364/01), OJ C 364, 18 Dec. 2000.

142 Para. 2 of the preamble of the Charter of Fundamental Rights of the European Union states that "[c]onscious of its spiritual and moral heritage, the Union is founded on the indivisible, universal values of human dignity freedom, equality and solidarity; ..."
} 
It must be respected and protected." 143 Moreover, EU Sixth and Seventh Framework Programmes require research projects, including hESC research, to be carried out respecting "fundamental ethical principles" including inter alia the "protection of human dignity". ${ }^{144}$ The European Group of Ethics (EGE) acknowledges the "principle of respect for human dignity" as a fundamental ethical principle in hESC research. ${ }^{145}$ As mentioned before, human dignity has been incorporated into the EU Biotech Directive, and has played an important role in determining the patent eligibility of hESC-related inventions in the EU, particularly reflected in Brüstle case. ${ }^{146}$ This thesis will return to this case for further discussion later. ${ }^{147}$

It is evident that there is a rise of "human dignity" in recent European regulation and legal instruments on biotechnologies. Through an analysis of the evolution of the term "human dignity" and relevant European human rights instruments on biotechnologies, Professor Aurora Plomer has pointed out that the concept of human dignity is inherently indeterminate, and that it is unclear whether the subject of human dignity is just a human person already born or also attaches to potential persons, including the human embryo. ${ }^{148}$ Interestingly, through the decision of the CJEU in the Brüstle case, it appears that human dignity has gradually extended to human embryos from fully developed human beings.

In contrast, China has a totally different moral, religious, and cultural background from the West, and thus the construction and application of human dignity, such as whether human dignity extends to human embryos, in China vary from those in Europe. ${ }^{149}$ The next section will discuss the human dignity issue concerning the human embryo in China.

\subsection{Human Dignity and the Human Embryo in China}

In China, the same as Article 6(1) of the EU Biotech Directive, the CPL also has a general morality clause. Human dignity in this respect could be a potential argument to exclude hESC-related inventions from patent eligibility in China. Recurring questions with respect to the construction and application of human dignity in China include the following: whether there is the concept of human dignity in China? Is there any legal

143 Article 1 of the Charter of fundamental rights of the European Union.

144 See supra note 43.

145 EGE, supra note 42, at 14.

146 See C-34/10 (Oliver Brüstle v. Greenpeace eV) OJ C 362/7 [2011].

147 See infra Sect. 4.2, Chap. 5.

148 See generally, Plomer, supra note 124.

149 See id., at 226 (pointing out that the construction and application of human dignity, such as whether human dignity extends to human embryos, ultimately depends on the overarching moral, religious, and cultural background.) 
instrument prescribing human dignity in China? Moreover, as analyzed earlier, a human embryo is not regarded to be a person from the Chinese perspective. Based on this, is human dignity an attribute of existing persons only or does it extend to the unborn, including a human embryo?

\subsubsection{International Human Rights Instruments}

To understand the relationship between human dignity and an embryo in China, it will be helpful to first review, briefly, the international human rights instruments that China has been involved in. The Chinese government has ratified dozens of international human rights treaties, which to some extent have impact upon the attitudes of China towards human dignity. The Charter of the United Nations (1945) emphasized in its preamble "faith in fundamental human rights, in the dignity and worth of the human person". ${ }^{150}$ It is said that the public concern in the matter of human dignity virtually emerged after the World War II, which caused a human catastrophe. In addition, human dignity has particularly been introduced into the Universal Declaration of Human Rights (1948), signed by the General Assembly of the United Nations (UN) in Paris in December $1948 .^{151}$ This declaration clearly points out that it is necessary to recognize the inherent dignity and the equal and inalienable rights of human beings as the foundation of freedom, justice and peace in the world, ${ }^{152}$ which mirrors the Charter (1945) in reaffirming faith in the dignity of the "human person". ${ }^{153}$ Similarly, as the two most significant human rights covenants of the UN, the International Covenant and Civil and Political Rights (1966) $)^{154}$ and International Covenant on Economic, Social and Cultural Rights (1966) $)^{155}$ both reaffirmed in their preambles that basic human rights derive from the core values of human dignity. ${ }^{156}$ The Vienna Declaration on Human Rights (1993) in a similar way asserted "all human rights derive from the dignity and worth inherent in the human person". ${ }^{157}$ China has ratified over 20 international human rights treaties,

150 The Charter of the United Nations, signed on 26 Jun. 1945, came into force on 24 Oct. 1945. Currently, China is one of five permanent members of the UN Security Council.

151 See General Assembly of United Nations, Resolution 217 A (III) Universal Declaration of Human Rights, Dec. 10, 1948.

152 See Preamble of the General Assembly Resolution 217 A (III).

153 See Plomer, supra note 124, at 210.

154 International Covenant on Civil and Political Rights, adopted 16 Dec. 1966, entered into force 23 Mar. 1976.

155 International Covenant on Economic, Social and Cultural Rights, adopted 16 Dec. 1966, entered into force 3 Jan. 1976

156 Both the two covenants of the UN stressed in their preambles that "in accordance with the principles proclaimed in the Charter of the United Nations, recognition of the inherent dignity and of the equal and inalienable rights of all members of the human family is the foundation of freedom, justice and peace in the world" and "recognizing that these rights derive from the inherent dignity of the human person".

157 Vienna Declaration and Programme of Action, adopted by the World Conference on Human Rights in Vienna on 25 June 1993. 
which indicates that China has clearly approved the international human rights norms and given prominence to respecting human dignity. ${ }^{158}$

\subsubsection{Human Dignity and the Chinese Constitution}

In China's 1982 Constitution, there is no precise reference to human dignity. The most relevant provision is Article 38 of the Constitution, which only mentions "the personal dignity of citizens" rather than human dignity. ${ }^{159}$ It is said that the introduction of "the personal dignity of citizens" into the 1982 Constitution was based on the bitter lesson of the Culture Revolution, when there was massive violation of citizens' dignity, and on reference to other countries' legislation. ${ }^{160}$ In Article 38 of the Chinese Constitution, however, from the wording it is evident that "personal dignity" is different from "human dignity", and the subject of the personal dignity is only citizens. Most scholars view "the personal dignity" in the Constitution refers to personal rights, and believe that "the personal dignity of citizens is inviolable" normally refers to the fact that a citizen's personal rights in civil law, including the rights of personal name, reputation, portrait, etc. are inviolable. ${ }^{161}$ Recently, there is growing body of literature arguing that although the Chinese Constitution does not mention the term "human dignity", it still shows respect for human dignity and provides protection of human dignity. ${ }^{162}$ However, as one Chi-

158 See Haocai Luo, Different Cultures Show Same Respect for Human Dignity, PEOPLE'S DAILY USA, (Sept. 22, 2011), http://usa.chinadaily.com.cn/opinion/2011-09/22/content_13764204.htm. A Chinese version can also be available at http://paper.people.com.cn/rmrbhwb/html/2011-09/22/content_929388.htm.

159 Constitution of the PRC, adopted at the 5th Session of the 5th NPC, promulgated for implementation by the Announcement of the NPC on Dec. 4, 1982. The last amendment was on Mar. 14, 2004. Article 38 of the Constitution stipulates that "the personal dignity of citizens of the PRC is inviolable. Insult, libel, false accusation or false incrimination directed against citizens by any means is prohibited."

160 See Chongde Xu (许崇德), ZHonghuA Renmin GONGHeguo XIANFA SHI (中华人民共和国宪法史) [HISTORY OF THE COnstitution Of THE PEOPLE'S Republic of CHINA], 794-796 (Fujian Renmin Chuban She (福建人民出版社) [Fujian People Press]. 2003).

161 Quanguo Renda Changweihui Bangongting Yanjiushi Zhengzhizu (全国人大常委会办公厅研究室政治组) [General Office of NPC Standing Committee], ZHONGGUO XIANFA JINGSHI (中国宪法精释) [EXPLANATION FOR CHINA'S COnSTITUTION], 163 (Zhongguo Minzhu Fazhi Chuban She (中国民主法制出版社) [Press of Chinese Democratic Legal System] 1996).

162 See Laifan Lin (林来梵), Ren de Zunyan yu Ren'ge Zunyan-Jianlun Zhongguo Xianfa Di 38 Tiao de Jieshi Fangan (人的尊严与人格尊严——兼论中国宪法第38条的解释方案) [Personal Dignity and Personality Dignity: on the Interpretation of Article 38 of the Chinese Constitution], 3 ZHEJIANG SHEHUI KEXUE (浙江社会科学) [ZHEJIANG SOCIAL SCIENCES] 47, 47-55 (2008) (from perspective of comparative Constitutional jurisprudence, Lin compared "the personal dignity" referred in the Chinese Constitution with "human dignity" mentioned in several Western countries' constitutions, such as the Constitution of Germany, analyzed the structure of Article 38 of the Chinese Constitution, and then he concluded that "the personal dignity of citizens ... is inviolable" can be understood to express a principle of fundamental value similar to "human dignity".) See also Qianfan Zhang (张千帆), XIANFA XUE DAOLUN (宪法学导论) [INTRODUCTION TO CONSTITUTIONAL JURISPRUDENCE] 507-509 (Falü ChubanShe (法律出版社) [Law Press, China]. 2004) (considering that "the personal dignity" in the Chinese Constitution can be viewed as "human dignity".) Haiping Li (李海平), Lun Ren de Zunyan zai Woguo Xianfa Shang de Xingzhi Diwei (论人的尊严在我国宪法上的性质地位) [On the Qualitative Orientation of Human Dignity in Chinese Constitution], 12 SHEHUI KEXUE (社会科学) [SOCIAL SCIENCE] 101-110 (2012) (through analyzing the constitutional purpose stated in the Chinese Constitution preface, the structural arrangement of the main body of the Constitution and the contents of fundamental rights, Li argued that human dignity is a supreme principle of the Chinese Constitution.) 
nese legal scholar mentioned, even if China, like Western countries, also regards human dignity as the supreme principle of its Constitution, it does not mean human dignity should be reflected in the same way; China can choose its own rules and regulations to protect human dignity under its own national conditions and traditions. ${ }^{163}$ In addition, even if the Chinese Constitution to some extent shows respect for human dignity, the wording points to persons rather than the unborn as the bearers or the subjects of human dignity, and it is hard to find any clue that human dignity extends to potential persons, including human embryos.

\subsubsection{The Attitude of the Chinese Government Towards Human Dignity}

While human dignity has not yet been explicitly introduced into Chinese legislation, the Chinese government has claimed safeguarding and promoting human dignity as a starting point and the ultimate aim of governmental work. To some extent, recognizing and respecting human dignity, at least ostensibly, has been the basic opinion of the Chinese government. In April of 2006, former President Hu Jintao mentioned in a speech delivered at Yale University that "the Chinese civilization always gives prominence to the principle of putting the people first and respects the dignity and value of the human being." Similarly, in March of 2010, former Prime Minister Wen Jiabao, while delivering the Report on the Work of the Government at the Third Session of the 11th National People's Congress (NPC), clearly put forward, "all the things we do aim at improving people's welfare, letting them have more dignity and making the society fairer and more harmonious." ${ }^{164}$ In addition, China's current President Xi Jinping also pointed out that "each country and people should be entitled to dignity," 165 which is considered to be China's positive response to the universal respect of the international community for human dignity. ${ }^{166}$

Recently in China, there are several normative legal documents directly stipulating the dignity of the person, and considering safeguarding human dignity as an important task of the governmental work. For instance, the Notice on Issuing the Plan for the Basic Public Services System During the 12th Five-Year Plan, issued by the State Council, sets forth that "the State shall establish a basic social service system, to provide material assistance to the basic livelihood of urban and rural residents, especially the disadvantaged groups, and to guarantee the dignity and equal participation of special groups,

163 See id., at 104.

164 Luo, supra note 158.

165 Jinping Xi (习近平), XI JINPING TAN ZHIGUO LIZHENG (习近平谈治国理政) [XI JINPING: THE GOVERNANCE OF CHINA] 273 (Waiwen Chuban She (外文出版社) [Foreign Languages Press] 2014).

166 Yuhong Hu (胡玉鸿), Ren de Zunyan de Falü Shuxing Bianxi (人的尊严的法律属性辨析) [An Analysis of the Legal Attributes of Human Dignity], 5 ZHONGGUO SHEHUI KEXUE (中国社会科学) [SOCIAL SCIENCE IN CHINA] 101, 101 (2016). 
such as the elderly, the disabled and orphans, in social development." ${ }^{167}$ Opinions of the State Council on Division of Work for Departments for the Implementation of Key Work in the "Government Work Report" specifically points out that "[the State] shall strive to create more employment opportunities with higher-quality, so as to make workers' lives more decent and dignified." ${ }^{168}$ Opinions of the State Council on Accelerating the Progress of Building the Wellbeing of Disabled Persons emphasize that "[the State] should let the disabled live and work in peace, make their life worry-free, and let them live better off, happier, and more dignified." 169

Through the claims of government officials, no doubt, safeguarding and promoting human dignity has become a starting point and the aim of the governmental work of China. ${ }^{170}$ The Chinese government aims to increase China's international influence, and thus it needs a positive international image. In addition to China always facing fierce criticism from the Western world for failing to meet international human rights standards, it is not surprising that Chinese government officials, on all kinds of national and international occasions, often showcase this country's positive attitude towards safeguarding and promoting human dignity. However, the speeches of China's top leaders and normative legal documents mentioned above primarily focus on the dignity of fully developed human beings, especially disadvantaged groups such as the disabled and orphans. No clue can be found to support human dignity has been attached to a human embryo or to early forms of human biological life.

To sum up, the concept of human dignity originated in Europe, and subsequently has gradually expanded worldwide. Meanwhile, due to the influence of religious thought, particularly Catholic theology, the bearer of human dignity has gradually extended from fully developed human beings towards unborn biological life, such as human embryos. This phenomenon is especially reflected in European human rights instruments. However, by virtue of diverse moral, and religious traditions and cultures, the construction and application of human dignity differ from region to region. China has not been particularly influenced by religious, especially Catholic, thought. While the

167 Guowuyuan Guanyu Yinfa Guojia Jiben Gongong Fuwu Tixi Shi'er Wu de Guihua de Tongzhi ( 《国务院关于印发 国家基本公共服务体系“十二五”规划的通知》国发[2012] 29号) [Notice of the State Council on Issuing the Plan for the Basic Public Services System During the 12th Five-Year Plan, Guofa [2012] No.29], promulgated by the State Council of PRC on July 11, 2012.

168 Guowuyuan Guanyu Luoshi Zhengfu Gongzuo Baogao Zhongdian Gongzuo Bumen Fengong de Yijian ( 《国 务院关于落实〈政府工作报告〉重点工作部门分工的意见》国发[2014]15号) [Opinions of the State Council on Division of Work for Departments for the Implementation of Key Work in the "Government Work Report"Guofa [2014] No.15], promulgated by the State Council of PRC on March 23, 2014.

169 Guowuyuan Guanyu Jiakuai Tuijin Canjiren Xiaokang Jincheng de Yijian (《国务院关于加快推进残疾人小康进程 的意见》国发[2015] 7号) [Opinions of the State Council on Accelerating the Progress of Building the Wellbeing of Disabled Persons, Guofa [2015] No.7], promulgated by the State Council of the PRC on January 20, 2015.

170 See Luo, supra note 158; Hu, supra note 166, at 108. 
Chinese government has gradually given prominence to respecting human dignity, there is no clue to support the notion that human dignity has been attached to a human embryo or to early forms of human biological life in this country. Moreover, the concept of human dignity has not yet been explicitly introduced into Chinese legislation, which contrasts sharply with the emphasis on human dignity in some European human rights instruments.

\section{OTHER POSSIBLE FACTORS INFLUENCING THE ACCEPTABILITY OF MANIPULATING HESCS}

In addition to cultural and legal factors, the acceptability of hESC research in a society is also influenced by historical, social, and economic factors. It is worth mentioning scientism, which also may have great impact upon the acceptability of research on human embryos and hESCs in China. Moreover, in the age of globalization with increasing international communication, the moral concerns also may be affected by culture from outside the national boundaries. Thus, this section explores the impact of scientism (Sect. 5.1), as well as the influence from the West based on scientific communication and the spread of imported religion. (Sect. 5.2).

\subsection{The Impact of Scientism}

The process of China's modernization was carried out under the background of foreign invasions and the struggle for national life. In the 1840 Opium War, China was defeated by powerful British gunboats. The closed and conservative market of China was opened to the West by force. The Chinese were first impressed by the power of S\&T. The minds of Chinese were therefore deeply influenced by the goal of "making the country wealthy and the military powerful." Since the May Fourth Movement in 1919, Chinese had gradually called for Western ideals of "Mr. Science" (Sai Xiansheng) and "Mr. Democracy" (De Xiansheng) to save and strengthen China. Since then, there started to be a belief among Chinese intellectuals that S\&T could figure out all problems faced by China. ${ }^{171}$ Against this background, the study of Western S\&T has almost become the only means to boost China's national power, and meanwhile scientism has become popular in China.

In 1988, Deng Xiaoping, who was the paramount leader of China and the chief architect of the reform and opening up policy, put forward the philosophy that "science and technology is the first productive force". ${ }^{172}$ This proposition has been introduced into Chinese students' educational materials ranging from primary schools to colleges.

\footnotetext{
171 See Qiu, supra note 51, at 55.

172 See Xin Zhongguo Dang'an: Deng Xiaoping Tichu Kexue Jishu shi Diyi Shengchanli (新中国档案: 邓小平提出 科学技术是第一生产力) [Archives of New China: Deng Xiaoping pointed out S\&T is the First Productive Force], www.GOV.cn, (Oct. 10, 2009), http://www.gov.cn/test/2009-10/10/content_1435113.htm.
} 
In 1995, China adopted the strategy of invigorating the country through the development of science and education in order to strengthen its national power. The utmost importance has been placed on scientific fields in the Chinese education system. Thus, in most Chinese people's minds, the advancement of S\&T stands for the growth of the economy, the progress of society, and the prosperity of this country.

China has been fixated on playing "catch up" with its technologically advanced counterparts in the scientific arena. Over the last few decades, China has been striving to develop its own biotechnology, and attempting to enter the ranks of S\&T power. The Chinese government has been greatly propagating the notion of advancing biotechnology. It considers the advancement of biotechnology able to not only boost national pride, but also can promote the growth of this country's economy, in turn providing political leverage and stability. S\&T has a sacred place in the minds of the Chinese public. Based on the pragmatic attitude towards science and in the absence of religious objections, hESC research has not evoked the same controversies in China as it has in the West. ${ }^{173}$ Conducting scientific research on human embryos and hESCs is relatively acceptable to the Chinese, since they believe the advancement of such research would promote the growth of the economy as well as the level of S\&T of China.

\subsection{Influence from the West}

Over the last several decades, China's local biotechnology research practice has never been isolated from global controversies. With increasing foreign investment, transnational natural resources and academic research exchange in China, ethics or morality in this country is no longer isolated from foreign culture, but influenced and shaped by the international scientific and bioethical communities. ${ }^{174}$ Especially in recent decades, more and more Chinese have been abroad, mainly to Western countries (e.g., the UK and the US), and have learnt not only advanced techniques from the West but also Western cultures. After returning to China, they then play an important role in tailoring ethical and regulatory schemes. Not surprisingly, with increasing international communication, China gradually has been a recipient of international research norms. As will be shown in Chapter 4, when China imports Western advanced technology in the field of hESC research, it also imports many Western concerns.

However, the abovementioned influence in China is limited, and mainly concentrated in the Chinese scientific community, rather than altering the overarching moral concerns regarding embryos and hESCs in China. In effect, the Chinese public is not influenced

\footnotetext{
173 See Joy Yueyue Zhang, The Cosmopolitanization of Science: Stem Cell Governance in China 5 (Palgrave Macmillan 2012).

174 Seeid., at 6.
} 
by the Western disputes as much as Chinese scientists are. Moreover, one may debate whether the moral or ethical concerns of the Chinese may be influenced by foreign religions, such as Christian, particularly Catholic, teaching. Indeed, in contemporary China, there are various religions, with approximately 100 million believers, including Buddhism, Taoism, Islam, and Christianity, and the number of adherents is increasing all the time. ${ }^{175}$ However, it should be admitted that in terms of China's huge population, religious people constitute but a very small proportion. In this regard, their viewpoints on the moral status of human embryos cannot be regarded as necessarily reflecting mainstream thought in China. ${ }^{176}$ Generally speaking, China is still a religiously atheistic country, and the influence of Catholic teaching in this country is considerably limited.

In short, although in the age of globalization with increasing international communication, Chinese moral culture may have been affected and shaped by culture from outside the national boundaries, the influence is very limited and mainly concentrated in the Chinese scientific community, rather than altering the overarching moral concerns over human embryos and hESCs in China.

\section{CONCLUSION}

Debates regarding research on human embryos and hESCs, and by extension regarding patenting hESC-related inventions, are universal, but also demonstrate unique characteristics in China, due partly to moral culture regarding the embryo and the public perceptions of patents in this jurisdiction. The Chinese public does not have any strong moral concerns about the human embryo. The Chinese only consider an early stage embryo as some kind of biological life which deserves special respect, rather than as a human being. Chinese morality concerning a human embryo, to some extent, can be regarded as pragmatic and utilitarian. On the one hand, the Chinese believe a human embryo has some inherent moral status and deserves special respect and protection, but on the other they are more likely to tolerate the use and destruction of human embryos, particularly when certain elements prevail over the interests of the human embryo. Not surprisingly, the Chinese support research on human embryos and hESC research, for example, for the sake of achieving cures and hope for sufferers of debilitating diseases. This is quite different from religiously inspired, particularly Catholic, thinking in the West that human life is sacred from the moment of conception.

175 See Green, supra note 50, at 24.

176 See Xu Zhao (肇旭), Renlei Peitai Ganxibao Yanjiu de Lunli Guan Fenxi (人类胚胎干细胞研究的伦理观分析) [A Study on Ethical Values of Human Embryonic Stem Cell Research], 1 LUNLI XUE YAN JIU (伦理学研究) [STUDIES IN ETHICS] 82, 88 (2012). 
Regarding the legal status of a human embryo in China, under Chinese law, a human embryo is not considered to be a person; there is no legal principle whereby it should be treated as such. Human beings only become part of the community of law at birth. Nevertheless, this does not mean a human embryo has no legal protection whatsoever. A recent remarkable judicial decision in China reveals that although Chinese courts do not consider the embryo to be a human person, they regard the embryo as a property deserving special respect and protection, which is in line with Chinese morality mentioned above. It is evident that the viewpoint that a human embryo is sacred from the moment of fertilization is not compatible with the moral and legal status of the embryo in China.

In addition, appeals to human dignity as a criterion for embryo policy are also frequent. The concept of human dignity originated in Europe, and subsequently has gradually expanded worldwide. Due to the introduction of foreign religious thought, particularly Catholic theology, the recognition of human dignity has gradually extended from fully developed human beings to unborn biological life, such as human embryos. However, religiously inspired ideals are not universally shared, and China is little influenced by religious, particularly Catholic, thought. While the Chinese government has gradually given prominence to respecting human dignity, there is no sign that human dignity has been attached to a human embryo or to early forms of human biological life in this country. Meanwhile, the concept of human dignity has not yet been explicitly introduced into Chinese legislation, which contrasts sharply with the emphasis on human dignity in some European human rights instruments and constitutions of several EU member states. In this regard, it can be concluded that it is not appropriate to utilize the human dignity argument to oppose hESC research and the patenting of hESC-related inventions in China.

Indeed, over the last decades in the age of globalization, with increasing international communication, Chinese morality may be influenced by culture from outside the national boundaries. However, the impact is very limited and mainly concentrated among the Chinese scientific community, rather than altering the overarching moral concerns in China. Moreover, another aspect worth considering is scientism in China. A manifestation of this scientism is that S\&T has a sacred place in the minds of the Chinese public. In most Chinese people's minds, the advancement of hESC research stands for growth of the economy, the progress of society, and the prosperity of this country. In this regard, scientism to some extent has propelled the public to accept hESC research in China.

Since the Chinese public has a pragmatic moral position concerning the human embryo, and at the same time, they are not influenced by Western religions, the destruction of 
human embryos, such as in hESC research, has not provoked a backlash in China. The popular scientism in this country as well as the Chinese government's publicity and emphasis on hESC research have further won public support and removed barriers to such research. At the same time, the Chinese public hold a pro-patent stance, and many of them think of a patent almost as standing for a guarantee of quality and representing technical authority and advanced technology. All in all, in the context of the Chinese public's pragmatic moral position, and the Chinese government's considerable support for hESC research, as well as the public's favourable view of patents, it appears that the Chinese public will not have much strong moral resistance to patenting most hESCrelated inventions, as long as the patenting shows certain respect for human embryos under Chinese moral culture. 



\section{4 \\ Governments' Policy Towards hESC Research}

\section{INTRODUCTION}

Commentators have observed that the exclusions of hESC-related inventions from patent eligibility on moral or ethical grounds are closely related to the policy approaches to hESC research. ${ }^{1}$ That is, the policy approach to hESC research to some extent reflects the moral and social value (e.g., the social construction of a human embryo), which in turn may influence granting patents for hESC-related inventions in a jurisdiction. In this regard, the exploration of regulating $\mathrm{hESC}$ research as well as associated debates in the three jurisdictions (i.e., the US, EU and China) will contribute to better understanding the concerns surrounding patenting hESCs-related inventions. Moreover, to tailor China's own patent policy, it is necessary for its legislators and regulators of the country to know the value orientation and policy approaches of other jurisdictions, which can help avoid the collisions caused by diverse culture, values and religions. Only based on sufficient knowledge of the diverse values towards hESC research of the Western world and China, and underlying rationales, can legislators and regulators tailor an appropriate patent framework and policies for hESC research in China.

For these reasons, before deeply examining and investigating patent issues, this chapter of the thesis goes through the policy approaches the three jurisdictions (i.e., the US, EU and China) have taken towards such research in Sections 2, 3, and 4, respectively. Through this analysis, it can reveal the underlying considerations of these jurisdictions, and further assist in figuring out the options for tackling the problems raised by patenting hESC-related inventions in China. In addition, when discussing the policy approaches to $\mathrm{hESC}$ research in China, the place of China's hESC research and development in the

See Åsa Hellstadius, A Comparative Analysis of the National Implementation of the Directive's Morality Clause, in Embryonic Stem Cell PATENTS: EuRopeAn LAW And ETHICS 134 (Aurora Plomer \& Paul Torremans ed., Oxford University Press 2009). 
world as well as the stage of hESC research in this country will also be analyzed. This chapter on the one hand articulates the contours of the policies themselves and on the other hand provides a comprehensive discussion of the lessons of the governments' approaches. Meanwhile, in order to better understand the various policy approaches, their other aspects, including historical, cultural, economic, and sociological contexts also are briefly referred to. ${ }^{2}$ Since the EU has a very limited competence in regulating $\mathrm{hESC}$ research, and that regulatory approaches to $\mathrm{hESC}$ research in the EU are a matter of member states, it is necessary to analyze the policy approaches of a number of EU member states. In this regard, when discussing and analyzing the policy approaches in the EU, policy approaches adopted by the governments of Germany, the Netherlands and the UK are taken as examples to be examined in detail. The variety in legal settings and regulatory frameworks across the EU offers the opportunity to test diverse policy and research approaches, which could provide China a great lesson in governing hESC research and further contribute to patent policymaking regarding hESC-related inventions there.

\section{APPROACHES TAKEN BY THE US}

No doubt, the US has been leading the world in biotechnology, including hESC research, for years. At the same time, in controversial scientific research, typically the US legislation and regulatory policy is also at the forefront around the world. Regulating research on human embryos and hESC research is a significant example. In fact, the regulation of hESC research in the US is deeply rooted in its scientific and political history. Before the successful establishment of the first hESC line in the world, the US federal government had already discussed the appropriateness of embryo research. Whenever new morally controversial techniques in biology research field emerge, the US federal government always responds expeditiously and is willing to discuss pertinent political and moral issues. When it comes to hESC research, the regulation also turns out to be highly controversial, and moral concerns are at the center of the debate. As shown in Chapter 2 , regarding the moral debate in $\mathrm{hESC}$ research, on one side are those who believe that the destruction of embryos that otherwise could develop into human persons is inherently morally unacceptable, and on the other are those pursuing cures for deadly or disabling diseases. Facing the moral dilemma of regulating hESC research, not surprisingly, it is difficult for the US to tackle.

2 See Rosario M Isasi \& Bartha M Knoppers, Towards Commonality? Policy Approaches to Human Embryonic Stem Cell Research in Europe, in EMBryonic STEM CELL PATENTS: EUROPEAN LAW AND ETHICS 37 (Aurora Plomer \& Paul Torremans ed., Oxford University Press 2009) (stating that "the policy frameworks would be better understood by referring to their historical, cultural, economic, and sociological contexts.") 
As will be shown in the next chapter, in the US recently moral issues have had a very limited place in its patent system. ${ }^{3}$ Several times the courts of the US pointed out that they do not have the competence to tackle these contentions, including moral issues. ${ }^{4}$ As such, moral issues have been removed from determining the patent eligibility of hESCrelated inventions, and left to the US government or Congress to deal with. This section of the thesis mainly explores how the US has dealt with hESC research and related moral concerns beyond patent law. The exploration of this section aims to assist in the examination of the relevant regulation in China. It may provide a lesson in regulating hESC research, and clarify whether it is effective and practical for China to remove the moral assessment within the patent law in determining patent eligibility, leaving such assessment to other agencies. The analysis of this section is divided into two parts: policy approaches at the federal level (Sect. 2.1) and those at the state level (Sect. 2.2).

\subsection{The US Federal Approaches}

In order to comprehend the US federal policy towards regulating hESC research in its full context, one needs a concise consideration of the federal government's historical role in the regulation of human embryo research. ${ }^{5}$ In this regard, this section of the thesis first provides a brief review on the history of the US federal policy on embryo research (Sect. 2.1.1). Because the Dickey-Wicker Amendment is still in force and is considered to have great impact on governing $\mathrm{hESC}$ research in the US, the second part of this section analyzes this legal document (Sect. 2.1.2). At last, policy approaches of successive US governments, including the Clinton, George W. Bush, Obama, Trump administrations, are discussed, to see how the US federal government has dealt with hESC research in detail (Sect. 2.1.3 and Sect. 2.1.4). The 2009 NIH Stem Cell Guidelines and the case Sherley $v$. Sebelius are also analyzed to highlight the current federal funding policy in the US (Sect. 2.1.4).

\subsubsection{The History of Federal Policy on Embryo Research}

In the American scientific and political history, issues surrounding human embryo research were noticed by the US federal government a long time prior to the establishment of the first hESC line in the world. For instance, as early as the mid-1970s, when human IVF was still an experimental technique, the US federal government started paying close

See infra Sects. 2.3.1 and 3.1.3, Chap. 5 .

See e.g., Diamond v. Chakrabarty 447 US 303, 317 (1980); Juicy Whip, Inc. v. Orange Bang, Inc., 185 F.3d 1364 (Fed. Cir. 1999)

5 See O Carter Snead, The Pedagogical Significance of the Bush Stem Cell Policy: A Window into Bioethical Regulation in the United States, 5 Yale Journal of HeALTH Policy, LAW, AND ETHICS 491, 493 (2005). 
attention to relevant issues. ${ }^{6}$ In 1978, the world's first "test tube baby" ${ }^{\prime 7}$ spurred the Carter Administration to set up an Ethics Advisory Board (EAB) for the Department of Health, Education and Welfare (HEW), the forerunner of Health and Human Services (HHS). ${ }^{8}$ Since then, any embryo research supported by federal funding must undergo the EAB's review before proceeding. ${ }^{9}$ When reviewing human IVF research and tackling its associated scientific, ethical, and legal issues, the EAB conducted much analysis and discussion regarding the status of the embryo. It asserted that although a human embryo was entitled to profound respect, it did not necessarily possess the same full legal and moral status as persons. ${ }^{10}$ Thus, in the EAB's view, it was morally acceptable to conduct IVF research and federal funds could be used to support such research conditionally. ${ }^{11}$ However, the HEW did not act on this recommendation, ${ }^{12}$ and federally funded research on human IVF was in effect prohibited by HEW for a long time. ${ }^{13}$

6 For example, in 1975, a federal rule was issued stipulating that "[n]o application or proposal involving human in vitro fertilization may be funded by the Department [of HHS] [until it] has been reviewed by the Ethical [later 'ethics'] Advisory Board and the Board has rendered advice as to its acceptability from an ethical standpoint." See Ethical Advisory Boards, 45 CFR § 46.204(d) (1982) (later repealed).

7 See Profile of Louise Brown, BBC, (Jul. 24, 2003), http://news.bbc.co.uk/2/hi/health/3091241.stm. The world's first "test tube baby" was born in the UK through human IVF, and thus the fertilization of a human ovum outside the body became a reality.

8 See Amy Miller, The Effect of Federal Funding Restrictions for Embryonic Stem Cell Research on Colleges and Universities: The Need for Caution when Ethical Objections to Research are Raised, 41 JoURNAL OF College AND University LAW 147, 159 (2015). See also Judith A Johnson \& Edward C Liu, Stem Cell Research: Science, Federal Research Funding, and Regulatory Oversight, (Jan. 17, 2012), https://www.hsdl. org/?view\&did=707460. The Department of HHS currently is the chief US government agency providing human services, granting federal research funds, and providing health insurance. The mission of the HHS is to "enhance and protect the health and well-being of all Americans, by providing for effective health and human services and fostering advances in medicine, public health, and social services." For more information, please see US Department of Health \& Human Services, http://www.hhs.gov/about/index.html.

9 See Lyria Bennett Moses, Understanding Legal Responses to Technological Change: The Example of In Vitro Fertilization, 6 MINNESOTA JOURNAL OF LAW SCIENCE \& TECHNOLOGY 505, 539 (2004). See also Snead, supra note 5, at 493 (in 1993, Congress rescinded the Ethics Advisory Board approval requirement, which effectively cleared the way for the federal funding of embryo research.)

10 See Report and Conclusions: HEW Support of Research Involving Human In Vitro Fertilization and Embryo Transfer, 44 Fed. Reg. 35,033, 35,056 (May 4, 1979).

11 See id., at 35,055-35,058.

12 See Snead, supra note 5, at 493. See also National Bioethics Advisory Commission (hereafter NBAC), Ethical Issues in Human Stem Cell Research, Rockville, MD, Sept. 1999, at 34 ("No action was ever taken by the Secretary with respect to the board's report; for other reasons, the Department dissolved the EAB in 1980. Because it failed to appoint another EAB to consider additional research proposals, HEW effectively forestalled any attempts to support IVF, and no experimentation involving human embryos was ever funded pursuant to the conditions set forth in the May 1979 report or through any further EAB review.")

13 US Congress, House Committee on Energy and Commerce, National Institutes of Health Revitalization Act of 1993, report to accompany H.R. 4, 103rd Cong., 1st sess., March 9, 1993, H. Rept. 103-28 (Washington: GPO, 1993), at 80 ("Since 1979, this research [on human IVF] has been effectively banned by HHS under regulations which require the approval of such research by an Ethics Advisory Board. Because no such Board has been appointed by the Secretary ..., no review of any application for in vitro fertilization has been allowed to go forward at NIH. The effect of this de facto moratorium has been to hobble this area of research, relying only on the private sector without regulation or clear ethical or medical guidelines.") During a long period, the Carter, Reagan, and first Bush administrations actually limited the federal funding for human IVF research by refusing to fund the EAB. See O Carter Snead, supra note 5, at 493; Moses, supra note 9 , at 539 . 


\subsubsection{Dickey-Wicker Amendment}

Before exploring the policies of the US federal government towards hESC research, it is essential to refer to the Dickey-Wicker Amendment (or hereafter Amendment), which was passed by the US Congress in 1995, aiming to intervene in the policy of the Clinton Administration. ${ }^{14}$ In September 1994, on President Clinton's request, the NIH Human Embryo Research Panel released a report recommending permitting federal funding for embryo research and ESC research. ${ }^{15}$ Specifically, the panel recommended that several fields of human embryo research should be considered for federal funding, including SCNT, ${ }^{16}$ stem cells and, embryos created specifically for research purposes under certain limited conditions. ${ }^{17}$ President Clinton accepted most of the panel's advice, but directed the NIH not to fund the creation of embryos specifically for research purposes. ${ }^{18}$ This prohibiting directive did not include research involving surplus IVF embryos and research upon embryos created through parthenogenesis. ${ }^{19}$ The NIH then proceeded with plans to develop guidelines to support research on surplus IVF embryos. ${ }^{20} \mathrm{How}$ ever, before any proposals concerning embryo research were funded by federal money, Congress passed the Dickey-Wicker Amendment.

The Amendment has been carried over through NIH appropriations acts every year since. ${ }^{21}$ It forbade the NIH from funding the creation of human embryos for research purposes or for research in which human embryos are destroyed or discarded. ${ }^{22}$ That is, research should either enhance or at least not shorten the "life" of the embryo. ${ }^{23}$ Projects involving cloning and creating embryos for research purposes are forbidden from receiving federal funding. ${ }^{24}$ The focus of the Amendment is only on regulating federal

14 See Sherley v. Sebelius, 644 F.3d 388, 390-391 (D.C. Cir. 2011). See also Snead, supra note 5, at 493-494.

15 SeeNIH, Report of the Human Embryo Research Panel (Vol. 1), xvi-xviii, (Sept. 1994), https://repository.library. georgetown.edu/bitstream/handle/10822/559352/human_embryo_vol_1.pdf?sequence=1\&isAllowed=y. See also Johnson \& Liu, supra note 8 (the NIH Human Embryo Research Panel was established, in response to the NIH Revitalization Act of 1993 (P.L. 103-43, Sect. 121(c)), to assess the moral and ethical issues raised by human embryo research and to develop recommendations for NIH review and conduct of this research.)

16 Concerning the scientific background of SCNT, please See supra Sect. 3.2.1.3, Chap. 2.

17 See NIH, supra note 15, at xvi-xviii.

18 President Clinton's Comments on NIH and Human Embryo Research, US NATIONAL ARCHIVES, (Dec. 2, 1994), http://clinton6.nara.gov/1994/12/1994-12-02-president-on-nih-and-human-embryo-research.html.

19 See Johnson \& Liu, supra note 8 , at 9.

20 Seeid.

21 See Robert J Levine, Federal Funding and the Regulation of Embryonic Stem Cell Research: The Pontius Pilate Maneuver, 9 YALE JOURnAL OF HEALTH POLICY, LAW, AND ETHICS 552, 557 (2009).

22 The Dickey-Wicker Amendment, Pub. L. No. 104-99 § 128, 110 Stat. 26, 34 (1996). Specifically, in accordance with the amendment, federally appropriated funds could not be used for: "(1) the creation of a human embryo or embryos for research purposes; or (2) research in which a human embryo or embryos are destroyed, discarded, or knowingly subjected to risk of injury or death greater than that allowed for research on fetuses in utero under 45 CFR $\S 46.208$ (a) (2) and 42 USC $\S 289 \mathrm{~g}(\mathrm{~b})$ of the Public Health Service Act."

23 See Levine, supra note 21 , at 558.

24 See Moses, supra note 9, at 540; Maite S Kollmann, Taking the Moral High Road: Why Embryonic Stem Cell Research Should Be Strictly Regulated, 2 FAULKNER LAW REVIEW 145, 162 (2010). 
funding in the research area, rather than to ban any kind of research. ${ }^{25}$ Concerning hESC research, the Amendment did not foresee and mention it. ${ }^{26}$ In this regard, it was unclear whether the general ban of the Dickey-Wicker Amendment would apply to subsequent research on existing hESC lines, which have been already derived from embryos. However, based on the existing technology in which the derivation of hESCs necessitates the use and destruction of human embryos, it is possible that this ban could extend to the derivation activities of hESCs.

\subsubsection{Policies Before the Obama Administration}

Probably due to the fact that the US federal government has always paid close attention to the development of biotechnology and the associated public concerns, only ten days after the announcement of the successful isolation of the world's first hESC line, ${ }^{27}$ then-President Clinton expeditiously responded and instructed the National Bioethics Advisory Commission (NBAC) "to conduct a thorough review of the issues associated with ... human stem cell research, balancing all medical and ethical issues." ${ }^{28}$ The NBAC advised the Clinton Administration to start allowing federal funding for research in which stem cells were derived from surplus IVF embryos. ${ }^{29}$ The authority of the federal government to regulate such research via federal funding is based on the "conditional spending power" provisions of the Constitution. ${ }^{30}$ However, as mentioned above, the Dickey-Wicker Amendment did not foresee and mention hESC research, and thus it was unclear to what extent the federal funding for hESC research would be influenced by this amendment.

The NIH thus requested a legal opinion from the HHS on the appropriateness of federal financial support for hESC research. ${ }^{31}$ Harriet Rabb, the General Counsel for the HHS, released his own opinion to interpret the Dickey-Wicker Amendment and concluded that it would allow federal funding for hESC research, since Rabb did not consider human pluripotent stem cells, including hESCs, to fall within the definition

25 See id., at 154.

26 The primary reason might be that the Dickey-Wicker Amendment was passed in 1995, and at that moment, researchers at the University of Wisconsin had not yet discovered the method for isolating hESCs.

27 See James A Thomson, et al., Embryonic Stem Cell Lines Derived from Human Blastocysts, 282 SCIENCE 1145 (1998).

28 See NBAC, supra note 12. The NBAC was established by Executive Order 12975, signed by President Clinton on Oct. 3, 1995. For more information, please see President Clinton's Comments on NIH and Human Embryo Research, US NATIONAL ARCHIVES, (Dec. 2, 1994), http://clinton6.nara.gov/1994/12/1994-12-02-president-onnih-and-human-embryo-research.html ("In order to ensure that advice on complex bioethical issues that affect our society can continue to be developed, we are planning to move forward with the establishment of a National Bioethics Advisory Commission over the next year.") See also Exec. Order No. 12975, 3 CFR 1759 (1995) (according to this order, the NBAC was created to pursue "protection of the rights and welfare of human research subjects.")

29 See NBAC, supra note 12 , at 70

30 US Constitution, Article I, § 8, Clause 1. See also Levine, supra note 21, at 556.

31 Johnson \& Liu, supra note 8, at 10. 
of "human embryo". 32 The federal funding ban of the Amendment was construed by the General Counsel Rabb as not including subsequent research on existing hESC lines already derived from embryos. ${ }^{33}$ The Clinton Administration to some extent accepted Rabb's interpretation. ${ }^{34}$ Based on Rabb's opinion, the NIH declared that it planned to fund hESC research. ${ }^{35}$ After over a year of drafting guidelines and receiving public comments, on August 25, 2000, the NIH published its final guidelines. ${ }^{36}$ The guidelines specifically stated that hESC research may proceed with NIH funds only if the stem cells were derived (without federal funds) from surplus IVF embryos. ${ }^{37}$ Thus, as can be seen, the Clinton Administration had already opened the door for supporting hESC research with federal funding. However, before the Clinton funding policy was implemented, President George W. Bush was elected. ${ }^{38}$

Right after coming into power, Bush was confronted with deciding his own policy towards hESC research. At the time, on one side, patient groups, the scientific community, and the biotechnology industry expected Bush to move forward with federal funding for $\mathrm{hESC}$ research, but on the other side conservative anti-abortion groups and the Catholic Church were deeply opposed to him doing so. ${ }^{39}$ It is worth noting that different from that of President Clinton, Bush's viewpoint concerning hESC research was leaning towards moral consideration rather than scientific consideration. Specifically, Bush held that the federal government should not provide financial incentives for the destruction of human embryos, even for the sake of beneficial scientific research. ${ }^{40}$

32 See Memorandum from Harriet S. Rabb, General Counsel of the Department of HHS, to Harold Varmus, Director of the NIH (Jan. 15, 1999). Pursuant to the Dickey-Wicker Amendment, it defined the phrase "human embryo or embryos" to "include any organism, not protected as a human subject under 45 CFR 46 as of the date of enactment of the Act, that is derived by fertilization, parthenogenesis, cloning, or any other means from one or more human gametes." See the Dickey-Wicker Amendment, Pub. L. No. 104-99 § 128, 110 Stat. 26, 34 (1996).

33 Kollmann, supra note 24, at 155.

34 See Eliot Marshall, Ethicists Back Stem Cell Research, White House Treads Cautiously, 285 SCIENCE 502, 502 (1999).

35 See Kollmann, supra note 24, at 154-155.

36 See NIH, National Institutes of Health Guidelines for Research Using Human Pluripotent Stem Cells, F. R., Vol. 65, No. 166, 51975, 51976 (On Dec. 2, 1999 (64 F.R. 67576), the NIH released Draft Guidelines. Until Feb. 22, 2000, the NIH received approximately 50,000 comments from members of Congress, patient advocacy groups, scientific societies, religious organizations, and private citizens.)

37 Id (hESC research may proceed with NIH funds "only if the cells were derived (without Federal funds) from human embryos that were created for the purposes of fertility treatment and were in excess of the clinical need of the individuals seeking such treatment.")

38 See Snead, supra note 5, at 494; Johnson \& Liu, supra note 8, at 13.

39 See Sheryl Gay Stolberg \& David E Sanger, Bush Aides Seek Compromise on Embryonic Cell Research, NEW YORK TIMES, (Jul. 4, 2001), http://www.nytimes.com/2001/07/04/us/bush-aides-seek-compromise-onembryonic-cell-research.html?pagewanted=all.

40 See George W Bush, Stem Cell Science and the Preservation of Life, NEW YoRK TImES, (Aug. 12, 2001), http:// www.nytimes.com/2001/08/12/opinion/stem-cell-science-and-the-preservation-of-life.html. 
However, ultimately Bush decided to cater to both the scientific community and pro-life community. ${ }^{41}$

The Bush policy attempted to limit but not completely eliminate potential federal funding for hESC research, ${ }^{42}$ which is considered to be a compromise between the options available. ${ }^{43}$ To be specific, the Bush policy was to limit federal funding of hESC research to existing stem cells lines which had already been created prior to August 9, $2001 .{ }^{44}$ President Bush believed that the decision "allows us to explore the promise and potential of stem cell research without crossing a fundamental moral line, by providing taxpayer funding that would sanction or encourage further destruction of human embryos that have at least the potential for life." 45 In Bush's opinion, since the destruction of human embryos had already occurred and "the life and death decision has already been made", hESC research could take place. ${ }^{46}$ Despite many strict conditions, it was the first time that the US federal funding was available for hESC research. ${ }^{47}$

The Bush policy is actually a restrictive approach, which to some extent turned out not to meet the practical demand for hESC research in the US. ${ }^{48}$ Based on the Bush policy, the NIH examined the derivation of existing hESC lines and identified only research that utilized sixty-four existing hESC lines could receive federal funding. ${ }^{49}$ However, in effect

41 See Patrick Walsh, Stemming the Tide of Stem Cell Research: The Bush Compromise, 38 JOHN MARSHALL LAW REVIEW 1061, 1077 (2004).

42 See George W Bush, President Discusses Stem Cell Research, THE WHITE House, (Aug. 9, 2001), http:// georgewbush-whitehouse.archives.gov/news/releases/2001/08/20010809-2.html.

43 See Stolberg \& Sanger, supra note 39; Kollmann, supra note 24, at 156 (It is said that there could have been five options for President Bush: (1) to prohibit all use of human embryos for hESC research; (2) to allow the use of human embryos for research without any restriction, even including their creation for research purposes; (3) to allow the cloning of embryos for research purposes involving hESCs; (4) to allow research on excessively created embryos only; or, as decided, (5) to allow that only certain excess embryos can be used, namely those destroyed before August 9, 2001.) See also Nigel M de S Cameron, Pandora's Progeny: Ethical Issues in Assisted Human Reproduction, 39 FAMILY LAW QUARTERLY 745, 768 (2005).

44 See Bush, supra note 42 (there are some other requirements that hESCs should be obtained (1) with the informed consent of the donors, (2) from excess embryos created solely for reproductive purposes, and (3) without any financial inducements to the donors.)

45 Id.

46 Id.

47 See The Stem Cell Debates: Lessons for Science and Politics, THE NEw ATLANTIS 9, 12 (2012), http://www. thenewatlantis.com/docLib/20120125_TNA34Report.pdf. See also Miller, supra note 8, at 161-162.

48 See id., at 162; Johnson \& Liu, supra note 8, at 13 ("In reaction to the limitations imposed by the Bush policy, several US research groups decided to develop additional human embryonic stem cell lines using private funding or funds provided by state governments.")

49 See NIH, Update on Existing Human Embryonic Stem Cells, NATIOnAL InSTITUTES Of HeALth, (Aug. 27, 2001), https://stemcells.nih.gov/policy/archive.htm. 
only twenty-one of those hESC lines could be used for scientific research. ${ }^{50}$ This restrictive compromise policy led to concerns about the US falling behind and not playing a leading role in the field of hESC research. ${ }^{51}$ In this regard, during the two terms of Bush, more than once the US Senate attempted to expand federal funding of hESC research via voting to pass bills. ${ }^{52}$ However, Bush stood his ground by adhering to the restrictions on hESC research. He claimed that hESC research "crosses a moral boundary that our decent society needs to respect." ${ }^{23}$ On June 20, 2007, Bush signed Executive Order 13435, which reaffirmed his policy that HHS would not allocate federal funding to research upon stem cells derived from embryos specifically created for research purposes, or research which would destroy embryos. ${ }^{54}$ Thus, despite some concerns from the scientific community that the US would fall behind in the field of hESC research, the Bush Administration all along persisted in the restrictive compromise policy, curbing federal funding for hESC research by forbidding research using hESC lines, the derivation process of which was initiated prior to a cut-off date.

\subsubsection{The Obama Policy: Lifting the Restriction}

President Barack Obama revoked Bush-era hESC research federal funding restrictions. In fact, during his first presidential campaign run, Obama started to support hESC research

50 See Janet Kelly, All NIH Human Embryonic Stem Cell Registry Lines Now Deposited at NSCB, UNIVERSITY OF Wisconsin-MAdison News, (Jan. 12, 2009), http://www.news.wisc.edu/16120. See also Johnson \& Liu, supra note 8 , at 13 (stating that many of the identified hESC lines by the NIH actually were found to be either unavailable or unsuitable for research. Moreover, these pre-August $2001 \mathrm{hESC}$ lines were created with 1990s techniques and, thus, they were much more difficult for researchers to work with and genetically unstable compared to newer stem cell lines.)

51 See Kollmann, supra note 24, at 158. In terms of people's concerns about the impediment of advancement in the hESC research field, please see Bush Responds to Congress Stem Cell Letter, BIONEws, (May 17, 2004), http://www.bionews.org.uk/page_11949.asp. See also Johnson \& Liu, supra note 8, at 13-14 (For instance, in April 2004, over 200 House members sent a letter to President Bush calling for the Administration to change its hESC research funding policy. On June 4, 2004, a similar letter signed by 58 senators also urged President Bush to expand the federal stem cell research funding policy, holding that "despite the fact that US scientists were the first to derive human embryonic stem cells, leadership in this area of research is shifting to other countries such as the United Kingdom, Singapore, South Korea and Australia.")

52 See Clive N SVendsen \& Allison D Ebert, Encyclopedia of Stem Cell ResearCh (Vol. 1 \& 2) 502-503 (SAGE Publications 2008) ("On July 18, 2006, the US Senate convened to vote on a proposed bill (H.R. 810) that would amend the Public Health Service Act and provide federal funding for research on human embryonic stem cells. This bill was passed by both the Senate and the House of Representatives but was later vetoed by President George W. Bush.") Laurie Kellman, Senate Approves Embryo Stem Cell Bill, THE WASHINGTON POST, (Jul. 18, 2006), http://www.washingtonpost.com/wp-dyn/content/article/2006/07/18/AR2006071801071. html (On July 19, 2006, President Bush vetoed a bill that would have expanded federal funding to ESC research that uses embryos left over from IVF procedures.)

53 Charles Babington, Stem Cell Bill Gets Bush's First Veto, Washington Post, (Jul. 20, 2016), http://www. washingtonpost.com/wp-dyn/content/article/2006/07/19/AR2006071900524.html.

54 See George W Bush, Executive Order: Expanding Approved Stem Cell Lines in Ethically Responsible Ways, THE WHITE HOUSE, (Jun. 20, 2007), https://georgewbush-whitehouse.archives.gov/news/ releases/2007/06/20070620-6.html (President Bush directed the HHS to "conduct and support research on the isolation, derivation, production, and testing of stem cells that are capable of producing all or almost all of the cell types of the developing body and may result in improved understanding of or treatments for diseases and other adverse health conditions, but are derived without creating a human embryo for research purposes or destroying, discarding, or subjecting to harm a human embryo or fetus.") 
and made it one of his campaign promises to overturn the Bush policy. ${ }^{55}$ After becoming President, Obama signed Executive Order 13505 titled Removing Barriers to Responsible Scientific Research Involving Human Stem Cells, and revoked the Bush policy, taking more consideration of the potential benefits of hESC research. ${ }^{56}$ Obama noted that the goal of this Executive Order was "to enhance the contribution of America's scientists to important new discoveries and new therapies for the benefit of humankind." 57 The Obama policy thus lifted Bush's restrictive policy on federal funding for hESC research, and changed the way that NIH can support and conduct hESC research. ${ }^{58}$

\subsubsection{NIH Stem Cell Guidelines (2009)}

Shortly after the Obama executive order was issued, in July 2009 the NIH released new guidelines. ${ }^{59}$ The 2009 NIH guidelines emphasize that hESCs are not human embryos even though they are derived from embryos. In accordance with the guidelines, NIH funding can be used to support hESC research in which stem cells were derived from surplus IVF embryos. ${ }^{60}$ These guidelines have grouped research on hESCs derived from surplus IVF embryos into two categories. One is the derivation activities that destroy embryos directly, for which federal funding is prohibited; the other one is subsequent research involving existing hESCs that does not involve embryos nor result in the embryo's destruction directly, for which federal funding is permitted. However, research using hESCs derived from other sources, including embryos created expressly for research purposes through SCNT or parthenogenesis, cannot receive federal funding. The moral position reflected here is quite similar to that of the Dutch government. ${ }^{61}$ That is, while the purpose for which an embryo is created does not influence the status of the embryo, it could impact upon the moral acceptability of embryo research; deriving hESCs from surplus IVF embryos is more morally acceptable since these embryos are no longer needed for reproductive purposes and will be disposed of anyway.

55 See Stem Cell Research, Election Center 2008, CNN POLITICS.com, http://edition.cnn.com/ELECTION/2008/ issues/issues.stemcell.html (Barack Obama was one of the co-sponsors of the Stem Cell Research Enhancement Act of 2007, which expands the number of hESCs eligible for federally funded research.) See also Ceci Connolly \& R Jeffrey Smith, Obama Positioned to Quickly Reverse Bush Actions, WASHINGTON POST, (Nov. 9 , 2008), http://www.washingtonpost.com/wp-dyn/content/article/2008/11/08/AR2008110801856.html.

56 See Exec. Order No. 13505, 74 Fed. Reg. 10,667 (Mar. 9, 2009).

57 Id.

58 See Federal Policy, NATIONAL InSTITUTES OF HEALTH, http://stemcells.nih.gov/policy/Pages/Default.aspx.

59 Initially, the NIH released new draft guidelines for research involving hESCs in the Federal Register for public comment. After taking consideration of public comments, the NIH released its final guidelines on July 6 , 2009. See NIH, Draft National Institutes of Health Guidelines for Human Stem Cell Research Notice, 74 Fed. Reg. 18578-18580 (Apr. 23, 2009); NIH, National Institutes of Health Guidelines on Human Stem Cell Research, US DEPARTMENT OF HEALTH \& HUMAN SERVICES, (2016), http://stemcells.nih.gov/policy/pages/2009guidelines. aspx.

60 See id (there are some other requirements, such as informed consent, written policies, and other documentations, etc.)

61 The policy approach that the Dutch government has taken towards hESC research will be discussed later, see infra Sect. 3.2.2, Chap. 4 of this thesis. 


\subsubsection{Sherley v. Sebelius}

The Obama policy was challenged by the case Sherley $v$. Sebelius, in which the federal funding of hESC research was asserted to be banned by the Dickey-Wicker Amendment. ${ }^{62}$ Specifically, the central prohibition of the Amendment was that "[n]one of the funds made available by [the appropriation] may be used for ... research in which a human embryo or embryos are destroyed...." ${ }^{63}$ The key dispute of the litigation concentrated on whether the term "research" in the Amendment was ambiguous, ${ }^{64}$ or, in other words, whether HHS could lawfully construe the term "research" to include only activities performed once hESCs had been derived or to include the previous hESC derivation process which led to the destruction of embryos as well. ${ }^{65}$ On August 23, 2010, Chief Judge Royce Lamberth of the US District Court for the District of Columbia enjoined the NIH from funding hESC research, holding that there was "a strong likelihood of success" for the claim that the Guidelines violated the "unambiguous" Dickey-Wicker Amendment. ${ }^{66}$ In contrast, in 2011, the US Court of Appeals for the District of Columbia Circuit (D.C. Circuit) took into consideration the text and legislative history of the Amendment, and held that it would be appropriate to construe the Amendment in a narrow way as the NIH did. ${ }^{67}$ Subsequently, Chief Judge Lamberth basically followed the D.C. Circuit's prior decision. ${ }^{68}$ On August 24, 2012, the D.C. Circuit ruled that hESC research was just

62 Sherley originated in the US District Court, District of Columbia in August of 2009. See Sherley v. Sebelius, 686 F. Supp. 2d 1 (D.D.C. 2009) (initially, the court ruled that none of the plaintiffs had standing and thus dismissed the suit.) However, an appeal to the US Court of Appeals for the D.C. Circuit followed. See Sherley v. Sebelius, 610 F.3d 69 (D.C. Cir. 2010) (the case was reversed and remanded back to the District Court since the court considered the two adult stem cell researchers, Drs. Sherley and Deisher, to have sufficient alleged standing that they would suffer irreparable harm via increased competition for NIH grants if more hESCs were made eligible for federal funds.) Ultimately, Sherley v. Sebelius was decided by the D.C. Circuit in 2012. See Sherley v. Sebelius, 689 F.3d 776, 776 (D.C. Cir. 2012), petition for cert. filed, (US Oct. 10, 2012) (No. 12-454).

63 See Sherley v. Sebelius, 704 F. Supp. 2d 63 (D.D.C. 2010).

64 Id., at 70.

65 See Johnson \& Liu, supra note 8, at 15-16.

66 Sherley v. Sebelius, supra note 63, at 70-71 (to be specific, the Court found no ambiguity concerning the use of "research" in the Dickey-Wicker Amendment. The Court considered the central prohibition in the Amendment, "encompasses all 'research in which' an embryo is destroyed," antithetical to the NIH's interpretation of the prohibition as just including the derivation activities in which an embryo is destroyed. The Court pointed out that "despite defendants' attempt to separate the derivation of ESCs from research on the ESCS, the two cannot be separated. Derivation of ESCs from an embryo is an integral step in conducting ESC research.... If one step or "piece of research" of an ESC research project results in the destruction of an embryo, the entire project is precluded from receiving federal funding by the Dickey-Wicker Amendment. Because ESC research requires the derivation of ESCS, ESC research is research in which an embryo is destroyed. Accordingly, the Court concludes that, by allowing federal funding of ESC research, the Guidelines are in violation of the Dickey-Wicker Amendment.")

67 See Sherley v. Sebelius, supra note 14, at 396, 399 (the court sided with the NIH, concluding that its interpretation of the Dickey-Wicker Amendment was reasonable "[b]ecause the Congress wrote with particularity and in the present tense - the statute says 'in which' and 'are' rather than 'for which' and 'were." Thus, the court vacated the preliminary injunction).

68 See Sherley v. Sebelius, 776 F. Supp. 2d 1 (D.D.C. 2011) (in terms of the question of the ambiguity of "research", the District Court followed the D.C. Circuit's decision. Moreover, the District Court also dismissed the plaintiffs' alternative claim which asserted that providing federal money for hESC research encouraged the derivation of new hESC lines, thereby subjecting human embryos to an increased risk of destruction.) 
research which provided incentives to harm, destroy, or place at risk human embryos, but not "research in which ... embryos are ... destroyed." ${ }^{69}$ The D.C. Circuit made a final decision in favor of the NIH's position that hESC research was not research that harmed embryos, and thus did not violate the Dickey-Wicker Amendment. ${ }^{70}$ With the closing of the Sherley case, the challenge to the Obama policy came to an end temporarily. Based on the Obama policy, hESC research using stem cells derived from surplus IVF embryos may receive federal funding, but due to the general prohibition of the Dickey-Wicker Amendment, the derivation of new hESC lines still may not.

\subsubsection{The Trump Policy: Still Unclear}

President Donald J. Trump, until now, has not taken any stance or made any public comments on research that involves using hESCs or fetal tissues. ${ }^{71}$ To hESC researchers' relief, Trump has appointed Dr. Francis Collins as the director of the NIH. Collins has championed hESC research for a long time, and he believes that cloned embryos do not deserve the same moral status as naturally generated embryos. ${ }^{72}$ However, a group of conservative members of Congress wrote to Trump and urged the president to fire Collins since this man supports hESC research and is not pro-life enough. ${ }^{73}$ Currently, Trump is surrounded with many overtly conservatives and, until now, he has not yet nominated any science advisor for key leadership positions at the government research funding agencies. ${ }^{74}$ Trump has proposed major budget cuts to $\mathrm{NIH},{ }^{75}$ and has consistently shown opposition to scientific research. ${ }^{76}$ Unsurprisingly, it has been feared that hESC research will not continue getting support from the federal government. ${ }^{77} \mathrm{Com}-$ mentators even consider the US to have "returned to a darker time of uncertainty for science". ${ }^{78}$ In general, there has been no mention of a policy concerning hESC research

\footnotetext{
69 See Sherley v. Sebelius, 689 F.3d 776 (D.C. Cir. 2012),

70 Seeid.

71 See Emily Mullin, Under Trump, Biologists Fear Political Risks of Controversial Research, MIT TECHNOLOGY REviEw, (Nov. 9, 2017), https://www.technologyreview.com/s/609323/under-trump-biologists-seek-a-lowprofile-for-controversial-research/.

72 See Jamie Reno, Is Human Embryonic Stem Cell Research in Jeopardy? HeALTHLine, (Jun. 14, 2017), https:// www.healthline.com/health-news/is-human-embryonic-stem-cell-research-in-jeopardy\#1. See also Maggie Fox, Conservative Reps Urge Trump to Fire NIH Chief Francis Collins Over Stem Cells, NEWS, (May 23, 2017), https://www.nbcnews.com/health/health-news/conservative-reps-urge-trump-fire-nih-chieffrancis-collins-over-n763301.

73 Seeid.

74 See Jonathan R Cole, 'Political' Science: It's Déja Vu All Over Again, HuffPost, (Jan. 10, 2018), https://www. huffingtonpost.com/entry/trump-administration-science_us_5a56d1f8e4b03bc4d03df30e.

75 See Jocelyn Kaiser, Trump Wants 2018 NIH Cut to Come from Overhead Payments, SCIENCE, (May 29, 2017), http://www.sciencemag.org/news/2017/03/trump-wants-2018-nih-cut-come-overhead-payments.

76 See Cole, supra note 74.

77 See e.g., Jonathan D Moren, Will A Trump Administration Let Sleeping Cells Lie? 35 NATURE BIOTECHNOLOGY 20, 20 (2017); Jamie Reno, supra note 72; Katharine Tippins, Funding Stem Cell Research Crucial for Scientific Advancement, Should Not be Inhibited by Politicians, THE BADGER HERALD, (Feb. 6, 2018), https://badgerherald.com/opinion/2018/02/06/funding-stem-cell-research-crucial-for-scientific-advancement-shouldnot-be-inhibited-by-politicians/; Mullin, supra note 71. 
from the Trump Administration, and it is still unclear what position the president will take when it comes to the policy towards hESC research.

\subsection{Policy Approaches at the State Level}

As can be seen, at the federal level of the US, there has been no comprehensive federal legislation concerning hESC research. The only restriction is imposed on federal public funding by the federal government. In the meantime, federal policies have never imposed any restriction on private funds within the realm of hESC research. ${ }^{79}$ In this regard, the US federal government's approach towards hESC research has left great room for state governments to tailor their own policies. In other words, each state of the US is responsible for and can decide independently on policies and funding for hESC research. It is therefore unsurprising that when federal funding for hESC research has been limited, much of the support has instead come from state governments. ${ }^{80}$

In the US, generally states can be divided into two categories, including states that are permissive towards hESC research and those are prohibitive. Of the thirty-one or so states which have taken a stance on the issue, a majority are reluctant to support hESC research. ${ }^{81}$ Among the states which are permissive, California is often cited by commentators as a typical example, since this state is generally regarded as offering the most supportive and permissive environment for stem cell research in the US. The California Institute of Regenerative Medicine (CIRM) was created as a result of Proposition 71 (also known as the California Stem Cell Research and Cures Initiative), passed in 2004, just three years after the issuing of the Bush Policy, to provide money for stem cell and related scientific and medical research. ${ }^{82}$ Through the CIRM, over a 10-year period $\$ 3$ billion in state funds has been allocated to stem cell research, with priority given to hESC research. ${ }^{83}$ This is the largest source of American funding in the hESC research filed. $^{84}$

79 See Snead, supra note 5, at 496; Levine, supra note 21, at 558.

80 See Michael S Mireles, States as Innovation System Laboratories: California, Patents, and Stem Cell Technology, 28 CARDOZO LAW REVIEW 1133, 1135 (2006) (noting that "the unintended consequence of [the Bush Administration's] decision was to provide the impetus for states to commit large amounts of research dollars to fill the federal funding gap for embryonic stem cell research.")

81 See SVENDSEN \& EBERT, supra note 52, at 451 ("[s]tates that are permissive of embryonic stem cell research include California, Connecticut, Illinois, Indiana, Maryland, Massachusetts, and New Jersey; states that are prohibitive with regard to embryonic stem cell research include Arizona, Arkansas, Florida, lowa, Kentucky, Louisiana, Maine, Michigan, Minnesota, Missouri, Montana, New Hampshire, New Mexico, North Dakota, Ohio, Oklahoma, Pennsylvania, Rhode Island, South Dakota, Tennessee, Texas, Utah, Virginia, and Wyoming. States that do not appear in these lists do not have laws identified by the National Conference of State Legislatures.")

82 California Stem Cell Research and Cures Bond Act of 2004, CAL. Health \& SAFETY COdE $§ 125291.30$ (West 2004).

83 See Sect. 3 of Proposition 71. See also SVENDSEN \& EBERT, supra note 52, at 53 (2008).

84 See id. 
Some US states are strongly against hESC research, and some even regard such research as criminal. ${ }^{85}$ For instance, South Dakota has one of the country's strongest laws concerning hESC research. Its state law has criminalized such research, specifically and rigorously prohibiting research on hESCs, regardless of the source of the embryos. ${ }^{86}$ Based on this, even in universities in South Dakota, biological research cannot directly study stem cell biology. ${ }^{87}$ In Indiana, stem cell research is allowed on adult stem cells and fetal stem cells with the full consent of the contributors. ${ }^{88}$ Yet, Indiana prohibits research on hESCS on the basis that Indiana has made it a crime to use a human embryo created with an ovum provided to a fertility or similar clinic for hESC research. ${ }^{89}$

All in all, it is evident that in the US regulating hESC research has been extremely controversial, particularly in the moral aspect. Facing the moral dilemma of regulating hESC research, successive US federal governments have adopted various and even conflicting policy approaches. At the federal level the US merely relies on the distribution of federal public funding to regulate embryo and hESC research, rather than promulgating any legislation or regulation to specifically prohibit it. Under the current federal funding policy regarding hESC research in the US, due to congressional restrictions (i.e., the Dickey-Wicker Amendment), research "in which a human embryo or embryos are destroyed ..." is prevented from receiving federal funding, and based on this, federal funding is not available for the creation of new hESC lines. However, federal funding can be used to support hESC research in which stem cells were derived from surplus IVF embryos. Also, private investment has never gotten any restrictions within the realm of hESC research, at least at the federal level. Given this, the "bad deeds" of destroying embryos for deriving hESCs can be done in the private sector, and the public sector can reap the benefits of hESC research. ${ }^{90}$ More importantly, the US allows its states to regulate such research by legislation and tailoring their local policies based on specific circumstances. Regulatory approaches in each state differ considerably ranging from supportive to prohibitive. Because of moral concerns, most states do not encourage $\mathrm{hESC}$ research, and some have even issued laws and regulations to explicitly prohibit it.

85 See id., at 451 (States that are restrictive with respect to hESC include Arizona, Arkansas, Florida, Iowa, Kentucky, Louisiana, Maine, Michigan, Minnesota, Missouri, Montana, New Hampshire, New Mexico, North Dakota, Ohio, Oklahoma, Pennsylvania, Rhode Island, South Dakota, Tennessee, Texas, Utah, Virginia, and Wyoming.)

86 South Dakota Codified Laws 34-14-16 stipulates that "[r]esearch that destroys [a] human embryo [is] prohibited--Violation as misdemeanor. No person may knowingly conduct nontherapeutic research that destroys a human embryo. A violation of this section is a Class 1 misdemeanor." See also SVENDSEN \& EBERT, supra note 52, at 502.

87 See id., at 503.

88 See id., at 256.

89 Indiana Code (2015) § 35-46-5-3(d) stipulates that "[a]ny person who recklessly, knowingly, or intentionally uses a human embryo created with an ovum provided to a qualified third party under this section for purposes of embryonic stem cell research commits unlawful use of [an] embryo, a Level 5 felony." 
Finally, it is important to note that through the federal government's funding policies, combined with the states' local policies and laws, the US indeed has always tried to solve the social and moral concerns within hESC research. Just as the US courts have asserted, moral issues in the field of hESC research have in practice been left to other regulations or laws, rather than patent law, to deal with.

\section{POLICIES AND REGULATORY FRAMEWORIKS IN THE EU}

At the outset of exploring the policies and regulatory frameworks in the EU, it is vital to mention that it would be inappropriate to refer to one general approach towards hESC research in the EU, since hitherto no harmonized regime has been established, although patent legislation concerning biotechnological inventions has been harmanized. ${ }^{11}$ Indeed, it is not an easy task to adopt common policies with regard to hESC research across Europe. ${ }^{92}$ In this regard, concerning policy approaches towards hESC research in the EU, this section of the thesis primarily focuses on two levels. The first level is the EU level (Sect. 3.1). However, because the EU has very limited competence in regulating hESC research, primarily via funding policy, and because regulatory approaches to $\mathrm{hESC}$ research in the EU are in effect a matter of its member states, it is necessary to analyze the policy approaches that EU member states have taken towards hESC research, and meanwhile to dig deeply into the underlying reasons behind each policy choice (Sect. 3.2). The variety in legal settings and regulatory frameworks across the EU offers the opportunity to test diverse policy and research approaches, ${ }^{93}$ which provides a great lesson for China's governing of hESC research and further contributes to patent policymaking regarding hESC-related inventions.

\subsection{Policy Approaches at the EU Level}

Although regulatory approaches to hESC research in the EU are a matter of national jurisdictions, the EU still has gained some de facto authority to regulate such research, primarily via funding policies and its authority over public health matters. ${ }^{94}$ In terms of funding policies, since 2002 the EU has had an ethical and legal framework on hESC research funded from the EU budget. ${ }^{95}$ Currently, under the Horizon 2020 program, research is qualified to receive funding only if it is legally allowed in the country where

91 See Benjamin Farrand, Human Embryonic Stem Cells and Patent Law in the EU and China: Convergence in Standards Through Divergence in Institutions, 3 INTELLECTUAL PROPERTY QUARTERLY 260, 261 (2016).

92 See Isasi \& Knoppers, supra note 2, at 29.

93 See Vanessa Campo-Ruiz, Human Stem Cell Research and Regenerative Medicine: Focus on European Policy and Scientific Contributions, EUROPEAN SCIENCE FOUNDATION 8 (2013), http://archives.esf.org/fileadmin/ Public_documents/Publications/HumanStemCellResearch.pdf.

94 See Isasi \& Knoppers, supra note 2, at 37.

95 See European Commission, European Citizens' Initiative: European Commission Replies to "One of Us", (Brussels, May 28, 2014). 
it is implemented and has passed a scientific and ethical review. ${ }^{96}$ Scientists receiving EU funding may use surplus embryos from IVF treatment, ${ }^{97}$ but are not permitted to destroy embryos or create new hESC lines. ${ }^{98}$ Also, it is not allowed to use EU funding to purchase hESCs. ${ }^{99}$

Although the EU does not explicitly set out to support hESC research, it in effect has invested remarkable great amounts of money in this research field. For instance, under the previous EU research program, from 2007 to 2013, the EU invested $€ 156.7$ million, which represents $2.6 \%$ of the total EU spending, in health research involving the use of hESCs. ${ }^{100}$ HESC research projects amount to approximately one third of health projects on all forms of stem cells. ${ }^{101}$ Interestingly, even after the final decision of the Brüstle $v$. Greenpeace case by the CJEU, ${ }^{102}$ which considered hESC-related inventions to be against ordre public or morality and thus unpatentable, ${ }^{103}$ the EU still conditionally supports and funds hESC research, mainly based on scientific considerations, including the great therapeutic potential concerning a massive amount of life-threatening diseases. ${ }^{104}$ Together the relatively conservative requirements of funding policy and the de facto great financial support demonstrate an intermediate policy approach taken by the EU. This is deemed to be the product of political compromises and trade-offs, seeking to balance various interests and values that could otherwise obstruct the employment of any legal framework. ${ }^{105}$

Moreover, at the European level, there are several other multilateral treaties, in which rules related to governing hESC research exist. For instance, most EU countries have signed and many have also ratified the ECHRB, ${ }^{106}$ in which Article 18 stipulates that "[w] here the law allows research on embryo in vitro, it shall ensure adequate protection of the embryo" and "[t]he creation of human embryos for research purposes is

96 Horizon 2020 is the biggest EU Research and Innovation program ever with nearly $€ 80$ billions of funding available over 7 years (2014 to 2020). See European Commission, Horizon 2020, http://ec.europa.eu/ programmes/horizon2020/en/what-horizon-2020; European Commission, supra note 95. See also Tania Rabesandratana, EU Commission Rejects Plea to Block Stem Cell Research Funding, SCIENCE, (May 20, 2014), http://news.sciencemag.org/europe/2014/05/e-u-commission-rejects-plea-block-stem-cell-researchfunding.

97 Seeid.

98 See European Commission, supra note 95.

99 Seeid.

100 Seeid.

101 Seeid.

102 See C-34/10 (Oliver Brüstle v. Greenpeace eV) OJ C 362/7 [2011].

103 Article 6(1) of the EU Biotech Directive states that "[i]nventions shall be considered unpatentable where their commercial exploitation would be contrary to ordre public or morality; however, exploitation shall not be deemed to be so contrary merely because it is prohibited by law or regulation."

104 See European Commission, supra note 95.

105 See Isasi \& Knoppers, supra note 2, at 42.

106 Convention for the protection of Human Rights and Dignity of the Human Being with regard to the Application of Biology and Medicine: Convention on Human Rights and Biomedicine, Oviedo, 4.IV.1997, ETS 164. 
prohibited." ${ }^{107}$ However, the UK and Belgium have neither signed nor ratified the ECHRB, since both countries permit creating embryos for research purposes under certain conditions. ${ }^{108}$ Also, the Additional Protocol to the Biomedicine Convention with regard to the Application of Biology and Medicine, on the Prohibition of Cloning Human Beings (Biomedicine Convention) prohibits the creation of embryos specifically for research purposes. ${ }^{109}$ However, under the Biomedicine Convention, signing or ratifying countries are allowed to reserve the right not to apply a provision or provisions stipulated in the Convention. In addition, hESC lines obtained through destroying human embryos cannot be registered in the European Human Embryonic Stem Cell Registry. ${ }^{110}$

\subsection{Policy Approaches at EU Member States}

Since the EU has very limited competence in regulating hESC research, an examination of the policy approaches that EU member states have taken is necessary. Moreover, as mentioned previously, diverse policy approaches across the EU can also provide a great lesson for China's governing hESC research and further contribute to tailoring the patent policy in China. For this purpose, this part of the thesis mainly discusses the policy approaches towards hESC research at the EU member states level, and at the same time takes the UK, the Netherlands, and Germany as typical examples to illustrate considerations behind varying policy approaches.

Most EU countries have chosen specific legislation directly regulating hESC research. Several countries govern hESC research indirectly via legislation for embryo research in general or via regulating medically assisted reproduction. A few EU countries have neither specific nor nonspecific legislation to regulate $\mathrm{hESC}$ research, but have adopted a restrictive attitude toward funding, and thus do not provide regional funding for such research. ${ }^{111}$ No EU country has adopted a market approach. ${ }^{112}$ In general, in terms of policy approaches towards hESC research, EU member states can be grouped under three broad categories, as summarized in Table 1. Specifically, approaches to embryo and $\mathrm{hESC}$ research policy in the EU is heterogeneous, ranging from a liberal approach, such as in Belgium, Spain, and the UK, to a complete prohibition against research

107 Article 18 of the ECHRB.

108 See Heidi Mertes, Understanding the Ethical Concerns that Have Shaped European Regulation of Human Embryonic Stem Cell Research, 1 Proceedings of THE Belgian Royal Academies of Medicine 127, 128 (2012).

109 Additional Protocol to the Convention for the Protection of Human Rights and Dignity of the Human Being with regard to the Application of Biology and Medicine, on the Prohibition of Cloning Human Beings (CETs No. 168, Jan. 12, 1998), Preamble (it is prohibited to create genetically identical human beings since this technique is "contrary to human dignity and thus constitutes a misuse of biology and medicine.")

110 Isasi \& Knoppers, supra note 2, at 31. The European Embryonic Stem Cell Registry was founded in 2007, and is supported by the European Commission.

111 See Campo-Ruiz, supra note 93, at 8 (there are a small number of EU countries where there is no legislation on hESC research, such as Austria, Ireland, Luxembourg, Poland); Isasi \& Knoppers, supra note 2, at 38.

112 See Thomas H Murray, Ethical (and Political) Issues in Research with Human Stem Cells, 265 NovARTIS FOUNDATION SYMPOSIUM 188 (2008). 
employing hESCs, such as in Lithuania and Denmark. ${ }^{113}$ Most EU member states adopt intermediate policy approaches to embryo and hESC research, such as Greece, France, Finland, the Netherlands, and Portugal. ${ }^{114}$

\section{Table 1: Various Policy Approaches Towards hESC Research in the EU}

\begin{tabular}{|c|c|c|}
\hline Policy Types & Allowed and Prohibited Techniques & Countries \\
\hline $\begin{array}{l}\text { Liberal or Very } \\
\text { Permissive }\end{array}$ & $\begin{array}{l}\text { Even the creation of embryos for research } \\
\text { purposes is allowed. }\end{array}$ & UK, Belgium, Sweden, Spain \\
\hline $\begin{array}{l}\text { Intermediate } \\
\text { or Permissive } \\
\text { Compromise }\end{array}$ & $\begin{array}{l}\text { HESC research is allowed using surplus } \\
\text { IVF embryos, but the creation of embryos } \\
\text { specifically for research purposes is } \\
\text { prohibited. }\end{array}$ & $\begin{array}{l}\text { Bulgaria, Croatia, Cyprus, Czech Republic, } \\
\text { Denmark, Estonia, Finland, France, Greece, } \\
\text { Hungary, Iceland, Latvia, Netherlands, } \\
\text { Portugal, Romania, Slovenia }\end{array}$ \\
\hline $\begin{array}{l}\text { Restrictive } \\
\text { (including } \\
\text { Restrictive } \\
\text { Compromise) }\end{array}$ & $\begin{array}{l}\text { Research using embryos or cell products } \\
\text { derived from embryos is prohibited or hESC } \\
\text { research is only permitted using cell lines } \\
\text { created before a certain date. }\end{array}$ & $\begin{array}{l}\text { Germany, Italy, Austria, Lithuania, Poland, } \\
\text { Slovakia }\end{array}$ \\
\hline
\end{tabular}

\subsubsection{Liberal or Very Permissive Policies and the UK}

A small number of EU member states, such as the UK, Sweden, Belgium, adopt liberal or permissive policies towards hESC research. ${ }^{115}$ Within these countries, a wide range of techniques, even including the creation of embryos for research purposes as well as for the production of hESC lines and for research cloning, are allowed conditionally. ${ }^{116}$ The rationale behind the liberal policy approach is to further the progress of science and medicine, since hESC research is considered to be potentially beneficial to humanity. ${ }^{117}$ However, this approach not only pursues scientific advances, but also seeks to address several other issues, such as to safeguard public interests, as well as to deal with societal concerns. ${ }^{118}$ For instance, in the UK the Human Fertilization and Embryology Authority (HFEA) Code of Practice declares that it not only "secure[s] the safety or efficacy of particular clinical or scientific practices", but also pays close atten-

113 This classification is only intended to better understand the various policy approaches among European countries. Some commentators might have other classifications. For instance, Dr. Vanessa Campo-Ruiz has grouped 30 studied European countries into five broad categories: very permissive, permissive with restrictions, restrictive by default, very restrictive, and unlegislated. See Campo-Ruiz, supra note 93. See also Europe: Map, The Hinxton Group: An InTERnAtional Consortium on STEM Cells, ETHics \& LaW, http:// www.hinxtongroup.org/wp_eu_map.html (classifying European countries into four categories: Permissive, Permissive Compromise, Restrictive Compromise, and Prohibitive.) See also Isasi \& Knoppers, supra note 2, at 40-44; Rabesandratana, supra note 96.

114 See Isasi \& Knoppers, supra note 2, at 42.

115 See Campo-Ruiz, supra note 93, at 8. See also Europe: Map, The HinXton Group: An INTERnATIOnAL ConsorTIUm ON STEM CELLS, ETHICS \& LAW, http://www.hinxtongroup.org/wp_eu_map.html.

116 See Isasi \& Knoppers, supra note 2, at 43. See also Rosario M Isasi \& Bartha M Knoppers, Mind the Gap: Policy Approaches to Embryonic Stem Cell and Cloning Research in 50 Countries, 13 EUROPEAN JOURNAL OF HEALTH LAW 9, 22 (2006).

117 See Isasi \& Knoppers, supra note 2, at 43.

118 Seeid. 
tion to ethical and social concerns. ${ }^{119}$ However, the liberal policy approach often fails to specifically "enunciate the value-choices underlying their acceptance or to explain why certain constraints have been instituted." ${ }^{120}$ Meanwhile, the challenge for this approach is to come up with "a coherent, transparent, flexible, and yet enforceable system that also takes into account opposing socio-cultural and ethical values or beliefs." ${ }^{121}$ The remainder of this section investigates in detail the UK policy approach towards hESC research, which offers a specific example of the liberal pattern.

The UK has had a long history of embryo research and stem cell research, and has consistently favored hESC research. ${ }^{122}$ In general, from the perspective of allowed types of embryo and hESC research, the UK policy is largely permissive approach, since it has made the promotion of such research a priority and even allows the creation of embryos specifically for research purposes. However, from the perspective of degree of regulation and oversight, the UK is not so "permissive". ${ }^{123}$ The UK has a stringent control and monitoring regulatory framework for embryo and hESC research, and has channeled the related moral concerns into the retention of control over scientists' actions. ${ }^{124}$ To understand the underlying rationale behind the UK approach towards hESC research, it is better to first sketch the legal history of research on human embryos in the UK, as well as relevant arguments for or against such research.

\subsubsection{Warnock Report and Public Debates}

In fact, research on human embryos was brought into the UK's public eye by the world's first "test tube baby" in $1978 .{ }^{125}$ This remarkable event provoked a backlash of moral indignation and led UK citizens to call for an examination of the social, legal and moral implications of embryo research. ${ }^{126}$ In response, the UK government established a Com-

119 Sect. 1(2) of the Code of Practice of UK Human Fertilisation and Embryology Authority (7th ed. 2007).

120 Bartha Maria Knoppers, et al., Commercialization of Genetic Research and Public Policy, 286 SCIENCE 2277, 2277 (1999).

121 See Isasi \& Knoppers, supra note 2, at 43.

122 See Robin Lovell-Badge, The Regulation of Human Embryo and Stem-cell Research in the United Kingdom, 9 Nature Reviews Molecular Cell Biology 998, 998 (2008) (this is reflected in a number of vital milestones, in particular the pioneering studies of Edwards and Steptoe that resulted in the first baby born from IVF in 1978, the derivation of mouse ESCs by Evans and Kaufmann, published in 1981, and the cloning of the sheep Megan and Morag in 1996 and the far more famous Dolly in 1997 by Campbell, Wilmut and colleagues.) See also Jody Schechter, Promoting Human Embryonic Stem Cell Research: A Comparison of Policies in the United States and the United Kingdom and Factors Encouraging Advancement, 45 TEXAS INTERNATIONAL LAW JOURNAL 603, 614 (2009).

123 See Lovell-Badge, supra note 122, at 998 ("It is often said that the UK laws are permissive, but this is not strictly true. It is a regulatory system, in which nothing is allowed without a license from the HFEA, and the penalties of proceeding without a license or breaking its conditions are severe.")

124 See Schechter, supra note 122, at 614.

125 In 1978 the world's first "test tube baby", Louise Brown, was born in the UK.

126 See Lovell-Badge, supra note 122, at 998 (People started to realize the IVF technology could change and not just help the way that humans reproduce. Thus, the first IVF baby event immediately raised strong public debates.) 
mittee of Inquiry into Human Fertilisation and Embryology, known as the "Warnock Committee", 127 "to examine the social, ethical and legal implications of recent, and potential developments in the field of human assisted reproduction." ${ }^{28}$

When examining the legal status of embryos in the UK, the Warnock Committee observed that while "the human embryo per se has no legal status", the UK legislation did "give some level of protection in various respects." ${ }^{129}$ Concerning the moral status of the embryo, the Committee realized that public viewpoints differed considerably, and that no solution could be reached on this disagreement. ${ }^{130}$ The Committee attempted to adopt "a steady and general point of view", ${ }^{131}$ and pointed out that although the embryo should not be endowed the same moral status as a living child or an adult, the embryo ought to have a "special status" and "should be afforded some protection in law." "132 Based on its conclusion in respect of the legal and moral status of human embryos, the Committee made a "pragmatic and utilitarian" decision, ${ }^{133}$ on the one hand choosing to make the furtherance of embryo research a priority, but on the other hand stating that such research should be under stringent controls and monitoring to ensure against misuse. ${ }^{134}$ Thus, finally the Committee proposed a regulatory system that is constrained by law, rather than one based entirely on legal ban. ${ }^{135}$

The Warnock Committee's recommendations subsequently caused quick response from both conservative government officials and the community. Particularly the Committee's stance concerning embryo research was thought of as a middle ground approach, which initially was vociferously condemned by both scientific community and anti-abortion groups. ${ }^{136}$ There was even a private bill being introduced to ban embryo

127 The Warnock Committee was established in 1982 by the Department of Health and Social Security of the UK government, chaired by the philosopher Mary Warnock, and consisted of several individuals with different backgrounds, such as theologians, social workers, legal professionals, and people working in a range of medical disciplines.

128 MARY WARNOCK, REPORT OF THE COMMITTEE OF INQUIRY INTO HUMAN FERTILIZATION AND EMBRYOLOGY iv (HM Stationery Office 1984).

129 See id., at 62-63.

130 See id., at 1. See also Schechter, supra note 122, at 615.

131 WARNOCK, supra note 128 , at 1.

132 Id., at 63.

133 Margaret Foster Riley \& Richard A Merrill, Regulating Reproductive Genetics: A Review of American Bioethics Commissions and Comparison to the British Human Fertilisation and Embryology Authority, 6 CoLUmBIA SCIENCE \& TECHNOLOGY LAW REVIEW 1, 44 (2005).

134 SeeWARNOCK, , supra note 128 , at 63-64.

135 See Lovell-Badge, supra note 122, at 998.

136 See Riley \& Merrill, supra note 133, at 44 (2005) ("Abortion opponents were unhappy that the Report not only failed to insist on the fundamental importance of marriage but also would allow assisted reproductive techniques to be available to unmarried couples. Most importantly, they were scandalized that the Report recommended a mechanism to continue research on embryos. While scientists did not reject oversight of clinical applications, they did reject the notion that research also required oversight-or that unapproved research could be subject to criminal prosecution.") 
research in the House of Commons. However, the bill in the end did not pass the House, since the government failed to support the bill. ${ }^{137}$ At the same time, the scientific community started to realize a possibility of banning such research in the UK, and promptly shifted its debate strategy and made a compromise to accept the notion that research required oversight. ${ }^{138}$

\subsubsection{Governing Research on Embryos}

After a long period of vigorous debate, in 1990, the UK Parliament ultimately accepted most of the Warnock Committee's recommendations and issued the Human Fertilization and Embryology Act (HFE Act). ${ }^{139}$ Since then, the UK primarily has relied on the HFE Act to regulate research involving human embryos. Based on this Act, the UK has concentrated its regulation of embryo research into one centralized entity, the Human Fertilisation and Embryology Authority (HFEA), which was set up to grant and sustain licenses for research on human embryos. ${ }^{140}$ In accordance with the HFE Act, embryo research may only be conducted with a license, up to the appearance of the primitive streak, which is taken to occur no later than 14 days after fertilization. ${ }^{141}$ Additionally, the HFE Act confined the purposes of any proposed research project on embryos into reproduction and congenital disease. ${ }^{142}$ In other words, research on early embryos is permitted and can obtain licenses from the HFEA only in the context that the use of embryos can be justified for certain specific purposes. This reflects the notion that embryos should not be arbitrarily utilized in research. ${ }^{143}$

Through the legal history of embryo research and the regulatory scheme embodied in the HFE Act, the UK policy approach concerning such research is actually a compromise between philosophical and ethical considerations and scientific considerations-the viewpoint that early embryo merits respect, and the acknowledgement that the po-

137 See id., at 45.

138 Initially, the scientific community in the UK strongly rejected the notion that research required oversight, though scientists acknowledged the oversight of clinical applications. See id.

139 The Human Fertilization and Embryology Act (HFE Act) 1990 c 37 (UK) was originally passed in 1990, and amended by the Human Fertilization and Embryology Act (HFE Act) 2008 c 22 (UK).

140 See Schechter, supra note 122, at 616-617. See also Sect. 3 of the HFE Act (1990), which provided that "no person shall (a) bring about the creation of an embryo, or (b) keep or use an embryo, except in pursuance of a licence." Sect. 5(1) of the HFE Act (1990) stipulated that "there shall be a body corporate called the Human Fertilisation and Embryology Authority."

141 Sect. 3 of the HFE Act (1990).

142 Schedule 2, par. 3.2 of the HFE Act (1990), stipulating that research on embryos should be "necessary or desirable for the purpose of (a) promoting advances in the treatment of infertility, (b) increasing knowledge about the causes of congenital disease, (c) increasing knowledge about the causes of miscarriages, (d) developing more effective techniques of contraception, or (e) developing methods for detecting the presence of gene or chromosome abnormalities in embryos before implantation, or for such other purposes as may be specified in regulations."

143 See Samantha Halliday, A Comparative Approach to the Regulation of Human Embryonic Stem Cell Research in Europe, 12 MEDICAL LAW REVIEW 40, 46 (2004). 
tential benefits of embryo research are so huge that some research ought to be permitted. ${ }^{144}$ Based on the statutory control, the UK gives prominence to embryo research, and at the same time channeled the related moral concerns into retention of control over scientists' actions. Under the governance of the 1990 HFE Act, research on embryos in the UK has been developing rapidly during the last ten years of the twentieth century. As a report showed, between August 1991 and March 1998 in the UK, approximately 48,000 surplus embryos created by IVF were used in research and 118 embryos were created for research. ${ }^{145}$

\subsubsection{Governing hESC Research}

It is evident that prior to 1998, when the first successful derivation of an hESC line was announced, the UK had already established a legal framework on regulating embryo research. Nevertheless, the 1990 HFE Act did not foresee hESC research. In fact, this Act neither contained the purposes for developing methods of therapy for diseased or damaged tissues or organs, ${ }^{146}$ nor set forth any provision concerning the creation or use of hESCs. With the advent of hESC techniques as well as the arising of related legal, political and moral issues, the $1990 \mathrm{HFE}$ Act, which was supposed to regulate embryo research, could not adequately address some issues in the emerging areas of research related to embryos, including but not limited to hESC research. Hence, right after the announcement of the derivation of the first hESC line, such research in the UK faced a temporary regulatory vacuum and raised a heated debate again.

In response, the UK government, in June 1999, established an expert group chaired by the Chief Medical Officer, Professor Liam Donaldson, to suggest on "whether new areas of research using embryos should be permitted that could lead to broader understanding of, and eventually to new treatments for, a range of disorders where there is disease or damage to tissues or organs." 147 Then, the expert group made a series of recommen-

144 See Emily Jackson, Regulating Reproduction: LaW, Technology and Autonomy 230 (Hart Publishing 2001).

145 See Department of Health, Stem Cell Research: Medical Progress with Responsibility, http://webarchive. nationalarchives.gov.uk/20130107105354/http://www.dh.gov.uk/prod_consum_dh/groups/dh_digitalassets/@dh/@en/documents/digitalasset/dh_4065085.pdf.

146 The Human Genetics Advisory Commission and the HFEA, Cloning Issues in Reproduction, Science and Medicine (1998), http://www.hfea.gov.uk/docs/Cloning_Issue_Report.pdf, para. 5.9. See also Schechter, supra note 122, at 617 (pointing out that research into diseases which are neither congenital nor a factor in infertility or miscarriage was not included in the originally permitted purposes mentioned in the 1990 HFE Act); Lovell-Badge, supra note 122, at 999 (none of the original five "purposes" specified in the [1990 $\mathrm{HFE}$ ] Act was a sufficient justification for the derivation of hESCS, especially for studying early embryos and diseases or for developing stem-cell-based therapies.)

147 Department of Health, supra note 145, at 12. As has been noted in chapter 2, the greatest therapeutic promise of hESCs is to give rise to particular cells to replace ailing or destroyed tissues in patients who are suffering from diverse degenerative diseases. 
dations to modify the original HFE Act, ${ }^{148}$ especially in favor of permitting the derivation of hESCs, not just from surplus IVF embryos but also from embryos created by SCNT. ${ }^{149}$ However, votes on the amendments in the House of Commons and the House of Lords were confronted with some debate, ${ }^{150}$ though the debate was said to be not so fierce as the debate surrounding embryo research in the $1980 \mathrm{~s} .{ }^{151}$ Eventually the UK Parliament accepted the amendments and the government issued the Human Fertilisation and Embryology (Research Purposes) Regulations (2001) to add three new purposes to the original: increasing knowledge about the development of embryos, increasing knowledge about serious disease, and enabling any such knowledge to be applied in developing treatments for serious disease. ${ }^{152}$ Based on the extension of the permitted purposes, the derivation of hESCs falls under the HFE Act.

In accordance with the modified HFE Act, only with authority from the HFEA can human embryos be used to derive hESCs. Thus, before starting the derivation of hESCs, researchers first should justify the use of human embryos and obtain a license from the HFEA. These embryos not only can be surplus IVF embryos donated with the full consent of the contributors, but also can be embryos created by SCNT specifically for research. This means that in the UK therapeutic cloning is permitted. However, human reproductive cloning is not allowed, since in accordance with the HFE Act 2008, it is absolutely prohibited to use SCNT, or any other technique, to create a baby. ${ }^{153}$

Once established, the use of hESCs in research is no longer covered by the HFE Act. Currently, there is no specific statutory regulation for hESC research in the UK. This country primarily relies on the Code of Practice for the Use of Human Stem Cell Lines

148 See id., at 45-48 (for example, the expert group advised that research using embryos, whether created by IVF or SCNT, to boost understanding about human disease and disorders and their cell-based treatments should be allowed, subject to the controls in the HFE Act. When it comes to hESC research, the expert group recommended the HFEA monitor jointly with the Human Genetics Commission the progress of hESC research, the implications for health and health care, and any concerns which may arise, which is utilitarian. Additionally, the group felt that stem cell research should be encouraged, and advocated considering the feasibility of establishing collections of stem cells for research use.)

149 For more information regarding SCNT, see supra Sect. 3.2.1.3, Chap. 2.

150 The debate was especially concerning the proposed use of cloning methods. See Lovell-Badge, supra note 122, at 999.

151 See Riley \& Merrill, supra note 133, at 51. (The reason might be moral fatigue. A larger battle over embryo research had already been fought within the 1980s, and when hESC techniques came about in 1998, there did not seem to be widespread willingness to rejoin the battle.)

152 Article 2(2) of the Human Fertilisation and Embryology (Research Purposes) Regulations 2001, No. 188, which was issued on Jan. 24, 2001, and came into force on Jan. 31, 2001. See also Lovell-Badge, supra note 122, at 999 ("Modifications were possible because of a provision (a regulation-making power) in the original Act that specifically allowed Parliament to add additional purposes.")

153 Human reproductive cloning used to be prohibited by the Human Reproductive Cloning Act 2001. On Nov. 13, 2008, the HFE Act 2008 repealed the Human Reproductive Cloning Act 2001. Thus, currently, human reproductive cloning in the UK is prohibited under the HFE Act 2008. 
to provide guidance and assistance on research involving established hESC lines. ${ }^{154}$ The UK government believes that hESCs do not amount to human embryos, and once derived, hESCs do not by themselves have the potential to develop into human beings; thus hESCs do not have the moral status of human embryos and do not need the same level of regulation to which embryo research is subject. ${ }^{155}$ The generation of hESC lines is still under statutory control by the HFE Act, since it necessitates the use and destruction of human embryos. Pursuant to the Code of Practice, research involving hESCs is supervised by the Stem Cell Bank Steering Committee. ${ }^{156}$

Through the analysis above, several conclusions can be drawn. The UK is an enthusiastic backer of hESC research. Indeed, the UK has adopted a relatively liberal approach, but it is just from the perspective of allowed research types. Particularly, in the UK hESCS may be derived not only from surplus IVF embryos but also from embryos created by SCNT. However, from the perspective of degree of regulation and oversight, the UK's approach is not so permissive, since it has a stringent control and monitoring regulatory framework for hESC research, especially regarding the creation of hESC lines. In addition, the UK's regulatory system has distinguished the derivation of hESC lines from research involving already established hESC lines. It is primarily based on the moral and legal status of embryos and hESCs in this country: an embryo per se does not have any legal status, but it possesses a certain level of legal protection; an embryo cannot be considered to have the same moral status as a living child or an adult, but it should have a "special status" and cannot be misused in research; hESCs are deemed to have much less moral value than embryos, and thus they do not need the same level of regulation as that of embryos.

Besides social-cultural factors, there are several other factors that have influenced the tailoring of the policy approach. The participatory element of citizens and scientists has played a very important role in establishing the regulation of hESC research. The always prompt response of the UK government and the Parliament's willingness to openly discuss the issues have also contributed greatly. The UK's desire to retain its leading role in embryo research and stem cell research no doubt is a driver in terms of the liberal approach.

\footnotetext{
154 See Code of Practice for the Use of Human Stem Cell Lines (Apr. 2010), https://www.mrc.ac.uk/documents/ pdf/code-of-practice-for-the-use-of-human-stem-cell-lines/.

155 See id., at 2. See also Lovell-Badge, supra note 122, at 1000.

156 The National UK Stem Cell Bank, established in 2003, regulates the repository of hESCs and seeks to facilitate the sharing of quality-controlled stem cell lines among the clinical and research communities.
} 


\subsubsection{Intermediate or Permissive Compromise Policies and the Netherlands}

The majority of EU member states adopt an intermediate approach, allowing hESC research but with a series of restrictions. ${ }^{157}$ For instance, the Netherlands, France and Portugal adhere to an intermediate position which implies that normally research on surplus IVF embryos is permitted, but the creation of human embryos for research purposes is forbidden. ${ }^{158}$ This probably implies that isolation of hESC lines is allowed only from surplus IVF embryos, but not from embryos created by SCNT. The goal of the intermediate approach is to relieve human suffering and enhancing (collective or individual) human health and well-being. ${ }^{159}$ This type of policy approach could be considered the result of political compromises and trade-offs. It on the one hand attempts to balance different-if not colliding-interests and values that could otherwise prevent the conducting of research, ${ }^{160}$ and on the other hand tries to provide efficient and safe mechanisms for carrying out research. ${ }^{161}$ However, because of its compromise nature, the intermediate approach might be ambiguous and internally inconsistent. Such internal inconsistency often can be found in policies which set up a moral or legal separation between the destruction of embryos and their use. ${ }^{162}$ In terms of the intermediate approach, commentators often cite the Netherlands as a specific example within the EU.

For regulating embryo and hESC research, the Netherlands primarily relies on the Embryos Act, ${ }^{163}$ which was passed in 2002 after a heated debate. Pursuant to this Act, any research involving embryos, including the derivation of hESCs as well as subsequent research on these cells, must undergo review by a regulatory agency, the Central Committee for Research involving Human Subjects. The Dutch Embryos Act allows research to be carried out upon surplus IVF embryos less than 14 days old, ${ }^{164}$ on the condition that there is no alternative research method; ${ }^{165}$ that research must comply with one of several specific research purposes; ${ }^{166}$ and that the Act's consent requirement has

157 Isasi \& Knoppers, supra note 116, at 22; Campo-Ruiz, supra note 93, at 8 (studying the legislative and governance frameworks for stem cell research in 30 European countries, and showing that countries adopting a permissive approach with restrictions included Cyprus, Czech Republic, Denmark, Estonia, Finland, France, Greece, Hungary, Iceland, the Netherlands, Norway, Portugal, Slovenia, Spain, Switzerland, and Bulgaria.)

158 See Gerard Porter, The Drafting History of the European Biotechnology Directive, in EMBRYONIC STEM CELL PATENTS: EUROPEAN LAW AND ETHICS 24 (Aurora Plomer \& Paul Torremans ed., Oxford University Press 2009); Campo-Ruiz, supra note 93, at 8.

159 See Aurora Plomer \& Paul Torremans, Embryonic Stem Cell Patents: European Law and Ethics xxxviii (Oxford University Press 2009).

160 See Isasi \& Knoppers, supra note 116, at 22.

161 See Isasi \& Knoppers, supra note 2, at 42.

162 See id., at 42-43. See also Isasi \& Knoppers, supra note 116, at 22.

163 Wet houdende regels inzake handelingen met geslachtscellen en embro's: Embrowet (2002).

164 Sect. 24(e) of the Embryos Act, stipulating that "the following procedures are prohibited: (e) allowing an embryo to develop outside the human body for longer than fourteen days."

165 Sect. 10(b) of the Embryos Act.

166 Sects. 8-11 of the Embryos Act. 
been observed. ${ }^{167}$ Moreover, the Act specifically prohibits reproductive cloning. ${ }^{168}$ Due to the fact that the derivation of hESCs necessities the use of embryos, the derivation activities are regulated by the Embryos Act. Under this Act, hESCs may be derived from surplus IVF embryos with up to 14-day development and with full informed consent. The creation of hESC lines is unlawful unless it is licensed by the statutory regulatory body. It must fulfil the necessity principle and accord with the stipulated purposes. Derivation of hESCs from specifically created embryos is not allowed.

The permission granted to research on surplus IVF embryos is deemed to be based on a general consensus in the Netherlands that a human embryo has a definite value, and thus it deserves certain protection. ${ }^{169}$ This protection contains the principle that embryos should not be used or created for trivial purposes, but could be used for important scientific or therapeutic ends. ${ }^{170}$ Although the Embryos Act allows research on surplus IVF embryos, the creation of embryos specifically for research purposes is prohibited. ${ }^{171}$ This position is based on a view that while the purpose for which the embryo is generated does not influence the embryo's status, it could affect upon the moral acceptability of embryo research. ${ }^{172}$ As the Health Council has pointed out, ${ }^{173}$ although both surplus IVF embryos and specifically created embryos are instrumentalized if used for research, there is an added element of instrumentalization in the creation of embryos specifically for research purposes; surplus IVF embryos would be disposed of anyway since they were no longer needed for assisted reproduction. ${ }^{174}$

Generally, the approach that the Dutch Embryos Act has taken towards regulating embryo and hESC research is also pragmatic and utilitarian, similar to the position of the

167 Sects. 5, 6, 8 and 9 of the Embryos Act.

168 Sect. 24(f) of the Embryos Act, stipulating that "the following procedures are prohibited: (f) performing procedures with gametes or embryos with a view to the birth of genetically identical human individuals."

169 See Wybo Dondorp \& Guido de Wert, Embryonic Stem Cells Without Moral Pain? 10 (Health Council of the Netherlands 2005).

170 See id. See also Health Council of the Netherlands, IVF-related Research, No. 1998/08E, Rijswijk (Mar. 19 , 1998), https://www.gezondheidsraad.nl/sites/default/files/9808e.pdf, at 12 ("while a given value should be assigned to the embryo in vitro (by virtue of which it deserves respect), this value is relative and can be overridden when other, more imperative interests are involved.")

171 Sect. 24(a) of the Embryos Act. However, the ban is temporary. In accordance with Sects. 32 and 33 of the Embryos Act, it has set up a three- to five-year moratorium on the creation of embryos for research with the presumption that the ban will be lifted within that period of time.

172 See Health Council of the Netherlands, supra note 170, at 52-53.

173 See Halliday, supra note 143, at 52 (the Health Council had provided a series of recommendations and the Embryos Act accepted many of them.)

174 See id., at 52-54; JACKSON, supra note 144, at 230 ("If the disposal of spare embryos is inevitable, it is difficult to see why washing an embryo down the drain would be morally preferable to using it in order to carry out valuable research.") 
HFE Act of the UK. ${ }^{175}$ The Dutch Embryos Act attempts to balance diverse interests and values, such as the special moral status of human embryos and potential benefits of hESC research. However, the major difference between the Dutch approach and the UK approach is that the former is relatively conservative, and currently bans the creation of embryos specifically for research purposes, based on the Netherlands' different views concerning the acceptability of research involving embryos. Commentators regard the Dutch approach to be strict, and feel it may lead to a disadvantage in research. ${ }^{176}$ For example, an evaluation report of the Dutch Embryos Act was released in September 2012 and mentioned that there was an impediment of scientific research because of the prohibition on the creation of embryos. ${ }^{177}$ The Dutch intermediate approach is considered to be a compromise between the liberal approach adopted by the UK and the prohibitive approach adopted by Germany. ${ }^{178}$

\subsubsection{Restrictive Compromise or Blank Prohibition Policies and Germany}

In the EU, countries that adopt restrictive policies with regards to hESC research usually prohibit techniques via tight regulations or blank prohibitions. ${ }^{179}$ Yet, those countries adopting tight regulations do not necessarily prohibit all hESC research. Some prohibit hESC derivation, and some prevent using hESC lines or their products, while some adopt exceptions for imported hESC lines. ${ }^{180}$ The underlying reason for these restrictive policies is that these countries hold the opinion that even the early human embryo has moral status of full a personhood and it should be protected to preserve human dignity. ${ }^{181}$ In these countries, to maintain or improve the embryo's health or to become pregnant via IVF is the only ethical justification for embryo research. ${ }^{182}$ For instance, Austria has adopted an extremely restrictive approach and prohibits almost all embryo

175 It can also be seen from the statement of the Health Council concerning embryo research; see Health Council of the Netherlands, supra note 170, at 57-58 ("while a given value should be assigned to the embryo in vitro, by virtue of which it deserves respect, this value is relative and can be overridden when other, also morally more imperative interests are involved ... allowing scope for research using human embryos can be justified on the basis of a balanced appraisal of [the relative importance of the value of the embryo in vitro, and the moral importance of the proposed research]. The greater evil would be to abandon embryo research concerned with major human health issues.")

176 See Research with Gametes and/or (leftover) Embryos and the Foetus, CEnTRAL COMmitTEE ON RESEARCH INVOLVING HUMAN SUBJECTS, http://www.ccmo.nl/en/research-with-gametes-and-or-leftover-embryos-andthe-foetus.

177 See id (an evaluation report of the Embryos Act was released in September 2012 and mentioned "the obstruction of scientific research as a result of the ban on the creation of embryos (section 24a).") See also DONDORP \& WERT, supra note 169, at 9 ("scientists do increasingly feel impeded by these restrictions [on creating embryos through SCNT]. This is shown by the recent interest in attempts to release research on embryonic stem cells from the grip of this moral and legal discussion.")

178 See Halliday, supra note 143, at 51-52.

179 See Isasi \& Knoppers, supra note 116, at 20; Campo-Ruiz, supra note 93, at 8 (there might be another restrictive policy approach-restrictive by default-where legislation is not explicit but national practices are quite restrictive in practice, such as Romania and Turkey.)

180 See Isasi \& Knoppers, supra note 116, at 20-21.

181 See Hellstadius, supra note 1 , at 125.

182 See Isasi \& Knoppers, supra note 2, at 45-46. 
research, ${ }^{183}$ only with the possible exception of treatments beneficial to that particular embryo or treatments necessary to achieve a pregnancy. ${ }^{184}$ Germany has adopted a slightly more permissive position, specifically prohibiting the derivation of hESCs but allowing research on imported hESC lines which were generated before a defined cutoff date.

In Germany, the Embryo Protection Act (ESchG) regulates the use of reproduction technology and the handling of human embryos. ${ }^{185}$ Under the ESchG, the improper use of reproduction technology, improper use of human embryos, unauthorized fertilization, and cloning are generally prohibited. ${ }^{186}$ Specifically, the ESchG prohibits the creation of an embryo "for any purpose other than bringing about a pregnancy." ${ }^{187}$ Moreover, the Act prohibits any use of a human embryo in vitro for purposes other than for its own preservation. ${ }^{188}$ Through these sections, the ESchG confines the possible industrial, commercial, and even therapeutic and diagnostic uses of human embryos in Germany to an absolute minimum. With respect to the definition of the human embryo, Section 8.1 of the ESchG sets forth that an embryo "means the human egg cell, fertilized and capable of developing, from the time of fusion of the nuclei, and further, each totipotent cell removed from an embryo that is assumed to be able to divide and to develop into an individual under the appropriate conditions for that." 189 This definition is based upon the material having the capability of developing into a human being, thus, totipotent cells would be covered by the scope of this Act. As can be seen, the ESchG has established a strong protection for the human embryo in Germany.

The legislators of the ESchG did not take hESC research into consideration, since the ESchG was passed in 1990 and the first hESC line in the world was not successfully established until 1998. It seems that, generally, research on pluripotent hESC lines is not prohibited, since hESCs do not fall under the definition of a human embryo under the ESchG. However, since current techniques of creating hESC lines necessitate the use and destruction of human embryos, and the use of human embryos for research is seriously restricted by the ESChG, it makes the creation of hESC lines a criminal offence, and

183 The Austrian Reproductive Medicine Act (Fortpflanzungsmedizingesetz) (1992) strictly forbids usage of cells showing developmental potential for any purpose other than assisted reproduction (§ 9.1). See also Porter, supra note 158 , at 24.

184 See Isasi \& Knoppers, supra note 116, at 21.

185 German Embryo Protection Act, Gesetz zum Schutz von Embryonen (ESchG), 1990 (BGBI. I S. 2746).

186 See Sects. 1, 2, 4, and 6 of the ESchG.

187 Sect. 1 of the ESchG.

188 Sect. 2 of the ESchG stipulates that "(1) Anyone who disposes of, or hands over or acquires or uses for a purpose not serving its preservation, a human embryo produced outside the body, or removed from a woman before the completion of implantation in the uterus, will be punished with imprisonment up to three years or a fine. (2) Likewise anyone will be punished who causes a human embryo to develop further outside the body for any purpose other than the bringing about of a pregnancy. (3) Any attempt is punishable." 
such activities are clearly prohibited by the ESchG ${ }^{190}$ In this regard, the ESchG has not only prohibited the creation of human embryos for research purposes, but also banned the derivation of hESCs within Germany.

Because the ESchG primarily regulates the use of human embryos, the provisions in this Act are not directly applicable to research on already established, imported hESC lines. In Germany, there is a piece of legislation, the Stem Cell Act (StZG), ${ }^{191}$ regulating importation and utilization of externally established hESC lines for research and diagnostic purposes. The StZG aims to prevent demand for the derivation of hESCs or for the creation of human embryos for such purpose within Germany. ${ }^{192}$ Pursuant to the StZG, Germany permits research on imported hESC lines if these cell lines were legally derived from spare embryos prior to May 1st, 2007. ${ }^{193}$ Additionally, imported hESC lines can only be used for research if they are critical in developing new medical and scientific knowledge. As a result, the StZG has made an exception to the ban on hESC research established within the ESchG. Based on this exception, although the derivation of hESCS is not permitted in Germany, downstream research based on already established hESC lines in effect has never ceased within this country. ${ }^{194}$

In general, Germany adopts a restrictive approach towards hESC research via tight regulation, forbidding the establishment of hESC lines and only permitting research on imported hESC lines under certain strict conditions. However, the German approach is also considered to be a compromise which attempts to satisfy all sides, but skewing towards restrictive across the spectrum of restrictive to liberal policy frameworks. One possible reason behind such a policy choice is the impact of the devaluation of life during the Nazi era. ${ }^{195}$ Meanwhile, the German approach is criticized as setting a dubious ethical standard and being hypocritical, since it rests its ethical grounding on the lack of ethics elsewhere. ${ }^{196}$

To sum up, to date in the $\mathrm{EU}$, no harmonized regime has been established in regulating the field of hESC research. Since the EU is not an independent sovereign state but a

190 See Hellstadius, supra note 1 , at 125.

191 Gesetz zur Sicherstellung des Embryonenschutzes im Zusammenhang mit Einfuhr und Verwendung menschlicher embryonaler Stammzellen (StZG), Stammzellgesetz vom 28. Juni 2002 (BGBI. I S. 2277).

192 See Hellstadius, supra note 1 , at 126.

193 See Sects. 4 and 6 of the StZG. See also Mertes, supra note 108, at 133-134 (the effectiveness of the cut-off date is unstable and not eternally fixed. The date used to be January 1st, 2002, but was amended to move the cut-off point to May 1st, 2007 so as to meet the demand for hESC research and clinical trials, since the quality of later established hESC lines improved.)

194 See Hellstadius, supra note 1 , at 125.

195 See EU to Fund Embryo Cell Research, BBC NEws, (Jul. 242006), http://news.bbc.co.uk/2/hi/europe/5209106. stm ("some of the countries which oppose stem cell research are influenced by Roman Catholic teaching. In Germany, memories are coloured by Nazi experiments during World War II.")

196 See Isasi \& Knoppers, supra note 116, at 21-22. 
politico-economic union of many member states, and since different member states may have diverse concerns regarding embryo and hESC research, it is difficult to adopt a common policy at the EU level, especially within such a controversial research field. The EU has gained only very limited competence to regulate such research, primarily via funding policies. Currently, EU funding is granted for hESC research, but not for the derivation of hESCs. Regulatory approaches to hESC research in the EU are in effect a matter of member states.

Based on a variety of ways in which the status of the embryo is defined and perceived, EU member states have adopted a wide range of policy approaches from liberal, to intermediate, to restrictive. A small number of EU member states adopt liberal or permissive policies towards $\mathrm{hESC}$ research. Within these, a wide range of techniques, even including the creation of embryos for research purposes as well as for the production of hESC lines, are allowed conditionally. The primary reason is that these countries do not consider the human embryo to possess a high moral and legal status, and at the same time, they emphasize the significance of the advancement of embryo and hESC research and by extension the benefits to mankind. Most EU member states adopt an intermediate approach towards hESC research. These countries almost hold views concerning the legal and moral status of the human embryo similar to those of countries adopting a liberal approach. However, the difference is that these countries feel that the purpose for which the embryo is generated influences the moral acceptability of embryo research. In this regard, in these countries holding an intermediate position, normally isolation of hESCs is permitted from surplus IVF embryos, but prohibited from embryos created specifically for research. Within the countries adopting the restrictive approach, human dignity generally is emphasized. These countries hold the opinion that even the early human embryo has moral status concomitant with full personhood, and it should be protected to preserve human dignity. Based on their view of the high moral status of the human embryo, these countries choose either to prohibit using embryos to derive hESCs, or to prevent using such cell lines, or at most make exceptions for imported hESC lines.

In addition, with respect to regulating hESC research, several interests and values inevitably are involved, such as the special moral status of human embryos and potential benefits of research. Countries normally attempt to balance the various interests and values, while at the same time choosing one as a priority. Liberal and intermediate approaches seem inclined to prioritize scientific benefits, that is, the great potential of hESC research. In contrast, a more restrictive approach tends to preserve the moral principle. It seems that no matter what type of approach a country adopts, internal inconsistency is inevitable. Moreover, it is interesting that almost all types of approaches show some degree of respect for human embryos in their regulatory system. Indeed, 
through an exploration of the substantive requirements as well as procedural and ethical safeguards in the regulations concerning hESC research across Europe, commentators have observed that there is a trend towards policy convergence in the regulation, showing respect for human life starting from the fertilization of a zygote. ${ }^{197}$ Even so, showing a certain respect for a human embryo is reflected in the close monitoring of such research, but nothing more. There seems to be a gradually shift in approaches from restriction to the liberalization of national policies. ${ }^{198}$ It is thus difficult to imagine that EU member states moving toward a unified, high moral and legal status for human embryos and hESCs, and ultimately enacting an absolute ban on hESC research.

\section{GOVERNING AND DEVELOPMENT DEGREE IN CHINA}

China has the biggest population in the world, and it is confronted with the coming peak of an aging population. It is facing the increasing healthcare burden of degenerative diseases, tumors, tissue and organ defects and other age-related diseases. This country also is suffering a shortage of replacement organs and tissues. As emphasized in Chapter 1 of the thesis, China indeed has many pragmatic reasons to promote stem cell research, including hESC research. ${ }^{199}$ This section primarily discusses the specific policy approach that the Chinese government has taken towards hESC research, as well as the underlying rationale. In this regard, before commencing the analysis of the policy approach of the Chinese government, it is necessary to have a sketch of the driving force behind China's regulation of hESC research (Sect. 4.1). In order to explore in depth how the Chinese government has regulated hESC research, including the Ethical Guidelines for hESC research (Sect. 4.3) and the funding policy concerning hESC research in China (Sect. 4.4), an examination of the drafting history of the Ethical Guidelines (Sect. 4.2) is conducted then. Finally, the development of China's hESC research and industry, particularly in terms of China's position in the world, is investigated (Sect. 4.5), so as to ultimately provide a reference for rule setting and policymaking regarding whether and how to provide patent protection in this research field.

\subsection{Initial Motivation for Regulating hESC research}

In fact, China made its position clear on therapeutic cloning and reproductive cloning almost as early as its Western counterparts. Right after the "Dolly technique", which is cloning, was invented, China responded and took a clear stand on related issues, declaring to support for therapeutic cloning, but it did "not agree, nor support, nor al-

197 See Isasi \& Knoppers, supra note 2, at 55.

198 See id., at 40.

199 See supra Sect. 2, Chap. 1. 
low, nor accept" reproductive cloning. ${ }^{200}$ For years, the Chinese government has firmly opposed any research for purpose of human cloning, but supported hESC research for treatment and prevention of disease. For instance, on 22 October 2001, Cheng Jinpei, a Vice Minister of the Ministry of Science and Technology (MOST) of China, at a round-table conference of UN Organization for Education, Science and Culture in Paris, pointed out that China subscribed to hESC research for curing and preventing diseases, but firmly objected to any experiment for human cloning. ${ }^{201}$ On 29 November 2001, the Ministry of Health $(\mathrm{MOH})$ announced the same opinion. ${ }^{202}$ While China took a stand on these issues, it did not take any further measures to adopt more specific policy protocols or regulations. For several years, hESC research in China encountered a regulatory vacuum. Regulating such research mainly relied on rules set by individual ministries or funding agencies, and research standards adopted by local institutions. ${ }^{203}$

The regulatory vacuum raised research uncertainty in China. For a long time, China followed the biotechnical research of technologically advanced countries, and it also started hESC research later than its counterparts. ${ }^{204}$ At the onset of hESC research in China, with the increasingly generous financial support of the Chinese government and the rapid development in the hESC research field around the world, a growing group of scientists in this country started to enter the field of hESC research. However, there was a big problem confronting Chinese scientists in this research field-they were confused about what to do in light of the regulatory vacuum. They sought explicit answers on how research should be done. When those scientists communicated with their foreign colleagues they got more confused, since they found themselves holding a different reasoning on hESCs as compared to the Western "mainstream". ${ }^{205}$ In this regard, Chinese scientists started to call for setting up domestic codes of conduct concerning hESC research.

Moreover, China's research practice on human embryos and hESCs has not been entirely shielded from global disputes. External criticism also placed great pressure on

200 The speech of Chen Minzhang, who was the Minister of Health of China, to the assembly of the "Ad hoc Committee at the International Convention against the Reproductive Cloning of Human Beings" at the UN in March 1997.

201 See China Firmly Opposes Human Cloning, CHINA.ORG.CN, (Oct. 26 2001), http://www.china.org.cn/english/21193.htm.

202 See Yahong Li, Imitation to Innovation in China: the Role of Patents in Biotechnology and Pharmaceutical INDUSTRIES 37 (Edward Elgar 2010) ("the Ministry of Health (MOH) announced on 29 November 2001, that China opposed any experiments for the purpose of human cloning, but it would allow 'closely monitored' ESC research for treatment and prevention of disease." Quoted in Chinese Government, Scientists Oppose Human Cloning, XINHUA ECONomic NeWS SerVICE (2001).)

203 See Joy Yueyue Zhang, The Cosmopolitanization of Science: Stem Cell Governance in China 45 (Palgrave Macmillan 2012).

204 See infra Sect. 4.5.1, Chap 4.

205 See ZHANG, supra note 203, at 46. 
China to establish a regulatory scheme. ${ }^{206}$ At the onset of research on human embryos and hESCs in China, there was misunderstanding and criticism from the Western world. In that case, Chinese policy makers worried that hESC research in this country "would not be fully recognized or endorsed by the wider scientific community." 207 As such, both Chinese scientists and policy makers considered it necessary to clarify the basic principles and code of conducts concerning hESC research in China. ${ }^{208}$ Put another way, in the face of such internal and external "troubles", that is, domestic uncertainty about $\mathrm{hESC}$ research practices and the pressure from cross-border communication, there was motivation for regulating hESC research in China.

It is still worth mentioning here that there was only a small-circle discussion on practical solutions concerning regulating hESC research, unlike the wider public debate in the Western world, such as in the US and EU. As analyzed earlier in this chapter, in the US and in member states of the EU, initial calls for regulating hESC research were based not only on the scientific uncertainty about hESC research but also on its ethical issues. In contrast, moral and legal issues regarding embryo research and hESC research did not get any public attention in China, and only led to debate within a small circle in academia. Meanwhile, the demand for regulating hESC research in China was based on the research uncertainty and international rivals' views, rather than local moral concerns. ${ }^{209}$ One possible reason is that China's policymaking primarily is a top-down approach, and the public lacks sufficient impact on what the government decides, ${ }^{210}$ which reduces the public's desire to participate in policymaking. Another possible reason might be that, as Chapter 3 has shown, the Chinese public to some extent has accepted research on embryos and hESCs. Therefore, the motivation of for creating regulation concerning $\mathrm{hESC}$ research in China was not based on uneasiness from within Chinese culture, but was a response to ethical concerns originally identified in foreign countries, especially in Europe and the US. From another point of view, when China imports Western advanced technology, it also imports many Western concerns. ${ }^{211}$

\subsection{Drafting the Ethical Guidelines for $h E S C$ Research}

As the necessary condition for the Chinese government's intervention was increasingly strongly felt by stakeholders, and as scientists, ethicists, and directors of local

\footnotetext{
206 See id., at 47.

207 Id., at 48.

208 See id., at $47-48$.

209 See id., at 45-48.

210 See Luozhong Wang (王洛忠), Woguo Zhuanxingqi Gonggong Zhengce Guochengzhong de Gongmin Canyu Yanjiu_-Yizhong Liyi Fenxi de Shijiao (我国转型期公共政策过程中的公民参与研究———种利益分析的视角) [Study on the Participation of Citizens in Public Policy Making During China's Transition: From the Interest Analysis Perspective], ZhongGuo XINGZHeng GUANLI (中国行政管理) [ChINESE PUBLIC AdMINISTRATION] 86, 86 (2005).

211 See ZHANG, supra note 203, at 5.
} 
institutions began to invest in a variety of disputes and research initiatives, around 2000 , the $\mathrm{MOH}$ and the MOST decided to jointly release the Ethical Guidelines ${ }^{212}$ to specifically regulate $\mathrm{hESC}$ research. ${ }^{213}$ In the process of drafting the Ethical Guidelines, various experts, including medical professionals and ethicists, were involved. However, the debate concerning the proposal of the Ethical Guidelines remained superficial, and some key issues were somehow circumvented and not quite to the point. ${ }^{214}$ This is deemed to be based on China's regulatory rationale. In other words, a conventional rationale in Chinese policymaking was problem-solving, rather than addressing wider social concerns, such as moral concerns in the EU member states mentioned before. As Sleeboom-Faulkner has pointed out, China's hESC research policies "should be seen in the light of policies of innovation and development", rather than considering them as mainly addressing moral concerns. ${ }^{215}$ At the time of drafting the Ethical Guidelines, the foremost troubles confronting Chinese policy makers were how to reduce foreign misunderstandings and how to make China's hESC research practice acceptable to the West. ${ }^{216}$ In this regard, it is not surprising that many Western rules on how to deal with moral or ethical issues surrounding hESC research were uncritically introduced into Chinese guidelines.

In addition, it is worth mentioning that China's National Center for Biotechnology Development, which was in charge of drafting the Ethical Guidelines, was in fact one of the MOST's affiliated institutions. ${ }^{217}$ This institution mostly comprises life scientists and techno-bureaucrats. When discussing the draft of the Ethical Guidelines, Chinese policy makers in the $\mathrm{MOH}$ and the MOST preferred the opinions of scientists known as "hardcore experts" rather than other experts (e.g., ethicists), since as scientists themselves they felt that scientists know best. ${ }^{218}$ They believed scientific issues should be settled by scientists. Even at the time of drafting the Ethical Guidelines, there was skepticism towards the necessity of involving social groups in research policies. ${ }^{219}$ While the initial draft of the Ethical Guidelines involved various experts, the redrafting or revising of the

212 See Renlei Peitai Ganxibao Yanjiu Lunli Zhidao Yuanze (人胚胎干细胞研究伦理指导原则) [Ethical Guidelines for Human Embryonic Stem Cell Research], Guokefashengzi (国科发生字) [2003] No. 460, jointly issued by the $\mathrm{MOH}$ and the MOST of China on Dec. 24, 2003.

213 See ZHANG, supra note 203, at 48.

214 Seeid., at 49.

215 See Margaret E Sleeboom-Faulkner, National Risk Signatures and Human Embryonic Stem Cell Research in Mainland China, 12 HEALTH, RISK \& SOCIETY 491, 496 (2010).

216 See ZHANG, supra note 203, at 51-52.

217 China's National Center for Biotechnology Development was set up on Nov. 3, 1983 under the MOST. One of its missions is "to take the responsibility and participate in the revision and formulation of biotechnology and bio-industry development laws, policies, projects and plans." See CHINA NATIONAL Center FOR BIOTECHNOLOGY DEVELOPMENT, http://www.cncbd.org.cn.

218 See ZHANG, supra note 203, at 52.

219 See id., at 57-58. 
Ethical Guidelines was carried out behind ministries' closed doors. ${ }^{220}$ The final version of the Ethical Guidelines was published without being reviewed by the experts who originally contributed to the debate. In a sense, the final version of the Ethical Guidelines was a product of top-down authoritarian convention, without any public participation.

\subsection{Ethical Guidelines for $h E S C$ Research}

In July 2003, the MOST and the MOH took a rare collaborative stance in jointly issuing the Ethical Guidelines, which is the first time the Chinese government has released a document to introduce a policy towards hESC research. ${ }^{221}$ The issuing of the Ethical Guidelines was commonly considered to be a political signal from China in raising the significance of regulating hESC research. ${ }^{222}$ The Ethical Guidelines are the most important existing official regulations on hESC research, and, currently, are still in force and influence hESC research in China. ${ }^{223}$ This document is over-condensed, and consists of twelve short articles. Only six articles (Articles 4-9) target the actual research procedure. Article 1 points out that this document aims to ensure hESC research activities conducted in China comply with internationally recognized bioethical guidelines and domestic relevant regulations, and to promote healthy development of hESC research. ${ }^{224}$ However, in China, except the Ethical Guidelines, there are no other relevant regulations specifically regarding $\mathrm{hESC}$ research. As such, the purposes provided in Article 1 support the rationale underlying the issuance of the Ethical Guidelines by the Chinese government, which is to address existing problems. That is, to ensure hESC research activities conducted in China comply with internationally recognized bioethical guidelines implies that the goal is to address foreign media's criticism and to make China's hESC research results more acceptable to the international scientific community. To promote "healthy" development of hESC stands for ensuring the ongoing practice of hESC research in China.

As mentioned before, the Ethical Guidelines closely follow the principles widely used in other countries. For instance, Article 4 specifically states that any research on reproductive cloning is prohibited, ${ }^{225}$ which means that cloning for disease treatment

220 See id., at 53.

221 See Qiu, supra note 46, at 68.

222 See ZHANG, supra note 203, at 45.

223 There is another regulation entitled Guanyu Yinfa Ganxibao Linchuang Yanjiu Guanli Banfa (Shixing) de Tongzhi (《关于印发干细胞临床研究管理办法（试行）的通知》国卫科教发[2015]48号) [Measures for the Administration of Stem Cell Related Clinical Research (for Trial Implementation), Guoweikejiaofa [2015] No. 48], jointly issued by the National Health and Family Planning Commission of the PRC and the China FDA on Jul. 20, 2015. However, this regulation focuses on clinical research, and pays more attention to procedure, such as conditions and responsibility of institutes, project approval and records of a research projects. This regulation does not provide any substantial contents with regard to regulating ethical issues in stem-cellrelated clinical research.

224 See Article 1 of the Ethical Guidelines.

225 See Article 4 of the Ethical Guidelines. 
and prevention is permitted. Article 7 bans the commodification of human gametes, zygotes, embryos and fetal tissues. ${ }^{226}$ This document also provides the 14-day criterion for in vitro research, which stipulates that the in vitro culture period of created embryos should be less than 14 days starting from fertilization or nuclear transfer. ${ }^{227}$ In addition, Article 6 forbids implanting any research-use embryos into human or animal wombs, and prohibits the fusion of human gametes and animal gametes. ${ }^{228}$ The Ethical Guidelines also emphasize the principles of informed consent and informed choice. ${ }^{229}$

In addition, it is worth noting that the Ethical Guidelines follow the international practice in regulating hESC research, requiring China's institutions engaged in hESC research to set up ethical committees, with the responsibility of reviewing, consulting on, and supervising hESC research. ${ }^{230}$ However, this document neither further defines the limits of the responsibility, nor vests the ethical committees with any substantial power to influence proposed projects or research. In this regard, ethical committees are not able to play any important role in regulating hESC research, and turn out to be in name only. Interestingly, concerning the expert composition of the ethical committees, the Ethical Guidelines only mention experts in "biology, medicine, law and sociology",231 without referring to professional ethicists, although the terms "ethics" and "ethical" are mentioned many times in the Ethical Guidelines, and "ethical" was even put into the title of this document. One possible reason is that the drafters of the Ethical Guidelines might consider the term "sociology" to cover other disciplines, such as ethics. Another possible reason is that the absence was an oversight, based on the narrow regulatory rationale that concentrates on the most pressing matters. ${ }^{232}$

The Ethical Guidelines prescribe a limit to the source of hESCs, and require that such stem cell lines should only be obtained through techniques including IVF, SCNT, and parthenogenesis. ${ }^{233}$ This implies that from the perspective of allowed types of embryo and hESC research, the Chinese approach is considerably permissive. In particular, it is quite similar to the UK policy approach analyzed earlier in this chapter. ${ }^{234}$ Regarding the degree of regulation and oversight, from the wording of the document, it ostensibly places stringent requirements on hESC research in China. However, the Ethical Guidelines only refer to the techniques of creating embryos, but do not given any additional

226 See Article 7 of the Ethical Guidelines.

227 See Article 6(1) of the Ethical Guidelines.

228 See Article 6(2) and 6(3) of the Ethical Guidelines.

229 See Article 8 of the Ethical Guidelines.

230 See Article 9 of the Ethical Guidelines.

231 Id

232 See ZHANG, supra note 203, at 58.

233 See Article 5 and Article 6(1) of the Ethical Guidelines.

234 See supra Sect. 3.2.1.3, Chap. 4. 
explanation on how these techniques should proceed in Chinese settings. ${ }^{235}$ Article 10 provides that "research institutions engaged in research related to hESCs shall formulate corresponding detailed measures and regulatory rules in compliance with the Ethical Guidelines." ${ }^{236}$ No further explanations are given concerning how to follow the Ethical Guidelines, and there is no clarification on hESC-related techniques, other than formally mentioning ethical committees. It is thus evident that regulating hESC research in China in effect is left to individual research institutions, and the oversight is in practice extremely liberal. Most importantly, there is no mention of any penalty in this one-page document, which to some extent renders the document to become a dead letter. This is in sharp contrast to the stringent control and monitoring regulatory framework for hESC research in most EU countries, such as the UK and the Netherlands. Therefore, in terms of allowed types of hESC research and the degree of regulation and oversight, the Chinese approach is quite permissive.

The Ethical Guidelines further demonstrate that regulating hESC research in China is merely a product of Chinese policy makers' attempting to blunt foreign criticism and to make China's hESC research results more acceptable to the international scientific community, and ultimately to promote the advancement of domestic hESC research. Social and moral concerns were not a vital problem that Chinese policy makers desired to tackle when tailoring hESC research governance policy. The risk of the approach adopted by China in governing hESC research through guidelines alone, without any active monitoring and sanctions, is to end up as self-serving and following a market consumer model. ${ }^{237}$ Particularly in the case where increasing private investment enters the $h E S C$ research field, governing hESC research through government guidelines alone will be inadequate. ${ }^{238}$ This document therefore has been criticized as unable to provide any assistance for related regulatory bodies to regulate hESC research, and is condemned as not helping clarify how administrative instruments should be operated. ${ }^{239}$ As many Chinese scientists have acknowledged, China's existing regulation towards hESC research still needs further improvement. ${ }^{240}$

\footnotetext{
235 See ZHANG, supra note 203, at 55.

236 Article 10 of the Ethical Guidelines.

237 See Isasi \& Knoppers, supra note 116, at 24.

238 See Linzhao Cheng, et al., Ethics: China Already Has Clear Stem-cell Guidelines, 440 NATURE 992,992 (2006) (arguing that in China nearly all scientific research relied on government funding.) Although it was true at the moment when the Ethical Guidelines were promulgated, with the advancement of the economy and science in China, there is no doubt that vast increases in private investment are entering the hESC research field.

239 See ZHANG, supra note 203, at 55-56.

240 See Cheng, et al., supra note 238, at 992.
} 


\subsection{Investment and Encouragement Policies}

In addition to adopting a considerably liberal regulatory policy towards $\mathrm{hESC}$ research, China has been providing policies to encourage such research. Indeed, the Chinese government perceives the biotech industry as a strategic sector and treats it as a top priority in the nation's development plan. ${ }^{241}$ As the former Premier Wen Jiabao pointed out, in a bid to push forward China's scientific and technological development, the development of biological technology should be beefed up. ${ }^{242}$ Regarding supporting the advancement of stem cell research, the government has issued and implemented various research development plans. In the National Medium- and Long-Term Program for S\&T Development (2006-2020), the government emphasizes the significance of stem cell research, and it also mentions that "critical breakthroughs are required in the fields of ... stem cells". ${ }^{243}$ Similarly, in the National 12th Five-Year Development Plan of S\&T, which was issued by the MOST in July 2011, stem cell research is considered to be one of six major national science programs. ${ }^{244}$ Also, in the 13th Five-Year Plan (for the period of 2016-2020), stem cell research and regenerative medicine are considered to be the key R\&D programs of national importance. ${ }^{245}$ Through these documents concerning development plans, it is evident that the Chinese government has set very clear targets for stem cell research and been highly devoted in promoting the development of stem cell research in China.

Huge amounts of money pumped into the field of stem cell research come from the MOST programs such as the National High Technology Research and Development Program (the 863 Program) and the National Basic Research Program (the 973 Program). ${ }^{246}$ By way of example, it was reported that the MOST would spend around \$211 million on six major science programs in areas including stem cells. ${ }^{247} \mathrm{~A}$ great deal of investment and emphasis on stem cell research can be also seen in the Guideline for Project

241 See LI, supra note 202, at 38.

242 See Premier Calls for Building Innovation-oriented nation, MINISTRY OF SCIENCE AND TECHNOLOGY OF THE PEOPLE'S REPUBLIC OF CHINA, http://www.most.gov.cn/eng/photonews/200601/t20060112_27803.htm.

243 The Outline of the National Medium- and Long-Term Program for S\&T Development (2006-2020) of China.

244 See Guojia “Shi'er Wu” Kexue he Jishu Fazhan Guihua (国家“十二五”科学和技术发展规划) [The National “Twelfth Five-Year” Development Plan of S\&T], MINISTRY of SCIENCE AND TECHNOLOGY OF THE PEOPLE'S REPUBLIC OF CHINA, (Jul. 4, 2011), http://www.most.gov.cn/mostinfo/xinxifenlei/gjkjgh/201107/t20110713_88230_6.htm.

245 See Jane Qiu, Stem-cell Research and Regenerative Medicine in China, 3 NATIONAL SCIENCE REVIEW 257, 259 (2016).

246 The 863 Program or the National High Technology Research and Development Program of China is a program funded in 1986 and administrated by the Chinese government, intending to boost innovation capacity in high technologies. See National High-tech R\&D Program (863 Program), MINISTRY OF SCIENCE AND TECHNOLOGY of THE PEOPLE'S RePuBlic OF CHINA, http://www.most.gov.cn/eng/programmes1/200610/t20061009_36225. htm. The 973 Program, or the National Basic Research Program of China, is China's persistent national keystone basic research program, and was funded by the Chinese government in June 1997; it is organized and implemented by the MOST. See generally, http://program.most.gov.cn.

247 See Jane Qiu, China Goes Back to Basics on Research Funding, 507 NATURE 148, 149 (2014). 
Application of the 863 Program and the 973 Program (2015). ${ }^{248}$ In this Guideline, stem cell research is emphasized as a key area for national support. In addition, research funding also comes from the Natural Science Foundation of China (NSFC), the Ministry of Finance, local governments, and enterprises. ${ }^{249}$ As a professional funding agency, the NSFC does not have a formal role in policymaking, but based on its high prestige within distributing funding, its preference is considered to be the wind vane for China's scientific funding policy. In fact, the number of stem-cell-related projects, including hESC research projects, financed by the NSFC has increased from nine projects in 1999 to 566 in $2016 .{ }^{250}$

As well as considerable funding, great efforts have been made to tempt overseas talent to return. ${ }^{251}$ In the meantime, the Chinese government has also been actively building a stem cell research infrastructure. For instance, China has established the National Engineering Research Center for Stem Cell Research and the National Engineering Research Center of Cell Products in 2000 and 2004, respectively. Consequently, on the one hand the Chinese government is encouraging hESC research, by issuing positive policies and investing enormous sums of money in this research field, ${ }^{252}$ and on the other hand it adopts a liberal policy regulating hESC research. The intent of China to promote the advancement of hESC research is evident.

\subsection{HESC Research and Industry in China}

After exploring the specific policy approach that the Chinese government has taken towards hESC research, as well as the rationale behind this approach, this section attempts to make a sketch of the place of China's hESC research and development in the world, and the stage of hESC research in China, which are quite significant when

248 Ministry of Science and Technology of the People's Republic of China, Guojia Zhongdian Jichu Yanjiu Fazhan Jihua he Zhongda Kexue Yanjiu Jihua 2015 Niandu Xiangmu Shenbao Zhinan (国家重点基础研究发展计划 和重大科学研究计划2015年度项目申报指南) [Guideline for Project Application of 863 Program and 973 Program (2015)], Ministry of SCienCE And TeChnology of the People’s Republic of China, (Feb. 20, 2014), http://program. most.gov.cn/htmledit/CFC828AD-B2B5-61E6-171D-FAD56CB48C0B.html.

249 See Haidan Chen, Stem Cell Governance in China: from Bench to Bedside? 28 NEW GENETICS AND SOCIETY 267, 270 (2009)

250 Internet-based Science Information System of the Natural Science Foundation of China, https://isisn.nsfc. gov.cn/egrantweb/ (searched on 12 Dec. 2016).

251 See Margaret Sleeboom-Faulkner \& Prasanna Kumar Patra, The Bioethical Vacuum: National Policies on Human Embryonic Stem Cell Research in India and China, Journal of INTERNATIONAL BIOTECHNOLOGY LAW, 25 (Dec. 2008), http://www.therapy.centreforbionetworking.org/wp-content/uploads/2012/06/TheBioethical-Vacuum.Sleeboom-Faulkner.Patra-for-merge.pdf; Chen, supra note 249, at 270.

252 For more discussion on China's industrial policy concerning stem cells, see also Brian Salter, et al., China and the Global Stem Cell Bioeconomy: An Emerging Political Strategy? 1 REGENERATIVE Medicine 671 (2006); Chen, supra note 249 . 
tailoring patent rules and policies in this jurisdiction. ${ }^{253}$ For this purpose, the focus in this section is on the development of China's hESC research (Sect. 4.5.1) and industry (Sect. 4.5.2).

\subsubsection{The Development of hESC Research}

Over the last decade, the Chinese government has greatly invested in stem cell research, including hESC research, concentrated in several key labs nationwide. ${ }^{254}$ For example, the Chinese Academy of Sciences currently has an established stem cell research network composed of the Institute of Health Sciences, Shanghai Institutes for Biological Sciences, Guangzhou Institutes of Biomedicine and Health, Biology Physics Institute, Zoology Institute, Genetics and Development Institute and Kunming Zoology Institute. Nowadays, in China a large number of researchers are working on hESCs. For instance, a research group at the Central South University isolated three Chinese hESC lines from the ICM of human blastocysts in 2002. ${ }^{255}$ Another research group in Key Laboratory of Stem Cell Biology, Institute of Health Sciences, Shanghai Institutes for Biological Sciences, have also been working on hESC research for a long time. ${ }^{256}$ These examples just exemplify that hESC research in China is underway. But as regards the position of hESC research of China in the world, more discussion is needed.

In order to get a general understanding of the current development of hESC research in China, particularly compared with other countries, this section attempts to use the Thomson Web of Science to collect data regarding hESC research publications of several countries, such as China, the US, Germany, England, Japan, and South Korea. The search date is 11th October 2016, and search terms are "human embryonic stem cell" and each country's name (Table 2 and Figure 1). As the data analysis has shown, China's hESC research started relatively late compared to other, technologically advanced countries, since in 2001 there was only one scientific article from China published. In contrast, other countries evidently started hESC research much earlier than China. However, with

253 When the development of research and industry is at an early stage, the country may lack a technological base to take advantage of the opportunities created by the patent system. Providing patent protection in a developing country, especially in a research field which is backward compared to technologically advanced countries, may benefit foreign applicants over domestic ones and slow the progress of domestic research, thereby making it difficult for the country to catch up with its counterparts. The stages of research with which patents are concerned are of extreme importance to the role of patents in innovation, whether positive or negative, and further eventually influence policymaking regarding whether and how to provide patent protection in this research field.

254 Concerning the funding policy regarding hESC research in China, please see supra Sect. 4.4, Chap. 4.

255 See generally, Di Zhou, et al., Establishment and Maintenance of Three Chinese Human Embryonic Stem Cell Lines, 46 In Vitro Cellular \& Developmental Biology-Animal 192 (2010).

256 See Chunliang Li, et al., Efficient Derivation of Chinese Human Embryonic Stem Cell Lines from Frozen Embryos, 46 In Vitro Cellular \& Developmental Biology-Animal 186 (2010); Chenlin Zhou, et al., Comprehensive Profiling Reveals Mechanisms of SOX2-mediated Cell Fate Specification in Human ESCS and NPCS, 26 CELL RESEARCH 171 (2016). 
the prominence given to $\mathrm{hESC}$ research by the government, China has gradually caught up with its counterparts in this research field. China's share of hESC research publications in the world total has gradually increased since 2001. China's annual number of scientific articles in this research field has surpassed that of other countries, except the US, as of 2009. This implies that China has made considerable progress in basic research on hESCs over the past decade. At least through the number of published scientific articles, hESC research of China to some extent has caught up and kept pace with other countries. Over the last decade, rapid research advances, generous government financial support and recruitment of highly trained oversea scientists, coupled with domestic outstanding researchers, have made it possible for China to become an important player on the international stage of stem cell research. ${ }^{257}$

Table 2: hESC Research Publications, 2001-2015

\begin{tabular}{ccccccccccccccccc}
\hline & 2001 & 2002 & 2003 & 2004 & 2005 & 2006 & 2007 & 2008 & 2009 & 2010 & 2011 & 2012 & 2013 & 2014 & 2015 \\
\hline China & 1 & 13 & 25 & 46 & 52 & 55 & 93 & 167 & 256 & 300 & 341 & 422 & 481 & 492 & 453 \\
Japan & 43 & 58 & 83 & 108 & 126 & 136 & 162 & 196 & 205 & 191 & 209 & 233 & 239 & 246 & 194 \\
USA & 201 & 206 & 283 & 407 & 510 & 599 & 694 & 889 & 1,074 & 1,158 & 1,218 & 1,278 & 1,302 & 1,177 & 936 \\
Germany & 32 & 40 & 58 & 77 & 84 & 86 & 116 & 156 & 181 & 200 & 237 & 259 & 213 & 208 & 195 \\
England & 39 & 52 & 61 & 96 & 113 & 125 & 169 & 178 & 202 & 230 & 230 & 250 & 242 & 219 & 212 \\
South Korea & 5 & 5 & 16 & 43 & 45 & 56 & 75 & 74 & 94 & 126 & 129 & 118 & 125 & 118 & 97 \\
World Total & 391 & 459 & 654 & 934 & 1,126 & 1,298 & 1,580 & 1,950 & 2,357 & 2,591 & 2,735 & 2,881 & 2,881 & 2,783 & 2,375 \\
China (\%) & 0.26 & 2.83 & 3.82 & 4.93 & 4.62 & 4.24 & 5.89 & 8.56 & 10.86 & 11.58 & 12.47 & 14.65 & 16.7 & 17.68 & 19.07 \\
\hline
\end{tabular}

Note: All publication counts were obtained from an ISI Thomson Web of Science search on 11/11/ 2016. Search terms used therein: $\mathrm{CU}=$ country name AND TS=human embryonic stem cell Indexes=SCI-EXPANDED

257 See XiaoBing Fu, Regenerative Medicine Research in China: From Basic Research to Clinical Practice, 57 SCIENCE CHINA LIFE SCIENCES 155, 155 (2014). 


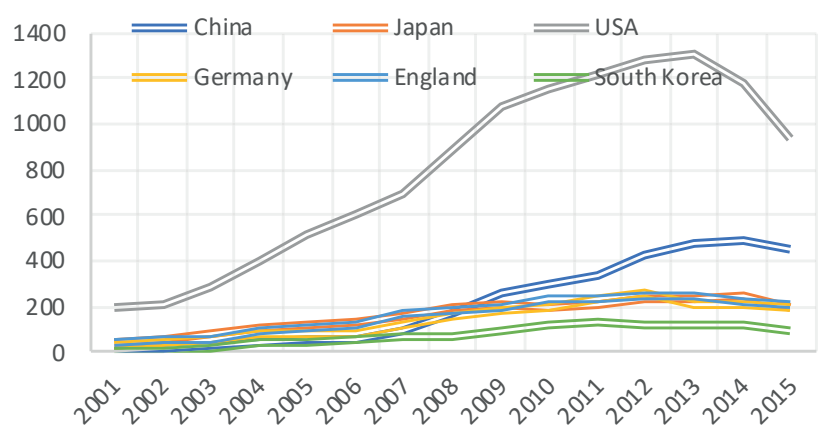

Figure 1: hESC Research Publications, 2001-2015

While the number of published China's scientific articles regarding hESC research has reached world levels, the research quality and innovative ability of Chinese researchers in this research field is still considered to lag behind that of the technologically advanced countries. ${ }^{258}$ Too much of China's stem cell and hESC research remains derivative. ${ }^{259}$ For instance, some scholars conducted interviews in 2007 with over 30 stem cell researchers who had trained abroad, and found out that none considered China a world leader in the field. ${ }^{260}$ As a leading Chinese stem cell scientist, Zhou Qi, mentioned, "although stem cell research in China has made great progress in recent years, there are still some gaps in the field of stem cell research and its clinical translation between China and its counterparts, including Europe, the US and Japan."261

\subsubsection{The Development of hESC Industry}

In China, an hESC industry as a matter of fact has not been established. The stem cell industry mainly focuses on adult stem cells. For example, China has set up several adult stem cell banks, such as umbilical cord blood stem cell banks and mesenchymal stem cells banks. As early as 2001, the MOH started to set up umbilical cord blood stem cell banks. ${ }^{262}$ Currently, there are seven legal umbilical cord blood stem cell banks in China,

258 See Wei Li \& Lisheng Cai, The Scope of Patent Protection for Gene Technology in China, 32 NATURE BIOTECHNOLOGY 1001, 1003 (2014) (holding that China has been a relatively late starter in the development of biotech and has relatively little research expertise.)

259 See Weiping Yuan, et al., Stem Cell Science On the Rise in China, 10 Cell Stem Cell 12, 13 (2012).

260 See Sleeboom-Faulkner \& Patra, supra note 251, at 16.

261 Qi Zhou (周琪), Zhongguo ji Zhongguo Kexueyuan Ganxibao yu Zaisheng Yixue Yanjiu Gaishu (中国及中国科 学院干细胞与再生医学研究概述) [An Overview of Stem Cell and Regenerative Medicine in China and at Chinese Academy of Sciences], 28 CHINESE BULLETIN OF LIFE SCIENCES 833, 837 (2016).

262 Weisheng Bu Bangong Ting Guanyu Xiafa Qidai Xue Zaoxue Ganxibao Ku Shezhi Guihua de Tongzhi (卫生部 办公厅关于下发脐带血造血干细胞库设置规划的通知) [Notice Issued by the Ministry of Health on the Plan to Set up Banks of Umbilical Cord Blood Stem Cells], promulgated by the National Health and Family Planning Commission of the PRC on 22 May 2001, http://www.nhfpc.gov.cn/yzygj/ws/gf/201308/d4e9f5662ed24d0c$99 \mathrm{c} 76 \mathrm{fc} 72 \mathrm{~d} 21 \mathrm{a} 4 \mathrm{ee} . \mathrm{shtml}$ (this document indicated that China was planning to establish five to ten banks of umbilical cord blood stem cells nationwide between 2001 and 2005.) 
located in Beijing, Tianjin, Shanghai, Shandong, Guangdong, Zhejiang and Sichuan, aiming for future transplantation treatment for children. ${ }^{263}$ Two mesenchymal stem cell banks, located in Shenzhen and Shandong, have been established as well, in order to someday treat hematic and immune systematic diseases. ${ }^{264}$ It is worth noting that in 2012, the Institute of Human Reproduction and Stem Cell Engineering, Central South University, leaded by Professor Lu Guangxi, announced the establishment of the biggest hESC bank, with various histocompatibility antigens, in the world. ${ }^{265}$

Besides setting up stem cell banks, in China companies also cooperate with research institutions to develop pharmaceutical medicine research and new drugs with stem cells. Meanwhile, a number of hospitals, such as Beijing Tiantan Puhua Hospital, Beijing Xishan Hospital, People's Liberation Army 261 Hospital, Xiamen University Medical College Ophthalmology Centre and Peking University People's Hospital, have been dealing with various kinds of stem cell transplantation and therapy. ${ }^{266}$ However, China's stem cell industry has just started, and it is still considerably immature and underway. It is dominated by foreign manufacturers, since products from Chinese companies and research institutions in this field cannot meet the technical requirements. ${ }^{267}$ Until now, there have been no domestic stem cell products, including hESC products, for clinical therapy in China. ${ }^{268}$ In short, China's stem cell industry is still at the starting stage, and it primarily focuses on adult stem cells; an hESC industry in China has not been established. Based on the lack of indigenous innovation capacity, China's domestic stem cell industry is somewhat behind. ${ }^{269}$

All in all, China established its regulations on hESC research based on multilayered demands, including internal and external ones. At the onset of hESC research just entering China, Chinese researchers felt confused about the code of conduct in the field of hESC research, especially when communicating with their foreign peers, since the Chinese public, including researchers, hold a different reasoning on hESCs as compared

263 See Jingwen Cao, et al., Trends and Prospects of Stem Cell Research in China, 31 CHINESE MEDICAL SCIENCES JOURNAL 116, 119 (2016).

264 Seeid.

265 See Ge Cheng (成舸), et al., Woguo Jiancheng Shijie Zuida Ren Peitai Ganxibao Ku (我国建成世界最大人胚胎干细 胞库) [China Established the Biggest hESC Bank in the World], CHINA SCIENCE DAILy, (Mar. 6, 2012), http://news. sciencenet.cn/dz/dznews_photo.aspx?id=13850.

266 See Renzong Qiu (邱仁宗), Cong Zhongguo “Ganxibao Zhiliao” Re Lun Ganxibao Linchuang Zhuanhua Zhong de Lunli he Guanli Wenti (从中国“干细胞治疗”热论干细胞临床转化中的伦理和管理问题) [Behind the Vogue for "Stem Cell Therapy": Ethical and Regulatory Issue in Clinical Translation of Stem Cells in China], 3 KEXUE YU SHEHUI (科学与社会) [SCIENCE \& SOCIETY] 8, 10 (2013).

267 See Cao, et al., supra note 263 , at 119.

268 See id., at 120.

269 Concerning obstacles to the development of China's stem cell research and industry, commentators have also pointed out others, such as defective regulations in China. See e.g., Cao, et al., supra note 263, at 120; Qiu, supra note 245; Yuan, et al., supra note 259. 
to the Western world, as analyzed in Chapter 3 of this thesis. At the same time, criticism for China's "unethical" hESC research from outside also placed great pressure on this country to establish a regulatory scheme. Therefore, the demand for regulating hESC research in China was based on the research uncertainty and views of international rivals, rather than domestic moral concerns. However, when formulating the governance policy, Chinese policy makers were not fully aware of the root of the problem in the public debate in the West. They just were eager to solve existing problems, such as upholding China's ongoing research practice, disseminating research findings, promoting its global recognition, and mitigating Western criticism. In this regard, the Chinese government just uncritically followed many ethical principles widely accepted by the Western world, and issued the Ethical Guidelines to regulate hESC research.

Compared with the US approach and various approaches in the EU, the Chinese approach is more similar to the UK approach. Yet, China merely relies on government policy, rather than laws, to regulate hESC research. Through analyzing the provisions of the Ethical Guidelines, one can observe that China has taken a considerably permissive approach towards regulating hESC research, in terms of allowed types of hESC research and the degree of regulation and oversight. Moreover, different from the UK approach, which not only pursues scientific advances, but also seeks to address several other issues (e.g., societal concerns), the current Chinese approach only pursues the advancement of $\mathrm{hESC}$ research, rather than paying any close attention to local social or moral concerns. Put differently, it is hard to find any information concerning domestic moral concerns within China's current regulation of hESC research. From the drafting history of the Ethical Guidelines and the provisions of the document, one may observe that societal concerns, especially moral concerns, do not play any important role in the regulation of $\mathrm{hESC}$ research in China. The reason why China placed an ostensible ethical control over hESC research is that it uncritically introduced Western principles, for purely pragmatic reasons. In other words, rather than considering moral issues, the decision-makers of the Ethical Guidelines focused more on the development of hESC research in China. Thus, the rationale behind the regulation of hESC research in China was pragmatic, and based not on moral or ethical concerns but on purely scientific and economic considerations. ${ }^{270}$

270 With the economy advancing and deeper understanding of embryo and hESC research, China's regulators, scientists and ethicists have gradually become more aware of the significance of bridging divergence and promoting mutual trust with their foreign peers, rather than previous uncritical approaches blindly following Western principles. They also have gradually realized the significance of social concerns in hESC research, and have increased transnational communications, and meanwhile have attempted to respond to their foreign peers, so as to make the Western world understand China's relevant moral culture. For more discussion, please see ZHANG, supra note 203, at 82-105. 
Based on quite liberal regulations and generous government funding policy, over the past decade, China has indeed made considerable progress in hESC research. However, through a close analysis, it can be seen that China is still lagging behind its technologically advanced counterparts, including Europe, the US and Japan, in this research field. In the meantime, China's stem cell industry is at the starting stage, and it primarily focuses on adult stem cells; an hESC industry in China has not been established. Based on the lack of indigenous innovation capacity, China's domestic stem cell industry is postponed to some extent, and dominated by foreign manufacturers.

\section{CONCLUSION}

Regulating hESC research has proven to be a highly controversial issue in the US and $\mathrm{EU}$, but in China it does not seem to be so contentious. China has its practical demands for developing hESC research. At the same time, it is a country aiming to become one of the world's leading powers not only in economic but also in scientific areas, including the hESC research field. Not surprisingly, China has attempted to support its domestic hESC research by creating a relaxed regulatory environment and providing substantial research funding. Indeed, over the past decade, China has made considerable progress in this research field, but compared with its technologically advanced counterparts (e.g., Europe, the US, and Japan), it is still well behind.

China mainly relies on the Ethical Guidelines, rather than laws, to regulate hESC research. Through an analysis of the drafting history of the document and its provisions, one can observe that the Chinese approach towards regulating hESC research is considerably permissive, not only from the perspective of the allowed research types but also from the perspective of the degree of regulation and oversight. The rationale behind issuing the Ethical Guidelines is the Chinese government's desire to solve existing problems (e.g., hESC researchers' confusion in social approval), to cope with identifiable disadvantage (e.g., foreign media's criticism) and to confirm the existing research practice. Put another way, the Chinese approach towards regulating hESC research is primarily aiming at promoting China's domestic hESC research and industry to catch up with the technically developed countries.

In the West, the initial driving force for regulating hESC research normally comes from moral concerns of the public. Meanwhile, whether in the US or in the EU, policy approaches towards hESC research not only pursue scientific advances, but also seek to address several other issues (e.g., societal or moral concerns). However, the initial motivation for creating the regulation concerning hESC research in China was not based on uneasiness from within Chinese culture, but was in response to moral concerns originally identified in foreign countries, especially in Europe and the US. Even 
worse, the policy makers behind the Chinese approach were not fully aware of the root of the problem in the public debate in the West. The Chinese approach only attempts to pursue the advancement of hESC research. Yet, unfortunately, local moral concerns regarding $\mathrm{hESC}$ research in China have not been paid close attention by policy makers.

The findings of Chapter 3 and Chapter 4 constitute the basis for the following chapters: together they reveal that within the field of hESC research, China has its unique characteristics regarding social and moral culture, institutional structure, and desire for scientific progress and economic development, which may determine how to tailor patent rules and policies in this research field. In order to demonstrate the problems of the patent system in dealing with specific hESC-related inventions, the next chapter examines the patent legal frameworks, policies of each patent office (i.e., the USPTO, EPO, and SIPO), and relevant judicial decisions of the US, EU, and China. It further evaluates the current Chinese patent system, and tests the possible solutions derived from the experiences of the US and EU. 


\section{5 \\ A Comparative Analysis of Patenting hESC- related Inventions Under Current Legal Frameworks of the US, EU, and China}

\section{INTRODUCTION}

As previously pointed out, the primary purpose of this thesis is to approach, investigate and ultimately figure out suitable solutions for determining the patent eligibility of hESC-related inventions in China. Before deeply digging into the options for tackling problems raised by patenting hESC-related inventions and looking for answers on how to achieve a delicate balance in designing patent rules and policies, it is crucial to go through the laws with regard to patenting hESC-related inventions, and see what the patent offices and courts have done under the laws, as well as what else can be deduced from doing so.

To be specific, this chapter begins by discussing the details and specific provisions of the three systems (i.e., the US, EU, and China) to clarify legal issues regarding the patent eligibility of hESC-related inventions, and then the following sections will attempt to explain and analyze how these pertinent provisions have been applied in these jurisdictions and why. In the following sections, this chapter conducts a comparative analysis on the patent legal frameworks (Sect. 2), policy approaches (Sect. 3), and judicial decisions (Sect. 4) in the three jurisdictions. Although the comparison mainly focuses on the three jurisdictions, in some cases, the legislation and case law of other jurisdictions, such as Germany, the UK, and the international standards, such as the TRIPS Agreement, are also referred to in order to explain and clarify statements or arguments. ${ }^{1}$ Section 5 of this chapter considers the question of whether it is proper for China to follow the US or the EU approach in terms of patenting hESC-related inventions. It also analyzes and evaluates the actual determination of the patent eligibility of hESC-related inven-

See e.g., Sect. 2.1, Chap. 5, which discuss the TRIPS Agreement; and Sect. 4.3, Chap. 5, which investigates German court's decision (X ZR 58/07) following the Brütle case. 
tions in China, and proposes possible solutions for the improvement of Chinese law and policies on patenting hESC-related inventions in the context of global competition, domestic innovation promotion, and Chinese moral culture.

\section{PATENT LEGAL FRAMEWORIKS}

Harmonization in the patent regime around the world has achieved great progress, and providing technology-neutral protection to all kinds of technologies seems to have become an international standard. ${ }^{2}$ However, as mentioned in Chapter 1 of this thesis, an increasing divergence between different jurisdictions concerning patenting biotechnological inventions, especially in the field of hESC research, has recently been noticed. In the following discussion, this thesis primarily focuses on the current patent-related legislation and case law of the US, EU, and China. This section starts by analyzing Article 27 of the TRIPS Agreement (Sect. 2.1), and then follows an examination of patent legislation and case law regarding patentable subject matter, particularly in relation to patenting hESC-related inventions (Sect. 2.2). Subsequently, this section continues an analysis on moral considerations provided in the current patent legal frameworks (Sect. 2.3). This section provides the statutory and/or common law basis for the following two parts (Sects. 3 and 4), which investigate how the patent offices and courts interpret the law and deal with the questions of subject matter eligibility, especially concerning patenting hESC-related inventions, in these three jurisdictions.

\subsection{Article 27 of the TRIPS Agreement}

Before analyzing and comparing the specific legislation that governs patenting hESCrelated inventions, it is worthwhile to mention and understand the relevant international law. The most pertinent international treaty concerning patent rights is the TRIPS Agreement, of which the EU and its member states, as well as the US and China are all contracting parties. In the TRIPS Agreement, Article 27(1) requires the contracting parties to ensure patents are available for all types of product and process inventions in all fields of technology. ${ }^{3}$ No doubt, this provision has established a general principle of eligibility to be patented, and speaks about the patent eligibility in broad terms. ${ }^{4}$ However, Article 27(2) of the TRIPS Agreement allows (but does not mandate) limited exceptions to patent eligibility, that is, to allow its contracting parties to optionally enact their domestic laws to preclude inventions from patent eligibility if the commercial exploitation of these inventions could contravene ordre public or morality within the

See infra Sect. 2.1, Chap. 5.

See Article 27(1) of the TRIPS Agreement, which stipulates that "patents shall be available for any inventions, whether products or processes, in all fields of technology, provided that they are new, involve an inventive step and are capable of industrial application".

4 See Daniel Gervals, The TRIPS Agreement: Drafting History and Analysis 337 (Sweet \& Maxwell 3rd ed. 2008), 
territory of the World Trade Organization (WTO) Member concerned. ${ }^{5}$ It is said that this provision probably follows the long-established tradition in patent law, particularly in the European context such as Article 53(a) EPC. ${ }^{6}$

In Article 27(2) of the TRIPS Agreement, the concept of "ordre public" is closer to "public policy." The term ordre public is considered to express concerns about matters threatening the social structures that tie a society together. ${ }^{8}$ The concept of morality is different, and naturally depends to some extent upon the specific culture of a country or region. ${ }^{9}$ In other words, morality is not static, and it may differ from country to country, and change over time. ${ }^{10}$ As Ladas points out, morality “... reflects customs and habits anchored in the spirit of a particular community. There is no clearly objective standard of feeling, instincts, or attitudes toward a certain conduct. Therefore, specific prescriptions involving uniform evaluation of certain acts are extremely difficult."11 In addition, Article 27(2) attempts to further clarify that the protection of ordre public or morality contains the protection of "human, animal or plant life or health or to avoid serious prejudice to the environment". ${ }^{12}$ Nevertheless, even if this short list to clarify the scope of the protection of ordre public or morality, it is still broad and vague, and the application of the morality exclusion should be subject to particular conditions of the state and society. ${ }^{13}$ In another sense though, it is common for international treaties to provide general principles for signatories regarding specific issues, so as to attract as many contracting parties as possible. As can be seen, if hESC research is put in the scenario, it is evident that no clear answer about the patent eligibility of hESC-related inventions can be found from the TRIPS Agreement. Instead, the morality clause in the

5 Article 27(2) of the TRIPS Agreement sets forth that "[m]embers may exclude from patentability inventions, the prevention within their territory of the commercial exploitation of which is necessary to protect ordre public or morality, including to protect human, animal or plant life or health or to avoid serious prejudice to the environment, provided that such exclusion is not made merely because the exploitation is prohibited by their law." As analyzed in Chap. 2 of this thesis, patenting hESC-related inventions to some extent concerns public policy, since the technology and research have great therapeutic promise. It is evident that patenting these inventions does not relate to the violation of "ordre public". In this regard, this thesis primarily focuses on the issues concerning the other concept of morality in terms of patenting hESC-related inventions.

6 See Pedro Roffe, et al., Resource Book on TRIPS and Development: an Authoritative and Practical Guide to the TRIPS Agreement, IPRSONLINE.ORG, 375-376 (Jun. 1, 2005), http://www.iprsonline.org/unctadictsd/ResourceBookIndex.htm; Aurora Plomer, et al., Stem Cell Patents: European Patent Law and Ethics Report, 94 (Jul. 28, 2006), http://www.nottingham.ac.uk/ Ulzwww/StemCellProject/project.report.pdf; SIGRID STERCKX \& JULIAN COCKBAIN, EXCLUSIONS FROM PATENTABILITY: HOW FAR HAS THE EUROPEAN PATENT OfFICE ERODED BOUNDARIES? 289 (Cambridge University Press 2012). Concerning Article 53(a) EPC, it will be discussed in detail later on; please see e.g., Sect. 2.3.2.2, Chap. 5 of this thesis.

7 See GERVAIS, supra note 4, at 343.

8 See Roffe, et al., supra note 6, at 375; Plomer, et al., supra note 6, at 95.

9 See GERVAIS, supra note 4, at 345.

10 See Roffe, et al., supra note 6, at 375; Plomer, et al., supra note 6, at 95.

11 Stephen P Ladas, Patents, Trademarks, and Related Rights: National and International Protection 1685 (Harvard University Press 1975).

12 Article 27(2) of the TRIPS Agreement.

13 See GERVAIS, supra note 4, at 346-349. 
TRIPS Agreement has left great room for a WTO member to tailor its own national patent rules and policies, ${ }^{14}$ based on its own interests, such as its scientific research strength or the weakness of its competitive position in the global economy. ${ }^{15}$

\subsection{Excluded Subject Matter in Each Jurisdiction}

In patent law, a subject matter that is eligible to be patented is called patentable subject matter. The first and foremost requirement for a claimed invention seeking patent protection is that it needs to fall into the scope of patentable subject matter, otherwise it cannot be patented, no matter how novel, inventive, or suitable for industrial application the invention is. However, according to previous studies and through a brief review of patent laws around the world, one can easily observe that not all inventions are to be the proper subject of patent protection. In most legal systems, there are well-established lists of exclusions from patentable subject matter. It is critical to understand both what is on the lists, especially concerning patenting hESC-related inventions, and why the subject matter is excluded in the legal system. This section discusses the excluded subject matter, particularly concerning hESC-related inventions, in the US (Sect. 2.2.1), EU (Sect. 2.2.2), and China (Sect. 2.2.3).

\subsubsection{The US}

In the current US patent system, patent eligibility requires that the subject matter clear two principal obstacles. The first one is that the claimed invention must fall within the scope of the statutory bucket. However, besides a set of legal rules established in the patent statute, the doctrine of stare decisis is important to courts in the US patent system, since the US is a representative common law jurisdiction. The US courts should follow a precedent which has been set up in a previous legal case when deciding subsequent cases with similar issues or facts. In this regard, another barrier that patent eligibility needs to remove is that the claimed invention must fall outside of common law exceptions, ${ }^{16}$ which amounts to judicial redefinitions of statutory subject matter. ${ }^{17}$ This section starts with a discussion about the statutory patentable and excluded

14 Commentators have put forward the concern that the ambiguity of Article 27(2) of the TRIPS Agreement may make room for a WTO Member to reject the patentability of inventions developed in other countries on moral grounds, but then copy and manufacture the invention itself or allow its domestic manufactures to take advantage of the foreign technology. See e.g., Yael Bregman-Eschet, et al., The Ripple Effect of Intellectual Property Policy: Empirical Evidence from Stem Cell Research and Development, 19 JoURNAL OF TECHNOLOgY LAW \& Policy 227, 240 (2014); Gerard Porter, Human Embryos, Patents and Global Trade: Assessing the Scope and Contents of the TRIPS Morality Exception, in EMBRYONIC STEM CELL PATENTS: EUROPEAN LAW AND ETHICS (Aurora Plomer \& Paul Torremans eds., 2010).

15 See Brian Salter, Patenting, Morality and Human Embryonic Stem Cell Science: Bioethics and Cultural Politics in Europe, 2 REgenERATIVE MEDICINE 301, 303 (2007).

16 See Mark A Lemley, et al., Life After Bilski, 63 StANFORD LAW REview 1315, 1325 (2011). See also § 2106 of the USPTO's Manual of Patent Examining Procedure (MPEP).

17 See Max Stul Oppenheimer, Patents 101: Patentable Subject Matter and Separation of Powers, 15 VANDERBILT JOURNAL OF ENTERTAINMENT \& TECHNOLOGY LAW 1, 13 (2012). 
subject in the US patent statute (Sect. 2.2.1.1), then continues to explore the "product of nature" exemption that the US Supreme Court has imposed (Sect. 2.2.1.2). Also, this section investigates two cases, Diamond v. Chakrabarty (Sect. 2.2.1.3), and Myriad (Sect. 2.2.1.4), which are considered to be the two most relevant cases to patenting hESCrelated inventions in the US. ${ }^{18}$

\subsubsection{Statutory Bucket: $\S 101$ and the Exclusion of Human Organisms}

The most important provision concerning patentable subject matter is laid down in Title 35 United States Code (35 USC $\S 101$ ), which requires the invention to be of the right type. Specifically, it stipulates that any invention of "new and useful process, machine, manufacture, or composition of matter, or any new and useful improvement thereof" may constitute patentable subject matter. ${ }^{19}$ This article classifies patent eligible inventions with a general statement, and it is considered by the US courts to be a gatekeeper for the granting of patents..$^{20}$ It also has been considered to be the most significant battlefield with regard to patenting biotechnological inventions, ${ }^{21}$ although the US patent law does not mention anything specifically about biotechnological inventions. Based on this article, in the US no patent can be granted for an invention that does not fall within the four categories: processes, machines, manufactures, and compositions of matter. These four categories are not mutually exclusive, and an invention can be classified in more than one category. ${ }^{22}$ In this regard, under 35 USC $\S 101$ the scope of patentable subject matter is extremely broad, and it is hard to imagine what subject matters are not proper for patent protection in the US. As the Supreme Court most famously pointed out, the scope of patentable subject matter includes "anything under the sun that is made by man."23 In the US patent legislation, there are no other rules or regulations explicitly excluding inventions from being patented, except for the recent exclusion of the "human organism" from patent eligibility.

18 See Derek Van den Abeelen, Harnessing Human Potential: Induced Pluripotent Stem Cell Patentability Under the Lens of Myriad, 7 WILLIAM \& MARY BUSINESS LAW REVIEW 855, 864 (2016).

19 Article 101 of 35 USC. As a matter of fact, this statutory subject matter language has been amended twice over the long period of US patent history, and currently it slightly differs from the original language. The change, however, has been held by the US Supreme Court to be non-substantive. See Diamond v. Diehr, 450 US 175, 182 (1981). See also Oppenheimer, supra note 17, at 13.

20 See e.g., In re Comiskey, 499 F.3d 1365, 1371 (Fed. Cir. 2007); State St. Bank \& Trust Co. v. Signature Fin. Grp., Inc., 149 F.3d 1368, 1372 n.2 (Fed. Cir. 1998) (observing 35 USC $\S 101$ to be a threshold issue that must be solved before other questions of patentability); In re Bergy, 596 F.2d 952, 960 (C.C.P.A. 1979) ("the first door which must be opened on the difficult path to patentability is $\S 101 . ")$

21 See Margo A Bagley, Patent First, Ask Questions Later: Morality and Biotechnology in Patent LaW, 45 WILLIAM AND MARY LAW REVIEW 469, 484 (2003).

22 See Diamond v. Chakrabarty 447 US 303, 305-306 (1980).

23 Id., at 309. 
In 2011, the US Congress passed a federal statute, the Leahy-Smith America Invents Act (AIA), ${ }^{24}$ which represents the most significant change to the US patent system since 1952. Section 33(a) of the AIA specifically eliminates any claimed invention directed to or encompassing human organisms from patentable subject matter. ${ }^{25}$ This exclusion is believed to be in accordance with the 13th Amendment to the US Constitution that precludes anyone from possessing property rights over a human being. ${ }^{26}$ The legislative history of the AIA has shed light on the meaning of this provision, stating that this amendment simply affirmed the USPTO's existing patent practices. Specifically, it stated that "the US Patent Office has already issued patents on genes, stems cells, animals with human genes, and a host of non-biologic products used by humans, but it has not issued patents on claims directed to human organisms, including human embryos and fetuses. My amendment would not affect the former, but would simply affirm the latter." $^{27}$

It is inferred that claims directed to totipotent stem cells, that is, cells with the capacity of developing into an entire human embryo and potentially a human being, might be considered unpatentable, since such claims could be read as containing human beings. ${ }^{28}$ HESCs seem to be identified as not falling within this specific exclusion of "human organism", and the legislative history appears to reinforce the notion that hESCS are patent eligible. However, since the AIA does not further provide any definition of the term "human organism", the ambiguity of this term might make the patent eligibility of hESCs unstable. This blank can only be left to patent decisions of the USPTO and the eventual judicial decisions of the US Supreme Court to fill in, unless Congress provides a further clarification about the meaning of the term "human organism".

\subsubsection{The "Products of Nature" Doctrine and Its Evolution}

Excluding a human organism as mentioned above, it seems that 35 USC $\S 101$ has no limits and embraces every subject matter. However, determining that a claimed inven-

24 The AIA is a US federal statute to provide for patent reform. It was passed by Congress and signed into law by President Barack Obama on Sept. 16, 2011. The various provisions contained in the AlA took effect on different dates.

25 Sect. 33(a) of the AIA states that "notwithstanding any other provision of law, no patent may issue on a claim directed to or encompassing a human organism."

26 Amend. XIII, § 1 of the US Const. states that "neither slavery nor involuntary servitude, except as a punishment for crime whereof the party shall have been duly convicted, shall exist within the United States, or any place subject to their jurisdiction." The amendment was passed by the Senate on Apr. 8, 1864, by the House on Jan. 31, 1865, and adopted on Dec. 6, 1865. It abolished slavery and involuntary servitude.

27157 Cong. Rec. E1177-04 (testimony of Representative Dave Weldon previously presented in connection with the Consolidated Appropriations Act, 2004, Public Law 108-199, 634, 118 Stat. 3, 101, and later resubmitted with regard to the AIA; see 149 Cong. Rec. E2417-01).

28 See Raymond R Mandra \& Alicia A Russo, Stem Cells and Patenting and Related Regulatory Issues: A United States Perspective, 7 BIO-SCIENCE LAW REVIEW 143, 145 (2004). Concerning a brief discussion about the scientific background of totipotent stem cells, please see supra Sect. 3.2.1, Chap. 2. 
tion falls within the statutory bucket does not end the eligibility analysis. The courts of the US have imposed several exemptions amounting to judicial redefinitions of statutory subject matter. Specifically, for more than a century, US courts have created three categories excluded from patentable subject matter, no matter how valuable and vital to the progress of "useful arts" they might be: scientific principles, laws of nature, and abstract ideas. This reflects the courts' view that the basic tools of scientific and technological work cannot be monopolized by anyone. ${ }^{29}$ Hereinto, the "laws of nature" exception, which is also often referred to as the "products of nature" doctrine, is the most pertinent to patenting hESC-related inventions.

\subsection{The "Products of Nature" Doctrine}

The US Supreme Court fully endorsed the "laws of nature" exception, or the "products of nature" doctrine, to patentable statutory subject matter in the famous case of Funk Bros. Seed Co. v. Kalo Inoculant Co. in $1948 .{ }^{30}$ In this case, the inventor discovered "strains of each species of root-nodule bacteria which do not exert a mutually inhibitive effect on each other," ${ }^{31}$ and these bacteria could be used with certain field crops to increase yield. ${ }^{32}$ However, the Court denied the patent on the grounds that it was merely a "discovery of the phenomena of nature" and did not "create state of inhibition or of noninhibition in the bacteria". ${ }^{33}$ Moreover, the Court drew a distinction between discovering a law of nature and applying it, stating that "the qualities of these bacteria, like the heat of the sun, electricity, or the qualities of metals, are part of the storehouse of knowledge of all men. They are manifestations of laws of nature, free to all men and reserved exclusively to none. He who discovers a hitherto unknown phenomenon of nature has no claim to a monopoly of it which the law recognizes. If there is to be invention from such a discovery, it must come from the application of the law of nature to a new and useful end." 34 The Court held that "manifestations of laws of nature" were "free to all men and reserved exclusively to none", and thus "fell short of invention within the meaning of the patent statutes". 35 One can observe that the Funk Brothers Court was sensitive to the impediment effect of patents which would purely exploit inherent laws of nature. ${ }^{36}$ This landmark case therefore has established one Supreme Court exception to the statutory language of 35 USC $\S 101 .{ }^{37}$ In short, the fundamental point of the "laws

See $\$ 2106$ of the USPTO'S MPEP.

See Funk Bros. Seed Co. v. Kalo Inoculant Co., 333 US 127 (1948).

31 At that time, it was commonly believed that inoculants depended on the type of crop and could not be mixed due to mutual inhibition. See id., at 129-130.

32 See id., at 128.

33 Id., at 130.

34 Id., at 130.

35 Id., at 130-131.

36 See Eneda Hoxha, Stemming the Tide: Stem Cell Innovation in the Myriad-Mayo-Roslin Era, 30 BerkElEY TECHNOLOGY LAW JOURNAL 567, 581 (2015).

37 See Oppenheimer, supra note 17 , at 20. 
of nature" exception is that the mere discovery of laws of nature or a naturally occurring product is not patent eligible, since the basic tools of scientific and technological work should be "free to all men and reserved exclusively to none," 38 and patenting such subject matter "might tend to impede innovation more than it would tend to promote." 39

\subsection{Diamond v. Chakrabarty}

A landmark case, Diamond v. Chakrabarty, however, has set down a principle that the human intervention may transform a product of nature into a man-made product and thus become patent eligible..$^{40}$ In fact, the US Supreme Court in Chakrabarty has made an unprecedented judicial expansion in the scope of patentable subject matter to include "life"-living biological organisms-which in US patent history were not considered to be patent eligible on grounds that they were perceived of as products of nature. The Chakrabarty case involved a patent concerning a living, genetically modified bacterium, Pseudomonas, that could consume crude oil. ${ }^{41}$ Initially Dr. Chakrabarty's product claims for bacteria per se were denied by a patent examiner on grounds that these bacteria were products of nature. The Patent Office's internal Board of Appeals, however, ruled that the bacteria at issue were not products of nature since these bacteria did not occur naturally. But, in the view of the Board, while the genetically engineered bacteria might not occur naturally, "a human being with a transplanted liver or heart is also not naturally occurring." ${ }^{2}$ The Board shifted the issue to the patent eligibility of living matter. The Board held that 35 USC $\S 101$ was not intended to cover living matter, such as laboratory generated organisms, and concluded that the bacteria were not patent eligible, since they were living organisms. ${ }^{43}$

When addressing this case, the US Supreme Court held "while laws of nature, physical phenomena, and abstract ideas are not patent eligible, respondent's claim is not to a hitherto unknown natural phenomenon, but to a non-naturally occurring manufacture or composition of matter-a product of human ingenuity 'having a distinctive name, character [and] use."." 44 After exploring the language as well as the legislative history of the American patent law, the Court deduced that Congress contemplated 35 USC

38 Diamond v. Chakrabarty, supra note 22, at 309 (quoting Funk Bros. Seed Co. v. Kalo Inoculant Co., 333 US 127,130 (1948)).

39 Mayo Collaborative Servs. v. Prometheus Labs., Inc., 132 S. Ct. 1289, 1293 (2012).

40 See Diamond v. Chakrabarty, supra note 22.

41 Seeid.

42 See Daniel J Kevles, A History of Patenting Life in the United States with Comparative Attention to Europe and Canada, 17 (Jan. 12, 2002), https://scholarworks.iupui.edu/bitstream/handle/1805/757/ Patenting\%20Life\%20-\%20Comparative\%20Study\%20US\%2C\%20CN\%2C\%20EU\%202002. pdf? sequence=1\&isAllowed=y.

43 See Diamond v. Chakrabarty, supra note 22, at 306.

44 Id., at 303. 
$\S 101$ should be construed broadly, ${ }^{45}$ to include "anything under the sun that is made by man". ${ }^{46}$ Therefore, the US judiciary has construed the patentable subject matter under the patent law to cover both living and non-living biological matters. The Court in Chakrabarty held that a transgenic organism had "markedly different characteristics from any found in nature" and was a product of human ingenuity. ${ }^{47}$ Thus, the Chakrabarty case has set down a test for patentable subject matter where the living matter is the result of human intervention ${ }^{48}$ which may transform a product of nature into a product of human ingenuity. ${ }^{49}$ At the same time, the "markedly different characteristics from any found in nature" language has been adopted by the USPTO in the Manual of Patent Examining Procedure (MPEP) guidelines and is a staple in $\S 101$ patentability analysis today. ${ }^{50}$

\subsection{Molecular Pathology v. Myriad}

The US Supreme Court directly dealt with the issue of whether products of nature could be patented in a landmark case, Association for Molecular Pathology v. Myriad Genetics. ${ }^{51}$ This case primarily concerned patents regarding isolated DNA sequences which could be used to identify propensity to breast cancer. ${ }^{52}$ Myriad discovered the location and isolated BRCA1 and BRCA2 genes and obtained patents on the genes. ${ }^{53}$ In the Myriad case, the Court paid close attention to the public interest, and was sensitive to patents' potential negative effect upon future innovation. The Court knew Myriad had done lots of work to identify and sequence the genes that would aid researchers and clinicians in their understanding and treatment of breast and ovarian cancers. However, the Court stated that under $\S 101$ of the Patent Act there were several judicial exceptions, including "laws of nature, natural phenomena, and abstract ideas", which were "basic tools of scientific and technological work", and thus should "lie beyond the domain of patent protection." ${ }^{54}$ The Court also emphasized that the products of nature were "free to all men and reserved exclusively to none." 55 Concerning gene patents, the Court held that merely isolating genes from their surrounding genetic material was not an act of inventions, but a discovery, which "by itself, does not render the BRCA genes"

\footnotetext{
45 See id.

46 See id., at 309. Some commentators argued that this statement has been taken outside of context and that Congress intended to retain the traditional requirements of patentability, which may not have permitted patents upon living things. See L. T Demaine \& A X Fellmeth, Reinventing the Double Helix: A Novel and Nonobvious Reconceptualization of the Biotechnology Patent, 55 STANFORD LAW REVIEW 303, 373-374 (2002).

47 Diamond v. Chakrabarty, supra note 22, at 310.

48 See $\$ 2105$ of the USPTO's MPEP.

49 See Diamond v. Chakrabarty, supra note 22.

50 See Hoxha, supra note 36, at 581.

51 See Association for Molecular Pathology v. Myriad Genetics, Inc., 133 S. Ct. 2107 (2013).

52 Seeid.

53 Seeid.

54 Id., at 2116.

55 Id.
} 
patent eligible. ${ }^{56}$ This is in sharp contrast to the judicial decision in Chakrabarty, where the Court considered the bacterium in issue was non-naturally occurring and a manmade product. ${ }^{57}$

The Myriad Court, however, ruled cDNA, a synthetically created form of DNA, was patent eligible, ${ }^{58}$ on the grounds of chemical differences between native DNA and cDNA. ${ }^{59}$ The Court held that while cDNA contained the same nucleotide sequence that was found in naturally occurring DNA, "the lab technician unquestionably creates something new when cDNA is made". ${ }^{60}$ The Court identified cDNA as distinct from a "product of nature." ${ }^{61}$ Therefore, it seems that the Court in Myriad has modified the human intervention principle, which was set down in Chakrabarty, and has made clear that mere isolation is not enough to make a composition of matter patent eligible. ${ }^{62}$

\subsection{In re Roslin Institute}

Another important case in the US worth mentioning in connection with patenting products of nature is In re Roslin Institute, decided by the Federal Circuit. ${ }^{63}$ In 2014, the Court of Appeals for the Federal Circuit (CAFC) made a decision affirming a rejection by the Patent Trial and Appeal Board regarding claims 155-159 and 164 of the US patent application No. 09/225,233 (the '233 patent application) based on unpatentable subject matter under 35 USC $\S 101 .^{64}$ The patent application at issue concerned a mammal cloned from an adult somatic cell, such as Dolly the sheep. Roslin made two main arguments concerning the patent eligibility of claims of the '233 patent application: ${ }^{65}$ first, copies (clones) were eligible for patent protection as "the product of human ingenuity" and "not nature's handiwork, but [their] own;" able from the donor animals used to create them since environmental factors led to phenotypic differences, their mitochondrial DNA was different.

\footnotetext{
$56 \quad$ Id., at 2117.

57 See Diamond v. Chakrabarty, supra note 22, at 309.

58 cDNA contains the "same protein-coding information found in a segment of natural DNA but that omits portions within the DNA segment that do not code for proteins." See Association for Molecular Pathology v. Myriad Genetics, supra note 51, at 2118.

59 See id., at 2119-2120.

60 Id., at 2119.

61 See id.

62 See id., 2111.

63 See In re Roslin Inst., 750 F.3d 1333 (Fed. Cir. 2014).

64 See id., at 1334

65 The '233 patent application was directed to the product of the cloning method. The method for producing such clones was separately patented (US Pat. No. 7,514,258). Representative Claims of the '233 patent application at issue were Claims 155 and 164. Claim 155 stated that "a live-born clone of a pre-existing, nonembryonic donor mammal, wherein the mammal is selected from cattle, sheep, pigs, and goats." Claim 164 stated that "the clone of any of claims 155-159, wherein the donor mammal is non-foetal." 
When addressing the validity of the claims, the CAFC began by emphasizing that even before the recent decision in Myriad, the Supreme Court had already made clear that naturally occurring organisms were not patentable in Funk Brothers and Chakrabarty. ${ }^{67}$ In terms of Roslin's first argument, the CAFC held that "Dolly herself is an exact genetic replica of another sheep and does not possess 'markedly different characteristics from any [farm animals] found in nature," and thus "Dolly's genetic identity to her donor parent renders her unpatentable." 68 The court also analogized the case to Myriad, stating that Roslin "did not create or alter any of the genetic information" of its claimed clones, "[n]or did [Roslin] create or alter the genetic structure of [the] DNA" used to make its clones. ${ }^{69}$ In contrast, Roslin's primary contribution was to preserve the donor DNA so that the clone was an exact copy, and such a copy was not eligible for patent protection. ${ }^{70}$ With respect to Roslin's second main argument, the court pointed out that none of the alleged differences were claimed in the patent application. ${ }^{71}$ Relying on Funk Brothers and Chakrabarty, the court asserted that any phenotypic differences between the cloned and the donor animal were the production of environmental factors, and were produced "quite independently of any effort of the patentee."72 Moreover, regarding differences resulting from the mitochondrial DNA, the court held that the patentee did not initially claim and explain how the mitochondrial DNA could influence the characteristics of the cloned mammal. ${ }^{73}$ As a result, by using a test of whether DNA is identical to measure whether a claimed product falls under the "product of nature" eligibility exemption, the CAFC affirmed the Board's finding that the Roslin clones were not patent eligible under $\S 101$.

\subsubsection{The EU}

When discussing patent issues regarding biotechnological inventions at the EU level, it is necessary to mention both the Directive 98/44/EC of the European Parliament and of the Council of 6 July 1998 on the Legal Protection of Biotechnological Inventions

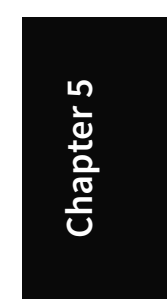


(the Biotech Directive or Directive) ${ }^{74}$ and the EPC. ${ }^{75}$ The Biotech Directive was initially proposed by the European Commission in $1988,{ }^{76}$ and its original purpose was to facilitate the competitiveness of the European biotechnology industry, by harmonizing biotechnology patent law across the EU and clarifying patentable subject matter in biotechnology. ${ }^{77}$ Nevertheless, the Directive turned out to be one of the most contentious pieces of legislation in the EU's legislative history, ${ }^{78}$ primarily due to widespread concerns about the role for "morality" as an evaluative criterion within biotechnological patenting. ${ }^{79}$ The final Directive text in effect ultimately was a political compromise among the European Parliament, the Commission, and the Council after ten years of heated discussion. ${ }^{80}$ In the final Directive text, unlike the single purpose provided in the US Constitution, ${ }^{81}$ in addition to mentioning the purpose of promoting the advancement of Europe's biotechnology industry, it also points out the significance of protecting the dignity and integrity of the human person. ${ }^{82}$ The Biotech Directive aims to strike a balance between, on the one hand, promoting the advancement of European biotechnology research and industry by means of patent law and, on the other hand,

74 The directive is just one of five types of EU legislative acts, which include regulations, directives, decisions, recommendations and opinions. A directive is binding as to the result to be achieved and leaves room for EU member states to choose forms and methods to implement it. But a directive does not automatically form part of the domestic legal order of each member state, except for a specific situation. Member states have the obligation to transpose a directive into their domestic legal system. See Case 8/81 (Ursula Becker v. Finanzamt Münster-Innenstadt) [1982] ECR 53; DAMIAN CHALMERS, et al., EUROPEAN UNION LAW: CASES AND MATERIALS 98-99 (Cambridge University Press 2010).

75 Convention on the Grant of European Patents (the European Patent Convention or the EPC) was issued by European countries on 5 Oct. 1973, intended to establish a unified legal framework for the granting of European patents. It was revised by the Act revising art. 63 EPC of 17 Dec. 1991 and the Act revising the EPC of 29 Nov. 2000.

76 See EC, Proposal for a Council Directive on The Legal Protection of Biotechnological Inventions COM (88) 496 final, 17 Oct. 1988.

77 See e.g., Barbarasy Rigby, Revocation of European Patent for Neural Progenitors Highlights Patent Challenges for Inventions Relating to Human Embryonic Stem Cells, 23 EXPERT OPINION ON THERAPEUTIC PATENTS 1397 (2013); Porter et al., at 653 (2006).

78 See Nick Scott Ram, Biotechnology Patenting in Europe: The Directive on the Legal Protection of Biotechnological Inventions: Is This the Beginning or the End? 2 BIO-SCIENCE LAW REVIEW 43, 43 (1998).

79 See Aurora Plomer \& Paul Torremans, Embryonic Stem Cell Patents: European LaW and Ethics xxxvii (Oxford University Press 2009).

80 See Gerard Porter, The Drafting History of the European Biotechnology Directive, in EMBRYONIC STEM CELL PATENTS: EuROPEAN LAW AND ETHICS 7-14 (Aurora Plomer \& Paul Torremans ed., Oxford University Press 2009).

81 Art. I, $\S 8, \mathrm{Cl}$. 8 of the US Const. stipulates that "[t] he Congress shall have power ... to promote the progress of science and useful arts, by securing for limited times to authors and inventors the exclusive right to their respective writings and discoveries." Based on this article, it is clear that the purpose of the US patent system is relatively single, that is, to promote the progress of "useful arts", at least as stated in the Constitution.

82 For instance, Recital 16 of the EU Biotech Directive stipulates that "[p]atent law shall be applied so as to respect the fundamental principles safeguarding the dignity and integrity of the human person”. Recital 38 of the Directive notes that "... whereas processes, the use of which offend against human dignity, such as processes to produce chimeras from germ cells or totipotent cells of humans and animals, are obviously also excluded from patentability". 
respect for the fundamental principles safeguarding the dignity and integrity of the human person. ${ }^{83}$

The EPC is not an instrument of EU law but an independent multilateral treaty, whose parties also include states which are not members of the EU. ${ }^{84}$ Despite this, the EPC and the EU Biotech Directive have influenced each other profoundly. For instance, before the issuing of the Directive, human or hybrid cells had been patented for several years in the EPO, and the Directive merely confirmed the EPO's practice. ${ }^{85}$ While each contracting state of the EPC has its own patent system, and neither the EPO nor the provisions of the EPC require the contracting states to bring their domestic patent laws and practice into line with the EPC, most states have modified their national law to comply with the EPC, and national patent authorities follow the case law of the EPO ${ }^{86}$ What is more, the EPC has already absorbed some provisions of the Directive, and thus it is unsurprising that some articles regarding biotechnological inventions in the EPC are the same as rules in the Directive in terms of the wording. ${ }^{87}$ Rule 26(1) of the Implementing Regulations to the EPC (EPC Rules) specifically stipulates that the EPO shall adopt the Directive as a supplementary means of interpretation. ${ }^{88}$ As such, when it comes to discussing patent issues concerning biotechnological inventions at the EU level, in addition to referring to the Biotech Directive, it is often necessary to mention pertinent provisions in the EPC. In the EPC, although it excludes "discoveries" from the scope of patentable subject matter, the exclusion is still ambiguous, particularly regarding biotechnological inventions. Based on this, to encourage patenting biotechnological inventions, the Directive

83 See also C-364/13 (International Stem Cell Corporation v. Comptroller General of Patents, Designs and Trade Marks) OJ C 65/10 [2015], para. 19.

84 See Plomer, et al., supra note 6, at 13. For instance, Switzerland, Liechtenstein, Monaco, Turkey, Romania, Iceland, Norway, the Former Yugoslav Republic of Macedonia, San Marino, and Albania are member states of the EPO, but not members of the EU. Moreover, the EPO has signed validation agreements with four nonmember states, such as Morocco, the Republic of Moldova, Tunisia, and Cambodia, and the agreements with the former three have entered into force.

85 See Philippe Bouvet, Patentability of Inventions Involving Human Stem Cells in Europe, 9 JoURNAL OF ComMERCIAL BIOTECHNOLOGY 40, 40 (2002).

86 See Åsa Hellstadius, A Comparative Analysis of the National Implementation of the Directive's Morality Clause, in Embryonic STem Cell PATENTS: EUROPEAn LAW AND ETHICS 118 (Aurora Plomer \& Paul Torremans ed., Oxford University Press 2009); Margo A Bagley, A Global Controversy: The Role of Morality in Biotechnology Patent Law, in Intellectual Property and Information Wealth: Issues and Practices in the Digital Age (Vol. 2) 332 (Peter K Yu ed., Praeger 2006).

87 The EPO, independent of the EU, did not have the obligation to amend the EPC to accommodate to provisions within the EU Biotech Directive, which only could oblige the EU member states to transform the Directive into their domestic patent laws. However, it voluntarily inserted several clauses into the Implementing Regulations to the EPC (hereafter EPC Rules) in June 1999, and began examining and granting patents in line with the principles set out by the EU Biotech Directive. For instance, Rules 27, 28 and 29 of the EPC Rules, in fact, were not the original part, but were inserted in Part II of the Implementing Regulations by the Administrative Council Decision of the European Patent Organization in June 1999, with the intention of being consistent with provisions in the EU Biotech Directive. See Administrative Council Decision, OJ EPO 7/1999, at 437-440. See also Porter, supra note 80, at 16.

88 See Rule 26(1), Part II, Chap. V of the EPC Rules. See also Part G, Chap. II, Sect. 5.2 of the EPO's Guidelines for Examination. 
attempts to break down the boundary between invention and discovery, which is reflected in several provisions in the Directive.

\subsubsection{Exclusion of "Discoveries"}

In the EPC, Article 52(1) gives a general provision allowing patents for any inventions, in all fields of technology, if those inventions are new, involve an inventive step and are susceptible of industrial application. ${ }^{89}$ It is not difficult to observe that under Article 52(1) EPC, the scope of patent eligible "inventions" is quite broad. Meanwhile, the same as international common practice, Article 52(2) EPC further gives a precise list of exclusions, which are set to cover the items that are deemed unpatentable, including "discoveries". ${ }^{90}$ Based on this provision, the EPO's Guidelines for Examination consider that to find a previously unrecognized substance occurring in nature is mere discovery and therefore unpatentable. ${ }^{91}$ However, the distinction between an "unpatentable discovery" and a "patentable invention" in the field of biotechnology is very thin, and the distinction can often be a conceptual challenge for patent offices and the courts. ${ }^{92}$ Based on Article 52(2) EPC, there seems to exist no clear information about whether biotechnological inventions, including hESC-related inventions, can obtain patent protection or not, which could confuse European researchers and companies.

In this regard, to clarify patentable subject matter particularly in the field of biotechnology, Article 3 of the Biotech Directive reaffirms the patent eligibility of biotechnological inventions even if that involves biological material. ${ }^{93}$ Additionally, Recital 34 points out that the Directive is "without prejudice to concepts of invention and discovery." Indeed, the Directive also indicates that the simple discovery of one of the human body's elements, including the sequence or partial sequence of a gene, cannot be patented. ${ }^{95}$ However, it seems that the Directive specifically attempts to demolish the boundary between invention and discovery. This is reflected in several other provisions in the Directive, which will be discussed in the following section.

\subsubsection{Isolation Principle in the Directive}

Several provisions in the Directive have been established to erase the boundary between invention and discovery, particularly in the field of biotechnology. In other

89 See Article 52(1) of the EPC.

90 See Article 52 of the EPC. According to the explanation in the EPO Guidelines for Examination, "discoveries" are too abstract and have no technical effect, and thus are not "inventions" within the meaning of Article 52(1) of the EPC. See G-II, 1 and 3.1, the EPO's Guidelines for Examination.

91 See G-II, 3.1, the EPO's Guidelines for Examination.

92 See Plomer, et al., supra note 6, at 18.

93 See Article 3 of the EU Biotech Directive.

94 Recital 34 of the EU Biotech Directive.

95 See Article 5(1) of the EU Biotech Directive. 
words, certain provisions of the Directive attempt to make exceptions to the exclusion of "discoveries." Article 3(2) of the Directive, which is identical to the statement of Rule 27 (a) of the EPC Rules, ${ }^{96}$ puts forward that "biological material which is isolated from its natural environment or produced by means of a technical process may be the subject of an invention even if it previously occurred in nature." ${ }^{.77}$ This provision sets out a legal distinction between discoveries and inventions, caused by the element of human intervention. Thus, biological material may be considered patentable even if it already occurs in nature. ${ }^{98}$ This implies that both the Biotech Directive and the EPC have accepted the argument that an element of "human ingenuity" would give biological materials the patent eligibility. ${ }^{100}$

Based on the same notion, Article 5(2) of the Biotech Directive provides an isolation principle specifically relating to human biological materials, such as cells, tissues, and organs. ${ }^{101}$ To be specific, Article 5(2) of the Directive, which is identical to the statement of Rule 29 of the EPC Rules, ${ }^{102}$ stipulates that "an element isolated from the human body or otherwise produced by means of a technical process, including the sequence or partial sequence of a gene, may constitute a patentable invention, even if the structure of that element is identical to that of a natural element." 103 This article was one of the most controversial provisions during the legislative process, and the direct outcome of this debate was to emphasize that "simple discoveries" cannot be patented in the final text, but elements isolated from the human body or produced by means of a technical process can be granted patents. ${ }^{104}$ It is argued that Article 5(2) was added to justify the

96 See Rule 27, Part II, Chap. V of the EPC Rules. Rule 27(a) EPC provides that "[b]iotechnological inventions shall also be patentable if they concern: (a) biological material which is isolated from its natural environment or produced by means of a technical process even if it previously occurred in nature." Moreover, based on this provision, the EPO's Guidelines provide for patentability of "[b]iological material which is isolated from its natural environment or produced by means of a technical process even if it previously occurred in nature". See G-II, 5.2(i), the EPO's Guidelines for Examination.

97 Article 3(2) of the EU Biotech Directive.

98 See G-II, 5.2, the EPO's Guidelines for Examination.

99 The "human ingenuity" argument can be found in the case Diamond v. Chakrabarty (see supra note 22), in which there were some statements about distinguishing between "products of nature" and "products of human ingenuity".

100 See Marton Varju \& Judit Sándor, Patenting Stem Cells in Europe: The Challenge of Multiplicity in European Union Law, 49 Common MARKET LAW ReVIEW 1007, 1016 (2012).

101 See Article 5(2) of the EU Biotech Directive.

102 See Rule 29, Part II, Chap. V of the EPC Rules. Based on this provision of the EPC Rules, G-II, 5.2 of the EPO's Guidelines provide that "[a]lthough the human body, at the various stages of its formation and development, and the simple discovery of one of its elements, including the sequence or partial sequence of a gene, cannot constitute patentable inventions (see G-II, 5.3), an element isolated from the human body or otherwise produced by means of a technical process, which is susceptible of industrial application, including the sequence or partial sequence of a gene, may constitute a patentable invention, even if the structure of that element is identical to that of a natural element."

103 Article 5(2) of the EU Biotech Directive.

104 See Duncan Curley \& A Sharples, Patenting Biotechnology in Europe: the Ethical Debate Moves on, 24 EuROPEAN INTELLECTUAL PROPERTY REVIEW 565, 568 (2002). 
patenting of genetic materials isolated from the human body. ${ }^{105}$ Moreover, Recital 20 of the Directive also emphasizes that an element isolated from the human body or otherwise produced by means of a technical process is not excluded from patent eligibility, even where the structure of that element is identical to that of a natural element. ${ }^{106}$ Recital 21 further explains the reason, which is that such an element is the result of human intervention and it cannot naturally occur. ${ }^{107}$

Based on Article 3(2) and Article 5(2) of the Directive, it seems that if hESCs are isolated from human body environment or "produced by means of a technical process", then they would not be "simple discovery", and, thus are patent eligible, even if the structure of the hESCs is identical to that of their naturally occurring state. However, the Commission's European Group on Ethics in Science and New Technologies (EGE) ${ }^{108}$ once pointed out that "[i]solated stem cells which have not been modified do not, as product, fulfil the legal requirements, especially with regards to industrial applications, to be seen as patentable." ${ }^{109}$ Admittedly, this is probably true, and proper consideration for a patent office. ${ }^{110}$ However, this statement is more related to the requirement of industrial applications, rather than patent eligibility, and the opinion of the EGE is not legally binding on the decision of the CJEU. In a word, in the EU, particularly under the Biotech Directive, the isolation principle allows legal room for the granting of patents on "elements", including hESCs, by making a distinction between the object in vivo and isolated components of the body obtained through human intervention using inventive processes. $^{111}$

105 See Graeme Laurie, Patenting Stem Cells of Human Origin, 26 European Intellectual Property Review 59, 63 (2004).

106 See Recital 20 of the EU Biotech Directive.

107 Recital 21 of the EU Biotech Directive provides that "whereas such an element isolated from the human body or otherwise produced is not excluded from patentability since it is, for example, the result of technical processes used to identify, purify and classify it and to reproduce it outside the human body, techniques which human beings alone are capable of putting into practice and which nature is incapable of accomplishing by itself." Moreover G-II, 5.2(i) of the EPO's Guidelines for Examination also point out that "such an element is not a priori excluded from patentability since it is, for example, the result of technical processes used to identify, purify and classify it and to produce it outside the human body, techniques which human beings alone are capable of putting into practice and which nature is incapable of accomplishing itself (EU Dir. 98/44/EC, rec. 21)."

108 Article 7 of the EU Biotech Directive provides that "the Commission's European Group on Ethics in Science and New Technologies evaluates all ethical aspects of biotechnology."

109 European Group on Ethics in Science and New Technologies (EGE), Opinion No. 16: Ethical Aspects of Patenting Inventions Involving Human Stem Cells, 15 (May. 7, 2002), http://biotech.bioetica.org/new/ ege16_complet_en.pdf.

110 See Laurie, supra note 105, at 63.

111 See G Bahadur \& M Morrison, Patenting Human Pluripotent Cells: Balancing Commercial, Academic and Ethical Interests, 25 HUMAN RePRODUCTION 14, 16 (2010). 


\subsubsection{China}

Unlike the US and EU, which have developed case law to accommodate to rapid advances in society, China only relies on codes of law to ensure consistency of legislation. In China, the patent eligibility of a subject matter first should be assessed under Articles 2, 5 and 25 of the CPL. ${ }^{112}$ Article 2, as a general rule about appropriate patentable subject matter, attempts to define the term "invention", that is, "any new technical solution relating to a product, a process, or improvement thereof." ${ }^{113}$ However, this general "patentable subject matter" clause in the CPL is quite broad, similar to 35 USC $\S 101$ in the US patent law, and cannot give any clear and specific guidance to the determination of patent eligibility. The only conclusion that can be drawn from this clause is that patent eligible inventions in China are divided into two categories: products and processes.

Article 5 and Article 25(1) of the CPL provide several statutory exclusions to the patentable subject matter in China. Article 5(1) is the general morality clause in the CPL, which in practical effect is the main battlefield concerning patenting hESC-related inventions in China, similar to the situation in the EU. Concerning the ethical and moral considerations in the Chinese patent system, this thesis will in detail explore the issues later on. Article 25(1) of the CPL provides a well-established list of exclusions from patent eligibility, in which the "scientific discoveries" exception is most relevant concerning patenting hESC-related inventions. This section will start with investigating the "scientific discoveries" exception in the CPL.

\subsubsection{Exclusion of Scientific Discoveries}

Article 25(1)(1) of the CPL specifically sets forth that "scientific discoveries" cannot be granted any patent right. ${ }^{114}$ The fundamental point is that the Chinese legislators do not consider scientific discoveries to belong to inventions provided in Article 2 of the CPL. However, neither the CPL nor other laws give any specific explanation for this exception, except some detailed statement in the SIPO's Guidelines, which were issued by the SIPO to detail and supplement the provisions of the CPL and the Implementing

112 See Jing Zhao (赵晶), Zhuanli Shencha Guocheng Zhong “Lunli Shencha” zhi Chutan_-You Liangjian Mingjiao Zhuanli Xingfa de Sikao (专利审查过程中“伦理审查”之初探一一由两件明胶专利引发的思考) [Preliminary Study on the Morality Exclusion in Patent Examination: Thinking from Two Gelatin Patents], ZHongGuo FAMING YU ZHUANLI (中国发明与专利) [CHINA INVENTION \& PATENT] 92, 93 (2013) (stating that Article 5 and Article 25 of the CPL are considered the gatekeepers of patentability in China.)

113 Article 2 of the CPL. Concerning the technical solution, Part II, Chap. 1, Sect. 2 of the SIPO's Guidelines further points out the technical solution as "an aggregation of technical means applying the laws of nature to solve a technical problem. Usually, technical means are embodied as technical features”. However, there is no legal definition of invention in most patent laws around the world. See HECTOR MACQUEEN, et al., CONTEMPORARY INTELLECTUAL PROPERTY: LAW AND POLICY 421 (Oxford University Press 2008); WIPO, Understanding Industrial Property, 8, http://www.wipo.int/edocs/pubdocs/en/wipo_pub_895_2016.pdf ("Most laws dealing with the protection of inventions do not actually define the notion of an invention. A number of countries, however, define inventions as new solutions to technical problems.")

114 Article 25(1)(1) of the CPL. 
Regulations of the Patent Law of the PRC (IRPL). ${ }^{115}$ It is important to bear in mind that this document (i.e., the SIPO's Guidelines) essentially is a department regulation, which only assists examiners in the SIPO, including the Patent Office and the PRB, in assessing applications, but does not have legally binding force in front of the courts. Based on this, any patent granted that seems to be inconsistent with the Guidelines is not necessarily invalid. ${ }^{116}$

The SIPO's Guidelines explain that scientific discoveries refer to "the revelations of substances, ... and their feature and laws, which objectively exist in nature. ... All of these are the extension of the cognition of human beings. Because these discovered substances, ... are different from the technical solutions of reforming the objective world, they are not inventions-creations as referred to in the Patent Law and therefore cannot be granted patent rights." ${ }^{117}$ The Guidelines further provide two examples-the discovery of the photosensitive property of a silver halide under illumination and the finding of a previously unknown substance in nature existing in its natural state-both of which are considered scientific discoveries, and thus cannot be patented. ${ }^{118}$ Therefore, under the "scientific discoveries" exception in the CPL, according to the explanation of the SIPO's Guidelines, a substance found in nature and existing in its natural state would be considered merely an object of discovery in the sense of "scientific discoveries" and be excluded from patent eligibility. ${ }^{119}$ For instance, a microorganism, a gene or DNA fragment existing in nature without any human intervention is merely discovery and cannot be patented. At the same time, the Guidelines also acknowledge that although discoveries and inventions are different essentially, it would be difficult to draw a clear line between unpatentable discoveries and patentable inventions, since many discoveries can lead to inventions, and inventions in turn often are made based on discoveries. ${ }^{120}$ Thus, in China the "scientific discoveries" exception in the CPL can be a potential obstacle to the patent eligibility of several hESC-related inventions, particularly hESCs per se, since hESCs may be construed or considered to be merely an object of discovery.

115 Zhonghua Renmin Gongheguo Zhuanlifa Shishi Xize (中华人民共和国专利法实施细则) [Implementing Regulations of the Patent Law of the PRC], promulgated by Decree No. 306 of the State Council of the PRC on June 15, 2001, amended the first time on December 28, 2002 according to the Decision of the State Council on Amending the IRPL, and amended the second time on January 9, 2010 according to the Decision of the State Council on Amending the IRPL.

116 See Benjamin Farrand, Human Embryonic Stem Cells and Patent Law in the EU and China: Convergence in Standards Through Divergence in Institutions, 3 INTELLECTUAL PROPERTY QUARTERLY 260, 269 (2016).

117 Part II, Chap. 1, Sect. 4.1 of the SIPO's Guidelines.

118 See id.

119 See Part II, Chap. 10, Sect. 2.1 of the SIPO's Guidelines.

120 See Part II, Chap. 1, Sect. 4.1 of the SIPO's Guidelines. 


\subsubsection{Isolation Principle in China}

Just like the isolation principle established in the EU Biotech Directive, China also has set up its own isolation principle in its patent system, but only through the SIPO's Guidelines. For instance, when assessing patent applications for chemical inventions, the Guidelines point out that "a substance, found in the nature and existing in its natural state, is merely an object of discovery" and thus cannot be patented. ${ }^{121}$ However, if the substance is isolated or extracted from the nature for the first time and can be precisely characterized, the substance per se and the process for obtaining it are all patent eligible under the CPL. ${ }^{122}$ As mentioned earlier, the Guidelines consider a microorganism, gene or DNA fragment existing in nature without any human intervention to be merely a discovery and, hence, not patent eligible. However, based on the isolation principle, the Guidelines put forward that when a microorganism is isolated into a pure culture and has particular industrial use, then it per se is eligible for patent protection. ${ }^{123} \mathrm{Ad}-$ ditionally, in accordance with the Guidelines, "a gene or a DNA fragment per se and the process to obtain it are subject matters of patent protection if it is isolated or extracted for the first time from the nature, its base sequence is unknown in the prior art and can be definitely characterized, and it can be exploited industrially."124

As can be seen, the Chinese patent system has already accepted the notion that human intervention (e.g., isolation, extraction, and purification) may transform unpatentable discoveries into patent eligible inventions, such as isolated microorganisms, genes, or DNA fragments. Additionally, although a mere scientific discovery is not patent eligible, the application of the scientific discovery is. In other words, a product with using the scientific discovery, and its corresponding production process may obtain patents. Thus, in accordance with the isolation principle established in the Guidelines, at least from the SIPO's viewpoint, at present the "scientific discoveries" exception in the CPL will not become an obstacle to patenting both hESCs per se, and the methods of producing hESC lines. Also, cells that are differentiated from hESC lines and the differentiating method would not be excluded from patent eligibility.

Compared with the US and EU, it is not difficult to observe that all the three jurisdictions have attempted to eliminate simple discoveries or products of nature from patentable subject matter, and the rationales behind them are almost the same. That is, the basic tools of scientific research and technological work should be free to all men, and cannot be reserved exclusively to anybody by patents. Nevertheless, all three jurisdictions have tried to make a narrow exception from the "discoveries" exclusion or the "products of

\footnotetext{
121 Part II, Chap. 10, Sect. 2.1 of the SIPO's Guidelines.

122 Seeid.

123 See Part II, Chap. 10, Sect. 9.1.2.1 of the SIPO's Guidelines.

124 Part II, Chap. 10, Sect. 9.1.2.2 of the SIPO's Guidelines.
} 
nature" doctrine, considering that human intervention can play a significant role in transforming a discovery or a product of nature into a man-made product and, thus, a patent eligible invention. It is worth noting that the US has moved back a step within the Myriad case, holding that merely isolation is not enough to make a composition of matter patent eligible, and within the Roslin case, holding that "markedly different characteristics from any found in nature" should be dependent upon some effort of the patentee rather than environmental factors. In contrast, the other two jurisdictions (i.e., the EU and China) still retain the isolation principle, namely that human intervention may transform unpatentable discoveries into patent eligible inventions. Meanwhile, at least for now there is no indication that these two jurisdictions have the intention of modifying their isolation principle in the patent system.

Moreover, it is worth noting that unlike the EU, which has issued the Biotech Directive on regulating the patenting of biotechnological inventions, China has not issued any specific patent legislation in this specific area. Nor has China introduced any specific rules concerning patenting biotechnological inventions into the CPL or the IRPL. Instead, China has merely established a series of relevant provisions in the SIPO's Guidelines since 1993, and at the same time has often adjusted them or introduced new provisions. ${ }^{125}$ In this regard, comparable to the US and EU, China has more flexibility in adjusting the patenting of biotechnological inventions, since China mainly relies on the SIPO's Guidelines, which can fairly easily be revised to accommodate to rapid advances in the biotechnology industry. However, adopting this approach to some extent sacrifices the predictability of law, which in turn may undermine the role of the patent system in China.

\subsection{Moral Exceptions to Patentability}

As previously discussed, the most controversial issue in regulating hESC research is the social and moral concerns. Meanwhile, the social and moral concerns about hESC research also have crossed over into patenting hESC-related inventions, since moral arguments also enter the patent arena directly through the gateway of morality exclusion clauses, such as Article 53 EPC, Article 6(1) of the EU Biotech Directive, and Article 5(1) of the CPL, which is allowed in the TRIPS Agreement. This section mainly focuses on moral considerations in the patent legal framework, and examines the patent eligibility of hESC-related inventions under these considerations in the US (Sect. 2.3.1), the EU (Sect. 2.3.2), and China (Sect. 2.3.3).

125 See Qiongdi Chen, Patent biotechnology invention in China, 32 EUROPEAN INTELLECTUAL PROPERTY REVIEW 9, 10 (2010). 


\subsubsection{The US}

While Article 27(2) of the TRIPS Agreement permits its contracting parties to impose a morality exception to patent eligibility, and some jurisdictions indeed do so, the US patent law contains no substantial content that explicitly mentions morality or public order. Put another way, the US patent law does not provide any statutory basis for the USPTO or a court to reject patent protection to subject matter on moral grounds. ${ }^{126}$ Indeed, in patent practice the USPTO does not make any moral judgments about patent applications. ${ }^{127}$ However, this was not the case in US patenting history. The courts of the US historically have incorporated moral judgment into the utility requirement. How did courts in the US apply moral judgement and why did they ultimately abandon such assessment? This section mainly analyzes these issues.

\subsubsection{1 "Moral Utility" Doctrine in US Patent History}

There once existed a period of time in which courts in the US often were willing to deny patents for inventions which they thought to be immoral. These inventions fell primarily into two categories: inventions used to defraud buyers and machines used for gambling. ${ }^{128}$ The early view about immoral subject matter is believed to have originated from Justice Story's opinion in the 1817 Lowell v. Lewis decision, a circuit court case. ${ }^{129}$ In this case, when deciding whether the invention was useful, Justice Story pointed out that "law will not allow the plaintiff to recover, if the invention be of a mischievous or injurious tendency." ${ }^{130}$ He went on to explain, "invention should not be frivolous or injurious to the well-being, good policy, or sound morals of society". ${ }^{131}$ In addition, Justice Story enumerated examples of immoral inventions, such as "a new invention to poison people, or to promote debauchery, or to facilitate private assassination." 132 Thus stating, Justice Story in fact had incorporated a moral assessment into the utility requirement. Story's view concerning utility then became the so-called "moral utility" doctrine.

126 See Bagley, supra note 86 , at 318 .

127 See Juicy Whip, Inc. v. Orange Bang, Inc., 185 F.3d 1364, 1368 (Fed. Cir. 1999). For more discussion about the practice concerning morality judgment when determining patentability in the USPTO, please see infra Sect. 3.1.3, Chap. 5.

128 See Robert P Merges, Intellectual Property in Higher Life Forms: The Patent System and Controversial Technologies, 47 MARYLAND LAW REVIEW 1051, 1062 (1987).

129 See Lowell v. Lewis, 15 Fed. Cas. 1018 (C.C.D. Mass. 1817). See also Nathan Machin, Prospective Utility: A New Interpretation of the Utility Requirement of Section 101 of the Patent Act, 87 CALIFORNIA LAW REVIEW 421, 435 (1999). (holding that "[m]oral utility is a particular formulation of the general utility requirement. Its origins lie in dictum in Lowell v. Lewis.")

130 Lowell v. Lewis, supra note 129, at 1019.

131 Id.

132 Id ("[t]he word 'useful', therefore, is incorporated into the act in contradistinction to mischievous or immoral. For instance, a new invention to poison people, or to promote debauchery, or to facilitate private assassination, is not a patentable invention.") 
Not surprisingly, the "moral utility" doctrine was invoked by courts many times in over 150 years to deny patents, especially in cases concerning gambling devices and fraud. ${ }^{133}$ Regarding gambling devices, early courts of the US took a strict attitude. For instance, in the 1889 decision National Automatic Devise Co. v. Lloyd, the court invalidated a patent for a "toy automatic race horse" that was used "in saloons, bar-rooms, and other drinking places, where the frequenters of such places make wagers as to which of the toy horses will stop first ... by dropping a nickel in the slot." ${ }^{134}$ Although the court acknowledged that the device might have other potential uses, such as a child's toy which involved no gambling, the court considered that to date the only use of the device was "pernicious and hurtful" and, thus, the device was unpatentable. ${ }^{135}$ In addition to the fight against immoral inventions involving gambling devices, patents for inventions that could be used only to defraud were rejected as well. For instance, in Richard v. Du Bon, the patent at issue concerned a process for artificially producing spots on domestic tobacco. ${ }^{136}$ The Second Circuit held the invention was unpatentable and invalidated the patent, since the court found that the only use for the process was to make domestic tobacco to look like imported tobacco of a superior quality. ${ }^{137}$

\subsubsection{The Abandonment of Moral Assessment}

As time passed by, several judicial decisions have challenged the "moral utility" doctrine through interpretation of the scope of "utility" and subject matter standards under the US patent law. ${ }^{138}$ Important reasons probably are, among other things, both dynamic societal views on morality and increasing difficulties in defining morally acceptable inventions. ${ }^{139}$ Views of the US courts have changed and started to hold that merely because an invention was deceptive did not necessarily imply it lacked utility. ${ }^{140}$ That is to say, an invention could meet the utility requirement if it had at least one moral, legal purpose. $^{141}$

In the 1980 case Chakrabarty, the US Supreme Court specifically rejected the relevance of potential hazards, such as moral issues, possible pollution and disease that genetic

\footnotetext{
133 See e.g., Merges, supra note 128, at 1063; Bagley, supra note 21, at 476; OLIVER MILLS, BIOTECHNOLOGICAL INVENtions: Moral Restraints and Patent LaW (Revised Edition) 46 (Ashgate Publishing Limited 2010).

134 National Automatic Device Co. v. Lloyd, 40 F. 89, 89-90 (N.D. III. 1889).

135 See id., at 90.

136 See Richard v. Du Bon, 103 F. 868 (2d Cir. 1900).

137 Seeid.

138 See e.g., Brenner v. Manson, 383 US 519, 533 (1966); Juicy Whip, Inc. v. Orange Bang, Inc., supra note 127, at 1367.

139 See Bagley, supra note 86 , at 320.

140 See MILLS, supra note 133, at 47.

141 See Bagley, supra note 86, at 320.
} 
research may cause, in considering the patent eligibility of living matter. ${ }^{142}$ The Court considered itself to be "without competence" to tackle these contentions, which should be left to the political branches of the government, Congress and the Executive Branch. ${ }^{143}$ The Court identified its role as "the narrow one of determining what Congress meant by the words it used in the statute; once that is done, our powers are exhausted .... [U]ntil Congress takes ... action, this Court must construe the language of $\S 101$ as it is." ${ }^{144}$ Through broadly interpreting 35 USC $\S 101$, the Court in Chakrabarty declined to impose any moral constraints on patent eligibility.

More recently, the 1999 Juicy Whip Inc. v. Orange Bang inc. decision, handed down by the CAFC, explicitly sounded the "death-knell" ${ }^{145}$ for the moral utility requirement. ${ }^{146}$ Initially the district court invalidated the patent for lack of utility since the invention was designed to deceive customers by counterfeiting. ${ }^{147}$ Yet, the CAFC reversed it, declaring that the utility requirement in patent law was not a directive to the USPTO or courts to "serve as arbiters of deceptive trade practices" and that it was not the job of the USPTO to displace the police powers of the States and promote the health, order, peace, and welfare of the community. ${ }^{148}$ In this case, Judge Bryson even mentioned "the principle that inventions are invalid if they are principally designed to serve immoral or illegal purposes has not been applied broadly in recent years. For example, years ago courts invalidated patents on gambling devises on the ground that they were immoral, ..., but that is no longer the law." ${ }^{149}$ In light of the decision of Juicy Whip Inc. v. Orange Bang inc., courts in the US have in effect abandoned or overturned the "moral utility" doctrine.

142 See Diamond v. Chakrabarty, supra note 22, at 316-317. The US Supreme Court in Chakrabarty acknowledged the possible repercussions of its decision that "[w]e are told that genetic research and related technological developments may spread pollution and disease, that it may result in a loss of genetic diversity, and that its practice may tend to depreciate the value of human life. These arguments are forcefully, even passionately, presented; they remind us that, at times, human ingenuity seems unable to control fully the forces it creates - that, [as] with Hamlet, it is sometimes better 'to bear those ills we have than fly to others that we know not of."'

143 Id., at 317.

144 Id., at 318.

145 Bagley, supra note 86, at 321.

146 See Juicy Whip, Inc. v. Orange Bang, Inc., supra note 127.

147 See id.

148 Id. In this case, the CAFC held that "[t] he requirement of 'utility' in patent law is not a directive to the Patent and Trademark Office or the courts to serve as arbiters of deceptive trade practices. Other agencies, such as the Federal Trade Commission and the Food and Drug Administration, are assigned the task of protecting consumers from fraud and deception in the sale of food products. As the Supreme Court put the point more generally, 'Congress never intended that the patent laws should displace the police powers of the States, meaning by that term those powers by which the health, good order, peace and general welfare of the community are promoted'". Further the court stressed that there was "no basis in section 101 to hold that inventions can be ruled unpatentable for lack of utility simply because they have the capacity to fool some members of the public".

149 See id., at 1366-1367. 
Consequently, moral concerns traditionally within the US patent law have eventually been removed from determining the patentability of subject matter at all. The courts recognized that such morality-laden "high policy" arguments should be left to Congress to legislate, or other agencies, such as the Federal Trade Commission (FTC) and the Food and Drug Administration (FDA), to deal with, but that such determinations were beyond the powers of the judiciary or the USPTO. As a result, currently the US in effect has adopted a "patent first, ask questions later" approach, ${ }^{150}$ which is totally different from the EU and Chinese approaches.

\subsubsection{The EU}

In contrast to the US "patent first" approach, in the EU whether under the Biotech Directive or under the EPC, the determination of patent eligibility of hESC-related inventions should take account of moral issues. This section seeks to analyze morality exclusions within the Biotech Directive (Sect. 2.3.2.1) and the EPC (Sect. 2.3.2.2).

\subsubsection{Morality Exclusions in the Directive}

Unlike the US, which currently includes no basis for assessing moral issues in its patent system, the EU has incorporated the morality assessment into its patent law. To be specific, Article 6(1) of the EU Biotech Directive serves as a general morality clause, which explicitly prevents patents from being granted on inventions when the commercial exploitation of these inventions is against ordre public or morality. ${ }^{151}$ In order to clarify how the general morality requirement provided in Article 6(1) should be implemented and interpreted, ${ }^{152}$ Article 6(2) of the Directive uniquely enumerates a non-exhaustive list of some biological inventions that should be excluded from patent eligibility on ordre public and moral grounds, ${ }^{153}$ including cloning humans, modifying the germ line genetic identity of humans, and "uses of human embryos for industrial or commercial purposes". ${ }^{154}$ In addition, Article 5(1) of the Directive explicitly excludes "the human body, at the various stages of its formation and development" from patent eligibility. ${ }^{155}$

150 See generally, Bagley, supra note 21.

151 Article 6(1) of the EU Biotech Directive states that "[i]nventions shall be considered unpatentable where their commercial exploitation would be contrary to ordre public or morality; however, exploitation shall not be deemed to be so contrary merely because it is prohibited by law or regulation."

152 See C-456/03 (Commission v. Italy) [2005] ECR I-5335, para. 78 (the CJEU pointed out that the main aim of Article 6(2) of the EU Biotech Directive was to give definition to the exclusion provided in Article 6(1).)

153 While some moral exclusions can be found in previous international law, such as Article 27(2) of the TRIPS Agreement, these exclusions normally were general clauses and did not contain any specific examples to prevent inventions from patentability on moral grounds. See Plomer, et al., supra note 6, at 9, footnote 4. Concerning the discussion of Article 27(2) of the TRIPS Agreement, please see supra Sect. 2.1, Chap. 5.

154 See Joshua Whitehill, Patenting Human Embryonic Stem Cells: What is so Immoral? 34 BrooKLYN JOURNAL OF INTERNATIONAL LAW 1045, 1078-1079 (2008); Varju \& Sándor, supra note 100, at 1017.

155 Article 5(1) of the EU Biotech Directive. 


\subsection{General Morality Clause}

When it comes to the general morality clause (i.e., Article 6(1)), this provision in effect was not contained in the original version of the Directive, which, however, was rejected by the European Parliament in 1995, since the Parliament believed that the Directive needed to pay greater attention to the moral aspects of biotechnological patenting. ${ }^{156}$ Meanwhile, the Commission also felt the need to respond to moral and practical developments in the potential patenting of human stem cells and cell lines differentiated from stem cells. ${ }^{157}$ In this regard, after a long and heated discussion, finally the Parliament, the Commission, and the Council reached a political concession to establish a moral evaluation criterion within the patenting of materials, in particular those of human origin. ${ }^{158}$

As a general principle, Article 6(1) of the Directive sets out a requirement of ordre public or morality to judge the patent eligibility of a subject matter, which implies that patent protection would be denied to morally undesirable inventions. However, it does not give the precise definition of ordre public or morality, and sets out that the prohibition by law or regulation cannot amount to ordre public or morality. This recognizes the possibility of differing ethical assessment of biotechnological inventions in different EU States, and thus this article should be applied with the intention of accommodating the value judgments of different communities. ${ }^{159}$ To put the moral evaluation into practice, Article 7 of the Directive provides that the EGE shall evaluate all ethical aspects of biotechnology. ${ }^{160}$ Moreover, Recital 38 of the Directive underpins the general morality clause by stressing the necessity to protect human dignity and the integrity of human body. ${ }^{161}$ To be sure, moral evaluation is now a fixture of the EU patent legislation. ${ }^{162}$ As can be seen, in terms of patenting morally controversial biotechnological inventions, this is the most crucial distinction between the EU Biotech Directive and US patent law.

\subsection{The "Human Embryos" Exclusion}

Article 6(2) of the Biotech Directive has provided a list of examples which should be excluded from patent eligibility on ordre public and moral grounds. This list of examples represents a minimal consensus on which specific types of subject matter are unpatent-

\footnotetext{
156 See Gerard Porter, et al., The Patentability of Human Embryonic Stem Cells in Europe, 24 NATURE BIOTECHNOLOGY 653, 653 (2006).

157 See Laurie, supra note 105, at 59.

158 See E Richard Gold \& Alain Gallochat, The European Biotech Directive: Past as Prologue, 7 EUROPEAN LAW JournaL, 332 (2001); Aurora Plomer, et al., Challenges to Human Embryonic Stem Cell Patents, 2 CeLL STEM CELL 13, 15 (2008).

159 See Varju \& Sándor, supra note 100, at 1018.

160 See Article 7 of the EU Biotech Directive.

161 See Recital 38 of the EU Biotech Directive.

162 See Porter, et al., supra note 156, at 653.
} 
able due to being contrary to ordre public or morality among the EU member states. ${ }^{163}$ In this specific list, Article 6(2)(c) of the Directive-the exclusion of "uses of human embryos for industrial or commercial purposes"-is the most important provision in relation to patenting hESC-related inventions. Similarly, Recital 42 of the Directive also notes the same notion but emphasizes a narrow exception from this exclusion that such "exclusion does not affect inventions for therapeutic or diagnostic purposes which are applied to the human embryo and are useful to it." ${ }^{164}$ In fact, the human embryo exemption provision facilitates the exclusion of hESC-related inventions from being patented, as the creation of hESC lines traditionally necessitates the use of human embryos. ${ }^{165}$

It is noteworthy that the Directive neither explains what is to be understood by the term "human embryos" nor provides a clear definition of "uses of human embryos", which causes the interpretation of the human embryo exclusion to be genuinely controversial. For instance, in terms of the understanding of human embryos, Estonia, Germany and the UK consider an embryo to begin from fertilization, while Spain regards the human embryo as such from the time the ovum is transplanted into the uterus. ${ }^{166}$ Moreover, Article $6(2)$ (c) of the Directive only relates to embryos per se and keeps silent about hESCs. It is believed that one of the important reasons for this silence is that hESCs were not specifically contemplated when drafting Article 6(2) of the Directive. ${ }^{167}$ Indeed, four months after the adoption of the Directive there started to be a report about successful isolation of an hESC line from human embryos by James Thomson in November $1998 .{ }^{168}$ Due to the lack of a clarification of "human embryos" and "uses of human embryos" as well as the silence in relation to hESCs, the question regarding how to apply Article 6(2) (c) in the patenting of hESC-related inventions has become a source of great uncertainties since the Directive was issued, ${ }^{169}$ and leaves room for long-running legal, ethical, and policy debates.

Indeed, based on the uncertainty of the human embryo exclusion, the CJEU has been required several times to interpret this provision. For instance, in the Oliver Brüstle v. Greenpeace (Brüstle) case, the CJEU decided to interpret the notion of human embryo in Article 6(2)(c) of the Biotech Directive in a wide fashion, based on the capacity of

163 See C-456/03 (Commission v. Italy), supra note 152, para. 78.

164 Recital 42 of the EU Biotech Directive.

165 See Ella O'Sullivan, International Stem Cell Corp v. Comptroller General of Patents: the Debate Regarding the Definition of the Human Embryo Continues, 36 EUROPEAN INTELLECTUAL PROPERTY REVIEW 155, 157 (2014). Concerning a discussion about the creation of hESC lines, see supra Sect. 3.2.1, Chap. 2.

166 See Opinion of Advocate General Bot delivered on 10 Mar. 2001 in Case C-34/10 Oliver Brüstle v. Greenpeace eV, paras. 68-69.

167 See T-1374/04, OJ EPO 313, 337 [2007].

168 See James A Thomson, et al., Embryonic Stem Cell Lines Derived from Human Blastocysts, 282 SCIENCE 1145 (1998).

169 See Porter, supra note 80, at 5. 
"commencing the process of development of a human being". ${ }^{170}$ Based on this broad definition, the CJEU considered the human embryo to encompass both conventionally fertilized embryos and synthetically created embryos, such as zygotes or embryos formed by SCNT as well as by parthenogenesis. ${ }^{171}$ However, in a later case, International Stem Cell Corporation (ISCO) v. Comptroller General, ${ }^{172}$ the CJEU clarified and revised the definition of the human embryo, with profound impact upon the patent eligibility of hESC-related inventions. Regarding judicial cases decided by the CJEU, the thesis will discuss them in detail later.

\subsection{Exclusion of Human Body}

Article 5(1) of the Directive also explicitly prohibits "the human body, at the various stages of its formation and development" from patent eligibility. ${ }^{173}$ The underlying rationale is considered to be aiming to pay respect for the ethical constrains, following from human dignity, which prohibit the commercialization of the human body through the patent system in Europe. ${ }^{174}$ Put another way, Article 5(1) of the Directive represents the recognition of the longstanding ethical prohibition on commercial or property rights over the human body. ${ }^{175}$ Concerning patenting hESC-related inventions, there is a possibility that hESCs may be regarded as one stage of the human body, particularly considering the diversity of viewpoints on the "human body" across Europe. As the EGE mentions in a report that, since isolated hESCs are so close to the human body or the human embryo from which they have been isolated, their patenting may be considered a form of commercialization of the human body. ${ }^{176}$

\subsubsection{Morality Exclusions in the EPC}

In fact, the general morality exclusion in Article 6(1) of the Directive echoes the preexisting ordre public or morality exclusion in Article 53(a) EPC. Article 53(a) EPC states that European patents shall not be granted in respect of "inventions the commercial exploitation of which would be contrary to 'ordre public' or morality; such exploitation shall not be deemed to be so contrary merely because it is prohibited by law or regulation in some or all of the Contracting States." ${ }^{177}$ As the EPO's Guidelines point out,

170 C-34/10 (Oliver Brüstle v. Greenpeace eV) OJ C 362/7 [2011], para. 37.

171 See id., paras. 34-38.

172 See C-364/13 (International Stem Cell Corporation v. Comptroller General of Patents, Designs and Trade Marks), supra note 83.

173 Article 5(1) of the EU Biotech Directive.

174 See C-377/98 (The Netherlands v. Parliament and Council) [2001] ECR I-7079, paras. 70-77.

175 See Bahadur \& Morrison, supra note 111 , at 16.

176 See EGE, supra note 109, at 16.

177 Article 53(a) of the EPC. See STERCKX \& COCKBAIN, supra note 6, at 243 (pointing out that Article 53(a) in fact was amended when the EPC was revised in 2000. This article no longer excludes inventions the publication of which would be contrary to ordre public or morality. That is, the word "publication" was removed and, at the same time, the word "commercial" was inserted before "exploitation".) 
the purpose of this provision is to deny protection to inventions likely to induce riot or public disorder, or to lead to criminal or other generally offensive behavior. ${ }^{178}$ Ordre public and morality are the two key concepts in this important morality clause. As far as ordre public in the clause, the EPO provides a sound interpretation that it encompasses the protection of public security, the physical integrity of individuals as part of society, and the environment. ${ }^{179}$ Under Article 53(a) EPC, inventions "the exploitation of which is likely to breach public peace or social order (for example, through acts of terrorism) or to seriously prejudice the environment" are regarded as unpatentable on ground of being contrary to ordre public. ${ }^{180}$

In terms of morality in the EPO, it is stated that "the concept of morality is related to the belief that some behaviour is right and acceptable whereas other behaviour is wrong, this belief being founded on the totality of the accepted norms which are deeply rooted in a particular culture. For the purposes of the EPC, the culture in question is the culture inherent in European society and civilisation. Accordingly, under Article 53(a) EPC, inventions the commercial exploitation of which is not in conformity with the conventionally accepted standards of conduct pertaining to this culture are to be excluded from patentability as being contrary to morality." ${ }^{181}$ However, each contracting state of the EPC has its own patent laws and its own sovereign right, and meanwhile has its own understanding of morality. Some individuals might also consider it necessary to acknowledge the differences concerning ethics and morality between various cultures. In this regard, it would be difficult to tell what the "particular culture" is in European society and civilization, and quite difficult to find conventionally accepted standards of conduct pertaining to the culture. Generally speaking, the lack of an exact and precise definition of morality and common understanding of morality leaves room for different stockholders to interpret differently on the one hand, and creates uncertainty and interpretive difficulty on the other. ${ }^{182}$

In addition, as mentioned earlier, in September 1999 the EPO followed the EU's footsteps and incorporated Article 6(2) of the Directive into the EPC Rules. ${ }^{183}$ Article 6(2)(c) of the Directive, which is the human embryo exclusion of patentable subject matter, has

\footnotetext{
178 See G-II, 4.1, the EPO's Guidelines for Examination.

179 See T 356/93 (Plant cells) OJ EPO [1995], point 5 of Reasons.

180 Id

181 Id., point 6 of Reasons.

182 This can be seen from the notable cases from the EPO, such as Harvard/Oncomouse, Greenpeace v. Plant Genetic Systems, the Edinburgh patent decision, the European WARF case, etc. These cases will be discussed in detail later; please see infra Sect. 3.2, Chap. 5.
}

183 See supra Sect. 2.2.2, Chap. 5. 
been incorporated into the EPC Rules and became Rule $28(1)(\mathrm{c}) \cdot{ }^{184}$ In this regard, the human embryo exclusion is now also binding on the EPO and the Boards of Appeal. It in effect has become one legal basis for the EPO to reject granting any patent over hESCS and related inventions. ${ }^{185}$ Nevertheless, commentators put forward concerns that the express list of exclusions might generate an overly rigid framework, binding regulators to moral definitions unreflective of changing societal views. ${ }^{186}$ Furthermore, probably because of the legislative defects (e.g., the broad wording and the lack of definitions) in the human embryo exclusion of the Directive, Rule 28(1)(c) EPC also has the same problems.

The human embryo exclusion clause could be interpreted in either a narrow or a broad fashion, ${ }^{187}$ which was mentioned by the OD of the EPO in the Edinburgh patent decision. ${ }^{188}$ However, the OD ultimately chose to interpret it in a broad way based on the aims of the EU Biotech Directive, and decided that the clause excluded not only "uses of human embryos" but also hESCs, the derivation of which led to the destruction of those embryos, from patent eligibility. ${ }^{189}$ The decision in Edinburgh put embryo destruction at the center of the "human embryos" exclusion clause. ${ }^{190}$ In the WARF case, ${ }^{191}$ the Enlarged Board of Appeal (EBA) ${ }^{192}$ of the EPO noted that the originating intent of the exclusion under Article 6(2)(c) was to hold back the misuse, through commodification, of human embryos in Europe. ${ }^{193}$ As can be seen, the lack of precise definition and uncertain scope concerning morality exclusions not only in the EU Biotech Directive but also in the EPC have already created difficulties for patent applications and decisions in patent offices and courts. In the meantime, the task of determining the accurate scope of moral exclusions while maintaining the autonomy of member states in a diverse and pluralistic Europe creates a great legal and constitutional challenge. ${ }^{194}$

184 Rule 28(1) of the Implementing Regulations of EPC used to be Rule 23d of the EPC 1973. It was revised into Rule 28 and entered into force on 13 Dec. 2007. Moreover, Rule 28 EPC has been again amended by decision of the Administrative Council CA/D 6/17 of Jun. 29, 2017 (OJ EPO 2017, A56), and entered into force on Jul. 1, 2017. Another paragraph has been added to Rule 28 EPC and, thus, the "old" Rule 28 EPC has become Rule 28(1). Currently, Rule 28(1)(c) of the Implementing Regulations of EPC provides that "under Article 53(a), European patents shall not be granted in respect of biotechnological inventions which, in particular, concern the following: (c) ... uses of human embryos for industrial or commercial purposes."

185 See e.g., G 2/06 (Use of embryos/WARF) OJ EPO 306 [2009]; T 2221/10 (Culturing stem cells/TECHNION) [2014].

186 See Plomer, et al., supra note 158, at 15.

187 See Porter, supra note 80, at 25.

188 See Decision of the OD of 21 July 2003 on European patent No. EP0695351 (University of Edinburgh).

189 See id. The Edinburgh case will be discussed in detail later, see infra Sect. 3.2.5.1, Chap. 5.

190 See Varju \& Sándor, supra note 100, at 1026.

191 See G 2/06 (Use of embryos/WARF), supra note 185. This case will be discussed in detail later, see infra Sect. 3.2.5.3, Chap. 5.

192 The EBA is the supreme judicial body of the EPO responsible for ensuring the unified application of the EPC.

193 See G 2/06 (Use of embryos/WARF), supra note 185, at 323-324. The European WARF case will be discussed in detail later on in Sect. 4.2.5.2, Chap 5.

194 See Plomer, et al., supra note 158, at 15. 


\subsubsection{China}

Just like the EU, China has a morality-based patent eligibility bar in its patent law. In other words, both the EU and China can be considered to have adopted an "ask questions first, then patent" system. ${ }^{195}$ Article 5(1) of the CPL, as the general morality clause, forbids granting a patent to any invention that is "contrary to the laws or social morality or... is detrimental to [the] public interest". ${ }^{196}$ This article does not emphasize "commercial exploitation", which is quite different from the general morality provisions in the EPC as well as the EU Biotech Directive. Article 5(1) is considered to be the most pertinent provision in the CPL when determining whether hESC-related inventions are patent eligible. ${ }^{197}$ The general morality clause in the CPL is regarded as the reflection of the principle of public order and good morals of traditional civil law. ${ }^{198}$ This section first analyzes the general morality clause in the CPL as well as the historical development (Sect. 2.3.3.1). Then, the human embryo exclusion in the SIPO's Guidelines is discussed in detail (Sect. 2.3.3.2). Moreover, unlike the EU, in China hESCs per se and their preparation methods have been explicitly excluded by the SIPO's Guidelines under the CPL, which is also investigated in this section (Sect. 2.3.3.3).

\subsubsection{General Morality Clause}

In fact, moral considerations have been taken into account in patent system since 1984 when the first CPL was issued. ${ }^{199}$ As analyzed in Chapter 3 of this thesis, China historically did not have any substantive patent law. ${ }^{200}$ At the moment of drafting the first CPL, the legislators and policy makers of China did not have any experience concerning the patent regime. ${ }^{201}$ In this regard, the first CPL was drafted primarily based on referring to patent laws from other jurisdictions, such as the US, Japan, France, Germany, Switzerland, Sweden, Italy, the Soviet Union, Romania, Yugoslavia, Poland, Hungary, North Korea, the UK, Brazil, India, Thailand, Mexico, Honduras, and Taiwan, as well as the EPC, Patent Cooperation Treaty (PCT), WIPO Model Law for Development Countries on Inventions, Paris Convention for the Protection of Industrial Property, etc. ${ }^{202}$ At the time when the legislators of China started to draft their first patent law in 1979, the general morality clause in patent law was rarely employed in practice and, thus, did not

195 See generally, Bagley, supra note 86.

196 Article 5(1) of the CPL.

197 Article 5 of the CPL is considered one of the first gatekeepers of patentability in China. The other is Article 25 of the CPL; and for more discussion, please see Zhao, supra note 112, at 93.

198 See Qiang Liu (刘强) \& Wei Sheng (沈伟), 3D Dayin Renti Qiguan Ke Zhuanlixing Yanjiu (3D打印人体器官可专 利性研究) [The Patentability of 3D Printed Human Organs], 6 KEJI YU FALU (科技与法律) [JOURNAL OF SCIENCE, TECHNOLOGY AND LAW] 1098, 1104 (2015).

199 See the first version of the CPL (1984).

200 See supra Sect. 2.1, Chap. 3.

201 See YUANGUO ZHAO (赵元果), ZHONGGUO ZHUANLIFA DE YUNYU YU DANSHENG (中国专利法的孕育与诞生) [THE DRAFTING HISTORY OF THE PATENT LAW OF CHINA] 42 (Zhishi Chanquan Chubanshe (知识产权出版社) [Intellectual Property Publishing House] 2003).

202 See id., at 47. 
cause any debate around the world. Meanwhile in China, the introduction of the general morality clause also did not cause any debate in 25 drafts of the first CPL. ${ }^{203}$ Therefore, as can be seen, this general morality clause within the CPL arguably was "copied" into the law from patent laws of other jurisdictions without, in the beginning, having much knowledge about what this clause might imply.

Article 5(1) of the CPL does not further explain the terms of social morality and public interest, let alone provide any specific information regarding patenting hESC-related inventions. In accordance with the construction of this provision by the Commission of Legislative Affairs, the term "social morality" refers to ethical or moral norms and rules generally regarded as justifiable and accepted by the public. ${ }^{204}$ In addition, the SIPO further provides some guidance on the interpretation of Article 5(1) of the CPL. Regarding social morality, the SIPO's Guidelines use almost the same explanation as the Commission of Legislative Affairs, considering the social morality standard depending on the acceptability to the public, and emphasizing that the concept of morality should be based on Chinese culture. ${ }^{205}$ In the meantime, the Guidelines recognize that Chinese social morality can change with time and scientific progress. ${ }^{206}$ Based on the interpretation of morality by the Commission of Legislative Affairs as well as the SIPO's Guidelines, it seems that China has chosen an "unacceptability" standard to evaluate the morality of an invention under Article 5(1) of the CPL. ${ }^{207}$

\subsubsection{The Human Embryo Exclusion in the SIPO's Guidelines}

When further explaining the concept of social morality, the SIPO's Guidelines uniquely provide a non-exhaustive list of examples which shall be excluded from patent eligibility. One example provided in this specific list is the "use of human embryos for industrial or commercial purposes". ${ }^{208}$ However, the Guidelines do not provide any further interpretation of this human embryo exclusion. The terms "human embryos" and "use of human embryos", for instance, in this exclusion are not defined in the Guidelines. Sig-

203 See id., at 208-300.

204 See JIAN AN (安建), ZHONGHUA RENMIN GONGHEGUO ZHUANLI FA SHIYI (中华人民共和国专利法释义) [THE INTERPRETATION of the PAtent LaW of THe People's Republic of China] 11 (Quanguo Renmin Daibiao Dahui Changwu Weiyuanhui Fazhi Gongzuo Weiyuanhui (全国人民代表大会常务委员会法制工作委员会) [The Commission of Legislative Affairs of the Standing Committee of the NPC] ed., Zhongguo Falü Chubanshe (中国法律出版社) [Law Press China] (2009).

205 See Part II, Chap. 1, Sect. 3.1.2, para. 1 of the SIPO's Guidelines.

206 Seeid.

207 Concerning the "unacceptability" standard, please see infra Sect. 3.2, Chap. 5.

208 Part II, Chap. 1, Sect. 3.1.2, para. 2 of the SIPO's Guidelines provides that "where an invention-creation is contrary to social morality, it shall not be granted a patent right. For example, ... a process for modifying the germ line genetic identity of human beings or a human being thus modified, a process for cloning human beings or a cloned human being, use of human embryos for industrial or commercial purposes, a process for modifying the genetic identity of animals which is likely to cause them suffering without any substantial medical benefit to human-beings or animals, are contrary to social morality and thus shall not be granted patent rights." 
nificantly, there is no legal definition of the term "human embryo" in other Chinese laws or regulations either. ${ }^{209}$ Consequently, concerning patenting hESC-related inventions, it remains unclear whether an hESC falls under the definition of an embryo, as well as whether inventions involving hESCs fall within the scope of "use of human embryos".

Interestingly, the wording of the human embryo exclusion in the SIPO's Guidelines is almost the same as Article 6(2)(c) of the EU Biotech Directive. ${ }^{210}$ If one pays close attention to this whole list of morality exclusions in the SIPO's Guidelines, it can be found that the wording of these exclusions is extremely similar to that of Article 6(2) of the EU Biotech Directive. ${ }^{211}$ As a matter of fact, the SIPO incorporated these specific moral exclusions into its Guidelines in 2001, ${ }^{212}$ and the EU Biotech Directive was officially adopted in 1998. Therefore, the wording of the human embryo exclusion in the SIPO's Guidelines has highly likely been inspired by Article 6(2)(c) of the EU Biotech Directive. Meanwhile when introducing this specific exclusion, the drafters of the Guidelines arguably might not know what it meant and its potential consequences. By the same token, the legislative defects (e.g., the broad wording and the lack of definitions) in the human embryo exclusion of the EU Biotech Directive, as mentioned earlier, also appear in the SIPO's Guidelines. ${ }^{213}$

\subsubsection{Specific Exclusion of hESCs and Their Preparation Methods}

In the SIPO's Guidelines, besides the above-mentioned human embryos exclusion, there is another specific provision which explicitly precludes the granting of any patents upon "both hESCs and their preparation methods" based on Article 5(1) of the CPL. ${ }^{214}$ In 2006, this specific exclusion was introduced into the Guidelines for the first

209 See Jiangsu Wuxi Yixing Lengdong Peitai Jiufen An (江苏无锡宜兴冷冻胚胎纠纷案) [Shen Xinnan and Shao Yumei v. Liu Jinfa and Hu Xinxiang], (Intermediate People's Court of Wuxi, Xi Min Zhong Zi No. 01235, Sep. 17, 2014) (江苏省无锡市中级人民法院 (2014) 锡民终字第01235号) (China). For more discussion concerning this case, please see supra Sect. 3.3.2, Chap. 3.

210 See supra Sect. 2.3.2.1.2, Chap. 5.

211 Article 6(2) of the EU Biotech Directive provides "on the basis of paragraph 1, the following, in particular, shall be considered unpatentable: (a) processes for cloning human beings; (b) processes for modifying the germ line genetic identity of human beings; (c) uses of human embryos for industrial or commercial purposes; (d) processes for modifying the genetic identity of animals which are likely to cause them suffering without any substantial medical benefit to man or animal, and also animals resulting from such processes."

212 This can be found through comparing different editions of the Guidelines for Patent Examination, which are the 1993, 2001, 2006, and 2010 editions. See also GUOJIA ZHISHI CHANQUAN JU ZHUANLI JU SHENCHA YEWU GUANLI BU (国家知识产权局专利局审查业务管理部) [DEPARTMENT OF EXAMINATION AND BUSINESS MANAGEMENT OF THE SIPO], SHENCHA ZHINAN XIUDING DAODU 2006 (DI 2 BAN) (审查指南修订导读2006 (第二版)) [AN INTRODUCTION TO THE REVISION OF GUIDELINES FOR PATENT EXAMINATION 2006 (2ND ED.)] 220 (Zhishi Chanquan Chubanshe (知识产权出版 社) [Intellectual Property Publishing House] 2006).

213 The most likely reason for the failure to clarify the human embryo exclusion is that the EU Biotech Directive did not make clear of Article 6(2)(c). One of the significant reasons for this omission in the EU Biotech Directive is that hESCS were not specifically contemplated when drafting Article 6(2) of the EU Biotech Directive. See T-1374/04, supra note 167, at 337, para. 50.

214 Part II, Chap. 10, Sect. 9.1.1.1 of the SIPO's Guidelines. 
time. ${ }^{215}$ In the matter of the reason for introducing this exclusion, the SIPO simply noted the reason for this revision was that "due to the emergence of patent applications for hESC-related inventions, it is necessary to prevent hESCs per se and the preparation methods thereof from constituting patentable subject matter". ${ }^{216}$ So far the Guidelines, nonetheless, have not mentioned anything concerning the patent eligibility of other inventions related to hESCs, such as their downstream inventions (e.g., the enrichment and differentiation of hESCS). ${ }^{217}$

All in all, in connection with the morality assessment of patenting hESC-related inventions, there is only a general morality clause (i.e., Article 5(1) of the CPL) prescribed in the CPL. The specific list of morally controversial biotechnological inventions, including the human embryo exclusion, which can be found in the EU Biotech Directive, is only introduced into the SIPO's Guidelines based on the general morality exclusion of the CPL. The Guidelines do not give any further explanation of the human embryo exclusion. It is arguable that the lack of further explanation of the terms "human embryos" and "use of human embryos" stems from the legislative defects in the human embryo exclusion within the EU Biotech Directive. In addition, the SIPO's Guidelines do explicitly preclude the granting of any patents on "both hESCs and their preparation methods", but keep silence on patenting downstream hESC inventions. Patenting hESC-related inventions in practice, therefore, in China depends to a large extent upon how the examiners of the SIPO interpret and apply the human embryo exclusion and the exclusion of "hESCs and the preparation methods" in the Guidelines. In general, despite differences of terminology, both patent laws in Europe, including the Biotech Directive and the EPC, and Chinese patent law have used morality exclusions to assess patent eligibility of subject matter. This approach is called by Professor Margo Bagley as "ask questions first, then patent." 218

\section{POLICY APPROACHES OF PATENT OFFICES UNDER CURRENT LEGAL FRAMEWORIKS}

The previous part has investigated patent laws and related regulations, and based on this investigation one gets a preliminary impression of the patent legal frameworks as well as the differences, particularly in terms of patenting hESC-related inventions, in these three jurisdictions (i.e., the US, EU, and China). The approach of the previous section was confined to an exploration of statutes and case law practices. This section now

\footnotetext{
215 This can be found through comparing different editions of the Guidelines for Patent Examination, which are the 1993, 2001, 2006, and 2010 editions.

216 See DEPARTMENT OF EXAMINATION AND BUSInESS MANAGEMENT OF THE SIPO, supra note 212, at 220-221.

217 For more information concerning the types of hESC-related inventions, please see supra Sect. 4, Chap. 2.

218 See generally, Bagley, supra note 21.
} 
continues to deal with how patent offices of the three jurisdictions, under the current legal frameworks, cope with the patent eligibility of hESC-related inventions in patent practice. To be specific, this section first discusses the USPTO's patent policy most pertinent to patenting hESC-related inventions (Sect. 3.1). As discussed earlier, it can be seen that with regard to patenting biotechnological inventions, the EU Biotech Directive and the EPC have influenced each other profoundly. ${ }^{219}$ Moreover, in Europe, most patents currently are granted via the EPO. In this regard, when discussing patent issues in the EU it is necessary to explore the decisions in the EPO. This section primarily focuses on several decisions of the EPO (Sect. 3.2). Through this exploration it can shed light on the approaches that the EPO has adopted to tackle morally controversial biotechnological inventions, including hESC-related inventions. At last, this section of the thesis seeks to analyze a number of patent re-examinations in the SIPO (Sect. 3.3), so as to illustrate the dynamic development, and the current patent policy of China concerning patenting hESC-related inventions, as well as the rationale behind it.

\subsection{The USPTO}

The USPTO does not have the power to determine the scope and limits of patentable subject matter, but Congress, with the Supreme Court as ultimate interpreter, sets patent eligibility limits. ${ }^{220}$ Unless Congress issues any law or the Supreme Court makes decisions, the USPTO would be reluctant to impose any limitation upon subject matter eligibility. The USPTO has merely adjusted its patent policy according to the continually changing common law and patent statute. For instance, shortly after the Supreme Court's 1980 Chakrabarty decision, the USPTO started issuing patents over isolated and purified proteins, DNA sequences, and cells. ${ }^{221}$ This section mainly analyzes the patent policy of the USPTO concerning hESC-related inventions. It begins by analyzing the USPTO's patent practice regarding living organisms (Sect. 3.1.1), as well as an explicit prohibition of patents on the "human organism" (Sect. 3.1.2). Subsequently, it discusses the role that moral considerations may play in the practice of the USPTO (Sect. 3.1.3), especially considering the stormy debates that hESC research has created within governmental policies in the US. At the same time, this section explores several documents that the USPTO has issued recently, which aim to guide patent examiners in determining the patentability of a nature-based product (Sect. 3.1.4). At last, it investigates the famous WARF case before the USPTO, which is directly related to patenting hESCs (Sect. 3.1.5).

219 See supra Sects. 2.2.2 and 2.3.2, Chap. 5.

220 See Bagley, supra note 86 , at 323.

221 See Porter, supra note 80, at 9. 


\subsubsection{Patent Eligible Living Organisms}

In the US, as shown previously, the landmark decision of the Supreme Court in Diamond v. Chakrabarty not only has set down the principle that human intervention may transform a product of nature into a man-made product, but also has already opened the door for multi-cellular organism patenting. ${ }^{222}$ Indeed, the Court's Chakrabarty decision has profoundly influenced the patent practice of the USPTO concerning living matter. In 1987, Ex parte Allen before the USPTO tested the strength of the Chakrabarty decision for the first time. ${ }^{223}$ Ex parte Allen concerned a patent application claiming a genetically engineered multi-cellular organism, a polyploid Pacific coast oyster. ${ }^{224}$ The USPTO initially denied the patent application, since the invention was naturally occurring subject matter and obvious. ${ }^{225}$ Allen appealed the rejection to the Board of Patent Appeals and Interferences (BPAI). The BPAI then determined that patentable subject matter under 35 USC $\S 101$ should extend to man-made life forms. Thus, when observing that the organism was not found in nature in this manipulated state, the BPAI held the organism was patentable subject matter as a man-made invention. ${ }^{226}$ Shortly following the Allen decision, the USPTO announced that it would grant patents upon non-naturally occurring, nonhuman multicellular living organisms, including animals, within the scope of 35 USC $\S 101$. The USPTO also stressed that, in order to be patent eligible, a living organism must be "given a new form, quality, properties or combination not present in the original article existing in nature in accordance with existing law."227

\subsubsection{Bar on Patenting "Human Organism"}

As discussed earlier, the courts of the US historically had incorporated moral judgment into the utility requirement. Correspondingly, based on the judicially created "moral utility" doctrine, the USPTO also used to deny granting patent upon inventions, which were deemed to be "injurious to the well being, good policy, or good morals of society." 228 For instance, in 1999 the USPTO declared its position that inventions directed to human or non-human chimera could not be patented due to the public policy and morality considerations. ${ }^{229}$ Recently, as the common law of the US has gradually abandoned the "moral utility" doctrine, moral issues have had limited place in the US patent law, and correspondingly the USPTO gave up using the "moral utility" doctrine in its patent prac-

222 See also Carrie F Walter, Beyond the Harvard Mouse: Current Patent Practice and the Necessity of Clear Guidelines in Biotechnology Patent Law, 73 IndIANA LAW JouRnAL 1025, 1036 (1997).

223 See id.

224 See generally, Ex parte Allen, 2 USPQ2d 1425 (Bd. Pat. App. \& Inter. 1987).

225 See id., at 1426.

226 See id., at 1427 (Although the Board considered genetically engineering oysters to be patentable, in the end it still rejected the patent application on the grounds of obviousness.)

227 Notice: Animals-Patentability, 1077 Official Gazette US Pat. \& Trademark Off. 8 (Apr. 21, 1987).

228 Lowell v. Lewis, supra note 129.

229 Facts on Patenting Life Forms Having a Relationship to Humans, THE UnITED STATES PATENT AND TRADEMARK OFFICE, (Apr. 01, 1998), http://www.uspto.gov/news/pr/1998/98-06.jsp. 
tice. However, even so, the patent policy of the USPTO concerning inventions directed to human or non-human chimera has been incorporated into Section 33 of the AIA. ${ }^{230}$ In this regard, the USPTO's existing policy which imposed a bar on patenting human organisms on moral grounds has in effect been confirmed by the US patent statute. ${ }^{231}$ In an internal memorandum of September 20, 2011, the USPTO informed its examiners that the newly incorporated clause merely codified existing USPTO's policy that human organisms are not patent eligible. ${ }^{232}$ In turn, based on Section 33 of the AIA, the USPTO's 2015 MPEP specifically excludes "a human per se" from patent eligibility. ${ }^{233}$

As a result, interestingly, while currently moral issues have had a very limited place in the US patent law, the AIA has incorporated the USPTO's previous position concerning inventions directed to human or non-human chimera, which was mainly based on moral consideration. From this perspective, it is not that the US patent law does not respond to moral concerns, but in the US the moral issues concerning patents should be left to Congress to deal with, since no general morality clause provided in the US patent law confers the authority to the courts or the USPTO to assess morality when determining patentability.

\subsubsection{Morality Judgment in the USPTO}

Regarding utilizing moral arguments, there has been only one case where the USPTO denied in part a patent application which involved a chimera. In December 1997, Stuart Newman and Jeremy Rifkin filed a patent application for combining human and nonhuman embryonic cells to develop a human-animal chimera. ${ }^{234}$ The USPTO rejected the patent claim since it observed that the claimed inventions might be interpreted to encompass a human being. ${ }^{235}$ The USPTO held that inventions involving a human/ non-human chimera could, under certain circumstances, not be patentable, particularly since they would fail to meet the public policy and morality aspects of the utility requirement. ${ }^{236}$

230 See supra Sect. 2.2.1.1, Chap. 5.

231 See $\$ 2105$ of the USPTO's MPEP.

232 See Ulrich Storz, The Limits of Patentability: Stem Cells, in Limits of PATENTABILITY: PLANT SCIENCES, STEM CELLS AND NUCLEIC ACIDS 19 (Andreas Hübel, et al. ed., Springer 2013).

233 See $\S 2106$ of the USPTO's MPEP.

234 US patent application No. 08/993,563. See also Sander Rabin, The Human Use of Humanoid Beings: Chimeras and Patent Law, 24 NATURe BioteChnology 517, 517 (2006); Audrey R Chapman, The Ethics of Patenting Human Embryonic Stem Cells, 19 KEnNEDY INSTITUTE OF ETHICS JOURNAL 261, 264 (2009) (the aim of filing such a patent application was to bring attention to questions concerning the ethics of genetic engineering and the appropriateness of patenting engineered life forms.)

235 See Rabin, supra note 234, at 517.

236 Seeid. 
However, as the judicially created moral utility requirement is currently defunct, the USPTO correspondingly has refused to impose the requirement at all. The USPTO does not consider it the proper purview to reject a patent on moral grounds. For instance, in responding to opponents of granting patents to DNA on the grounds of public good, the USPTO declared that " $[\mathrm{t}]$ he scope of subject matter that is eligible for a patent, the requirements that must be met in order to be granted a patent, and the legal rights that are conveyed by an issued patent, are all controlled by statutes which the USPTO must administer.... Congress creates the law and the Federal judiciary interprets the law. The USPTO must administer the laws as Congress has enacted them and as the Federal courts have interpreted them. Current law provides that when the statutory patentability requirements are met, there is no basis to deny patent applications." ${ }^{237}$ Consequently, the USPTO does not conduct any morality assessment of inventions when determining their patentability, and has issued increasing numbers of patents on arguably morally controversial biotechnological inventions since the Chakrabarty case flung open the doors of the USTPO to biotech subject matter. ${ }^{238}$

\subsubsection{Products of Nature}

Based on the judicial exception, the "products of nature" doctrine, the USPTO has to assess whether patent applications fall into this category. Meanwhile, recently the Supreme Court has made several decisions, such as Myriad and Mayo Collaborative Services v. Prometheus Laboratories, Inc. (Mayo), ${ }^{239}$ that may influence the determination of patentable subject matter that is derived from natural sources or products. Given this, the USPTO has correspondingly adjusted its patent practice policy. This section investigates the patent examination policy of the USPTO particularly concerning the "products of nature" doctrine. To be specific, the first part of this section analyzes a guidance memorandum issued by the USPTO (Sect. 3.1.4.1) which aims to solve the implications of the Myriad case and Mayo case. Subsequently, the second part of this section explores an interim guidance of the USPTO (Sect. 3.1.4.2) which illustrates a further development concerning the judicial "product of nature" exception.

\subsubsection{Myriad-Mayo Guidance}

In order to solve changes in the law relating to subject matter eligibility under 35 USC $\S 101$ in light of recent court decisions, particularly including the Myriad and Mayo decisions, the USPTO issued a guidance memorandum titled Guidance for Determining Subject Matter Eligibility of Claims Reciting or Involving Laws of Nature, Natural

237 Examination Guidelines for the Utility Requirement, 66 Fed. Reg. 1092, 1095 (Jan. 5, 2001).

238 See Bagley, supra note 86, at 322.

239 See Mayo Collaborative Servs. v. Prometheus Labs., Inc., supra note 39. 
Phenomena, \& Nature Products (hereafter Myriad-Mayo Guidance) on March 4, $2014 .{ }^{240}$ Although the primary aim of the Myriad-Mayo Guidance is to address the impact of the Myriad decision, ${ }^{241}$ and the holding in the Myriad case was limited to isolated DNA, this Guidance goes far beyond to encompass a wide array of subject matter. ${ }^{242}$ In the Myriad-Mayo Guidance, the USPTO requires its examiner to answer three questions under 35 USC $\S 101$ when determining the patent eligibility of a claimed invention. ${ }^{243}$ To be specific, the first step requires an examiner to assess whether the claimed invention is directed to one of the four statutory patent-eligible subject matter categories: a process, machine, manufacture, or composition of matter. The second step requires a determination as to whether the claim involves one or more judicial exceptions. If the claim is directed to one of the judicial exceptions, the examiner should answer the third question, to decide whether the claimed invention as a whole is significantly different from the judicial exception(s).

In terms of natural products, the Myriad-Mayo Guidance has provided multiple examples, among which organisms (e.g., bacteria, plants and multicellular animals) are explicitly mentioned, ${ }^{244}$ without referring to stem cells or hESCs. However, based on the breadth of this Guidance, hESCs and its differentiated cells should be examined according to the third question. As can be seen from the above-mentioned three questions, the Myriad-Mayo Guidance in effect requires not only that the claimed invention be non-naturally occurring and different from natural products, but also that the differences be significant or marked. ${ }^{245}$ It is worth noting that the differences referred to in this Guidance are merely required in structure. The Myriad-Mayo Guidance does not consider all differences to rise to the level of marked differences, and it takes isolating DNA as an example: in the Myriad case, the differences in structure between a merely isolated nucleic acid and its naturally occurring counterpart should not be considered

240 USPTO, Guidance for Determining Subject Matter Eligibility of Claims Reciting Or Involving Laws of Nature, Natural Phenomena, \& Natural Products (the Myriad-Mayo Guidance), issued on March 4, 2014, http:// www.uspto.gov/patent/patents-announcements/guidance-determining-subject-matter-eligibility-claimsreciting-or (the Myriad-Mayo Guidance is mainly used for determining the patent eligibility of "all claims (i.e., machine, composition, manufacture and process claims) reciting or involving laws of nature/natural principles, natural phenomena, and/or natural products." However, there is no change to examination of claims reciting an abstract idea, which would continue to be analyzed for subject matter eligibility using the existing guidance in MPEP § $2106($ II).)

241 Seeid.

242 See id., at 1 ("while the holding in Myriad was limited to nucleic acids, Myriad is a reminder that claims reciting or involving natural products should be examined for a marked difference under Chakrabarty"); See also Sarah E Fendrick \& Donald L Zuhn, Patentability of Stem Cells in the United States, 5: a020958 CoLD SPRING HARB PERSPECT MED 1, 3 (2015).

243 See the Myriad-Mayo Guidance, supra note 240, at 2-3.

244 See id., at 3.

245 In accordance with the Myriad-Mayo Guidance, when examining the claimed inventions, the USPTO should ask (Question 3 in the Guidance) "does the claim as a whole recite something significantly different than the judicial exception(s)?" 
to be marked, since the changes in structure are only due to breaking bonds rather than changing the nucleotide sequence. ${ }^{246}$

Throughout the Myriad-Mayo Guidance, there is no wording mentioning stem cells or hESCs. However, it is believed that this Guidance is not only limited to the specific subject matter at issue in Myriad, and it would extend to any natural product, including stem cell claims. ${ }^{247}$ It is currently uncertain as to how the USPTO would apply this "marked difference" test to isolated hESCs. As such, the current patent policy of the USPTO concerning isolated hESCs is on unstable ground. But if the patent applicants can present evidence to prove that the claimed hESCs are markedly different from their naturally occurring counterparts in structure, these claimed hESCs still can be patented.

\subsubsection{Interim Eligibility Guidance}

On December 16, 2014, in order to address and clarify several issues based on some of the public comments upon the Myriad-Mayo Guidance, the USPTO further released the Interim Guidance on Patent Subject Matter Eligibility (hereafter 2014 Interim Eligibility Guidance or 2014 IEG). ${ }^{248}$ The USPTO points out that the analysis set forth in the 2014 IEG differs from the Myriad-Mayo Guidance in certain respects. ${ }^{249}$ The USPTO specifically states that the 2014 IEG "offers a comprehensive view of subject matter eligibility in line with Alice Corp, ${ }^{250}$ Myriad, Mayo, and the related body of case law" and "promotes examination efficiency and consistency across all technologies." ${ }^{251}$ In the 2014 IEG, the three-step test for determining whether a product or process is patent eligible under 35 USC $\S 101$ is almost the same as the three-questions test required in the Myriad-Mayo Guidance. Moreover, the overriding test in the matter of patent eligibility applied in the 2014 IEG is also similar to that of the Myriad-Mayo Guidance, that a patent eligible product must be "significantly different from the product as it occurs in nature."

246 See the Myriad-Mayo Guidance, supra note 240, at 5.

247 See Fendrick \& Zuhn, supra note 242, at 4.

248 USPTO, 2014 Interim Guidance on Patent Subject Matter Eligibility, 79 FR. Reg. 74618 (Dec. 16, 2014). See also Hoxha, supra note 36 , at 587.

249 See Footnote 2 in USPTO's 2014 IEG (stating that "[t]his analysis differs from the March 2014 Procedure in certain respects. Note, for example, the test for determining whether a claim is directed to a "product of nature" exception is separated from the analysis of whether the claim includes significantly more than the exception. Also, the application of the overall analysis is based on claims directed to judicial exceptions (defined as claims reciting the exception, i.e., set forth or described), rather than claims merely "involving" an exception. For instance, process claims that merely use a nature-based product are not necessarily subject to an analysis for markedly different characteristics. Additionally, the markedly different analysis focuses on characteristics that can include a product's structure, function, and/or other properties as compared to its naturally occurring counterpart in its natural state.")

250 See Alice Corporation Pty. Ltd. v. CLS Bank International, 573 US __, 134 S. Ct. 2347 (2014).

251 USPTO'S IEG, supra note 248, at 74619-74620.

252 See David E Eyre \& George W Schlich, Patenting Stem Cell Technologies Following Guidelines issued by the EPO, USPTO, JPO and SIPO, 4 PHARMACEUTICAL PATENT ANALYST 431(2015). 
Unlike the Myriad-Mayo Guidance, in which only structural changes are sufficient to show a marked difference, the 2014 IEG states that "changes in functional characteristics and other non-structural properties" also can evidence markedly different characteristics. ${ }^{253}$ Given this, markedly different characteristics can be expressed not only as the product's structure, but also as its function, and/or other properties. In addition, the 2014 IEG notes that "even a small change can result in markedly different characteristics from the product's naturally occurring counterpart." ${ }^{254}$ However, in accordance with this document, a difference in characteristic that resulted independently of any effort or influence by the applicant cannot be interpreted as marked difference. ${ }^{255}$ This requirement is very challenging, since it requires that the inventors not only be aware of the end result they are trying to attain, but also the molecular and genetic details that lead to the process, at the time of filing patent applications. ${ }^{256}$

Based on the test that the 2014 IEG has laid down, the Nature-Based Product Examples, issued by the USPTO on December 16, 2014, provide a set of examples, in which Example 9 expressly refers to human cells (e.g., pacemaker cells), differentiated from stem cells. ${ }^{257}$ The 2014 Nature-Based Product Examples emphasize that a nature-based product should be analyzed to determine whether it has "markedly different characteristics from any naturally occurring counterpart(s) in their natural state." 258 Mere isolation of the man-made cells does not change them in any way. The claimed cells that are identical to what exists in nature (e.g., same genotype and phenotype) do not have markedly different characteristics, and thus fall into the judicial "product of nature" exception. ${ }^{259}$ However, man-made cells that are phenotypically different than natural pacemaker cells (e.g., able to express marker $Z$ and have increased oxygen utilization efficiency) are considered to be markedly different, and accordingly not a "product of nature" exception. ${ }^{260}$

\subsubsection{WARF's Patents in the US}

In 1998, James Thomson became one of the first researchers to develop specific procedures for isolating, purifying and maintaining hESCs. ${ }^{261}$ Before Thomson published his

253 See Footnote 27 in USPTO's IEG, supra note 248, at 74623.

254 See id., at 74623.

255 See id., footnote 28.

256 See Hoxha, supra note 36, at 589.

257 See USPTO, Nature-Based Product Examples, (16 Dec. 2014), http://www.uspto.gov/patents/law/exam/ mdc_examples_nature-based_products.pdf (Pacemaker cells are able to generate electrical impulses to directly control the heart rate.)

258 Id., at 14.

259 See id., at 14.

260 See id., at 13-14 ("the pace maker cells contain genes that are capable of expressing a protein called marker Z, but in nature these genes are never expressed (there are no naturally occurring pacemaker cells that have marker Z on their surface).")

261 See Thomson, et al., supra note 168. 
work on the isolated primate ESC lines, he had filed patent applications, within which the inventions covered three key features: (i) the ESCs isolated per se, (ii) the process for isolating ESCs, and (iii) the process of maintaining these pluripotent cells. ${ }^{262}$ Correspondingly, the USPTO issued Thomson three basic patents and he assigned these patent rights to the University of Wisconsin Alumni Research Foundation (WARF), which later on licensed these rights to a commercial corporation. ${ }^{263}$

Over the past ten years WARF's three patents concerning hESCs and the isolating methods, however, have actually been seriously challenged by two public interest groups, Consumer Watchdog (formerly known as California's Foundation for Taxpayer and Consumer Rights) and New York's Public Patent Foundation. On 18 July 2006, the groups filed formal requests with the USPTO to revoke WARF's three patents for the reason that these patents were overreaching and "significantly undermine research and waste taxpayer money". ${ }^{264}$ Subsequently, the USPTO reviewed the patents and decided to reject the claims in each of the involved patents, considering them obvious in light of previous scientific research. In response to the USPTO's rejection, WARF then appealed and modified the claims. WARF narrowed the claims and announced more favorable licensing requirements for the patents during the challenge. ${ }^{265}$ Then the USPTO determined that the modified claims in each of the challenged patents were directed to patent-eligible subject matter; it reversed its ruling and decided to reissue patents based on the narrowed claims. ${ }^{266}$

In 2008, Consumer Watchdog and the Public Patent Foundation filed an appeal to the BPAI of the USPTO concerning WARF's US Patent 7,029,913 (the ' 913 patent). ${ }^{267}$ The BPAl at first rejected the ' 913 patent claims, ${ }^{268}$ but subsequently reversed their decision

262 See id. See also Hoxha, supra note 36 , at 590.

263 The WARF patents include Patent US5,843,780 (filed Jan. 18, 1996); Patent US6,200,806 (filed June 26, 1998); Patent US7,029,913 (filed Oct. 18, 2001).

264 Santa Monica, Groups Challenge Stem Cell Patents That Loot Taxpayer Funds and Force Research Overseas, PUBPAT, (Jul. 18, 2006), http://www.pubpat.org/warfstemcellsfiled.htm. See also E Kintisch, Groups Challenge Key Stem Cell Patents, 313 SCIENCE 281, 281 (2006) (WARF required that university researchers and those at other nonprofit institutions acquire licenses before they used the cells lines. Harvard University pancreatic researcher Douglas Melton called WARF's licensing terms "onerous, restrictive, and uncooperative" barriers to cures.)

265 See Fendrick \& Zuhn, supra note 242, at 5.

266 See John M Simpson, Consumer Groups File Appeal in Challenge of Human Stem Cell Patent Held by WARF, CONSUMER WATCHDOG, (Jul. 18 2008), http://www.consumerwatchdog.org/newsrelease/consumer-groupsfile-appeal-challenge-human-stem-cell-patent-held-warf.

267 See id. Since the re-examinations of the '780 and '806 patents were ex parte re-examinations, the final decisions of the two could not be appealed. But the re-examination of the '913 patent was inter partes re-examination, and thus it could be appealed.

268 See Kathleen Gallagher, WARF Loses a Round in Stem Cell Patent Dispute, JouRnAL Sentinel, (May. 3, 2010), http://archive.jsonline.com/business/92682039.html/. 
based on a previous "flawed understanding of facts". ${ }^{269}$ In 2013, Consumer Watchdog continued to file an appeal to the CAFC to challenge the patentability of claims 1-4 of the '913 patent. ${ }^{270}$ Consumer Watchdog held the argument that the work done in the '913 patent was too similar to previous research on mouse embryonic stem cells, and applying it to hESCs was obvious to anyone skilled in the field. ${ }^{271}$ Additionally, Consumer Watchdog argued that the claims of the '913 patent fell within the judicial subject matter exception "product of nature", by drawing analogies between its appeal and the Myriad case. ${ }^{272}$

On January 17,2014 , the USPTO responded to a request by the CAFC panel regarding Consumer Watchdog's standing in this appeal. The USPTO argued that Consumer Watchdog lacked standing to appeal the USPTO's decision, since Consumer Watchdog had no "concrete or particularized interest" in the issue of the '913 patent, did not face a plausible risk of an infringement claim, and even failed to show any "injury or harm" to justify an appeal. On June 4, 2014, the CAFC decided to dismiss the appeal since that Consumer Watchdog had not proved that it had legal grounds or "standing" to sue. ${ }^{273}$ Specifically, the CAFC observed that Consumer Watchdog did not allege any activity involving hESCs or any connection to the '913 patent or the claimed subject matter. ${ }^{274}$ Based on the dismissal of this case, the CAFC did not give any opinion regarding the patentability of hESCs and their isolating methods, which leaves the issue for other days. ${ }^{275}$

All in all, influenced by the Chakrabarty case, the USPTO has opened the door to granting patents for living organisms which are considered man-made inventions. The USPTO has not issued any official documents to specifically exclude hESC-related inventions from patent eligibility. As the moral utility requirement in US patent law has been currently abandoned, ${ }^{276}$ moral issues have no place in assessing the patentability before the USTPO. Given this, the most likely obstacle that may prevent granting any patents over hESCs is the judicially created "products of nature" doctrine. In order to determine

269 See Bradley J Fikes, New Stem Cell Patent Action Filed, The SAn Diego Union-Tribune, (Jul. 2, 2013), http:// www.sandiegouniontribune.com/business/biotech/sdut-warf-patent-stem-2013jul02-story.html.

270 See Consumer Watchdog v. Wisconsin Alumni Research Found., 753 F.3d 1258 (Fed. Cir. 2014).

271 Seeid.

272 See id.

273 See id. (the CAFC noted that Consumer Watchdog had not established an injury, which is in fact necessary for Article III standing. The CAFC "do not have authority to entertain every dispute. Relevant to this appeal, Article III only allows the federal courts to adjudicate 'Cases' and 'Controversies'." See US Const. Art. III, § 2, Cl. 1. In addition, in its decision, the CAFC pointed out that although Article II standing is not necessarily a requirement to appear before an administrative agency, such as the USPTO, it must be satisfied once a party seeks review in a federal court.)

274 See id. (the CAFC also observed that "as Consumer Watchdog only has a general grievance against the '913 patent, the 'conjectural or hypothetical' nature of any injury flowing from the estoppel provisions is insufficient to confer standing upon Consumer Watchdog.")

275 See Fendrick \& Zuhn, supra note 242, at 6.

276 See supra Sect. 2.3.1.1, Chap. 5. 
whether a claimed nature-based product, including hESCs, falls within the "products of nature" exception, through the Myriad-Mayo Guidance and the 2014 IEG as well as its updates, the USPTO has set forth a "marked difference" test. Under the "marked difference" test, the differences can be structural, functional or other properties'. The marked difference in characteristics should be dependent on effort or influence by the applicant.

It is worth noting that the date on which the USPTO issued its re-examination decision of WARF's patents was, in fact, prior to the Supreme Court's Myriad case. Given this, had the USPTO taken account of the implication of the Myriad case as well as its own Myriad-Mayo Guidance and the 2014 IEG, then the final decision of the re-examination might have turned out another way. Based on the "marked difference" test, it is perfectly possible a merely isolated hESC cannot be patent eligible, since it might be considered to not be changing the stem cell in any way. It would be a great opportunity for the CAFC in the Consumer Watchdog v. WARF case to clarify the patent eligibility of hESC-related inventions, but unfortunately the CAFC has dismissed this case, and did not give any opinion regarding the patentability, which leaves the issue for the future.

\subsection{The EPO}

Unlike the USPTO, which primarily focuses on applying the "products of nature" doctrine to determining the patent eligibility of hESC-related inventions, the EPO mainly concentrates on moral concerns regarding these inventions. Over the past two decades, the EPO has been called on several times to determine if inventions should be denied patent protection under the general morality clause (i.e., Article 53(a) EPC). In fact, through these decisions the EPO has principally developed some approaches and standards to help in assessing ordre public or morality when determining the patent eligibility of morally controversial biotechnological inventions. The exploration of cases in the EPO may shed light on both benefits and challenges, as well as how to apply the general morality provision in a practical sense in a fair way. It also will help the analysis of decisions directly with regard to hESC-related inventions in the EPO later on. This section first analyzes several cases, including Harvard/Oncomouse (Sect. 3.2.1), Greenpeace v. Plant Genetic Systems (Sect. 3.2.2), and Howard Florey/Relaxin (Sect. 3.2.3), so as to reveal the underlying approaches and standards that the EPO has adopted when applying the general morality exclusion. Subsequently, it discusses both benefits and challenges that these approaches and standards may bring about to the patent system (Sect. 3.2.4). Finally, this section focuses on recent decisions that the EPO has made, which directly dealt with the patent eligibility of hESC-related inventions (Sect. 3.2.5). 


\subsubsection{Harvard/Oncomouse}

In the famous 1990 Harvard/Oncomouse case, the EPO gauged the morality of an invention under Article 53(a) EPC, and the invention concerned a genetically modified or transgenic mouse that can be used in cancer research. ${ }^{277}$ At first, the Examining Division (ED) refused to apply Article 53(a) EPC to the Oncomouse, since the ED considered it inappropriate to regulate problems arising in relation to genetic modification of organisms via the general morality clause. ${ }^{278}$ However, on appeal the Technical Board of Appeal (TBA) disagreed with the ED, and asserted that in a case of this kind there were "compelling reasons to consider the implications of Article 53(a) EPC in relation to the question of patentability." 279 In the meantime, the TBA set out a morality test approach, which entailed "a careful weighing up of the suffering of animals and possible risks to the environment on the one hand, and the invention's usefulness to mankind on the other." 280 In this regard, the TBA proposed three interests that needed to be balanced: the interest in preventing cruelty to animals, the protection of environment, and the interest in remedying human diseases. ${ }^{281}$

Based on the position, the case was remitted to the ED, and the "balancing exercise" approach was subsequently applied for the first time. In the decision, the ED held that "[f]or each individual invention [involving higher life forms] the question of morality has to be examined and possible detrimental effects and risks have to be weighed and balanced against the merits and advantages aimed at." ${ }^{282}$ When balancing the three interests, the ED highly appreciated the great benefit that the Oncomouse might bring to mankind, since the test animal was useful in cancer research. ${ }^{283}$ The ED did not consider the concerns about unforeseen environmental problems which the genetically altered animals might cause as an obstacle to the patent, since the ED felt that the modified animals would be only used exclusively in the laboratory, and no release was intended into the general environment. ${ }^{284}$ Moreover, concerning the interest in avoiding cruelty to animals, the ED asserted that although there would be more animals suffering painful cancer as a result of introducing foreign oncogenes, the invention would contribute to a reduction of the overall extent of animal suffering. ${ }^{285}$ This implied that the ED considered the suffering caused to animals in the invention would be acceptable based on overall considerations. Indeed, the ED concluded that, in the overall balance,

\footnotetext{
277 See T 19/90 (Harvard/Oncomouse) OJ EPO 469, 476 [1990].

278 See id., at 490, point 5 of the Reasons.

279 ld

280 Id

281 See Bagley, supra note 86, at 331.

282 Harvard/Oncomouse, Communication about Intention to Grant a European Patent, the Examining Division, 4 Oct., 1991, page 3, point 3, para. 4 of the Comments.

283 See id., at 4, point 4 (i) of the Comments.

284 See id., at 5, point 4 (iv) of the Comments.

285 See id., at 4, point 4 (ii) of the Comments.
} 
the invention "can generally be regarded as beneficial to mankind" and should not be considered immoral or contrary to public order. ${ }^{286}$

By applying such a "balancing exercise" approach, the ED in fact implicitly adopted an "unacceptability" standard for evaluating the morality of the invention in Harvard/ Oncomouse. As the ED pointed out, "[the suffering caused to animals and risks posed to the environment] may well justify regarding an invention as immoral and therefore unacceptable unless the advantages, i.e., the benefit to mankind, outweigh the negative aspects." 287 In addition, the "unacceptability" standard adopted in Harvard/Oncomouse was confirmed by the TBA when the Board explicitly held that the degree of suffering by animals did not need to be considered, ${ }^{288}$ which once again demonstrates that there could be "acceptable suffering." ${ }^{289}$ Consequently, in Harvard/Oncomouse the EPO has applied an "unacceptability" standard and a "balancing exercise" approach to evaluate the morality of an invention under Article 53(a) EPC. ${ }^{290}$

\subsubsection{Greenpeace v. Plant Genetic Systems}

In the 1995 Greenpeace v. Plant Genetic Systems (PGS) case, the EPO once again was confronted with the evaluation of ordre public or morality of an invention under Article 53(a) EPC. ${ }^{291}$ In this case, the opponents, Greenpeace, attempted to revoke a patent on transgenic plants developed to be resistant to a particular class of herbicides based on Article 53(a) EPC. ${ }^{292}$ Specifically, the opponents challenged the patent based on "the alleged environmental consequences" as well as "concerns about the dominion gained by man over the natural world" ${ }^{293}$ When applying Article 53(a) EPC, the TBA described the concept of morality as relating to the belief in European society that some behavior was right and acceptable whereas other behavior was wrong, this belief being founded on "conventionally-accepted standards" inherent in "European society and civilisation." 294 When evaluating the morality of the invention at suit, the TBA first pointed out the impressive potential of plant biotechnology. ${ }^{295}$ Then, the TBA neither found that plant biotechnology rendered "activities in this technical field intrinsically

\footnotetext{
286 See id., point 4 (v) of the Comments.

287 See id., point 4, para. 1 of the Comments.

288 See T315/03 (Oncomouse II) OJ EPO [2005], para. 9.4 of Reasons.

289 See Amanda Warren-Jones, Vital Parameters for Patent Morality-A Question of Form, 2 JOURNAL OF INTELLECTUAL PROPERTY LAW \& PRACTICE 832, 837 (2007).

290 Seeid.

291 See T 356/93 (Plant cells), supra note 179 (The invention in this suit concerned developing plants and seeds which were resistant to a particular class of herbicides (e.g., glutamine synthetize inhibitors) and, thus, were selectively protected against weeds and fungal diseases.)

292 Seeid.

293 See id., point 16 of the Reasons.

294 See id., point 6 of the Reasons.

295 See id., point 17.1 of the Reasons.
} 
wrong," 296 nor observed that the subject matter claimed in the inventions was related to a misuse or destructive use of plant biotechnological techniques. ${ }^{297}$ The TBA therefore ruled that the invention was not in violation of the conventionally accepted standards of conduct of European culture. As can be seen, in this case the TBA also tied patent eligibility to the "public acceptability" of the general categories of subject matter. ${ }^{298}$ However, as opposed to Oncomouse, in which the two terms ordre public and morality were treated conjunctively, in PGS the TBA treated them separately. The TBA defined ordre public as pertinent to the protection of public security and the environment. ${ }^{299}$ The TBA considered the documentary evidence presented by the opponents to be "not sufficient to substantiate the existence of a threat to the environment such as to represent a bar to patentability under Article 53(a) EPC."300

When discussing what approach should be applied in terms of assessing morality and ordre public in this case, the TBA held that the "balancing exercise" was not the only way of assessing the patent eligibility of an invention under Article 53(a) EPC, but "just one possible way, perhaps useful in situations in which an actual damage [e.g., suffering of animals] ... exists." ${ }^{301}$ Since "no sufficient evidence of actual disadvantages has been adduced," the TBA decided not to apply the "balancing exercise" approach which was utilized in Harvard/Oncomouse. ${ }^{302}$

\subsubsection{Howard Florey/Relaxin}

In the 1995 Howard Florey/Relaxin (hereafter Relaxin) case, a patent on the hormone Relaxin was opposed before the EPO on the grounds that the patent covered human genes and involved taking tissue from a pregnant woman and, thus, was argued to constitute a violation of Article 53(a) EPC. ${ }^{303}$ The OD of the EPO disagreed with the objections. The OD described the function of Article 53(a) EPC as "a measure to ensure that patents would not be granted for inventions universally regarded as outrageous. This interpretation is reflected in the relevant passages of the Guidelines (C-IV, 3.1). There it is stated that Article 53(a) is likely to be invoked only in rare and extreme cases." ${ }^{304}$ The OD further articulated the "abhorrence" standard that "[a] fair test to apply is to consider whether it is probable that the public in general would regard the invention as

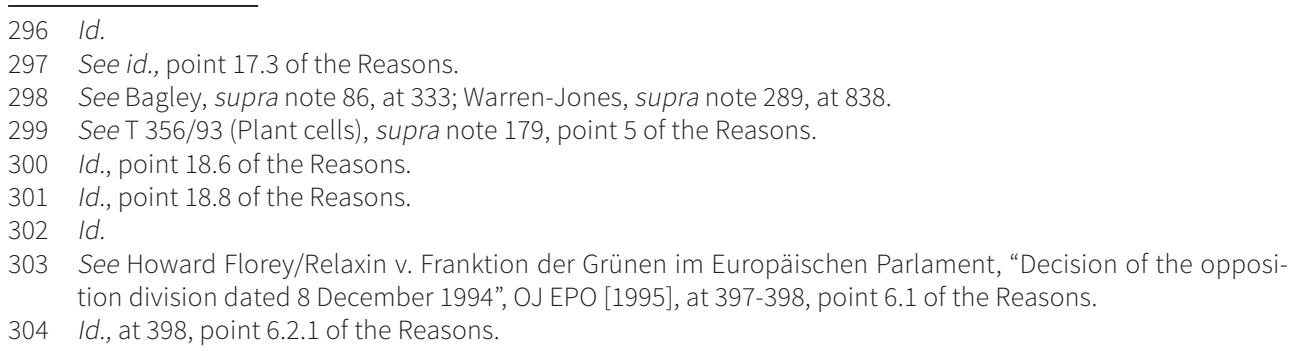


so abhorrent that the grant of patent rights would be inconceivable. If it is clear that this is the case, objection should be raised under Article 53(a); otherwise not." ${ }^{305}$

The OD, therefore, applied an "abhorrence" standard to assess the morality of the invention in suit. The OD emphatically rejected the opponents' arguments, since it did not find the invention abhorrent for the vast majority of the public amongst the contracting states. ${ }^{306}$ The OD referred to several examples which would be abhorrent to the overwhelming majority of the public, such as inventions involved the patenting of life, an abuse of pregnant women, or a return to slavery and the piecemeal sale of women. ${ }^{307}$ Meanwhile, the OD acknowledged that there were a very limited number of cases in which inventions might meet the "abhorrence" standard. ${ }^{308}$ Thus, it is evident that the standard that the OD has adopted in the Relaxin case is the "abhorrence" standard. What is more, concerning the approach that the OD has applied together so as to reach the "abhorrence" standard, Amanda Warren-Jones described it as a "rebuttable presumption" approach, ${ }^{309}$ which is utilized "where the presence of moral aspects raises a favorable presumption, which the immoral aspects can only rebut where they are so significant that a favorable decision would be untenable". 310

\subsubsection{Approaches and Standards to Apply the General Morality Provision}

As can be seen from the cases analyzed above, in order to help assess the morality regarding patent eligibility under Article 53(a) EPC (i.e., the general morality clause), primarily the EPO has established two approaches for its moral decision-making: the "balancing exercise" and the "rebuttable presumption". In the "balancing exercise" approach, the issues are considered together to be competing and contradictory claims. This approach permits a negative decision to be reached even where the moral and immoral issues are closely tied, making the outcome potentially highly controversial. ${ }^{311}$ Commentators also have pointed out that one significant flaw of the "balancing exercise" approach is that it may be difficult to give explanations regarding the rational basis for choosing those specific factors to balance, as well as to provide a method for assessing those factors. ${ }^{312}$ Despite this criticism, until now there seems to have been little repugnance towards the invention in Harvard/Oncomouse expressed by the public. ${ }^{313}$ In contrast, the "rebuttable presumption" approach mainly focuses on detecting

\footnotetext{
305 Id. See also G-II, 4.1, the EPO's Guidelines for Examination.

306 See Howard Florey/Relaxin v. Franktion der Grünen im Europäischen Parlament, supra note 303, at 399-402, points 6.3.1-6.4.4 of the Reasons.

307 See id., at 399, point 6.3 of the Reasons.

308 Id., at 403, point 6.5 of the Reasons.

309 See Warren-Jones, supra note 289, at 838.

310 Seeid., at 834.

311 Seeid., at 835.

312 See Bagley, supra note 86, at 332; MILLS, supra note 133, at 60.

313 See id.
} 
the strongest immorality. ${ }^{314}$ In this regard, a decision made through this approach will be irrefutable. ${ }^{315}$

Meanwhile, the EPO has set up two standards to gauge the morality of an invention: the "unacceptability" standard and the "abhorrence" standard. The standard of morality is fundamentally linked to the approach. Put another way, the "unacceptability" standard is inextricably linked to the "balancing exercise" approach, and "abhorrence" can merely be reached by adopting a "rebuttable presumption" approach. ${ }^{316}$ Under the "unacceptability" standard, the decision seems to be more conscious and rational, but under the "abhorrence" standard decision is largely intuitive and may have no discernible means of validation. ${ }^{317}$ Comparing the two standards, it is not difficult to observe that the "abhorrence" standard provides an even lower hurdle to remove a morally controversial invention from patent eligibility than the "unacceptability" standard. Many inventions which may be deemed "unacceptable" would not be considered to be abhorrent to the public. ${ }^{318}$ Applying the "abhorrence" threshold increases legal certainty, which can send a clear message to anyone wishing to pick the invention up in order to exploit it. ${ }^{319}$ In this regard, the "abhorrence" standard is much more favorable to the patentee than the "unacceptability" standard, since the former represents more legal certainty and only a few categories of subject matter could be excluded from patent eligibility. The "abhorrence" standard needs an overwhelming consensus in a society upon an immoral invention. In the context of the EPC, consensus among Contracting States should be the controlling factor. ${ }^{320}$ However, there is no intrinsic power in the EPO or other European institutions to decide what inventions should be considered abhorrent. ${ }^{321}$ In this regard, the "abhorrence" standard in effect gives EPO Contracting States the discretion to take moral considerations into account in the determination of patent eligibility. That is, it appears that there was no intention to allow the EPO wider latitude in determining moral issues. ${ }^{322}$

\subsubsection{Decisions Regarding hESC-related Inventions}

In addition to the abovementioned representative EPO decisions concerning assessing moral issues of inventions under the general morality clause (i.e., Article 53(a) EPC), there are several other decisions in which the EPO has directly dealt with the patent

\footnotetext{
314 See Warren-Jones, supra note 289, at 834.

315 See id., at 835.

316 Seeid.

317 See id.

318 See Bagley, supra note 86 , at 333.

319 See Warren-Jones, supra note 289, at 839.

320 See MILLS, supra note 133, at 62.

321 Seeid.

322 Seeid., at 63.
} 
eligibility of hESC-related inventions under morality exclusions over the past decades. This section continues to investigate these cases, including Edinburgh case (Sect. 3.2.5.1), European WARF case (Sect. 3.2.5.2), and the TECHNION case (Sect. 3.2.5.3).

\subsubsection{Edinburgh Patent}

The 2003 decision of the Edinburgh patent in the EPO in effect is the first of its type concerning hESC-related inventions. ${ }^{323}$ This case involved the methods of isolating stem cells from animal embryos, genetically manipulating these cells, and cultivating genetically manipulated embryos from them. ${ }^{324}$ The Edinburgh patent was initially granted, but later it faced stiff opposition and sparked a major public debate on the patenting of stem cell technology. ${ }^{325}$ The essential issue in this case was how to interpret Rule 28(1)(c) EPC (formerly 23d(c) EPC 1973, equivalent to Article 6(2)(c) of the EU Biotech Directive), which is the human embryo exclusion. The OD of the EPO observed that a narrow interpretation of Rule 28(1)(c) only resulted in the exclusion from the patent eligibility of commercial uses of embryos per se. However, the OD held that a narrow interpretation would render Rule 29 (formerly 23(e), equivalent to Article 5(1) of the Directive) redundant and weaken the intention of the legislature, since under Rule 29 embryos per se had been already protected. ${ }^{326}$ After considering various recitals and articles of the Directive, the OD concluded that Rule 28(1)(c) should be interpreted broadly, ${ }^{327}$ so as to embrace not only the use of human embryos but also hESCs which were derived from these embryos by destroying them. ${ }^{328}$ In doing so, the decision by the $\mathrm{OD}$ in the Edinburgh case put the embryo destruction at the center of the human embryo exclusion clause. ${ }^{329}$

\subsubsection{European WARF Case}

The approach that the OD adopted in the Edinburgh decision was followed by the seminal 2009 decision of the European WARF case, ${ }^{330}$ which involved patent claims to primate

323 See Decision of the OD of 21 July 2003 on European patent No. EP0695351 (University of Edinburgh).

324 European Patent No. EP0695351, entitled "Isolation, selection and propagation of animal transgenic stem cells".

325 See Plomer, et al., supra note 6, at 31; CATHERINE SEVILLE, EU INTELLECTUAL PROPERTY LAW AND Policy 139 (Edward Elgar 2009); Brian Salter, Patents and Morality: Governing Human Embryonic Stem Cell Science in Europe 8-9 (2009), http://www.kcl.ac.uk/sspp/departments/politicaleconomy/research/biopolitics/publications/ workingpapers/wp29.pdf. Opposition came from the governments of Germany, Italy, the Netherlands, the European Parliament, and Greenpeace on the grounds that the patent contravened ordre public and morality pursuant to Article 53(a) in connection with Rule 28(1)(c).

326 See Porter, supra note 80, at 25. See also Paul Torremans, The Construction of the Directive's Moral Exclusions Under the EPC, in Embryonic Stem Cell Patents: European Law and ETHics 152 (Aurora Plomer \& Paul Torremans ed., Oxford University Press 2009).

327 See SEVILLE, supra note 325, at 139.

328 See Varju \& Sándor, supra note 100, at 1026; Torremans, supra note 326, at 152.

329 See Varju \& Sándor, supra note 100, at 1026.

330 See G 2/06 (Use of embryos/WARF), supra note 185. See Robert Fitt, New Guidance on The Patentability of Embryonic Stem Cell Patents in Europe, 27 NATURE BIOTECHNology 338, 338 (2009). 
embryonic stem cells. ${ }^{331}$ In the European WARF case, the patent application was initially rejected, essentially because the claimed method used a primate embryo (including human $)^{332}$ as the raw material and the embryo was destroyed previously in the extracting process. ${ }^{333}$ On appeal, the core issue was the patent eligibility of hESCs, which could only be produced by destroying human embryos at the filing date. ${ }^{334}$ Having reviewed the preparatory documents of Article 6 of the Directive, ${ }^{335}$ the EBA held that the original intention of the exclusion under Article 6(2)(c) was to hold back the misuse, through commodification, of human embryos within Europe. ${ }^{336}$ The EBA stressed that one of the essential objectives of the whole Directive was to protect human dignity. ${ }^{337}$ Based on the purposes of protecting human dignity and prohibiting the commercialization of embryos, the EBA considered that it would be better not to give any restrictive definition of "embryo" in Rule 28(1)(c) EPC, and what an embryo was should be identified case by case. $^{338}$

WARF argued that, in order to fall within the prohibition of the human embryo exclusion, the use of human embryos must be claimed. ${ }^{339}$ However, the EBA held that when assessing the exclusion from patent eligibility it was necessary to take the entire technical teaching of the invention into account, rather than "just the explicit wording of the

331 European patent No. EP0770125, entitled "Primate embryonic stem cells". This patent application was filed in 1996, and concerned a method for obtaining ESC cultures from a primate embryo, as well as cultures themselves. See Porter, supra note 80, at 26.

332 WARF acknowledged that "primate embryonic stem cells" included human embryonic stem cells. See T-1374/04, supra note 167 , at 340.

333 See Fitt, supra note 330, at 338; Porter, supra note 80, at 26.

334 In light of the latent impact of the EPO's interpretation of the EPC provisions on future patentees and stem cell research in general, in 2005, the TBA referred four questions to the EBA. The most moral pertinent one is the following: "(2) If the answer to question 1 is yes, does Rule 23d(c) [now 28(c)] EPC forbid the patenting of claims directed to products (here: human embryonic stem cell cultures) which - as described in the application - at the filing date could be prepared exclusively by a method which necessarily involved the destruction of the human embryos from which the said products are derived, if the said method is not part of the claims? See also G 2/06 (Use of embryos/WARF), supra note 185.

335 See id., at 323. The EBA considered it necessary to "look at the ordinary meaning to be given to the terms of a provision in its context and in light of its object and purpose, including the preparatory documents".

336 see id., at 324.

337 See id.

338 See id., at 325-326.

339 Seeid., at 326. 
claims". ${ }^{340}$ The EBA thus considered that the use involving the destruction of human embryos was an integral and essential part of the industrial or commercial exploitation of the claimed invention. ${ }^{341}$ Moreover, the EBA relied upon the legislative history of Rule $28(1)$ (c) and chose a broad interpretation of the reference to industrial or commercial purposes. ${ }^{342}$ Eventually, the EBA concluded that Rule 28(1)(c) EPC excluded the patenting of "claims directed to products which-as described in the application-at the filing date could be prepared exclusively by a method which necessarily involved the destruction of the human embryos". ${ }^{343}$ Later, this statement was incorporated into the EPO's Guidelines for Examination. ${ }^{344}$

As described above, it can clearly be seen that the EBA avoided referring to the general morality exclusion, but merely concentrated on the stipulative example, that is, the human embryo exclusion. It is felt that by doing so, the EBA hoped to keep away from the disputes surrounding the phrases "commercial exploitation" and "contrary to morality", and to keep its mind on an entirely legal, mostly morally neutral, construction of the text in the human embryo exclusion. ${ }^{345}$ Moreover, by the EBA declaring unpatentable the inventions prepared only by a method destroying human embryos at the date of filing, it seems that the exclusion should not apply if the invention and the raw material used for the invention were based on already established hESC lines available in biobanks. ${ }^{346}$ Moreover, the focus of WARF was on the destruction of human embryos; it appears that if new hESC technologies to isolate the stem cells from an embryo could retain the viability of the embryo, then inventions concerning hESCs would be patented. ${ }^{347}$ In this regard, the decision of the WARF case by the EPO left national courts and patent

340 Id. (Point 22 states that "however, this Rule [28(c) EPC] (as well as the corresponding provision of the Directive) does not mention claims, but refers to "invention" in the context of its exploitation. What needs to be looked at is not just the explicit wording of the claims but the technical teaching of the application as a whole as to how the invention is to be performed. Before human embryonic stem cell cultures can be used they have to be made. Since in the case referred to the Enlarged Board the only teaching of how to perform the invention to make human embryonic stem cell cultures is the use (involving their destruction) of human embryos, this invention falls under the prohibition of Rule 28(c) (formerly 23d(c)) EPC (compare also the decision of the BPatG of 5 December 2006, loc. cit., points IV 2.1 to 2.3). To restrict the application of Rule 28(c) (formerly 23d(c)) EPC to what an applicant chooses explicitly to put in his claim would have the undesirable consequence of making avoidance of the patenting prohibition merely a matter of clever and skilful drafting of such claim.")

341 Id., at 327.

342 See Malene Rowlandson, WARF/Stem Cells (G2/06): The Ordre Public and Morality Exception and Its Impact on The Patentability of Human Embryonic Stem Cells 32 EuRopean InTELleCtuAl Property Review 67, 71 (2010). See also G 2/06 (Use of embryos/WARF), supra note 185, at 327-330.

343 See id., at 307.

344 See G-II, 5.3, the EPO's Guidelines for Examination.

345 See Kathleen Liddell, Immorality and Patents: The Exclusion of Inventions Contrary to Ordre Public and Morality, in NEW Frontiers in the Philosophy of InTELleCtual Property 156 (Annabelle Lever ed. 2012).

346 See Torremans, supra note 326, at 171; A Mahalatchimy, et al., Exclusion of Patentability of Embryonic Stem Cells in Europe: Another Restriction by the European Patent Office, 37 EUROPEAN INTELLECTUAL PROPERTY REVIEW 25, 26 (2015).

347 See Torremans, supra note 326 , at 171. 
authorities with some room for manoeuvre with respect to patenting downstream hESC inventions. $^{348}$

\subsubsection{TECHNION Case}

On February 4, 2014, the TBA deviated from the EBA's decision in the WARF case, deciding instead to correspond with the CJEU's decision in Brüstle. ${ }^{349}$ The applicant Technion Research and Development Foundation (hereafter Technion) had filed a European patent application ${ }^{350}$ which concerned methods of maintaining hESCs in an undifferentiated state as well as a cell culture comprising both human foreskin cells and hESCs. ${ }^{351}$ The ED of the EPO initially rejected the Technion patent application, stating that the hESC lines employed to make the invention were not publicly available at the date of filing. ${ }^{352}$ On appeal, the TBA referred to the decision G2/06 of the WARF case, holding that when assessing the patent eligibility of an invention what needed to be looked at was the whole technical teaching of the application as to how the invention was to be performed. ${ }^{353}$ The TBA held that although the application disclosed several ways of obtaining hESCs, the evidence on file to establish public availability of hESC lines at the date of filing was insufficient. ${ }^{354}$ Moreover, through analyzing the embodiments of the application, the TBA observed that for the purpose of carrying out the claimed invention, de novo destruction of human embryos was necessary. ${ }^{355}$ The appellant, Technion company, argued that "it would go too far if one were to take into account all the steps preceding an invention." 356 However, the TBA disagreed with Technion and held that "all steps preceding the claimed use of HES cells which are a necessary precondition for carrying out the claimed invention have to be considered." 357

In the final decision, the TBA focused only on the destruction of human embryos, chose to avoid the question of what a human embryo is, and did not refer to the definition given by the CJEU in Brüstle. ${ }^{358}$ The TBA decided that inventions could not be patented, which depended wholly on the use of hESCs, obtained either by de novo destruction of human embryos or by using established hESC lines which originally were produced by a method involving the destruction of human embryos. ${ }^{359}$ In this regard, TECHNION closed

\footnotetext{
348 See Hellstadius, supra note 86 , at 138.

349 See Aurélie Mahalatchimy, et al., The Impact of European Embryonic Stem Cell Patent Decisions on Research Strategies, 33 NATURE BIOTECHNOLOGY 41, 41 (2015); Mahalatchimy, et al., supra note 346, at 25.

350 European patent application No. 03751238.1.

351 See T 2221/10 [2014], supra note 185, at 6, point 1 of the Reasons.

352 Seeid., at 5.

353 See id., at 7-8, points 5-6 of the Reasons.

354 See id., at 9, point 14 of the Reasons.

355 See id., at 10-12, points 16-22 of the Reasons.

356 Id., at 13, point 25 of the Reasons.

357 Id., at 13, point 26 of the Reasons.

358 See Mahalatchimy, et al., supra note 346, at 27.

359 See T 2221/10 [2014], supra note 185, at 16, point 35 of the Reasons.
} 
the door that the WARF case had left open: even though hESC lines are publicly available, inventions employing hESCs cannot obtain patents from the EPO. ${ }^{360}$ Moreover, it is important to note that the consideration of harmonization of European patent law arguably has played a significant role in the TECHNION decision. As TBA pointed out, judgements of the CJEU would be considered persuasive, and the need for uniformity in harmonized European patent law was important. ${ }^{361}$

The decisions of the EPO in Harvard/Oncomouse, PGS, and Relaxin, have in effect established two test approaches to assess the morality of an invention under the general morality provision (i.e., Article 53(a) EPC). Nevertheless, in terms of patenting hESCrelated inventions, the EPO primarily focuses on the application and interpretation of the specific human embryo exclusion (i.e., Rule 28(1)(c), equivalent to Article 6(2) (c) of the Directive), but attempting to avoid directly applying the general morality clause. In the Edinburgh case, considering the relationship between Rule 28(1)(c) and Rule 29 EPC, the EPO made a broad interpretation of the human embryo exclusion, and excluded from patent eligibility both the use of human embryos as well as hESCs which necessitated the previous destruction of the embryo. Meanwhile, the EPO in the WARF case in fact followed the decision of Edinburgh. By emphasizing the original intention of the human embryo exclusion and one of the essential objectives of the whole Directive, i.e., to protect human dignity, the EPO in the WARF case also decided to interpret the human embryo exclusion broadly, to exclude hESCs, which could be created exclusively by a method which necessarily involved the destruction of human embryos at the filing date, from patent eligibility. ${ }^{362}$ The WARF decision of the EPO had actually left room for the patent eligibility of downstream hESC inventions which did not require the destruction of human embryos and only used already established hESC lines as the raw material. ${ }^{363}$ However, the TECHNION decision by the TBA of the EPO has deviated from the WARF decision, and closed the door that the WARF case had left open: even though hESC lines are established and publicly available, inventions utilizing hESCs still cannot be patented. In other words, as the current EPO Guidelines for Examination point out that

360 See Mahalatchimy, et al., supra note 346, at 25.

361 See T 2221/10 [2014], supra note 185, at 18, points 39, 40 of the Reasons.

362 Based on the WARF case (G 2/06), the EPO Guidelines for Examination further clarify Rule 28(1)(c) of the Implementing Regulations of EPC (i.e., the human embryo exclusion), stating that "[a] claim directed to a product which at the filing date of the application could be exclusively obtained by a method which necessarily involved the destruction of human embryos from which the said product is derived is excluded from patentability under Rule28(1)(c), even if said method is not part of the claim (see G 2/06)."

363 There are other two cases in the EPO concerning the patenting of hESC-related inventions, see T 1441/13 (Embryonic stem cells, disclaimer /ASTERIAS) [2014]; T 1808/13 (Neural Progenitor cells/BRÜSTLE) [2015]. In general, these two cases followed the decision of the WARF case (G 2/06). Nevertheless, in the two cases, the TBA of the EPO in fact primarily focused on the question of whether the subject matter of the invention remaining in the claim after the introduction of the disclaimer was available at the filing date. 
"the point in time at which such destruction takes place is irrelevant". ${ }^{364}$ The rationale behind the TECHNION decision is to protect human dignity, which corresponds with the CJEU's decision in Brüstle.

In summary, in order to assess ordre public or morality to determine the patent eligibility of subject matter, the EPO has already established several test approaches to apply the general morality clause. However, concerning patenting hESC-related inventions, the EPO focused on the interpretation of the human embryo exclusion, but without directly applying the general morality clause. Moreover, influenced by the Directive and the decision of the CJEU, the EPO put more importance on the protection of human dignity when deciding the patent eligibility of hESC-related inventions.

\subsection{The SIPO}

The SIPO's Guidelines have been investigated in detail previously, ${ }^{365}$ and thus this section focuses on several patent re-examinations in the SIPO. It is important to note that in China, there is no stare decisis, and thus judicial decisions, unlike those in the US or at the EU level, do not have a binding effect for other courts as well as for the SIPO's policies. The decisions of courts may only serve as a reference. ${ }^{366}$ Moreover, in the Chinese patent system, the courts of China have seldom challenged the authority of the SIPO's Guidelines, and in most cases the courts are inclined to apply the provisions within the Guidelines as the grounds for their judgments. ${ }^{367}$ Given this, the provisions within the Guidelines as well as the application or interpretation of them by the SIPO play a critical role in determining the patent eligibility of subject matter in China.

In patent practice, traditionally the SIPO did not encounter many cases in which it needed to apply the general morality clause within the CPL. However, recently this type of cases has increased gradually. The SIPO has issued several patent re-examination decisions that are regarded as having profoundly influenced the patent practice related to patenting hESC-related inventions. In this section, a number of paradigmatic patent re-examinations decided by the SIPO are explored. This part of the thesis attempts to divide the SIPO's progress related to patenting hESC-related inventions into three

364 This statement was added into the EPO Guidelines for Examination to further clarify Rule 28(1)(c) of the Implementing Regulations of EPC, based on the TECHNION case (T 2221/10).

365 See supra Sects. 2.2.3 and 2.3.3, Chap. 5.

366 See Peter Ganea \& Thomas Pattloch, Intellectual Property LaW In China 293 (Christopher Health ed., Kluwer Law International 2005).

367 See GUOBIn CUI (崔国斌), ZHUANLI FA YUANLI YU ANLI (专利法: 原理与案例) [PATENT LAW: CASES AND MATERIALS] 126 (Beijing Daxue Chubanshe (北京大学出版社) [Peking University Press] 2012) (pointing out that the patent system in China has the administration-oriented nature. This nature helps implement the industry policy of the government effectively, but considerably decreases the motivation of society to modify the patent law through judicatory means, which to some extent slow down the speed of improvement of China's patent law.) 
phases: initial touch (Sect. 3.3.1), persistence of complete prohibition (Sect. 3.3.2), and the momentous change (Sect. 3.3.3), which helps to illustrate the dynamic development of the SIPO's patent policy, and sheds light on the trend of changes. Dividing the development into different phases does not mean such transitions are abrupt or clear-cut. Instead, the development of the SIPO's patent policy with regard to patenting hESC-related inventions actually is a gradual and ongoing process. Moreover, this section explores a patent re-examination concerning human parthenogenetic stem cell (hPGSC) lines and the preparation methods (Sect. 3.3.4), which specifically dealt with the definition of the human embryo under Article 5(1) of the CPL.

\subsubsection{Phase 1: Initial Touch}

In 2004, the issue of the patent eligibility of ESCs first came before the SIPO in the patent re-examination FS4237. ${ }^{368}$ This case concerned an application (Chinese patent application No. 97198083.7, referred to as the 83.7 patent application) from the University of Massachusetts for a patent on an invention related to embryonic or stem-like cells and the method of producing them. The issue was whether or not the invention involved a process for cloning human beings and, if so, should be precluded from patent eligibility. ${ }^{369}$ The Patent Examination Department (PED) of the SIPO initially refused the application, holding that Claim 1 involved a process for cloning human beings, and that the wording "until greater than the 2-cell developmental stage" in Claim 1 included the whole developmental stage after the 2-cell stage and the human embryo per se, which contravened social morality. ${ }^{370}$ However, the PED did not give any explanation for this argument, nor any explanation of potentially associated social morality. Subsequently, the applicant filed amended claims and lodged an appeal to the PRB, arguing that the purpose of this invention was not for cloning human beings, but simply a method of producing embryonic stem cells or embryonic cells. ${ }^{371}$

The PRB disagreed with the PED, stating that Claim 1 of the 83.7 patent application was merely seeking patent protection for "a new and improved method of producing embryonic or stem-like cells" and "using said embryonic or stem-like cells to diagnose

368 The patent re-examination No. 4237 (FS4237) of the SIPO Patent Re-examination Board, decided on Feb. 9, 2004. The patent application No. 97198083.7 was filed on Jul. 28, 1997, entitled Tongguo Zhongjian Heyizhi Zhibei Peitai Xibao Huo Ganxibao Yang Xibaoxi (通过种间核移植制备胚胎细胞或干细胞样细胞系) [Embryonic or stem-like cell lines produced by cross-species nuclear transplantation].

369 See id. The SIPO's Guidelines also exclude from patent eligibility "a process for cloning human beings or a cloned human being” under Article 5(1) of the CPL; please see Part II Chap. 1, Sect. 3.1.2, Para. 2 of the SIPO's Guidelines. Since the patent eligibility of "a process for cloning human beings or a cloned human being" is beyond the discussion of the thesis, it will not be analyzed more here.

370 See FS4237 of the PRB, supra note 368. See also LIPU TIAn [田力普], ZHongGuO ZHISHI CHANQUAN NIANJIAN 2004 (中国知识产权年鉴（2004年）) [CHINESE INTELLECTUAL PROPERTY YEARBOOK 2004] 364 (Zhishi Chanquan Chubanshe (知识产权出版社) [Intellectual Property Publishing House] 2004).

371 See FS4237 of the PRB, supra note 368. 
or treat a disease", rather than cloning human beings or making this invention a step towards cloning human beings. ${ }^{372}$ Furthermore, the PRB stressed that there was no evidence to prove that the said method in this patent application was a necessary step towards a process for cloning human beings. Thus, the PRB held that "this invention was not for cloning human beings and, therefore, did not contravene Article 5 of the CPL". ${ }^{373}$ In February 2004, the PRB reversed the rejection of the 83.7 patent application that the previous examination department had made. ${ }^{374}$

In this instance, when the SIPO initially encountered a patent application in relation to the human embryo, the evaluation criterion that the PRB adopted was whether the method constituted a process for cloning human beings. As such, the PRB did not directly apply Article 5 of the CPL, nor did it use the human embryo exclusion in the SIPO's Guidelines to judge the patent eligibility of the said inventions. This implies that the SIPO was reluctant to directly apply Article 5 of the CPL and the human embryo exclusion, or the SIPO was inexperienced in how to apply the human embryo exclusion in patent examination at that time.

\subsubsection{Phase 2: Persistence of Complete Prohibition}

As noted above, since 2006 it has been clear in the SIPO's Guidelines that neither hESCS nor their preparation methods can be patented, yet until now the Guidelines have remained silent on whether downstream hESC technologies can be patented. In the following three cases, it will be seen that during the second phase the SIPO held an extremely conservative attitude towards patenting hESC-related inventions, including not only hESCs per se and the preparation methods, but also downstream hESC inventions.

\subsubsection{Re-examination of the 19.5 Patent Application}

In 2009, the PRB of the SIPO tackled the question of whether or not an invention involving techniques for the growth and differentiation of human pluripotent stem cells (including hESCs) constituted patentable subject matter in the re-examination FS17820 of a Chinese patent application No. 01806319.5 (the 19.5 patent application). ${ }^{375}$ The PED observed that Claims 1-12 involved pluripotent stem cells derived from a human blastocyst, and the preparation method including culturing undifferentiated primate

\footnotetext{
372 Id.

373 Id

374 See id. However, according to the official website of the SIPO, the status of the 83.7 patent application was deemed to have been withdrawn on Sept. 7, 2005.

375 The patent re-examination No. 17820 (FS17820) of the SIPO Patent Re-examination Board, decided on Jul. 2, 2009. The patent application No. 01806319.5 was filed on Jan. 10, 2001, entitled Ren Duoneng Ganxibao Shengzhang he Fenhua de Jishu (人多能干细胞生长和分化的技术) [Techniques for Growth and Differentiation of Human Pluripotent Stem Cells].
} 
pluripotent stem cells (pPSCs) derived from blastocysts. Moreover, Claim 13 involved a method of producing a population of differentiated cells. Claims $15-16$ covered a method of producing differentiated cells from undifferentiated pluripotent stem cells. It can be clearly seen that Claims 1-12 involved hESCs per se and the preparation methods while the other claims covered the methods of differentiating hESCs. Therefore, the PED considered the 19.5 patent application to directly involve "hESCs and the preparation methods thereof", and this invention thus contravened Article 5 of the CPL. ${ }^{376}$

The applicant argued that pPSCs were readily available from commercial vendors, so the source of the pPSCs would not involve moral issues. Moreover, the applicant declared that with the advancement of S\&T it would soon be possible to obtain embryonic stem cells without destroying a human embryo. ${ }^{377}$ Nevertheless, the PED held that even though hESCs were available through commercial channels at the filing date, the obtaining of hESCs still required the destruction of human embryos before the filing date, ${ }^{378}$ and that the application involved the use of human embryos for industrial or commercial purposes. The PED thus rejected the claims on the grounds that they contravened social morality.

In the decision, the PRB agreed with the PED's decision to reject it, holding that regardless of whether the materials were from established cell lines or obtained directly from embryonic tissues, such as blastocysts, they all needed to be obtained from a human embryo and, at the same time, needed the destruction of human embryos. ${ }^{379}$ The PRB further noted that evidence on file could not prove that obtaining hESCs by destroying embryos was publicly acceptable, even if using surplus embryos produced in vitro. ${ }^{380}$ Additionally, the PRB was reluctant to consider as relevant the potential benefits of the research and the attitudes towards the patent eligibility of hESC-related inventions in

376 As noted above, the exclusion "hESCs per se and the preparation methods thereof" was introduced into the SIPO's Guidelines in 2006. The 19.5 patent application was filed on October 1, 2001, almost five years before the emergence of the exclusion of "hESCs and preparation methods thereof" in China. However, the SIPO applied this specific exclusion to judge the patent application that was filed before. This means that the SIPO considers the exclusion "hESCS and preparation methods thereof" to apply to all applications, including those filed prior to its entry into force.

377 Until now, under current scientific knowledge, it has not been possible to create an hESC without the destruction of a human embryo. See Ciara Staunton, Brüstle v Greenpeace, Embryonic Stem Cell Research and the European Court of Justice's New Found Morality, 21 MEDICAL LAW REVIEW 310, 314 (2013).

378 In terms of using the date of patent application filing as the time point to assess moral issues concerning the invention, Sterckx and Cockbain felt it was wrong. They held that it would be better to take later evidence into account, since the moral exclusions are based on ethical and public policy grounds and, thus, might be subject to "fluctuation." See footnote 15 on STERCKX \& COCKBAIN, supra note 6, at 290. However, it seems that until now, at least, both the EPO and the SIPO are using the date of filing to gauge moral issues, and this point does not cause any hot debate in practice in these two patent offices.

379 See FS17820 of the PRB, supra note 375.

380 See id. 
other jurisdictions. ${ }^{381}$ The PRB concluded that under the current Chinese patent legal framework, the destruction of human embryos, the use of human embryos for industrial or commercial purposes, as well as hESCs per se and the preparation methods were all regarded as being against social morality and, thus, should not be patented.

\subsubsection{Re-examination of the 91.6 Patent Application}

In 2010, the PRB of the SIPO issued a re-examination decision FS22325, of which the corresponding patent application No. 01805291.6 (the 91.6 patent application) concerned a method of making embryoid bodies from primate embryonic stem cells. ${ }^{382}$ Initially, the PED held that both Claims 1 and 10 directly or indirectly involved the technical solution to make embryoid bodies from hESCs, and that obtaining hESCs would result in the destruction of human embryos. ${ }^{383}$ In addition, the PED noted that the applicant did not explicitly explain or confine the source of the hESCs, even if they were already established hESC lines from commercial vendors. ${ }^{384}$ It seems that had the patent application explained or confined the source of the hESCs precisely, such as confining hESCs to established and commercial hESC lines, then the invention might well have been patented. In this regard, it appears that the viewpoint of the PED had begun to change.

Nevertheless, the PRB still followed the re-examination decision of the 19.5 patent application, stating that no matter whether it involved using human blastocysts as the starting materials to make hESCs or used established hESC lines, with respect to the prior art at the date of filing, both ways required obtaining hESCs from human embryos. The process of obtaining hESCs needed the destruction of a human embryo or a fetus. ${ }^{385}$ Moreover, the PRB pointed out that any inventions relating to methods of or procedures for obtaining hESCs from human embryos must involve the use of human embryos for industrial or commercial purposes and, therefore, contravened social morality. ${ }^{386}$ Thus, these inventions could not constitute patentable subject matter according to Article 5(1) of the CPL.

\subsubsection{Re-examination of the 38.7 Patent Application}

In the same year, 2010, the SIPO issued another re-examination decision FS25050, ruling on patent application No. 01811938.7 (the 38.7 patent application) relating to a method

381 Seeid.

382 The patent re-examination No. 22325 (FS22325) of the SIPO Patent Re-examination Board, decided on Mar. 24, 2010. The patent application No. 01805291.6 was filed on Feb. 20, 2001, and assigned to WARF, entitled Cong Lingzhanglei Dongwu Peitai Ganxibao Zhibei Peizhuangti de Fangfa (从灵长类动物胚胎干细胞制备胚状体 的方法) [Method of making embryoid bodies from primate embryonic stem cells]. See FS22325 of the PRB.

384 Seeid.

385 See id.

386 Seeid. 
of differentiating hESCs. ${ }^{387}$ This case concerned an invention related to differentiating hepatocyte lineage cells from pluripotent stem cells. The PED initially objected to this patent application for its failure to conform with Article 5 of the CPL. Subsequently, the applicant appealed to the PRB. The PRB held that the claims of the 38.7 patent application necessarily involved the human embryo, in which the industrial or commercial use of human embryos would be concerned. The description mainly illustrated the method of producing pluripotent stem cells rather than mentioning the established cell lines or ways to acquire these cell lines. ${ }^{388}$ The PRB, therefore, ruled that there was no evidence to prove that hESCs were available from commercial channels without destroying human embryos before the date of filing. ${ }^{389}$ Moreover, the PRB stressed that social morality varied from region to region, and that the attitudes of other jurisdictions towards the patent eligibility of hESC-related inventions could only be used as a reference. ${ }^{390}$ It then reasserted the PED's position that this invention could not be patented.

Subsequently, the applicant amended the patent application to mention specifically "providing an established cell line culture of human pluripotent stem cells" in Claim 1 , removed certain expressions, such as "embryos or fetus", from the description, and provided more evidence to prove there were established hESC lines available to the public before the date of filing. ${ }^{391}$ Nevertheless, the PRB insisted that the evidence provided by the applicant was insufficient. In the meantime, the PRB reiterated that the obtaining of hESCs could directly lead to the destruction of human embryos and indirectly involve the use of human embryos for industrial or commercial purposes. ${ }^{392}$ Finally, in July 2010, the PRB reaffirmed its position that since the method of induced differentiating of hESCs used hESCs as the starting materials, the obtaining of hESCS violated social morality and, therefore, the induced differentiation of hESCs would contravene social morality. ${ }^{393}$

In summary, it can be clearly seen that during the second phase between 2004 and 2010, the SIPO held a consistently negative attitude towards the patenting not only of "hESCs and the preparation methods", but also of the other downstream hESC inventions, despite the CPL as well as the SIPO's Guidelines being silent on the patent eligibility of downstream hESC technologies. The SIPO broadly interpreted the human

387 The patent re-examination No. 25050 (FS25050) of the SIPO Patent Re-examination Board, decided on Jul. 26, 2010. The patent application No. 01811938.7 was filed on Apr. 26, 2001, and assigned to Geron Corporation, entitled Yansheng Zi Duoneng Ganxibao de Ganxibao Puxi Xibao (衍生自多能干细胞的肝细胞谱系细胞) [Hepatocyte lineage cells derived from pluripotent stem cells].

388 See id.

389 Seeid.

390 Seeid.

391 See id.

392 Seeid.

393 Seeid. 
embryo exclusion and the "hESCs per se and the preparation methods" exclusion to preclude from patent eligibility any hESC-related inventions that destroyed an embryo at any point in the making of the inventions. However, it is worth noting that the SIPO gradually started to notice and discern the source of hESCs.

\subsubsection{Phase 3: Momentous Change}

\subsubsection{Re-examination of the 27.5 Patent Application}

In October 2012, the SIPO issued a patent re-examination decision FS46359, whose corresponding patent application was No. 02813927.5 (the 27.5 patent application). ${ }^{394}$ This application concerned a method of producing a cell composition containing human cardiomyocytes or cardiomyocyte precursor cells and a method of enriching several cardiomyocyte cells differentiated from established hESC lines. ${ }^{395}$ These technical solutions used hESCs as starting materials. The arguments for the Previous Examination Department's ${ }^{396}$ rejection of the 27.5 patent application were similar to those in the reexamination of the 19.5 patent application. The PRB initially held that the description neither eliminated the technical content about directly obtaining hESCs from human embryos nor illustrated that the said hESCs would not involve the destruction of human embryos. ${ }^{397}$ The PRB then regarded the implementation of the technical solution, which inherently required using human embryos as source materials, as the "use of human embryos for industrial or commercial purposes", and hence declared it to be unpatentable under Article 5(1) of the CPL. ${ }^{398}$

The applicant submitted arguments, provided more evidence to prove the established undifferentiated hESC lines, and pointed out that "when there had been established hESC lines in the prior art, tracing their origin was unreasonable". ${ }^{399}$ The applicant revised the application and further deleted the contents relating to isolating hESCs from a human embryo. After the applicant had revised its patent application, the PRB ruled that the patent application had already specified both the purpose of this invention and the origin of hESCs. In addition, the description had specifically eliminated

394 The patent re-examination No. 46359 (FS46359) of the SIPO Patent Re-examination Board, decided on Oct. 24, 2012. The patent application No. 02813927.5 was filed on Jul. 12, 2002, and assigned to Geron Corporation, entitled Cong Ren Duoneng Ganxibao Chansheng Xinji Xibaoxi Xibao (从人多能干细胞产生心肌细胞系细胞) [Cells of the cardiomyocyte lineage produced from human pluripotent stem cells].

395 Seeid.

396 According to Article 3(1), Chap. 2, Par. IV of the SIPO's Guidelines, "the Patent Re-examination Board shall transfer the request for re-examination (including any proof documents and amended application documents attached thereto) having passed formal examination to the previous examination department which made the decision of rejection for interlocutory examination, together with the application dossier." 
the possibility of obtaining hESCs from the human embryo. The PRB believed that the purpose of the 27.5 patent application was simply to use established hESC lines as the starting materials, and to improve culture conditions to produce controlled differentiated cardiomyocytes, rather than mainly focusing on manipulating human embryos for industrial or commercial purposes. Furthermore, the PRB observed that the patent applicant had already provided sufficient evidence to prove that established hESC lines were available from commercial channels. ${ }^{400}$

Most importantly, the PRB stressed that "when inventions involve biological materials from the human body, if tracing back, all original materials would come from the human body or human embryo. Thus, it is unreasonable to trace the inventions' raw materials without limit" ${ }^{401}$ The PRB concluded that it would be unconvincing to reject a patent right simply because an application which involved the use of established hESC lines constituted the destruction of the human embryo and thus contravened social morality. Moreover, in the PRB's opinion, such a rejection could not uphold both the limits on the misuse of human embryos and the maintenance of social morality, but may unduly constrain future technological advances. ${ }^{402}$ Finally, the PRB declared that the revised patent application did not fall within the scope of unpatentable subject matter under Article 5(1) of the CPL. ${ }^{403}$

\subsubsection{Re-examination of the 84.2 Patent Application}

In the same year 2012, the SIPO issued another patent re-examination decision FS42698, ${ }^{404}$ similar to FS46359 mentioned above. This case concerned patent application No. 03816184.2 (the 84.2 patent application) from the Regents of the University of California for a patent on an invention that involved the use of hESCs. ${ }^{405}$ Initially in July 2011, Claims 1-51 and the description ${ }^{406}$ were rejected by the PED with the arguments that these claims and descriptions involved hESCs derived from human embryos and, therefore, the invention was related to "use of human embryos for industrial or

\footnotetext{
400 See id.

401 ld.

402 Seeid.

403 Seeid.

404 The patent re-examination No. 42698 (FS42698) of the SIPO Patent Re-examination Board, decided on May. 29, 2012.

405 The patent application No. 03816184.2 (the 84.2 patent application) was filed on Jul. 11, 2003, entitled Yansheng zi Ren Peitai Ganxibao de Yongyu Jisui sunshang de Zai Suiqiaohua he Zhiliao de Shaotu Jiaozhi Xibao (衍生自人胚胎干细胞的用于脊髓损伤的再髓鞘化和治疗的少突胶质细胞) [Oligodendrocytes Derived from Human Embryonic Stem Cells for Remyelination and Treatment of Spinal Cord Injury].

406 See FS42698 of the PRB, supra note 404. The text files of the application on which the rejection was based were: pages 1-2, 14-37 of the description, pages 1-20 of the figures, and summary, submitted when entering the national phase on January 07, 2005; pages 3-13 of the description submitted on October 22, 2010; Claims 1-51 submitted on May 11, 2010.
} 
commercial purposes". ${ }^{407}$ Subsequently, on October 20, 2011, the applicant filed a reexamination request with the $\mathrm{PRB}$, and revised the title of the patent application from "human embryonic stem cells" to "primate pluripotent stem cells", as well as adding the technical features "the said established cell lines do not contain pPS or hES cells directly isolated from human embryos or blastocysts" into certain claims. ${ }^{408}$ Moreover, the applicant pointed out that "the established cell lines had been accepted by the public and also patented", and that " $\mathrm{H} 1$ and $\mathrm{H} 7$ cell lines described in the embodiment were available from commercial vendors before the priority date". 409

On re-examination, in the Note of Interlocutory Examination Opinion, ${ }^{410}$ the Previous Examination Department held that, even if the claims specifically eliminated directly isolating hESCs from human embryos or blastocysts, the invention should still be regarded as the manipulation or use of human embryos, and thus contravened Article 5(1) of the CPL. ${ }^{411}$ In contrast, the PRB disagreed with the decision of the Previous Examination Department. The PRB observed that although the technical solution of this patent application involved using pPSCs or hESCs as starting materials, the claims and description had excluded contents that directly disaggregated a human embryo or blastocyst. Moreover, the embodiments described in the description used hESC H1 and $\mathrm{H} 7$ lines. ${ }^{412}$ Thus, the PRB believed that the cell lines used in this invention were established and originated from commercial lines.

Concerning the initial rejection and the Note of Examination Opinion, the PRB took almost the same viewpoint as it had in the re-examination (FS46359) of the 27.5 patent application noted above. The PRB stressed that there were several ways of acquiring these mature and stable cell lines in the prior art and, hence, it was unnecessary to trace how the starting materials had been obtained. In the eyes of the PRB, this practice was able not only to "limit the misuse of human embryos", but also confine the used hESC lines to the mature and commercial lines. ${ }^{413}$ This would neither overly constrain

407 See FS42698 of the PRB, supra note 404.

408 Id. According to the re-examination decision, the patent applicant added the technical features into Claims $1,14,28,42$, and 47.

409 Id.

410 According to Art. 3(1), Par. IV, Chap. 2 of the SIPO's Guidelines, "the previous examination department shall provide its opinion on interlocutory examination, and make a Note of Interlocutory Examination Opinion. Except in special situations, interlocutory examination shall be completed within one month after receipt of the dossier."

411 See FS42698 of the PRB, supra note 404.

412 See id. In the final decision, the PRB also mentioned that according to the prior art and Appendix 10 in this application, $\mathrm{H} 1$ and $\mathrm{H} 7$ were the earliest established cell lines. In 2001, the US government allowed a non-profit institute, the WiCell Research Institute, to provide researchers with $\mathrm{H} 1$ and $\mathrm{H} 7$ cell lines. Thus, the $\mathrm{PRB}$ believed that $\mathrm{H} 1$ and $\mathrm{H} 7$ cell lines were established hESC lines, which could be propagated indefinitely in vitro.

413 Id. 
the development of S\&T nor encourage more new hESC lines, which satisfied Chinese contemporary social morality. ${ }^{414}$ Interestingly, it seems that when dealing with the patent eligibility of downstream hESC inventions under Article 5(1) of the CPL, the PRB of the SIPO unconsciously has adopted the "balancing exercise" approach and the "unacceptability" standard. Specifically, in the opinion of the PRB, provided the patent application confined the used hESCs to already established hESC lines, the sacrifice of the respect to the human embryo is acceptable since the advantages of the advancement of S\&T, which may provide benefit to mankind, outweigh the negative aspects.

In the same way, over recent years within several similar re-examination cases, such as FS73397, ${ }^{415} \mathrm{FS} 78768,{ }^{416} \mathrm{FS} 76279,{ }^{417} \mathrm{FS} 78111,{ }^{418} \mathrm{FS} 83865,{ }^{419} \mathrm{FS} 98883,{ }^{420} \mathrm{FS} 101914,{ }^{421}$ the PRB has pointed out almost the same statement: when the starting materials of an invention involved human beings, if tracing back, almost all those materials would come from human bodies or human embryos. In this regard, it was irrational to trace the invention's raw materials without limit. Provided the patent application confined the used hESCs to already established hESC lines, it would be inappropriate for the patent examiners to refuse to grant a patent on the grounds that the invention at issue involved the destruction of human embryos and as a result contravened social morality. The PRB felt its new stance would not only constrain the misuse of human embryos,

\section{Seeid.}

415 The patent re-examination No. 73397 (FS73397) of the SIPO Patent Re-examination Board, decided on Sept. 26, 2014. The patent application No. 200680022866.6 was filed on Jun. 20, 2006, entitled Shi Lingzhanglei Duoneng Ganxibao Fenhuacheng Xinji Xibaoxi Xibao (使灵长类多能干细胞分化成心肌细胞系细胞) [Differentiation of primate pluripotent stem cells to cardiomyocyte-lineage cells].

416 The patent re-examination No. 78768 (FS78768) of the SIPO Patent Re-examination Board, decided on Dec. 10, 2014. The patent application No. 200910129670.2 was filed on Jan. 10, 2001, entitled Ren Duoneng Ganxibao Shengzhang he Fenhua de Jishu (人多能干细胞生长和分化的技术) [Techniques for growth and differentiation of human pluripotent stem cells].

417 The patent re-examination No. 76279 (FS76279) of the SIPO Patent Re-examination Board, decided on Oct. 13, 2014. The patent application No. 200880107638.8 was filed on Jul. 21, 2008, entitled Shi Peitai Ganxibao Fenhuacheng Biaoda AQP-1 de Xibao de Fangfa (使胚胎干细胞分化成表达AQP-1的细胞的方法) [Method for differentiating embryonic stem cells into cells expressing aqp-1].

418 The patent re-examination No. 78111 (FS78111) of the SIPO Patent Re-examination Board, decided on Nov. 24, 2014. The patent application No. 201010528128.7 was filed on Apr. 26, 2001, entitled Yansheng zi Duoneng Ganxibao de Ganxibao Puxi Xibao (衍生自多能干细胞的干细胞谱系细胞) [Hepatocyte lineage cells derived from pluripotent stem cells].

419 The patent re-examination No. 83865 (FS83865) of the SIPO Patent Re-examination Board, decided on Feb. 28, 2015. The patent application No. 200680027460.7 was filed on Jun. 20, 2006, entitled Ren Peitai Ganxibao de Xuanfu Peiyangwu (人胚胎干细胞的悬浮培养物) [Suspension culture of human embryonic stem cells].

420 The patent re-examination No. 98883 (FS98883) of the SIPO Patent Re-examination Board, decided on Oct. 9, 2015. The patent application No. 200880109580.0 was filed on Jul. 31, 2008, entitled Ren Peitai Ganxibao de Fenhua (人胚胎干细胞的分化) [Differentiation of human embryonic stem cells].

421 The patent re-examination No. 101914 (FS101914) of the SIPO Patent Re-examination Board, decided on Nov. 16, 2015. The patent application No. 200980116566.8 was filed on Mar. 26, 2009, entitled Shi Lingzhanglei Duoneng Ganxibao Fenhuacheng Zaoxue Puxi Xibao (使灵长类多能干细胞分化成为造血谱系细胞) [Differentiation of primate pluripotent stem cells to hematopoietic lineage cells]. 
but also permit utilizing mature and commercial hESC lines to invent, which satisfied Chinese contemporary social morality.

Thus, recently the SIPO has changed its viewpoint and started to loosen restrictions on the patent eligibility of downstream hESC inventions. ${ }^{422}$ To be specific, it has started to distinguish the source of hESCs and is reluctant to trace the starting materials involved in hESC-related inventions. As long as the patent application avoids the contents of isolating or obtaining hESCs from a human embryo, and provides sufficient evidence to prove that the invention uses already established hESC lines which are obtainable from commercial channels, then downstream hESC inventions are regarded as patent eligible. It is evident that the SIPO feels that it would go too far if one were to take into account all the steps preceding an invention. Interestingly, this argument in fact had been proposed by the appellant in the TECHNION case in the EPO, but the TBA of the EPO had explicitly refused this argument. ${ }^{423}$

\subsubsection{Definition of A "Human Embryo" and the SIPO's ISCO Case}

As shown in previous chapters of this thesis, there is no legislation, including the CPL, exactly defining the term "human embryo". Although the SIPO's Guidelines exclude from patent eligibility "uses of human embryos for industrial or commercial purposes" under Article 5(1) of the CPL, the Guidelines do not give any definition of the human embryo. Concerning the definition of a human embryo under patent law, in June 2015, the PRB of the SIPO in effect dealt with it within re-examination FS91797, and defined the human embryo in a traditional way. ${ }^{424}$ Specifically, in this re-examination decision, the PRB held that a human embryo included any stage of development from the beginning of the fertilized ovum to the moment before the newborn, including embryos within stages of cleavage, morula, blastula, implantation, as well as embryonic differentiation; the human embryo could be from any source. ${ }^{425}$ Concerning the sources of an embryo the PRB provided several examples, including embryos from IVF and donated embryos from induced abortion. ${ }^{426}$

422 See also Yaojin Peng, The Patentability of Human Embryonic Stem Cell Technology in China, 34 NATURE BIOTECHNOLOGY 37, 38-39 (2016).

423 See supra Sect. 3.2.5.3, Chap. 5.

424 The patent re-examination No. 91797 (FS91797) of the SIPO Patent Re-examination Board, decided on Jun. 25, 2015. The patent application No. 200880013190.3 was filed on Feb. 22, 2008, entitled Chongbiancheng Fenhua Xibao he Cong Chongbiancheng de Xibao Chansheng Dongwu he Peitai Ganxibao de Gaoxiao Fangfa (重编程分化细胞核从重编程的细胞产生动物和胚胎干细胞的高效方法) [Highly efficient methods for reprogramming differentiated cells and for generating animals and embryonic stem cells from reprogrammed cells].

425 See FS91797 of the PRB, supra note 424.

426 See id. 
However, in another patent re-examination, FS73216, which can be considered the SIPO's ISCO case, the PRB provided a different definition of the "human embryo", ${ }^{427}$ in fact extending its scope. To be specific, this re-examination concerned a Chinese patent application involving parthenogenetic stem cell (PGSC) lines and the preparation methods. ${ }^{428}$ The focus of the controversy in this case was whether "unfertilized human ova whose division and further development have been stimulated by parthenogenesis" constitute a "human embryo" within the meaning of the human embryo exclusion (i.e., Pt. II, Chap. 1, Sec. 3.1.2, Para. 2, of the SIPO's Guidelines) under Article 5(1) of the CPL. ${ }^{429}$

Initially, on March 7, 2012, the PED of the SIPO rejected the patent application on the grounds that the inventions were excluded from patent eligibility based on their constituting uses of human embryos under Article 5(1) of the CPL. ${ }^{430}$ Subsequently, the applicant, ISCO, filed a re-examination request with the PRB, primarily making two arguments. First, ISCO argued that there had never been any definition of a human embryo in China's legislation, including the CPL. ${ }^{431}$ In China's patent practice, under the human embryo exclusion within the SIPO's Guidelines, a human embryo should be defined as any embryonic form starting from the moment of fertilization to the point before birth. ${ }^{432}$ Second, ISCO argued that under Article 5(1) of the CPL, a human embryo should have the inherent capacity of developing into a human being, namely human embryos from IVF, SCNT, and fetuses in spontaneous abortions. ${ }^{433}$ But due to the absence of paternal gene imprinting, parthenogenetically activated oocytes were incapable of initiating the process of development of a human being and, thus, they were not human embryos or an embryo equivalent. ${ }^{434}$ Moreover, ISCO, while amending the claims of its application, introduced the word "pluripotent" before "stem cell line" thereby making it clear that the claimed stem cells lacked paternal gene imprinting. ${ }^{435}$

427 The patent re-examination No. 73216 (FS73216) of the SIPO Patent Re-examination Board, decided on Sept. 23, 2014. The patent application No. 200880018767.X was filed on Apr. 7, 2008, entitled Yuanyu Ren Danxing Shengzhi Peipao de Huanzhe Teyixing Ganxibao Xi (源于人单性生殖胚泡的患者特异性干细胞系) [patient-specific stem cell lines derived from human parthenogenetic blastocysts]. Since the patent application was filed on by ISCO, this case before the PRB of the SIPO can be called as ISCO case.

428 See FS73216 of the PRB, supra note 427.

429 See id.

430 Seeid.

431 Seeid.

432 Seeid.

433 Seeid.

434 Seeid.

435 See id. It has been said that the amendment was intended to exclude any method of genetic manipulation, which could overcome the lack of genomic imprinting. See Ana Nordberg \& Timo Minssen, A "Ray of Hope" for European Stem Cell Patents or "Out of the Smog into the Fog"? An Analysis of Recent European Case Law and How it Compares to the US, 47 International ReVIEW of INTELleCtual PROPERTY AND COMPETITION LAW 138, 146 (2016). 
The PRB, however, disagreed with ISCO. Concerning ISCO's first argument, the fertilization criterion, the PRB held that under Article 5(1) of the CPL, the understanding of "human embryos" in the exclusion provision of "uses of human embryos for industrial or commercial purposes" should be considered within the context of social morality, rather than being confined only to a biological definition, that is, natural forms ranging from zygote to the organism before newborn. ${ }^{436}$ The generation of a human embryo did not necessarily involve the process of fertilization, such as human embryos from SCNT. ${ }^{437}$ Moreover, the PRB asserted that there was no evidence to prove that the "fetus" in spontaneous abortion must go through fertilization, and it was possible that the "fetus" was developed from an unfertilized egg. ${ }^{438}$ For ISCO's second argument, the PRB took a method of analogy. The PRB first provided a number of examples, such as fetuses in spontaneous abortions and fetuses which stopped developing due to various reasons. Then, the PRB asserted that since these entities, which could not develop into human beings, were included within the scope of the notion of human embryos, then those entities which were not capable of developing into human beings should not be excluded from the scope of the human embryo. ${ }^{439}$ In this regard, the PRB felt that the inherent capability of developing into a human being could not be a criterion to define the human embryo.

Interestingly, the PRB mentioned the decision of Brüstle (C-34/10), stating that the broad interpretation of a human embryo by the CJEU from a perspective of safeguarding human dignity, and the incorporation of "any non-fertilized human ovum whose division and further development have been simulated by parthenogenesis" into the notion of a human embryo, to some extent, supported the viewpoints of the PRB panel. ${ }^{440}$ However, in fact in a later decision of International Stem Cell Corporation v. Comptroller General of Patents (ISCO), the CJEU delivered a complete reversal with respect to parthenotes, acknowledging that it had made a mistake by judging parthenotes to be human embryos, primarily based its findings on submitted written observations which considered these parthenotes to be capable of full development. ${ }^{441}$

In the final decision of FS73216, in September 2014, the PRB of the SIPO concluded that the definition of human embryos was not limited to the development of human embryos in nature; fertilization and the inherent capability of developing into a human being should not be criteria for defining a human embryo. Meanwhile, the PRB

436 See FS73216 of the PRB, supra note 427.
437 See id.
438 See id.
439 See id.
440 See id.
441 See C-364/13 (International Stem Cell Corporation v. Comptroller General of Patents, Designs and Trade
Marks), supra note 83. This case will be discussed in detail later in Sect. 4.4, Chap. 5. 
held that the human parthenogenetic blastocyst in this application went through the same developmental process, and formed a blastocyst with the same morphology as a traditional human embryo which started from fertilization. ${ }^{442}$ In this regard, the PRB considered such a human parthenogenetic blastocyst to be a developmental stage of a human embryo, which was thus a human embryo under Article 5(1) of the CPL. ${ }^{443}$ The production of human pluripotent stem cell lines from the human parthenogenetic blastocyst involved the "uses of human embryos for industrial or commercial purposes" and contravened social morality, and thus should be excluded from patent eligibility. ${ }^{444}$ It seems that the PRB in the ISCO decision did not provide an exact definition of a human embryo, but just excluded two criteria. However, through the statement that the PRB included human parthenogenetic blastocyst in the scope of a human embryo as well as through the two excluded criteria, a definition of the human embryo can be reached: an entity which is able to commence the process of development of a human being or a similar process, but does not necessarily have the capability of developing into a human being. As a result, the PRB in fact has given an extremely broad definition of the term human embryo under the CPL.

\section{JUDICIAL DECISIONS CONCERNING PATENTING HESC-RELATED INVENTIONS}

After exploring in detail the current status of patenting hESC-related inventions in the USPTO, EPO, and SIPO within the previous section, this section primarily focuses on judicial decisions in the three jurisdictions. In the US, according to the previous discussion in this chapter, before the court there was only one case involving patentability of claims concerning stem cells. However, this case was simply struck down by the CAFC because of the lack of standing. ${ }^{445}$ In China, according to the CPL, a patent applicant who is not satisfied with the decision made by the PRB may institute legal proceedings in the People's Court. ${ }^{446}$ However, so far there has no case concerning the patent eligibility of biotechnological inventions before China's courts, not to mention hESC-related inventions. There has been no significant litigation concerning patenting hESC -related inventions in the US and China. Thus, this section mainly focuses on several juridical decisions in the EU. Before investigating those, opinions of the EGE in terms of patenting hESC-related inventions is discussed first in this section (Sect. 4.1). Then, the judicial decisions of Oliver Brüstle v. Greenpeace eV (Brüstle) ${ }^{447}$ before the CJEU and the German Federal Court of Justice (FSC) are discussed in detail (Sects. 4.2 and 4.3). Moreover, the

\footnotetext{
442 See FS73216 of the PRB, supra note 427.

443 Seeid.

444 Seeid.

445 See Consumer Watchdog v. Wisconsin Alumni Research Foundation, supra note 270. See also supra Sect. 3.1.5, Chap. 5.

446 See Article 41(1) of the CPL.

447 See C-34/10 (Oliver Brüstle v. Greenpeace eV), supra note 170.
} 
decision of the International Stem Cell Corporation v. Comptroller General ${ }^{448}$ of the CJEU is also explored in this section (Sect. 4.4), since it concerns the definition of a human embryo and patenting stem-cell-related inventions.

\subsection{Opinions of the EGE}

The Biotech Directive has granted the EGE the task of gauging all ethical aspects of biotechnology. ${ }^{449}$ The opinions of the EGE, however, are strictly advisory and not legally binding on any of the national or European patent offices or courts. ${ }^{450}$ In May 2002, the EGE released its Opinion No. 16 entitled "Ethical Aspects of Patenting Inventions Involving Human Stem Cells," which demonstrated the EGE's considerations on the meaning and scope of application of Article 6(2)(c) of the Biotech Directive with regard to hESC-related patent applications. ${ }^{451}$ The EGE felt that the prohibition on patenting hESCs would greatly slow this research field, which would be contrary to the public's, and particularly patients', interests. ${ }^{452}$ In this regard, the EGE attempted to define the conditions required to patent and the limits of the patenting of hESC-related inventions in relation to ethical considerations.

In Opinion No. 16, the EGE distinguished unmodified isolated hESCs, which it suggested should not be patentable, from modified hESCs, which should. ${ }^{453}$ It stated that such isolated hESCs "are so close to the human body, to the foetus or the embryo they have been isolated from, that their patenting may be considered as a form of commercialization of the human body." ${ }^{454}$ At the same time, the EGE was aware that unmodified hESC lines would lead to overly broad patents, which may impede further research and development and by extension have adverse impacts on the aim to support further innovation to improve of health care. ${ }^{455}$ Concerning the patenting of processes involving hESCs, the EGE stated there was no specific ethical obstacle. ${ }^{456}$ It can be clearly seen that the EGE primarily focused on two aspects in its opinion: the moral considerations, and the potential negative effects of patents on follow-on research.

\subsection{Oliver Brüstle v. Greenpeace $\mathrm{eV}$ at the CJEU}

In the EU, the first seminal judgement directly relating to the patent eligibility of hESC-related inventions that the CJEU has made was Brüstle on 18 October 2011. This

\footnotetext{
448 See C-364/13 (International Stem Cell Corporation v. Comptroller General of Patents, Designs and Trade Marks), supra note 83.

449 See Article 7 of the EU Biotech Directive.

450 See Plomer, et al., supra note 6, at 13.

451 See EGE, supra note 109.

452 Seeid., at 14.

453 Seeid., at 15.

454 Id.

455 See id., at 15, 17.

456 Seeid., at 15.
} 
case involved a dispute regarding a patent concerning neural precursor cells and the processes for creating them from ESCs, as well as their use for therapeutic purposes. ${ }^{457}$ Initially, the German Federal Patent Court invalidated the patent. On appeal, the German FCJ referred the case to the CJEU for further clarification, by asking what is to be understood by "human embryo" and by "use for industrial or commercial purposes", particularly where the embryo is used for the purposes of scientific research. ${ }^{458}$

To be specific, one question that the CJEU needed to tackle was how to interpret the term "human embryo" within the meaning of and for the purposes of the application of Article 6(2)(c) of the Biotech Directive. ${ }^{459}$ The CJEU stated that the term "human embryo" must be given an independent and uniform interpretation throughout the territory of the EU. ${ }^{460}$ The CJEU stressed that to protect human dignity was one aim of the Directive, and the EU legislature intended to exclude from patent eligibility any subject that could contravene human dignity. ${ }^{461}$ It is from this perspective that the CJEU decided to interpret the notion of human embryo in Article 6(2)(c) of the Biotech Directive in a wide fashion, based on the capacity of "commencing the process of development of a human being". ${ }^{462}$ Moreover, as the CJEU stated, this broad interpretation of the human embryo encompassed both conventionally fertilized embryos and synthetically created embryos, such as the zygote, and embryos formed by SCNT as well as by parthenogenesis. $^{463}$

Concerning whether a stem cell is included in the scope of a human embryo, the CJEU did not see itself as being in the position to decide, and held that this issue should be for national courts to ascertain, in light of scientific developments, whether stem cells comply with this definition. ${ }^{464}$ Based on the expansive interpretation of Article 6(2)(c) and "human embryos" by the CJEU in Brüstle, hESCs isolated from human embryos could fall within the definition of human embryos if found by a deciding court to be capable of commencing the process of development of a human being. Moreover, the

457 See DE 19756864 entitled "Neurale Vorläuferzellen, Verfahren zu ihrer Herstellung und ihre Verwendung zur Therapie von neuralen Defekten”. See C-34/10 (Oliver Brüstle v. Greenpeace eV), supra note 170.

458 See id. See also European Commission, Summary of the Judgement in Case C-34/10, (May 2010), http:// ec.europa.eu/dgs/legal_service/arrets/10c034_en.pdf.

459 See C-34/10 (Oliver Brüstle v. Greenpeace eV), supra note 170, para. 24.

460 The CJEU acknowledged up front that the EU Biotech Directive did not define human embryo, nor did it contain any reference to national laws. It then put forward that the lack of unified definition of the concept of human embryo would cause different patenting practice situations in member states, so as to contradict the object and the aim of the Directive. See id., paras. 25-28.

461 See id., paras. 32-34. See also Martina Ines Schuster, The Court of Justice of the European Union's Ruling on the Patentability of Human Embryonic Stem-Cell-Related Inventions (Case C-34/10), 43 INTERNATIONAL REVIEW OF INTELLECTUAL PROPERTY ANd COMPETITION LAW 626, 628 (2012).

462 C-34/10 (Oliver Brüstle v. Greenpeace eV), supra note 170, para. 37.

463 See id., paras. 34-38. Concerning SCNT and parthenogenesis, please see supra Sects. 3.2.1.3 and 3.2.2.4, Chap. 2.

464 See Schuster, supra note 461, at 630. 
German FCJ asked whether an invention was unpatentable even if its purpose was not the use of human embryos, where it involved a product whose production necessitated the prior destruction of human embryos or a process which required a raw material obtained by the destruction of human embryos. ${ }^{465}$ The CJEU determined that the exclusion from patent eligibility did not shift merely because the previous destruction of human embryos was not contained in the claims. ${ }^{466}$ Concerning whether use for scientific research is covered by "use for industrial or commercial purposes", the CJEU observed that granting a patent means, in principle, the industrial or commercial application of an invention, and thus the use of human embryos for scientific research could not be separated from the patent itself and the rights attaching to it. ${ }^{467}$ Then, the CJEU concluded that the human embryo exclusion also precluded the patent eligibility of the use of human embryos for purposes of scientific research.

The Brüstle decision has made the EPO change its patent policy very quickly, which can be seen from the decision in the 2014 TECHNION case. ${ }^{468}$ Through the CJEU's ruling in Brüstle and the EPO's decisions, the patent eligibility of hESC-related inventions in European patent law is more unified and in harmony within both the EPO and EU. However, the definition of a human embryo provided in Brüstle still had created divergent interpretation, ${ }^{469}$ and it gave rise to another case before the CJEU shortly after. ${ }^{470}$

\subsection{German Court's Decision (X ZR 58/07) Following Brüstle}

Perhaps surprisingly, the German FCJ did not apply the prior CJEU considerations in a strict manner, but interpreted the CJEU's explanations in a patent-friendly way. ${ }^{471}$ To be specific, the German FCJ decided to merely partially revoke Oliver Brüstle's patent. The German FCJ did not consider the use of hESCs itself to constitute the use of the human embryo within the meaning of Section 2(2) No. 3 German Patent Act, ${ }^{472}$ since hESCs did not have the capacity to commence the process of development of a human being. ${ }^{473}$ According to the German FCJ, the use of cell lines isolated from organisms that are no longer able to develop would not be excluded from patent eligibility. Moreover, the German FCJ held that based on the human embryo exclusion the process that used hESCs was only excluded from patent eligibility if it included the prior destruction of embryos,

\footnotetext{
465 See C-34/10 (Oliver Brüstle v. Greenpeace eV), supra note 170, para. 47.

466 See id., paras. 49-52.

467 See id., paras. 41-43.

468 See supra Sect. 3.2.5.3, Chap. 5.

469 See generally, e.g., O'Sullivan, supra note 165; Hubertus Schacht MA, Commencement or Completion: What Constitutes a "Human Embryo" Within the Meaning of the EU Biotechnology-Directive? 36 EUROPEAN INTELLECTUAL PROPERTY REVIEW 66 (2014).

470 The ISCO case of the CJEU will be discussed in detail later, see infra Sect. 4.4, Chap. 5.

471 See Case X ZR 58/07, German Federal Court of Justice, decided on 27 Nov. 2012.

472 Section 2(2) No. 3 German Patent Act is identical to Article 6(2)(c) of the EU Biotech Directive.

473 See Case X ZR 58/07, supra note 471.
} 
or their uses as starting material. ${ }^{474}$ The German FCJ left open a possibility that if the derivation of hESC lines did not necessitate the destruction of human embryos, then they were patent eligible. In the view of this, it seems that the German FCJ was attempting to consider the continuous development of technology, and the fact that there might emerge new technology which could produce hESC-related inventions based on non-destructive methods. ${ }^{475}$ As a result, it can be seen that the German court took a more permissible approach in terms of patenting hESC-related inventions, compared with the Brüstle decision of the CJEU. However, it raised a potential problem that the decision of the German FCJ might misinterpret the CJEU's preliminary ruling, and also might conflict with the current approach adopted by the EPO. ${ }^{476}$

\subsection{ISCO Case at the CJEU}

Before the CJEU, there arose another crucial case concerning the definition of a human embryo, though it did not directly relate to hESC-related inventions. The ISCO case mainly involved patent applications concerning hPGSC lines and the preparation methods. ${ }^{477}$ The patent claims were initially rejected by the UK IPO based on the use of human embryos under paragraph 3(d) of Schedule A of the Patents Act 1977, which adopted Article 6(2)(c) of the Biotech Directive. ${ }^{478}$ Given this, the applicant, ISCO, brought an appeal against the UK IPO's decision before the UK High Court of Justice (England \& Wales) (HCJ), arguing that only "organisms capable of commencing the process of development which leads to a human being" should be excluded from patent eligibility under the decision in Brüstle. ${ }^{479}$ Meanwhile, ISCO asserted that PGSCs were not totipotent but rather pluripotent, could not fully develop, and thus should be eligible for patent protection. ${ }^{480}$ ISCO's reasoning turned on the fact that mammalian pluripotent cells themselves are unable to develop into an entire organism. ${ }^{481}$ However, the UK HCJ was unsure of whether the CJEU intended to preclude PGSCs from patent eligibility in its Brüstle ruling, and thus referred the case to the CJEU. To be specific, the UK HCJ inquired whether "unfertilized human ova whose division and further development have

\footnotetext{
474 Seeid.

475 See Nordberg \& Minssen, supra note 435, at 145.

476 See id.

477 See Application GB0621068.6, entitled "Parthenogenetic activation of oocytes for the production of human embryonic stem cells" (filed 23 Jan. 2006) and Application GB0621069.4 entitled "Synthetic cornea from retinal stem cells" (filed on 23 Oct. 2006). For more information concerning parthenogenesis technology and parthenogenetic stem cells, please see supra Sect. 3.2.2.4, Chap. 2.

478 See C-364/13 (International Stem Cell Corporation v. Comptroller General of Patents, Designs and Trade Marks), supra note 83, para. 13.

479 Id., para. 15.

480 Seeid.

481 See Vincenzo Senatore, et al., Patenting Parthenotes in the US and Europe, 33 NATURE BIOTECHNOLOGY 1232 , 1233 (2015).
} 
been stimulated by parthenogenesis" constitute "human embryos" within the meaning of Article 6(2)(c) of the Biotech Directive. ${ }^{482}$

Prior to delivering the decision by the CJEU, the Advocate General (AG) proposed that the criterion used in Brüstle to include an organism in the definition of "human embryos" was whether such an organism is "capable of commencing the process of development of a human being", which should be comprehended as an organism possessing the inherent capability of developing into a human being. ${ }^{483}$ The AG pointed out that provided that parthenotes and organisms resulting from parthenogenesis were not "capable of developing into a human being and have not been genetically manipulated to acquire such a capacity", they were not included in the definition of human embryos. ${ }^{484} \mathrm{Con}$ firming the opinion of the AG, the CJEU ruled that Article 6(2)(c) of the Biotech Directive should be construed in the sense that a human parthenote or organism resulting from parthenogenesis did not constitute a "human embryo", as long as "in the light of current scientific knowledge, it does not, in itself, have the inherent capacity of developing into a human being." 485 This, in effect, has established a test of "inherent capacity" for determining a human embryo. Regarding determining whether the provided conditions are met, the CJEU has left the discretion to the national courts. ${ }^{486}$ In the meantime, the CJEU has set up a criterion "current scientific knowledge" for such evaluation. Based on the decision of ISCO, it can be inferred that under the Biotech Directive, prohibitions against patents upon hESC-related inventions merely apply to stem cells derived from the embryos, which have the capability of developing into human beings. Thus, the decision by the CJEU in ISCO has significantly modified the landscape for hESC patenting established in Brüstle.

Through the abovementioned two judgements by the CJEU, the definition of a human embryo within Article 6(2)(c) of the Biotech Directive basically has been set down, which is based on the inherent capacity of developing into a human being in light of current scientific knowledge. In the matter of patenting hESC-related inventions, according to the CJEU, provided that an invention involves the destruction of human embryos, no matter when the destruction takes place, the invention would be excluded from being patented. This broad application of the human embryo exclusion to patenting hESCrelated inventions has resulted in the concerns of researchers and scientists about

482 C-364/13 (International Stem Cell Corporation v. Comptroller General of Patents, Designs and Trade Marks), supra note 83 , para. 20.

483 Opinion of Advocate-General Cruz Villalón, delivered on 17 July 2014, Case C-364/13, International Stem Cell v. Comptroller General of Patents, paras. 67, 71.

484 Id., para. 80.

485 C-364/13 (International Stem Cell Corporation v. Comptroller General of Patents, Designs and Trade Marks), supra note 83 , para. 38.

486 See id., paras. 36-37. 
potential discouragement over future investment in this research field. ${ }^{487}$ However, to the relief of these researchers and scientists, the CJEU only focused on the destruction of embryos and left open a possibility that inventions which rely on a non-destructive use of human embryos may be patent eligible. ${ }^{488}$ This is reflected in the decision of the German case X ZR 58/07 after the Brüstle decision of the CJEU. ${ }^{489}$ In addition, it is worth noting that the decision of the CJEU in Brüstle has been criticized for creating a fictional consensus in Europe on the definition of human embryos, which may have violated the autonomy of member states. ${ }^{490}$

\section{ASSESSING THE ISSUES IN CHINA}

The comparative analysis has demonstrated a detailed picture of the US, EU and Chinese legal systems concerning patenting hESC-related inventions. The purpose of conducting such a comparison is to review the current status of the Chinese patent system in relation to patenting hESC-related inventions, so as to make suggestions for further improvements. This section continues the analysis and evaluations of the actual operation of the patent eligibility of hESC-related inventions in China, and suggests solutions for the improvement of Chinese law or policies on patenting hESC-related inventions in the context of global competition, domestic innovation promotion, and Chinese moral culture. These recommendations are grounded in the theoretical foundations of patent law, China's unique national conditions, and the results of the comparative analysis of the American, European and Chinese legal systems in this thesis. As the aim of the thesis states, this section focuses more particularly on patenting hESC-related inventions, but may also have a general and broader application to patenting biotechnological inventions in China.

\subsection{To Remove Moral Assessment}

It is evident that with the development of modern biotechnology, patenting morally controversial biotechnological inventions, including hESC-related inventions, has created significant public concerns, regardless of whether assessing moral issues (e.g., in

487 See Alison Abbott, German Science Organizations Slam European Court over Stem-cell Ruling, NATURE News, (Dec. 8, 2011), 10.1038/nature.2011.9606.

488 See Sven Bostyn, et al., Final Report of the Expert Group on the Development and Implications of Patent Law in the Field of Biotechnology and Genetic Engineering, 142-145 (May 17, 2016), https://www.ivir.nl/ publicaties/download/Report-of-Biotech-Expert-Group.pdf (in this report, two experts held that the human embryo exclusion interpreted in the CJEU Brüstle decision should exclude any use of a human embryo from patentability. But the majority of the experts felt that the judgement should be understood to refer to "destructive use only.")

489 Concerning the discussion of the German case X ZR 58/07 after the Brüstle decision of the CJEU, see supra Sect. 4.3, Chap. 5.

490 See Bostyn, et al., supra note 488, at 142-145. See also generally, Aurora Plomer, After Brüstle: EU Accession to the ECHR and the Future of European Patent Law, 2 QueEn MARY Journal of INTELLECTUAL ProperTY 110 (2012). 
the EU and China) or not (e.g., in the US) when determining the patent eligibility of subject matter. There is no doubt that it is necessary for legislation and policies to respond, but the question is merely whether it is necessary to assess moral issues when a patent office or a court determines the patent eligibility of subject matter. Interestingly, concerning the solutions to the problems raised by patenting morally controversial biotechnologi-cal inventions, one option is to follow the American approach, that is, to remove the morality assessment requirement from determining patent eligibility.

It has been argued that granting a patent gives a patentee only the right to prevent others from exploiting the invention, but not the affirmative right to practice the subject matter of invention. In this view, whether the patentee has the right to utilize the invention should be determined by other laws and regulations. Accordingly, moral issues should be left entirely to other bodies, rather than the patent system, to deal with. Patent law then can maintain its purely technical color, and there is no need to consider these moral issues. ${ }^{491}$ These commentators opine that the real issue is the underlying research, rather than patents, and moral considerations have no place in patent law. ${ }^{492}$ It also has been argued that the assessment of morality in the patent system is not an effective way to regulate immoral research in the field of biotechnology. ${ }^{493}$ Withholding patent protection on moral grounds cannot put an end to the development and application of inventions, but merely slows their development. Instead, immorality is repeated when the invention is utilized after marketing, ${ }^{494}$ since if the invention were excluded from patent eligibility on moral grounds, it would be put into the free market or the public domain, and can be pursued to market or utilized by any third parties. ${ }^{495}$ Also, the commentators feel that the predominant purpose of patent law is to encourage investment and innovation, and that the economic policy lies at the heart of patent law. ${ }^{496}$ Based on the vagueness of morality and associated conflicting interpretations, they criticize the assessment of morality in determining patent eligibility as a step which may impede the economic aim of patent law. ${ }^{497}$

In addition, it has been argued that social morality is a vague concept which changes with time; given this, it is not proper for a patent examiner, who holds a primarily scientific educational background and knows little about morality or ethics, to evaluate

491 See STERCKX \& CockBAIn, supra note 6, at 290, 299-300.

492 See e.g., Sigrid Sterckx, European Patent Law and Biotechnological Inventions, in BIOTECHNOLOGY, PATENTS AND MORALITY 7-9 (Sigrid Sterckx ed., Ashgate Publishing 1997).

493 See e.g., Li Jiang, Regulating Human Embryonic Stem Cell in China: A Comparative Study on Human Embryonic STEM CELL'S PATENTABILITY AND MORALITY IN US AND EU (Springer 2016).

494 See Amanda Warren-Jones, A Mouse in Sheep's Clothing: the Challenge to Patent Morality Criterion Posed by “Dolly", 20 European InTEllectual Property ReVIEW 445, 446 (1998).

495 See Warren-Jones, supra note 289, at 833.

496 See MILLS, supra note 133, at 11.

497 See Bagley, supra note 86, at 335. See also MILLS, supra note 133, at 11-12. 
moral issues concerning inventions. ${ }^{498}$ Some commentators argue that in a modern democratic country, only the legislature has the competence to decide the scope of patentable subject matter. In their view, administrative or judicial officials should not be allowed to determine patent eligibility on moral grounds. Similarly, the CAFC of the US asserted that it was not appropriate for the USPTO or courts to "serve as arbiters of deceptive trade practices" and it was not the job of the USPTO to displace the police powers of the states and promote the health, order, peace, and welfare of the community. ${ }^{499}$

\subsection{The Case for Keeping Moral Assessment in China}

Several commentators have analyzed patenting hESC-related inventions in Europe, and found that morality assessment in the EPC and the Biotech Directive has created heated debate and confusion concerning patenting morally controversial biotechnological inventions. They concluded that the morality assessment requirement should be removed from patent law, and at the same time suggested China follow the American approach. ${ }^{500}$ There is no doubt that, as previously articulated, confusion concerning the application of the general morality clause clearly exists in the EPO, particularly between different parts (e.g., the ED and the OD of the EPO). However, this at most indicates that patent law at the European level may not be at the correct stage to deal with moral issues, or that the application of morality assessment should be improved. It does not necessarily imply the morality assessment should be removed from determining patent eligibility in China. In other words, the confusion concerning the application of moral considerations which exists at the European level does not justify a conclusion that the morality assessment should also be removed from the determination of patent eligibility in China. Instead, there are several reasons that China still needs to keep the moral assessment within its patent system. The reasons can be summarized as follows:

First, laws cannot reject moral norms. To be sure, legal norms are not moral norms, and laws cannot act as a tool to promote morality. However, laws cannot reject moral norms. ${ }^{501}$ The Fourth Plenary Session of the 18th Central Committee of the CPC pointed out that "the law is an instrument of great value in the governance of a country and good laws are a prerequisite for good governance." 502 This document also mentioned

\footnotetext{
498 See e.g., Bagley, supra note 86, at 335; JIANG, supra note 493, at 160; MILLS, supra note 133, at 139.

499 Juicy Whip, Inc. v. Orange Bang, Inc., supra note 127, at 1368.

500 See e.g., JIANG, supra note 493; Huan Zhu, A Comparative Study on Human Embryonic Stem Cell's PatentEligibility in the United States, the European Patent Organization and China, BEPRESS, (Mar. 23, 2012), https:// works.bepress.com/huan_zhu/1/.

501 See Rainer Moufang, Patenting of Human Genes, Cells and Parts of the Body?-The Ethical Dimensions of Patent Law, 25 International REVIEW of Industrial PROPERTY ANd COPYRIGHT LAW 487, 497 (1994).

502 Zhongguo Gongchandang Di Shiba Jie Zhongyang Weiyuanhui Di Sici Quanti Huiyi Gongbao (中国共产党第十 八届中央委员会第四次全体会议公报) [Communiqué of the Fourth Plenary Session of the 18th Central Committee of the CPC], held in Beijing from Oct. 20 to 23, 2014.
} 
it is necessary to boost the moral implication of rule by law. ${ }^{503}$ Good laws indicate the inner morality of the law, which means the law needs to absorb the basic moral norms or values, in order to guide the formulation and operation of the law. ${ }^{504}$ Although the law is not morality, the law should reflect the bottom line of morality. Morality provides the formulation and operation of the law with an essential reference which prevents the law from slipping to the opposite side of social morality. ${ }^{505}$ As a branch of law, patent law should also have its moral basis. ${ }^{506}$ Moreover, the granting of a patent in effect is not as morally neutral as described by those who advocate removing the morality assessment from the patent system. Technology is objective and neutral, but the choice and use of technology depends on the subjective preferences of individuals. As Peter Drahos points out, "[l]ike it or not, the creation, operation and interpretation of the patent system is linked to moral standards. Patent law is located within and not outside a public ethic of community values and shared economic and social interests. There is nothing surprising about this." ${ }^{507}$ Additionally, in China it is a legislative tradition to incorporate moral considerations into its legislation. ${ }^{508}$ Thus, the incorporation of the morality assessment in China's patent law is understandable.

Second, patent law should never act as a tool to provide incentives for research that contravenes social morality or ordre public. ${ }^{509}$ Patenting is an incentive which motivates innovation, facilitates investment, and promotes patent owners' efficient use and commercialization of unrealized ideas. ${ }^{510}$ Given this, the patent eligibility of certain subject matter in one nation or another plays a significant role in the future development direction of research and industry, and can push research towards a specific direction. Without patent protection (e.g., excluding the subject matter from patent eligibility on moral grounds), there would be less incentive for inventors and investors to enter a research field where the inventions are costly to make. Then there would be far fewer inventions being created launched into the free market. Put another way, by removing the financial incentive, which patent law may otherwise provide, to conduct immoral and unethical research, it is possible to decrease investment and activity in a research filed in this nation. Moreover, Professor Eugene Volokh has pointed out the "political

503 Seeid.

504 See Yuhong Hu (胡玉鸿), Ren de Zunyan de Falü Shuxing Bianxi (人的尊严的法律属性辨析) [An Analysis of the Legal Attributes of Human Dignity], 5 Zhongguo Shehui Kexue (中国社会科学) [SoCIAL SCIENCE IN CHINA] 101, 108 (2016)

505 See id.

506 See Moufang, supra note 501, at 498-450.

507 Peter Drahos, Biotechnology Patents, Markets and Morality, 21 EUROPEAN INTELLECTUAL PROPERTY REVIEW 441 , 441 (1999).

508 SeeXianwen Zheng (郑显文), Gongxu Liangsu Yuanze zai Zhongguo Jindai Minfa Zhuanxing zhong de Jiazhi (公序良俗原则在中国近代民法转型中的价值) [The Value of the Principle of Public Order and Good Morals in the Transformation of the Civil Law of Modern China], 11 FAXUE (法学) [LAW SCIENCE] 87, 88-91 (2017).

509 See also STERCKX \& COCKBAIN, supra note 6, at 290-291.

510 See supra Sect. 2.2, Chap. 2. 
power" slippery slope. ${ }^{511}$ He worried that permission to patent morally controversial biotechnological inventions may provide extra incentives for relevant patentees or interest groups to lobby the legislature to lift the ban on research or funding. ${ }^{512}$ Similarly, Professor Margo Bagley also has expressed the concern that the availability of patents on morally controversial biotechnological subject matter, such as embryonic stem cells and methods of mammalian cloning, in the US may have already affected Congress' ability to pass legislation prohibiting such research. ${ }^{513}$

Patent law is also able to promote the disclosure of inventions and make new knowledge available to all. This disclosure enables others to build on the achieved knowledge. ${ }^{514}$ In view of this, the morality assessment in the patent system will result in a majority of immoral inventions being terminated from the beginning of research, and then no disclosure of those immoral inventions. Furthermore, withholding patent protection could also have a role in keeping immoral research hidden from public view and potential regulations. ${ }^{515}$ As previously analyzed, the main purposes of China's patent law are to promote technical innovation and the dissemination of its fruits, with the final goal being promotion of the economic and social development. ${ }^{516}$ From this perspective, the dissemination of the fruits of immoral technical innovation should never be promoted by China's patent law.

In addition, the fact is that in China, research on many potential morally controversial subject matters is not legally prohibited, ${ }^{517}$ as mentioned previously in Chapter 4, but without the promise of lucrative licensing contracts and royalties from the governmentgranted patent protection, much of the research likely would not continue. ${ }^{518}$ Of course, there might be a situation in which even if certain inventions are excluded from patent eligibility on moral grounds, scientists would still be extremely interested in creating those biotechnological inventions. But in that case, it is not the issue of the morality assessment within patent law which matters; rather it should be the issue of justification of patent protection, because for those scientists, patent protection would not be so important. Thus, although preclusion of the patent eligibility of morally problematic inventions, by withdrawing the incentives that the patent law is supposed to provide, cannot stop the immoral research in a society, patent law at least should never provide the incentives to immoral inventions and discoveries.

\footnotetext{
511 See Eugene Volokh, The Mechanisms of the Slippery Slope, 116 HARVARD LAW REVIEW 1026, 1114-1121 (2003).

512 Seeid., at 1115.

513 See Bagley, supra note 21, at 514.

514 See supra Sect. 2.2, Chap. 2. See also EGE, supra note 109.

515 See Bagley, supra note 86, at 336-337.

516 See supra Sect. 2.1, Chap. 2.

517 See supra Sects. 4.1, 4.2 and 4.3, Chap. 4.

518 See Bagley, supra note 86 , at 329.
} 
Third, the morality assessment within the determination of patent eligibility should be considered a filter which complements the sanctioning role of other agencies. ${ }^{519}$ It is true, as some individuals have argued, that excluding immoral inventions from patent eligibility cannot completely avoid the development and application of undesirable inventions. However, the morality assessment within the patent system should not be expected to regulate per se, and there seems little evidence to demonstrate that it has played such as role. ${ }^{520}$ Instead, it should be considered a filter which complements the sanctioning role of other agencies. Conducting a moral analysis within patent law context does not mean to deny any role, such as granting permissions for research or market, which other regulatory bodies have in determining the issues. It is just a component in regulating, albeit indirectly, the creation of technologies and inventions. ${ }^{521}$ Through a proper morality analysis within the determination of patent eligibility, which functions as a filter, it is possible to minimize the undesirable discoveries and innovations in certain morally problematic biotech areas, and make great efforts to use the positive potential of technologies fully. In this regard, the morality assessment in the patent system does not conflict with the regulation of moral issues within other laws or regulations, and they together build successive barriers to ensure technology develops into a moral direction. Moreover, the existence of the morality assessment makes the patent system the only legal arena in which technologies are investigated on a case-bycase basis. ${ }^{522}$

In the US, although regulation of embryo and hESC research merely relies on the distribution of federal public funding, rather than on promulgation of any legislation or regulation to specifically prohibit it, it allows states to regulate biotechnological research by legislation and tailoring their local policies based on specific circumstances. ${ }^{523}$ In this respect, it can be said that the US has a relatively comprehensive legislative regulatory system concerning biotechnological research, including hESC research. However, unlike the US, especially in this research field, as can be seen in Chapter 4, China does not have a comprehensive regulatory framework. What is more, China merely relies on government policy, rather than laws or regulations, to regulate hESC and human

519 See Warren-Jones, supra note 289, at 832.

520 See MILLS, supra note 133, at 11.

521 See id.

522 See STERCKX \& CockBAIn, supra note 6, at 300. See also Daniel Alexander, The Case For and Against the Patenting of Biotechnological Inventions, in BIOTECHnOLOGY, PATENTS AND MORALITY 255-256 (Sigrid Sterckx ed., Ashgate Publishing 2000) ("it is only in [patent offices] that these issues may be addressed on a sufficiently case-by-case basis, because a lot of these questions that one has to address are very particular questions, involving very particular facts and, for instance, if one is to go into environmental risks, very detailed evidence as to what those risks and benefits are. That is one reason why one might say that an institution such as the EPO is in fact not unsuited, but might be particularly suited to making decisions of this kind and ought to do so.")

523 See supra Sect. 2, Chap. 4. 
embryo research. Through analyzing the provisions of the Ethical Guidelines in Chapter 4 , one can observe that China has taken a considerably permissive approach towards regulating hESC research, in terms of allowed types of hESC research and the degree of regulation and oversight. The focus of the regulation approach that the Chinese government has taken is primarily on pursuing the advancement of hESC research, rather than paying any close attention to local social or moral concerns. The regulation on hESC research is just a miniature of how China regulates research and development in the field of biotechnology. Moreover, it can be said that in the foreseeable future, the Chinese approach towards regulating biotechnology research is unlikely to change considerably. At this point, it is inappropriate for China to remove the morality assessment from determining patent eligibility and to leave moral issues to other agencies to deal with, since the other agencies are not prepared to do so, and it can even be said that other agencies may not want to deal with such "indifferent" issues. Instead, retainning the morality assessment within patent law would be good for China to change the impression that this country is a "Wild East" in biotechnological research, which can in turn promote this research field of China to be fully recognized in the world.

In addition, to remove the morality assessment requirement from the determination of patent eligibility is essentially nothing less than to directly place the patent eligibility decision-making power into the hands of scientists and researchers. ${ }^{524}$ However, scientists and researchers are not superior in dealing with moral or ethical issues related to S\&T. They are not the optimal unit to determine what the limits of patentable subject matter should be. ${ }^{525}$ When attempting to start morally controversial research and then applying for a patent, many scientists do not know where to draw the line, or whether there must even be a line when dealing with morally unacceptable invention, even for reaching a moral "end". ${ }^{526}$ This should not be surprising, since as Drs. Maureen and Samuel Condic noted:

When it comes to morals, the key insight to remember is that scientific research is about the possible, not about the ethical or the good. As such, scientific evidence can inform society whether something can, at this point in time, be done and ... can predict whether it is probable something will be done in the future, but science is inherently silent on the topic of whether it should be done. In other words, a scientist, qua

524 See Bagley, supra note 86, at 327 (Professor Bagley points out that, under the US patent law, a person can obtain a patent provided the invention meets the statutory requirements. In this regard, without clear congressional action, researchers are in essence formulating patent policy and determining the patent eligibility limits by the subject matter described in their applications.)

525 See id., at 328.

526 Seeid. 
scientist is no better equipped to weigh-in on the moral implications of some new technology by virtue of his scientific training than is any other person. Indeed, scientists are, in many respects, uniquely unsuited to make moral [j]udgments-precisely due to their focus on the possible. Much that is 'possible,' and a legitimate topic of investigation, from the perspective of science, is nonetheless objectively evil. ${ }^{527}$

As can be seen, it is not realistic to expect patent applicants to set constraints on the moral aspects of patent eligibility of subject matter. ${ }^{528}$

Fourth, considering that the Chinese public has not established a comprehensive perception of patents, it is also inappropriate for China to remove morality assessment from the determination of patent eligibility. In morally controversial research fields of biotechnology, public trust is undoubtedly fragile. ${ }^{529}$ Policy makers may turn a deaf ear to the public's moral concerns based on their belief that the research is being conducted in the public's interests. ${ }^{530}$ In that case, the public's trust could be easily lost once the public becomes suspicious of the motivations behind biotechnology innovation and perceives that commercial interests predominate over ethics. ${ }^{531}$ The loss of the public's trust regarding a specific research field in turn may highly impede the advancement of this and related research fields.

Indeed, a patent right is a negative right. Nevertheless, patent owners have the right not only to exclude others from their invention, but also to alienate their property right, by sale, license, bequest, or otherwise. ${ }^{532}$ Moreover, particularly in China, as stated in Chapter 3, patents can be utilized by students to get bonus points on entrance examinations, can help doctors, technicians, teachers, and researchers to obtain extra points in their professional tittle evaluation, and can help civil servants or officials eliminate a record of disciplinary action and demerit punishment. Moreover, patents can bring their owners rewards from local governments. Patents also can help creative prisoners to get out of jail earlier, since Chinese laws provide that if prisoners obtain invention

527 Maureen L Condic \& Samuel B Condic, The Appropriate Limits of Science in the Formation of Public Policy, 17 Notre Dame Journal of LaW, Ethics \& Public Policy 157, 161-162 (2003).

528 See Bagley, supra note 86, at 328.

529 See Timothy Caulfield, Biotechnology Patents, Public Trust and Patent Pools: the Need for Governance? in The Role of Intellectual Property Rights in Biotechnology Innovation 361 (David Castle ed., Edward Elgar 2009).

530 See id.

531 See id. See also Timothy Caulfield, et al., Trust, Patents and Public Perceptions: The Governance of Controversial Biotechnology Research, 24 NATURE BIOTECHNOLOGY 1352, 1353 (2006).

532 See Bagley, supra note 86, at 339. 
patents, they can get their sentences reduced. ${ }^{533}$ In this regard, the patent right in China is no longer merely a negative right.

Additionally, to the Chinese public, a patent is a thing with a sense of mystery, and to some extent, a patent has an almost "omnipotent" presence in front of them. ${ }^{534}$ To the Chinese people, granting a patent over an invention is highly analogous to giving the general public an impression that such technology has been given the "go-ahead" endorsement by the government. Put differently, to the Chinese public granting a patent is just like the government giving an endorsement to a high-tech product or process, and implies a moral support and a potential moral compliment from the government. As a result, at least in the eyes of the Chinese public, obtaining a patent means that the government commends inventors' technological achievements. In this case, in China granting a patent upon an immoral invention may give rise to a public backlash against such research and even the patent system, which might ultimately hinder the development of S\&T and meanwhile undermine the authority of the government. For instance, in 2012, there was a capsule safety and patent scandal in China in which some contaminated gelatin capsules were made from leather waste, which contained excessive levels of a toxic material (chromium). ${ }^{535}$ The thing that made the Chinese public even more outraged was that two patents had been granted over the processes of using leather waste to make edible gelatin, which was considered to have undermined the Chinese patent system and the authority of the government. ${ }^{536}$ In any case, it is a big problem if most people have the feeling that the inventions are morally offensive. In such a situation, it is reasonable to impose certain public order and moral restraints on patentable subject matter, or prevent undesirable values from spreading in today's society. ${ }^{537}$

To sum up, whether including morality assessment within the determination of patent eligibility is in essence a complicated issue, which is related to a country's legislative tradition, and the degree of development of its science, industry, economy and regulatory system, as well as public perception of patents. Based on these factors mentioned above, it can be concluded that it is not appropriate or realistic for China to follow-

533 See supra Sect. 2.2, Chap. 3.

534 See supra Sect. 2, Chap. 3.

535 See Pige Shiyong Mingjiao Zhuanli-Burong Qingmiao Danxie (“皮革食用明胶专利”不容轻描淡写) [Patents upon the Methods of Using Leather Waste to Make Edible Gelatin—A Serious Thing], XIN JING BAO (新京报) THE BEIJING NEWS, (Apr., 28, 2012), at A5.

536 See id. See also Cao Quan (荃草), Pige Mingjiao Zhuanli de Lunli Wenti, Zenme Jiejue (皮革明胶专利的伦理问 题, 怎么解决) [How to Solve the Problem concerning Patents upon the Methods of Using Leather Waste to Make Edible Gelatin], XINJING BAO (新京报) THE BEIJING News, (May 3, 2012), at A03.

537 See Koichi Sumikura, The Issues Surrounding Patent Protection for Human-Embryonic Stem Cells and Therapeutic Cloning in Japan, in PATENTSChUtz Und StAmmZElLforschung 114 (Josef Drexl et al., ed. Springer 2009). 
ing the American approach to remove the morality assessment requirement from the determination of patentability, particularly concerning patenting biotechnological inventions, as such a solution does not match the conditions of current China.

\subsection{Assessing the Issues}

\subsubsection{General Legislation and Policies}

In general, the Chinese legal system for the protection of patents in the field of biotechnology has made significant achievements. While China has just started its modern patent system since the early 1980s, it has set up a trend towards harmonization with international norms and the laws of other countries. With its catching-up economy and as a technology-importing country, particularly in terms of biotechnology research, China has gradually achieved its policy goal of achieving parity with its technologically advanced counterparts as well as promoting its economy in the field of hESC research. In the matter of patenting hESC-related inventions, China has developed its own way.

Currently, in China the CPL explicitly excludes "scientific discoveries" from patent eligibility, but at the same time through the SIPO's Guidelines an isolation principle, under which an isolated or extracted substance from nature may be patented, has been established. The CPL contains a general morality clause (i.e., Article 5(1) of the CPL) but does not specifically exclude any subject matter from patent eligibility based on moral grounds, which leaves great room for the SIPO and courts to adjust the patenting of morally controversial inventions. Under the general morality clause, the SIPO's Guidelines have incorporated a number of exclusions concerning patenting biotechnological inventions, such as the human embryo exclusion as well as the hESCs exclusion. By applying and interpreting these exclusions, the SIPO has attempted to develop its own way in terms of determining the scope of patent protection for hESC technology. Moreover, through thoroughly investigating a series of re-examinations of the SIPO, a change in the patenting of patenting hESC-related inventions in China can be clearly observed: initially the SIPO was reluctant to grant any patents over hESC-related inventions, but recently it has gradually changed its patent policy to loosen the restrictions on patenting downstream hESC inventions. ${ }^{538}$

From the perspective of the history of China's patent system, the dynamic development of patenting hESC-related inventions is understandable and reasonable. As illustrated in the previous analysis in this thesis, China historically did not have any substantive patent law. ${ }^{539}$ It introduced the modern patent system less than 40 years ago, and had

538 See supra Sects. 3.3.1, 3.3.2, 3.3.3, Chap. 5.

539 See supra Sect. 2.1, Chap. 3. 
no experience with this foreign legal system. For instance, as analyzed before, the general morality clause within the CPL arguably was "copied" into the law from patent laws of other jurisdictions without in the beginning having much knowledge about what this clause might imply. ${ }^{540}$ In addition, the wording of the human embryo exclusion in the SIPO's Guidelines was almost certainly inspired by Article 6(2)(c) of the EU Biotech Directive. Given this, the legislative defects (e.g., the broad wording and the lack of definitions) in the human embryo exclusion of the Directive also appear in the SIPO's Guidelines. ${ }^{541}$ In the case of ambiguity in provisions and the absence of any experience, the decision by the SIPO to exclude any hESC-related inventions from patent eligibility temporarily is a reasonable response. As Huang Kunyi mentioned in the document Explanation on the Patent Law of the PRC (Draft):

Considering China's low level of S\&T and industrial development and its lack of experience with implementing the patent system, the Draft limits the scope of patent protection relatively stringently [...] After gaining experience for a period, we will broaden the protection scope gradually. Currently, the patent system temporarily excludes some substances from patent protection, such as pharmaceuticals, food, and new varieties of synthetic chemicals, and also eliminates animals and plant new varieties and so forth, which are not suitable for patent protection. This is because these substances will affect Chinese livelihoods, health, and the processing industry. ${ }^{542}$

In this regard, the dynamic development concerning patenting hESC-related inventions can be perceived as the manifestation of the process of China learning how to harness its patent system, which, to borrow Deng Xiaoping's phrase, is just like crossing a river by feeling the stones (being cautious in doing a thing, and trying to find out the solution while doing it).

Moreover, the dynamic development and the SIPO's current policy concerning patenting hESC-related inventions can be considered to be in conformity with the development of China's hESC research and industry, as well as the purpose of the Chinese patent system. As stated previously, China in fact started stem cell research relatively late compared with technologically advanced countries, such as the US, Japan, and

\footnotetext{
540 See supra Sect. 2.3.3.1, Chap. 5.

541 See supra Sect. 2.3.3.2, Chap. 5.

542 Kunyi Huang (黄坤益), Guanyu Zhonghua Renmin Gongheguo Zhuanli Fa (Cao'an) de Shuoming (关于《中华 人民共和国专利法 (草案) 》的说明) [Explanation on the Patent Law of the People's Republic of China (Draft)], (Dec. 2, 1983), http://www.npc.gov.cn/wxzl/gongbao/2000-12/26/content_5001493.htm.
} 
several European countries. ${ }^{543}$ Not until around 2010 had China caught up with other countries in the field of hESC research, which can be in part reflected in the fact that the number of published scientific articles regarding hESC research of China surpassed that of other countries (except the US). ${ }^{544}$ Thus, roughly before 2010, China in a way was merely a technology-importing country in this research field. At the early stage of the development of the hESC research and industry, China lacked an hESC technological base to take advantage of the opportunities created by the patent system. Providing patent protection for hESC-related inventions, especially hESCs and their preparation methods, would have benefitted foreign applicants over domestic ones and slowed the progress of domestic research, thereby making it difficult for China to catch up with technologically advanced counterparts. ${ }^{545}$ Additionally, the Chinese government funds the majority of hESC research, ${ }^{546}$ with most participants being universities and state-owned research institutes. ${ }^{547}$ In this regard, during that stage, on the one hand introducing numerous encouragement policies and offering abundant public funding, and on the other hand adopting a conservative policy approach with regard to patenting hESC-related inventions was in conformity with the stage of development at that time of China's hESC research and industry. ${ }^{548}$

In the long run, China's success in hESC research and industry will depend upon more than simply the government's positive policies and raw investment. As the country's domestic technological capability grows, there is expected to be increased demand for international technology transfer, and growth in the local market for technology. ${ }^{549}$ IP protection is one of the most important factors that encourage foreign direct investment and technology transfer. ${ }^{550}$ As China's economy grows and hESC research capacity advances, it seems necessary to provide patent protection in order to attract international technology transfer, promote local technology progress, ${ }^{551}$ and attract more private investment into this research field. ${ }^{552}$ From this perspective, the current patent policy

543 See supra Sect. 4.5, Chap. 4.

544 See supra Table 2 and Figure 1 in Chap. 4.

545 See supra Sect. 2.3, Chap. 2.

546 See supra Sect. 4.4, Chap. 4. See also Yahong LI, Imitation to InNovation IN ChinA: THE Role of PATENTS IN BIOTECHNOLOGY AND PHARMACEUTICAL INDUSTRIES 40-41 (Edward Elgar 2010).

547 See Zhu, supra note 500, at 33-34; Sleeboom-Faulkner \& Patra, supra note 251, at 14.

548 As has been investigated in Sect. 3.3, Chap. 5 of this thesis, during the first two phases, the SIPO in fact held an extremely conservative attitude towards patenting hESC-related inventions, excluding not only hESCS per se and their preparation methods, but also downstream inventions, from patent eligibility.

549 See Keun LEE, et al., Industrial Property (IP) Rights and Technological Development in the Republic of Korea, 119 (Apr. 2003), http://webcache.googleusercontent.com/search?q=cache:ZflSifmnp4QJ:www. keunlee.com/modules/board/bd_download_db.html\%3Fid\%3Deng_research_book\%26no\%3D201+\&cd= $1 \& h l=e n \& c t=c l n k \& g l=s g$.

550 See generally, Keith E Maskus, The Role of Intellectual Property Rights in Encouraging Foreign Direct Investment and Technology Transfer, 9 DUKE JOURNAL OF COMPARATIVE \& INTERNATIONAL LAW 109 (1998).

551 See LEE, et al., supra note 549, at 119.

552 See Mahalatchimy, et al., supra note 349, at 42; Bregman-Eschet, et al., supra note 14, at 239. 
of the SIPO, broadening the scope of patent eligibility in the field of hESC research, i.e., loosening restrictions on the patent eligibility of downstream hESC inventions, would actually be more in line with China's current interests. The approach of gradually broadening the scope of patentable subject matter with the advancement of S\&T and industrial development in China can also be seen in some other fields of technology, such as pharmaceuticals, food, and chemical substances. ${ }^{553}$ In addition, the dynamic approach towards patenting hESC-related inventions conforms with the purpose of the Chinese patent system, to promote China's indigenous technological capabilities and enhance its international competitiveness.

Lastly, the current patent policy of China as regards to patenting hESC-related inventions also corresponds with Chinese moral culture. As the exploration of Chinese moral culture in Chapter 3 has shown, the Chinese public does not have any strong moral concerns about human embryos. Chinese morality concerning the human embryo, in a way, can be regarded as pragmatic and utilitarian. The Chinese on the one hand believe a human embryo to have some inherent moral status and deserve special respect and protection, but on the other hand they are more likely to tolerate the use and destruction of human embryos, particularly when certain elements prevail over the interests of the human embryo, such as the benefits of achieving cures and providing hope for sufferers of debilitating diseases. In this regard, it is reasonable for the SIPO to exclude inventions that necessitate the destruction of human embryos from patent eligibility. Moreover, considering the great therapeutic promise of hESC research and its importance to China, ${ }^{554}$ as well as the "tolerance" characteristic of Chinese morality towards the destruction of human embryos, granting patents to downstream hESC inventions is also reasonable.

In short, the policy concerning the patenting of hESC-related inventions in China not only has contributed to promoting China's domestic innovation in this research field, but also is in conformity with Chinese moral culture. Put another way, the mechanisms for the patenting of hESC-related inventions in China have received support from the results of China's technical, social and economic development, as well as Chinese social morality.

553 See Handong Wu (吴汉东), Zhongguo Zhuanli Fa de Fazhan Daolu: Xiandaihua, Guojiahua yu Zhanlüehua - - Zai Zhongguo Zhuanli Fa Banbu 30 Zhounian Zuotanhui Shang de Fayan (中国专利法的发展道路: 现代化、 国际化与战略化一一在中国专利法颁布30周年座谈会上的发言) [The Development Paths of the Chinese Patent Law: Modernizing, Internationalizing, Strategizing - An Address in Colloquia "the Issuing of the Chinese Patent Law” 30th Anniversary], ZHISHI CHANQUAN (知识产权) [INTELLECTUAL PROPERTY JOURNAL] 10, 11 (2014).

554 For more discussion about the great therapeutic promise of hESC research, please see supra Sect. 3.2.1, Chap. 2. Concerning the importance of hESC research and this industry to China, see supra Sect. 2, Chap. 1. 


\subsubsection{Specific Issues}

After assessing the general legislation and policies concerning patenting hESC-related inventions in China, this section continues to conduct an evaluation of specific issues. While in general the approach that China has adopted towards patenting hESC-related inventions fits this country's technical development and social morality, it still needs further improvement or clarification, particularly regarding the human embryo exclusion as well as the specific exclusion of "hESCs per se and their preparation methods" in the SIPO's Guidelines.

\subsubsection{Meaning of the Term "Human Embryo"}

As emphasized in Chapter 3, there has been a lack of an explicit definition of a human embryo in China's legislation. Even in a crucial case, the Yixing Frozen Human Embryo case in 2012, the courts merely focused on the legal status of (frozen) human embryos, but did not pay any attention to the notion of a human embryo. ${ }^{555}$ Within the patent system, as shown in Chapter 5 previously, although the SIPO's Guidelines have introduced the human embryo exclusion, the SIPO has not given any precise definition of a human embryo in the Guidelines, either. So far, there have been two patent re-examinations in the SIPO dealing with the definition of a human embryo. ${ }^{556}$ In re-examination FS91797, the PRB of the SIPO held that a human embryo should be defined in a traditional way, to include any stage of development from the beginning of the fertilized ovum to the moment before birth. ${ }^{557}$ Based on this definition, any human egg cell must, as soon as fertilized, be regarded as a "human embryo". Moreover, the PRB further asserted that a human embryo could be from any source, and provided several examples, including embryos from IVF and donated embryos from induced abortion. ${ }^{558}$ However, it was unclear whether an entity produced by the process of SCNT or cloning was included in the notion of a human embryo, since this type of entity does not need fertilization but is able to develop into a human being.

However, the PRB of the SIPO in another patent re-examination, the China's ISCO case (FS73216), delivered a complete different definition of a human embryo. ${ }^{559}$ In this decision, the PRB considered human parthenogenetic blastocyst to undergo through the same developmental process, and form a blastocyst with the same morphology as the traditional human embryo which starts from fertilization. ${ }^{560}$ Thus, the PRB has broadly defined a human embryo as an entity which is able to commence the process of

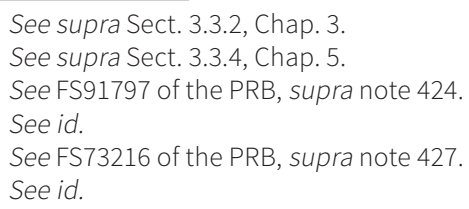


development of a human being or a similar process, and can be a human embryo, but does not necessarily have the capability of developing into a human being. ${ }^{561}$ Based on this extremely broad definition, the PRB considered a parthenote, which is incapable of developing into a human being, to be a human embryo.

In the ISCO decision, the PRB asserted that the broad definition of a human embryo was based on Chinese social morality. ${ }^{562}$ However, according to the study undertaken in this thesis, within Chinese moral culture only an entity with the capability of developing into a human being has a much higher degree of moral status in China. ${ }^{563}$ An entity which does not have the capacity of developing into a human being cannot even be called a viable biological life, not to mention a human person. Moreover, in the Yixing Frozen Human Embryo case, ${ }^{564}$ although the courts did not specifically address the definition of a human embryo, both the first instance court and the appeal court have mentioned many times that the key characteristic of a human embryo was the potential to develop into a human being. ${ }^{565}$ In this regard, an entity lacking the capacity to develop into a human being at most can be treated as equivalent to an organ or a mass of cells, but by no means as a human embryo.

In addition, according to the previous analysis in Chapter 3, the Chinese social morality concerning a human embryo is more pragmatic and utilitarian. Even in the EU, in order to ensure the necessary respect for human dignity, the CJEU ultimately only defined the human embryo based on the inherent capability of developing a human being, ${ }^{566}$ rather than a broader one like that given by the SIPO. That is, with a less restrictive moral culture concerning the human embryo as well as a more liberal governmental policy in China, the interpretation of the term "human embryo" under patent law should not be broader than that given by the CJEU.

It is worth noting that when conducting a moral assessment and defining a human embryo, it is necessary to bear in mind that the definition not only should be considered based on the biological definition as well as within the context of social morality, but also should be considered within the context of patent law. As analyzed previously, unlike the EU Biotech Directive, the CPL does not have the purpose of safeguarding the

\footnotetext{
561 See supra Sect. 3.3.4, Chap. 5.

562 See FS73216 of the PRB, supra note 427.

563 See supra Sect. 3.2, Chap. 3.

564 See Shen Xinnan and Shao Yumei v. Liu Jinfa and Hu Xinxiang, supra note 209. This case has been discussed in the thesis; see supra Sect. 3.3.2, Chap. 3.

565 Seeid.

566 See C-364/13 (International Stem Cell Corporation v. Comptroller General of Patents, Designs and Trade Marks), supra note 83.
} 
dignity and integrity of the human person. ${ }^{567}$ There is no need to interpret the concept of "human embryo" in a broad way, even though in the EU, the CJEU has not provided such a broad definition of a human embryo. This excessively broad interpretation of a human embryo by the SIPO, to some extent, would appear to slow down the development of the stem cell industry and research in China, which does not conform with the aim of the CPL. Accordingly, it is recommended that the SIPO redefine the concept "human embryo", and that the definition be written into the SIPO's Guidelines.

It is better to consider the definition based on the inherent capability of developing into a human being. On the one hand, the revised definition is much narrower, and able to fit the aim of the Chinese patent system, not to slow down the advancement of stem cell research in China. On the other hand, it would not only be more in conformity with the current level of scientific development and Chinese moral culture concerning human embryos, but also be in line with the statement of judicial decisions of China's courts. In fact, the definition of a human embryo based on the inherent capability of developing into a human being can be also found in German legislation, such as Section 8(1) of the ESchG, ${ }^{568}$ as well as the Brüstle and ISCO decisions by the CJEU. ${ }^{569}$ In this regard, the revised definition, to some extent, would also contribute to the harmonization of international patent legislation.

\subsubsection{Meaning of the Term "Use"}

Based on the analysis of patent re-examination decisions of the SIPO regarding patenting hESC-related inventions, under the CPL in terms of the "use of a human embryo" there can be four possible meanings: (a) A process or substance which requires the direct and destructive use of a human embryo; (b) A process or substance which requires the direct but non-destructive use of a human embryo; (c) A process or substance which depends on a prior, "upstream," destruction of a human embryo; (d) A process or substance which depends on a prior, "upstream" non-destructive use of a human embryo.

As analyzed previously, through several patent re-examinations the PRB of the SIPO has set out the current policy that as long as a patent application avoids the contents of isolating or obtaining hESCs from a human embryo, and provides sufficient evidence to prove that the invention uses already established hESC lines which are attainable from commercial channels, then downstream hESC inventions are regarded as patent

567 See supra Sect. 2.1, Chap. 2. Moreover, based on the discussion about the possible connection between human dignity and a human embryo under Chinese law, see supra Sect. 4, Chap. 3, there is no basis for using the human dignity argument in China to deny granting any patent over hESC-related invention, since human dignity has not been attached to a human embryo or to early forms of human biological life in this country, and the concept of human dignity has not yet been explicitly introduced into Chinese legislation.

568 See supra Sect. 3.2.3, Chap. 4.

569 See supra Sects. 4.2 and 4.4, Chap. 5. 
eligible. ${ }^{570}$ Thus, it is clear that the human embryo exclusion within the SIPO's Guidelines includes meaning (a), but does not contain meanings (c) and (d). However, what is much less certain is whether the exclusion includes meaning (b) or not. As mentioned before, the SIPO's Guidelines have specifically excluded the patent eligibility of "hESCs per se and their preparation methods" on moral grounds. However, it is not clear underlying reason is that these substances and processes involve the direct use of human embryos, or merely that these substances and processes involve the direct destruction of human embryos. Even in patent re-examination decisions, the PRB of the SIPO seems to have been inconsistent in terms of the meaning (b).

In the patent re-examination decision FS46359, ${ }^{771}$ for instance, the PRB asserted that "Claims 1-5 have explicitly described the used hESCs are from established hESC lines, which means that the patent application has already deleted the contents that involve directly isolating hESCs from a human embryo." 572 The term "directly isolating" could be interpreted as excluding any direct use of a human embryo from patent eligibility. Moreover, the PRB stressed that "when inventions involve biological materials from the human body, if tracing back, all original materials would come from the human body or the human embryo. Thus, it is unreasonable to trace the inventions' raw materials without limit". ${ }^{573}$ From these statements, it seems that the PRB of the SIPO focused on the direct use of a human embryo. In the same decision, the PRB held that "it would be unconvincing to reject a patent right simply because that this application, which involved the use of established hESC lines, constituted the destruction of the human embryo, and thus it contravened social morality." 774 From this statement, the PRB instead seemed to turn its attention to the destruction of a human embryo.

Moreover, in another patent re-examination decision FS98883 of the PRB in 2015, there was a statement that: "the specification of the patent application does not state that the used hESCs are obtained through the destruction of a human embryo and, meanwhile, it has already deleted the contents that concern directly destroying hESCs from a human embryo. While the original source of hESCs is necessarily human embryos, the PRB panel considers it unsuitable to unboundedly trace the way of obtaining raw materials ... to be sure on the one hand neither to encourage the willful destruction of a human embryo, which is against social morality, and on the other hand nor to unduly constrain future technological advances. ${ }^{275}$ In this statement, it seems that the PRB

\footnotetext{
570 See supra Sect. 3.3.3, Chap. 5.

571 See FS46359 of the PRB, supra note 394.

572 Id.

573 Id.

574 Id

575 See FS98883 of the PRB, supra note 420.
} 
panel focused on the destruction of a human embryo, and considered the destruction of the embryo to run counter to Chinese social morality. From this statement, it seems that the PRB put the destruction of the human embryo into the center of interpretation of the human embryo exclusion.

As a result, it is not clear whether the human embryo exclusion in the SIPO's Guidelines includes meaning (b). Put another way, in order to perform the invention, the direct use of a human embryo is necessary, but the used embryo will not be destroyed; in this case, whether the invention is patent eligible or not is uncertain based on the current patent practice of the SIPO. Based on the uncertainty, it is necessary for the SIPO to clarify this issue. As seen from the investigation in Chapter 3 , the Chinese public has a pragmatic moral position concerning a human embryo. The destruction of human embryos, such as $\mathrm{hESC}$ research, does not result in any strong moral concerns in China. The Chinese public do consider a human embryo worthy of special respect, but the embryo is not sacred or inviolable within Chinese moral culture. Considering that the development of hESC research of China has gradually caught up with other, technologically advanced counterparts, properly broadening the scope of patent eligibility would benefit China in terms of promoting its domestic innovation in this research field. Given this, it would be better for the SIPO to interpret the human embryo exclusion not to include the meaning (b), which can be a narrow interpretation.

This narrow interpretation of the human embryo exclusion only includes meaning (a), which excludes the patent eligibility of "a process or substance which requires the direct and destructive use of a human embryo". In this way, the patent policy will not encourage the destruction of human embryos, and instead will provide incentives for the research and investment towards developing new hESC-related technologies that do not destroy human embryos. In addition, even if in $\mathrm{hESC}$ research the destruction of human embryos is inevitable, granting patents upon inventions that use established hESC lines would be an option. By doing this, it can strike a balance between respect for a human embryo and the advancement of hESC research: on the one hand, it is able to show respect for human embryos under Chinese moral culture, and on the other hand it would not greatly slow the research field.

\subsubsection{Exclusion of "hESCs and Their Preparation Methods"}

The SIPO's Guidelines regard as unpatentable "hESCs per se and their preparation methods" on moral grounds under Article 5(1) of the CPL. ${ }^{576}$ However, concerning the exact reason the Guidelines do not provide any explanation. There are two possible reasons from the morality perspective: (a) The narrow reason, that is, the destruction of

576 See supra Sect. 2.3.3.3, Chap. 5. 
a human embryo contravenes the Chinese social morality. In other words, the SIPO considers the preparation of hESCs as requiring the direct destruction of a human embryo, which is against Chinese social morality, and thus believes this should be excluded from patent eligibility. (b) The broad reason, that is, the use of a human embryo contravenes the Chinese social morality. As stated before, within Chinese moral culture and under the CPL, it would be better to take the narrow interpretation that the direct destruction of a human embryo is excluded from patent eligibility. In that way, invention that requires the direct destruction of a human embryo can be excluded by the human embryo exclusion under Article 5(1) of the CPL. Given this, the exclusion of "hESCs and their preparation methods" on moral grounds seems to be redundant based on the existence of the human embryo exclusion.

This does not mean, however, that hESCS or hESC lines which do not require the direct destruction of a human embryo should be included within the scope of patentable subject matter in China. When determining the patent eligibility of hESCs or hESC lines, the potential negative impact of granting patents to research tools on further innovation should be taken into serious consideration as well. A patent right is an exclusionary right, which not only provides incentives to help progress $S \& T$, but also may impede future advancements of critical technologies. ${ }^{577}$ In the field of hESC research, innovation and discoveries, as well as downstream therapy and diagnosis, are dependent on building on fundamental techniques and fundamental research tools (e.g., hESCs or hESC lines). As the analysis has pointed out in Chapter 2, the cumulative innovation maps very well onto research and development in the area of hESC research. ${ }^{578}$ In this regard, patenting fundamental stem-cell techniques and research tools may seriously stifle further life-saving innovations, from basic research to marketable products.

577 See also Karl Bergman \& Gregory D Graff, The Global Stem Cell Patent Landscape: Implications for Efficient Technology Transfer and Commercial Development, 25 NATURE BIOTECHNOLOGY 419, 422 (2007) (warning that stem cell patents could give rise to a patent thicket and workarounds would be difficult in this area); David C Hoffman, Modest Proposal: Toward Improved Access to Biotechnology Research Tools by Implementing a Broad Experimental Use Exception, 89 CoRNELL LAW REVIEW 993, 1028-1031 (2003) (pointing out that biotechnological upstream patents may have a greater impact on slowing downstream innovation than in other science and technology fields); Michael A Heller \& Rebecca S Eisenberg, Can Patents Deter Innovation? The Anticommons in Biomedical Research, 280 SCIENCE 698 (1998) (proposing that owners of different patents can block each other from conducting socially important research); Jordan Paradise, et al., Patents on Human Genes: an Analysis of Scope and Claims, 307 SCIENCE 1566 (2005); Dean Baker, Stagnation in the Drug Development Process: Are Patents the Problem? (Mar. 2007), http://www.cepr.net/documents/ publications/healthcare_stagnation_2007_03.pdf (holding how perverse incentives created by patent monopolies in the pharmaceutical industry have already stifled research on new drugs); On the impact of patents on follow-on innovation, see also Kenneth G Huang \& Fiona E Murray, Does Patent Strategy Shape the Long-run Supply of Public Knowledge? Evidence From Human Genetics, 52 ACADEMy OF ManAGement JOURNAL 1193 (2009).

578 See supra Sect. 2.2, Chap. 2. 
The US provides one of the best examples. In the US, in several cases concerning the patent eligibility of subject matter, such as Funk Brothers, Chakrabarty, and Myriad, the potential negative impact of patents for "basic tools of scientific research and technological work" was placed at the heart of the patenting issue. ${ }^{579}$ In addition, hESC-related patents have been criticized by commentators and scientists as an impediment to a free and clear research environment, hampering valuable basic research and innovation, by virtue of these patents' broadness and the aggressive actions of patent holders. ${ }^{580}$ The US legislation does not prescribe for exemptions research and experimental use. ${ }^{581}$ Given this, although financial interests and the pressure of public opinion may motivate patent holders to share their innovations, ${ }^{582}$ such means of sharing hESC-related patents still has proved to be onerous for both commercial hESC endeavours and academic research. ${ }^{583}$ This shows that the potential hindrance impact of patents granted to research tools on further innovation in the US has caused enormous concerns. In China, the patent system has established the academic exemption. ${ }^{584}$ However, this exemption under the CPL only applies if the research is directed to the patented subject matter as such. It does not cover research which utilizes the patented process or product as a tool to obtain other products and processes. ${ }^{585}$ In this regard, the pursuit of a balance in the Chinese patent system also needs to consider this possibility seriously, that exclusive rights over hESCs or hESC lines per se may discourage further innovation.

As mentioned in Chapter 2, cumulative innovation maps very well onto research and development in the area of hESCs. In other words, in this field of research an established hESC line is the basic material, and is considered to be a fundamental research tool, indispensable for both upstream and downstream research. Without established stable hESC lines, downstream research (e.g., creating specialized cells and tissues by differentiating stem cell lines) cannot proceed. The follow-on innovations need to build on the previous innovative steps and products, which may be covered by a patent, of other researchers or companies. The cumulative nature of hESC research therefore

579 See supra Sect. 2.2.1.2, Chap. 5.

580 See, e.g., Sander Rabin, The Gatekeepers of hES Cell Products, 23 NATURE BIOTECHNOLOGY 817 (2005); Kenneth S Taymor, et al., The Paths around Stem Cell Intellectual Property, 24 NATURE BIOTECHNology 411, 412-413 (2006); Bergman \& Graff, supra note 577, at 419; Aurora Plomer, et al., supra note 158, at 13-14; Fiona Murray, The Stem-cell Market - Patents and the Pursuit of Scientific Progress, 356 New EngLAND JoURnAL OF MEdicine 2341, 2341-2343 (2007).

581 See EGE, supra note 109, at 9.

582 Both WARF-through its affiliate, WiCell Research Foundation-and Geron have created individually negotiated materials transfer agreements (MTAS) to allow other institutions or firms to use their hESC related patents. However, those MTAs necessitate an initial cash payment from the researchers and forbid commercial research without an additional license. Commercial licenses require a profit sharing with WiCell and Geron.

583 See Taymor, et al., supra note 580, at 411.

584 Article 69(4) of the CPL provides that "any person who uses a patent concerned solely for the purposes of scientific research and experimentation" shall be considered to be infringing the patent.

585 See Cul, supra note 367 , at 582 . 
raises the danger that patenting hESCs or hESC lines (the research tool) could hinder advances from basic research to marketable products.

As a result, merely isolated hESCs or hESC lines which have not been modified should not be considered patent eligible, since they are basic tools of scientific research and technological work and should be free to all men, and cannot be reserved exclusively to anybody by patents. Moreover, as the EGE mentioned in its opinion report, "to patent such unmodified stem cell lines would also lead to too broad patents." ${ }^{\text {" }} 56$ All in all, based on both the theoretical foundations of patent law and the nature of hESC research and Chinese moral culture, it is not appropriate to exclude all "hESCs and their preparation methods" from patent eligibility on moral grounds under Article 5(1) of the CPL. Instead, it would be more reasonable to exclude merely isolated hESCs or hESC lines from patent eligibility under the exclusion of "scientific discoveries" in the CPL.

\section{CONCLUSION}

This chapter has investigated the patent eligibility of hESC-related inventions under US, EU and Chinese law through a comparative analysis. It clearly demonstrates that concerning this issue, rules and policy approaches are divergent among these three jurisdictions. In general, the patent eligibility of hESC-related inventions faces two principal obstacles. One is the "discoveries" exclusion or the "product of nature" doctrine, and the other one is the morality assessment in the patent system. In the US, due to the absence of a general morality clause in its patent statute, the USPTO and courts have abandoned any attempt to gauge moral issues when determining patentability. Given this, currently the biggest challenge that the patent eligibility of hESC-related inventions is confronted with, in the US, is the judicial subject matter exception "product of nature". In contrast, in the EU and China, the morality debate dominates the patenting of hESC-related inventions, since both jurisdictions have incorporated a general morality clause into their patent laws. Moreover, in the EU, the Biotech Directive not only aims to promote the advancement of technology, but also emphasizes the necessity of protecting human dignity and the integrity of the human body. In addition, when the CJEU interpreted the provisions in the EU Biotech Directive, the aim of preventing heterogeneous development of national laws to ensure a unified solution within the EU carries an extremely crucial weight. Thus, although the EU is made up of many individual countries and there is no Europe-wide moral consensus about the human embryo and hESC research, the CJEU still provided a definition of the human embryo, and has excluded from the patent eligibility almost all hESC-related inventions in the

586 EGE, supra note 109, at 15. 
EU. The EPO followed the case law of the CJEU primarily in consideration of harmonization.

China all the while has been attempting to learn patent rules and policies from abroad. In particular, with regard to patenting biotechnological inventions, including hESC-related inventions, the drafting of the CPL as well as the SIPO's Guidelines has highly likely been inspired by the provisions within the EU Biotech Directive and the EPC. However, with the introduction of the human embryo exclusion from the EU Biotech Directive into the SIPO's Guidelines, the problems mentioned in the thesis caused by the legislative defects in the former have also appeared in China. ${ }^{587}$ In addition, while the SIPO's Guidelines point out the exclusion of "both hESCs and their preparation methods" from patent eligibility, the patenting of downstream hESC inventions still remains unclear.

Considering both the fact that the introduction of the human embryo exclusion from the EU Biotech Directive into the SIPO's Guidelines faces interpretation problems, and the uncertainty of patentability of downstream hESC inventions, it is both urgent and necessary to explore the existing approaches, and to see whether there are better options or not. This chapter has argued that the American approach is not so helpful in the case of patenting morally controversial biotechnological inventions in China based on the various reasons discussed above. It is also naive to indiscriminately imitate the current EU approach, in particular considering that the provisions within the EU Biotech Directive and the EPC, as well as the approaches that the CJEU and the EPO have adopted, are essentially based on the European situation, while China has a different degree of domestic development of research and industry, ${ }^{588}$ a specific local moral culture and legal system concerning the human embryo, ${ }^{589}$ and an immature regulatory system concerning hESC research. ${ }^{590}$

China has developed its own approach concerning patenting hESC-related inventions over the last dozen years. In general, from the SIPO's re-examination practice, it can be seen that over the last decade it has been reluctant to grant any patents over not only hESCs and their preparation methods, but also downstream hESC inventions. However, the SIPO has recently changed its patent policy to loosen the restrictions on downstream hESC inventions, asserting that as long as the patent application avoids the contents of isolating or obtaining hESCs from a human embryo, and provides sufficient evidence to prove that the invention uses already established hESC lines which are obtainable from commercial channels, then downstream hESC inventions would

587 See supra Sects. 2.3.2.1.2 and 2.3.3.2, Chap. 5.

588 See supra Sect. 4.5, Chap. 4.

589 See supra Sect. 3, Chap. 3.

590 See supra Sect. 4, Chap. 4. 
be regarded as patent eligible. This thesis concludes that the current approach, which utilizes the general morality clause to gauge the patent eligibility of hESC-related inventions, in general not only takes into consideration Chinese moral culture to show respect for human embryos, but also has in mind the need for the development of S\&T. In short, the mechanisms for the patenting of hESC-related inventions in China, in principle, have received support from the results of China's technical, social and economic development, as well as Chinese social morality.

China currently is still catching up in the fields of biotechnology and research. ${ }^{591}$ With its fledgling biotech industry, China should support the development of hESC research, and a step in this direction would be to make its patent rules and policies clearer. Rather than instigating radical reform plans for the patent law, it would be better for the SIPO to modify provisions of the Guidelines, so as to provide further clarification. Based on the current level of development of biotechnology, Chinese moral culture, and the purpose of the CPL, it is recommended that the SIPO redefine the concept of a "human embryo", and apply a narrower interpretation to the definition based on the inherent capability of developing into a human being. Moreover, it is recommended that the SIPO narrowly interpret the "use of a human embryo" in the human embryo exclusion within the Guidelines, to merely exclude the patent eligibility of a process or substance which requires the direct and destructive use of a human embryo. Based on the provision of the human embryo exclusion under the general morality clause, the exclusion of "hESCs and their preparation methods" seems to be redundant, and thus should be removed. Meanwhile, judging from the theoretical foundations of patent law, it would be more reasonable to exclude merely isolated hESC or hESC lines from patent eligibility under the exclusion of "scientific discoveries" in the CPL.

591 See supra Sect. 4.5, Chap. 4. 



\section{Conclusions and Recommendations}

\section{INTRODUCTION}

The past dozen years have been witnessed the rapid evolution of biotechnology, but meanwhile, relevant inventions from this sector have created heated controversies and tremendous challenges to the patent system. ${ }^{1}$ In particular, since in 1998 the successful isolation of the first hESC line in the world was announced, ${ }^{2}$ the corresponding patent applications have been placed on the tables before patent offices and courts, and the determination of the patent eligibility of hESC-related inventions seems to have become a considerably difficult and sensitive mission. ${ }^{3}$ Indeed, within a jurisdiction, how the legislation and policies respond to the issue of patenting in a specific field of research and industry, to some extent, will influence whether and how research and the industry develops there. However, concerning the patenting of hESC-related inventions, it has not proven to be an easy issue.

Patents, on the one hand, can promote the development of S\&T in this field, which further can be conducive to health care. But on the other hand, patents may also impede access to basic research tools, and further hinder access to the health care. Research on hESCs holds great promise for biomedical science, and it has a close relationship with health care. On this basis, when setting forth patent rules or tailoring policies, to achieve a relatively fair balance between the granting of patents and the need to access

1 See e.g., Yusing Ko, An Economic Analysis of Biotechnology Patent Protection, 102 YALE LAW JoURNAL 777, 783-791 (1992); Andreas Hübel, General Issues of Biotech Patents, in BIOPATENT LAW: PATENT STRATEGIES AND PATENT MANAGEMENT 1-9 (Ulrich Storz ed., Springer 2012).

2 See James A Thomson, et al., Embryonic Stem Cell Lines Derived from Human Blastocysts, 282 SCIENCE 1145 (1998).

3 See e.g., Aurora Plomer, et al., Stem Cell Patents: European Patent Law and Ethics Report, (Jul. 28, 2006), http://www.nottingham.ac.uk/ Ulzwww/StemCellProject/project.report.pdf; Margo A Bagley, Stem Cells, Cloning and Patents: What's Morality Got to Do with it? 39 NEW ENGLAND LAW REvIEW 501 (2004); Yaojin Peng, The Patentability of Human Embryonic Stem Cell Technology in China, 34 NATURE BIOTECHnologr 37 (2016). 
knowledge and technologies in such research fields is especially important. Moreover, hESC research necessitates the use and even the destruction of a human embryo. Based on this fact, the moral debates over $\mathrm{hESC}$ research have crossed over from $\mathrm{hESC}$ research into the patenting of hESC-related inventions. On the one hand, as an incentive, patent law should be used to promote the development of hESC research and industry so as to ultimately benefit health care. Nevertheless, one the other hand, hESC research and by extension hESC-related inventions involve moral or ethical concerns, based on which the patenting of these inventions is highly controversial. Not surprisingly, the existing law causes confusion in this field and, correspondingly, the patenting of hESC-related inventions bears watching.

The central focus of the thesis is the patent eligibility of hESC-related inventions, and particularly in China, which currently is considered to be the largest developing country as well as one of fastest-growing economies in the world. This thesis seeks to answer the main research question: is there any need to improve patent rules and policies regarding the patent eligibility of hESC-related inventions in China, and if so, how should this be done so as, on the one hand, to ensure that the biotechnology industry has sufficient incentives to continue to research and develop hESC-related products while, on the other hand, recognizing the value of Chinese and outside moral culture? In order to answer this question, this thesis has illustrated the unique characteristics of social morality regarding a human embryo, the human dignity argument, and public perceptions of patents in China (Chap. 3). It has demonstrated a whole picture both of the Chinese legal system for regulating hESC research and of the Chinese policies of promoting the research and industry (Chap. 4). It has provided a comprehensive comparative analysis of the US, EU and Chinese law so as to search for useful avenues that can be utilized to help China improve its rules and policies concerning the patenting of hESC-related inventions (Chap. 5). It has also evaluated China's current approach dealing with the patent eligibility of hESC-related inventions, including the achievement and shortcomings (Chap. 5).

It is now time, in this final chapter (Chap. 6), to summarize the findings of this study as well as recommendations for the improvement of Chinese patent rules and policies in relation to the patenting of hESC-related inventions. These suggestions are grounded in the theoretical foundations of patent law, the international legal frameworks on patent protection, and the Chinese moral culture, and the results of the comprehensive comparative analysis of the US, EU, and Chinese patent and regulation systems. As the aim of the thesis states, the thesis focuses more specifically on the patent eligibility of hESC-related inventions, but may also have general application to the broader system of patenting morally controversial biotechnological inventions in China. After the introduction (Sect. 1) of the last chapter, it continues to present the main findings of the research and make final conclusions (Sect. 2). Subsequently, this chapter summarizes the 
recommendations from the perspectives of general policy (Sect. 3) and improvement of the SIPO's Guidelines (Sect. 4), respectively. Finally, it briefly conducts a discussion of limitations of the thesis as well as future research (Sect. 5).

\section{FINDINGS AND CONCLUSIONS}

In this thesis, results are presented of a study on the patent eligibility of hESC-related inventions. More importantly, the investigation of the thesis is not merely confined to patent law per se, but it also looks at issues beyond patent law. Chapter 2 of this thesis has laid the foundations for the discussion of patent issues in the field of hESC research. It has shown patent protection is important to hESC research and industry (Sect. 2.2, Chap. 2). Even if in a developing country or an emerging economy like present China, providing patent protection is also indispensable to stimulate innovation and private investment in research (Sect. 2.3, Chap. 2). However, after analyzing several important patent theories most pertinent to the biotechnology industry as well as the role that patent protection is playing in developing countries, it has observed that two things need to be paid attention in terms of patenting hESC-related inventions in China. One is that the cumulative nature of hESC research may raise the danger that patents over research tools, such as hESCs or hESC lines per se, could hinder advances from basic research to marketable products (Sect. 2.2, Chap. 2); the other one is the potential negative impact upon the advancement of China's domestic research and industry when tailoring patent rules and policies (Sect. 2.3, Chap. 2). Since patents may hinder developing countries from gaining access to knowledge and technologies that are required for the development of S\&T, it is crucial to achieve a fair balance in the hESC research field in China between granting patents and the need to access knowledge and technologies.

As a next step, Chapter 2 explores the scientific background of hESC-related technologies (Sect. 3, Chap. 2). It finds that any research on hESCs requires the use of hESCs as the material basis, and the creation of these stem cells normally necessitates the use and destruction of otherwise viable human embryos. Moreover, one important issue which needs to be emphasized here is that although hESCs are derived from human embryos, they are not human embryos and do not have the capability of developing into human beings. After covering the patent protection theories and the scientific background of hESC-related technologies, Chapter 2 analyzes in depth the general debate concerning $\mathrm{hESC}$ research per se and by extension the debate, in particular morally, over patenting hESC-related inventions (Sect. 4, Chap. 2). It shows that hESC research is under moral, political and legal controversies is partly based on the fact that such research directly or indirectly needs the use or destruction of a human embryo. Meanwhile, social or moral concerns about hESC research have crossed over into the patenting of hESC-related 
inventions, since moral arguments enter the patent arena directly through the gateway of the morality exclusion clauses in patent law. More importantly, it observes that the question of how to perceive "a human embryo" lies at the heart of the moral debates concerning hESC research and by extension the patenting of hESC-related inventions. In this regard, it is essential to explore the moral and legal status of a human embryo in China.

Chapter 3 of this thesis tackles the sub-questions: What is the public perception of patents in China? What is the moral and legal status of a human embryo in China? Can the human dignity argument be raised in China to oppose the granting of patents over hESC-related inventions? How might the Chinese public respond to hESC research and by extension the patenting of hESC-related inventions? To answer these questions, Chapter 3 first attempts to discuss the public perception of patents in China (Sect. 2, Chap. 3). It reveals that the Chinese public holds a more pro-patent stance, and many of them think of a patent almost as standing for a guarantee of quality and representing technical authority and advanced technology. It also explores the characteristics of the moral and legal status of a human embryo in China (Sect. 3, Chap. 3). It investigates the potential human dignity concerns that might be proposed to argue against the patenting of hESC-related inventions in China through the general morality clause within the CPL (i.e., Article 5(1) of the CPL) (Sect. 4, Chap. 3). At the same time, it tries to offer additional explanations for the moral concerns regarding the acceptability of hESC research in China (Sect. 5, Chap. 3).

With regard to the moral status of a human embryo in China (Sect. 3.2, Chap. 3), it detects that the Chinese public does not hold a strong moral position concerning a human embryo, and they are not influenced by Western religions. ${ }^{4}$ The viewpoint that the human embryo is sacred from the moment of fertilization is not compatible with the moral and legal status of the embryo in China. The Chinese consider an early stage embryo as some kind of biological life, which deserves special respect, rather than a human being. Chinese morality concerning the human embryo, to some extent, can be regarded as pragmatic and utilitarian. On the one hand, the Chinese believe a human embryo has some inherent moral status and deserves special respect and protection, but on the other they are more likely to tolerate the use and destruction of human embryos, particularly when certain elements prevail over the interests of the human embryo. In terms of the legal status of a human embryo in China (Sect. 3.3, Chap. 3), the thesis finds that under Chinese law, a human embryo is not considered to be a person, and

4 See supra Sect. 5.2, Chap. 3. It argues that although in the age of globalization with increasing international communication, Chinese moral culture might have been influenced and shaped by culture from outside the national boundaries, the impact is very limited and mainly concentrated in the Chinese scientific community, rather than altering the overarching moral concerns regarding human embryos and hESCs in China. 
there is no legal principle whereby it should be treated as such. Nevertheless, this does not mean a human embryo has no legal protection whatsoever. A recent remarkable judicial decision in China reveals that although Chinese courts do not consider a human embryo to be a human person, they regard the embryo as a property deserving special respect and protection (Sect. 3.3.2, Chap. 3).

Moreover, the thesis considers that the human dignity argument does not play an important role in the objections against patenting hESC-related inventions in China, because, as analyzed in Chapter 3, this concept is only attached to a human being rather than a human embryo or to early forms of human biological life in this country (Sect. 4, Chap. 3). In addition, the popular scientism in this country as well as the Chinese government's publicity and emphasis on hESC research have further won public support and removed barriers to such research (Sect. 5, Chap. 3). Based on the previous analysis, in the context of the Chinese public's strongly favourable stance vis-à-vis patents, and their pragmatic moral position concerning a human embryo, as well as the Chinese government's considerable support for hESC research, it can be seen that the Chinese public will not have much strong moral resistance to patenting most hESCrelated inventions, except for showing certain respect for the embryo.

The policy approaches that a jurisdiction has taken towards hESC research, to some extent, also reflect its moral and legal values, and can contribute to better understanding the concerns surrounding patenting hESCs-related inventions. ${ }^{5}$ In this regard, after having identified the crux in Chinese morality and debates concerning hESCs and associated research in China, Chapter 4 then tries to deal with the sub-questions: How do the governments of the US, EU, and China regulate hESC research? What are the underlying considerations behind regulating hESC research in these jurisdictions when dealing with highly contentious and sensitive moral issues? What is the current development level of China's hESC research and industry?

Chapter 4 of the thesis first examines the approaches that the US federal government has taken as well as the policy approaches at the state level (Sect. 2, Chap. 4). In the US, regulating hESC research has been extremely controversial, particularly in terms of the moral aspect. At the federal level, the US merely relies on the distribution of federal public funding to regulate embryo and hESC research, rather than promulgating any legislation or regulation to prohibit it. More importantly, the US allows its states to regulate such research by legislation and tailoring their local policies based on specific

5 See Åsa Hellstadius, A Comparative Analysis of the National Implementation of the Directive's Morality Clause, in Embryonic Stem Cell PATEnTs: European LAW And Ethics 134 (Aurora Plomer \& Paul Torremans ed., Oxford University Press 2009). 
circumstances. Moreover, it is important to note that through the federal government's funding policies, combined with the states' local policies and laws, the US has always tried to solve the social and moral concerns within hESC research. (Sect. 2, Chap. 4) This chapter then analyzes the policy approaches that EU member states have taken towards hESC research, ranging from permissive (e.g., the UK), to intermediate (e.g., the Netherlands), to restrictive (e.g., Germany), and digs deeply into the underlying reasons behind each policy choice (Sect. 3, Chap. 4). It has indicated that in most countries of the West, such as the US, UK, Netherlands, and Germany, a relatively comprehensive regulatory framework regarding hESC research has been established, and the initial driving force for regulating such research came from domestic moral concerns of the public. The approaches that these governments have taken not only pursue scientific advances, but also seek to address several other issues (e.g., societal or moral concerns). (Sects. 2 and 3, Chap. 4)

However, after exploring the policy approach that the Chinese government has taken towards regulating hESC research, Chapter 4 shows that in China, the initial motivation was merely in response to moral concerns originally identified in foreign countries. Due to the social moral culture, institutional structure, desire for scientific progress or economic development in China, local moral concerns regarding hESC research have not been paid close attention by policy makers when establishing China's own regulation system. Instead, the Chinese approach has placed more emphasis on the advancement of hESC research and the acceptability of China's hESC research to the international community. (Sects. 4.1 and 4.2, Chap. 4) This chapter shows that China has not yet established a comprehensive regulatory framework in terms of governing hESC research. The Chinese approach towards regulating hESC research, from both the perspectives of allowed types of hESC research and the degree of regulation and oversight, is relatively permissive, which has created a relaxed regulatory environment for hESC research in China (Sect. 4.3, Chap. 4). By analyzing the relevant industrial policy of the Chinese government (Sect. 4.4, Chap. 4), it can be seen that recently China has provided enormous encouragement policies and substantial research funding in this sector. Moreover, Chapter 4 has explored the place of China's hESC research and development in the world, as well as the stage of hESC research in this country through data analysis (Sect. 4.5, Chap. 4). It demonstrates that over the last decade China has made considerable progress in this research field. However, it is also important to be aware of that in this research field, compared with its technologically advanced counterparts (e.g., Europe, the US, and Japan), China is still well behind for the moment. When tailoring the patent rules and policies, this fact should be taken into serious account.

Chapter 5 focuses on the comparative analysis of the patent eligibility of hESC-related inventions. It attempts to address the sub-questions: Is there any international consensus 
on the patenting of hESC-related inventions? What are the specific provisions regarding the patent eligibility of hESC-related inventions in the three systems (i.e., the US, EU, and China)? How have these pertinent provisions been applied and construed by the courts or patent offices of the three jurisdictions and why? Is it necessary to assess moral issues when a patent office or a court determines the patent eligibility of subject matter? Is there any need to reform the Chinese patent rules or policies concerning patenting hESC-related inventions? Is it proper for China to follow the US or the EU approach in terms of dealing with this issue? How can China's current approach be improved?

Chapter 5 has demonstrated that, the debates regarding the patenting of hESC-related inventions are universal, but the situation in China has specific characteristics and is considerably complicated. It first discusses the international standard (Sect. 2.1, Chap. 5), and reveals that until now there has been no international consensus on the patenting of hESC-related inventions. Subsequently, Chapter 5 examines the specific provisions regarding the patent eligibility of hESC-related inventions under the legal frameworks of the US, EU, and China (Sect. 2, Chap. 5), and reveals that the patenting of hESC-related inventions in these jurisdictions primarily centers on two kinds of exclusions. One is the exclusion of "product of nature" or discoveries (Sect. 2.2, Chap. 5), and the other is the morality exclusions (Sect. 2.3, Chap. 5). In general, in the US, its patent system focuses more on the scientific and economic issues, but in the EU and China, moral issues have taken top billing.

After examining the exclusion of "product of nature" or discoveries (Sect. 2.2, Chap. 5), the chapter demonstrates that all the three jurisdictions have attempted to eliminate simple discoveries or products of nature from patentable subject matter, and the rationales are almost the same. That is, the basic tools of scientific research and technological work should be free to all men, and cannot be reserved exclusively to anybody by patents. More importantly, in China (Sect. 2.2.3, Chap. 5), although there is an explicit exclusion of "scientific discoveries" (i.e., Article 25(1)(1)) within the CPL, the SIPO's Guidelines have tried to make a narrow exception from this exclusion, considering that human intervention can play a significant role in transforming a discovery or a product of nature into a man-made product and, thus, a patent-eligible invention. It might also be noted that the US patent system focuses heavily on the "product of nature" doctrine when dealing with the patenting of biotechnological inventions (Sect. 2.2.1, Chap. 5). Recently, the US has moved back a step within the Myriad case, holding that merely isolation is not enough to make a composition of matter patent eligible, and within the Roslin case, holding that "markedly different characteristics from any found in nature" should depend upon some effort of the patentee rather than environmental factors. Based on the US experience, the significant role hESCS per se play in the research as the basic material, as well as China's current relatively backward hESC research and 
industry, the thesis concludes that the exclusion of "scientific discoveries" may play a more active role in the patenting of hESC-related inventions. (Sect. 5.3.2.3, Chap. 5)

Chapter 5 further explores the morality exclusions in patent law in these jurisdictions. It finds that in terms of patenting hESC-related inventions, the provisions in Chinese law (Sect. 2.3.3, Chap. 5) are quite similar to the EU Biotech Directive and the EPC (Sect. 2.3.2, Chap. 5). The CPL has provided a general morality clause within Article 5(1), and under this provision the SIPO's Guidelines have introduced two specific morality exclusion clauses. One is the human embryo exclusion, which excludes the "use of human embryos for industrial or commercial purposes" from patent eligibility; ${ }^{6}$ the other is the exclusion of "both hESCs and their preparation methods". ${ }^{7}$ The thesis finds the wording of the human embryo exclusion in the SIPO's Guidelines probably to have highly likely been inspired by Article 6(2)(c) of the EU Biotech Directive, since the wording of two provisions are almost the same. The legislative defects (e.g., the lack of definitions of the terms "human embryos" and "use of human embryos") in the human embryo exclusion of the EU Biotech Directive also appear in the SIPO's Guidelines. Moreover, it notes that the SIPO's Guidelines have only referred to "hESCs and their preparation methods", which in fact are upstream products and technologies, but have not mentioned anything concerning the patent eligibility of downstream hESC inventions (e.g., the enrichment and differentiation of hESCs).

Subsequently, Chapter 5 explores the policies of each patent office (i.e., the USPTO, EPO, and SIPO) and associated judicial decisions in these three jurisdictions. It confirms that the patent eligibility of hESC-related inventions is in effect controversial and unstable under the current legal frameworks of the three jurisdictions, due to either the concern about impediment of scientific advances or moral considerations. Based on the detailed analysis of the EPO's decisions (Sect. 3.2, Chap. 5), including the decision of Edinburgh patent, the European WARF case, and the TECHNION case, it detects that although the approaches that the EPO has taken to deal with the patent eligibility of hESC-related inventions are inconsistent, there is a trend toward an increasingly important role played by the protection of human dignity. It in fact is profoundly influenced by the provisions of the EU Biotech Directive as well as the seminal decision of the Brüstle case by the CJEU. In the Brüstle decision (Sect. 4.2, Chap. 5), the CJEU has banned the patent eligibility of all hESC-related inventions, including not only inventions that necessitate the direct destruction of a human embryo, but also those which are produced by using already established hESC lines. However, considering the desire for further scientific development, when applying the interpretation provided by the CJEU in the Brüstle

Part II, Chap. 1, Sect. 3.1.2, para. 2 of the SIPO's Guidelines.

Part II, Chap. 10, Sect. 9.1.1.1 of the SIPO's Guidelines. 
case, the German FCJ in its decision (X ZR 58/07) has left open a possibility that if the creation of hESC lines does not necessitate the destruction of a human embryo, then hESC-related inventions may be patent eligible (Sect. 4.3, Chap. 5).

After a careful exploration of a series of the SIPO's patent re-examination decisions (Sect. 3.3, Chap. 5), it is observed that there is a dynamic development of the SIPO's patent policy concerning the patenting of hESC-related inventions: the SIPO used to prohibit granting any patent over hESC-related inventions, but recently it has changed its viewpoint and started to loosen restrictions on the patent eligibility of downstream hESC inventions. The chapter demonstrates that the SIPO's current approach dealing with the patent eligibility of hESC-related inventions is that: as long as the patent application avoids the contents of isolating or obtaining hESCs from a human embryo, and provides sufficient evidence to prove that the invention uses already established hESC lines which are obtainable from commercial channels, then downstream hESC inventions would be regarded as patent eligible. This implies that the SIPO considers the direct destruction of a human embryo to be against Chinese social morality. It also can be found from the SIPO's current approach that the SIPO takes into serious consideration the desire for the promotion of hESC research in China. Moreover, based on the analysis of the SIPO's ISCO case (3.3.4, Chap. 5), it is clear that the SIPO defines a human embryo as an entity which is able to commence the process of development of a human being or a similar process, but does not necessarily have the capability of developing into a human being. Compared with the definition of the human embryo (an entity which has the capability of developing into human beings) provided by the CJEU in the Brüstle case and ISCO case (Sects. 4.2 and 4.4, Chap. 5), it is evident that the SIPO's definition is much broader, and may greatly slow down the development of the stem cell research and industry in China.

Based on the previous comparative analysis of patent rules and policies among the US, $\mathrm{EU}$, and China, it is evident that in general there are two existing approaches dealing with the patenting of morally controversial biotechnological inventions, including hESC-related inventions. One is the US approach, which is "patent first, ask questions later", and the other one is the EU or Chinese approach, "ask questions first, then patent". ${ }^{8}$ This thesis (Sect. 5.2, Chap. 5) argues that the US approach, which has abandoned the moral assessment in patent law, is not ideal in the case of patenting morally controversial biotechnological inventions in China based on the various reasons discussed in Chapter 5. Thus, the thesis concludes that removing morality assessment

8 See generally, Margo A Bagley, Patent First, Ask Questions Later: Morality and Biotechnology in Patent Law, 45 William AND MARY LAW REVIEW 469 (2003). 
from the Chinese patent system, following the US model, is completely inappropriate and unrealistic.

After comprehensive comparative analysis, and based on the previous discussions about the Chinese specific moral culture (Chap. 3), the regulatory framework regarding hESC research and the development situation of such research in China (Chap. 4), Chapter 5 conducts an evaluation of China's current specific approach dealing with the patenting of hESC-related inventions, so as to propose recommendations for further improvements (Sect. 5.3, Chap. 5). It notes that the current approach, as mentioned above, in general not only takes into consideration of Chinese moral culture to show respect for a human embryo, but also has in mind the need for the development of S\&T (Sect. 5.3.1, Chap. 5). It is naive to indiscriminately imitate the current EU approach, in particular considering that the provisions within the EU Biotech Directive and the EPC, as well as the approaches that the CJEU and the EPO have adopted, are essentially based on the European situation, while China has a different level of domestic development in research and industry, a unique local moral culture and legal system concerning a human embryo, and an immature regulatory system. Completely excluding hESC-related inventions from the patent eligibility on moral grounds, like in the EU and the EPO, is thus inappropriate for China. It is concluded that there is no need, at this time, to make any substantive changes in China's patent law and the general patent policy. However, in order to accommodate to the current development of biotechnology, the current development of China's domestic research and industry, Chinese moral culture, and the purpose of the CPL, it is suggested that several adjustments and further clarification are still necessary within the SIPO's Guidelines (Sect. 5.3.2, Chap. 5). So far, the primary research question of this thesis is resolved. With a number of proper adjustments and clarification in the SIPO's Guidelines and its patent practice, greater certainty and a fair balance can be established between patent rights and the need to access knowledge and technologies in China, and the value of Chinese and outside moral culture could be properly recognized under the general morality clause in patent law.

Based on the study of this thesis, a number of concrete conclusions can be summarized as follows:

(i) Providing patent protection in the field of hESC research is indispensable to stimulate innovation. However, it is important to ensure the granting of patents will not hinder further advance and marketing of innovation in this field. It is also critical to consider the potential negative impact upon the advancement of China's domestic research and industry when tailoring patent rules and policies, especially under the context of global competition. Achieving a fair balance between the granting of patents and the need to access knowledge and technologies in this field in China is vital. (Sect. 2, Chap. 2) 
(ii) Moral arguments against the patenting of hESC-related inventions enter the patent arena directly through the gateway of the morality exclusion clauses in patent law. The patenting of hESC-related inventions is considerably controversial, partly based on hESC research itself, which normally necessitates the use and destruction of human embryos. (Sects. 3 and 4, Chap. 2)

(iii) The Chinese public does not have any strong moral concerns about the human embryo. Chinese morality concerning the human embryo, to some extent, can be regarded as pragmatic and utilitarian. (Sect. 3.2, Chap. 3) Under Chinese law, a human embryo is not considered to be a person; there is no legal principle whereby it should be treated as such in China. (Sect. 3.3, Chap. 3) The viewpoint that a human embryo is sacred from the moment of fertilization is not compatible with the moral and legal status of the embryo in China. (Sect. 3, Chap. 3)

(iv) With regard to patenting hESC-related inventions, the protection of human dignity has played an increasingly important role under the EU Biotech Directive and the EPC (Sects. 3.2.5 and 4, Chap. 5); In contrast, there is no indication that the human dignity argument can play any important role in the objections against patenting hESC-related inventions in China. (Sect. 4, Chap. 3)

(v) In the context of the Chinese public's pragmatic moral position concerning human embryos, and the Chinese government's considerable support for hESC research, as well as the public's favourable stance vis-à-vis patents (Sect. 2, Chap. 3), it appears that the Chinese public will not have much strong moral resistance to patenting most hESC-related inventions, as long as the patenting shows certain respect for human embryos under Chinese moral culture. (Chap. 3)

(vi) China primarily relies on the Ethical Guidelines, rather than laws or regulations, to regulate $\mathrm{hESC}$ research. Compared with the approaches that the US and most EU member states have taken towards regulating hESC research (Sects. 2 and 3, Chap. 4), the Chinese approach is relatively permissive, not only from the perspective of the allowed research types but also from the perspective of the degree of regulation and oversight. (Sect. 4, Chap. 4)

(vii) The Chinese approach towards regulating hESC research is primarily aiming at promoting domestic hESC research and industry, but has not paid too much attention to solving local moral issues. (Sect. 4, Chap. 4)

(viii) Over the past decade, China has made considerable progress in the field of hESC research, but compared with its technologically advanced counterparts (e.g., Europe, the US, and Japan), it is still well behind. (Sect. 4, Chap. 4)

(ix) In terms of patenting hESC-related inventions, the US focuses heavily on the scientific and economic issues, that is, the "product of nature" doctrine. In contrast, the EU and China pay more attention to moral issues, that is, gauging the moral issues concerning hESC-related inventions under morality exclusions. (Chap. 5) 
(x) The "scientific discoveries" exception in the CPL could play a more active role, going forward, in determining the patent eligibility of isolated biological basic materials, such as hESCs per se, particularly since these materials are fundamental tools of scientific research and technological work, and cannot be reserved exclusively to anybody by patents. (Sects. 2.2 and 5.3.2.3, Chap. 5)

(xi) The SIPO's Guidelines have not made further interpretation or explanation of the terms "human embryos" and "use of human embryos" in the human embryo exclusion under the CPL, which has resulted in legal uncertainty and interpretation inconsistency in the SIPO (Sect. 3.3, Chap. 5). The definition of "a human embryo" provided by the SIPO in the ISCO case is too broad, which will neither achieve the objective of encouraging innovation of the CPL, nor correspond with the Chinese social morality concerning a human embryo (Sect. 3.3.4, Chap. 5). Regarding the term "use", it is not clear whether the SIPO focused on the destruction of a human embryo or the use of a human embryo (Sect. 3.3, Chap. 5).

(xii) Simply following the US model, which has abandoned the moral assessment in patent law, is not ideal in the case of patenting morally controversial biotechnological inventions in China. China's current approach, which utilizes the general morality clause (i.e., Article 5(1) of the CPL) to gauge the patent eligibility of hESCrelated inventions, in general not only takes into consideration Chinese moral culture to show respect for human embryos, but also has in mind the need for the development of S\&T. Although there is no need, at this time, to make any substantive changes in China's patent law and the general patent policy, several proper adjustments and further clarification in the SIPO's Guidelines are still needed. (Sect. 5, Chap. 5)

\section{GENERAL POLICY RECOMMENDATIONS}

Although this thesis focuses particularly on patenting hESC-related inventions, it may also have a general and broader application to patenting biotechnological inventions in China. In this regard, this section attempts to provide some recommendations to the general policy covering the patenting of morally controversial biotechnological inventions, especially in terms of utilizing the general morality clause to gauge the morality of a subject matter. From the discussion of the thesis, it can be seen that the biggest challenge for the application of the general morality clause in patent law is the difficulties in defining morally acceptable inventions. That is, when applying the general morality clause to determine the patent eligibility of morally controversial biotechnology inventions, a relatively clear and certain approach and standard is needed.

According to the analysis in Chapter 5, the EPO, in its practice dealing with the patenting of morally controversial biotechnology inventions, has in fact established two test 
approaches to applying the general morality clause (i.e., Article 53(a) EPC), ${ }^{9}$ which China can draw lessons from. Specifically, one is a combination of the "rebuttable presumption" approach and the "abhorrence" standard; the other one is a combination of the "balancing exercise" approach and the "unacceptability" standard. The former combination requires the invention to be excluded from patent eligibility on moral grounds only when an invention is considered to be abhorrent by the vast majority of the public. It mainly focuses on detecting the strongest immorality, and a decision made through this combination will be less controversial. Applying this combination to assessing moral issues in the patent system implies that only a few categories of subject matter could be excluded from patent eligibility. In light of this, this combination increases legal certainty and can send a clear message to anyone wishing to pick the invention up in order to exploit it. Therefore, this combination would be optimal for legislators to use within patent legislation. By way of example, China's legislators (i.e., the NPC and the NPC Standing Committee) try their best to list subject matter that is "abhorrent" to the Chinese public on moral grounds, and then specifically exclude these inventions from patent eligibility via the CPL. If a case falls within one of the listed exclusions, it must be denied a patent.

However, inventions that are not abhorrent to the public, that is, cases not falling within the list, then can be left to the patent office, such as the SIPO, to consider patent eligibility by applying the combination of the "balancing exercise" approach and the "unacceptability" standard to assess moral issues of an invention. Under this combination, several interests, including advantages and negative aspects, are weighed and balanced against each other, and the SIPO then considers whether the negative aspects are acceptable based on the overall considerations, and finally reaches a decision upon the patent eligibility of a subject matter. By doing so, the SIPO could balance different competing interests, such as the benefits that the research may bring about, and the harm the inventions may do, as well as the strength or weakness of China's competitive position in the global economy. Under the pragmatic and utilitarian moral culture regarding living matter, such as a human embryo, in China, it would be a good opportunity for the SIPO to utilize the morality assessment to tailor its own patent policy to serve China's domestic research and industry. In addition, as mentioned in Chapter 5, the general morality assessment is a flexibility that the TRIPS Agreement has left for its member states to take advantage of. ${ }^{10}$ Maximizing the utilization of the general morality exclusion in patent law will help China to not only protect its domestic research and industrial development, at least not hindering its develop-ment, but also avoid the violation of mandatory provisions in the TRIPS Agreement. As a consequence,

$9 \quad$ See supra Sect. 3.2, Chap. 5.

10 See supra Sect. 2.1, Chap. 5. 
by utilizing the combination of the "balancing exercise" approach and the "unacceptability" standard to apply the general morality clause in patent law to determine the patent eligibility of morally controversial biotechnological inventions, the SIPO can have a valuable opportunity to optimize its patent policy and apply the policy flexibly based on the level of scientific development of China.

\section{RECOMMENDATIONS TO THE SIPO'S GUIDELINES}

In the last part of the previous chapter (Sect. 5.3.2, Chap. 5), the thesis has already put forward a number of recommendations for the adjustment and further clarification of the provisions concerning patenting hESC-related inventions within the SIPO's Guidelines. These specific recommendations for the SIPO's interpretations as well as the improvement of the Guidelines can be briefly summarized as follows:

- To define "a human embryo" based on the inherent capability of developing into a human being

Since the lack of a definition of a human embryo in China's legislation, including patent law, has resulted in legal uncertainty and interpretational inconsistency in the SIPO, it is recommended that the SIPO should redefine the concept of a human embryo. It is better to consider the definition based on the inherent capability of developing into a human being. When defining or interpreting a term in the patent system under the general morality clause, it is necessary to bear in mind that the definition or interpretation should be based on the purpose of the CPL as well as Chinese social morality. Since the purpose of the CPL is to stimulate technical innovation and the dissemination of its fruits, and to finally realize the promotion of economic and social development, a broad definition of a human embryo, as in China's ISCO case (FS73216), is not appropriate. In contrast, the revised definition, which is much narrower, is more in line with the purpose of the CPL. Moreover, to define a human embryo based on the capability of developing into a human being is more compatible with Chinese social morality and more acceptable to the international scientific community. It is also recommended that the revised definition of a human embryo be written into the SIPO's Guidelines, which would improve legal certainty in terms of patenting those inventions involving a human embryo.

- To interpret the term "use" in the human embryo exclusion in a narrow way, merely to include the process or substance which requires the direct and destructive use of a human embryo 
It is recommended that the term "use" in the human embryo exclusion within the SIPO's Guidelines be interpreted in a narrow way, merely to include the process or substance which requires the direct and destructive use of a human embryo. As analyzed previously, the PRB of the SIPO in several patent re-examinations has made inconsistent interpretations of the term "use", and it is not clear the PRB focused on the destruction of a human embryo or the use of a human embryo. By the same token, it is optimal to interpret the term "use" in a narrow way which does not include a process or substance which requires the direct but non-destructive use of a human embryo. In this way, the interpretation on the one hand is able to show certain respect for the human embryo, since although the embryo is not sacred or inviolable within Chinese moral culture, the Chinese public still do consider the human embryo worthy of special respect. On the other hand, the narrow interpretation would not greatly slow the research field, but will provide incentives into the research and investment towards developing new hESCrelated technologies that do not destroy human embryos.

- To remove the exclusion of "hESCs and their preparation methods" and to exclude merely isolated hESCs or hESC lines from patent eligibility under the exclusion of "scientific discoveries" in the CPL

It would be more reasonable to exclude merely isolated hESCs or hESC lines from patent eligibility under the exclusion of "scientific discoveries" in the CPL, rather than under the general morality clause of the CPL. Since the human embryo exclusion within the SIPO's Guidelines is able to cover the patenting issue under Article 5(1) of the CPL, then the exclusion of "hESCs and their preparation methods" under this provision would be redundant. However, this does not mean that China should provide patent protection to hESCS or hESC lines which do not require the direct destruction of a human embryo. We should bear in mind that hESCs or hESC lines essentially are basic tools of scientific research and technological work, as the US patent law considers, and they should be free to all men, and cannot be reserved exclusively to anybody by patents. When determining whether to provide patent protection to a subject matter, the potential negative impact of patents granted to research tools on further innovation should also be taken into serious consideration. Cumulative innovation maps very well onto the research and development in the area of hESCs. Granting patents over hESC or hESC lines may impede the follow-on innovations. Moreover, China's hESC research and industry are still at the starting stage, and this country is lagging behind its technologically advanced counterparts, such as Europe, the US, and Japan. From this perspective, providing patent protection to hESC or hESC lines per se may hinder China's domestic research and industry. All in all, based on the theoretical foundations of patent law, and according to the nature of hESC research and Chinese moral culture, it is not appropriate to exclude all "hESCs and their preparation methods" from patent eligibility on moral grounds 
under Article 5(1) of the CPL. Instead, it is recommended that the SIPO exclude merely isolated hESCS or hESC lines from patent eligibility under the exclusion of "scientific discoveries" in the CPL.

\section{LIMITS AND FUTURE RESEARCH}

The research of this thesis attempts to propose some recommendations for the improvement of the rules and policies concerning patenting hESC-related inventions in China. Patenting hESC-related inventions in fact is a good illustration of China's continuous efforts to learn from the experiences of other jurisdictions, particularly in the matter of IP protection. A comparative analysis, especially under the US, EU, and Chinese patent law, is used to design such a system. The thesis is not limited to patent law per se, but looks at issues beyond patent law, since parts of the debates concerning the patenting of hESC-related inventions in fact stem from outside of patent law. This study has analyzed several patent theories that are mostly pertinent to biotechnology. However, these theories primarily focus on developed countries or technologically advanced countries. The impact of patents on developing countries and technologically deprived countries is still under controversy. This study tries to collect some information about moral concerns concerning a human embryo and hESC research in China. The data collected in some empirical studies mentioned in the thesis merely covers thousands of Chinese people, which may reflect the moral position of Chinese people concerning human embryos. However, the number of the surveyed people is not that big in terms of the large population of China. In the US system, it is more concerned with the potential impediment effect of patents granted upon research tools. When discussing the issues in China, the thesis also pays attention to the cumulative innovation nature of the hESC research, and recommends that the SIPO not grant any patent over hESCs or hESC lines per se. However, it is very difficult to gather sufficient data on what extent in China patents granted on research tools, such as hESCs or hESC lines, impede the following-on innovations, so a sound conclusion on this issue is difficult to make. Since hESCs or hESC lines cannot obtain patents in China, the further empirical research on the actual effect may only be conducted in other, similar scientific research fields, such as gene research.

Within the comparative analysis, the thesis has investigated the patent system of the EU. Under the EU Biotech Directive, it has established the EGE, which is used to evaluate all moral aspects of biotechnology. The ethics commission in the patent system might be helpful to providing some suggestions to guide the decisions of the patent agencies, especially in terms of patenting morally controversial inventions. However, the thesis does not examine this type of commission in depth. Further, comprehensive research concerning the ethics commission and the feasibility of setting up such a similar com- 
mission within the Chinese patent system can be undertaken in the future. The abovementioned issues and others undoubtedly merit further research into this fascinating field of patenting hESC-related inventions. 



\section{Bibliography}

\section{Books}

Alford, William P, To Steal A Book is An Elegant Offense: Intellectual Property Law in Chinese Civilization (Stanford University Press 1995).

An, Jian (安建), Zhonghua Renmin Gongheguo Zhuanli Fa Shiyi (中华人民共和国专利法释义)

[The Interpretation of the Patent Law of the People's Republic of China] (Quanguo Renmin Daibiao Dahui Changwu Weiyuanhui Fazhi Gongzuo Weiyuanhui (全国人民代 表大会常务委员会法制工作委员会) [The Commission of Legislative Affairs of the Standing Committee of the National People's Congress] ed., Zhongguo Falü Chubanshe (中国法 律出版社) [Law Press, China] 2009).

Barfield, Claude \& Calfee, John E, Biotechnology and the Patent System: Balancing Innovation and Property Rights (The AEI Press 2007).

Bently, Lionel \& Sherman, Brad, Intellectual Property Law (Oxford University Press 4th ed. 2014).

Blackburn, Simon, The Oxford Dictionary of Philosophy (Oxford University Press 2nd ed. 2005).

Braga, C Primo, The Developing Country Case For and Against Intellectual Property Protection (Wolfgang E Siebeck ed., The World Bank 1990).

Castle, David, The Role of Intellectual Property Rights in Biotechnology Innovation (Edward Elgar 2009).

Chalmers, Damian, et al., European Union Law: Cases and Materials (Cambridge University Press 2010).

Chen, Jianfu, Chinese Law: Towards an Understanding of Chinese Law, Its Nature and Developments (Kluwer Law International 1999).

Colston, Catherine \& Galloway, Jonathan, Modern Intellectual Property Law (Routledge 3rd ed. 2010).

Cui, Guobin (崔国斌), Zhuanli Fa Yuanli Yu Anli (专利法: 原理与案例) [Patent Law: Cases and Materials], (Beijing Daxue Chubanshe (北京大学出版社) [Peking University Press] 2012). 
Dikötter, Frank, Sex, Culture and Modernity in China: Her Tumultuous Life's Journey to the West (Vol. 1) (Hong Kong University Press 1995).

Dondorp, Wybo \& Wert, Guido de, Embryonic Stem Cells Without Moral Pain? (Health Council of the Netherlands 2005).

Dutfield, Graham, Intellectual Property Rights and the Life Science Industries: Past, Present and Future (World Scientific 2nd ed. 2009).

Feng, Peter, Intellectual Property in China (Sweet \& Maxwell Asia 2nd ed. 2003).

Furth, Charlotte, A Flourishing Yin: Gender in China's Medical History (University of California Press 1999).

Ganea, Peter \& Pattloch, Thomas, Intellectual Property Law in China (Christopher Health ed., Kluwer Law International 2005).

Gervais, Daniel, The TRIPS Agreement: Drafting History and Analysis (Sweet \& Maxwell 3rd ed. 2008).

Guojia Zhishi Chanquan Ju Zhuanli Ju Shencha Yewu Guanli Bu (国家知识产权局专利局审 查业务管理部) [Department of Examination and Business Management of the SIPO], Shencha Zhinan Xiuding Daodu 2006 (Di 2 Ban) (审查指南修订导读2006 (第二版)) [An Introduction to the Revision of Guidelines for Patent Examination 2006 (2nd ed.)] (Zhishi Chanquan Chubanshe (知识产权出版社) [Intellectual Property Publishing House] 2006).

Hübel, Andreas, et al., Biopatent Law: Patent Strategies and Patent Management (Springer 2012).

Hübel, Andreas, et al., Limits of Patentability: Plant Sciences, Stem Cells and Nucleic Acids (Springer Science \& Business Media 2012).

Jackson, Emily, Regulating Reproduction: Law, Technology and Autonomy (Hart Publishing 2001).

Jiang, Li, Regulating Human Embryonic Stem Cell in China: A Comparative Study on Human Embryonic Stem Cell's Patentability and Morality in US and EU (Springer 2016).

Ladas, Stephen P, Patents, Trademarks, and Related Rights: National and International Protection (Harvard University Press 1975).

$\mathrm{Li}$, Yahong, Imitation to Innovation in China: the Role of Patents in Biotechnology and Pharmaceutical Industries (Edward Elgar 2010).

Liu, Chuntian (刘春田), Intellectual Property Law (知识产权法) (Xianyi Zeng (曾宪义) \& Liming Wang (王利明) ed., Zhongguo Renmin Daxue Chubanshe (中国人民大学出版社) [China Renmin University Publishing] 4th ed. 2009).

Liu, Yinliang (刘银良), Shengwu Jishu de Falü Wenti Yanjiu (生物技术的法律问题研究) [Studies on Legal Issues for Biotechnology] (Kexue Chubanshe (科学出版社) [Science Publishing House] 2007).

Locke, John, Second Treatise of Government (CB Macpherson ed., Hackett Publishing Company 1980). 
Machlup, Fritz, An Economic Review of the Patent System: Study of the Subcommittee on Patents, Trademarks, and Copyrights of the Committee on the Judiciary (US Government Printing Office 1958).

MacQueen, Hector, et al., Contemporary Intellectual Property: Law and Policy (Oxford University Press 2008).

Malpas, Jeff \& Lickiss, Norelle, Perspectives on Human Dignity: A Conversation (Springer 2007).

Marx, Karl, Theses on Feuerbach (Vol. 5) (Karl Marx \& Frederick Engels ed., Lawrence \& Wishart 2010).

Merges, Robert P, et al., Intellectual Property in the New Technological Age (Wolters Kluwer Law \& Business 2007).

Mills, Oliver, Biotechnological Inventions: Moral Restraints and Patent Law (Revised Edition) (Ashgate Publishing Limited 2010).

Moore, Keith L, et al., The Developing Human: Clinically Oriented Embryology (Elsevier Sauders 9th ed. 2013).

National Research Council (US) and Institute of Medicine (US) Committee on the Biological and Biomedical Applications of Stem Cell Research, Stem Cells and the Future of Regenerative Medicine (National Academies Press (US) 2002).

Nie, Jing-Bao, Behind the Silence: Chinese Voices on Abortion (Rowman \& Littlefield Publishers 2005).

Plomer, Aurora \& Torremans, Paul, Embryonic Stem Cell Patents: European Law and Ethics (Oxford University Press 2009).

Quanguo Renda Changweihui Bangongting Yanjiushi Zhengzhizu (全国人大常委会办公厅研 究室政治组) [General Office of NPC Standing Committee], Zhongguo Xianfa Jingshi (中 国宪法精释) [Explanation for China’s Constitution] (Zhongguo Minzhu Fazhi Chubanshe (中国民主法制出版社) [Press of Chinese Democratic Legal System] 1996).

Resnik, David B, Owning the Genome: A Moral Analysis of DNA Patenting (State University of New York Press 2004).

Rimmer, Matthew, Intellectual Property and Biotechnology: Biological Inventions (Edward Elgar 2008).

Ruse, Michael \& Pynes, Christopher A, The Stem Cell Controversy: Debating the Issues (Prometheus Books 2006).

Sandel, Michael J, The Case Against Perfection: Ethics in the Age of Genetic Engineering (Belknap Press of Harvard University Press 2007).

Seville, Catherine, EU Intellectual Property Law and Policy (Edward Elgar 2009).

Snow, Nancy E, Stem Cell Research: New Frontiers in Science and Ethics (University of Notre Dame Press 2003).

Sreenivasulu, NS \& Raju, CB, Biotechnology and Patent Law: Patenting Living Beings (Manupatra 1st ed. 2008). 
Stazi, Andrea, Biotechnological Inventions and Patentability of Life: The US and European Experience (Edward Elgar 2015).

Sterckx, Sigrid \& Cockbain, Julian, Exclusions from Patentability: How Far Has the European Patent Office Eroded Boundaries? (Cambridge University Press 2012).

Svendsen, Clive N \& Ebert, Allison D, Encyclopedia of Stem Cell Research (Vol. 1 \& 2) (SAGE Publications 2008).

Tian, Lipu [田力普], Zhongguo Zhishi Chanquan Nianjian 2004 (中国知识产权年鉴 (2004 年)) [Chinese Intellectual Property Yearbook 2004] (Zhishi Chanquan Chubanshe (知 识产权出版社) [Intellectual Property Publishing House] 2004).

Tian, Zhikang (田志康), Shengming Xingshi Zhishi Chanquan ji Guojia Zhengce (生命形 式知识产权及国家政策) [Intellectual Property Right of Life Form and National Policies] (Zhongguo Nongye Chubanshe (中国农业出版社) [China Agriculture Press] 2003).

Tong, Rou (佟柔), Zhongguo Minfa Xue MinFa Zongze (中国民法学民法总则) [Chinese Civil Law Science: General Principles of Civil Law] (Zhongguo Gong'an Daxue Chubanshe ( 中国公安大学出版社) [Peoples Public Security University of China Press] 1990).

UNDP China and Development Research Center of the State Council of China, China National Human Development Report 2016: Social Innovation for Inclusive Human Development (China Translation \& Publishing House 2016).

Warnock, Mary, Report of the Committee of Inquiry into Human Fertilization and Embryology (HM Stationery Office 1984).

Weber, Max, et al., The Religion of China: Confucianism and Taoism (Collier Macmillan 1964).

Wing-Tsit, Chan, A Source Book in Chinese Philosophy (Princeton University Press 1973). Xi, Jinping (习近平), Xi Jinping Tan Zhiguo Lizheng (习近平谈治国理政) [Xi Jinping: the Governance of China] (Waiwen Chubanshe (外文出版社) [Foreign Languages Press] 2014).

Xu, Chongde (许崇德), Zhonghua Renmin Gongheguo Xianfa Shi (中华人民共和国宪法史) [History of the Constitution of the People's Republic of China], (Fujian Renmin Chubanshe (福建人民出版社) [Fujian People Press] 2003).

Yin, Xintian [尹新天], Zhongguo Zhuanlifa Xiangjie (中国专利法详解) [Introduction To The Patent Law Of China] (Zhishi Chanquan Chubanshe (知识产权出版社) [Intellectual Property Press] 2011).

Zhang, Joy Yueyue, The Cosmopolitanization of Science: Stem Cell Governance in China (Palgrave Macmillan 2012).

Zhang, Qianfan (张千帆), Xianfa Xue Daolun (宪法学导论) [Introduction to Constitutional Jurisprudence] (Falü Chubanshe (法律出版社) [Law Press, China] 2004).

Zhang, Qingkui (张清奎), Yiyao ji Shengwu Jishu Lingyu Zhishi Chanquan Zhanlü Shiwu (医药及生物技术领域知识产权战略实务) [Strategy and Practice of Intellectual Property in the Fields of Medicine and Biotechnology] (Zhishi Chanquan Chubanshe (知识产权出版 社) [Intellectual Property Press] 2008). 
Zhang, Xiaodu (张晓都), Zhuanli Shizhi Tiaojian (专利实质条件) [Substantial Requirements for Patent] (Chengsi Zheng ed., Law Press 2002).

Zhao, Yuanguo (赵元果), Zhongguo Zhuanlifa de Yunyu Yu Dansheng (中国专利法的孕育与诞 生) [The Drafting History of the Patent Law of China] (Zhishi Chanquan Chubanshe (知 识产权出版社) [Intellectual Property Publishing House] 2003).

Zheng, Chengsi \& Pendleton, Michael D, Chinese Intellectual Property and Technology Transfer Law (Sweet \& Maxwell 1987).

\section{Book Contributions}

Alexander, Daniel, The Case For and Against the Patenting of Biotechnological Inventions, in Biotechnology, Patents and Morality (Sigrid Sterckx ed., Ashgate Publishing 2000).

Bagley, Margo A, A Global Controversy: The Role of Morality in Biotechnology Patent Law, in Intellectual Property and Information Wealth: Issues and Practices in the Digital Age (Vol. 2) (Peter K Yu ed., Praeger 2006).

Caulfield, Timothy, Biotechnology Patents, Public Trust and Patent Pools: the Need for Governance? in The Role of Intellectual Property Rights in Biotechnology Innovation (David Castle ed., Edward Elgar 2009).

Fiechter, Armin, Preface, in History of Modern Biotechnology II (Armin Fiechter ed., Springer 2000).

Hellstadius, Åsa, A Comparative Analysis of the National Implementation of the Directive's Morality Clause, in Embryonic Stem Cell Patents: European Law and Ethics (Aurora Plomer \& Paul Torremans ed., Oxford University Press 2009).

Hübel, Andreas, General Issues of Biotech Patents, in Biopatent Law: Patent Strategies and Patent Management (Ulrich Storz ed., Springer 2012).

Isasi, Rosario M \& Knoppers, Bartha M, Towards Commonality? Policy Approaches to Human Embryonic Stem Cell Research in Europe, in Embryonic Stem Cell Patents: European Law and Ethics (Aurora Plomer \& Paul Torremans ed., Oxford University Press 2009).

Liddell, Kathleen, Immorality and Patents: The Exclusion of Inventions Contrary to Ordre Public and Morality, in New Frontiers in the Philosophy of Intellectual Property (Annabelle Lever ed., Cambridge University Press 2012).

Overwalle, Geertrui Van \& Berthels, Nele, Patents and Venus: About Oocytes and Human Embryonic Stem Cells, in Stem Cells and Women's Health - Cellules souches et santé des femmes - Stamcellen en vrouwengezondheid (Anthemis-Intersentia 2007).

Overwalle, Geertrui Van, Patenting Stem Cell Research in Europe and in the United States, in Crossing Borders: Cultural, Religious and Political Differences Concerning Stem Cell Research (W Bender et al. ed., Agenda Verlag 2005).

Plomer, Aurora, Human Dignity, Human Rights, and Article 6(1) of the EU Directive on Biotechnological Inventions, in Embryonic Stem Cell Patents: European Law and Ethics (Aurora Plomer \& Paul Torremans ed., Oxford University Press 2009). 
Plomer, Aurora, Towards Systemic Legal Conflict: Article 6(2)(c) of the EU Diretive on Biotechnological Inventions, in Embryonic Stem Cell Patents: European Law and Ethics (Aurora Plomer \& Paul Torremans ed., Oxford University Press 2009).

Porter, Gerard, Human Embryos, Patents and Global Trade: Assessing the Scope and Contents of the TRIPS Morality Exception, in Embryonic Stem Cell Patents: European Law and Ethics (Aurora Plomer \& Paul Torremans ed., Oxford University Press 2010).

Porter, Gerard, The Drafting History of the European Biotechnology Directive, in Embryonic Stem Cell Patents: European Law and Ethics (Aurora Plomer \& Paul Torremans ed., Oxford University Press 2009).

Qiu, Renzong, Cloning Issues in China, in Cross-Cultural Issues in Bioethics: The Example of Human Cloning (Heiner Roetz ed., Rodopi 2006).

Qiu, Renzong, Reshaping the Concept of Personhood: A Chinese Perspective, in The Moral Status of Persons: Perspectives on Bioethics (Gerhold K Becker ed., Rodopi 2000).

Sterckx, Sigrid, European Patent Law and Biotechnological Inventions, in Biotechnology, Patents and Morality (Sigrid Sterckx ed., Ashgate Publishing 1997).

Storz, Ulrich, The Limits of Patentability: Stem Cells, in Limits of Patentability: Plant Sciences, Stem Cells and Nucleic Acids (Andreas Hübel, et al. ed., Springer 2013).

Sumikura, Koichi, The Issues Surrounding Patent Protection for Human-Embryonic Stem Cells and Therapeutic Cloning in Japan, in Patentschutz und Stammzellforschung: Internationale und rechtsvergleichende Aspekte (Josef Drexl et al., ed. Springer 2009).

Torremans, Paul, The Construction of the Directive's Moral Exclusions Under the EPC, in Embryonic Stem Cell Patents: European Law and Ethics (Aurora Plomer \& Paul Torremans ed., Oxford University Press 2009).

Turovets, Nikolay, et al., Derivation of Human Parthenogenetic Stem Cell Lines, in Human Pluripotent Stem Cells: Methods and Protocols (Philip H Schwartz \& Robin L Wesselschmidt ed., Springer 2011).

Viens, AM, Morality Provisions in Law Concerning the Commercialization of Human Embryos and Stem Cells, in Embryonic Stem Cell Patent: European Law and Ethics (Aurora Plomer \& Paul Torremans ed., Oxford University Press 2009).

Zaninovic, Nikica, et al., Derivation of Human Embryonic Stem Cells (hESC), in Human Fertility: Methods and Protocols (Zev Rosenwaks \& Paul M Wassarman ed., Springer 2014).

\section{Articles}

Abeelen, Derek Van den, Harnessing Human Potential: Induced Pluripotent Stem Cell Patentability Under the Lens of Myriad, 7 William \& Mary Business Law Review 855 (2016). Allison, Kirk C, et al., Historical Development and Current Status of Organ Procurement from Death-row Prisoners in China, 16 BMC Medical Ethics 85 (2015).

Amit, Michal \& Itskovitz-Eldor, Joseph, Derivation and Spontaneous Differentiation of Human Embryonic Stem Cells, 200 Journal of Anatomy 225 (2002). 
Bagley, Margo A, Patent First, Ask Questions Later: Morality and Biotechnology in Patent Law, 45 William and Mary Law Review 469 (2003).

Bagley, Margo A, Stem Cells, Cloning and Patents: What's Morality Got to Do with it? 39 New England Law Review 501 (2004).

Bahadur, G \& Morrison, M, Patenting Human Pluripotent Cells: Balancing Commercial, Academic and Ethical Interests, 25 Human Reproduction 14 (2010).

Baharvand, Hossein, et al., Generation of New Human Embryonic Stem Cell Lines with Diploid and Triploid Karyotypes, 48 Development, Growth \& Differentiation 117 (2006).

Barad, Lili, et al., Human Embryonic Stem Cells vs Human Induced Pluripotent Stem Cells for Cardiac Repair, 30 Canadian Journal of Cardiology 1279 (2014).

Bergman, Karl \& Graff, Gregory D, The Global Stem Cell Patent Landscape: Implications for Efficient Technology Transfer and Commercial Development, 25 Nature Biotechnology 419 (2007).

Bouvet, Philippe, Patentability of Inventions Involving Human Stem Cells in Europe, 9 Journal of commercial biotechnology 40 (2002).

Bregman-Eschet, Yael, et al., The Ripple Effect of Intellectual Property Policy: Empirical Evidence from Stem Cell Research and Development, 19 Journal of Technology Law \& Policy 227 (2014).

Brevini, TAL \& Gandolfi, F, Parthenotes as a Source of Embryonic Stem Cells, 41 Cell Proliferation 20 (2008).

Brownsword, Roger, et al., Human Genetics and the Law: Regulating a Revolution, 61 The Modern Law Review 593 (1998).

Burk, Dan L \& Lemley, Mark A, Biotechnology's Uncertainty Principle, 54 Case Western Reserve Law Review 691 (2003).

Burk, Dan L \& Lemley, Mark A, Policy Levers in Patent Law, 89 Virginia Law Review 1575 (2003).

Burns, James H, Happiness and Utility: Jeremy Bentham's Equation, 17 Utilitas 46 (2005).

Byrnes, W Malcolm, The Flawed Scientific Basis of the Altered Nuclear Transfer-oocyte Assisted Reprogramming (ANT-OAR) Proposal, 3 Stem Cell Reviews 60 (2007).

Cameron, Nigel M de S, Pandora's Progeny: Ethical Issues in Assisted Human Reproduction, 39 Family law quarterly 745 (2005).

Cao, Jingwen, et al., Trends and Prospects of Stem Cell Research in China, 31 Chinese Medical Sciences Journal 116 (2016).

Caulfield, Timothy, et al., Trust, Patents and Public Perceptions: The Governance of Controversial Biotechnology Research, 24 Nature Biotechnology 1352 (2006).

Chan, Albert Wai-Kit, et al., A Patent Perspective on US Stem Cell Research, 32 Nature Biotechnology 633 (2014).

Chang, Howard F, Patent Scope, Antitrust Policy, and Cumulative Innovation, 26 The RAND Journal of Economics 34 (1995). 
Chapman, Audrey R, The Ethics of Patenting Human Embryonic Stem Cells, 19 Kennedy Institute of Ethics Journal 261 (2009).

Chapman, Demian D, et al., Virgin Birth in a Hammerhead Shark, 3 Biology Letters 425 (2007).

Chen, Haidan, Stem Cell Governance in China: from Bench to Bedside? 28 New Genetics and Society 267 (2009).

Chen, Hong, et al., The Derivation of Two Additional Human Embryonic Stem Cell Lines from Day 3 Embryos with Low Morphological Scores, 20 Human Reproduction 2201 (2005).

Chen, Qiongdi, Patent biotechnology invention in China, 32 European Intellectual Property Review 9 (2010).

Cheng, Linzhao, et al., Ethics: China Already Has Clear Stem-cell Guidelines, 440 Nature 992 (2006).

Cheng, Qun (程群), Daojiao Shengsi Guan Yanjiu (道教生死观研究) [Research on Taoist View of Life and Death], Sichuan Daxue (四川大学) [Sichuan University] (2007).

Chung, Young, et al., Human Embryonic Stem Cell Lines Generated Without Embryo Destruction, 2 Cell Stem Cell 113 (2008).

Cohen, Stanley N, et al., Construction of Biologically Functional Bacterial Plasmids In Vitro, 70 Proceedings of the National Academy of Sciences 3240 (1973).

Condic, Maureen L \& Condic, Samuel B, The Appropriate Limits of Science in the Formation of Public Policy, 17 Notre Dame Journal of Law, Ethics \& Public Policy 157 (2003).

Condic, ML, Alternative Sources of Pluripotent Stem Cells: Altered Nuclear Transfer, 41 Cell Proliferation 7 (2008).

Crowne, Emir, The Utilitarian Fruits Approach to Justifying Patentable Subject Matter, 10 John Marshall Review of Intellectual Property Law 753 (2011).

Curley, Duncan \& Sharples, A, Patenting Biotechnology in Europe: the Ethical Debate Moves on, 24 European Intellectual Property Review 565 (2002).

Daughtry, Brittany \& Mitalipov, Shoukhrat, Concise Review: Parthenote Stem Cells for Regenerative Medicine: Genetic, Epigenetic, and Developmental Features, 3 Stem Cells Translational Medicine 290 (2014).

Davis, Amy Rachel, Patented Embryonic Stem Cells: The Quintessential "Essential Facility"? 94 Georgetown Law Journal 205 (2005).

Demaine, LT \& Fellmeth, AX, Reinventing the Double Helix: A Novel and Nonobvious Reconceptualization of the Biotechnology Patent, 55 Stanford Law Review 303 (2002).

Deng, Zhiwei (邓志伟) \& Luo, Lishi (罗理事), Lun Zeren Lunli Shijiao Xia Lengdong Peitai Baohu Guize de Sifa Xuzao-_Cong Woguo Shouli Lengdong Peitai de Jicheng Jiufen'an Qieru (论责任伦理视角下冷冻胚胎保护规则的司法续造-一从我国首例冷冻胚胎的继承纠纷案切 入) [Judicial Enforcement of Frozen Embryo Protection Rules from the Perspective of Ethics of Responsibility: the First Succession Dispute Case Concerning Frozen Embryos 
in China], Quanguo Fayuan Di 26 Jie Xueshu Taolunhui Lunwenji (全国法院第二十六届学 术讨论会论文集) [the 26th Symposium of Courts in China] 1262 (2015).

Devolder, Katrien \&Ward, Christopher M, Rescuing Human Embryonic Stem Cell Research: the Possibility of Embryo Reconstitution After Stem Cell Derivation, 38 Metaphilosophy 245 (2007).

Drahos, Peter, Biotechnology Patents, Markets and Morality, 21 European Intellectual Property Review 441 (1999).

Erramouspe, Matthew, Staking Patent Claims on the Human Blueprint: Rewards and Rent-Dissipating Races, 43 UCLA Law Review 961 (1995).

Eyre, David E \& Schlich, George W, Patenting Stem Cell Technologies Following Guidelines issued by the EPO, USPTO, JPO and SIPO, 4 Pharmaceutical Patent Analyst 431 (2015).

Falvey, Rod, et al., Intellectual Property Rights and Economic Growth, 10 Review of Development Economics 700 (2006).

Farrand, Benjamin, Human Embryonic Stem Cells and Patent Law in the EU and China: Convergence in Standards Through Divergence in Institutions, 3 Intellectual Property Quarterly 260 (2016).

Fendrick, Sarah E \& Zuhn, Donald L, Patentability of Stem Cells in the United States, 5: a020958 Cold Spring harb Perspect Med 1 (2015).

Ferrer, Marcela, et al., The Scientific Muscle of Brazil's Health Biotechnology, 22 Nature Biotechnology DC8 (2004).

Fitt, Robert, New Guidance on The Patentability of Embryonic Stem Cell Patents in Europe, 27 Nature Biotechnology 338 (2009).

Fu, XiaoBing, Regenerative Medicine Research in China: From Basic Research to Clinical Practice, 57 Science China Life Sciences 155 (2014).

Galasso, Alberto \& Schankerman, Mark, Patents and Cumulative Innovation: Causal Evidence from the Courts, 130 The Quarterly Journal of Economics 317 (2015).

George, Erin P, The Stem Cell Debate: The Legal, Political and Ethical Issues Surrounding Federal Funding of Scientific Research on Human Embryos, 12 Albany Law Journal of Science \& Technology 747 (2001).

Gerecht-Nir, Sharon \& Itskovitz-Eldor, Joseph, Cell Therapy Using Human Embryonic Stem Cells, 12 Transplant Immunology 203 (2004).

Gerecht-Nir, Sharon \& Itskovitz-Eldor, Joseph, The Promise of Human Embryonic Stem Cells, 18 Best Practice \& Research Clinical Obstetrics \& Gynaecology 843 (2004).

Golan-Mashiach, Michal, et al., Design Principle of Gene Expression Used by Human Stem Cells: Implication for Pluripotency, 19 The FASEB Journal 147 (2005).

Gold, E Richard \& Gallochat, Alain, The European Biotech Directive: Past as Prologue, 7 European Law Journal 331 (2001).

Green, Ronald M, Stem Cell Research: A Target Article Collection Part III-Determining Moral Status, 2 The American Journal of Bioethics 20 (2002). 
Grundmann, Helge E, The Economic Arguments for Patents and Their Validity for Developing Countries, 19 Indian Economic Journal 193 (1970).

Haase, Alexandra, et al., Generation of Induced Pluripotent Stem Cells from Human Cord Blood, 5 Cell Stem Cell 434 (2009).

Halliday, Samantha, A Comparative Approach to the Regulation of Human Embryonic Stem Cell Research in Europe, 12 Medical Law Review 40 (2004).

Han, Xiao (韩啸), et al., Lengdong Peitai de Lunli Wenti Yanjiu (冷冻胚胎的伦理问题研究) [An Analysis on the Ethical Problem of Frozen Embryos], 15 Kunming Ligong Daxue Xuebao (昆明理工大学学报) Journal of Kunming University of Science and Technology 15 (2015). Hardee, Karen, et al., Family Planning and Women's Lives in Rural China, 30 International Family Planning Perspectives 68 (2004).

Harmon, Shawn HE, et al., Organ Transplantation in China and Beyond: Addressing the 'Access Gap', 10 Medical Law International 191 (2010).

Harn, Ren-How, Keeping the Gates Open for Human Embryonic Stem Cell Research, 13 Cardozo Public Law, Policy \& Ethics Journal 525 (2015)

He, Huanfeng (何焕锋), Daxuesheng Zhishichanquan Jiaoyu Tanxi-_Yi Shandongsheng Daxuesheng zhishichanquan Yishi Diaocha wei Jichu (大学生知识产权教育探析一一以山东 省大学生知识产权意识调查为基础) [Analysis on the Education of Intellectual Property for College Students], 27 山东青年政治学院学报 [Journal of Shandong Youth University of Political Science] 42 (2011).

Heins, Nico, et al., Derivation, Characterization, and Differentiation of Human Embryonic Stem Cells, 22 Stem Cells 367 (2004).

Heller, Michael A \& Eisenberg, Rebecca S, Can Patents Deter Innovation? The Anticommons in Biomedical Research, 280 Science 698 (1998).

Heller, Michael A, The Boundaries of Private Property, 108 Yale Law Journal 1163 (1999). Heller, Michael A, The Tragedy of the Anticommons: Property in the Transition from Marx to Markets, 111 Harvard Law Review 621 (1998).

Hesketh, Therese, et al., The Effect of China's One-child Family Policy After 25 Years, 353 New England Journal of Medicine 1171 (2005).

Hoffman, David C, Modest Proposal: Toward Improved Access to Biotechnology Research Tools by Implementing a Broad Experimental Use Exception, 89 Cornell Law Review 993 (2003).

Holden, Constance \& Vogel, Gretchen, A Seismic Shift for Stem Cell Research, 319 Science 560 (2008).

Hoxha, Eneda, Stemming the Tide: Stem Cell Innovation in the Myriad-Mayo-Roslin Era, 30 Berkeley Technology Law Journal 567 (2015).

$\mathrm{Hu}$, Yuhong (胡玉鸿), Ren de Zunyan de Falü Shuxing Bianxi (人的尊严的法律属性辨析) [An Analysis of the Legal Attributes of Human Dignity], 5 Zhongguo Shehui Kexue (中国社会 科学) [Social Science in China] 101 (2016). 
Huang, Kenneth G \& Murray, Fiona E, Does Patent Strategy Shape the Long-run Supply of Public Knowledge? Evidence From Human Genetics, 52 Academy of Management Journal 1193 (2009).

Hurlbut, William B, Ethics and Embryonic Stem Cell Research: Altered Nuclear Transfer as a Way Forward, 21 Biodrugs 79 (2007).

Ilic, Dusko, et al., Derivation of Human Embryonic Stem Cell Lines from Biopsied Blastomeres on Human Feeders with Minimal Exposure to Xenomaterials, 18 Stem Cells and Development 1343 (2009).

Isasim, Rosario M \& Knoppers, Bartha M, Mind the Gap: Policy Approaches to Embryonic Stem Cell and Cloning Research in 50 Countries, 13 European Journal of Health Law 9 (2006)

Jacobs, Philippe, Gene Patents: A Different Approach, 23 European Intellectual Property Review 505 (2001).

Johnson, Martin H, Human ES Cells and a Blastocyst from One Embryo: Exciting Science but Conflicting Ethics? 2 Cell Stem Cell 103 (2008).

Kim, Hee Sun, et al., Methods for Derivation of Human Embryonic Stem Cells, 23 Stem Cells 1228 (2005).

Kintisch, E, Groups Challenge Key Stem Cell Patents, 313 Science 281 (2006).

Kirkland, Russell, "Enhancing Life?" Perspectives from Traditional Chinese Value-Systems, 36 The Journal of Law, Medicine \& Ethics 26 (2008).

Kitch, Edmund W, The Nature and Function of the Patent System, 20 Journal of Law and Economics 265 (1977).

Kitch, Edmund W, The Patent Policy of Developing Countries, 13 Pacific Basin Law Journal 166 (1994).

Knoppers, Bartha Maria, et al., Commercialization of Genetic Research and Public Policy, 286 Science 2277 (1999).

Ko, Yusing, An Economic Analysis of Biotechnology Patent Protection, 102 Yale Law Journal 777 (1992).

Kollmann, Maite S, Taking the Moral High Road: Why Embryonic Stem Cell Research Should Be Strictly Regulated, 2 Faulkner Law Review 145 (2010).

Landry, Donald W \& Zucker, Howard A, Embryonic Death and the Creation of Human Embryonic Stem Cells, 114 Journal of Clinical Investigation 1184 (2004).

Lanfang, Fei \& Peng, Zhou, The Law Itself is not Above Human Beings: Comments on China's First Case on Frozen Embryos, 29 International Journal of Law, Policy and the Family 260 (2015).

Lanzendorf, Susan E, et al., Use of Human Gametes Obtained from Anonymous Donors for the Production of Human Embryonic Stem Cell Lines, 76 Fertility and Sterility 132 (2001).

Laurie, Graeme, Patenting Stem Cells of Human Origin, 26 European Intellectual Property Review 59 (2004). 
Lemley, Mark A, et al., Life After Bilski, 63 Stanford Law Review 1315 (2011).

Levenberg, Shulamit, et al., Endothelial Cells Derived from Human Embryonic Stem Cells, 99 Proceedings of the national Academy of Sciences 4391 (2002).

Levine, Robert J, Federal Funding and the Regulation of Embryonic Stem Cell Research: The Pontius Pilate Maneuver, 9 Yale Journal of Health Policy, Law, and Ethics 552 (2009).

Levron, Jacob, et al., Male and Female Genomes Associated in A Single Pronucleus in Human Zygotes, 52 Biology of Reproduction 653 (1995).

Li, Chunliang, et al., Efficient Derivation of Chinese Human Embryonic Stem Cell Lines from Frozen Embryos, 46 In Vitro Cellular \& Developmental Biology-Animal 186 (2010).

Li, Haiping (李海平), Lun Ren de Zunyan zai Woguo Xianfa Shang de Xingzhi Diwei (论人的 尊严在我国宪法上的性质地位) [On the Qualitative Orientation of Human Dignity in Chinese Constitution], 12 Shehui Kexue (社会科学) [Social Science] 101 (2012).

Li, Wei \& Cai, Lisheng, The Scope of Patent Protection for Gene Technology in China, 32 Nature Biotechnology 1001 (2014).

Liang, Puping, et al., CRISPR/Cas9-mediated Gene Editing in Human Tripronuclear Zygotes, 6 Protein \& Cell 363 (2015).

Lin, Laifan (林来梵), Ren de Zunyan yu Ren'ge Zunyan-_Jianlun Zhongguo Xianfa Di 38 Tiao de Jieshi Fangan (人的尊严与人格尊严——兼论中国宪法第38条的解释方案) [Personal Dignity and Personality Dignity: on the Interpretation of Article 38 of the Chinese Constitution], 3 Zhejiang Shehui Kexue (浙江社会科学) [Zhejiang Social Sciences] 47 (2008).

Lindvall, Olle, et al., Stem Cell Therapy for Human Neurodegenerative Disorders-How to Make It Work, 10 Nature Medicine S42 (2004).

Liu, Deming, Now the Wolf Has Indeed Come! Perspective on the Patent Protection of Biotechnology Inventions in China, 53 The American Journal of Comparative Law 207 (2005).

Liu, Deming, Reflections on Lack of a Patent System throughout China's Long History, 12 The Journal of World Intellectual Property 122 (2009).

Liu, Hua (刘华), Ying Zhou (周荣), Woguo Shehui Gongzhong Zhishichanquan Yishi Xianzhuang Diaocha Fengxi ji Duice Yanjiu (我国社会公众知识产权意识现状调查分析及对策研究) [Survey of Chinese Public's IP Protection Awareness and Sone Recommendations], 10 Zhongguo Ruankexue (中国软科学) [China Soft Science] 103 (2006).

Liu, Jie \& Fan, Daiming, Hepatitis B in China, 369 The Lancet 1582 (2007).

Liu, Qiang (刘强) \& Sheng, Wei (沈伟), 3D Dayin Renti Qiguan Ke Zhuanlixing Yanjiu (3D打印 人体器官可专利性研究) [The Patentability of 3D Printed Human Organs], 6 Keji yu Falu (科 技与法律) [Journal of Science, Technology and Law] 1098 (2015).

Lovell-Badge, Robin, The Regulation of Human Embryo and Stem-cell Research in the United Kingdom, 9 Nature Reviews Molecular Cell Biology 998 (2008).

Luk, Bernard Hung-kay, Abortion in Chinese Law, 25 The American journal of comparative law 372 (1977). 
MA, Hubertus Schacht, Commencement or Completion: What Constitutes a "Human Embryo" Within the Meaning of the EU Biotechnology-Directive? 36 European Intellectual Property Review 66 (2014).

Machin, Nathan, Prospective Utility: A New Interpretation of the Utility Requirement of Section 101 of the Patent Act, 87 California Law Review 421 (1999).

Mahalatchimy, Aurélie, et al., Exclusion of Patentability of Embryonic Stem Cells in Europe: Another Restriction by the European Patent Office, 37 European Intellectual Property Review 25 (2015).

Mahalatchimy, Aurélie, et al., The Impact of European Embryonic Stem Cell Patent Decisions on Research Strategies, 33 Nature Biotechnology 41 (2015).

Mai, Qingyun, et al., Derivation of Human Embryonic Stem Cell Lines from Parthenogenetic Blastocysts, 17 Cell Research 1008 (2007).

Mandra, Raymond R \& Russo, Alicia A, Stem Cells and Patenting and Related Regulatory Issues: A United States Perspective, 7 Bio-Science Law Review 143 (2004).

Marshall, Eliot, Ethicists Back Stem Cell Research, White House Treads Cautiously, 285 Science 502 (1999).

Maskus, Keith E, The Role of Intellectual Property Rights in Encouraging Foreign Direct Investment and Technology Transfer, 9 Duke Journal of Comparative \& International Law 109 (1998).

McCoy, Andrew, Biotechnology and Embryonic Stem Cells: A Comparative Analysis of the Laws and Politics of the United States and Other Nations, 8 Loyola Law and Technology Annual 63 (2008).

Menell, Peter S, Forty Years of Wondering in the Wilderness and No Closer to the Promised Land: Bilski's Superficial Textualism and the Missed Opportunity to Return Patent Law to Its Technology Mooring, 63 Stanford Law Review 1289 (2011).

Meng, Yanjuan (孟彦娟) \& Meng, Tiancai (孟天财), Zhishi Jingji Shidai de Daxuesheng Zhishichanquan Yishi he Renzhi Zhuangkuang Yanjiu (知识经济时代的大学生知识产权意识 和认知状况研究) [A study on University Students' Awareness and Cognition of Intellectual Property in an Era of Knowledge-based Economy], 24 南京理工大学学报（社会科学版） [Journal of Nanjing University of Science and Technology] 96 (2011).

Merges, Robert P, Contracting into Liability Rules: Intellectual Property Rights and Collective Rights Organizations, 84 California Law Review 1293 (1996).

Merges, Robert P, Intellectual Property in Higher Life Forms: The Patent System and Controversial Technologies, 47 Maryland Law Review 1051 (1987).

Mertes, Heidi, Understanding the Ethical Concerns that Have Shaped European Regulation of Human Embryonic Stem Cell Research, 1 Proceedings of the Belgian Royal Academies of Medicine 127 (2012).

Miller, Amy, The Effect of Federal Funding Restrictions for Embryonic Stem Cell Research on Colleges and Universities: The Need for Caution when Ethical Objections to Research are Raised, 41 Journal of College and University Law 147 (2015). 
Mireles, Michael S, States as Innovation System Laboratories: California, Patents, and Stem Cell Technology, 28 Cardozo Law Review 1133 (2006).

Mitalipova, Maisam, et al., Human Embryonic Stem Cell Lines Derived from Discarded Embryos, 21 Stem Cells 521 (2003).

Moon, Shin Yong, et al., Generation, Culture, and Differentiation of Human Embryonic Stem Cells for Therapeutic Applications, 13 Molecular Therapy 5 (2006).

Moren, Jonathan D, Will A Trump Administration Let Sleeping Cells Lie? 35 Nature Biotechnology 20 (2017).

Moses, Lyria Bennett, Understanding Legal Responses to Technological Change: The Example of In Vitro Fertilization, 6 Minnesota Journal of Law Science \& Technology 505 (2004).

Moufang, Rainer, Patenting of Human Genes, Cells and Parts of the Body?-The Ethical Dimensions of Patent Law, 25 International Review of Industrial Property and Copyright Law 487 (1994).

Mueller, Janice M, Patenting Human Embryonic Stem Cells in the United States: The Legal and Ethical Debate, 14 CASRIP Newsletter 1 (2007).

Murray, Fiona \& Spar, Debora, Bit Player or Powerhouse? China and Stem-cell Research, 355 New England Journal of Medicine 1191 (2006).

Murray, Fiona, The Stem-cell Market - Patents and the Pursuit of Scientific Progress, 356 New England Journal of Medicine 2341 (2007).

Murray, Thomas H, Ethical (and Political) Issues in Research with Human Stem Cells, 265 Novartis Foundation Symposium 188 (2008).

Muscati, Sina A, "Some More Human Than Others": Assessing the Scope of Patentability Related to Human Embryonic Stem Cell Research, Jurimetrics 201 (2004).

Nie, Jing-Bao, The Problem of Coerced Abortion in China and Related Ethical Issues, 8 Cambridge Quarterly of Healthcare Ethics 463 (1999).

Nordberg, Ana \& Minssen, Timo, A "Ray of Hope" for European Stem Cell Patents or "Out of the Smog into the Fog"? An Analysis of Recent European Case Law and How it Compares to the US, 47 International Review of Intellectual Property and Competition LAW 138 (2016).

Novak, Atara, et al., Enhanced Reprogramming and Cardiac Differentiation of Human Keratinocytes Derived from Plucked Hair Follicles, Using a Single Excisable Lentivirus, 12 Cellular Reprogramming 665 (2010).

O'Sullivan, Ella, International Stem Cell Corp v. Comptroller General of Patents: the Debate Regarding the Definition of the Human Embryo Continues, 36 European Intellectual Property Review 155 (2014).

Olson, David S, Taking the Utilitarian Basis for Patent Law Seriously: The Case for Restricting Patentable Subject Matter, 82 Temple Law Review 1 (2009).

Oppenheimer, Max Stul, Patents 101: Patentable Subject Matter and Separation of Powers, 15 Vanderbilt Journal of Entertainment \& Technology Law 1 (2012). 
Pan, Yuqiong, et al., In Vitro Neuronal Differentiation of Cultured Human Embryonic Germ Cells, 327 Biochemical and Biophysical Research Communications 548 (2005).

Paradise, Jordan, et al., Patents on Human Genes: an Analysis of Scope and Claims, 307 Science 1566 (2005).

Pehlivan, CN, The Creation of a Single European Patent System: From Dream to (Almost) Reality, 34 European Intellectual Property Review 453 (2012).

Peng, Yaojin, The Morality and Ethics Governing CRISPR-Cas9 Patents in China, 34 Nature Biotechnology 616 (2016).

Peng, Yaojin, The Patentability of Human Embryonic Stem Cell Technology in China, 34 Nature Biotechnology 37 (2016).

Pera, Martin F, et al., Human Embryonic Stem Cells, 113 Journal of Cell Science 5 (2000). Piao, Wenxuan (朴文铉), Daojia de Shengming Lunli he Ganxibao Yanjiu de Wenti (道家的 生命伦理和干细胞研究的问题) [Ethical View of Life in Taoism and Stem Cell Research], 9 Wuhan Keji Daxue Xuebao (Shehui Kexue Ban) (武汉科技大学学报（社会科学版) ) [Journal of Wuhan Univ. of Science and Technology (Social Science Edition)] 109 (2007).

Pige Shiyong Mingjiao Zhuanli-Burong Qingmiao Danxie (“皮革食用明胶专利”不容轻描淡写) [Patents upon the Methods of Using Leather Waste to Make Edible Gelatin-A Serious Thing], Xinjing Bao (新京报) The Beijing News A5 (Apr. 28, 2012).

Plomer, Aurora, After Brüstle: EU Accession to the ECHR and the Future of European Patent Law, 2 Queen Mary Journal of Intellectual Property 110 (2012).

Plomer, Aurora, et al., Challenges to Human Embryonic Stem Cell Patents, 2 Cell Stem Cell 13 (2008).

Porter, Gerard, et al., The Patentability of Human Embryonic Stem Cells in Europe, 24 Nature Biotechnology 653 (2006).

Pralong, Danièle, et al., Cell Fusion For Reprogramming Pluripotency: toward Elimination of the Pluripotent Genome, 2 Stem Cell Reviews 331 (2006).

Qiu, Jane, China Goes Back to Basics on Research Funding, 507 Nature 148 (2014).

Qiu, Jane, Stem-cell Research and Regenerative Medicine in China, 3 National Science Review 257 (2016).

Qiu, Renzong (邱仁宗), Cong Zhongguo “Ganxibao Zhiliao” Re Lun Ganxibao Linchuang Zhuanhua Zhong de Lunli he Guanli Wenti (从中国“干细胞治疗”热论干细胞临床转化中的伦理 和管理问题) [Behind the Vogue for “Stem Cell Therapy": Ethical and Regulatory Issue in Clinical Translation of Stem Cells in China], 3 Kexue yu Shehui (科学与社会) [Science \& Society] 8 (2013).

Qiu, Renzong (邱仁宗), Renlei Peitai Ganxibao Yanjiu de Lunli Wenti (人类胚胎干细胞研究 的伦理问题) [Ethical Issues of Human Embryonic Stem Cell Research], 7 Qun Yan (群言) [Popular Tribune] 18 (2002).

Qiu, Xiangxing (丘祥兴), et al., Renlei Peitai Ganxibao Yanjiu Lunli Wenti de Diaocha he Taolun (人类胚胎干细胞研究伦理问题的调查和讨论) [A Survey and Discussion on Ethical 
Issues of Human Embryonic Stem Cell Research], 25 Yixue yu Zhexue (医学与哲学) [Medicine and Philosophy] 8 (2004).

Quan, Cao (荃草), Pige Mingjiao Zhuanli de Lunli Wenti, Zenme Jiejue (皮革明胶专利的伦理问 题, 怎么解决) [How to Solve the Problem concerning Patents upon the Methods of Using Leather Waste to Make Edible Gelatin], Xinjing Bao (新京报) The Beijing News, A03 (May 3, 2012).

Rabin, Sander, The Gatekeepers of hES Cell Products, 23 Nature biotechnology 817 (2005).

Rabin, Sander, The Human Use of Humanoid Beings: Chimeras and Patent Law, 24 Nature Biotechnology 517 (2006).

Rai, Arti K, Fostering Cumulative Innovation in the Biopharmaceutical Industry: The Role of Patents and Antitrust, 16 Berkeley Technology Law Journal 813 (2001).

Rai, Arti K, The Information Revolution Reaches Pharmaceuticals: Balancing Innovation Incentives, Cost, and Access in the Post-Genomics Era, 2001 University of Illinois Law Review 173 (2001).

Ram, Nick Scott, Biotechnology Patenting in Europe: The Directive on the Legal Protection of Biotechnological Inventions: Is This the Beginning or the End? 2 Bio-Science Law Review 43 (1998).

Rao, Mahendra \& Condic, Maureen L, Alternative Sources of Pluripotent Stem Cells: Scientific Solutions to An Ethical Dilemma, 17 Stem Cells and Development 1 (2008).

Resnik, DB, Embryonic Stem Cell Patents and Human Dignity, 15 Health Care Analysis 211 (2007).

Reubinoff, Benjamin E, et al., Embryonic Stem Cell Lines From Human Blastocysts: Somatic Differentiation In Vitro, 18 Nature Biotechnology 399 (2000).

Revazova, ES, et al., Patient-specific Stem Cell Lines Derived from Human Parthenogenetic Blastocysts, 9 Cloning and Stem Cells 432 (2007).

Rigby Barbarasy, Revocation of European Patent for Neural Progenitors Highlights Patent Challenges for Inventions Relating to Human Embryonic Stem Cells, 23 Expert Opinion on Therapeutic Patents 1397 (2013)

Riley, Margaret Foster \& Merrill, Richard A, Regulating Reproductive Genetics: A Review of American Bioethics Commissions and Comparison to the British Human Fertilisation and Embryology Authority, 6 Columbia Science \& Technology Law Review 1 (2005).

Rimmer, Matthew, The Attack of the Clones: Patent Law and Stem Cell Research, 10 Journal of Law and Medicine 488 (2003).

Rowlandson, Malene, WARF/Stem Cells (G2/06): The Ordre Public and Morality Exception and Its Impact on The Patentability of Human Embryonic Stem Cells, 32 European Intellectual Property Review 67 (2010).

Salter, Brian, et al., China and the Global Stem Cell Bioeconomy: An Emerging Political Strategy? 1 Regenerative Medicine 671 (2006). 
Salter, Brian, Patenting, Morality and Human Embryonic Stem Cell Science: Bioethics and Cultural Politics in Europe, 2 Regenerative Medicine 301 (2007).

Schechter, Jody, Promoting Human Embryonic Stem Cell Research: A Comparison of Policies in the United States and the United Kingdom and Factors Encouraging Advancement, 45 Texas International Law Journal 603 (2009).

Schuster, Martina Ines, The Court of Justice of the European Union's Ruling on the Patentability of Human Embryonic Stem-Cell-Related Inventions (Case C-34/10), 43 International Review of Intellectual Property and Competition Law 626 (2012).

Schwartz, Steven D, et al., Embryonic Stem Cell Trials for Macular Degeneration: A Preliminary Report, 379 The Lancet 713 (2012).

Schwartz, Steven D, et al., Human Embryonic Stem Cell-derived Retinal Pigment Epithelium in Patients with Age-related Macular Degeneration and Stargardt's Macular Dystrophy: Follow-up of Two Open-label Phase 1/2 Studies, 385 The Lancet 509 (2015).

Séguin, Béatrice, et al., Genomic Medicine and Developing Countries: Creating a Room of Their Own, 9 Nature Reviews Genetics 487 (2008).

Senatore, Vincenzo, et al., Patenting Parthenotes in the US and Europe, 33 Nature Biotechnology 1232 (2015).

Shamblott, Michael J, et al., Derivation of Pluripotent Stem Cells from Cultured Human Primordial Germ Cells, 95 Proceedings of the National Academy of Sciences 13726 (1998).

Shroff, Geeta \& Hopf-Seidel, Petra, Use of Human Embryonic Stem Cells in the Treatment of Parkinson's Disease: A Case Report, 17 International Journal of Emergency Mental Health and Human Resilience 661 (2015).

Simon, Brenda M \& Scott, Christopher T, Unsettled Expectations: How Recent Patent Decisions Affect Biotech, 29 Nature Biotechnology 229 (2011).

Sleeboom-Faulkner, Margaret E, National Risk Signatures and Human Embryonic Stem Cell Research in Mainland China, 12 Health, Risk \& Society 491 (2010).

Snead, O Carter, The Pedagogical Significance of the Bush Stem Cell Policy: A Window into Bioethical Regulation in the United States, 5 Yale Journal of Health Policy, Law, and Ethics 491 (2005).

Staunton, Ciara, Brüstle v Greenpeace, Embryonic Stem Cell Research and the European Court of Justice's New Found Morality, 21 Medical Law Review 310 (2013).

Sun, Liangguo (孙国良), Fuqi Jian Lengdong Peitai Chuli Nanti de Falü Jiejue (夫妻间冷冻 胚胎处理难题的法律解决) [Legal Countermeasures of Issues in Frozen Embryo Disposition between the Couple], 23 Guojia Jiancha Guan Xueyuan Xuebao (国家检察官学院学报) [Journal of National Prosecutors College] 110 (2015).

Suss-Toby, Edith, et al., Derivation of a Diploid Human Embryonic Stem Cell Line from A Mononuclear Zygote, 19 Human Reproduction 670 (2004).

Takahashi, Kazutoshi \& Yamanaka, Shinya, Induction of Pluripotent Stem Cells from Mouse Embryonic and Adult Fibroblast Cultures by Defined Factors, 126 Cell 663 (2006). 
Takahashi, Kazutoshi, et al., Induction of Pluripotent Stem Cells from Adult Human Fibroblasts by Defined Factors, 131 Cell 861 (2007).

Tan, Ying (谭英), et al., Nongcun gongzhong dui Zhishichanquan de Renzhidu ji Guanzhudu Yanjiu (农村公众对知识产权的认知度及关注度研究) [Research on Rural Public's Awareness of and Attention to Intellectual Property Rights], 17 西北农林科技大学学报（社会科学版） [Journal of Northwest A\&F University (Social Science Edition)] 144 (2017).

Tännsjö, Torbjörn, Why No Compromise is Possible, 38 Metaphilosophy 330 (2007).

Taymor, Kenneth S, et al., The Paths around Stem Cell Intellectual Property, 24 Nature Biotechnology 411 (2006).

Thomson, James A \& Odorico, Jon S, Human Embryonic Stem Cell and Embryonic Germ Cell Lines, 18 Trends in Biotechnology 53 (2000).

Thomson, James A, et al., Embryonic Stem Cell Lines Derived from Human Blastocysts, 282 Science 1145 (1998).

Tur-Sinai, Ofer, Cumulative Innovation in Patent Law: Making Sense of Incentives, 50 Idea 723 (2009).

Varju, Marton \& Sándor, Judit, Patenting Stem Cells in Europe: The Challenge of Multiplicity in European Union Law, 49 Common Market Law Review 1007 (2012).

Vazin, Tandis \& Freed, William J, Human Embryonic Stem Cells: Derivation, Culture, and Differentiation: A Review, 28 Restorative Neurology and Neuroscience 589 (2010).

Verlinsky, Yury, et al., Cytoplasmic Cell Fusion: Stembrid Technology for Reprogramming Pluripotentiality, 2 Stem cell reviews 297 (2006).

Volokh, Eugene, The Mechanisms of the Slippery Slope, 116 Harvard Law Review 1026 (2003).

Walsh, Patrick, Stemming the Tide of Stem Cell Research: The Bush Compromise, 38 John Marshall Law Review 1061 (2004).

Walter, Carrie F, Beyond the Harvard Mouse: Current Patent Practice and the Necessity of Clear Guidelines in Biotechnology Patent Law, 73 Indiana Law Journal 1025 (1997).

Wang, Luozhong (王洛忠), Woguo Zhuanxingqi Gonggong Zhengce Guochengzhong de Gongmin Canyu Yanjiu-CYizhong Liyi Fenxi de Shijiao (我国转型期公共政策过程中的公民 参与研究———种利益分析的视角) [Study on the Participation of Citizens in Public Policy Making During China's Transition: From the Interest Analysis Perspective], 8 Zhongguo Xingzheng Guanli (中国行政管理) [Chinese Public Administration] 86 (2005).

Wang, Nian (王念), Guangxi Shehui Gongzhong Zhishichanquan Renzhidu Diaocha yu Fenxi ji Silu Tantao (广西社会公众知识产权认知度调查与分析及思路探讨) [The Survey, Analysis, and Discussion on Public Perceptions of IP in GuangXi], 3 Xiandai Shangye (现代商 业) [Modern Business] 175 (2016).

Warren-Jones, Amanda, A Mouse in Sheep's Clothing: the Challenge to Patent Morality Criterion Posed by "Dolly", 20 European Intellectual Property Review 445 (1998).

Warren-Jones, Amanda, Vital Parameters for Patent Morality-A Question of Form, 2 Journal of Intellectual Property Law \& Practice 832 (2007). 
Whitehill, Joshua, Patenting Human Embryonic Stem Cells: What is so Immoral? 34 Brooklyn Journal of International Law 1045 (2008).

Wu, Handong (吴汉东), Zhishi Chanquan Zhanlüe Shishi de Guoji Huanjing yu Zhongguo Changjing (知识产权战略实施的国际环境与中国场景) [The International Environment of Implementing Intellectual Property Strategy and China's Situation], 2 Faxue (法学) [Law Science] 3 (2012).

Wu, Handong (吴汉东), Zhongguo Zhuanli Fa de Fazhan Daolu: Xiandaihua, Guojiahua yu Zhanlüehua--Zai Zhongguo Zhuanli Fa Banbu 30 Zhounian Zuotanhui Shang de Fayan (中国专利法的发展道路：现代化、国际化与战略化一一在中国专利法颁布30周年座谈会上的 发言) [The Development Paths of the Chinese Patent Law: Modernizing, Internationalizing, Strategizing - An Address in Colloquia "the Issuing of the Chinese Patent Law" 30th Anniversary], 3 Zhishi Chanquan (知识产权) [Intellectual Property Journal] 10 (2014).

Wu, Yuehui (吴月辉) \& Yu, Siluan (喻思娈), Jinping Xi: Chuangxin Ganwei Tianxia Xian (习近 平: 创新要敢为天下先) [Xi Jinping: Innovation, Dare to be the First in the World], Renmin Ribao (人民日报) [People’s Daily] 2 (2017).

Xu, Haiyan (徐海燕), Lun Tiwai Zaoqi Renlei Peitai de Falü Diwei ji Chufen Quan (论体外早 期人类胚胎的法律地位及处分权) [The Legal Status of Early Embryos and the Right of the Disposition of Frozen Embryos], 29 Faxue Luntan (法学论坛) [Legal Forum] 146 (2014).

Xu, Yu, et al., Prevalence and Control of Diabetes in Chinese Adults, 310 Jama 948 (2013).

$\mathrm{Yu}$, Junying, et al., Induced Pluripotent Stem Cell Lines Derived from Human Somatic Cells, 318 Science 1917 (2007).

$\mathrm{Yu}$, Peter K, Building the Ladder: Three Decades of Development of the Chinese Patent System, Drake University Law School Research Paper (2012).

Yu, Peter K, From Pirates to Partners: Protecting Intellectual Property in China in the Twenty-first Century, 50 American University Law 131 (2000).

Yuan, Weiping, et al., Stem Cell Science On the Rise in China, 10 Cell Stem Cell 12 (2012). Zhang, Ping (张平), Shengwu Yixue Lingyu zhong de Zhishi Chanquan Baohu (生物医学领域 中的知识产权保护) [Intellectual Property Protection in BioMedicine Field], 39 Journal of Peking Univeristy (Health Sciences) 101 (2007).

Zhang, Xin, et al., Derivation of Human Embryonic Stem Cells from Developing and Arrested Embryos, 24 Stem Cells 2669 (2006).

Zhao, Jing (赵晶), Zhuanli Shencha Guocheng Zhong “Lunli Shencha” zhi Chutan--You Liangjian Mingjiao Zhuanli Xingfa de Sikao (专利审查过程中“伦理审查”之初探一一由两件明 胶专利引发的思考) [Preliminary Study on the Morality Exclusion in Patent Examination: Thinking from Two Gelatin Patents], 3 Zhongguo Faming yu Zhuanli (中国发明与专利) [China Invention \& Patent] 92 (2013).

Zhao, Tongbiao, et al., Immunogenicity of Induced Pluripotent Stem Cells, 474 Nature 212 (2011). 
Zhao, Xu (肇旭), Renlei Peitai Ganxibao Yanjiu de Lunli Guan Fenxi (人类胚胎干细胞研究的伦理 观分析) [A Study on Ethical Values of Human Embryonic Stem Cell Research], 1 Lunli Xue Yanjiu (伦理学研究) [Studies in Ethics] 82 (2012).

Zheng, Xianwen (郑显文), Gongxu Liangsu Yuanze zai Zhongguo Jindai Minfa Zhuanxing zhong de Jiazhi (公序良俗原则在中国近代民法转型中的价值) [The Value of the Principle of Public Order and Good Morals in the Transformation of the Civil Law of Modern China], 11 Faxue (法学) [Law Science] 87 (2017).

Zhou, Chenlin, et al., Comprehensive Profiling Reveals Mechanisms of SOX2-mediated Cell Fate Specification in Human ESCs and NPCs, 26 Cell Research 171 (2016).

Zhou, Di, et al., Establishment and Maintenance of Three Chinese Human Embryonic Stem Cell Lines, 46 In Vitro Cellular \& Developmental Biology-Animal 192 (2010).

Zhou, Qi (周琪), et al., Mianxiang Weilai de Xin Yilun Yiliao Jishu Geming--Ganxibao yu Zaisheng Yixue Yanjiu Zhanluexing Xiandao Keji Zhuanxiang Jinzhan (面向未来的新一 轮医疗技术革命一一干细胞与再生医学战略性先导科技专项进展) [Confronting Coming Medical Renovation: Progress on Stem Cell and Regenerative Medicine Research], 30 Zhongguo Kexueyuan Yuan Kan [中国科学院院刊] (China Academic Journal Electronic Publishing House) 262 (2015).

Zhou, Qi (周琪), Zhongguo ji Zhongguo Kexueyuan Ganxibao yu Zaisheng Yixue Yanjiu Gaishu (中国及中国科学院干细胞与再生医学研究概述) [An Overview of Stem Cell and Regenerative Medicine in China and at Chinese Academy of Sciences], 28 Chinese Bulletin of Life Sciences 833 (2016).

Zhou, Yan (周燕), Woguo Ganxibao Yanjiu Zhong de Lunli Weiji yu Falü Kunhuo jiqi Guojia Guanli de Yanjiu (我国干细胞研究中的伦理危机与法律困惑及其国家管理的研究) [Research on Ethical Crisis and Legal Issues Related to Stem Cell Research and National Regulatory Framework in China], Di San Junyi Daxue (第三军医大学) [Third Military Medical University of Chinese PLA] (2009).

\section{News Reports and Online Materials}

Abbott, Alison, German Science Organizations Slam European Court over Stem-cell Ruling, NATURE NeWs, (Dec. 8, 2011), 10.1038/nature.2011.9606.

Alternative Sources of Human Pluripotent Stem Cells, THE PRESIDENT'S COUNCIL ON BIOETHICS, (May 2005), http://www.bioethics.gov/.

Babington, Charles, Stem Cell Bill Gets Bush's First Veto, WAShington Post, (Jul. 20, 2016), http://www.washingtonpost.com/wp-dyn/content/article/2006/07/19/ AR2006071900524.html.

Baker, Dean, Stagnation in the Drug Development Process: Are Patents the Problem? (Mar. 2007), http://www.cepr.net/documents/publications/healthcare_stagnation_2007_03.pdf.

Bos, Carole, Alexander Fleming and Penicillin- "The Wonder Drug", AwesomeStories.com, (May 25, 2015), https://www.awesomestories.com/asset/view/Alexander-Flemingand-Penicillin-The-Wonder-Drug-. 
Bostyn, Sven, et al., Final Report of the Expert Group on the Development and Implications of Patent Law in the Field of Biotechnology and Genetic Engineering, (May 17, 2016), https://www.ivir.nl/publicaties/download/Report-of-Biotech-Expert-Group.pdf.

Brugger, E Christian, Stem Cells and Parthenogenesis: Are Parthenotes Human Embryos? CULTURE OF LIFE Foundation, (Mar. 3, 2011), http://www.cultureoflife.org/2011/03/03/ stem-cells-and-parthenogenesis-are-parthenotes-human-embryos/.

Bush, George W, Executive Order: Expanding Approved Stem Cell Lines in Ethically Responsible Ways, THE WHITE HOuSE, (Jun. 20, 2007), https://georgewbush-whitehouse. archives.gov/news/releases/2007/06/20070620-6.html.

Bush, George W, President Discusses Stem Cell Research, THE White House, (Aug. 9, 2001), http://georgewbush-whitehouse.archives.gov/news/releases/2001/08/20010809-2. html.

Bush, George W, Stem Cell Science and the Preservation of Life, NEW YoRK TIMES, (Aug. 12, 2001), http://www.nytimes.com/2001/08/12/opinion/stem-cell-science-and-thepreservation-of-life.html.

Bush Responds to Congress Stem Cell Letter, BioNews, (May 17, 2004), http://www. bionews.org.uk/page_11949.asp.

Campo-Ruiz, Vanessa, Human Stem Cell Research and Regenerative Medicine: Focus on European Policy and Scientific Contributions, EuRoPeAn SCIENCE Foundation (2013), http://archives.esf.org/fileadmin/Public_documents/Publications/HumanStemCellResearch.pdf.

Cheng, Ge (成舸), et al., Woguo Jiancheng Shijie Zuida Ren Peitai Ganxibao Ku (我国建 成世界最大人胚胎干细胞库) [China Established the Biggest hESC Bank in the World], CHINA SCIENCE DAILY, (Mar. 6, 2012), http://news.sciencenet.cn/dz/dznews_photo. aspx?id=13850.

China Concerned about Abortions, BBC NEws, (Jul. 30, 2009), http://news.bbc.co.uk/2/hi/ asia-pacific/8175864.stm.

China Firmly Opposes Human Cloning, CHINA.ORG.CN, (Oct. 26 2001), http://www.china. org.cn/english/21193.htm.

China National Center for Biotechnology Development, http://www.cncbd.org.cn.

China to stop harvesting executed prisoners' organs, BBC NEwS, (Dec. 4, 2014), http:// www.bbc.com/news/world-asia-china-30324440.

Clinton, Bill, President Clinton's Comments on NIH and Human Embryo Research, US NAtIONAl ARChiveS, (Dec. 2, 1994), http://clinton6.nara.gov/1994/12/1994-12-02president-on-nih-and-human-embryo-research.html.

Code of Practice for the Use of Human Stem Cell Lines (Apr. 2010), https://www.mrc. ac.uk/documents/pdf/code-of-practice-for-the-use-of-human-stem-cell-lines/.

Cole, Jonathan R, 'Political' Science: It's Déja Vu All Over Again, HuffPost, (Jan. 10, 2018), https://www.huffingtonpost.com/entry/trump-administration-science us_5a56d1f8e4b03bc4d03df30e. 
Commission on Intellectual Property Rights, Integrating Intellectual Property Rights and Development Policy, (Sept. 2002), http://www.iprcommission.org/papers/pdfs/ final_report/ciprfullfinal.pdf.

Connolly, Ceci \& Smith, R Jeffrey, Obama Positioned to Quickly Reverse Bush Actions, WASHINGTON POST, (Nov. 9, 2008), http://www.washingtonpost.com/wp-dyn/content/ article/2008/11/08/AR2008110801856.html.

Cyranoski, David \& Reardon, Sara, Chinese Scientists Genetically Modify Human Embryos, NATURE, (Apr. 22, 2015), doi:10.1038/nature.2015.17378.

Danish Council of Ethics, The Ethics of Patenting Human Genes and Stem Cells (Conference Report and Summaries, 2004), http://etiskraad.dk/en/Udgivelser/ /media/ bibliotek/rapporter/2004/2004-Patenting-Human-Genes-and-Stem-Cells.ashx.

Domestic Policy Council, Advancing Stem Cell Science Without Destroying Human Life, THE WHITE HOUSE, (Apr. 2007), https://georgewbush-whitehouse.archives.gov/dpc/ stemcell/2007/.

EGE, Opinion No. 15: Regarding Ethical Aspects of Human Stem Cell Research and Use Brussels, (Nov. 14, 2000), http://www.mpvroma.org/wp-content/uploads/2012/11/ UECE01.pdf.

EGE, Opinion No. 16: Ethical Aspects of Patenting Inventions Involving Human Stem Cells, (May. 7, 2002), http://biotech.bioetica.org/new/ege16_complet_en.pdf.

EU to Fund Embryo Cell Research, BBC NEws, (Jul. 24 2006), http://news.bbc.co.uk/2/hi/ europe/5209106.stm

Europe: Map, The Hinxton Group: An International Consortium on Stem Cells, Ethics \& LAW, http://www.hinxtongroup.org/wp_eu_map.html

European Commission, Summary of the Judgement in Case C-34/10, (May 2010), http:// ec.europa.eu/dgs/legal_service/arrets/10c034_en.pdf.

European Commission, What is Horizon 2020? http://ec.europa.eu/programmes/horizon2020/en/what-horizon-2020.

Facts on Patenting Life Forms Having a Relationship to Humans, THE UNITED STATES PATENT AND TRADEMARK OfFICE, (Apr. 01, 1998), http://www.uspto.gov/news/pr/1998/98-06.jsp.

Federal Policy, National INSTITUTES OF HeALTH, http://stemcells.nih.gov/policy/Pages/ Default.aspx.

Fikes, Bradley J, New Stem Cell Patent Action Filed, The SAn Diego Union-Tribune, (Jul. 2, 2013), http://www.sandiegouniontribune.com/business/biotech/sdut-warf-patentstem-2013jul02-story.html.

Fox, Maggie, Conservative Reps Urge Trump to Fire NIH Chief Francis Collins Over Stem Cells, NEWS, (May 23, 2017), https://www.nbcnews.com/health/health-news/conservative-reps-urge-trump-fire-nih-chief-francis-collins-over-n763301.

Gallagher, Kathleen, WARF Loses a Round in Stem Cell Patent Dispute, JouRnAL SENTINEL, (May. 3, 2010), http://archive.jsonline.com/business/92682039.html/. 
Gummer, Thomas, Rethinking Morality: Human Embryonic Stem Cell Innovation, to Patent or Not to Patent? The Student Journal OF LAW (2012), https://sites.google.com/ site/349924e64e68f035/issue-3/stem-cells.

Ho, David, Bacteriologist Alexander Fleming, TImE, (Mar. 29, 1999), http://content.time. com/time/magazine/article/0,9171,990612,00.html.

Huang, Kunyi (黄坤益), Guanyu Zhonghua Renmin Gongheguo Zhuanli Fa (Cao'an) de Shuoming (关于《中华人民共和国专利法 (草案)》的说明) [Explanation on the Patent Law of the People's Republic of China (Draft)], (Dec. 2, 1983), http://www.npc.gov. cn/wxzl/gongbao/2000-12/26/content_5001493.htm.Li Yun, Chinese Birth Defects Number Around 900,000 Cases Annually, EPOCH TIMES, (Sept. 19, 2012), http://www. theepochtimes.com/n3/1481726-chinese-birth-defects-number-around-900-000cases-annually/.

Human Genetics Advisory Commission and the HFEA, Cloning Issues in Reproduction, Science and Medicine (1998), http://www.hfea.gov.uk/docs/Cloning_Issue_Report. pdf.

Hunt, Katie, Why China Will Struggle to End Organ Harvesting from Executed Prisoners, CNN, (Dec. 5, 2014), http://edition.cnn.com/2014/12/05/world/asia/china-prisonersorgans/.

Irish Council of Bioethics, Ethical, Scientific and Legal Issues concerning Stem Cell Research: Opinion, THE IRISH COUNCIL OF BIOETHICS (2008), http://health.gov.ie/wpcontent/uploads/2014/07/Ethical_Scientific_Legal_Issues1.pdf.

Jiang, Chengcheng, Women Take the Pill: 13 Million Abortions, TImE, (Sept. 30, 2013), http://world.time.com/2013/09/30/what-happens-when-only-1-2-of-chinese-women-take-the-pill-13-million-abortions/.

Johnson, Judith A\& Liu, Edward C, Stem Cell Research: Science, Federal Research Funding, and Regulatory Oversight, (Jan. 17, 2012), https://www.hsdl.org/?view\&did=707460.

Kaiser, Jocelyn, Trump Wants 2018 NIH Cut to Come from Overhead Payments, SCIENCE, (May 29, 2017), http://www.sciencemag.org/news/2017/03/trump-wants-2018-nihcut-come-overhead-payments.

Kellman, Laurie, Senate Approves Embryo Stem Cell Bill, THE WASHINGTON POST, (Jul. 18, 2006), http://www.washingtonpost.com/wp-dyn/content/article/2006/07/18/ AR2006071801071.html.

Kelly, Janet, All NIH Human Embryonic Stem Cell Registry Lines Now Deposited at NSCB, UNIVERSITY OF WISCONSIN-MADISON NEWS, (Jan. 12, 2009), http://www.news.wisc. edu/16120.

Kevles, Daniel J, A History of Patenting Life in the United States with Comparative Attention to Europe and Canada, 17 (Jan. 12, 2002), https://scholarworks.iupui.edu/ bitstream/handle/1805/757/Patenting\%20Life\%20-\%20Comparative\%20Study\%20 US\%2C\%20CN\%2C\%20EU\%202002.pdf?sequence=1\&isAllowed=y. 
Kexue Jijin Wangluo Xinxi Xitong (科学基金网络信息系统) [Internet-based Science Information System of the Natural Science Foundation of China], https://isisn.nsfc.gov.cn/ egrantweb/.

Knapton, China Shocks World by Genetically Engineering Human Embryos, THE TELEGRAPH, (Apr. 23, 2015), http://www.telegraph.co.uk/news/science/11558305/China-shocksworld-by-genetically-engineering-human-embryos.html.

Krauthammer, Charles, Stem Cell Vindication, THE WASHINGTON PosT, (Nov. 2007), http:// www.washingtonpost.com/wp-dyn/content/article/2007/11/29/AR2007112901878. html.

LEE, Keun, et al., Industrial Property (IP) Rights and Technological Development in the Republic of Korea, (Apr. 2003), http://webcache.googleusercontent.com/ search?q=cache:ZfISifmnp4QJ:www.keunlee.com/modules/board/bd_download_ db.html\%3Fid\%3Deng_research_book\%26no\%3D201+\&cd=1\&hl=en\&ct=clnk\&gl= sg.

Luo, Haocai, Different Cultures Show Same Respect for Human Dignity, PeOPLE'S DAILY USA, (Sept. 22, 2011), http://usa.chinadaily.com.cn/opinion/2011-09/22/content_13764204.htm. A Chinese version can be available at http://paper.people.com. cn/rmrbhwb/html/2011-09/22/content_929388.htm.

McConchie, Daniel S, Using Stem Cells from Embryos Will Make Human Flesh Profitable, THE CENTER For BIOETHICS \& HUMAN Dignity, (Jun. 29, 2001), https://cbhd.org/content/ using-stem-cells-embryos-will-make-human-flesh-profitable.

MOH of China, Zhongguo Chusheng Quexian Fangzhi Baogao 2012 (中国出生缺陷防治报告 (2012) )[China's Birth Defect Prevention Report 2012], www.GOV.cN, (Sept. 12, 2012), http://www.gov.cn/gzdt/2012-09/12/content_2223371.htm.

Molloy, Mark, Prisoners in China Use Ingenious 'Loophole' to Get Out of Jail Early, TELEGRAPH, (Jan. 21, 2015), http://www.telegraph.co.uk/news/worldnews/asia/china/11359514/ Prisoners-in-China-use-ingenious-loophole-to-get-out-of-jail-early.html.

Monica, Santa, Groups Challenge Stem Cell Patents That Loot Taxpayer Funds and Force Research Overseas, PUBPAT, (Jul. 18, 2006), http://www.pubpat.org/warfstemcellsfiled.htm.

MOST, Guojia “Shi’er Wu” Kexue he Jishu Fazhan Guihua (国家“十二五”科学和技术发展规划) [The National "Twelfth Five-Year" Development Plan of S\&T], MINISTRY OF SCIENCE AND TeChnology of the People's Republic of China, (Jul. 4, 2011), http://www.most.gov.cn/ mostinfo/xinxifenlei/gjkjgh/201107/t20110713_88230_6.htm.

MOST, Guojia Zhongdian Jichu Yanjiu Fazhan Jihua he Zhongda Kexue Yanjiu Jihua 2015 Niandu Xiangmu Shenbao Zhinan (国家重点基础研究发展计划和重大科学研究计划2015年 度项目申报指南) [Guideline for Project Application of 863 Program and 973 Program (2015)], Ministry of Science And Technology of the People's Republic of China, (Feb. 20, 2014), http://program.most.gov.cn/htmledit/CFC828AD-B2B5-61E6-171D-FAD56CB48C0B.html. 
MOST, Premier Calls for Building Innovation-oriented nation, MINISTRY OF SCIENCE AND Technology of the People's Republic of China, http://www.most.gov.cn/eng/photonews/200601/t20060112_27803.htm.

Mullin, Emily, Under Trump, Biologists Fear Political Risks of Controversial Research, MIT TeChnology Review, (Nov. 9, 2017), https://www.technologyreview.com/s/609323/ under-trump-biologists-seek-a-low-profile-for-controversial-research/.

Muqian Zhishi Chanquan Gongzuo Zui Genben Buzu shi Zhishi Chanquan Yishi Jiaoruo (目 前知识产权工作最根本不足是知识产权意识较弱) [Currently the Most Fundamental Problem of IP Work is the Relatively Weak Awareness of IPRs], www.Gov.CN, (Apr. 23, 2007), http:// www.gov.cn/zxft/ft12/content_592314.htm.

$\mathrm{NIH}$, National Institutes of Health Guidelines on Human Stem Cell Research, US DEPARTMENT OF HEALTH \& HUMAN SERVICES, (2016), http://stemcells.nih.gov/policy/ pages/2009guidelines.aspx.

$\mathrm{NIH}$, Report of the Human Embryo Research Panel (Vol. 1), (Sept. 1994), https://repository. library.georgetown.edu/bitstream/handle/10822/559352/human_embryo_vol_1. pdf?sequence=1\&isAllowed=y.

NiH, Stem Cell Basics I (2009), Stem Cell Information, http://stemcells.nih.gov/info/ basics/pages/basics1.aspx.

NIH, Stem Cell Basics III, Stem Cell Information, https://stemcells.nih.gov/info/basics/3. htm.

NIH, Stem Cell Basics VII (2009), Stem Cell Information, https://stemcells.nih.gov/info/ basics/7.htm.

NIH, Update on Existing Human Embryonic Stem Cells, National INSTITUTES OF Health, (Aug. 27, 2001), https://stemcells.nih.gov/policy/archive.htm.

Plomer, Aurora, et al., Stem Cell Patents: European Patent Law and Ethics Report, (Jul. 28, 2006), http://www.nottingham.ac.uk/ 1lzwww/StemCellProject/project.report.pdf.

Pope John Paul II Addresses President Bush, American CATHolic.oRg, (Jul. 23, 2001), http:// www.americancatholic.org/News/StemCell/pope_to_bush.asp.

Presedent's Council on Bioethics, A White Paper: Alternative Sources of Human Pluripotent Stem Cells, (May 2005), https://bioethicsarchive.georgetown.edu/pcbe/reports/ white_paper/index.html.

Profile of Louise Brown, BBC, (Jul.24, 2003), http://news.bbc.co.uk/2/hi/health/3091241. stm.

Pyre, Stacy, Stem Cell for Parkinson's Disease? Prof. Jun Takahashi Study-Kyoto University, Stem Cell Therapy Journal, (Mar. 14, 2012), http://stemcelltherapyreviewjournal. com/stem-cells-can-treat-parkinsons-prof-jun-takahashi-kyoto-university-study/.

Qiao, Zhifeng (乔志峰), Jiangyu Famingjia Shi Shuide Faming (“监狱发明家”是谁的“发 明”) [Who Invents “Jail Inventors”], NewsSINA, (Jan. 19, 2015), http://news.sina.com. cn/o/2015-01-19/162831417619.shtml. 
Rabesandratana, Tania, EU Commission Rejects Plea to Block Stem Cell Research Funding, SCIENCE, (May 20, 2014), http://news.sciencemag.org/europe/2014/05/e-ucommission-rejects-plea-block-stem-cell-research-funding.

Reno, Jamie, Is Human Embryonic Stem Cell Research in Jeopardy? HeALTHLINE, (Jun. 14, 2017), https://www.healthline.com/health-news/is-human-embryonic-stem-cellresearch-in-jeopardy\#1.

Research with Gametes and/or (leftover) Embryos and the Foetus, CENTRAL COMMITTEE ON RESEARCH INVOLVING HUMAN SUBJECTS, http://www.ccmo.nl/en/research-with-gametesand-or-leftover-embryos-and-the-foetus.

Roffe, Pedro, et al., Resource Book on TRIPS and Development: an Authoritative and Practical Guide to the TRIPS Agreement, IPRSONLINE.ORG, (Jun. 1, 2005), http://www. iprsonline.org/unctadictsd/ResourceBookIndex.htm.

Safety and Tolerability of Sub-retinal Transplantation of Human Embryonic Stem Cell Derived Retinal Pigmented Epithelial (hESC-RPE) Cells in Patients With Stargardt's Macular Dystrophy (SMD), CLINICALTRIALS.Gov, https://clinicaltrials.gov/show/NCT01469832.

Salter, Brian, Patents and Morality: Governing Human Embryonic Stem Cell Science in Europe (2009), http://www.kcl.ac.uk/sspp/departments/politicaleconomy/research/ biopolitics/publications/workingpapers/wp29.pdf.

Shek, Colin, Stem Cell Research in China: Regenerative Economics, CKGSB KNowLEdGE, (May 5, 2014), http://knowledge.ckgsb.edu.cn/2014/05/05/technology/stem-cellresearch-in-china-regenerative-economics/.

Simpson, John M, Consumer Groups File Appeal in Challenge of Human Stem Cell Patent Held by WARF, CONSUMER WATCHDOG, (Jul. 18 2008), http://www.consumerwatchdog. org/newsrelease/consumer-groups-file-appeal-challenge-human-stem-cell-patentheld-warf.

Sleeboom-Faulkner, Margaret \& Patra, Prasanna Kumar, The Bioethical Vacuum: National Policies on Human Embryonic Stem Cell Research in India and China, JouRNAL OF INTERNATIONAL BIOTECHNOLOGY LAW, 25 (Dec. 2008), http://www.therapy.centreforbionetworking.org/wp-content/uploads/2012/06/The-Bioethical-Vacuum.SleeboomFaulkner.Patra-for-merge.pdf

Smith, Austin \& Blackburn, Clare, Do We Still Need Research on Human Embryonic Stem Cells? EuRoStEmCELL, (Feb. 1, 2012), http://www.eurostemcell.org/commentanalysis/ do-we-still-need-research-human-embryonic-stem-cells.

Stem Cell Research, Election Center 2008, CNN POLITICS.COM, http://edition.cnn.com/ ELECTION/2008/issues/issues.stemcell.html.

Stolberg, Sheryl Gay \& Sanger, David E, Bush Aides Seek Compromise on Embryonic Cell Research, NEW YORK TIMES, (Jul. 4, 2001), http://www.nytimes.com/2001/07/04/us/ bush-aides-seek-compromise-on-embryonic-cell-research.html?pagewanted=all.

The Stem Cell Debates: Lessons for Science and Politics, THE New ATLANTIS (2012), http:// www.thenewatlantis.com/docLib/20120125_TNA34Report.pdf. 
Tippins, Katharine, Funding Stem Cell Research Crucial for Scientific Advancement, Should Not be Inhibited by Politicians, THe BAdger HERALD, (Feb. 6, 2018), https:// badgerherald.com/opinion/2018/02/06/funding-stem-cell-research-crucial-forscientific-advancement-should-not-be-inhibited-by-politicians/.

UK Department of Health, Stem Cell Research: Medical Progress with Responsibility, http://webarchive.nationalarchives.gov.uk/20130107105354/http://www.dh.gov.uk/ prod_consum_dh/groups/dh_digitalassets/@dh/@en/documents/digitalasset/ dh_4065085.pdf.

WIPO, Understanding Industrial Property, http://www.wipo.int/edocs/pubdocs/en/ wipo_pub_895_2016.pdf

World Youth Alliance Commends Recommendation to Deny Patents for Embryonic Stem Cell Research, WORLD YOUTH ALLIANCE, http://www.wya.net/op-ed/world-youth-alliancecommends-recommendation-to-deny-patents-for-embryonic-stem-cell-research-2/. Xin Zhongguo Dang'an: Deng Xiaoping Tichu Kexue Jishu shi Diyi Shengchanli (新中国档 案: 邓小平提出科学技术是第一生产力) [Archives of New China: Deng Xiaoping pointed out S\&T is the First Productive Force], www.GOV.cN, (Oct. 10, 2009), http://www.gov.cn/ test/2009-10/10/content_1435113.htm.

Xunzi (荀子), Wangzhi (王制) [Regulations of the Sage Kings], WenYanHANYu.com (Oct. 8, 2012), http://www.wenyanhanyu.com/xunzi/7445.html.

Yang, Lixin (杨立新), Lengdong Peitai shi Juyou Ren'ge Shuxing de Lunli Wu (冷冻胚胎是具有 人格属性的伦理物) [Frozen Human Embryos are Ethical Objects Possessing the Property of Personality], JIANCHA RIBAO (检察日报) [PROSECUTE DAILY], (Jul. 19, 2014), http://newspaper.jcrb.com/page/1/2014-07/19/03/2014071903_pdf.pdf.

Zhu, Huan, A Comparative Study on Human Embryonic Stem Cell's Patent-Eligibility in the United States, the European Patent Organization and China, BEPRESS, (Mar. 23, 2012), https://works.bepress.com/huan_zhu/1/.

\section{Cases and Patents}

\section{Cases in the EU and the EPO}

C-34/10 (Oliver Brüstle v. Greenpeace eV) OJ C 362/7 [2011]

C-364/13 (International Stem Cell Corporation v. Comptroller General of Patents, Designs and Trade Marks) OJ C 65/10 [2015]

C-377/98 (The Netherlands v. Parliament and Council) [2001] ECR I-7079

C-456/03 (Commission v. Italy) [2005] ECR I-5335

Case 8/81 (Ursula Becker v. Finanzamt Münster-Innenstadt) [1982] ECR 53

Decision of the OD of 21 Jul. 2003 on European patent No. EP0695351 (University of Edinburgh)

G 2/06 (Use of embryos/WARF) OJ EPO 306 [2009] 
Harvard/Oncomouse, Communication about Intention to Grant a European Patent, the Examining Division, Oct. 4, 1991

Howard Florey/Relaxin v. Franktion der Grünen im Europäischen Parlament, "Decision of the opposition division dated 8 December 1994", OJ EPO [1995]

Opinion of Advocate General Bot delivered on 10 Mar. 2001 in Case C-34/10 Oliver Brüstle v. Greenpeace eV, ECLI:EU:C:2011:138

T 1441/13 (Embryonic stem cells, disclaimer /ASTERIAS) [2014]

T 1808/13 (Neural Progenitor cells/BRÜSTLE) [2015]

T 19/90 (Harvard/Oncomouse) OJ EPO 469 [1990]

T 2221/10 (Culturing stem cells/Technion) [2014]

T 315/03 (Oncomouse II) OJ EPO [2005]

T 356/93 (Plant cells) OJ EPO [1995]

T-1374/04, OJ EPO [2007]

X ZR 58/07, German Federal Court of Justice, decided on Nov. 27, 2012

\section{Cases in the US}

Alice Corporation Pty. Ltd. v. CLS Bank International, 573 US _-, 134 S. Ct. 2347 (2014)

Association for Molecular Pathology v. Myriad Genetics, Inc., 133 S. Ct. 2107 (2013)

Brenner v. Manson, 383 US 519 (1966)

Consumer Watchdog v. Wisconsin Alumni Research Found., 753 F.3d 1258 (Fed. Cir. 2014)

Diamond v. Chakrabarty 447 US 303 (1980)

Diamond v. Diehr, 450 US 175 (1981)

Ex parte Allen, 2 USPQ2d 1425 (Bd. Pat. App. \& Inter. 1987)

Funk Bros. Seed Co. v. Kalo Inoculant Co., 333 US 127 (1948)

In re Bergy, 596 F.2d 952 (C.C.P.A. 1979)

In re Comiskey, 499 F.3d 1365 (Fed. Cir. 2007)

In re Roslin Inst., 750 F.3d 1333 (Fed. Cir. 2014).

Juicy Whip, Inc. v. Orange Bang, Inc., 185 F.3d 1364 (Fed. Cir. 1999)

Lowell v. Lewis, 15 Fed. Cas. 1018 (C.C.D. Mass. 1817)

Mayo Collaborative Servs. v. Prometheus Labs., Inc., 132 S. Ct. 1289 (2012)

National Automatic Device Co. v. Lloyd, 40 F. 89 (N.D. III. 1889)

Richard v. Du Bon, 103 F. 868 (2d Cir. 1900)

Sherley v. Sebelius, 610 F.3d 69 (D.C. Cir. 2010)

Sherley v. Sebelius, 644 F.3d 388 (D.C. Cir. 2011)

Sherley v. Sebelius, 686 F. Supp. 2d 1 (D.D.C. 2009)

Sherley v. Sebelius, 689 F.3d 776 (D.C. Cir. 2012)

Sherley v. Sebelius, 704 F. Supp. 2d 63 (D.D.C. 2010)

Sherley v. Sebelius, 776 F. Supp. 2d 1 (D.D.C. 2011)

State St. Bank \& Trust Co. v. Signature Fin. Grp., Inc., 149 F.3d 1368 (Fed. Cir. 1998) 


\section{Cases in China}

FS17820 (patent re-examination of the patent application No. 01806319.5) [2009] FS22325 (patent re-examination of the patent application No. 01805291.6) [2010] FS25050 (patent re-examination of the patent application No. 01811938.7) [2010] FS4237 (patent re-examination of the patent application No.97198083.7) [2004] FS42698 (patent re-examination of the patent application No. 03816184.2) [2012] FS46359 (patent re-examination of the patent application No. 02813927.5) [2012] FS73216 (patent re-examination of the patent application No. 200880018767.X) [2014] FS73397 (patent re-examination of the patent application No. 200680022866.6) [2014] FS76279 (patent re-examination of the patent application No. 200880107638.8) [2014] FS78111 (patent re-examination of the patent application No. 201010528128.7) [2014] FS78768 (patent re-examination of the patent application No. 200910129670.2) [2014] FS83865 (patent re-examination of the patent application No. 200680027460.7) [2015] FS91797 (patent re-examination of the patent application No. 200880013190.3) [2015] FS98883 (patent re-examination of the patent application No. 200880109580.0) [2015] Jiangsu Wuxi Yixing Lengdong Peitai Jiufen An (江苏无锡宜兴冷冻胚胎纠纷案) [Shen Xinnan and Shao Yumei v. Liu Jinfa and Hu Xinxiang], (Intermediate People's Court of Wuxi, Xi Min Zhong Zi No. 01235, Sep. 17, 2014) (江苏省无锡市中级人民法院 (2014) 锡民终字第 01235 号) (China)

\section{Patents and Patent Applications}

Application GB0621068.6

Application GB0621069.4

Chinese patent application No. 01805291.6

Chinese patent application No. 01806319.5

Chinese patent application No. 01811938.7

Chinese patent application No. 02813927.5

Chinese patent application No. 03816184.2

Chinese patent application No. 200680022866.6

Chinese patent application No. 200680027460.7

Chinese patent application No. 200880013190.3

Chinese patent application No. 200880018767.X

Chinese patent application No. 200880107638.8

Chinese patent application No. 200910129670.2

Chinese patent application No. 200980116566.8

Chinese patent application No. 201010528128.7

Chinese patent application No. 97198083.7

European patent application No. 03751238.1

Patent DE 19756864

Patent EP0695351 
Patent EP0770125

Patent US5,843,780

Patent US6,200,806

Patent US7,029,913

Patent US7,514,258

US patent application No. 08/993,563

US patent application No. 09/225,233

\section{National Legislation and Regulatory Documents}

Act 1991: 115 on Measures for Purposes of Research and Treatment Involving Fertilized Human Ova, Sweden, Amendment in force on Apr. 1, 2005

Amendment XIII to the US Constitution

Artificial Insemination and Embryo Protection Act, Estonia, passed on Jun. 11, 1997, entered into force Jul. 17, 1997

Austrian Reproductive Medicine Act (Fortpflanzungsmedizingesetz) (1992)

California Stem Cell Research and Cures Bond Act of 2004, Cal. Health \& Safety Code $\S$ 125291.30 (West 2004)

Constitution of the PRC, adopted at the 5th Session of the 5th National People's Congress, promulgated for implementation by the Announcement of the National People's Congress on Dec. 4, 1982, amended on Mar. 14, 2004

Dickey-Wicker Amendment, Pub. L. No. 104-99 (1996)

Dutch Embryos Act, Wet houdende regels inzake handelingen met geslachtscellen en embro's: Embrowet (2002)

Ethical Advisory Boards, 45 CFR § 46.204(d) (1982)

Examination Guidelines for the Utility Requirement, 66 Fed. Reg. 1092 (Jan. 5, 2001)

Exec. Order No. 12975, 3 CFR 1759 (1995)

Exec. Order No. 13505, 74 Fed. Reg. 10,667 (Mar. 9, 2009)

Federal Act on Research on Surplus Embryos and Embryonic Stem Cells (Embryonic Research Act), Switzerland, approved by referendum in Nov. 2004

German Embryo Protection Act, Gesetz zum Schutz von Embryonen (ESchG), 1990 (BGBI. I S. 2746)

German Stem Cell Act, Gesetz zur Sicherstellung des Embryonenschutzes im Zusammenhang mit Einfuhr und Verwendung menschlicher embryonaler Stammzellen (StZG), Stammzellgesetz vom 28. Juni 2002 (BGBI. I S. 2277)

Guanyu Yinfa Ganxibao Linchuang Yanjiu Guanli Banfa (Shixing) de Tongzhi (《关于 印发干细胞临床研究管理办法（试行）的通知》国卫科教发[2015]48号） [Measures for the Administration of Stem Cell Related Clinical Research ( for Trial Implementation), Guoweikejiaofa [2015] No. 48], jointly issued by the National Health and Family Planning Commission of the PRC and the China FDA on Jul. 20, 2015 
Guojia “Shi'er Wu” Kexue he Jishu Fazhan Guihua (国家“十二五”科学和技术发展规划) [The National "Twelfth Five-Year" Development Plan of S\&T], Ministry of Science and Technology of the PRC

Guojia Zhong Changqi Kexue yu Jishu Fazhan Guihua Gangyao (2006-2020) (国家中长期科 学和技术发展规划纲要 (2006-2020)) [The outline of the National Medium- and Long-Term Program for S\&T Development (2006-2020)], issued by the Central People's Government of the PRC in 2006

Guowuyuan Guanyu Jiakuai Tuijin Canjiren Xiaokang Jincheng de Yijian（《国务院关于加 快推进残疾人小康进程的意见》国发 [2015] 7号) [Opinions of the State Council on Accelerating the Progress of Building the Wellbeing of Disabled Persons, Guofa [2015] No.7], promulgated by the State Council of PRC on Jan. 20, 2015

Guowuyuan Guanyu Luoshi Zhengfu Gongzuo Baogao Zhongdian Gongzuo Bumen Fengong de Yijian (《国务院关于落实 〈政府工作报告〉重点工作部门分工的意见》国发[2014]15 号) [Opinions of the State Council on Division of Work for Departments for the Implementation of Key Work in the "Government Work Report",Guofa [2014] No.15], promulgated by the State Council of PRC on Mar. 23, 2014

Guowuyuan Guanyu Yinfa Guojia Jiben Gongong Fuwu Tixi Shi'er Wu de Guihua de Tongzhi (《国务院关于印发国家基本公共服务体系 “十二五”规划的通知》国发[2012] 29号) [Notice of the State Council on Issuing the Plan for the Basic Public Services System During the 12th Five-Year Plan, Guofa [2012] No.29], promulgated by the State Council of P.R.C. on July 11, 2012

Guowuyuan Guanyu Yinfa Guojia Zhishi Chanquan Zhanlüe Gangyao de Tongzhi (《国 务院关于印发国家知识产权战略纲要的通知》国发[2008]18 号) [Outline of the National Intellectual Property Strategy], issued by the State Council of the PRC on 5 Jun. 2008

Health Council of the Netherlands, IVF-related Research, No. 1998/08E, Rijswijk (Mar. 19, 1998).

Human Fertilisation and Embryology (Research Purposes) Regulations, UK, 2001, S.I. 2001/188, issued on Jan. 24, 2001, came into force on Jan. 31, 2001

Human Fertilisation and Embryology Act 2008, UK

Leahy-Smith America Invents Act, Pub. L. No. 112-29, 125 Stat. 284 (2011) (to be codified in scattered sections of 35 USC)

Medical Research Act, Finland, 488/1999, amended 295/2004, 794/2010, 143/2015

Memorandum from Harriet S. Rabb, General Counsel of the Department of Health and Human Services, to Harold Varmus, Director of the National Institutes of Health (Jan. 15, 1999)

National Bioethics Advisory Commission, Ethical Issues in Human Stem Cell Research, Rockville, MD, September 1999

National Institutes of Health Guidelines for Research Using Human Pluripotent Stem Cells, F. R., Vol. 65, No. 166 
NIH, Draft National Institutes of Health Guidelines for Human Stem Cell Research Notice, 74 Fed. Reg. 18578-18580 (Apr. 23, 2009)

Notice: Animals-Patentability, 1077 Official Gazette US Pat. \& Trademark Off. 8 (Apr. 21, 1987)

Renlei Peitai Ganxibao Yanjiu Lunli Zhidao Yuanze (人胚胎干细胞研究伦理指导原则) [Ethical Guidelines for Human Embryonic Stem Cell Research], Guokefashengzi (国科发生字) [2003] No. 460, jointly issued by the MOH and the MOST of China on Dec. 24, 2003

Report and Conclusions: HEW Support of Research Involving Human In Vitro Fertilization and Embryo Transfer, 44 Fed. Reg. 35,033 (May 4, 1979)

The Human Fertilization and Embryology Act (HFE Act) 1990 c 37 (UK), passed in 1990, amended by the HFE Act 2008 c 22 (UK)

US Congress, House Committee on Energy and Commerce, National Institutes of Health Revitalization Act of 1993, report to accompany H.R. 4, 103rd Cong., 1st sess., March 9, 1993, H. Rept. 103-28 (Washington: GPO, 1993)

USPTO, 2014 Interim Guidance on Patent Subject Matter Eligibility, 79 FR. Reg. 74618 (Dec. 16, 2014).

USPTO, Guidance for Determining Subject Matter Eligibility of Claims Reciting Or Involving Laws of Nature, Natural Phenomena, \& Natural Products, issued on March 4, 2014 USPTO, Manual of Patent Examining Procedure (MPEP)

USPTO, Nature-Based Product Examples (Dec. 16, 2014),

Weisheng Bu Bangong Ting Guanyu Xiafa Qidai Xue Zaoxue Ganxibao Ku Shezhi Guihua de Tongzhi (卫生部办公厅关于下发脐带血造血干细胞库设置规划的通知) [Notice Issued by the Ministry of Health on the Plan to Set up Banks of Umbilical Cord Blood Stem Cells], promulgated by the National Health and Family Planning Commission of the PRC on May 22, 2001

Zhonghua Renmin Gongheguo Fu'nü Quanyi Baozhang Fa (中华人民共和国妇女权益保障法) [Law of the People's Republic of China on the Protection of Rights and Interests of Women], passed on Apr. 3, 1992, amended on Aug. 28, 2005

Zhonghua Renmin Gongheguo Jicheng Fa (中华人民共和国继承法) [Law of Succession of the People's Republic of China], adopted at the 3rd Session of the 6th National People's Congress, promulgated by No. 24 of the President of the PRC on Apr. 10, 1985 Zhonghua Renmin Gongheguo Minfa Tongze (中华人民共和国民法通则) [General Principles of the Civil Law of the People's Republic of China], adopted at the 4th Session of the Sixth National People's Congress on Apr. 12, 1986, promulgated by Order No. 37 of the President of the PRC on Apr. 12, 1986

Zhonghua Renmin Gongheguo Minfa Zongze (中华人民共和国民法总则) [General Rules of the Civil Law of the People's Republic of China], adopted at the 5th Session of the 12th National People's Congress of the PRC on Mar. 15, 2017, effective on Oct. 1, 2017. Zhonghua Renmin Gongheguo Zhuanli Fa (中华人民共和国专利法) [Patent Law of the People's Republic of China], adopted at the 4th Meeting of the Standing Commit- 
tee of the Sixth National People's Congress on Mar. 12, 1984, amended the third and adopted on Dec. 27, 2008

Zhonghua Renmin Gongheguo Zhuanlifa Shishi Xize (中华人民共和国专利法实施细则) [Implementing Regulations of the Patent Law of the PRC], promulgated by Decree No. 306 of the State Council of the PRC on June 15, 2001, amended the first time on December 28, 2002 according to the Decision of the State Council on Amending the IRPL, and amended the second time on January 9, 2010 according to the Decision of the State Council on Amending the IRPL

Zhuanli Shencha Zhinan (专利审查指南) [Guidelines for Patent Examination] (SIPO's Guidelines), revised and promulgated by the SIPO and entered into force on Feb. 1, 2010

\section{International Treaties and Materials}

Additional Protocol to the Convention for the Protection of Human Rights and Dignity of the Human Being with regard to the Application of Biology and Medicine, on the Prohibition of Cloning Human Beings (CETs No 168, Jan. 12, 1998)

Administrative Council Decision, OJ EPO [1999]

Agreement on Trade-Related Aspects of Intellectual Property Rights (TRIPS Agreement), Marrakech Agreement Establishing the World Trade Organization, Annex 1C, Legal Instruments-Results of the Uruguay Round (Marrakesh, 15 April 1994, 33 ILM 1197 (1994))

Charter of the United Nations, signed on Jun. 26, 1945, came into force on Oct. 24, 1945 Convention for the protection of Human Rights and Dignity of the Human Being with regard to the Application of Biology and Medicine: Convention on Human Rights and Biomedicine, Oviedo, 4.IV.1997, ETS 164

Convention on Biological Diversity (Rio de Janeiro, 5 June 1992)

Convention on the Grant of European Patents (the European Patent Convention or the EPC), issued by European countries on Oct., 5 1973, revised by the Act revising art.63 EPC of Dec. 17, 1991 and the Act revising the EPC of Nov., 292000

Decision No 1513/2002 of 27 June 2002 the European Parliament and the Council concerning the Sixth Framework Programme of the European Community for Research, Technological Development and Demonstration Activities, Contributing to the Creation of the European Research Area and to Innovation (2002-2006) Annex I [2002] OJ L232/1

Decision No 1982/2006/EC of the European Parliament and of the Council of 18 December 2006 concerning the Seventh Framework Programme of the European Community for research, technological development and demonstration activities (2007-2013) 1982/2006/EC [2006] OJ L 54/1

Directive 98/44/EC of the European Parliament and of the Council of 6 July 1998 on the legal protection of biotechnological inventions 
European Commission, European Citizens' Initiative: European Commission Replies to "One of Us", (Brussels, May 28, 2014)

European Commission, Proposal for a Council Directive on The Legal Protection of Biotechnological Inventions COM (88) 496 final, 17 Oct. 1988

European Parliament, the Council and the Commission, Charter of Fundamental Rights of the European Union (2000/C 364/01), OJ C 364, 18 Dec. 2000

Guidelines for Examination in the European Patent Office

Implementing Regulations to the EPC, adopted by decision of the Administrative Council of the European Patent Organization of Dec. 7, 2006, last amended by Oct. 14, 2015

International Covenant on Civil and Political Rights, adopted Dec. 16, 1966, entered into force Mar. 23, 1976

International Covenant on Economic, Social and Cultural Rights, adopted Dec. 16, 1966, entered into force Jan. 3, 1976

Protocol No. 13 to the Convention for the Protection of Human Rights and Fundamental Freedoms, Concerning the Abolition of the Death Penalty in All Circumstances, Vilnius, 3.V.2002, ETS 187

Resolution 217 A (III) Universal Declaration of Human Rights, General Assembly of United Nations, Dec. 10, 1948

Vienna Declaration and Programme of Action, adopted by the World Conference on Human Rights in Vienna on Jun. 25, 1993 


\section{Summary}

Over the last several decades, the advancement of biotechnology has resulted in inventions in the field increasingly involving living matter, even including materials from human beings, which not surprisingly has posed critical challenges to the current global patent regime. In particular, since the world's first successful isolation of an hESC line was announced, the patenting of hESC-related inventions has become a considerably difficult and controversial issue. It almost always intertwines with scientific or economic, and social or moral concerns. Jurisdictions around the world, such as the EU and China, have been struggling to seek their own appropriate ways of determining whether and how to patent these inventions. Interestingly, China is in dire need of breakthroughs and technological innovation, and has invested enormous amounts of money and provided various policies encouraging hESC research. However, merely relying on governmental funding without private investment would not be sufficient for a country to promote the development of such an industry and research. With regard to facilitating private investment in hESC research and industry, the role that patent law plays cannot be ignored. Moreover, even if it intends to take full advantage of the generous institutional patronage in the field of hESC research, China also needs to seek an appropriate patent system suitable to its particular legal system, moral culture and economic situation.

This doctoral thesis tries to answer the question: is there any need to improve patent rules and policies regarding the patent eligibility of hESC-related inventions in China, and if so, how should this be done so as, on the one hand, to ensure that the biotechnology industry has sufficient incentives to continue to research and develop hESC-related products while, on the other hand, recognizing the value of Chinese and outside moral culture? This research shows that China's current approach to dealing with the patenting of hESCrelated inventions, in general, not only takes into consideration Chinese moral culture with its respect for human embryos, but also has in mind the need for the development 
of S\&T. While there is no need, at this time, to make any substantive changes in China's patent law and the general policy, a number of adjustments and further clarification still need to be conducted by the SIPO within its Guidelines.

This thesis contains six chapters. Chapter 1 first briefly explores the dilemmas of patenting hESC-related inventions in general, and the relevant challenges for China in particular. Then it introduces the main research question. After that, the methodology and outline of the thesis are delineated. Chapter 2 attempts to build a fundamental basis for the subsequent discussion about the patenting of hESC-related inventions. It discusses important theories that justify the patent system most pertinent to the biotechnology industry, the scientific background of hESC-related technologies, and the social and moral debates concerning hESC research per se and by extension the debate, in particular on moral grounds, over patenting hESC-related inventions.

Chapter 3 explores the public perception of patents in China. It also discusses the specific moral culture and legal status of the human embryo in China, and at the same time it tries to offer additional explanations for the moral concerns regarding the acceptability of hESC research in this country. It investigates the potential human dignity argument, and finds that this argument does not play an important role in the objections against patenting hESC-related inventions in China. Based on the analysis, Chapter 3 demonstrates that in the context of the Chinese public's favourable stance toward patents, and the public's pragmatic moral position concerning human embryos, as well as the Chinese government's considerable support for hESC research, it concludes that the Chinese public will not have much strong moral resistance to patenting most hESCrelated inventions, as long as the patenting shows certain respect for the embryo under Chinese moral culture.

After having identified the crux in Chinese morality and debates concerning hESCs and associated research in China, Chapter 4 then tries to investigate the policy approaches that the three jurisdictions (i.e., the US, EU and China) have taken towards hESC research. It shows that in most countries of the West, such as the US, UK, Netherlands, and Germany, a relatively comprehensive regulatory framework regarding hESC research has been established, and the initial driving force for regulating such research came from domestic moral concerns of the public. However, due to the social moral culture, institutional structure, desire for scientific progress and economic development $a$ in China, local moral concerns regarding hESC research have not been paid close attention by policy makers when establishing China's own regulation system. The chapter also shows that China has not established a comprehensive regulatory framework in terms of governing hESC research; the Chinese approach is relatively permissive, and the rationale behind it is primarily economic and S\&T development considerations. 
Moreover, Chapter 4 indicates that while China recently has made considerable progress in the field of hESC research, it is still well behind its technologically advanced counterparts (e.g., Europe, the US, and Japan) for the moment.

Against the background of the abovementioned study, Chapter 5 conducts a comparative analysis of the patent eligibility of hESC-related inventions. It explores specific provisions in the three jurisdictions (i.e., the US, EU, and China), pertinent policies in patent offices (i.e., the USPTO, EPO, and SIPO), and judicial decisions of the courts (e.g., the CJEU). It shows that simply following the US model, which has abandoned the moral assessment in patent law, is not ideal in the case of patenting morally controversial biotechnological inventions in China. Meanwhile, it is also naive to indiscriminately imitate the current EU approach, in particular considering that the provisions within the EU Biotech Directive and EPC, as well as the approaches that the CJEU and EPO have adopted, are essentially based on the European situation, while China has a different degree of domestic development of research and industry, a unique local moral culture and legal system concerning a human embryo, and an immature regulatory system. In short, completely excluding hESC-related inventions from the patent eligibility on moral grounds, like in the EU and EPO, is not suitable in China's case. The chapter demonstrates that China's current approach is primarily based on the SIPO's policy: as long as the patent application avoids the contents of isolating or obtaining hESCs from a human embryo, and provides sufficient evidence to prove that the invention uses already established hESC lines which are obtainable from commercial channels, then downstream hESC inventions would be regarded as patent eligible. The chapter finds that this approach towards patenting hESC-related inventions, to some extent, on the one hand, satisfies Chinese moral culture to show respect for human embryos, and on the other hand, has in mind the need for the development of S\&T. However, a number of adjustments and further clarification still need to be conducted within the SIPO's Guidelines, such as to redefine the concept of a "human embryo", to narrowly interpret the term "use" in the human embryo exclusion, and to remove the specific exclusion of "hESCs and their preparation methods".

In the end, Chapter 6 presents the main findings of the research, makes final conclusions, and summarizes the recommendations from the perspectives of general policy and the improvement of the SIPO's Guidelines. It briefly conducts a discussion of limitations of the thesis and future research as well. 



\section{Samenvatting}

In de afgelopen decennia heeft de opmars van de biotechnologie geleid tot uitvindingen op het gebied van levende materie met inbegrip van materialen van menselijke wezens. Dit heeft, zoals te verwachten was, geleid tot kritische uitdagingen voor de huidige wereldwijde octrooisystemen. In het bijzonder, sinds de succesvolle isolatie van de eerste lijn van menselijke embryonale stamcellen (Engels: human embryonic stem cell, afgekort tot $\mathrm{hESC}$ ) wereldkundig is gemaakt, is de octrooiering van hESC-gerelateerde uitvindingen een moeilijk en controversieel onderwerp geworden. De octrooiering conflicteert bijna altijd met wetenschappelijke of economische en sociale of morele belangen. Jurisdicties overal ter wereld, zoals de Europese Unie en China, hebben moeite passende manieren te vinden voor de octrooieerbaarheid van deze uitvindingen. Interessant te constateren is dat China dringend behoefte heeft aan doorbraken en technologische innovatie, enorme hoeveelheden geld heeft geïnvesteerd alsmede diverse stimuleringsmaatregelen heeft genomen op het gebied van hESC-onderzoek. Louter een beroep doen op overheidsfinanciering zonder particuliere investeringen is niet voldoende voor een land om de ontwikkeling van dergelijk onderzoek en de industrie te bevorderen. Met betrekking tot het faciliteren van particuliere investeringen in hESConderzoek en de industrie, kan de rol die octrooiwetgeving speelt niet worden ontkend. Bovendien is China van plan ten volle te profiteren van het genereuze institutionele patronaat op het gebied van hESC-onderzoek, en moet ook een passend octrooisysteem worden gevonden dat geschikt is voor zijn specifieke rechtsstelsel, morele cultuur en de economische situatie.

Dit proefschrift probeert een antwoord te geven op de vraag: is er behoefte aan en, zo ja, hoe kunnen octrooiregels en -beleid met betrekking tot de octrooieerbaarheid van hESC-gerelateerde uitvindingen in China worden verbeterd, zodat enerzijds de biotechnologische industrie voldoende prikkels krijgt door te gaan met het onderzoeken en ontwikkelen van hESC-gerelateerde producten terwijl, anderzijds, de waarde van 
de Chinese en externe morele cultuur wordt erkend? Het onderzoek in dit proefschrift toont aan dat de huidige Chinese aanpak van het omgaan met de octrooiering van hESC-gerelateerde uitvindingen in het algemeen niet alleen rekening houdt met de Chinese morele cultuur om respect te tonen voor een menselijk embryo, maar ook oog heeft voor de ontwikkeling van het Chinese meerjarenprogramma voor wetenschap en technologie. Hoewel er op dit moment geen noodzaak is om substantiële wijzigingen aan te brengen in de Chinese octrooiwet en het algemene beleid, zou de Chinese nationale octrooi autoriteit (Engels: State Intellectual Property Office, afgekort SIPO) binnen zijn richtlijnen nog een aantal aanpassingen en verdere verduidelijkingen moeten doorvoeren.

Dit proefschrift bevat zes hoofdstukken. Hoofdstuk 1 bespreekt eerst in het kort de dilemma's van octrooiering van uitvindingen gerelateerd aan menselijke embryonale stamcellen (hESC) in het algemeen alsmede de relevante uitdagingen voor met name China. Vervolgens wordt in dit hoofdstuk de belangrijkste onderzoeksvraag geformuleerd. Daarna worden de methodologie en de hoofdlijnen van dit proefschrift afgebakend. Hoofdstuk 2 probeert een fundamentele basis te leggen voor de daaropvolgende discussie over de octrooiering van hESC-gerelateerde uitvindingen. Aan de orde komen de belangrijkste theorieën die, voor de biotechnologische industrie, het meest relevante octrooistelsel rechtvaardigen, de wetenschappelijke achtergrond van hESC-gerelateerde technologieën, alsmede de sociale en morele debatten over hESConderzoek per se en het morele debat inzake de octrooiering van hESC-gerelateerde uitvindingen.

Hoofdstuk 3 onderzoekt de specifieke morele cultuur en wettelijke status van een menselijk embryo in China, en probeert tegelijkertijd extra uitleg te geven voor de morele zorgen over de aanvaardbaarheid van hESC-onderzoek in dit land. In dit hoofdstuk wordt het potentiële menselijke waardigheidsargument onderzocht en wordt geopinieerd dat dit argument geen belangrijke rol speelt in de bezwaren tegen octrooiering van hESC-gerelateerde uitvindingen in China. Ook wordt de publieke perceptie van octrooien in China op dit gebied onderzocht. Op basis van de analyse laat hoofdstuk 3 zien dat in het kader van de Chinese publiek pragmatische morele positie met betrekking tot een menselijk embryo, en de aanzienlijke steun van de Chinese regering voor hESC-onderzoek, evenals de sympathie van het publiek voor octrooien, het Chinese publiek niet veel morele weerstand heeft tegen het octrooieren van de meeste hESCgerelateerde uitvindingen.

Na de kern van de Chinese moraal en in de debatten over hESC's en geassocieerd onderzoek in China te hebben geïdentificeerd, onderzoekt hoofdstuk 4 vervolgens de beleidsbenaderingen die drie relevante rechtsgebieden (d.w.z. de VS, de EU en China) 
hebben ontwikkeld met betrekking tot hESC-onderzoek. Het laat zien dat in de meeste westerse landen, zoals in de Verenigde Staten, het Verenigd Koninkrijk, Nederland en Duitsland, een relatief uitgebreid regelgevend kader met betrekking tot hESC-onderzoek is vastgesteld, en dat de drijvende kracht achter het reguleren van dergelijk onderzoek zijn oorsprong vond in binnenlandse morele zorgen van het publiek. Echter, vanwege de sociale moraalcultuur, institutionele structuur, wetenschappelijke vooruitgang of economische ontwikkeling en de pragmatische beleidsvorming in China, zijn lokale morele zorgen binnen hESC-onderzoek door de beleidsmakers bij de instelling van het eigen reguleringssysteem van China niet goed in de gaten gehouden. Het toont ook aan dat China geen alomvattend regelgevend kader heeft vastgesteld voor wat betreft hESC-onderzoek; de Chinese benadering is relatief vrijblijvend en de onderliggende redenering beperkt zich in eerste instantie tot economische en ontwikkelingsoverwegingen die voortvloeien uit het Chinese meerjarenprogramma voor wetenschap en technologie. Bovendien geeft hoofdstuk 4 aan dat China, hoewel recentelijk aanzienlijke vooruitgang is geboekt op het gebied van hESC-onderzoek, vergeleken met zijn technologisch geavanceerde tegenhangers (bijv. Europa, de VS en Japan) nog steeds een relatief grote achterstand heeft.

Tegen de achtergrond van bovengenoemde studie, ligt de focus van hoofdstuk 5 op de vergelijkende analyse van de octrooieerbaarheid van hESC-gerelateerde uitvindingen. In dit hoofdstuk worden de specifieke bepalingen in de drie rechtsgebieden onderzocht (dwz die van de VS, de EU en China), het relevante beleid in octrooibureaus (dwz USPTO, EOB en SIPO) en rechterlijke uitspraken van de rechtbanken (bijv. Het HvJEU). Aangetoond wordt dat het eenvoudig volgen van het Amerikaanse model, dat morele beoordeling in de octrooiwet heeft afgeschaft, niet ideaal is in het geval van het octrooieren van moreel controversiële biotechnologische uitvindingen in China. Ondertussen is het ook naïef om de huidige EU-aanpak zonder onderscheid na te bootsen, vooral gezien het feit dat de bepalingen in de Europese Biotech-richtlijn en in het Europees Octrooiverdrag, evenals de benaderingen die het Hof van Justitie van de Europese Unie en het Europees Octrooibureau (EOB) hebben aangenomen, in wezen gebaseerd zijn op de Europese situatie, maar dat in China een afwijkende binnenlandse ontwikkeling heeft plaatsgevonden in onderzoek en industrie. China heeft een unieke lokale morele cultuur en een relatief onvolwassen reguleringssysteem. Met andere woorden, het op morele gronden uitsluiten van hESC-gerelateerde uitvindingen van octrooieerbaarheid, zoals in de Europese Unie en door het Europees Octrooibureau, is niet op zijn plaats voor China. Ook wordt aangetoond dat de huidige aanpak van China primair gebaseerd is op het beleid van het SIPO: zolang de octrooiaanvrage geen referentie bevat naar het isoleren of verkrijgen van hESC's uit een menselijk embryo precies, en voldoende bewijs levert om te bewijzen dat de uitvinding reeds gevestigde hESC-lijnen gebruikt verkrijgbaar via commerciële kanalen, dan worden afgeleide uitvindingen van hESC 
als octrooieerbaar beschouwd. Het SIPO is van mening dat deze benadering van de octrooieerbaarheid van hESC-gerelateerde uitvindingen, tot op zekere hoogte, aan de ene kant voldoet aan de Chinese sociale moraliteit daarbij respect tonend voor het menselijk embryo, en aan de andere kant de ontwikkelingen binnen het Chinese meerjarenprogramma voor wetenschap en technologie niet uit het oog verliest. Er moet echter nog een aantal aanpassingen en verdere verduidelijkingen worden doorgevoerd in de SIPO-richtlijnen, zoals het herdefiniëren van het concept van een "menselijk embryo", het zo beperkt mogelijk interpreteren van de term "gebruik" bij de uitsluiting van menselijke embryo's, alsmede het afschaffen van de specifieke uitsluiting van "hESC's en hun bereidingsmethoden".

Tenslotte worden in hoofdstuk 6 de belangrijkste bevindingen van het onderzoek gepresenteerd, definitieve conclusies getrokken en een samenvatting gegeven van de aanbevelingen vanuit het perspectief van het algemene beleid van de Chinese overheid en ter verbetering van de SIPO-richtlijnen. Bovendien geeft hoofdstuk 6 een korte bespreking van de beperkingen van dit proefschrift, alsmede worden lijnen uitgezet voor toekomstig onderzoek. 


\section{List of Publications}

Parts of Chap. 5 in relation to the patentability of hESC-related inventions in China as well as the dynamic development of patenting these inventions in the SIPO are updated versions of: Yaojin Peng, The Patentability of Human Embryonic Stem Cell Technology in China, Nature BIOteChnology, 2016, 34(1). DOI:10.1038/nbt.3417.

Parts of Chap. 3, parts of Chap. 4, and parts of Chap. 5 in relation to regulating and patenting hESC-related inventions and some endemic problems in China are updated versions of: Yaojin Peng, Intellectual Property Protection Concerning Stem Cell Research in China: Predicament and Solutions, 28 CHINESE Bulletin OF LIFE SCIENCE, 2016, 28(8) (in Chinese). DOI:10.13376/j.cbls/20160.

Parts of Chap. 2, parts of Chap. 3, and parts of Chap. 5 in relation to patenting inventions concerning parthenogenetic stem cells and defining human embryos under Chinese moral culture in China, and some recommendations in Chap. 5 have been submitted for publication in: Nature Biotechnology Yaojin Peng, Patenting Human Parthenogenetic Stem Cells and Defining Human Embryos in China

Parts of Chap. 4 and Chap. 5 in relation to moral dilemma concerning patenting hESCrelated inventions in Europe and China, and some recommendations in Chap. 5 are updated versions of: Yaojin Peng, Europe and China in the Area of Patenting Human Embryonic Stem Cells: Finding the Way in the Moral Dilemma

A conference paper submitted to and presented at "Intellectual Property Work-inProgress Colloquium" held in the UW in 2015. 



\section{Curriculum Vitae}

Yaojin Peng (born July 1986) holds a Bachelor's degree in Biotechnology (University of Science and Technology Beijing, China, 2009) and a Master's degree in Law (Graduate School of Chinese Academy of Social Sciences, China, 2013). In September 2013, he joined the Faculty of Law, Maastricht University, the Netherlands, as a junior PhD researcher, and finished his PhD thesis in the winter of 2017. His research in Maastricht University was funded by the State Scholarship Fund, China Scholarship Council.

Mr. Peng's research in Maastricht focuses on intellectual property, particularly patent issues in technologies and industries. He also has a long-standing interest in the regulation of technological research, and bioethics, and he has published several articles in both English and Chinese in the IP field. During his stay in Maastricht, Mr. Peng was a fellow member of the lus Commune Research School, as well as a team advisor of the 17th Congress of the European Intellectual Property Institutes Network (EIPIN). In 2015, Mr. Peng was the principal investigator of the Intermediary Liability Research Project: Privacy Protection in China, funded by the University of Washington and Google. The project resulted in a report which was published online. From September 2017 to March 2018, Mr. Peng worked and conducted his research in the Applied Research Center for Intellectual Assets and the Law in Asia (ARCIALA), School of Law, Singapore Management University. His research there was funded by ARCIALA. 



\section{Valorization Addendum}

\section{SOCIAL AND ECONOMIC RELEVANCE}

Over almost the last two decades, the question of whether or not to grant and how to grant patents on hESC-related inventions has perplexed jurisdictions around the world, including China and the EU. Determining the patent eligibility of hESC-related inventions is important to the hESC industry and research. In a jurisdiction, how the legislation and policies respond to the issue of patenting, to some extent, will profoundly influence whether and how research and the industry develops there. Moreover, in terms of the patenting of hESC-related inventions, on the face of it, it seems to be an IP question. However, it requires a much deeper and more fundamental exploration, since this legal issue is intertwined with ethical, sociological, and economic issues. Given this, the thesis aims to seek fair designed patent rules and policies to ensure the hESC industry has sufficient incentives to continue to research and develop hESC-related inventions on the one hand, while recognizing the value of Chinese and outside moral culture on the other hand.

This thesis is the very first study to take on both the narrow IP issue-the patenting of hESC-related inventions, and the "broader" issues surrounding it, including ethical and sociological considerations, in China particularly. Indeed, it is believed that hESC research has opened the door to a wide variety of new therapies and other medical applications for mankind. Over recent years, results from hESC research have been increasingly applied in the fields of diagnostics and therapy for diseases. In this regard, promoting the advance of hESC research and industry through a series of fair designed patent rules and policies, based on the recommendations of the thesis, will of course be beneficial to finding cures for terrible diseases, and will indirectly facilitate the improvement of human healthcare. With regard to the wider ethical and sociological considerations that spring from the patenting of hESC-related inventions, these issues have been discussed in the thesis. One example concerns the legal and moral status 
of the human embryo in China, and another one concerns the public perception of patents in China. The analysis in this thesis will help the industry around the world pay more attention to China's specific culture and public debates surrounding hESC research and by extension the patenting of hESC-related inventions. It will also help scientists in China rethink the moral issues behind hESC research. The thesis shows that China's current development level of hESC research and industry is still relatively low, especially compared with its technologically advanced counterparts, such as the EU, the US, and Japan. Based on a careful consideration of this fact, the designed legal rules and policies concerning patenting hESC-related inventions proposed in the thesis will of course promote the advance of China's domestic research and industry. In other words, the results of the study, will hopefully help China take full of advantage of the government's generous institutional patronage in the field of hESC research. Moreover, the outcomes of the thesis will in general promote the advance of hESC and industry, and further promote socio-economic development.

\section{TARGET GROUPS}

In general, the thesis will be a useful and valuable read for legal scholars, students of IP and medical law, and executives and investors, as well as practitioners seeking a deeper understanding of the rules and policies regarding this topic. Legal scholars, who have problems, especially concerning patents, underlying the international and national regulation of stem cell research, will find in this thesis a relatively useful case study of China. The unique situations in China discussed in this thesis can provide observers a ready resource for future research. Certainly, executives and investors who are going to conduct investment and research in the hESC industry and seek reliable patent protection in China will also find value in this text. In addition, the exploration of these issues will be of interest to lawyers, law practitioners curious about patenting hESC-related inventions, even biotechnological inventions, in China, and scientists and researchers around the world who intend to conduct research or collaborate with their peers in the field of hESC research in China. Furthermore, industrialists and scientists working in $\mathrm{hESC}$ research and industry will also be interested in the thesis, since even if they are working outside China, if they are planning to market their products in China or file a patent application there, they still need to pay attention to the rules and policies in China. The legislators and policy makers in China should be quite interested in this thesis, particularly in terms of the analysis of China's patent legislation and the SIPO's policies in the thesis. Moreover, the recommendations proposed in the thesis should be valuable to the legislators of China and policy makers of the SIPO. Of course, legislators and policy makers from some other jurisdictions may find this thesis interesting, and may consider the discussion of the thesis as a course of legislation and as a forum for 
discussing issues regarding patenting morally controversial biotechnological inventions.

\section{ACTIVITIES AND PRODUCTS}

The results of this research will be published in the form of a book. As a result, it will be available to readers, as previous mentioned, including students, academics, judges, legislators, policy makers, scientists and researchers who are interested in or want to know something about this topic. Moreover, parts of this study have already been published in academic journals. For instance, parts of Chapter 5 in relation to the patentability of hESC-related inventions in China as well as the dynamic development of patenting these inventions in the SIPO are updated versions of the article "The Patentability of Human Embryonic Stem Cell Technology in China", published by Nature Biotechnology, Volume 34, Number 1, January 2016. Parts of Chapters 3, 4, and 5 in relation to regulating and patenting hESC-related inventions and some endemic problems in China are updated versions of a Chinese article "Intellectual Property Protection Concerning Stem Cell Research in China: Predicament and Solutions", published by Bulletin of Life Science, Volume 28, Number 8, August 2016. Parts of Chapters 4 and 5 in relation to the moral dilemma concerning patenting hESC-related inventions in Europe and China, and some recommendations in Chapter 5 are updated versions of a conference paper "Europe and China in the Area of Patenting Human Embryonic Stem Cells: Finding the Way in the Moral Dilemma", submitted to and presented at "Intellectual Property Workin-Progress Colloquium" held in the UW in 2015. In addition, during the period of this research, some findings and results have also been presented in many international academic conferences and workshops, held by organizations such as the Institute for Globalization and International Regulation (IGIR), the Ius Commune Research School, the European Intellectual Property Institutes Network (EIPIN), Applied Research Centre for Intellectual Assets and the Law in Asia (ARCIALA), etc.

\section{INNOVATION}

Recently, there have been an increasing number of studies on patent-related issues in the field of biotechnology in China. At the same time, there is considerable scholarship on patent-related issues concerning hESC research in Western countries, particularly in Europe and in the US. However, very little research can be found on patenting hESCrelated inventions in China, which has made considerable progress in this research field over the past decade. Moreover, previous studies using a comparative law analysis did not take into consideration China's specific social and moral culture or the domestic development stage of hESC research and industry, and instead only took the current 
legislation and practice of other jurisdictions as a reference, ${ }^{1}$ which may result in an inappropriate patent system for China's current research and industry environment.

This thesis tries to provide one of the first comprehensive, systematic, and comparative treatments of hESC technology and patent protection concerning Chinese law, which is increasingly important in the context of China's growing internal strategic needs and the growing impact of this country on the global stem cell market. It is an important narrative that suggests that developing countries with a relatively advanced technological capability, such as China, can tailor an optimal patent policy to promote the advancement of their domestic hESC research and industry. In other words, the practice of China in terms of patenting hESC-related inventions can provide an attractive alternative model for other developing countries that are struggling to catch up economically and technologically in the present international economic system. Moreover, the findings of the thesis will contribute to the setting of international and/or domestic patent rules and the tailoring of patent policies not just restricted to hESC-related inventions, but extending to biotechnological inventions, since the controversy over patenting hESC-related inventions is merely one of the most typical representatives of patenting biotechnological inventions in the past several decades.

The thesis attempts to draw all this complex IP issue and ethical content together in one place. The explicit focus on the patent issue concerning hESC-related inventions in China gives the research a unique flavour, since China is a newly emerging power as well as a jurisdiction where the public has not been influenced very much by religious ideas, especially Christian morality. Thus, research on the patenting of hESC-related inventions in China can offer a fresh look at how an emerging economic and legal power with its own socio-cultural, religious, economic, and historical considerations will utilize patent law to serve its own development of research and industry.

\section{SCHEDULE AND IMPLEMENTATION}

Whether and how to grant patents upon hESC-related inventions are still on-going, controversial issues, which have attracted and will continue to attract more attention of academics and practitioners. The problems addressed in the thesis are considerably complex. Not surprisingly, the long-term consequences of concrete policy recommendations proposed by the thesis are in most cases difficult to predict. But the foremost step for the policy options suggested by the thesis to be realized is to spread the outcomes of the thesis as much as possible. In this regard, the author plans on presenting the results

See generally, LI Jiang, Regulating Human Embryonic Stem Cell in China: A Comparative Study on Human Embryonic Stem CelL'S PATENTABILITY ANd MORALITY IN US AND EU (Springer 2016). 
of the study in more seminars, workshops, and conferences both within and outside China. Also, as mentioned above, some contents in the thesis have been published in academic journals during the $\mathrm{PhD}$ research, but some have not. Given this, it is planned that within one year (before 2019), some remaining parts of the thesis that have not been published will be singled out and be further polished, and then published in academic journals ultimately. Within two years (before 2020), the author will also try to publish this thesis in book form through an international publishing house. In that case, there will be both physical and e-book versions available. The author will try his best to make the outcomes of the thesis accessible to everyone who is interested in this topic. By doing so, the outcomes of the thesis can be better spread, and the content can be further polished, and the policy options proposed by the thesis can be further improved. It is hoped that the outcomes of this thesis will bear fruit by sparking deeper and wider discussions, and stimulate investigation and evaluation in future research, specifically concerning the topic of this thesis in China. Hopefully, the discussion in this thesis will have far-reaching consequences for our society at large. 